Szegedi Tudományegyetem Bölcsészettudományi Kar

Történettudományi Doktori Iskola Medievisztika program

\title{
Szőcs Tibor
}

A NÁdORI INTÉZMÉNY TÖRTÉNETE AZ ÁRPÁD- ÉS ANJOU-KOR ELSŐ FELÉBEN (1000-1342)

Doktori értekezés

Témavezető: Dr. Petrovics István

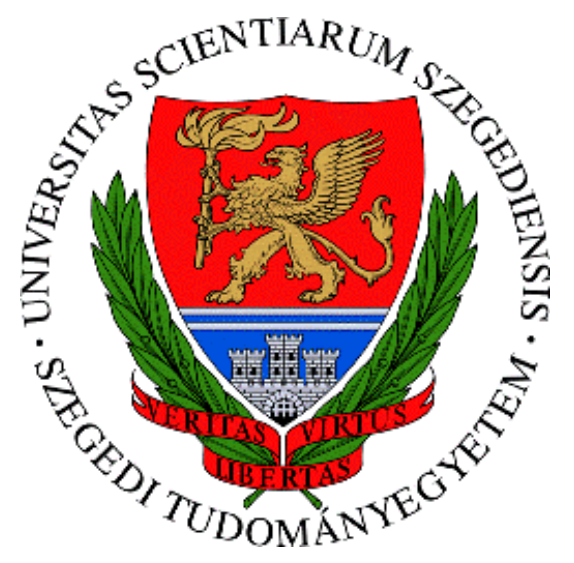

Szeged, 2013 


\section{TARTALOM}

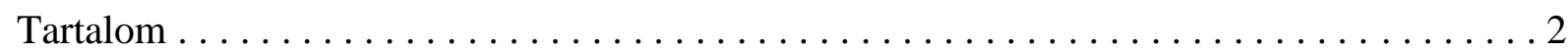

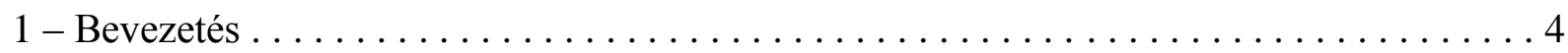

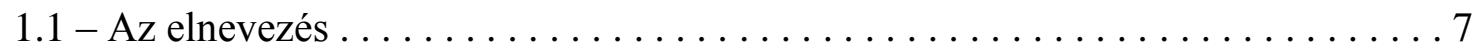

1.2 - A szó etimológiája $\ldots \ldots \ldots \ldots \ldots \ldots \ldots \ldots \ldots \ldots \ldots \ldots \ldots \ldots \ldots \ldots \ldots \ldots \ldots \ldots \ldots \ldots \ldots \ldots$

2 - A tisztség eredete és az első nádorok $\ldots \ldots \ldots \ldots \ldots \ldots \ldots \ldots \ldots \ldots \ldots \ldots \ldots \ldots \ldots \ldots \ldots \ldots \ldots \ldots \ldots$

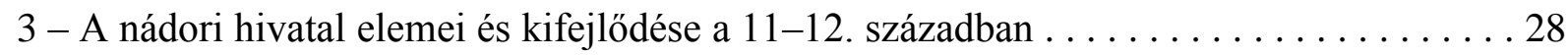

4 - Az ország nádorától az „ország nádoráig”. (A nádori intézmény vázlata

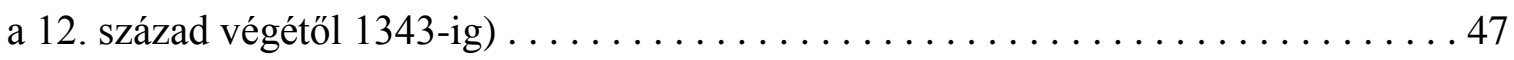

4.1 - A tatárjárásig terjedő időszak: a ,mobilis nádorok”. . . . . . . . . . 49

4.2 - A regionális nádorság kezdete $\ldots \ldots \ldots \ldots \ldots \ldots \ldots \ldots \ldots \ldots \ldots \ldots \ldots \ldots \ldots \ldots \ldots \ldots$

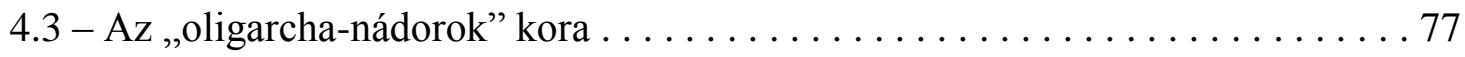

4.4. - I. Károly első nádorai - az „oligarchikus nádorság” öröksége . . . . . . . . 103

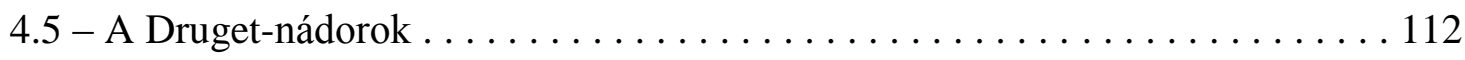

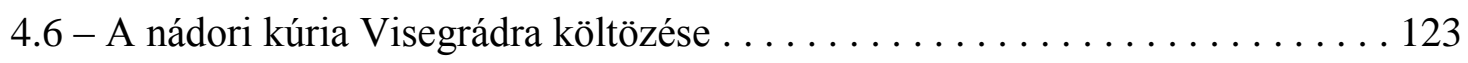

5 - A nádori joghatóság korlátai $\ldots \ldots \ldots \ldots \ldots \ldots \ldots \ldots \ldots \ldots \ldots \ldots \ldots \ldots \ldots \ldots \ldots \ldots \ldots \ldots \ldots \ldots \ldots$

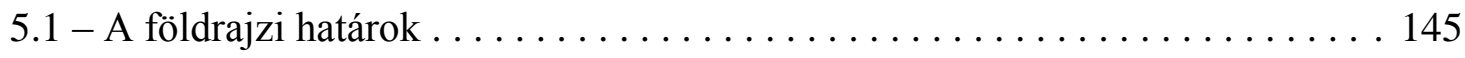

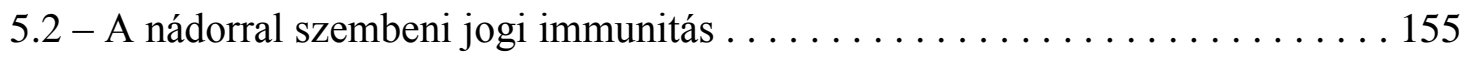

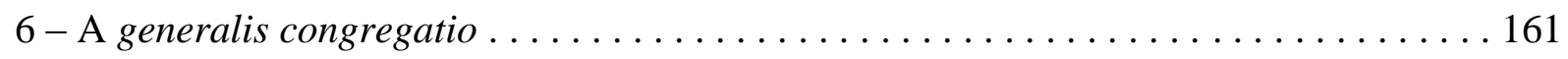

6.1 - A nádori közgyülés intézményének kialakulása $\ldots \ldots \ldots \ldots \ldots \ldots \ldots 1$

6.2 - A nádori generalis congregatio intézménye 1290-1343 között . . . . . . . . . 173

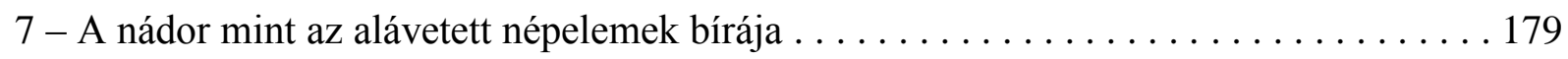

7.1 - Az udvarnokok feletti joghatóság . . . . . . . . . . . . . . . . . . 179

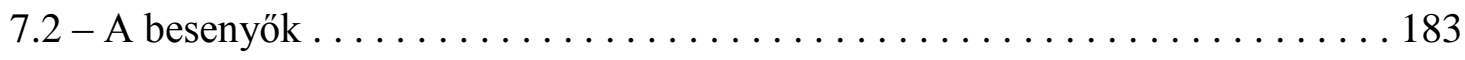


7.3 - A kunok

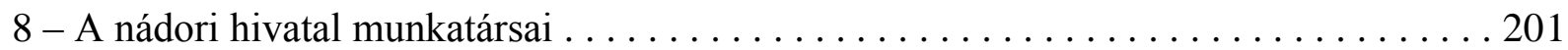

8.1 - A nádort helyettesítő tisztségek: alnádor, nádori albíró . . . . . . . . . . 202

8.2 - A nádori „,iroda” belső munkatársai: jegyzők, ítélőmesterek . . . . . . . . . . 220

8.3 - A nádori „iroda” külső munkatársai és segítői: az ítélőtárs, a poroszló

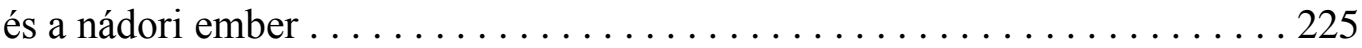

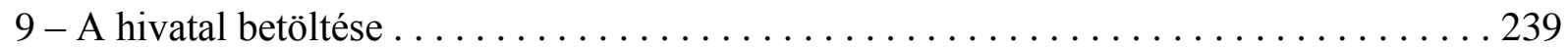

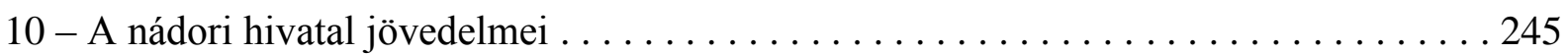

Függelék: kiegészítés Az Árpád-kori nádorok és helyetteseik kritikai jegyzékéhez . . . . . 256

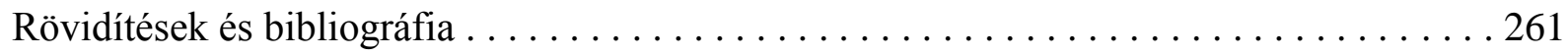




\section{1 - BEVEZETÉS}

Palatinus vocatur ille, qui est iusticiarus in toto regno. (,Azt nevezik nádornak, aki az egész országban az igazságszolgáltatás feje.”) Ezt a lakonikus tömörségű jellemzést 1308-ban írta le a Kelet-Európát bemutató Descriptio Europae Orientalis címü munka ismeretlen, de a magyar viszonyokat jól ismerő szerzője. ${ }^{1}$ Ha nem igazságszolgáltatási, hanem politikai szempontból akarnánk jellemezni a tisztséget, akkor azt mondhatnánk, hogy a nádor a magyar intézményrendszerben a legmagasabb, király után következő, (általában) nem dinasztikus föméltóság. Az intézmény Szent István korától kezdve egészen 1848-ig aktívan létezett, és hivatalosan 1867-ben sem törölték el, csak bizonytalan időre elhalasztották a nádorválasztást (1867. évi VII. tc.). Viselöi legtöbbször az ország legbefolyásosabb politikusai közül kerültek ki, és nem egyszer aktívan is alakították a történelmet.

Mindezek ellenére a nádori méltóságnak viszonylag kevés átfogó krónikása akadt, és a történettudomány müvelői legtöbbször csak egy-egy részletkérdésre, avagy a nádorok életrajzára koncentráltak. A 17-18. században, a kor stílusának megfelelően archontológiai és életrajzi névsorokat állítottak össze a történetírók. A legelső ilyen munka 1659-ben került ki egy német nemzetiségü győri ciszterci szerzetes és teológus-historikus, Caspar Iongelinus tollából. $^{2}$ A 18. századi jezsuita történetírói iskolához jó néhány latin nyelvủ nádori életrajzgyüjtemény füződik (némelyiket verses formában is „továbbfejlesztették”, veretes disztichonokban szólaltatva meg az életrajzokat). ${ }^{3}$ Ez a stílus napjainkig továbbélt, föként az ismeretterjesztő művekben, ${ }^{4}$ és ebböl a szemléletből nőttek ki az archontológiai munkák is, amelyek során egyre pontosabb névsorokat állítottak össze. A 19. század első felében Fejér György többször is mellékelt listákat a különféle egyházi és világi tisztségek betöltöiröl, így a nádorokról is. ${ }^{5}$ A reformkor híres régiséggyüjtője, Czech János (aki Fejér György Codex Diplomaticusának is munkatársa volt), 1848-ra szintén elkészítette a nádorok jegyzetekkel ellátott pontosabb rendjét, ám munkája kéziratban maradt, és csonka változata csak 1863-ban jelent meg. ${ }^{6}$ Fraknói névsorát már a 19. század végén pontosította Wertner Mór, aki először az

\footnotetext{
${ }^{1}$ Latinul: Descriptio 51. Magyarul: Károly emlékezete 75. (Borzákné Nacsa Mária ford.) A szerző leginkább Andreas Hungarusszal azonosítható, lásd Nacsa 1985. 86-97. A magyar viszonyokban való jártasságáról, és a müben előforduló nyelvi hungarizmusokról lásd még uo. 70-71., 87-88.

${ }^{2}$ Iongelinus 1659. 152-165.; vö. Szabados 2006. 103-105.

${ }^{3}$ Muszka 1736.; Schmitth 1739. (több kiadással); Babai 1775.

${ }^{4}$ Ezek közül jól használható, és modern szakirodalmi munkákon alapul: Markó 2006. 213-260.

${ }^{5}$ A leginkább teljes: CD VII/2. 279-282.

${ }^{6}$ A mü kéziratos címe: „Magyarország nádorainak és királyi helytartóinak korrendileg szerkesztett névsora.” A névsort végül Fraknói Vilmos használta fel nádorokról írott értekezésében, függelék gyanánt: Frankl 1863. 4.,
} 
Árpád-kori, majd később az Anjou-kori nádorokat gyüitötte össze. ${ }^{7}$ Az 1980-90-es években további három középkori nádornévsort is összeállítottak, ${ }^{8}$ ám a legpontosabb archontológiákat a 90-es évek modern kutatásai alapozták meg. A talán legkuszábbnak mondható Árpád-kori viszonyok összefoglalása nemrég látott napvilágot Zsoldos Attila tollából, míg az 1301 és 1457 közötti időszakra Engel Pál archontológiáját tekinthetjük a legpontosabbnak. ${ }^{9}$ Már készülőben van az 1457-1526 közötti archontológia is, addig is a fentebb említett általános névsorok használhatóak erre az időszakra is, egészen 1848-ig bezárólag.

Intézménytörténeti összefoglalóval elöször Timon Sámuel próbálkozott 1734-ben, majd Bél Mátyás fia, Bél Károly András, aki egy általános munkát írt Magyarország főméltóságairól, a hivatalok eredetéről, a rájuk vonatkozó jogszabályokról, és egyéb forrásokról. ${ }^{10}$ A 19. század első felében Fejér György a már említett okmánytára egyik kötetének elöszavában összefoglalta az ország föméltóságainak történetét, a nádorokkal kezdve, kitérve a rájuk vonatkozó törvényszövegekre is. ${ }^{11}$ Podhradczky József 1856 . évi, Fejérnél bővebb összefoglalója után ${ }^{12}$ végül Fraknói (akkori nevén: Frankl) Vilmos írta meg a nádori (és országbírói) hivatal azóta is egyetlen átfogó ismertetését. A munka két fő részre oszlik: a nádori, majd az országbírói hivatal kifejtésére, mindkét esetben a saját koráig, azaz a 19. század közepéig haladt el a szerző. A nádori intézményre vonatkozó részben először a „nádor” szó akkor már tekintélyes irodalmat felvonultató etimológiáját tárgyalta, majd a hivatali hatáskört elemezte három fejezeten át, Szent Istvántól a 19. századig. Az intézménytörténeti összefoglalót egy, a hivatal betöltését ecsetelö fejezet zárta, majd a könyv végén függelékként olvashatjuk Magyarország nádorainak és országbíróinak névsorát, Czech János kézirata alapján összeállítva. ${ }^{13} \mathrm{~A}$ forrásadottságok miatt a késő-középkori és újkori fejezetek igen elnagyoltak lettek, és az Árpád-kori részek is tartalmaznak pontatlanságokat.

155-165. Czech János a későbbiekben is foglalkozott a témával, tudunk arról, hogy az MTA 1850. augusztus 17 i ülésén tartott egy előadást „,a nádorok s az ország egyéb főtisztjei’ chronologiájáról”. Sajnos beszámolójának csak az említése maradt meg, az előadás szövege nem került külön kinyomtatásra. A Magyar Academiai Értesítő közléséből kiderül, hogy az „oklevelek nyomán táblás alakban eléadó” munkájából kiemelte a 13. századi viszonyokat, és azt, hogy a nádori hivatal akkori változásai kihatottak a többi tisztségviselőre is, lásd Czech 1850.

${ }^{7}$ Wertner 1894.; Wertner 1907. 26-30.

${ }^{8}$ MTK IV. 1142-1144.; Szentpétery 1985. 96-100.; KMTL 474-475. (Szovák Kornél szócikke)

${ }^{9}$ Archont. 1000-1301. 15-26; Archont. 1301-1457. 1-6.

${ }^{10}$ Timon 1734. 73-74.; Bél 1749. 5-23.

${ }^{11} \mathrm{CD}$ X/6. 4-11.

12 Podhradzky 1856.

${ }^{13}$ Frankl 1863. A könyv további „érdekessége”, hogy egy nyomdahiba folytán a 74-78. oldalak számozása elcsúszott, amit később korrigáltak, így a könyvnek nincsen 74. oldala (73. után rögtön 75. következik), viszont két 78. oldal is található benne. 
Bár Fraknói mủve a saját kora tudományának magas színvonalán megírt összefoglalója volt, a forráskiadványok gyarapodása és a történeti kutatások jelentős elörelépése miatt ma már inkább csak historiográfiai értékkel bír.

A 19. század pozitivista felfogásában az intézménytörténetet háttérbe szorította a genealógiai megközelítés, amelynek mủvelésében Wertner Mór járt az élen. ${ }^{14}$ Ekkor születtek az első olyan munkák is, amelyeket a mai napig mérvadónak szokás tekinteni a nádorsággal kapcsolatban. A genealógiai kutatásokon túl ilyenek Hajnik Imre megállapításai a nádori bíráskodásra vonatkozóan. ${ }^{15} \mathrm{Az}$ intézmény első két évszázadának a kereteit pedig Váczy Péter 1938-ban közzétett tanulmánya alapján határozzák meg szinte minden történeti munkában. ${ }^{16}$ Máig ható az Anjou-kori nádori bíráskodásról és oklevéladásról szóló mű Nyers Lajostól, ${ }^{17}$ míg az Árpád-kori részt feldolgozó Kommer Magda munkája kéziratban maradt. ${ }^{18}$ Istványi

${ }^{14}$ Számtalan olyan tanulmány született, amely egy-egy nádor családjában végzett „mélyfúrásokat”, vagy az életének egy-egy mozzanatát derítette föl. Ilyen esetekben az illető nádori mivolta lényegtelen is volt (Botka 1872; Bunyitai 1888; Pór 1889; Komáromy 1891; Wertner 1891a; Wertner 1892; Wertner 1893; Wertner 1895; Wertner 1897.). Wertner végül - részben elöbbi tanulmányai összegzéseként - az összes akkor ismert Árpádkori nádort is megvizsgálta genealógiai szempontból: Wertner 1898.

${ }^{15}$ Hajnik 1899. 6-9., 66-77.

${ }^{16}$ Váczy 1938. 49-56. Megállapításaira később részletesen visszatérünk.

${ }^{17}$ Nyers 1934.

${ }^{18}$ Két, egymástól eltérő kéziratról van szó. Az „MTA Kézirattár 4538/22.” jelzett alatt található bőrbe kötött, gépelt és tollal javított 91 oldalas kézirat három fö fejezetre oszlik (föcím nélkül). 1.: „A nádori hatáskör kifejlődésének vázlata” (1-34.); 2.: „A nádor oklevéladó müködése” (35-55.); 3.: „A nádori oklevelek belső és külső sajátosságai és a nádori kancellária" (56-91.). A munkában nagyobb súlyt kap az elméleti áttekintés, az oklevelek diplomatikai elemzése csak az utolsó fejezetben található meg, vázlatosan. Az „MTA Kézirattár 4538/23.” jelzet alatt található, géppel írt, füzött, de (ma már) kötéstábla nélküli kézirat főcíme: „A nádori oklevelek a XIII. században”. Láthatóan az előző munka után készült, és súlypontja egyértelműen a nádori oklevéladásra esik. Az elején található rövid intézménytörténeti összefoglaló után (ami az előző kéziratban leírtak kivonatos változata, azonban néhány helyen az ottaninál részletesebb kifejtéssel) következik a három főfejezet. 1.: „A XIII. századból fennmaradt nádori oklevelek chronologikus jegyzéke” (18-57.). Ebben Kommer 159 nádori oklevelet sorolt fel regesztaszerủen, az elején a kiadója, majd a kiadás éve, publikálásának helye, és egymondatos tartalma. Zömében az okmánytárakban addig már kiadott, és teljes szövegükben megmaradt okleveleket sorolt föl, kiadatlan levéltári anyagot csak néhány esetben használt. 2.: „A nádori oklevelek belső sajátságai" (58-85.). Itt a kor diplomatikai hagyományainak megfelelő részletes elemzések olvashatóak arról, hogy az egyes oklevélrészek hogyan váltakoztak a század folyamán. 3.: „A nádori oklevelek külső sajátságai” (85-102. - igazából 86-103., mert tévedésből az előző fejezet vége, és az itteni első lapja is a 85-ös oldalszámot kapta). Ebben a szerző az eredeti oklevelek hártyáját, írásképét, stb. elemezte (látszik, hogy a hozzáférhető okleveleket kézbe vette, helyenként egészen részletes leírást adva róluk). A müvet egy függelék zárja (104108.), amelyben három addig kiadatlan nádori oklevél szövegét írta át (kisebb hibákkal). Egyébként sem ebben, sem az előző kéziratban sehol sem bukkan föl sem az elkészültének éve, sem a szerző neve, és mivel az MTA Kézirattára a Domanovszky-hagyatékban őrzi, ez megtévesztő is lehetne. Ezekre az adatokra Nyers Lajos utalt a következőképpen: „A nádori méltóság eredetét és fejlődését, továbbá a nádor XIII. századi bírói és oklevéladó tevékenységét részletesen feldolgozta dr. Domanovszky Sándorné, dr. Kommer Magda 1925-ben készült, de nyomtatásban meg nem jelent doktori értekezésében: A nádori oklevelek a XIII. században.” (Nyers 1934. 3.). A művet Belitzky János is használta 1937-ben, hivatkozása szerint az akkori lelőhelye még „a Pázmány Péter Tudományegyetem [mai Eötvös Loránd Tudományegyetem] müvelödéstörténeti intézetében” volt (Belitzky 
Géza a nádori ítélkezés fő színhelyének tekinthető generalis congregatiókról írt egy kétrészes áttekintő tanulmányt, ${ }^{19}$ míg mások csak egy-egy konkrét megye nádori közgyüléseit foglalták össze. ${ }^{20}$ Leszükítve, csak az Anjou-kori nádori közgyüléseket tárgyalta általánosabb formában Török Pál, és a Nagy Lajos alatt tartottakat konkrétabban, rengeteg adattal Gábor Gyula. ${ }^{21}$ Legutóbb Kruták Anita tekintette át részletesen a Druget Vilmos nádorsága alatti közgyülések sajátosságait. $^{22}$ A hivatali müködéshez kapcsolhatóak Bónis György és Bertényi Iván tanulmányai a nádori és országbírói ítélőmesterekkel kapcsolatban (Bertényi a 14. századi nádori jogkört is összefoglalta egy ízben). ${ }^{23}$ Szovák Kornél a nádori bíráskodás több elemére kitért egy intézménytörténeti szempontból fontos írásában. ${ }^{24}$

A 21. század eleje új lendületet adott az addigra jobbára már csak saját magát ismételgető kutatásnak. Zsoldos Attila több tanulmányt tett közzé, amelyekben a 13. század legvégi, 14. század eleji nádorokkal, és föként a nádori hivatallal kapcsolatosak, átértelmezve jó néhány korábbi szakirodalmi beidegződést. ${ }^{25} \mathrm{C}$. Tóth Norbert az intézmény 1342 utáni történetével kapcsolatos tanulmányokat írt, fóként az 1342 utáni nádorváltások rendszerére koncentrálva ${ }^{26}$ (az 1342. évi nádorváltás sajátosságait $\mathrm{C}$. Tóth Norbert mellett külön tanulmányban elemezte Piti Ferenc is). ${ }^{27}$ Ezen kívül Zsoldos Attila és Tringli István az addig szinte teljesen elhanyagolt alnádori hivatallal foglalkoztak Pest megye kapcsán. ${ }^{28}$

\section{1 - Az elnevezés}

Bármilyen banálisnak is tünik, elöször érdemes tisztázni, hogy milyen elnevezésekkel illették a nádort. A hivatali tisztség magyar neve a ma használt nádor formájában egy

1937. 59. 4. jz.). Az onnan elkerült kéziratokra végül Szovák Kornél bukkant rá Nyers utalása alapján, és ő hivatkozott a jelzetükre is (Szovák 1989. 306. 2. jz.).

${ }^{19}$ Istványi 1939., Istványi 1940-1941.

${ }^{20}$ Holub 1929. 167-191 (Zala megye); Havassy 1986. 62-64. (Heves megye); Havassy 1989. (Hont és Nógrád megyék); Havassy 2000. (Gömör és Tolna megyék)

${ }^{21}$ Török 1907. 19-27.; Gábor 1908. 124-151. Gábor Gyula igyekezett számba venni és adatolni az összes általa ismert Lajos-korabeli generalis congregatiót, majd ismertette a gyülések szerepét, gyakorlati lefolyását. Istványi fentebb idézett összefoglalása előtt, ez tekinthető a téma legjobb feldolgozásának.

${ }^{22}$ Kruták 2012

${ }^{23}$ Bónis 1963; Bónis 1971. 46-73.; Bertényi 1964.; Bertényi 1965.

${ }^{24}$ Szovák 1989.

25 Zsoldos 2010a.; Zsoldos 2011a.; Zsoldos 2011b. 53-66.; Zsoldos 2012b.; Zsoldos 2012c. Az itt felsorolt tanulmányok megállapításaira alább még visszatérünk.

${ }^{26}$ C. Tóth 2009.; C Tóth 2011.; C Tóth 2012a.; C. Tóth 2012 b.

${ }^{27}$ Piti 2006

${ }^{28}$ Zsoldos 1998. 23-32. (vö. Zsoldos 2001. 44-50.); Tringli 2001. 154-158.; Tringli 2010. 378-382., 384-385. 
nyelvújítás kori elvonás eredménye, amely ebben az alakban 1784-ben bukkant fel először. ${ }^{29}$ A korábbi magyar megnevezése minden esetben nádorispán (illetve néhány, statisztikailag nem túl számottevő alkalommal nándorispán, vagy lándorispán), ahol az „-ispán” végződés mindig a szó szerves részét képezi. ${ }^{30} \mathrm{Ez}$ onnan tudható biztosan, hogy a tisztségnév átkerült jövevényszóként a szomszédos szerb, horvát és cseh nyelvekbe is, nadršpan, illetve náderšpan alakban, amely a magyar főméltóságra alkalmazott szakszó lett. ${ }^{31}$ Az átvétel idején (amelynek legkésőbb a 15. századra meg kellett történnie, mert a legkorábbi cseh nyelvemlékeink ebből a századból valók) tehát a magyarok folyamatosan az „-ispán” taggal emlegették a hivatalt, különben nem szilárdult volna meg így, egymástól függetlenül több magyarral kapcsolatban lévő idegen nyelvben is. A legkorábbi datálható magyar nyelvü felbukkanása, az 1405 körüli Schägli Szójegyzék rögtön megadja szavunk latin megfelelőjét is: „pallatinus - nadruspan.”32 Ennél korábbi datálható felbukkanást és azonosítást nem ismerünk, de valószínűsíthetjük, hogy a nádorispán kifejezés már az Árpád-korban is létezett. Eddig még nem adatolt azt a feljegyzés-csoport, amely egy 1227. évi oklevélnek és átírásainak a hátulján szerepel. Egy ismeretlen kéz 14. század végi, 15. századi írással magyar nyelven foglalta össze az 1227. évi oklevél tartalmát, amelyben Dénes nádorispánt is megemlítik minden alkalommal (nador ispan, nadyor ispan és nadior ispan formában). ${ }^{33}$ Szintén nem adatolt az a nyelvemlék, amely Héder nembéli Miklós nádor 1284. évi oklevelének a hátulján található késő-középkori (esetleg kora-újkori) kézírással (Azzonfalwä̈ donatio. Miklos nadrispan aggya Dorozlonak). ${ }^{34}$ A magyar titulus első datálható külföldi felbukkanása abban az 1415-1417 körül keletkezett (nem magyar kéz által írt) jegyzéken található, amely a konstanzi zsinat résztvevőinek névsorát tartalmazza, jelentősen elferdítve a neveket. Garai Miklós nádort kétszer is feltüntette írója: egyszer a „dominus magnus comes in Ungaria”, egyszer pedig „dominus natrespeyn” titulus alatt - ez utóbbi nyilván a nádorispán eltorzított formája. ${ }^{35}$ A latin „magnus comes” esetleg összefüggésben állhat azzal a névadási logikával, amely szerint a 15 . századi magyarországi németségben a nádort többször is „Gross

\footnotetext{
${ }^{29}$ TESZ II. 992.; Kniezsa 1955. I/1. 351.

${ }^{30}$ TESZ II. 992.; a 16. századi magyar nyelvü levelezés adatait is beledolgozva: Kovács 1964. 142.

${ }^{31}$ TESZ II. 992.; Sulán 1957. 163.

${ }^{32}$ Szamota 1894. 26. (476. sz.)

${ }^{33}$ DL 134., 135., 136. Az oklevelek 1227-ből, 1295-ből és 1395-ből valók, ám ugyanaz a kéz írta a hátuljukra a rövid tartalmukat, így a szövegeknek legkorábban 1395-ben kellett keletkezniük. Az 1395. évi feljegyzést átírta Wenzel Gusztáv: ÁÚO VI. 447.

${ }^{34}$ DL 49609.

${ }^{35}$ Zichy XII. 107. (DL 82956.) A forrásra C. Tóth Norbert hívta fel a figyelmemet, köszönet érte.
} 
Grafnak” hívták. ${ }^{36}$ A „,magnus comes” lényegében ennek a latin tükörfordítása, és a jegyzék valószínüsíthetően német anyanyelvü összeállítója nem csak a magyaroktól, de a Zsigmond kíséretében tartózkodó németektől is hallhatta Garai titulusát - beírta hát mindkétszer.

Latin nyelven a 11. század első felében még a comes palatii lehetett a bevett név. Ezzel az alakkal datálható módon mindössze egy alkalommal, az 1055. évi tihanyi alapítólevélben találkozhatunk, ám Gellért nagylegendája szintén így nevezte Sámuelt, aki Péter 1041. évi elüzésekor viselte e tisztet. ${ }^{37} \mathrm{Ez}$ a forma megfeleltethető a késő-karoling elnevezésnek: Hincmarnak a 9. századi karoling udvarszervezetet leíró műve (De ordine palatii) ugyancsak comes palatii formában említette a palotaispánt. ${ }^{38}$ A 11 . század második felétől - akárcsak a Német-római Császárság területén - a comes palatinus (vagy palatinus comes) forma lett az általános a korai oklevelekben, ${ }^{39}$ a törvényekben úgyszintén. ${ }^{40}$ Így, a comes taggal együtt találkozunk vele a 12. század folyamán is, amely forrásban pedig nem így nevezték, hanem egyszerüen csak palatinusnak, ott mindig bebizonyítható a forrás hamis mivolta, vagy hibás kiadása. ${ }^{41}$ Az egyetlen hiteles kivétel a 14. századi velencei Pactorum Liber egyik bejegyzése, amely a dalmát Arbe városának adott 1118. évi kiváltságát tartalmazza. A kiváltság adója, Ordelafus Faletrus velencei herceg ígéretet tett, hogy ugyanabban a szabadságban tartja meg a várost, mint amilyenben Kálmán, magyar király is megtartotta. Az oklevél vége után valaki odamásolt egy feljegyzést arról is, hogy Kálmán király milyen körülmények között tett esküt. Itt Johannes palatinus szerepel a Kálmán melletti főemberek felsorolásakor. ${ }^{42}$ Ezt a megnevezést azonban nem a magyar gyakorlatnak kell betudni, hanem a dalmáciai szemtanú megfogalmazásának. Kitünik, hogy ő is ispánnak tekintette a nádort, méghozzá a „,nagyobb ispánok" (comites magni) közé tartozóknak, hiszen az ő felsorolásukkor említette a nádort. A többi, ott leírt titulus nélküli név megyésispánokat takar, mint ez a zobori oklevéllel való összehasonlításból kitünik, bár egészen biztosan csak két nevet vélhetünk azonosnak, és még

\footnotetext{
${ }^{36}$ Podhradczky 1850. 36-37.

${ }^{37}$ DHA I. 152.; SRH II. 500. Ezt a névformát átvette Temesvári Pelbárt is Gellértről írván, lásd Frankl 1863. 43. 1. jz.

${ }^{38}$ Hincmarus 17. (cap. 21.)

39 „palatinus comes Rodowan” (százdi oklevél, 1067 k.); „Jula comite meo palatino” (garamszentbenedeki oklevél, 1075); „Gula comes palatinus” (Dávid-dux oklevél, 1090 k.); „,comes palatinus Petrus” (somogyvári alapítólevél, 1091); „Ego Joannes palatinus comes laudo et confirmo.” (Kálmán traui kiváltságlevele, 1108); „Johannes palatinus comes” (zobori oklevél, 1111, ill interpolált változatában ugyanígy); „Johannes palatinus comes" (zobori oklevél, 1113): DHA I. 185., 218., 265., 268., 357., 383., 385., 396.

${ }^{40}$ László ún. III. törvénykönyve: „De palatino comite” és „,palatinus comes”; Kálmán I. törvénykönyve: „per palatinum comitem” és ,a palatino comite”. Závodszky 1904. 174.; 188.

${ }^{41}$ A források pontos felsorolását lásd Szőcs 2009. 188-191.

${ }^{42}$ DHA I. 408.
} 
egyet esetlegesen. ${ }^{43}$ Ezt a megnevezést tehát nem tekinthetjük a magyarországi oklevéladás lecsapódásának. $^{44}$

III. Béla uralkodásának utolsó periódusában kezdett körvonalazódni a comes tag lekopása. Egyértelmű cezúrát nem lehet húzni, ám 1192-től kezdve a nádorságot elkezdték ispánsággal is párosítani, és ezért egy olyan újfajta kifejezés kezdett érvényesülni, ahol csak az egyik taghoz tették ki a comes titulust: „Mog palatino comite et eodem Bachyensi”, 45 vagyis „Mog nádorispán, és ugyanúgy (esetleg: ugyanő) bácsi”. Imre 1199. évi okleveleiben tértek át a méltóságsorokban arra a formulára, amelyben a comes már az ispánság neve mellett szerepelt: „Mogh palatino et comite Bachiensi”, illetve „Mogy palatino et Baciensi comite״46 Feltehetjük, hogy a szintagma végén található comes szót mindkét jelzőhöz odaértették, ám e formula gyakorivá válása megnyitotta a kaput afelé, hogy a palatinust ne a comes jelzőjeként, hanem önálló főnévként értelmezzék. 1199-től kezdve Imre okleveleiben mindvégig a fenti formulával emlegették a mindenkori nádort, és egy 1204. évi oklevélben találkozunk először azzal, amikor a palatinus már egyedüli elemként jelenik meg az akkori nádor, Benedek neve mellett. $^{47} \mathrm{Az}$ elterjedésére ennek ellenére még évtizedeket várni kell. Azt, hogy a hagyományos sorrendủ méltóságsorban még mennyire odaértették a csak a megyenév mellé kitett comes szót a palatinus elé is, mutatja, hogy amikor II. András ideje alatt néhány oklevélben felcserélődött a szintagmán belüli tételek egymásutánisága, akkor is csak egyszer, a szintagma végére írták oda a comest, a megyenevet hagyva csonkán: „Chepano filio Stephani Bachiensi et palatino comite” („István fia Csépán bácsi- és nádorispán”). ${ }^{48}$ Megfigyelhető, hogy az összes ilyen megfogalmazás egyetlen időpontban tömörül, 1207 és 1209 között, és Róbert, fehérvári prépost kancellársága alá esik. Minden olyan oklevélben, amelyen ő szerepel a datum per manus formula után, így említették a nádort, ám utódjának,

\footnotetext{
${ }^{43}$ Az itteni „Saulus” és „Theobaldus” magnus comes, azonos lehet a zobori oklevél „Saul de Bichar” és „Thebaldus Sumuginensis” ispánjaival. Továbbá „Cledinus” talán a zobori „Queledte de Bache” ispánja lehet (DHA I. 383, 408.), ez utóbbi név szinte biztosan Keledként értelmezendö, és talán az elöző is.

${ }^{44}$ Érdekes egyébként, hogy amikor ezen bejegyzés alapján elkészítették Kálmán oklevelének hamis változatát, akkor a hamisító a tanúsort átemelve „Johannis palatini comitis” formában írta át a titulust (DHA I. 388.).

45 1192: ÁÚO VI. 184.

${ }^{46}$ 1199: MES I. 160.; HO V. 4.

${ }^{47}$ A tágabb szövegkörnyezet: „,... Willermo Ultrasiluanensi episcopo, Benedicto palatino, Ypochio bano et Bachiensi comite...” ÁÚO I. 92.

${ }^{48}$ 1207: CD III/1. 47. Ugyanez a sorrendiség található meg: 1207: CD III/1. 44. (az oklevél vonatkozó része a föszövegben hibás, ám lentebb, apró betúvel maga Fejér közölte a helyesebb változatot is, vö: RA 230. sz.), ÁÚO VI. 315.; 1208: CD III/1. 58. RA 237. sz., CD III/2. 467., ÁÚO I. 98., ÁÚO VI. 325.; 1209: ÁÚO VI. 334., ÁÚO XI. 95. Ez utóbbi oklevél hamis, lásd RA 249. sz. Pont erre az időszakra esik János esztergomi érsek egyik oklevelének hasonló logikára épülő, noha másként megfogalmazott említése is: „Chepano comite palatino et Bachiensi” MES I. 187. (1208). Lásd még: RV 9. sz.: „Banc comes palatinus et Posoniensis” (1212).
} 
Tamásnak a kancellári szerepével egy csapásra visszaáll a régi forma az oklevelek méltóságsorában. Ugyanakkor növekedni kezdett azon említések száma, amelyekben a palatinus önmagában áll. ${ }^{49}$ Kán nembéli Gyula volt az első olyan nádor, akinek a megnevezésében a szimpla palatinus dominált. Köszönhető ez annak, hogy Gyula nagyrészt nem viselt a nádori tisztsége mellett semmilyen más ispánságot, ${ }^{50}$ és így a szokásos,$N$ palatino et $X$ comite" sablon helyett csak a szintagma eleje maradt meg. Ezek után a két kifejezés még ingadozott, de Gyula első nádorsága után már a palatinus alak vált gyakoribbá, egészen az 1220-as évek végéig. Ekkortól, Ampod fia Dénes nádorságával II. András haláláig még egyszer utoljára a comes palatinus alakok kerültek elötérbe, majd IV. Béla uralkodásától kezdve (1235) a palatinus szinte teljesen kizárólagossá vált. Innentől kezdve az egész középkor folyamán a nádor elnevezésére ez az egyetlen szó. ${ }^{51}$

Az intitulációs forma Zsámboki Miklós nádorságának első felétől (először 1342 decemberében, majd némi kihagyás után 1343. március 10-től kezdve) kiegészült azzal, hogy a nádor palatinus regni Hungarie, azaz „Magyarország nádora” volt. Az elnevezés nem volt előzmények nélküli. A palatinus regni (,az ország nádora”) kifejezés már a 13. században is megjelent, és volt, hogy csak a szövegösszefüggés kívánta meg a kifejezés használatát, egyéb „,ideológiai” tartalom nélkül. Egy 1262 körüli oklevélben azért nevezték a nádort így, mert egyszerre említették az esztergomi érsek palatinusával, és valahogy el kellett választani a két tisztséget, így a világi nádort a palatinus regni jelzővel különböztették meg a palatinus ecclesie Strigoniensistől. ${ }^{52}$ Ilyen okot nem fedezhetünk fel V. István 1271. évi oklevelében, amelyben elősorolva Kemény fia Lörinc szörényi bán érdemeit, megjutalmazta őt, többek között azért, mert amíg IV. Béla halála után egyes előkelők megszöktek az ország kincsivel, addig Lőrinc, ,akkor az ország nádora, valamint somogyi és kelméki ispán” (tunc palatinus regni et comes Simigiensis ac de Kemluk) megmaradt a hüségén. ${ }^{53}$ A szöveget egyébként csak Anjou-kori átiratokból ismerjük, és Szentpétery Imre értékelése szerint az „oklevél ekkor, legalább a királyi kancelláriában, még szokatlan kifejezéseket tartalmaz. Talán kancellárián

\footnotetext{
${ }^{49}$ P1. 1209: MES I. 194., Bártfai 1907. 66.; ÁÚO XI. 139. (1216). Ez utóbbi két adat azért figyelemreméltó, mert itt nem a méltóságnévsor „rutinszerü” formulájában szerepel a rövidebb forma, hanem folyószövegbe belefogalmazva. Az oklevél írója számára a nádori tisztség már csak ezt az egy szót jelentette. Hasonló jellegü pl. még: ÁÚO VI. 384. (1217)

50 1215-ben még soproni ispánként szerepel, ám ez a címe később nem bukkan föl: Archont. 1000-1301. 15., 197.

${ }^{51}$ Részletesen adatolva: Szőcs 2009. 190-193.

${ }^{52}$ MES I. 474. Az érseki „nádor” tisztségéről lásd ugyanezen fejezetet, alább.

53 ÁÚO XII. 41.
} 
kívül készült fogalmazattal van dolgunk." ${ }^{, 54}$ Hitelességét egyértelmű módon mindenesetre Szentpétery sem kérdőjelezte meg. Ugyancsak gyanúsnak, de nem egyértelmüen hamisnak találta a szakirodalom IV. László 1278. június 23-i oklevelét, amelyben különféle előjogokkal látta el a budai polgárokat, többek között „mentessé téve országunk nádorának joghatóságától”. 55 Egyértelmű ideológiai töltetet találunk ugyanakkor a kifejezés mögött Kézai Simonnál. Kézai az udvarnoki réteg eredetére keresett választ, akik szerinte idegen foglyok voltak, és az ország előkelői őket a saját szolgálatukra rendelték. Ám Kálmán király megtiltotta a nemeseknek, hogy saját udvarnokaik legyenek, és ezt csak a püspökök és a saját előjogává tette. De hogy a nemesek ne nehezményezzék mindezt, „az ország nádorának - akit a nemesek hasznára emelnek - adta át a király az udvarnokok haszonélvezetét". ${ }^{56}$ Kézaitól egyébként sem állt távol, hogy „fantasztikus” magyarázatokat keressen a saját kora társadalmi rétegeinek eredetére, és itt is azt hangsúlyozta ki, hogy a nádor alá rendelt udvarnokok tulajdonképpen a nemeseké maradtak, hiszen a palatinust egyébként is az ő hasznukra (utilitas) teszik előljáróvá (praeficitur). A palatinus regni kifejezés ennek a gondolatmenetnek a része, ahol a regnum az ország politikailag aktív közösségét jelentheti. ${ }^{57}$ Így tehát a nemesek nem lettek „meglopva” azáltal, hogy Kálmán király nem engedélyezte számukra a saját udvarnokokat, hiszen azok a nemesek hasznára felemelt, vagyis az egész regnum alá rendelt nádor tulajdonába kerültek. Az elmélet történeti értelemben több sebből is vérzik, ${ }^{58}$ ami viszont érdekes, hogy Kézainál egyfajta „eszmei enklávéként” már a 13. század utolsó harmadában megjelent az a szellemiség, amely majd a 14. század közepétől állandósítja a palatinus regni Hungarie kifejezést, hiszen itt Kézai a királyi hatalom és a nemesek között álló, és a két pólus között közvetítő szereppel felruházott nádorispán képét festette le. ${ }^{59}$

$\mathrm{Az}$ országnévvel kiegészített elnevezés a Druget-nádorok pecsétfeliratain és alkalmi címzéseikben jelent meg először. Druget János nagypecsétje „S ... PALATINI HVNGARIE” feliratú volt, ${ }^{60}$ és 1330 -ban egyik oklevelének intitulációjában is így címezte magát. ${ }^{61} \mathrm{Az}$

\footnotetext{
${ }^{54}$ RA 2083. sz.

55 „exemptam a iurisdictione regni nostri palatini” Elenchus III/2. 83. Az oklevél kiritikáját lásd RA 3449. sz. (összességében nem minősítve hamisnak). Györffy György szerint egy ,jogérvényre nem emelt fogalmazatnak tekinthető", mivel az ott leírt kiváltságok egyike, a vámmentes vásár, öt évvel később biztosan nem volt érvényben (Györffy 1997. 189.).

56 „palatino regni, qui pro utilitate nobilium praeficitur, rex suos udvornicos uti dedit” SRH I. 193.

${ }^{57}$ Lásd Gerics 1987. 258-259. ill. passim.

58 A nádor és az udvarnoki réteg kapcsolatának elemzését lásd a „7.1 - Az udvarnokok feletti joghatóság” c. alfejezetben.

${ }^{59}$ Vö. C. Tóth 2012b. 447.

${ }^{60}$ C. Tóth 2012b. 446.
} 
elnevezés azonban nem állandósult, és a néhány egyéb kivétel, amikor Druget Jánost így titulálták, könnyen magyarázható. ${ }^{62}$ Druget Vilmos nagypecsétjén már megjelent a teljesebb kifejezés („S ... PALATINI REGNI HVNGARIE ET IVDICIS COMANORUM”). ${ }^{63}$ Saját intitulációiban egyszer sem alkalmazta, ám 1335-ben, a híres „visegrádi királytalálkozó” egyik oklevelének méltóságsorában így tüntették fel öt. ${ }^{64}$ Mindez összhangban áll az oklevél „,nemzetközi” tartalmával, hiszen nem csak magyar tisztségviselőket tartalmazott. Így ezek az okleveles adatok nem állíthatók párhuzamba a Zsámboki Miklósnál megjelenő címmel. Nála először 1342 decemberében jelent meg az új intituláció, 1343 márciusától kezdve viszont már konzekvensen palatinus regni Hungarienak nevezte magát a nádor az egész középkor folyamán. A névváltozás valószínüleg azzal áll összefüggésben, hogy a nádort innentől kezdve már az országgyüléseken választotta a király a rendekkel egyetértésben, így az már nem csak a király, hanem a rendek (régi megfogalmazással élve: „az ország”) nádora lett. ${ }^{65}$

Még annyit érdemes megjegyezni, hogy a palatinus megnevezés nem minden esetben takarta a nádorispánt a magyarországi forrásokban. A magyar egyházi hierarchiában az esztergomi érsek udvarbíráját szintén így nevezték a 13. századtól kezdve. Ezen időtől fogva több egyházi és világi közösség (föpapok, a 13. sz. végi, 14. sz. eleji oligarchák) szervezték meg saját udvartartásukat a királyi udvar hierarchiájának másolásával, ám egy kivételével palatinust egyikük sem állított (sőt, a 14. század eleji oligarchák egy része még III. Andrással megegyezve maga birtokolta a címzetes nádori posztot, amely csak a saját territóriuma felett jelentett nádori jogkört). ${ }^{66}$ A magyar egyházszervezet csúcsán álló esztergomi érsek azonban kivétel volt, és a 13. század második felétől kezdve olyan tökélyre vitte a királyi kormányzat

61 „[N]os Johannes Drugetty palatinus Hungarie” DL 2576. (AOkl XIV. 22. sz.; vö. még AO II. 457., ahol a Hungarie szót kihagyták az intitulációból)

${ }^{62}$ 1333-ban XXII. János pápa küldött levelet több magyarországi elökelőségnek, köztük Druget Jánosnak is, Magyarország nádorának címezve őt (AOkl XVII. 288. sz.), ám egy külföldi levél esetében az országmegjelölés természtesnek tekinthető. 1330-ban a „drávántúli” Valkó megye küldött levelet Jánosnak, és a „domino Johanni palatino” címzés fölé ugyanaz a kéz beszúrta: „totius Hungarie”, vagyis „egész Magyarország nádora” (DL 91247., AOkl XIV. 370. sz.). A kiegészített kifejezés nyilván az ottani régióban a bánokra használatos „,banus totius Sclavonie” (,egész Szlavónia bánja”) titulus mintájára született meg.

${ }^{63}$ C. Tóth 2012b. 447.

${ }^{64}$ „Wyllermo Drugeth palatino regni Hungarie” DF 288349. (AOk1 XIX. 725. sz.). Egyébként Pál országbírót is „comite Paulo iudice curie regis Hungarie” címmel illették ugyanitt, pedig az akkor hagyományos intitulációja során ő sem tette ki az ország nevét.

${ }^{65}$ A palatinus regni Hungarie tituláció megjelenését részletesen áttekinti: C. Tóth 2012b. 444-447. C. Tóth Norbert vetette fel ezt az általunk is elfogadott politikai magyarázatot, szemben Nyers Lajossal, aki szerint az 1342/1343. évi névváltozás azzal áll összefüggésben, hogy a nádor onnantól kezdve betagozódott a királyi kúriába (Nyers 1934. 48.). Mint látni fogjuk, mindez nem 1342-ben, hanem már évekkel korábban végbement, így ez nem lehet magyarázat az intituláció megváltozására. Lásd erről részletesebben a „4.6 - A nádori kúria Visegrádra költözése" c. alfejezetet.

${ }^{66}$ Zsoldos $2011 \mathrm{a}$ 
másolását, hogy nem csak iudex curie vagy comes terrestris, hanem saját palatinus is tartozott alája. ${ }^{67}$ Már 1262 körül felbukkan a tisztség IV. Béla egyik adománylevelében (amennyiben hiteles oklevélről van szó). ${ }^{68}$ Eszerint az esztergomi érsek népeit, szolgáltatónépeit és nemeseit (populos ecclesie Strigoniensis, conditionarios et nobiles suos universos) semmilyen bíró, csak az esztergomi egyház bírái, ti. ,az érsek által rendelt palatinusa, avagy udvarbírája vagy comes terrestrise" (videlicet palatinus suus, vel iudex curie sue, aut terrestris comes per archiepiscopum deputati) ítélhetik el. A kiváltság azt is hozzátette, hogy „ha az esztergomi egyház nemeseit lopás vagy rablás vétkében találván az ország nádora, avagy a mi [ti. a király] vagy utódunk udvarának országbírója jog szerint megölné, az így megöltek birtokai ne az ország nádorára vagy az országbírójára szálljanak, hanem az esztergomi egyházra. És ha az esztergomi egyház palatinus-bírája az ország nádoránál, vagy országbírónknál, vagy az ország más jogszolgáltatójánál ugyanezen elfogottak után tudakolódzna, azok kötelesek ezen egyház palatinusának késlekedés nélkül kiadni őket törvénykezésre." ${ }^{\text {69 }}$ A méltóság talán ekkortájt jött létre, mert amikor IV. Béla egy 1256. december 16-i oklevelében hasonló módon megerősítette az esztergomi érsek jogait, akkor még csak megtiltotta az országbíró és a nádor számára, hogy az érsekség népei felett bíráskodjanak, ám az 1262 körüli privilégiummal ellentétben még nem tett említést az érseki palatinusról. ${ }^{70}$ 1272-ben hasonló módon bukkan föl a tisztség, miszerint az esztergomi érsekség alá tartozó nemes harcosok (nobiles exercituantes) és egyéb szolgáltatónépek a saját „,palatinusuk” alá tartoznak, aki akár elfoghatja és el is ítélheti őket. ${ }^{71}$ Lodomér esztergomi érsek 1291. évi oklevelében több karcsai lakost az érsekség nemes jobbágyává emelt, és olyan mentességet adott nekik, hogy csak a saját, és az ideiglenesen állított palatinusának a bírói fennhatósága alá tartozzanak (iudicio ... palatini curie nostre pro tempore constituti). ${ }^{72}$ Egy ugyanezen évben az esztergomi káptalan által kiadott oklevél pedig meg is nevezi a tisztség birtokosát: András,

\footnotetext{
${ }^{67}$ Bónis 2003. 144., 147. Az egyházi nemesek kormányzatának világival való egyéb párhuzamait részletesen elemzi Bónis: uo. 143-165.

${ }^{68}$ Az oklevél kiadása: MES I. 473-476. Hitelességére lásd RA 1302a. sz. (elfogadva hitelesnek, csak az évszámot 1262-re téve), ill. Györffy 1964. 6-7. (hamisnak, vagy legalábbis gyanúsnak tartva az oklevelet).

69 „Item si nobiles ecclesie Strigoniensis in furto vel spolio casu contingente per palatinum regni vel iudicem curie nostre vel successorum nostrorum ordine iuris servato interficiantur, possessiones taliter interfectorum non ad palatinum regni vel iudicem curie regni devoluantur, sed in ecclesiam Strigoniensem. Et si palatinus iudex ecclesie Strigoniensis apud palatinum regni vel iudicem regni curie nostre, aut alios iustitiarios regni eosdem captos esse sciverit, iidem eosdem ipsi palatino ecclesie praedicte ad iudicium reddere tenentur sine mora." MES I. 474. Lásd még Bónis 2003. 159.

${ }^{70}$ MES I. 436-438., RA 1122. sz.

${ }^{71}$ MES I. 604. (RA 2200. sz.)

${ }^{72}$ MES II. 298.
} 
ajkai nemes. ${ }^{73}$ A tisztség a 14. században is feltünik, ${ }^{74}$ és még a kora-újkorban is létezett. ${ }^{75} \mathrm{~A}$ forrásanyag egyértelmüen az egyház népei és nemesei feletti bíráskodási feladatait emeli ki, gyakran Pozsony és Nyitra megyék területén bukkanva föl. Egyéb téren is utánozta a világi nádort: 1339-ben ugyanúgy volt albírája (viceiudex), mint ekkor Druget Vilmosnak, továbbá 1337-ben és 1372-ben is ún. generalis congragatiot tartott az érsekség népei számára, akárcsak a nádor az egyes megyék lakosainak.

\section{2 - A szó etimológiája}

Bár nem intézménytörténeti kérdés, nem mehetünk el szó nélkül a megnevezés etimológiája körül zajló, több mint 250 éves vita mellett. Túlzás nélkül mondhatjuk, hogy a nádorispánnal kapcsolatban a legtöbb polémiát nem intézménytörténeti vagy jogi kérdésekről folytatták az elmúlt több mint 250 évben, hanem azért, hogy a nádor szó eredetét tisztázzák. Az egyetlen olyan állítás, amellyel mindenki egyetértett, mindössze az volt, hogy a nádorispán összetett szó, amelyből az „,-ispán” utótag a közkeletű magyar tisztségre utal. ${ }^{76} \mathrm{~A}$ szakirodalom további állandó eleme a szláv nyelvből való eredeztetés, amely mintegy „vörös fonalként" húzódik végig a kérdés historiográfiáján, és amellyel szemben folyamatosan más és más (ám egymástól gyökeresen eltérő) alternatívákat sorakoztattak fel az évszázadok folyamán. A szláv eredeztetés köztudatba való behozatala a jezsuita történetírói iskolához tartozó Timon Sámueltől ered, aki 1734-ben a következőket írta: „Magyarul a palatinust nádor- (régiesen: nádur-) ispánnak mondják. A nadur nem magyar eredetü, hanem jövevényszó, két szláv [szóból] áll (Na dwur) az udvari elöljárót jelentve. (...) És ezt nem kell csodálni, amikor az a név is, amellyel a királyt nevezik, a magyarban a szlávból kölcsönzött. A vajda és a bán vitán felül szláv."77 Bár ahogy Katona István leírta egy 1786. évi

\footnotetext{
${ }^{73}$ MES II. 296.: „Andream nobilem de Ayka, palatinum curie venerabilis patris, domini nostri, domini Lodomerii Strigoniensis archiepiscopi”

${ }^{74}$ 1337: MES III. 300. (AOkl XXI. 277. sz.); 1339: MES III. 345. (AOkl XXIII. 490. sz.); 1346: MES III. 606.; 1372: DF 227825., kiadása: Prímási nádor 473-474. (az oklevél kelte helyesen 1372. okt. 18., a DL-DF 5.1 nyilvántartásban szereplő nov. 12. helyett)

${ }^{75}$ A 16. században az esztergomi érsekségben az adminisztrátor nevezte ki az egyházi nemesek palatinusait, de ezt a kinevezést előtte a királlyal is jóvá kellett hagyatnia (Kenyeres 2002. 204.). I. Miksa 1574. febr. 15-én kelt, Zeleméry Lászlónak, az esztergomi érseki szék adminisztrátorának címzett utasításában feladatul adja neki, hogy „az egyházi nemeseket őrizze meg régi jogaikban és védelmezze őket a zaklatásoktól, amennyiben az egyházi nádorok (palatini eorum) nem tudják öket megvédeni”. (Kenyeres 2002. 216. vö. 224.)

${ }^{76} \mathrm{Az}$ ispán szó etimológiája sem problémák nélküli, ám erre most nem kívánunk kitérni. Lásd röviden Kristó 1988. 47-51.

77 „Hungaris Palatinus appellatur Nádor (antique Nádur) Ispán. Nadur non est nativum Ungaricum, sed ascititium vocabulum, aptum ex duobus ( $N a d w u r)$ Sclavoniscis, significans aulae praefectum ... Nec vero id
} 
munkájában, rendtársai már attól tartottak, hogy Timon Jupiterből is szlávot csinál, ${ }^{78}$ az eredeztetés mégis meggyökeresedett a magyar történetírásban és nyelvészetben a 18-19. század folyamán.

Hamarosan az ellenvélemények is megszülettek. 1749-ben Bél Károly András már azt vetette föl, hogy a Ludovicus Tuberónál olvasható nándor alak alapján a tisztség nem kapcsolható-e össze valahogy Belgrád magyar nevével, ${ }^{79}$ Orosz Ferenc 1754-ben pedig a magyar „Nagyúr-ispán” kifejezésből származtatta a szót. ${ }^{80}$ Ötletére ugyan csak röviden tért ki (egyedül a gy-d hangváltozásra hozva néhány példát, vagyis hogy a „nagyúrból” hogyan lehet „nadur”, később nádor), ám 1775-ben Szarka János már egy teljes könyvet szentelt ezen ötlet kidolgozásának. ${ }^{81}$ Bár végeredménye vitatható, módszere tulajdonképpen a korabeli nyelvtudomány magas szintjén állt. Rövid intézménytörténeti bevezető után ismertette Timon véleményét, majd ellentmondva annak belekezdett a „nagyúr” kifejezés igazolásába. Még több példát hozott a d-gy hangváltozásra, továbbá arra, hogy a nadur (vagyis nagyúr) szóból szabályosan nador lesz az u-o hangváltozás (ma úgy mondanánk: nyíltabbá válás) során. Ezek után illusztrálta, hogy VII. Konstantin és más történetírók alapján a korabeli fejedelem megszólítása „nagyúr” (magnus dominus) volt, történelmi keretekbe is illesztve az ötletet. ${ }^{82} \mathrm{~A}$ szláv származtatás mindamellett töretlenül élt tovább, ${ }^{83}$ és számtalan ellenvélemény is született. Másfajta magyar etimológiát alkotott Németh János 1839-ben, szerinte a szó a „,nagy udvar ispán” kifejezések összevonásából keletkezett. ${ }^{84} \mathrm{Ez}$ volt a szláv mellett a 19. század másik legnépszerübb álláspontja: elfogadta Fejér György, Fraknói Vilmos (megjegyezve, hogy Czech János is ezt tartotta a legvalószínübbnek kéziratos müvében), a korban népszerü Czuczor-Fogarasi szótár, illetve valószínünek tartotta a magyar nyelv eredetéről teljesen más elveket valló Budenz József is. ${ }^{85}$ Emellett a kor nyelvészei és

\footnotetext{
mirum est, quando nomen quoque, quo Regem appellant, Ungari a Sclavis mutuati sunt. Vajvoda, et Banus sine controversia Sclavonica sunt.” Timon 1734. 73-74. (kiemelések a szerzőtől)

${ }^{78}$ Vö: Püspöki 1978. 61.

${ }^{79}$ Bél 1749. 9-10. A szerző ugyanitt megemlíti, hogy Timon más etimológiát hoz, és láthatóan nem kötelezte el magát szilárdan egyik mellett sem. Egyébként, mint látni fogjuk, ugyanebbe az irányba kezd majd nyomozni 250 évvel később Róna-Tas András is.

${ }^{80}$ Orosz 1754. 114-115.

${ }^{81}$ Szarka 1775.

${ }^{82}$ Uo. $25-33$.

${ }^{83}$ Sándor 1801. 143.; Leschka 1825. 149-150.; Dankovszky 1833. 679., 697. Ezek az etimológiák nem voltak mindenben egyezőek, amíg pl. Sándor István csak a „na dwúr” szavakból eredeztette, addig Leschka István már szakszerübben, a „na + dvorınъ-jb” (később: nadvornyj) szavak összevonásának tartotta.

${ }^{84}$ Németh 1839

${ }^{85}$ CD X/6. 5.; Frankl 1863. 14-16., ill. 16. 2. jz.; CZ-F IV. 688.; MUSZ 390.
} 
történészei próbálkoztak arab, ${ }^{86}$ japán, ${ }^{87}$ vagy éppen vegyes, magyar-perzsa ${ }^{88}$ etimológiákkal. Viszont a szláv eredet pontos mibenléte körül is folytak viták. Miklosich Ferenc 1882-ben magyarul is megjelent müvében a *na dvorě župan szerkezetből vélte levezethetőnek, ám ezt Kniezsa István egy 1941-es tanulmányában nem tartotta lehetségesnek, mivel a jelentésének (,udvaron ispán”) nincs értelme, és az ilyen típusú locativusos szerkezetek egyébként sem léteznek a szláv nyelvben. ${ }^{89}$ Kniezsa ezen cikke a legjobban kidolgozott összefoglaló a szláv eredetre. Szerinte a szláv praepositio nem „na” (magyarul: on/en, ra/re), hanem „nadb” (magyarul: fölött, fölé), tehát „udvar feletti” ispán. Ám ez az elöljáró instrumentalissal jár, így nadb dvoromъ lenne. Másik, szerinte valószínübb lehetőségként felvetette, hogy a *nads dvorjb špan szerkezetből eredne, ahol is a „dvorjь” birtokos képzős melléknév volna. Végső soron egy olyan hármas szláv összetételből magyarázta a szó eredetét, mely a nadı (felett), dvorı (udvar), és špan (ispán) szavakból keletkezett. ${ }^{90}$

Kniezsa nem elégedett meg teljes mértékben szófejtésével, és éppen a szláv etimológiák „preferált korszakában”, az 1950-es években adott hangot kétségeinek. Szerinte az összes (a sajátját is ideértve) magyarázat gyöngéje, hogy „ennek a szerkezetnek a magyarnak megfelelő jelentésben sehol, semmiféle szláv nyelvben a legcsekélyebb nyoma sem található. Ahol a szó mégis megvan, ott kivétel nélkül a magyarból van átvéve". ${ }^{91}$ Mindezek ellenére azt mondhatjuk, hogy jelenleg a szó eredetét általában szlávból eredőnek magyarázzák az ezzel foglalkozó nyelvészeti munkák. ${ }^{92}$

A közelmúltban egy új, az eddigiektől teljesen eltérő alapokon nyugvó eredetet dolgozott ki a szóra a turkológus Róna-Tas András. Elgondolását nem foglalta össze egyetlen tanulmány keretein belül, így az elmélet részleteit a különféle helyeken tett megjegyzéseiböl kell összeszedni. Az ötlet alapját az az állítása képezi, hogy Árpádék bejövetelekor még élhettek török nyelvű népek a Kárpát-medencében. ${ }^{93}$ Ezzel megoldódhat az ispán szavunk

\footnotetext{
${ }^{86}$ Nagy János elgondolásának ismertetését és cáfolatát lásd Podhradczky 1850. 35.; Frankl 1863.9-10.

87 Kállay Ferencnek az MTA kézirattárában lévő értekezéséről lásd Frankl 1863. 10.; teljesen más megközelítésből, de szintén a japán nyelvre futott ki Podhorszky Lajos elgondolása, lásd CZ-F IV. 687.

${ }^{88}$ Podhradczky 1850. 36-37.

${ }^{89}$ Miklosich 1882. 563-564.; Kniezsa 1941. 17.

${ }^{90}$ Kniezsa 1941. 17-19. Horger Antal még ugyanezen évben publikált megjegyzésében elfogadta Kniezsa etimológiáját, bár néhány tételt vitatott a magyarba való átkerülését illetően: Horger 1941. Ugyancsak a szláv eredeztetést tartotta valószínűnek, Kniezsa elméletét az egyik lehetséges megoldásnak tartva Bárczi Géza (Bárczi 1941. 211-212.).

${ }^{91}$ Kniezsa 1955. 351.

${ }^{92}$ A magyar nyelv történeti-etimológiai szótára (TESZ II. 992.) még komolyabb kifogásokkal is élt, bár a szláv eredetet tartotta legvalószínűbbnek, de „forrása tisztázatlan, megfelelöje nem mutatható ki”. Német nyelvü változata már kevesebb kétségnek ad hangot: EWU II. 1012.; továbbá: Tótfalusi 2001. 354.; Zaicz 2006. 559.

${ }^{93}$ Róna-Tas 1995. 424-425.
} 
átvételének a kérdése is, mert - bár végső soron a szláv zsupánból jött - a magyar nyelvben az „u” kiesése nem magyarázható. Viszont ha egy török nyelvü nép a zsupán szót kölcsönzi a szlávból, „akkor abból szabályosan supán, majd talán spán lehet." ${ }^{94}$ Ebből ered a magyar ispán szó is, amely tehát nem közvetlenül a szláv, hanem a török nyelvből került volna át. Ez viszont magától értetődően azt jelenti, hogy a címet a török (onogundur-bolgár) népek is használták, részint az általuk hódoltatott szláv népek, részint a saját maguk vezető szervére. ${ }^{95}$ A bejövő magyarok meghagyták egy ideig ezt a zsupáni (spáni ispáni) rendszert, a saját maguk szolgálatába állítva. És mivel az onogundur bolgárok magyar neve nándor volt, ezért a bolgárok által a zsupánságok élére állított főzsupánt, a „bolgár spánt”, magyarul „nándor spánnak” nevezték, amiből a „nándorispán”, majd a nádorispán szó eredne. ${ }^{96}$ Mindennek nyelvészeti szempontból is lehetséges voltát Róna-Tas András úgy kívánta igazolni, hogy egyrészt nem egyedülálló, hogy népnévből cím váljék, erre példaként a keleti szlávban található bojár nemesi réteget hozta föl, továbbá kimutatta, hogy a nádorispán magyar megnevezései között valóban felbukkan a „nándorispán” és „lándorispán” alak is. ${ }^{97}$ És ha „ezek közül a nándor előtag az eredeti, akkor ez lehet a dunai bulgár-törökök vagy az onogundurok magyar neve, a nándor: ahogy Belgrádot Nándorfejérvárnak nevezték."98

Róna-Tas ötletét még nem tárgyalta ki a szakma kellő részletességgel, Makk Ferenc annyi megjegyzést füzött hozzá, hogy „,szellemes ötletnek minősül” Róna-Tas ezen állítása, ám „további vizsgálatra szorul egyrészt az általa adott etimológia nyelvészeti oldala, másrészt a történelmi körülmények közé való elhelyezése."99 Magunk csak annyit tennénk hozzá, hogy a kérdés nyelvészeti kulcsa véleményünk szerint Róna-Tas András következő megjegyzésében rejlik: „Ha ezek [ti: a „,nádorispán” különbözö korai megnevezései] közül a nándor előtag az eredeti..." ${ }^{\prime 100}$ Ennek a bizonyítása azonban még nem történt meg, sőt, a ránk maradt nyelvemlékek az ellenkezőjét sugallják. Ugyanis a „nándorispán” forma összesen két forrásban bukkan fel, a szintén ide sorolandó „landor ispan” pedig egyszer. Az említett két felbukkanás egyike egy raguzai szláv illetőségű szerző, Ludovicus Tubero (Ludovik Crijević) müvében található, másrészt egy lengyelországi illetőségü többnyelvü szójegyzékben. Tubero összesen négy alkalommal említi művében a kérdéses hivatalt, ebből három esetben

\footnotetext{
${ }^{94}$ Róna-Tas 1997. 101. Az ispán szó magyarba való átkerülésére ld. még Róna-Tas 1998. 945-948.

${ }^{95}$ Róna-Tas 1997. 101, 276, 303.; Róna-Tas 1999. 115, 353, 390.; Róna-Tas 2007. 58-59.

${ }^{96}$ Uo.

${ }^{97}$ Róna-Tas 1997. 101.; Róna-Tas 1999. 115.

${ }^{98}$ Róna-Tas 1997. 101.

${ }^{99}$ Makk 1998. 41. A cikk eredetileg 1997-ben jelent meg Róna-Tas egyik hivatkozott könyvének recenziójaként. A vita a könyvröl ugyan tovább folyt a két professzor között, de a nádorra többet nem tértek már ki.

${ }^{100}$ Róna-Tas 1997. 101.
} 
nazálissal, egyszer a nélkül. ${ }^{101}$ Adatai sajnos igen nehezen kezelhetőek nyelvészeti szempontból, mert a szöveg gondozója, Bél Mátyás (miként azt az előszóban írta) a korábbi kiadás elrontott névalakjait kijavította, és a korabeli magyar formába öntötte. Ez jól látszik a nevek és egyéb szavak helyesírásán. ${ }^{102}$ Viszont a névalak létezését támogatja, hogy ugyanúgy a nazálisos forma jelenik meg az 1533-ból való ún. Murmelius-féle szójegyzékben, ${ }^{103}$ bár itt felhozhatjuk azt, hogy a magyar részek készítője jól láthatóan bajban volt a magyar nyelvvel (egyes esetekben a latin szavaknak egyenesen a lengyel megfelelöjét adta meg), ${ }^{104}$ tehát az ő anyanyelve sem magyar volt, hanem lengyel. Ennek ellenére ilyen könnyen nem lehet figyelmen kívül hagyni ezt a két alakot, különösen, hogy egy harmadik esetben is találkozunk a nazálisos változattal. Az ún. „Kolozsvári glosszák” Ajtai Máté vagy Bölöni Fülöp által 1577 körül írt részében, ahol ez egyik lapszéli bejegyzésben a „landor ispan - comes palatinus” megfeleltetéssel találkozunk. ${ }^{105}$ A szerzők kétségtelenül magyar anyanyelvű háromszéki székelyek, ám a könyv egyes bejegyzései dunántúli nyelvjárásra is utalnak. ${ }^{106}$

A fenti három adat tehát bizonyítja, hogy a kérdéses forma valóban létezett. Ezekkel a 16. századi adatokkal szemben viszont ott áll az összes olyan korábbi nyelvemlék, amelyben nazális nélkül szerepel a nádor szó, és ami lényegesebb: a magyarból a szomszédos nyelvekbe átkerült jövevényszavak. Mint már a fejezet elején említettük, a cseh, horvát és szerb nyelvbe átkerült alakok mindegyike egymástól függetlenül jól felismerhetően a nádorispán és nem a nándorispán szó átvételén alapszik. ${ }^{107} \mathrm{Ez}$ alapján (ha már súlyoznunk kell) inkább azt mondhatjuk, hogy a nádor névforma tekinthető eredetibbnek. Valószínű, hogy a nazálissal felbukkanó alak tekinthető másodlagos fejleménynek, amely az országban található számos Nándor népnévi helynév ${ }^{108}$ miatt jött létre, amelyeket a népetimológia kapcsolhatott össze a hasonló hangzású tisztségnévvel. A magunk részéről a szó etimológiáját így mindenképpen bizonytalannak tekintenénk.

\footnotetext{
101 „Stephanum... absentem declarant Nándor Ispanum, ita Senatus Principem Hungari vocant” (Lib. I. cap. XIV.); „Michael Országhis, regni Hungarici Nándor-Ispanus” (Lib. II. cap. V.); „misso ... Stephano Bathore iuniore, Náder Ispano” (Lib. XI. cap. VI.); „Stephanus Báthor, Nander-Ispanus” (Lib. XI. cap. VII.) Tubero 1746. 129., 144., 368., 371.

${ }^{102}$ Bél előszava a latin kiadás fentebb idézett kötetében, IX. oldal, ld. még XIV.

103 „Comes palatinus - Nandor espan” Szamota 1896. 34. (2285-ös tétel)

${ }^{104}$ Szamota 1896. IV.

${ }^{105}$ Pálfi 1907. 36.

${ }^{106}$ Uo. 4-7.

107 Szerb-horvát: „nadršpan”: TESZ II. 992. A cseh nyelvre pontosabban adatol Sulán Béla (Sulán 1957. 163): 1457: „,nadoršpan”; 1487: „,nadrsspan”, ill. „naderspan”. A konstanci zsinat résztvevőinek a jegyzéke 1415-1417 körülről: „natrespeyn” (Zichy XII. 107.) A magyar nyelvemlékre: TESZ II. 992., további kiadatlan nyelvemlékek: DL 134., 135., 136., DL 49609. jelzetű oklevelek hátulján.

${ }^{108}$ Felsorolásukat lásd Korai helyneveink I. 15-16.
} 


\section{2 - A TISZTSÉG EREDETE ÉS AZ ELSŐ NÁDOROK}

A nádorispánra alkalmazott mindkét latin kifejezés (comes palatii ill. comes palatinus) feltünik külföldi forrásokban is, valamilyen magas rangú, az uralkodó mellett álló tisztviselőt takarva. Magának a palatinus szónak az eredete végső soron a római hét domb egyikére, a Palatium nevezetüre vezethető vissza. A korai császárkorban több császár is itt építtette föl rezidenciáját Augustustól Domitianusig, amitől is a császári lakhely, a „palota” megnevezése szintén palatium lett. ${ }^{109}$ Ezen szó melléknévi alakja a Palatinus, vagyis a „palatiumi dombhoz tartozó”, illetve a palatinus, a „palotához tartozó” jelentéssel. Ez a szó a késő császárkortól a további jelentéseket kapott: így kezdték el nevezni Nagy Konstantintól kezdve a császári adminisztráció magasabb hivatalaiban dolgozó vezetőit, vagyis lényegében a birodalom személyi vezetését is. ${ }^{110} \mathrm{~A}$ név aztán átkerült a Merovingokhoz is comes palatinus vagy comes palatii formában, amely a király melletti bírói feladatokat betöltő személy neve lett, és a Német-római császári intézményrendszer fontos szereplője maradt az egész középkor folyamán. ${ }^{111}$ A korábbi szakirodalom egyöntetủ véleménye, hogy a nádori tisztség már Szent István korától eredeztethető, és hogy ezt - sok máshoz hasonlóan - német mintára vette át az „államalapító” király. Comes palatinus ugyanakkor létezett a cseheknél, lengyeleknél, és a horvátoknál is, ${ }^{112}$ ám annak kicsi az esélye, hogy innen származtassuk, hiszen ez a két ország nem gyakorolt olyan jelentős hatást Magyarországon a Szent István-kori latin terminológiára az állami intézményrendszert illetően. ${ }^{113}$ A magyar szakirodalomban Váczy Péter és Györffy György olyan meggyőző párhuzamokkal mutatták ki, hogy a korai magyar udvari szervezet erős frank, és közelebbről bajorországi párhuzamokról tanúskodik, ${ }^{114}$ hogy ezzel az állítással - jelen tudásunk alapján - nemigen lehet vitába szállni. Így az is valószínűsíthető, hogy a keresztény udvarszervezet felállításakor a comes palatii tisztségét is nyugati mintára szervezték meg. Elvi szinten feltehetjük azt a kérdést is, hogy a nádori tisztségnek nem voltak-e prekeresztény előzményei. A Magyarországon elterjedt latin kifejezés teljesen a német minta átvétele, az bizonyos. De vajon nádor feladatköre is a frank palatinus egyszerü másolása volt, vagy átmentettek egy korábbi hivatalt, némileg átszervezve? E téren két elem

\footnotetext{
${ }^{109}$ OCD 770-771.; Haugwitz 1901. 41-76.

${ }^{110}$ OCD 771. A réteg bevett neve ,,palatini” volt, amely a ,palatinus” többes száma.

${ }^{111}$ LexMA VI. 2012-2013.

${ }^{112}$ LexMA VI. 1634.; Györffy 1977. 246.

113 A német hatásra a szentistváni államszervezésben lásd Váczy 1938. 48-49., a terminológiára: Kristó 1988. 60-61.

${ }^{114}$ Váczy 1938. 48.; Györffy 1977. 246-247.
} 
adhatna fogódzót. Egyrészt, a magyar kifejezés, a nádorispán etimológiája. Ha például RónaTas András fentebb ismertetett ötlete igaznak bizonyulna, az máris választ adna az előzmények kérdésére. Sajnos, mint láttuk, a szónak semmilyen biztos etimológiája nincs, és ha a problémái ellenére elfogadnánk a szláv eredeztetést, az is csak a latin kifejezés tartalmi fordítása (a palota comese az udvar comese, ahol a „királyi udvar”, mint szerv, lényegében megfeleltethető a „királyi palotával”). Egyébként sem árt óvatosan bánni a nyelvészet történelemmé formálásával, mert még a nyelvészetileg biztos etimológiák is könnyen vihetnek történelmi tévútra. A másik lehetőség az lenne, hogy ha a 11. század első felének nádori szerepkörét összevetnénk a mintaadóként tekintett nyugati palatinusi szereppel, és megmutatkozna, hogy van-e valamilyen markánsabb különbség a kettő között. De ez sem járható út, mert a nyugati feladatkör még csak-csak rekonstruálható, ám az első ilyen típusú magyarországi forrás már a 11. század második felére esik, és az is csak a hivatali teendők egy részére világít rá. Ha a 11. század első felének hivatali szerepére vagyunk kívácsiak, akkor meg kell elégednünk a későbbi források visszavetítésével. Ezekről alább részletesen szó lesz, itt csak annyit bocsátanánk elöre, hogy semmilyen olyan elem nem akad a későbbi nádori hivatalban, amelyet ne lehetne egyrészt nyugati párhuzamokból levezetni, másrészt 11-12. századi belső hivatalfejlődéssel indokolni. Hogy tehát valamilyen kereszténység előtti ismert „hivatalt” (pl. a horka tisztséget) beépítettek volna a nádoriba, bizonyítékok hiányában nem állíthatjuk. ${ }^{115}$

Ha arra keressük a választ, hogy ki hozta létre a nádori hivatalt, akkor a szakirodalom egyöntetűen és magától értetődően adja meg a választ Szent István személyében. Annak ellenére, hogy ez - szigorúan véve - nem bizonyítható forrástanilag. A legkorábbra visszavezethető említés magyarországi nádorispánról Gellért nagylegendájában található, amely szerint „Aba, a palota ispánja (Alba comes pallacii) letaszította Pétert, s azután a királyi koronát és a királyi udvart bitorló módon maga ragadta a hatalmába." ${ }^{116}$ Aba nádorsága így Péter elüzésének idejére, az 1041. évre bizonyítható forrásszerűen. Bár a 19. század végén a nagy tekintélyü történész, Pauler Gyula kétkedéssel fogadta Aba nádorságának tényét akár István, akár Péter alatt is, ${ }^{117}$ ám a felbukkanó elnevezés (comes palatii) a tisztség legkorábbi, csak a 11. század közepéig használt névalakja, így a legenda e része mindenképpen egy korai

\footnotetext{
${ }^{115}$ Párhuzamokat ugyan találhatunk a gyula vagy a horka tisztsége és a nádori hivatal között is: ilyen a bíráskodás, de ez annyira általános szerepkör, hogy nem lehet rá alapozni. Az sem biztos egyébként, hogy a gyula vagy a horka hivatala megérte az ezredfordulót.

${ }^{116}$ SRH II. 500. Magyarul ÁKÍF 424. (Almási Tibor ford.)

${ }^{117}$ Pauler 1879. 101. 5. jz.; Pauler 1899. I. 416. Szintén óvatosan fogalmazott e téren: Marczalli 1896. 13.; Wertner 1894. 1.
} 
forrásra megy vissza. Az adat tehát csak Péter korára szolgáltat információt, de abban igaza lehet Szabados Györgynek, hogy kicsi annak a valószínüsége, hogy pont (az egyébként is külföldi főemberekre támaszkodó) Péter nevezte volna ki Abát erre a tisztségre. Inkább arra érdemes gondolni, hogy Péter „,megörökölte” Sámuelt a nádorságában. ${ }^{118}$ A korábbi szakirodalomban ennek ellenére rendre felbukkantak olyan „fantomévszámok”, amelyek már Aba Szent István alatti nádorságát bizonyítanák. Már a nádori archontológiák első összeállítója, a 17. századi Iongelinus is azt írta (forráshivatkozás nélkül), hogy Aba 1034-ben nyerte el a nádorságát (ugyanekkor Sarolának nevezte Szent István nőtestvérét, Aba feleségét, amely adat szintén nem található meg középkori forrásokban, ám - hasonlóan a nádori évszámhoz - terjedt és továbbélt). ${ }^{119}$ A $18-19$. századi irodalomban vissza-visszatért Iongelinus évszáma. ${ }^{120}$ Fejér Györgynél már „1030-4” szerepel időmeghatározásként, érzékelve az évszám bizonytalan voltát, de még nem tudván teljesen elszakadni a bevett időponttól. $^{121}$ Új évszámra alapozott Czech János 1848-ban, levéltári források alapján összeállított kéziratában, amelyet - némi kétkedéssel - Fraknói Vilmos is közölt és átvett. Érdemes szavait szó szerint idézni: „Czech kéziratában a szent mártoni főapátság levéltárának (Caps. 14. La. A. act. AAbb.) egy oklevele nyomán 1023. teszi »Samuel Aba Palatinus sub Stephano et Petro.« Azon oklevelet nem ismerjük." Mindazonáltal Fraknói a könyve végén a nádorok felsorolásakor 1023-ra tette Aba Sámuel nádorságát, egyéb évszámot nem is jelölve. ${ }^{122}$ A hivatkozás eléggé furcsa, hiszen egyrészt pontos levéltári elérhetőséget ad, ugyanakkor 1023-ban kelt magyarországi oklevelet egyáltalán nem ismerünk, még hamisat, vagy említési szinten fennmaradtat sem. ${ }^{123}$ A Pannonhalmi Bencés Főapátság Levéltárában viszont őriznek egy oklevelet Capsa 14. A (338) jelzet alatt, amely I. Károly 1330. március 11-én kelt oklevelét tartalmazza, amely - átírva IV. Béla 1246. november 12-én kelt oklevelét - magába foglalja Szent István 1037-re keltezett Bakonybéli alapítólevelét. Ez az egyetlen olyan oklevél a Pannonhalmi Levéltárban jelenleg, amely Capsa 14. A kezdetű jelzetet tartalmaz (mint a Czech által megadott hivatkozás), és valamilyen formában kapcsolatba hozható Szent István okleveleivel. Lehet, hogy ennek az évszámát nézte el Czech János 1023 ra, bár a Károly-féle 1330-as átírás szép írásképpel rendelkezik, és eléggé egyértelműen,

\footnotetext{
${ }^{118}$ Szabados 2011.311.

${ }^{119}$ Iongelinus 1659. 152. Az évszám és a név forrását Szabados György sem tudta beazonosítani, Iongelinusnak tudván be a többletet: Szabados 2006. 104.

${ }^{120}$ Schmitth 1739. 9-17.

${ }^{121}$ CD VII/2 279.; Index 1. 37.

${ }^{122}$ Frankl 1863. 43, 1. jz., 155.

${ }^{123}$ Lásd DHA I.; DL-DF 5.1
} 
szinte eltéveszthetetlen módon hozza az 1037-es $\left(M^{o} X X X^{m o} V I I^{o}\right)$ évszámot. ${ }^{124}$ Ráadásul az oklevélben semmi olyan konkrét információt nem találunk, amely akár Abára, akár a nádorságra utalna. A másik lehetőség, hogy Czech (az egyébként szintén hamis), 1024-re keltezett zalavári oklevélből jutott el az 1023-as évszámig. Az oklevél szintén a Pannonhalmi Levéltárban található, jelenleg Capasa 13. D (400) jelzet alatt. Az ebben található egyik kitétel szerint István megadta azt a jogot a zalavári apátságnak, hogy csak a király, illetve az apát által választott személy bíráskodhasson felettük, és azt, hogy „minden bíró, és az összes megyésispán, vagy helyettes bíró, és a királyi udvarispánok bíráskodása és hatalmától meg joghatóságától” mentesek legyenek. ${ }^{125}$ Lehet, hogy az itt közölt királyi udvarispán (curialis comes regalis) méltóságot azonosította a nádori címmel. És mivel a közvélekedés szerint István nádora az uralkodásának második felében Aba Sámuel lett volna, ezért vélte úgy Czech, hogy a kinevezése az oklevél kelte elött történt, így tette az évszámot hipotetikusan 1023-ra - ti. akkor már nádor volt Aba. Magunk inkább ez utóbbi lehetőséget látjuk valószínünek, annál is inkább, mert Fraknói sem állítja, hogy egy 1023-ban kelt oklevélben említenék Abát nádorként, csak azt, hogy egy Pannonhalmán örzött oklevél alapján Czech 1023-ra tette Aba Sámuel nádorságát. A logika természetesen akkor sem elfogadható, ha a zalavári okmány hiteles lenne, ám hamis, és az idézett rész lényegében szó szerinti átvétel V. Istvánnak a pannonhalmi apátság részére adott 1270 . november $7-\mathrm{i}$ okleveléből. ${ }^{126} \mathrm{Ez}$ az évszám nem vert gyökeret a későbbi szakirodalomban. ${ }^{127}$ A 20 . századi történetírásban Aba nádorságának kezdetét általában István uralkodása alá helyezték a tudományos és népszerüsítő kiadványok, sőt, még az is elterjedt néhány archontológiai névsorban, hogy nádorságát „1038 előtt” kitétellel adják meg, mintha kizárólag István alatt viselte volna hivatalát. $^{128}$

Több olyan próbálkozás is volt, amely a Szent István alatti, de még Aba előtti nádorokat igyekezett beazonosítani. A pannonhalmi adománylevél végén szereplő Ceba comest szintén Iongelinus keverte először gyanúba, ${ }^{129}$ és bár Ceba személye a 19. század második felére ebből a szempontból elfelejtődött, újabb érvekkel próbálta igazolni nádori voltát Györffy György. 1977-ben megjelent Szent István-monográfiájában rámutatott, hogy Csaba és

\footnotetext{
${ }^{124}$ DF 207137.

$125, \ldots$ a iudicio et potestate ac iurisdictione omnium iudicum et universorum comitum parrochionalium seu viceiudicum et curialium comitum regalium" DHA I. 101.

$126, \ldots$ a iudicio et potestate ac iurisdictione omnium iudicum et universorum comitum parrochyalium seu viceiudicum et curialium comitum” (a „regalium” szó az eredetiből hiányzik). PRT II. 335.

${ }^{127}$ Elfogadta Kandra Kabos (Kandra 1891. 36-37.) Fraknóira hivatkozva, de mások nem nagyon.

${ }^{128}$ Az így eljáró archontológiai névsorok: MTK IV. 1142.; Szentpétery 1985. 96.; KMTL 474.

${ }^{129}$ Iongelinus 1659. 152.
} 
Sebestyén érsek 1005 körül voltak ott az apátság felszentelésénél, amikor a király nevében átadtak a monostornak még tíz falut, amelyek nevét az adománylevél kiegészítése fel is sorol. És mivel ezek a falvak nem egyetlen vármegyében feküdtek, hanem szétszórtan, ezért Csaba ( C Ceba) nem lehetett egy konkrét megye ispánja. A 10 falu a királyi udvarszervezet tartozékát alkothatta, ezért „Csaba comesben bizonyára az udvar ispánját kell látnunk”, amely a nádorispáni tisztséggel egyenlő. ${ }^{130}$ Györffy nem állt meg itt, hanem Csabát hozzákapcsolta az Aba nemzetséghez, a krónikás hagyományra és az 1067 körül kelt százdi oklevélre hivatkozva, amelyben felbukkan az Aba nemböl való Péter Csabarákosa nevü birtoka, továbbá a szintén hozzá tartozó Csobaj és Csabamezeje helynevek, amelyek a nemzetség ösi felmenőjére utalnának. Szerinte ez a Csaba azonos az említett nádorral, és ,alighanem Aba Sámel apja." "131 Györffy kitartott az elmélete mellett a későbbiekben is. ${ }^{132}$ A Csabára és rokonítására vonatkozó elgondolások bizonnyal a fantázia birodalmába tartoznak, ${ }^{133}$ ám az tény, hogy Ceba (és nem feltétlenül Csaba) comes itt a királyi udvarszervezet falvairól, ezáltal népeiről intézkedett (az oklevél szerint „,megnevezte” az apátsághoz tartozó falvakat, amely nevét záradékként felírták a levél végére, tehát nem csak tanúskodott az ügy körül, hanem az eljárásban is részt vett). ${ }^{134}$ Lehetséges azonban, hogy Ceba ekkor a király külön megbízásából járt el, amint erre számtalan példa akad a későbbiek folyamán is, tehát nem kell, hogy hivatali kötelességként alá tartozzanak a királyi udvarszervezet népei. Továbbá nem is érdemes a későbbi, megszilárdult terminológiát visszavetíteni az ezredforduló környékére. Valószínű, hogy ekkorra még nem épült ki a világi hierarchia, könnyen lehet, hogy egy-egy király körüli méltóságviselőnek „mindenféle” feladata lehetett. Logikailag valószínű ugyan, hogy a királyi udvarszervezet élén állt valaki, de úgy tünik, hogy a pontos terminológia ekkorra még nem kristályosodott ki. Cebát tehát legjobb esetben is egy olyasvalakinek tarthatjuk, akinek itteni feladata éppen átfedésben volt a későbbi nádor feladatával - csak éppen ezt a nevet nem használták rá.

Hasonló logika alapján keverték gyanúba István hadvezérét, majd egyik megyéjének első ispánját, Csanádot is. Anonymus szerint ő győzte le Ajtony vezért, cserébe Istvántól megkapta Ajtony feleségét és várát. Gellért nagylegendája sokkal részletesebben meséli el a történteket, de több részlet is más, például a jutalom, amelyet Csanád a győzelem után a királytól kapott: „Csanádot pedig ... azzal tisztelte meg a király, hogy megtette őt a királyi ház és Ajtony

\footnotetext{
${ }^{130}$ Györffy 1977. 241.

${ }^{131}$ Uo.

${ }^{132}$ MT I/1 838-839, I/2 1503; DHA I. 41. 37. jz.

${ }^{133}$ Legújabb kritikájára lásd Szabados 2007a. 153.

${ }^{134}$ ÁKÍF 44.
} 
házának intézőjévé. A király ezt mondta még azután: »Mától fogva azt a várost nem Maros városának hívják többé, hanem Csanád városa lesz a neve. Amiért te pusztítottad ki közepéből ellenségemet, te légy ennek a megyének az ispánja, amelynek majd a magad nevét adod, és hívják is Csanád megyének, míg csak az emberi nemzedék létezik.«"135 A jutalom azon elemét, hogy a „királyi ház intézőjévé” (princeps domus regis) tette meg őt a király, értelmezték úgy néhányan, hogy itt esetleg Csanád nádori tisztségre utalna a szöveg. Szabó Károly úgy fordította a kérdéses részt 1865-ben, hogy „Csanádot pedig ... a király a királyi palota és Óhton palotájának fejévé tőn.” Gálos Rezső 1928-ban nagyon hasonlóan: „Csanádot pedig ... a királyi palotának és Ajtony palotájának a fejévé tette meg."136 Ezen fordítások alapján Takáts Lajos már számolt azzal a lehetőséggel, hogy itt a kérdéses tisztségre történne utalás, viszont azonnal el is vetette, rossznak tartva az értelmezést, „mert a királyi palotának azaz a királyi udvar népének, a királyi várak és udvarházak ispánjainak a nádorispán volt a feje, ezzé pedig nem nevezhette ki Szent István Csanádot, mivel akkor mint a király helyettesének állandóan Esztergomban kellett volna maradnia, holott a marosi részeken csak ezután várt még rá az igazi munka". ${ }^{137}$ Takáts szerint találóbb Karácsonyi János értelmezése, aki „félig-meddig bibliai frázisként” kezelte a kérdéses részt, és úgy tekintette, hogy István Csanádot az udvar fötisztjei közé vette volna be. ${ }^{138}$ Pusztán a biblikus párhuzamot láttaláttatta benne Madzsar Imre is a kritikai kiadás elkészítésekor. ${ }^{139}$ Györffy György mégis úgy képzelte el, hogy a győzelem után István Ajtony territóriumának a kormányzását is rábízta Csanádra, és ezzel egy időben kapta volna meg a nádorságot. ${ }^{140}$ Kérdőjelesen, de elképzelhetőnek tartotta mindezt Almási Tibor is, jelezve, hogy a szöveghelynek bibliai párhuzama is van - láthatóan nem foglalva konkrétan állást a kérdésben. ${ }^{141}$ Legújabban Thoroczkay Gábor úgy kísérelte meg feloldani a Takáts Lajos által is jelzett problémát (ti. hogy nem valószínü, hogy a nádorságot és a csanádi ispánságot egyszerre viselte volna), hogy „,bizonyosan számolhatunk valamennyi idő elteltével” a két tisztség között, és Csanád először volt Ajtony javainak intézője, és a királyi udvari javak intézője (vagyis nádor), majd utána Csanád vármegye megszervezője és első ispánja. ${ }^{142}$ Magunk úgy látjuk, hogy nem sok esélye van annak, hogy a legenda passzusa tényleg a nádori címet takarná. Egyrészt a bibliai

\footnotetext{
${ }^{135}$ SRH II. 492. Magyarul: ÁKÍF 416. (Almási Tibor ford.)

${ }^{136}$ Szabó 1865. 66.; Gálos 1928. 21.

${ }^{137}$ Takáts 1931. 37.

${ }^{138}$ Uo. 36-37.

${ }^{139}$ SRH II. 492. 4. jz.

${ }^{140}$ Györffy 1977. 175-176, 241.

141 ÁKÍF 416. 1519. jz.

${ }^{142}$ Thoroczkay 2009. 363.
} 
párhuzam (Psal. 104. 21.) helytálló, és olyan közigazgatási fogalom, hogy domus regis (aminek a fejévé kinevezték Csanádot) a tudomásunk szerint ebben a formában nem létezett a középkori Magyarországon. Ráadásul pont az a Nagylegenda írta volna így körül a nádori tisztet, amelyik Sámuel kapcsán ismerte a tisztség pontos és archaikus nevét comes palatii formában. Másrészt tényleg nem valószínű, hogy Csanád az ispáni címe mellett lett volna nádor. A 12. század végétől ugyan általános, hogy a nádorok (és más nagyobb világi tisztségviselők) megyésispánok is voltak egyben, de az első ilyen, 1192. évi adat előtt nincs ilyenről tudomásunk. ${ }^{143}$ A 11. században még nem mutatható ki a tisztséghalmozás. Bár tény, hogy jóval kevesebb tisztviselö bukkan föl az oklevelekben, mint amennyi a tisztségek száma alapján elméletileg lehetséges volna, ${ }^{144}$ ezt annak tudhatjuk be, hogy a világi tisztségviselőkre vonatkozó fö forrástípus, az okleveles tanúnévsor, kezdetben ténylegesen tanú-sor volt, tehát csak a személyesen jelenlévőket írták bele. ${ }^{145}$ És mivel a világi tisztviselők soha nem tartózkodtak teljes számban a király környezetében (ez még a királyi udvarhoz kötött nádorra is vonatkozott, ${ }^{146}$ az ispánokra pedig különösen), ezért nem is kerülhettek be teljes számban a signum-sorokba. Thoroczkay Gábor elgondolása ugyan semmissé is tenné ezt a problémát, hiszen ő nem párhuzamos, hanem egymást váltó méltóságviselést feltételezett, de ne felejtsük el: sem bizonyítani, sem cáfolni nem lehet az elgondolást, mert ez az elmélet is az egyetlen vonatkozó forrás (a Gellért-legenda) felülbírálásával jár. Hiszen - miként Thoroczkay is utalt rá - a legenda szerint a két tisztség viselése lényegében egybeesett. Csanád nádori titulusa legalább annyira bizonytalan lábakon áll, mint Ceba comesé.

Összességében a következőket mondhatjuk. A nádori hivatal Péter első uralmának végén, 1041-ben már biztosan létezett, de erősen valószínü, hogy a tisztséget Szent István hozta létre, mert furcsa lenne, ha a frank-bajor mintára kiépített udvarszervezetének éppen az egyik fontos

\footnotetext{
${ }^{143}$ Hogy Ottó a zselicszentjakabi monostor alapításakor, 1061-ben somogyi ispán, felszentelésekor, 1066/68 táján pedig már nádor volt (ÍFMT 29, 377.) legfeljebb időközbeni rangemelkedését bizonyítja. II. Béla 1135 -ös oklevele hamis („Paulo palatino et comite Bachasiensi” ÁÚO I. 51.; vö: RA 60. sz.). Az első hiteles adat az nádor egyszerre több tisztségére valójában Színes úrnő végrendeletében található (1146): „Belus comes palatinus et ban” (CAH 57.). A következő szintén egy nádor-bán párosítás Ompod kapcsán (1167/69): CD II. 179., vö: RA 113. sz. Egy gyanús, hamisnak tekinthető oklevélben említik ugyanezen Ompod csanádi ispáni címét is (PRT VIII. 274.), de az első hiteles adat arra, hogy egy nádor más megye ispánságát is viselte, III. Béla 1192-ben kelt oklevelében található Mog nádor kapcsán: „Mog Palatino Comite et eodem Bachyensi” (ÁÚO VI. 184.)

${ }^{144}$ Vö. Zsoldos 1997a. 125.

145 Jól mutatja ezt pl. az 1055. évi tihanyi alapítólevél szövege: az oklevél megpecsételése után „híveinknek megerősítésre átadtuk” (IFFMT 23. - Piti Ferenc ford.). Százdi alapítólevélben a tanúnévsor után: „Miután ezen tanúk pedig az én mondott vagyonomról tanúbizonyságot tettek..." (ÍFMT 41. - Piti Ferenc ford.); László 1091es somogyvári alapítólevelében: „Tanúk, akik vele együtt megjelentek...” (ÍFMT 138. - Kiss Gergely ford.). Kristó Gyula 1192-től számította azt, hogy már a távollévőket is következetesen odaírták a méltóságsorokba (Kristó 1979. 111.).

${ }^{146}$ Vö. László III/3. tc., amely a birtokára hazatérő nádorispánról szól.
} 
elemét ne vette volna át valamilyen formában. A létrehozott tisztség latin neve comes palatii lehetett (hogy magyarul mi volt a megnevezése, és a nádorispán szó már kezdettől fogva megfelelője volt-e, arról semmilyen információnk nincs). ${ }^{147}$ Mivel semmi jel nem utal rá, hogy a nádor funkciójában továbbélt volna valamilyen korábbi tisztség, ezért a hivatalt egy tisztán nyugati mintára létrejött funkciónak foghatjuk fel. Feltünő ugyanakkor, hogy amikor a magyar nádorispán hivatalának egyes elemeiről információkat nyerhetünk (ez az időszak a 11. század második fele, 12. század eleje), akkor a feladatai nem egyeznek pontosan a nyugati palotagróf funkciójával. A tisztség eredete tehát nyugati, ám amivé vált, az már a 11. század második felében is sajátságosan magyar volt. Hogy az eltérés már kezdettől fogva létezett-e, vagy a későbbi évtizedek hivatali átalakulásának eredménye, nem tudni.

\footnotetext{
147 Mint láttuk, a szó magyar megfelelője a 14-15. sz. fordulójánál hamarabb nem bukkan föl, mellesleg az „ispán” szó sem adatolható a 13. sz. második felénél korábbról (TESZ II. 239.). Tény ugyanakkor, hogy ezek a hivatali elnevezések meglehetősen konzervatívak szoktak lenni.
} 


\section{3 - A NÁDORI HIVATAL ELEMEI ÉS KIFEJLŐDÉSE A 11-12. SZÁZADBAN}

Mint az előző fejezetben szó esett róla, a 11. század második feléig csak a nádori intézmény létezését tudjuk konstatálni, pontos feladatköréről nincsenek információk. A kezdetekre nézve két dolgot tehetünk: egyrészt megvizsgáljuk a frank-bajor párhuzamokat, feltételezve, hogy a funkcióit valamilyen formában a magyar nádorispán is gyakorolta. Másrészt számba kell venni az említett későbbi forrásokat, szintén feltéve, hogy az ott leírt hivatali funkciók részben visszavetíthetőek a kezdeti időkre.

A comes palatinus tisztséget a Német-római Császárságban többen is betöltötték: nem csak a császár mellett, hanem a hercegségek és grófságok udvartartásában is megtaláljuk őt. A német kutatás álláspontja eltér abban, hogy I. Ottó a grófok és hercegek ellenőrzése céljából helyezte őket melléjük, mintegy a császári hatalom meghosszabbított kezeként, ${ }^{148}$ avagy éppen fodítva: ezek a hercegségek állították a frank udvar mintájára maguk mellé a saját palatinusukat, reprezentálva ezzel önálló udvartartásukat. Ez utóbbi álláspont képviselői elfogadják forrásos bizonyítékként Eike von Repgow 12-13. századi szász szerző ${ }^{149}$ álláspontját, aki a Szász Tükör (Sachenspiegel) című törvénykönyvben e hercegségeknek tulajdonította a palatinusi hivatal megszervezését. ${ }^{150}$ A szentistváni tisztség legjobb párhuzamának tekinthető karoling-kori palatinus feladatai közé az udvari szervezet igazgatása és az udvari bíráskodás tartozott legfóképpen. ${ }^{151}$ A legalapvetőbb forrás minderre a későkaroling udvari szervezetet leíró Hinkmar De ordine palatii címü müve. A szerző ebben csak a palotagróf bíráskodási feladatait emeli ki: „A palotagrófnak (comes palatii) pedig csaknem megszámlálhatatlan gondja van, többek között leginkább abban, hogy mindazon törvény előtti vitát, amelyek másutt kezdődő bírói eljárásokként a palotához kerültek itélethozatal végett, [azokat] törvényesen és ésszerűen tárgyalja le, vagy a helytelen ítéleteket az igazság ösvényére terelje vissza, hogy Istennek a színe előtt az igazságosság miatt, az emberek színe előtt a törvények betartása miatt tetszen. Ha pedig az történne, hogy a világi törvényeknek nem lenne [valamire] cikkelye, vagy a nemzetségi szokásjog kegyetlenebb szankciót írna elö, úgy illő módon a keresztényi igazság vagy a szent akarat ne értsen egyet. Az ilyet adja át a király irányítása alá, hogy ő maga azokkal, akik mindkétfajta törvénykezésben járatosak, és inkább félik az isteni, mint az emberi törvények rendelkezéseit, úgy ítéljenek, úgy

\footnotetext{
${ }^{148}$ Pl. Mitteis 1953. 115-116.; Schmidt 1973. 2-3.

${ }^{149}$ Személyére lásd LexMA III. 1726-1727.

${ }^{150}$ Immo Eberl a Lexikon des Mittelalters vonatkozó szócikkében ezt a nézetet képviseli: LexMA VI. 2012 2013.

${ }^{151}$ Váczy 1938. 53.; Schmidt 1973. 2-3.; LexMA VI. 2012-2013.
} 
határozzanak, hogy ahol mindkét törvény [igazsága] szerint ítélhetnek, ott tegyenek úgy, ha pedig nem, illő módon a világi jog szenvedjen csorbát, és Isten igazságát tartsák meg."152

Ha tehát István kezdetben csak ezt a mintát másolta, akkor a magyarországi comes palatiinak is a királyi udvari szervezetben kellett az uralkodót helyettesítve bírói feladatokat ellátnia. Az első olyan törvényszöveg, amely a nádor feladatairól szól, éppen ezt a hatáskörét említi. A Szent Lászlónak tulajdonított ún. III. törvénykönyv (amely időben a legkorábbi, és talán nem is csak László alatt keletkezett cikkelyeket foglal egybe) a következőképpen rendelkezett a nádorispánról: „Az is tetszett, hogy ha valamikor a nádorispán hazamenne, a király és az udvar pecsétjét, aki helyetteseként hátramarad, annak adja át, hogy amint egyetlen udvara van a királynak, úgy egyetlen pecsétje is maradjon. Ameddig pedig ugyanez az ispán odahaza marad, senkire se küldjön pecsétet, kizárólag csak azokra, akiket udvornic-nak neveznek, és akik saját akaratukból mennek hozzá: az ilyen fölött legyen szabad bíráskodnia. Ha másképpen tenne, ötvenöt pensát fizessen." 153 A törvény arra volt kihegyezve, hogy a nádor a királyi udvarból eltávozván ne vigye magával a királyi pecsétet, és ez arra utal, hogy a 11. század második felére a királyi udvar pecsétje, tehát az ottani bíráskodás gyakorlati irányítása már összefonódott a nádor személyével. Hasonlóra utal Kálmán király 1100 körül keletkezett I. dekrétuma: „Bármely vár megyéjébe tér be a király, ott tartson vele a két megyebéli bíró: részint, hogy az ottani nép viszályainak hozzáértő vizsgálódással véget vessenek, részint, hogy ők maguk is a nádorispán ítélete alá essenek, amennyiben a nép panasza megsúlyosbodik." ${ }^{154} \mathrm{Az}$ itt említett két királybíró az ispánok mellett, de tőlük függetlenül ítélkezett a megyében, és joghatóságuk valamennyi világi személyre kiterjedt,

\footnotetext{
152 „comitis autem palatii inter caetera paene innumerabilia in hoc maxime sollicitudo erat, ut omnes contentiones legales, quae alibi ortae propter aequitatis iudicium palatium aggrediebantur, iuste ac rationabiliter determinaret seu perverse iudicata ad aequitatis tramitem reduceret, ut et coram Deo propter iustitiam et coram hominibus propter legum observationem cunctis placeret. Si quid vero tale esset, quod leges mundanae hoc in suis diffinitionibus statutum non haberent aut secundum gentilium consuetudinem crudelius sanctium esset, quam christianitatis rectitudo vel sancta auctoritas merito non consentiret, hoc ad regis moderationem perduceretur, ut ipse, cum his, qui utramque legem nossent et Dei magis, quam humanarum legum statuta metuerent, ita decerneret, ita statueret, ut, ubi utramque servari posset, utramque servaretur, sin autem, lex saeculi merito comprimeretur, iustitia Dei conservaretur.” Hincmarus 17. (c. 21.)

153 „De palatino comite. Placuit eciam, ut si aliquando palatinus comes domum ierit, regis et curie sigillum, qui in vice eius remanserit, illi dimittat, ut sicut regis una est curia, et ita unum sigillum persistat. Domi vero comes idem quamdiu manserit, super neminem sigillum mittat, nisi super eos dumtaxat, qui vocantur udornic et qui spontanea voluntate iverint ad eum, illi ei liceat iudicare. Quod si aliter fecerit, LV pensas solvat." Závodszky 1904. 174. Magyarul: ÍFMT 89. (Körmendi Tamás ford.)

154 „In quamcumquel civitatis megam rex digrediatur ibi iudices II megales cum eo co(m)migrent, et qui contenciones populi illius discreto examine dirimant, et ipsi, cum clamor populi ingravescat, a comite palatino diiudicentur.” Závodszky 1904. 188. Magyarul: ÍFMT 182. (Körmendi Tamás ford.)
} 
magának az ispánnak a kivételével. ${ }^{155}$ Itt is azt látjuk, hogy a nádor a királyi udvar bíróságát irányította, hiszen ha a király megérkezik valamelyik megyébe, akkor a két megyei királybíró székétől a nádorispánhoz lehet fellebbezni. Mindez párhuzamot mutat a Hincmar által leírt comes palatii feladatával, aki szintén a királyi udvar bírájaként az alsóbb fokú hatóságok fellebbezési fóruma is volt (ahogy Hincmar leírta: „,a helytelen ítéleteket az igazság ösvényére terelje vissza").

Mindezek alapján feltehetjük, hogy ez a funkció már a kezdetektől fogva a nádorispán fó feladata volt. Annál is inkább, mivel már az ún. „Intelmekben” ${ }^{156}$ is megtalálható az ideális királymodell kapcsán, hogy az udvari ítélkezést lehetőség szerint adja át más bírónak: „valahányszer méltó ügy kerül eléd ítélethozatalra, vagy főbenjáró bünnel vádolt személy ... mondj le róla, hogy az ilyesmit magad ítéld meg, nehogy önnön Királyi méltóságodat egy hozzád méltatlan üggyel való foglalkozás szennyezze be, hanem az efféle dolgot bízd inkább a bírákra, akikre az ilyesmi tartozik ... Óvakodj attól, hogy bíró legyél, örülj viszont annak, hogy király vagy és annak is neveznek." ${ }^{157}$ A király személyét mint az ispánok utáni fellebbezési fórumot szintén említik Szent István törvényei. ${ }^{158}$ A nádor ezen feladatköre tehát nagy valószínűséggel visszavezethető a kezdeti időkre is.

A nádorispánnak gazdasági funkciót is tulajdonít a korábbi szakirodalom, eszerint ő lenne a királyi udvar jövedelmeinek és a királyi birtokoknak a kezelője egészen addig, amíg az udvarispán a 12. század első felétől át nem veszi ebbéli szerepét (néhányan egyenesen úgy látják, hogy a nádor eredendően és elsősorban gazdasági feladatokat látott el a 11. század folyamán). ${ }^{159}$ Minderre közvetlenül ugyanakkor csak egyetlen kortárs adat utal. Kálmán I. törvénykönyvének 36. fejezete finanszírozási kérdésekről szól. Címe: „Bármely vármegyében a királynak ajándékozott lóról, hasonlóképpen a követeknek a nádorispán által fizetendő költségeiröl.” A nádorra vonatkozó rész így hangzik: „Ha fontos hír érkezne a

\footnotetext{
${ }^{155}$ Zsoldos 1991. 21-22.

${ }^{156}$ Az egyetlen hazai királytükörnek Szent István nagyobbik legendája alapján terjedt el ez a népszerủ címe. Késö-középkori kódexekben maradt fent a teljes szövege, és ekkor már rendszeresen Szent István törvényeivel együtt hagyományozódott (Mikó 2011. 140.). A kutatás nem vitatja, hogy a mü István idejében keletkezett, és ha nem is maga a király fogalmazta, tükrözi az általa elfogadott értékrendet. Lásd legújabban még Havas 2004. VII-C.

157 „causa digna iudicari ad te venerit, vel aliquis capitalis sententiae reus, noli ... per te ipsum diiudicare, ne tua Regalis dignitas usurpatione inferiorum negotiorum faedetur, des potius huiusmodi negotium ad iudices mitte, quibus hoc commissum est ... Time esse iudex, gaude vero rex esse et nominari.” Havas 2004. 32-34. Magyarul: Havas 2004. 33-35. (Havas László ford.)

${ }^{158}$ Istv. II/9.: Závodszky 1904. 154. vö.: ÁKÍF 73.

${ }^{159}$ Csak az elmúlt 20 év szakirodalmából idézve: KMTL 473. (Petrovics István szócikke); Zsoldos 1998. 28.; Kristó 1999a. 46.; Korm. rendsz. 16. (a fejezet Font Márta munkája); MaMüL VIII. 79. (Bánki Éva szócikke); Kis 2010. 27.
} 
határispánságba, az ispán irányítson a királyhoz két követet négy hadiménnel; amikor ezek a saját élelmükkel megérkeznek oda, útiköltségüket a nádorispántól kérjék ki, és ugyanennyit a visszaútjukra is." ${ }^{160}$ A gazdasági feladatokat tulajdonképpen ebből az egy adatból vezette le Váczy Péter, egyéb analógiák alapján. A külföldi párhuzamok nem támogatják, hogy a comes palatinusnak gazdasági feladatai is lettek volna. A már említett, késő-frank udvari szervezetet leíró Hincmar egyértelmü módon szétválasztotta a comes palatii és a camerarius funkcióját, utóbbi kapcsán említve a királyi jövedelmek kezelését, ${ }^{161}$ külön kiemelve, hogy a különféle követeknek szóló adományok is a camerarius hatáskörébe tartoznak. ${ }^{162}$ Mindez már Váczy Péternek is feltünt, aki szerint a 11. századi Magyarországon a „kezdetleges kamarai igazgatásnak ... nem volt külön központi szerve” és a magyar példa e tekintetben jóval archaikusabb, mint a nyugatiak. Mivel német analógiák nem támogatják a nádor gazdasági feladatait, ezért „nyilvánvaló, hogy a comes palatii hatásköre nálunk csak a helyi, magyar viszonyok hatása alatt bővült ki a camerarius teendőivel.” Ezzel a magyar palatinus eltávolodva a német mintától - a meroving kori majordomusok szerepköréhez került közelebb. ${ }^{163}$ Váczy szerint István még egy frank-bajor hivatali szervezetet valósított meg, ám a „német példa csak addig bizonyult hatóerőnek, ameddig a német befolyás tartott, tehát I. Géza király koráig bezárólag.” Szent László korától kezdve Szent István udvari szervezete elenyészett, hogy egy, a „magyarság igényeinek” jobban megfelelő lépjen a helyébe. ${ }^{164}$

Váczy szerint tehát István idejében a nádor még nem rendelkezett volna gazdasági hatáskörrel, és így gondolta Györffy György is, aki szerint István idején a királyi jövedelmek kezelője a fötárnok, vagyis camerarius volt, és ő kezelte a király „kamaráját”. ${ }^{65}$ Arra azonban, hogy a 11. század folyamán létezett volna a kamarási poszt, csak egy hamis forrásunk van. Egy kora-újkori másolatban fennmaradt oklevélben István a ravennai kolostor számára rendelt 25 ezüstmárkát a királyi kincstárból (de eadem regali camera nostra). Az oklevél végén megjegyzi, hogy mindezt betartja, és „sem mi, sem utódaink ne mondunk semmiben ellent a fent mondottaknak, és egyetlen kamarás (nullus ... camerarius) vagy

\footnotetext{
160 „De equo donato regi in quolibet comitatu; item de expensis nunciorum per palatinum comitem dandis... Si magna fama marchiam intraverit, comes nuncios II equis exercitualibus IIII ad regem dirigat, qui cum proprio cibo illuc pervenientes, precium viatici sui a palatino comite exigant, et tantumdem ad reditum suum. Závodszky 1904. 188. Magyarul: ÍFMT 182. (Körmendi Tamás ford.)

${ }^{161}$ Hincmarus 15. (16. c.), 17. (22. c.), 22. (32. c.)

162 Hincmarus 17. (22. c.). Tegyük hozzá: itt nem csak a belső küldöttekről lehet szó, mint Kálmán törvényében, hanem a külföldről érkező diplomáciai küldöttségekről is.

${ }^{163}$ Váczy 1938. 52-53.

${ }^{164}$ Váczy 1938. 52.

${ }^{165}$ Györffy 1977. 241.
} 
tanácsadó se merészelje ezt megengedni magának." 166 Az oklevelet valószínűleg egy 1233ban kiadott okmány alapján szövegezték meg. ${ }^{167}$ A királyi kincstárat mint szervezeti egységet ugyan sokszor emlegetik 11. századi hiteles(ebb) forrásokban, ${ }^{168}$ ám egyetlen adat sincs arra nézve, hogy pontosan ki állt az élén, így a nádor ezen funkcióját más pozitív források nem erősítik meg. A krónikás hagyománynak van ugyan egy szöveghelye, amely szerint az 1071. évi nándorfehérvári ostrom után a zsákmány felosztása egy olyan szűk kör tanácsára történt, amibe Bogár fia Radvány is beletartozott, ${ }^{169}$ és ezt a Radványt azonosítani szokták az 1067 körülre keltezett százdi oklevél Radowan nádorával. ${ }^{170}$ Ám egyrészt nem tudhatjuk, hogy 1071-ben is ő viselte-e a nádori tisztséget, másrészt, ha fel is tesszük, hogy így volt, a pénz felosztásában való tanácsadást sokkal inkább betudhatjuk itt egy király körüli szük csoport ráhatásának, mintsem egy gazdasági szerepkörből adódó aszisztálásnak. A gazdasági funkciót bizonyító egyetlen forrás, Kálmán törvénye az útiköltség kifizetéséről, pedig akár az ellenkezőjét is sugallhatná. Hiszen ha természetes, hogy a kincstári kifizetéseket a nádor intézi, minek kellett törvénybe foglalni éppen azt (és csak azt) az egyetlen esetet, hogy a követek költségeit is nála kell elszámolni - a törvényből akár egy kivételt is kiolvashatunk.

A gazdasági funkció meglétét ugyanakkor támogatják olyan logikai érvek, miszerint nincs adat arra nézve, hogy ki irányította az udvart e téren. I. András 1055. évi tihanyi alapítólevele részletesen felsorolja a király környezetében tarózkodókat. Itt olyan - ezek után vagy 150 évig fel nem tünő - világi tisztségeket is találunk, mint lovász (agaso) vagy asztalnok (infertor), továbbá a nádor (comes palatii) mellett ispánok (comes), bíró (iudex) és minister, vagyis szolgálattevő is előfordult. ${ }^{171}$ Annál feltünőbb, hogy ebben az udvartartásban sem találjuk meg a camerariust, vagy olyan személyt, akihez egyértelmü módon hozzá lehetne kapcsolni ezt a szerepet. Úgy tünik tehát, hogy mégis az ismert tisztségek között kell keresni azt, aki betöltötte ezt a feladatot.

A nádornak pedig többszörösen köze volt a királyi udvarhoz, nem csak úgy, mint a király képében ítélkező bíró, hanem úgy is, mint aki a királyi udvarnokoknak és az udvarnokföldekkel kapcsolatos ügyeknek a bírája. ${ }^{172}$ A legvalószínübb feltételezés, hogy ha

\footnotetext{
166 „,nec nos aliquatenus contra praedicta veniamus, nec successores nostri, et nullus aut camerarius sive consiliarius concedere hoc sit ausus." DHA I. 123.

${ }^{167}$ DHA I. 123., RA 10. sz.

${ }^{168}$ DHA I. 40., 162., 218., 285., 305.; Závodszky 1904. 145. (Istv. I/14. tc.), 167. (Lászl. II/1. tc.)

169 „Sed cum thezaurum dividerent, rex cum consilio Vyd et Frank episcopi et Radoan filii Bugar et Ilia, generis Vyd, in quatuor partes divisit" SRH I. 375.

${ }^{170}$ DHA I. 161-162., 185. vö. Szöcs 2007. 76., 79., 90.

${ }^{171}$ DHA I. 152.

${ }^{172}$ Lásd ezzel kapcsolatban a „7.1 - Az udvarnokok feletti joghatóság” c. alfejezetet.
} 
egyrészt a nádorispán volt a királyi udvarszervezet népeinek és földjeinek a bírája, másrészt nem ismerünk olyan tisztséget a 11. századból és a 12. század elejéröl, amelyről egyértelmủen tudnánk, hogy az udvarszervezet gazdasági irányítója volt, akkor a nádornak tulajdonítsunk ilyen szerepet is. De mindez csak logikai úton következik, és Kálmán vonatkozó törvénye is csak egy apró részletkérdésbe enged bepillantást.

Párhuzamként érdemes szemügyre venni, hogy a 12. század első harmadában megjelenő királyi udvarispáni tisztséghez (curialis comes [regis], a későbbi országbíró hivatali előképe), amelyhez már biztosan az udvar gazdasági irányítását köthetjük, milyen feladatok tartoztak. Mivel az udvarispán valószínűleg a nádor gazdasági funkcióját vette át (lásd alább), így feltehetjük, hogy a nádor is hasonló feladatokat látott el. II. Béla 1135-ben írásba foglalta a Hontpázmány nembéli Lampert ispán és családja által 1124/1127 és 1131 között alapított ${ }^{173}$ bozóki monostor birtokait. A monostor az alapításkor megkapta a Hont megyei Pásztó birtokát is, amelyen királyi udvarház állt, és amit még Szent László király adott Lampertnak hozományként, amikor az elvette a király nőtestvérét feleségül. ${ }^{174}$ Az oklevél szerint a volt udvarházba Gyula királyi udvarispán és poroszlója, Donk iktatta be a monostort. ${ }^{175}$ Mivel a többi birtok esetén nem szerepel a királyi udvarispán (comes curialis regis) a birtokba iktatások során, ezért gyaníthatóan azért jelent meg, mert egy királyi udvarházról volt szó, és aminek a magánemberként való eladományozásához is királyi engedélyre volt szüksége, Kálmán egyik törvénye miatt. ${ }^{176}$ Egy másik, keltezetlen, 1151 körül kiadott pannonhalmi oklevél pedig azt meséli el, hogy amikor II. Géza király találkozni készült az ausztriai herceggel, akkor megüzente a pannonhalmi apátnak, hogy adjon neki 40 ezüstmárkát. Az apát visszaüzent, hogy nincs pénze. Erre Henrik udvarispán (Heynricus comes curialis) az apát Oguz nevű kincstárnokát magához rendelte és öt megfenyegetvén elküldte, hogy teljesítse a

\footnotetext{
${ }^{173}$ Az alapítás pontos dátuma nem ismert, ám az oklevél szerint II. István király és Felicián esztergomi érsek idején történt. II. István 1131-ig uralkodott, így a terminus ante quem ez az időpont. A terminus post quemet már nehezebb meghatározni, Felícián 1127-ben bukkan föl először a forrásainkban esztergomi érsekként, viszont az öt megelőző Marcell csak 1124-ben. A közbeeső évek viszonyairól nincs tudomásunk (ha nem számítjuk egy olyan oklevelet, amely 1125-1128 k.-re datálható), így egyértelmủ módon csak az 1127-1131 közé eső időszak jöhet számításba, ám a kezdőpont feltételesen kitolható 1124-ig is. Lásd Archont. 1000-1301. 79-80.

174 „Nonum [ti: predium] vero Paztuch, ubi erat regalis curia, dedit rex Ladislaus comiti Lamperto cum sorore sua, quam dederat ei in uxorem" Az oklevél pontatlan kiadását (CD VII/5. 102-103. vö. RA 59. sz.) néhány részletben az eredeti (DL 5775.) alapján pontosítatta: Körmendi 2001. 109. 25. jz.

175 „Comes autem curialis regis erat Jula, qui pristaldum suum nomine Donk, idem predium predicto coenobio statuit.” DL 5775.

${ }^{176}$ Kálm. I/20. értelmében minden olyan birtokot, amelyet nem Szent István adományozott, csak a közvetlen leszármazottakra vagy a fivérekre lehet örökül hagyni, egyébként szálljon vissza a királyra (Závodszky 1904. 186.). Lampert ispán viszont a monostorra akarta hagyni ezt az udvarházat, ezért volt királyi engedélyre szüksége.
} 
király parancsát. A megrémített kincstárnok azonnal Pozsonyba ment, ott eladta az apátság egy birtokát, és az azért kapott 20 márkát eljuttatta a királyhoz. Mindezért cserébe az apát kapott egy udvarnokföldet két mansióval, amit a király parancsára Henrik udvarispán Csaba nevü poroszlójával adott át neki. ${ }^{177}$ Ez utóbbi eset példa arra, hogy az udvarispán egyszerre felelt a kincstár pénzügyeiért, és az udvarnokföldek iktatásáért. Az udvarnokföldek iktatása tehát mindkét példában megjelenik, és a nádor még a 13. század húszas éveiben is a hivatalához tartozónak mondta az udvarnokföldekkel kapcsolatos perek (vagyis az udvarbirtok-állomány jogi oldalának) intézését. ${ }^{178}$ Megfigyelhető, hogy az udvarispán itt megjelenő udvarnokföldekkel kapcsolatos feladata sem tisztán gazdasági jellegü volt, hanem inkább jogi természetü (a földek iktatását végezte). Az egyik megfogható „gazdasági” funkció tehát abban állt, hogy a nádorispán felelt az udvarnokföldekért, és ezáltal az eladományozásuk szentesítését is ő végezte el. Ahogy az udvarispán eljárt a királyi kincstár pénzügyeiben 1151 körül, úgy tartozhattak bizonyos ki- és befizetések a nádor alá, amint erre Kálmán törvénye is utal. Az viszont bizonyos, hogy a napi jellegü gazdasági teendők ellátását nem személyesen végezte, hanem hivatalnokok révén. Az 1111. évi zobori oklevél bepillantást enged a pénzügyigazgatás alsóbb szintjébe is. Az ítéletlevél a monostor nyitrai vámjövedelmeinek ügyében támadt per kapcsán megjegyzi, hogy Szent István az összes nyitrai vám harmadát a monostornak adta. Ám ezt megsértették ,a királyi kincstár behajtói ... akiket magyarul kálizoknak hívnak”. Az oklevél felsorolja a nevüket is, köztük a volt száznagyukat (centurio), Porcust. A vámjövedelmek elbitorlásában serénykedtek még ,az ispánjaik és pénzbeszedőik [vagy: pénzverőik], mindahányan csak voltak". ${ }^{179}$ Úgy tủnik, hogy a királyi kamara

\footnotetext{
$177, \ldots$ colloquii causa regis ac tocius regni cum duce Austrie habita est. Ad quod cum ut moris est rex cum suis proficisci voluisset, mandavit abbati sancti Martini Raphaeli... ut absque [ulla] dilatione XL marcas argenti examinatissimi mittere non differet. Qui cum nichil argenti se habere dixisset, Heynricus comes curialis dispensatorem abbatis nomine Ogguz accesiri fecit, et illum comminando, ut iussui regis satisfaceret, misit. Qui recedens ivit Posonium et illic uno predio ecclesie vendito, precium videlicet XX marcas regi obtulit. Post paulum vero Abbas, quia rex predictas marcas ab ecclesia mutuo acceperat, diligenter requisivit, et vice illius dati terram cuiusdam udornici cum duabus solummodo mansionibus, que ovili ecclesiae vicina habebatur, impetravit, et ex precepto regis comes Heynricus huius rei prestaldum nomine Caba constituit atque dedit." CAH 60. vö. RA 80. sz.

${ }^{178}$ MES I. 231. (RP 11. sz.)

179 „Institores ... regii fisci, quos Hungarice caliz vocant” „comites eorundem sed et monetarii, quotquot eant, cuncti” CAH 40. Magyarul: uo. 126. (Veszprémy László ford.). Veszprémy a monetarius szó többes számát pénzbeszedőnek fordította, ugyanakkor a szó alapjelentése: pénzverő. Így értelmezték mások is (Kristó 2003a. 45.). Mivel a konkrét behajtókat a szöveg fentebb institores néven emlegette, ezért filológiailag helyesebb, ha itt pénzverőnek fordítanánk a szöveget. Ám történetileg némileg logikátlan: jelen tudásunk szerint a pénzverés királyi jog volt, amit az országban egyetlen helyen (talán Esztergomban) gyakoroltak. Nem világos, hogy a királyi pénzverőknek milyen gyakorlati befolyása lett volna a nyitrai vámok behajtásakor, még akkor is, ha szervezetileg egy egységhez, a királyi kamarához tartoztak mindannyian.
} 
pénzbeszedői ekkor föként a keleti eredetű kálizok voltak, ${ }^{180}$ akiknek az élén - csakúgy, mint egy vármegyében - száznagyok álltak, fölöttük pedig az ispánjaik. Valószínü, hogy ezek az ispánok a nádor joghatósága alá voltak rendelve, és a gazdasági teendők gyakorlati részét levették a nádor válláról. Örá inkább csak a királyi udvar közvetlen pénzkezelése tartozott.

A 12. század első évtizedeiben került sor az udvar, és az udvari bíráskodás átszervezésére. Bizonyos változások már Kálmán uralkodása alatt megkezdődtek, aki arra tett kísérletet, hogy a királyi udvart (végső soron a nádort) tehermentesítse az odafordulóktól. Első törvénykönyvének 2. cikkelye szerint a népet meggyötrik az utazás fáradalmai, ezért nem tudnak minden ügyben a királyi udvarba (curiam regalem) menni. Éppen ezért elrendelte, hogy minden egyházmegyében évente kétszer tartsanak „zsinatokat” (synodum), amelyen az egyházmegye területének ispánjai és a püspökök közösen mondjanak ítéletet. ${ }^{181}$ Ezen ,zsinatokról” egyébként az itt közölteken kívül semmit nem tudunk, így azt sem, hogy a gyakorlatban megvalósultak-e egyáltalán. ${ }^{182}$ Életre hívásuk mindenesetre azt jelzi, hogy egyre többen keresték föl a királyi udvart peres ügyeik elrendezése céljából. Hosszú távú gyakorlati sikere ennek az intézménynek nem lett. A közismerten széles műveltségü és látókörü Kálmán a fenti püspöki elnökletü bíráskodással olyan - népszerü kánongyüjteményben továbbélő korai rendszert másolt, ${ }^{183}$ amelynek a magyar jogéletben nem lett hosszú távú foganatja. Ám annyit leszögezhetünk: egyfajta igény már megjelent a kúriai bíráskodás átszervezésére.

A nádori ítélkezés tehermentesítése végül más formában történt meg. A század elejétől fogva (adatolhatóan II. István uralkodása alatt) ${ }^{184}$ ugyanis egy másik méltóság is megjelent a forrásokban: a királyi udvarispán, latinul curialis comes (regis), amelyből a 13. századi országbírói tisztség eredeztethető, és a szakirodalom általános megállapítása szerint átvette a nádorispán több addigi funcióját is. Ám nem egyértelmű, hogy az udvarispán megjelenése milyen módon hatott ki a nádor bírói feladatkörére. Az bizonyosnak látszik, hogy a nádor egy idő múlva nem a király képében hozott ítéleteket, hanem struktúrálisan kivált a királyi kúriából, és a saját jogán ítélt. Ám a királyi udvar továbbra sem maradt bíró nélkül: a nádor szerepét az udvarispán vette át, aki továbbra is a király képében bíráskodott. A kérdés csak az, hogy az említett változás mikor zajlott le.

A 11-12. századi világi bíráskodás alapvonalát még Hajnik Imre rajzolta meg 1899-ben mejelenő művében. Szerinte a nádor „a XII. század végén, legkésőbb a XIII. elején” vált ki a

\footnotetext{
${ }^{180}$ A kálizokra összefoglalóan: KMTL 314. (Harmatta János szócikke); Kristó 2003a. 45-48.

181 Závodszky 1904. 184.

${ }^{182}$ Ezen rendelkezésekről lásd Gerics-Ladányi 1998. 112-113.

${ }^{183}$ Gerics-Ladányi 1998. 113-115.

${ }^{184}$ Archont. 1000-1301. 26.
} 
királyi kúriából, ekkor vette át ezirányú feladatait az udvarispán, aki a 13. század elejétől kezdve már nevet változtatván a iudex curiae címet viselte. ${ }^{185}$ Ugyanakkor a jelenleg leginkább elfogadott nézet az országbírói tisztség megjelenésével és korai feladataival kapcsolatban Váczy Péter nevéhez köthető. Szerinte a bírói fórumok első nagy átalakítása Kálmán korára tehető, aki gregoriánus szelleméből adódóan a (fentebb már említett) egyházmegyei zsinatokra próbálta terelni a felsőbbfokú bíráskodást. Ez viszont nem ment át hosszú távon a gyakorlatba, ezért II. István, Kálmán fia „egészen más irányba kereste a kérdés megoldását. A nádort felmentette az udvarispáni teendők alól és számára külön országos bírói széket szervezett, míg a királyi jelenlét új bírája az udvarispáni jogkör örököse, a curialis comes lett. Ettől az időtől kezdve a curialis comes töltötte be a nádor helyét a királyi udvarban. Az udvartartás gondjai reá hárultak, ő vette kezébe nemcsak az udvar, hanem a királyság pénzügyeinek a vezetését. A kincstárt is ő kezelte.” Váczy azért tette a tisztség megjelenését II. István korára, mivel az első király melletti udvarispánnak, Gyulának a müködése visszamenőlegesen 1127 és 1131 közé keltezhető egy későbbi adat alapján, viszont a Kálmán idején 1111-ben és 1113-ban kiadott zobori oklevelek tanúnévsorában még nem található ilyen poszt, ,pedig ezek az oklevelek a méltóságok teljes felsorolását adják”. Váczy hozzátette azt is, hogy a nádori és az udvarispáni tisztség különválása csak 1138-tól (tehát II. Béla korától) adatolható biztosan. ${ }^{186}$ Hogy az udvarispán átvette a nádor funkcióit, arra bizonyítékként felhozta az 1222. évi Aranybulla 9. cikkelyét, amely szerint az udvarispán, amíg a királyi udvarban tartózkodik, bárki fölött ítélhet, ám saját birtokára hazamenve nem küldhet poroszlót. Ez a cikkely párhuzamba állítható Szent László III. dekrétumának már idézett helyével, amely szerint a nádor is bárki felett ítélhet a királyi udvarban, de saját birtokán nem bíráskodhat szabadon. Váczy kiemelte és 13. századi példákkal igazolta azt is, hogy az országbíró a jelentéstételt a királyhoz címezteti, továbbá a poroszlói teendőkkel is a király emberét bízta meg. ${ }^{187}$ A szerző vitába szállt Hajnik elképzelésével is, szerinte tévedés, hogy a nádor kiválása csak a 12-13. század fordulóján ment volna végbe: „Hajnikot az Arany Bulla 8. pontja vezette félre, hol a nádor saját kuriájáról van szó ... Saját udvari bíráskodása azonban már előbb is volt, amikor a király nevében ítélkezett. A királyi kuriából nem vált ki, csak külön bírói széket kapott”" ${ }^{\circledR 88}$ Váczy nézetét lényegében elfogadta a kutatás, lényegesen

\footnotetext{
${ }^{185}$ Hajnik 1899. 8-9., 33. Hajnik véleményét vette át pl. Nyers 1934. 4.

${ }^{186}$ Váczy 1938. 56-57.

${ }^{187}$ Váczy 1938. 58.

${ }^{188}$ Uo. 58-59. 5. jz.
} 
más modellel nem is nagyon találkozunk a mérvadó történetírásban, ${ }^{189}$ néhány óvatosabb megfogalmazást leszámítva. ${ }^{190}$ A kortárs szakirodalomban egyedül Csukovits Enikő tette határozottan a 13. századra az időpontot. ${ }^{191}$

Véleményünk szerint Váczy a szükös források ellenére túlságosan is biztos kontúrokkal rajzolta meg a nádor és az udvarispán szétválásának folyamatát és korai funkcióikat. Kérdéses, hogy miért tulajdonított ő udvarbírói szerepet is a comes curialisnak. ${ }^{192}$ Azaz miért vélte úgy, hogy az udvari bíráskodásban már a 12. század első felében átvette a nádor helyét? Fentebb ismertetett összefoglalásában Váczy hozott példát a 12. századi forrásokból az udvarispán gazdasági müködésére, ám arra, hogy ítélkező szerepet is betöltött volna, csak 1314. századi példákat idézett. Abból a korból, amikor már az udvarispán (illetve akkor már az új nevén: országbíró) vitán felül átvette a nádor helyét a királyi udvarban, és ezeket a példákat vetítette vissza a 12. századba. Váczy a következőképpen vázolta föl az új helyzetet: „A királyi kúriának egysége az új reformok [ti. II. István reformjai] következtében megtört: a király nevében működő praesentia regia bírósága mellett ott találjuk a nádor országos jellegü bíráskodását is. A királyi udvarban külön bírói széke áll, elsősorban azonban saját portáján, vagy a megyékben utazgatva, gyakorolja a bírói hatalmát. Ezzel feleslegessé tette a Kálmán-

\footnotetext{
${ }^{189}$ Pl.: Bertényi 1976. 52.; MT I/2 1174. (a vonatkozó rész Kristó Gyula munkája); KMTL 511. (Petrovics István szócikke); Solymosi 2002. 521-522.; Korm. rendsz. 35. (a vonatkozó rész Font Márta munkája); Tóth 2007. 78.; MaMüL VIII. 79. (Bánki Éva szócikke); Kis 2010. 27-28.

${ }^{190}$ Gerics József - Váczy ezen tanulmányára hivatkozva! - a következőképpen foglalt állást 1962-ben: „[az udvarispán] Feladata ekkoriban [ti. a 12. század első felében] a királyi udvartartás és a pénzügyek intézése lehetett, csakúgy, mint korábban az utóbb országos bírósággá fejlödött nádoré. A curialis comes későbbi bírói hatóságának kialakulása szintén a nádoréhoz hasonló módon mehetett végbe: a királyi jelenléti bíráskodásnak alkalmi megbízásokból való képviselete alapján. Miután a XIII. század elején feltűnő tárnokmester átvette tőle az udvartartás gondját, hamarosan tisztségének új elnevezésével, a »judex curiae«-vel találkozhatunk 1219-ben.” (Gerics 1962. 651.). Gerics 1966-ban már azt írta, hogy a „nádor önálló bíráskodása a 12. században alakult ki és ezt a tényt törvényesen az 1222. évi Aranybulla rögzítette.” (Gerics 1966. 285.). Bertényi Iván egy 1996-os népszerüsítő-ismeretterjesztő írásában a következőképpen foglalt állást, már egyértelmübb módon: „[az országbíró] Elöször a gazdasági teendőket vette le a nádor válláról, majd miután a királyi birtokok felügyeletével, valamint a tárnokok, a kialakuló királyi városok szolgáltatásainak a kezelésével megbízott királyi tárnokmester tisztsége is létrejött, az országbíró az uralkodó székhelyén müködő állandó bíróság, a királyi jelenlét (praesentia regis) vezetője lett." (Bertényi 1996. 9.). Ezzel lényegében azt állította, hogy a curialis comes (a későbbi országbíró) csak a 13. század elejétől vette át a királyi udvarban a bírói teendőket, addig csak gazdasági feladatai voltak, hiszen a tárnokmesteri tisztség ekkortól adatolható. Szovák Kornél összefoglalóan csak annyit írt, hogy a „király ad hoc jellegủ helyettesítéséből ekkorra [ti. a 13. sz. elejére] kifejlődik a nádor önálló joghatósága" (Szovák 1989. 299.). Ám hogy a folyamat szerinte mikor zajlott le, abban itt nem nyilvánított véleményt. Zsoldos Attila ugyancsak annyit írt, hogy a 12. század első felében a nádornak a bírói tevékenysége került elötérbe, és a „század folyamán a nádori tisztség elszakadt a királyi udvartól”. De hogy ez már a 12. század első felétől megtörtént-e, azt nem hangsúlyozta ki (Zsoldos 1997a. 124.).

${ }^{191}$ Csukovits 2012. 85.: „A királyi jelenlét (praesentia regia) bírósága a 13. században került az országbíró kezébe" - írta. Bár nem hangsúlyozta ki, ez a nádori bíráskodás kiválását is ugyanerre az időpontra feltételezi.

${ }^{192}$ „a királyi jelenlét új bírája az udvarispáni jogkör örököse, a curialis comes lett” Váczy 1938. 56-57.
} 
féle szinodális bíráskodást, hiszen a szinodus-törvényszékeknek épp az volt a céljuk, hogy a perek nagy részét mint felsőbb vidéki fórum ne engedje a királyi jelenlét bírósága elé." Továbbá a nádor a „királyi kuriából nem vált ki, csak külön bírói széket kapott és bár tevékenysége nagyobb részt az udvaron kívül folyt le, mihelyt oly ügyek merültek fel, melyeket csak a király tudtával igazíthatott el, máshol, mint a királyi kuriában nem is tarthatott törvényszéket. Ilyenkor a per áttétele in curiam regiam, nostram in presenciam [a királyi udvarba a mi, ti. a nádor színe elé] történt." ${ }^{193}$ Váczy tehát egy olyan külön bírói intézményt vázolt föl, ahol a nádor még vegyesen a királyi udvarban, ám a presenciális bíráskodástól függetlenül ült törvényt, de főként vidéken ítélkezett, a meg nem valósult megyei zsinatokat kiváltandó.

Azonban a forrásokból egyrészt nem mutatható ki, hogy a 12. században a nádor kiszakadt volna a király környezetéből, hanem éppúgy az udvarban tartózkodott, mint az udvarispán. Ebben az időben ugyanis a királyi oklevelek végén nem rutinszerűen sorolják még föl az ország fontosabb tisztségviselőit, hanem tényleges tanúnévsort látunk: az a személy szerepel ott, aki tényleg jelen volt az okmány kiállításakor és jelenlétével is igazolni tudja annak hitelességét. Először III. István egy 1171. évi oklevelében tértek el ettől a rendszertől, ahol már mint „viventibus”, azaz ekkor élőként sorolták föl a méltóságviselőket. ${ }^{194}$ III. Béla korában, az 1180-as évek elejétől kezdve úgy tünik, hogy egyre gyakoribb a puszta felsorolás, „existentibus” bevezetéssel (bár Kristó Gyula szerint csak 1192-től érvényesül következetesen az az elv, hogy a távollévőket is odaírták volna az okleveles méltóságsorokba). ${ }^{195}$ Ha a tanúk jelen voltak, azt külön jelezték. ${ }^{196}$ Az automatikus felsorolást tartalmazó oklevelek (amelyek megjelenése egybeesett a királyi kancellária megszervezésének híres reformjával) nem jelentik azt, hogy az ottani méltóságok ne lettek volna jelen a király környezetében, ám bizonyítani nem tudjuk. Így ha 1180-ig nézzük át a királyi (tehát a királyi udvarban kiállított) oklevelek tanúnévsorait a curialis comes tisztség első felbukkanásától kezdve, ${ }^{197}$ akkor 37 olyan oklevelet találunk, amelynek a végén említik, hogy kik voltak jelen a kiállításakor. Ebből 6 hamis. ${ }^{198}$ A maradék 31 oklevélben 20 olyan

\footnotetext{
${ }^{193}$ Váczy 1938. 58-59. ill. 58. 5. jz.

${ }^{194}$ RA 116. sz.

${ }^{195}$ Kristó 1979. 111.

${ }^{196}$ Pl. RA 129. sz. (1178, de hamis), RA 131. sz. (1181), 136. sz. (1183), 138. sz. (1183), 140. sz. (1185) stb. existentibus vagy gubernante megjelöléssel. Ugyanekkor tanúként és jelenlévőként jelzi RA 130. sz. (1181), 133. sz. (1181), 137. sz. (1183).

${ }^{197}$ RA 59-129. sz.

${ }^{198}$ RA 60., 62., 66., 71., 87., 94. sz.
} 
esetet találunk, ahol együtt említik a palatinus és a curialis comest. ${ }^{199} 4$ alkalommal csak a nádorispánt, ${ }^{200}$ és 6 olyan oklevelünk is van, ahol egyiküket sem. ${ }^{201}$ Mindössze egyetlen olyan tanúnévsort találunk, ahol az udvarispán jelen van, a nádor pedig nem. ${ }^{202}$ Továbbá a csatári monostor alapításáról szóló II. Géza-kori oklevél is II. Béla környezetében említi Fancsal udvarispánt (a volt nádort) úgy, hogy nádort nem nevez meg. ${ }^{203}$ Bár az itteni számok nyilván nem jeleznek pontos arányokat arról, hogy az egyes előkelők milyen gyakorisággal tartózkodtak a királyi udvarban, de azt biztosan állíthatjuk, hogy a nádorispán az 1130-as és 1180-as évek között szinte mindig a király környezetében tartózkodott (tanúskodott), és az udvarispán úgyszintén.

Másrészt a 12. századból egyetlen adatot sem találunk arra, hogy az udvarispán átvette volna a királyi jelenlét bíróságát, és ilyen minőségben az udvar bírája lett volna. Az udvarispán a forrásokban többnyire csak említés szintjén (tanúként) jelent meg, néhány olyan adatunk van csak, amelyben valamilyen konkrét feladatot hajtott végre. Ha a hamis okleveleket nem számítjuk ide, ${ }^{204}$ akkor négy oklevelben találunk adatot valamilyen tevékenységéről. Ezek közül két oklevelet fentebb már tárgyaltunk, amelyekből gazdasági funkciójára következtethetünk (a bozóki monostor alapításáról szóló okirat, és a 12. század közepi pannonhalmi oklevél. Ezekben királyi udvarbirtokokat iktatott és a kincstár számára kölcsönügyletet intézett). ${ }^{205} \mathrm{~A}$ másik két oklevél látszólag ellentmond az általunk hangoztatottaknak, mert azokban az udvarispán bíróként járt el. Ám csak látszólag mond ellent, mert ezek az ítéletek más ítélőtársakkal (köztük a nádorral) együtt zajlottak, a király külön parancsára. Az ítéletlevelek megfogalmazásán jól látszik, hogy egyik méltóságviselő sem hivatalból járt el, hanem a király által tekintélyüknél fogva megbízott bírókként. 1152-

\footnotetext{
199 RA 73., 76-78., 82., 84-85., 101., 104-108., 110-112., 117., 120., 123., 126. sz. Ezek közül jó néhány alkalommal nincs a titulus kiírva teljesen, ám a személynévből következtethetünk a két méltóságviselő egyidejü jelenlétére. Pl. II. Géza okleveleiben Belos hol csak bán, hol csak nádor, hol nádor és bán méltósággal jelenik meg. Ugyanez a helyzet III. István alatt Ompod nádorral és bánnal. Máskor az udvarispán csak szimpla „comes” titulussal jelenik meg, de más oklevelek alapján ott is kikövetkeztethető, hogy valójában az udvarispán cím hiányos kiírásáról, és nem váratlan rangvesztésről, majd visszanyerésről volt szó (RA 76., 111., 117. sz.).

${ }^{200}$ RA 63., 72., 102., 113. sz.

${ }^{201}$ RA 69., 90-92., 103., 128. sz. Három oklevélben (RA 90-92. sz.), melyek keletje 1158-ra, vagy akörülre tehető csak Apa bánt említik, és talán feltételezhető, hogy a nádori hivatalt is viselte, mindamellett nem számoltuk a nádort említő oklevelek közé.

${ }^{202}$ RA 86. sz.

${ }^{203}$ Fejérpataky 1893. 14.

${ }^{204}$ RA 60., 71., 87., 94., 119., 123., 146., 148., 157., 159. sz. Hamis és több anakronizmust tartalmaz az a két oklevél is, amelyeket Mihály scardonai püspök nevében állítottak ki 1181. ill. 1189. évi dátummal, és amelyekben említik Makariás országbírót, akit semmilyen más oklevél nem ismer ezen a címen. Lásd ÁÚO VI. 145-146.; CD II. 247-248. ill. VII/1. 178-179. vö. Archont. 1000-1301. 27.

${ }^{205}$ CD VII/5. 102-103. vö. RA 59. sz.; CAH 60. vö. RA 80. sz.; ill. lásd még fentebb.
} 
ben Belos nádorispán, Henrik udvarispán, János ispán, István ispán és Jeromos ispán ítéltek a veszprémi egyház és szolgái ügyében. 1184-ben pedig a király által megbízott Dénes nádorispán, Charena udvarispán és Achilleus ispán mondott ítéletet az esztergomi királyi udvarnokok és a tihanyi egyház közötti perben. ${ }^{206}$ Ezekből az adatokból az udvarispán uralkodót helyettesítő bírói jogköre tehát éppen úgy nem következik, ahogy a többi felsorolt bírónak sem tulajdoníthatunk (legalábbis ezen források alapján) ilyen funkciót. Az udvarispánról tehát nagy vonalakban az deríthető ki a források alapján, hogy a 12. században főként a királyi udvarban tartózkodott, a királyi udvarszervezet földbirtokaiért és a királyi kincstárért felelt, alkalmanként pedig a király megbízásából bírói teendőket is ellátott tekintélyénél fogva.

Mi deríthető ki a 12. századi nádorról? Fentebb már szó esett róla, hogy a tanúsorok alapján javarészt ő is a királyi udvarban tartózkodott. Olyan konkrét adat, amely gazdasági jellegü tevékenységéről szólna, nincs, ellenben többször is feltűnik a király által megbízott bíróként. Ezeket az okleveleket még más hatóságok (a király, káptalan) foglalták írásba. Abból a szempontból különlegesnek tekinthetők, hogy valamennyi egy egyház, és a királyi népelemek közötti konfliktusról szól, ahol a bírák nem „,rutinszerüen” ítéltek, hanem külön királyi parancsra (kettőt közülük már említettünk az udvarispán kapcsán). 1131-re szokás keltezni II. Béla azon oklevelét, amelyben a bakonybéli monostor és Opus, az udvarnokok ispánja közötti vitát döntötte el Sár ispán és Foncsol nádorispán, négy másik főemberrel és egy poroszlóval egyetemben. Az oklevél kiemeli, hogy Béla király az ügyet Sár ispán kezébe adta, és a döntésnél jelen volt bírótársként öt főember (principes), köztük első helyen említve a nádor - tehát nem is ő volt a föbíró. ${ }^{207}$ Szintén királyi parancsra járt el öt előkelő, köztük Belos nádor 1152-ben. Az oklevél szerint „,a király szolgái a király elé tárták ügyüket, amely szerint több egyháznak és ezen föld nemeseinek az emberei közül többeket a saját társaiknak nyilvánítottak ki. Ugyanezen ügyben a király megbízásából Belos nádorispán, Henrik udvarispán, János ispán, István ispán és Jeromos ispán ítélkezett.” A mezősomlói Szent István egyházban összegyűlő előkelők tüzesvas-próbát rendeltek, majd a név szerint nevezett embereket a veszprémi egyház szolgáinak ítélték. ${ }^{208}$ Itt is látszik, hogy az előkelők nem saját

\footnotetext{
206 1152: CAH 61-62.; 1184: CAH 90.

207 „Qui [ti. a király] precepit, ut causa diligentissime inquireretur, iudicemque Sar comitem dedit; quorum diffinicioni interfuerunt principes Fonsol scilicet palatinus comes, Mutmer, Mahal, Janus, Marcus, pristaldus vero Butca extitit” CAH 48. vö.: RA 57. sz.

208 „servi regis ex multarum ecclesiarum atque noblium [hu]ius terre hominibus soci[o]s sibi vendicare vol[entes], causam suam regi manifestaverunt. Eadem causa iud[i]cio Beli palatini comit[is], et Hendrici curialis comiti[s] et Iohannis comitis et Stephani comitis atque Iheronimi comitis, [a] rege commissa est." CAH 61. vö.: RA 81. sz. A Mezeusumlu formában említett Mezősomlyó Temes megyében található.
} 
jogkörükből fakadóan bíráskodtak, bár közülük már a nádort sorolták fel első helyen. A fehérvári káptalan 1184-ben kiadott oklevele szerint az esztergomi királyi udvarnokok és a tihanyi egyház közötti perben a Béla király által kirendelt Dénes nádorispán, Charena udvarispán és Achilleus ispán mondott ítéletet. Hogy a három bíró szintén nem hivatalból, hanem külön királyi parancsra ítélt, azt maga az oklevél szövege árulja el. ${ }^{209}$ Bár ezekben az oklevelekben az egyik félként mindig a királynak alávetett (tehát elvileg a nádorispáni jogkör alá eső) népek szerepelnek, Kis Péter már helyesen hívta föl a figyelmet arra, hogy itt a nádor csak mint a királyi udvar legtekintélyesebb bírája jelenik meg. Hiszen „itt nem az udvarnokok egymás közti peréről, hanem egyes, királyi alapítású egyházakat érintő, udvarnokok (királyi szolgák), azaz eltérő jogállású felek részvételével zajló státusperekről van szó. ${ }^{, 10}$ De nem csak ilyenekről. Ezidőtájt, 1181-ben erősített meg III. Béla Farkas nádor ítéletét. Az ügyben a nádor szintén külön királyi megbízásra járt el, ám a fentiekkel ellentétben egyrészt egyedül, bírótársak nélkül (az oklevél legalábbis nem ejt szót másokról), másrészt az ügynek nem voltak királyi szolgálónépekkel kapcsolatos vonatkozásai. A Szamos melletti Szűz Mária monostor néhány jobbágya elszökvén Tatárhoz és Maradék fia Pálhoz menekült, mire a monostorbeliek a király előtt kérték őket vissza a maguk számára. „.. mi nekik Farkas nádorispánt jelöltük bírónak, akinek törvényes ítélete alapján megparancsoltuk Gyárfás fiának, Pósa poroszlónak, hogy a mondott jobbágyokat vitesse vissza az egyház földjére...” Ezután részletesen leírta a föld határait is. ${ }^{211}$

A fenti ügyek sajnos nem a nádorispán hivatali kötelességeiről adnak képet, hanem arról, hogy tekintélyénél fogva külön királyi engedéllyel egyéb ügyekben is eljárt. Ám méginkább megerősítik azt, hogy zömében a király környezetében tartózkodott, így Váczy Péter azon feltevése, hogy már a 12. század első felében számolhatunk az önálló nádori ítélőszék egyik fontos ismérvével, a nádor királyi udvaron kívüli (régies jogtörténeti kifejezéssel szólva: „vidéki”) bíráskodásával, nem tartható. Valószínűbb az, hogy a II. István (Kálmán?) idején lezajlott reform nem szervezett még önálló bírói széket a nádornak, hanem csak a gazdasági feladataitól tehermentesítette. Így az udvarispán lett a gazdasági ügyek intézője, a nádorispán

\footnotetext{
209 ,ad iudicium determinando prememoratorum comitum, Dyonisii videlicet, Charene et Achilley, quibus id rex discuciendum comiserat" CAH 90.

${ }^{210}$ Kis 2010. 30 .

211 „Noscat igitur omnis in Christo renatus, quod cum quidam iobagiones monosterii (!) gloriose dei genitricis semperque virginis Marie, quod Kulchey comes iuxta fluvium Zamos fondavit, ad Tatar et ad Paulum filium Maradek, fugissent et eos filii predicti monosterii Stephanus scilicet et Konchi filii Petri et Achileus filius Achilei in presentia nostra requirerunt, nos eis Farkasium palatinum comitem iudicem constituimus, cuius iusto mediante iudicio per prestaldum nostrum Posam scilicet filium Geruasii super dictos iobagiones ad terram ecclesie in villa Geruley, de qua prius fugierant, precepimus redigi.” RA 133. sz., amely az oklevél kiadása is. Magyarul: Helyt. olv. 19. (Spekner Enikő ford.)
} 
pedig a királyi jelenlét bíróságának a feje, továbbra is a király képében bíráskodva. A királyi udvarból való kiválása pedig csak a 12-13. század fordulójára tehető, ahogyan azt eredetileg is feltételezték. Ezzel mellesleg helyreállt az a modell, amely Nyugat-Európát jellemezte, és ami talán ideiglenesen Szent István udvarára is jellemző volt: a comes palatinus kizárólag a király képében való bíráskodással foglalkozik, az udvar gazdasági ügyeivel nem. Már Váczy Péter is jól vette észre, hogy a gazdasági funkciót magyar sajátosságnak kell tartani. ${ }^{212}$ A 12 . század elejétől megtörtént az első lépés egy „nyugatibb” udvari szervezet felé azzal, hogy a nádor gazdasági feladatait átvette a királyi udvarispán, így ő kizárólagosan a bírói teendőire koncentrálhatott - ez is az udvari bíróság egyfajta „kapacitásnövelését” jelenti.

Ezek után lényeges kérdés, hogy mikor történt meg az önálló nádori bírói szék létrehozása, azaz a nádorispán kiválása a királyi prezenciális bíróságból. A létrejöttének pontos ideje nem ismert. Azt az időpillanatot viszont, amikor már biztosan létezett, meg lehet mondani. Imre király 1201-ben a pataki hospeseknek többek között azt a kiváltságot adta, hogy ha nem tudják peres ügyeiket a maguk által választott elöljáróval elrendezni, akkor semmilyen más világi hatóság, csak a nádorispán, vagy a király bírói vizsgálata alá tartozzanak. $^{213}$ Hasonló módon erősítette meg II. András a bátyja egy 1204. évi kiváltságát, eszerint a megadományozott Jánosnak csak a király és a nádorispán elé kell járulnia. ${ }^{214} 1209$ ben II. András Adolf prépostot adományozta meg egy szepesi földdel, és olyan kiváltsággal is, hogy az általuk telepítettek felett senki ne merészeljen ítélkezni, kivéve a királyt és a nádort, vagy akit a prépost kérésére majd kirendel neki a király. ${ }^{215}$ Ha a nádor még ekkor is a király képében ítélkezett volna, akkor felesleges lett volna kiemelni az ő ítélőszékét, hiszen az a királyéval lenne egyenlő. A 13. század legelején tehát a nádori ítélőszék már nem volt azonos a királyéval. Olyan pontos évet sajnos nem tudunk mondani, amikor még biztosan azonos volt a kettő, de a fenti, udvarispánnal kapcsolatos gondolatmenet helyessége esetén kb. az 1180-as évekig még ezzel lehet számolni. Így a nádor kiválását a királyi prezenciális bíróságból és önálló bírói hatósággá emelkedését első körben III. Béla vagy Imre uralkodásának idejére, a 12. század végére tehetjük. Némi feltételezéssel azonban ez az

\footnotetext{
${ }^{212}$ Váczy 1938. 52-53.

213 „,concessimus statuentes, ut secundum sue gentis consuetudinem ab electo inter se iudicentur preposito, quo propter negociorum difficultatem non sufficiente, palatini comitis sive regis subeant iudiciumm[!], nec in secularibus alios habeant” Elenchus III/2. 22. vö. RA 194. sz. Hogy a kiváltságlevélben megjelölt Potok pontosan melyik mai településsel azonosítható, vitatottnak számít. Historiográfiai hátterét lásd Szende 2011. 33. 39. jz.

214 „in placito ad nullius iudicis adstet presensiam preter regie maiestatis et comitis palatini” ÁÚO XI. 84., RA 223. sz. (Imre adománya: ÁÚO I. 92., RA 210. sz.)

215 ,populos, quos collegerint vel unicuique adduxerint, nullus presumat iudicare inquietare excepto nobis et palatino, vel cui ad preces eiusdem prepositi et suorum heredum preceperimus” Bártfai 1907. 66. vö. RA 243. sz.
} 
időpont is tovább szükíthető. Nem lehetetlen ugyanis, hogy mindez összefüggött azzal a III. Béla korában kezdődő gyakorlattal, hogy egyes nagyobb hivatalok viselői egy-egy vármegye ispáni címét is megkapták. A nádorsághoz kezdetben a bácsi ispánság kapcsolódott, és 1192től egészen 1200-ig a mindenkori nádor bácsi ispán is volt egyben. ${ }^{216}$ Kezdetben mindez egy szervezett rendszert mutatott. ${ }^{217}$ Kérdés, hogy nem köthetjük-e ehhez a reformhoz az önálló nádori ítélőszék megszervezését? Néhány halvány nyom esetleg megengedi az igenlő választ. A nádori tisztség párosítása a bácsi ispánsággal 1192-ben történt meg, ugyanettől az évtől az udvarispán is kapott egy megyésispáni címet. Szintén 1192-ben kelt a veszprémi egyház mára már csak kora-újkori másolatban ismert kirografált oklevele a Hahót nemzetséghez tartozó Hahót miles két birtokpere kapcsán. Mindkét birtokperben Mog nádor ítélt. Hahót elöször Parisszal pereskedett, akitől megvásárolta a két birtokot, ám az egyik kapcsán a zalai várjobbágyok az eladott föld egy részét magukénak mondták. Hahót erre poroszlót véve maga mellé, Mog nádor elé idézte Parist. Ö elmondta, hogy nem eladta, csak zálogba adta a földet, mire Hahót hivatkozott István zalai ispán tanúságára, aki bizonyítani tudná az eladás tényét. A nádor maga elé idézte az ispánt, aki Hahót igazát bizonyította. A másik megvásárolt birtokot a zalai királyi udvarnokok próbálták elvitatni Hahóttól, és „ezen ügy pere is egészen Mog nádor színéig jutott” (huius rei controversia protensa est usque ad praesentiam palatini comitis Mochu). Az udvarnokok azt állították, hogy már volt egy per ez ügyben Tamás ispán előtt, és nekik lett igazuk, amit a per akkori poroszlója is bizonyíthat. A nádor maga elé rendelte a poroszlót, de ő azt állította, hogy sosem volt ilyesféle ügy tanúja. Így az udvarnokok elveszítették a pert, és Hahóté lett a 300 holdnyi föld, 10 háznép libertinusszal. A két pert a veszprémi egyházban foglalták írásba. ${ }^{218} \mathrm{Az}$ eset merőben különbözik az eddigi nádori ítélkezéseket magukba foglaló oklevelektől. Egyrészt nagyon úgy tűnik, hogy itt nem a király külön parancsára történő speciális ítélkezésről volt szó. Másrészt ez az első olyan nem királyi oklevél, amely kizárólag világiakat érintő jogi cselekményt rögzített, ${ }^{219}$ ráadásul az első perben kizárólag szabad jogállású felek ügyében ítélt a nádor. Elvi szinten nem zárhatjuk ki, hogy ez az ítélkezés a királyi udvarban, a király képében zajlott le, de erre a szövegben semmi nem utal. Ez utóbbi azért feltűnő, mert a királyi udvarban lezajló ítéleteket vagy rögtön a király nevében foglalták írásba, vagy ha más, egyházi hatóság állított ki erről oklevelet, akkor megemlítették a királyt, ám itt csak a nádorra hivatkoztak. Elképzelhető tehát, hogy az ispáni

\footnotetext{
${ }^{216}$ Archont. 1000-1301. 16-17.

${ }^{217}$ A kérdés részletes kifejtését lásd a „10 - A nádori hivatal jövedelmei” c. fejezetben.

${ }^{218}$ Az oklevél kiadása: Veszprém: pótkötet 53-54. (az idézett rész: 54.)

${ }^{219}$ Solymosi 1984. 108. (az esetröl bővebben uo. 107-109.)
} 
címet is elsőnek elnyerő Mog abban is első volt, hogy önálló nádori ítélőszéket kapott, és Hahót comes két ügyét tekinthetjük a saját jogú nádori bíráskodás első (két) ismert esetének. Ezek alapján a királyi udvar prezenciális bíróságát az udvarispánnak kellett átvennie. Hogy történt valami változás az udvarispáni teendők körül, arra az utal, hogy néhány évvel később, 1198-ban megjelent a kamarási poszt is. ${ }^{220}$ A poszt elszórtan ugyan már a 12. század korábbi időszakából is adatolható, ${ }^{221}$ de sosem tudott meggyökeresedni. A 13. század első felére viszont állandósult. Ekkor tehát már kellett egy olyan tisztség, amelynek betöltője a királyi kincstárat kezeli. Nyilván azért, mert az udvarispán már nem tudta ellátni ezt a feladatot, hiszen más állandó teendői akadtak: bizonnyal a királyi jelenlét bíróságának a vezetése. Ha ez korábban is az ő feladata lett volna, valószínüleg már korábban állandósult volna az a külön tisztség is, amely az udvar pénzügyeit kezelte.

Az önálló nádori ítélöszék megszervezése tehát feltételesen III. Béla 1192. évi hivatali reformjaihoz köthető. Kérdés, hogy ezzel a feltételezett időponttal nem áll-e ellentmondásban az a terminológiai tény, hogy az „udvarispán” (curialis comes) neve csak 1219-1220-tól kezdve alakult át az „udvarbíró” (iudex curie) elnevezéssé. ${ }^{222}$ Mert ez látszólag azt sugallja, hogy az udvarispán feladata csak ekkor változott meg, és ekkortájt vette át a nádor szerepét, vagyis nem tudjuk, hogy a két időpont között található legkevesebb 20 évben ki lehetett a királyi kúria bírája. A lehetséges válaszhoz figyelembe kell venni azt, hogy 1220 körül egy újabb közigazgatási reform betetőzésének lehetünk tanúi. Az már a korábbi szakirodalomban is feltünt, hogy ekkor II. András átszervezéseket hajtott végre a közigazgatásban. Nógrády Árpád úgy fogalmazott, hogy a „világi politikai elit jelentős átszervezésére 1219-20 táján került sor". Nógrády a szentföldi távvollét okozta belpolitikai válsággal vont összefüggést, és András arra adott válaszával. Ekkortól kezdődött ugyanis az egyéb udvari tisztségek (lovász-, pohárnok- és étekfogómester) felemelkedése, illetve ezen udvari tisztségek megyésispánságokkal történő párosítása is. ${ }^{223} \mathrm{Ha}$ a nádori intézményt tágabban érintő változásokra koncentrálunk, akkor azt látjuk, hogy 1219-ben Barc fia Miklós lett az új nádor, akinek müködési gyakorlatában több új elemet is találunk. Egyrészt nagyon úgy tủnik, hogy ekkortájt szervezték meg az alnádori intézményt. ${ }^{224}$ 1219-től indult meg a nádori ítéletlevélkibocsátás folyamata is (addig a nádorok mindig más hatósággal foglaltatták írásba

\footnotetext{
${ }^{220}$ Archont 1000-1301. 62.

${ }^{221}$ Archont 1000-1301. 61.

${ }^{222}$ Váczy 1938. 57. 5. jz. Tegyük hozzá: a királyi oklevelek méltóságsorai konzervatívabbak, és ott csak később jelenik meg a váltás az elnevezésekben, és csak lassan tudott állandósulni.

${ }^{223}$ Nógrády 1995. 180.

${ }^{224}$ Lásd a „4.1 - A tatárjárásig terjedő időszak: a »mobilis nádorok«”, és a „8.1 - A nádort helyettesítő tisztségek: alnádor, nádori albíró” c. alfejezeteket.
} 
döntéseiket, és csak a hivatali ügyintézésre használták az írásbeliséget). ${ }^{225}$ Mindezzel párhuzamosan változott meg a királyi udvar ispánjának a neve a fentebb ismertetett módon. Zsoldos Attila II. András politikáját elemezve arra a következtetésre jutott, hogy itt egy királyhoz hű elit kiépítésének lehetünk tanúi, akik hatalmát András a megyésispánok rovására növelte. Az új elit hivatalai (asztalnok-, lovász-, pohárnokmester) mellesleg megnevezésében is elkülönültek a comes névvel illetett ispánoktól, és a magister kifejezést használták rájuk, és ekkor alakult át a nádorispán latin megnevezése szimpla palatinusszá, és lett a curialis comesből iudex curie. ${ }^{226}$ A comes-tag lekopása a palatinus mellöl ugyan egy kicsit korábban kezdődő, hosszadalmasabb és összetettebb folyamat volt annál, hullámzó tendenciákkal, hogy csak ennek a terminológiai különválasztásnak tudjuk be, ${ }^{227}$ de ez nem jelenti azt, hogy a folyamat alakulásában ennek ne lett volna szerepe. A curialis comes név váltása viszont tényleg 1219-ben kezdődött, így azt teljesen András hivatali átszervezéseihez és a fenti logikához lehet kötni. Mindez azért fontos, mert ez alapján szögezhetjük le, hogy az „országbíró” név megjelenése nem feltétlenül esett egybe az udvarispáni funkció átszervezésével. Az udvarispán már korábban is megkaphatta a nádorispán feladatait, ám a terminológiai egyértelmüsítés csak II. András korában, az új hatalmi elit kiépítésekor következett be.

Az önálló nádori ítélőszék létrejöttének a folyamatát tehát a következőképpen vázolhatjuk föl. A nádorispán kezdeti feladata a királyi udvarban, a király képében történő ítélkezés volt, és a 11. század második felére már biztosan joghatósága alá tartoztak a királyi udvarszervezet népei (és egyéb etnikumoknak is a feje volt, lásd alább). Az udvarnokföldeket is ő kezelte, illetve a királyi udvar kincstárának egyes pénzügyeiért felelt. A Kálmán király által elindított reformok a központi bíráskodás tehermentesítésére végül úgy találtak maguknak utat, hogy a létrehozott udvarispáni tisztség átvette a nádor udvarnokföldekkel és kincstárral kapcsolatos teendőit, így a nádor kizárólag bírói feladatokat látott el: megmaradt a királyi jelenlét bíróságának élén. A következő nagyobb hivatali átszervezésre a 12. század végén (valószínűleg 1192-ben) került sor, amikor a nádor kivált a királyi prezenciális bíróságból, és saját jogán bíráskodó ítélőszékké szervezték. A negyedik (a következő fejezetben részletesebben tárgyalt) lépcsőfok 1219-1220-ra tehető, és Barc fia Miklós nádorságához köthető, aki „,professzionalizálta” az addigi nádori hivatalt. Megszervezte a helyettesítési rendszerét, egyszerre 3-4 alnádorral is dolgozva, és azzal is növelte hivatala

\footnotetext{
225 Szőcs 2010. 429-431.

${ }^{226}$ Zsoldos 2011a. 20-21.

${ }^{227}$ Lásd fentebb az „1.1 - Az elnevezés” c. alfejezetet.
} 
presztízsét, hogy az ítéleteinek egy részét immár saját pecsétje alatt kibocsátott oklevelekben fejezte be. Lényegében ettől az időtől fogva beszélhetünk „klasszikus” nádori hivatalgyakorlásról. 


\section{4 - AZ ORSZÁG NÁDORÁTÓL AZ „ORSZÁG NÁDORÁIG” (A NÁDORI INTÉZMÉNY VÁZLATA A 12. SZÁZAD VÉGÉTŐL 1343-IG)}

Az alábbi (bizonyos értelemben az értekezés gerincét is képező) főfejezetben azt a hosszú folyamatot mutatjuk be, ahogyan a nádori intézmény megváltozott: onnantól, hogy a palatinus kivált a királyi udvarból, egészen odáig, hogy az 1330-as évek legvégén kezdődő folyamat végállomásaként a nádori bíróság újra visszakerült a királyi udvar helyszínére. Röviden megelőlegezve az alább olvasottakat, a változás mibenléte főként a nádori bíráskodás területi vonatkozásain keresztül fogható meg. Maga a nádori jogkör grandiózus változásokon nem ment át a 13. század első felétől kezdve, amikor is az 1222. évi Aranybulla rögzítette: „A nádor országunk minden embere felett különbség nélkül ítélkezzék. De a nemesek olyan ügyeit, melyek a fővesztésre, vagy birtokaik feldúlására vonatkoznak, a király tudta nélkül ne fejezhesse be. Helyettes bírákat ne tartson, csak egyet a saját udvarában."228 A nádor tehát már országos főbíró volt, és akár a nemesek felett is hozhatott halálos ítéleteket (még ha ezt az Aranybulla királyi jóváhagyáshoz is kötötte). Az Aranybulla 1231. évi megújítása a következőképpen egészítette ki a fentieket: „A nádor pedig minden ember felett különbség nélkül ítélkezzék, kivéve az egyházi személyeket és klerikusokat, valamint a házassági és hitbérügyeket és más egyházi [vonatkozású] ügyeket, amelyek bármely címen egyházi vizsgálat alá tartozónak látszanak." ${ }^{229} \mathrm{Ez}$ az utóbbi kitétel összhangban állt a magyar szokásjoggal, ${ }^{230}$ kihangsúlyozása talán afféle „lex Dionisii” volt, mert Ampod fia Dénes 1227-1228 közötti nádorsága idején valószínűleg konfliktusba került az egyházzal. ${ }^{231}$ Ezen világos törvényi szabályozás ellenére a nádori hivatal elemeit és jellemzőit nem lehet világos módon, mindenkire jellemzően körülhatárolni a 13. századra vagy akár a 14. század első

\footnotetext{
228 „Palatinus omnes homines regni nostri indifferenter discutiat, sed causa nobilium, que ad perditionem capitis vel ad destructionem possessionum pertinet, sine conscientia regis terminare non possit; iudices vicarios non habeat, nisi unum in curia sua.” DRMH I/1. 35. Magyarul: Szöveggyüjtemény 270.

229 „Palatinus vero omnes homines indifferenter discuciet, preter personas ecclesiasticas et clericos, et preter causas matrimoniales et dotis, et alias ecclesiasticas, quacumque ratione videntur ad ecclesiasticum examen pertinere.” DRMH I/1. 40. Magyarul: Szöveggyüjtemény 276.

${ }^{230}$ Korm. rendsz. 111-113. (a fejezet Kiss Gergely munkája)

${ }^{231}$ Dénest külön, név szerint is kiközösítette Róbert érsek 1232-ben, felsorolva egyházellenes „bünlajstromát” is: „nemcsak javadalmaiktól, hivataluktól fosztott meg számos egyházi személyt, hanem mert több ily személyt megveretett $\mathrm{s}$ velök csúfosan bánt; a szepesi préposton és plébánoson többféle hatalmaskodást hajtott végre; János pozsonyi prépostot arcul verette..." (Theiner I. 108. Magyarul: Balics II/1. 263.). Tegyük hozzá: az Aranybulla kiegészítése nem az ilyen típusú hatalmaskodási ügyekre célzott, hanem az egyházi és világi joghatóság határvonalát konkretizálta. Arra, hogy bármelyik nádor az ott felsorolt ügyekben ítélkezett volna, írásos nyom nincs, így inkább csak sejthetjük, hogy történtek konfliktusok e téren, ha érdemesnek tartották ezt is külön leszögezni.
} 
felére nézve. Az Aranybullák szabályozása ugyanis csak elmélet volt, a részleteket a szokásjog szabta meg, és a főbírói jogkör gyakorlását nem minden nádor érvényesítette egyformán. Némi túlzással azt mondhatjuk, hogy ekkoriban a nádori hivatal annyira müködött, amennyire a betöltője komolyan vette a feladatát. Egyedüli különbség az 1320-as évektől kezdődően mutatkozott, amikor a mindenkori nádorispán már egy jól körülhatárolható szokásjogi normarendszer szerint gyakorolta tisztségét, de markáns különbségek, átalakulások természetesen ebben a korban is voltak.

Ám a nádor területi „hatósugara” (tehát nem az elméleti joghatósága!) drasztikus változásokon ment át e 150 év folyamán. Kezdetben a nádor - úgy tünik - ténylegesen az egész ország nádora kívánt lenni, mert kb. a tatárjárásig kimutatható az, hogy a tisztségviselő a királyi udvarhoz hasonlóan vándorolt az országban és bírói úton intézte az elé kerülő ügyeket. A tendencia az 1240-es évek végétől kezdett megfordulni, és ekkor a nádorok alapvetően egyetlen régióhoz kötődtek. Az 1260-as éveket jellemző belpolitikai megosztottság apa és fia között méginkább felerősítette ezt a folyamatot. Ekkorra a nádori poszt szinte kizárólagosan politikai tisztséggé vált, azaz viselője bármilyen téren bármire „,bevethető” volt, és teljesen mellékes, inkább csak presztízsokai voltak, hogy ő éppen a nádori tisztet viselte. A IV. László országlását követő politikai versenyben ez a tendencia ugyanúgy megmaradt, csak a körülményeknek megfelelően formálódott át. Az időszakra jellemző volt, hogy néhány kivétellel a korszak nádorai alig bíráskodtak, és aktív vagy passzív tevékenységük szinte soha nem mutatott túl egyetlen régió határain. Az 1270-es évek elején megjelenő generalis congregatio intézménye (azaz egy-egy vármegye számára tartott közgyülés, amelyen a megye ügyeit intézték) is meglehetősen ritka volt, és sohasem mutatott túl az adott nádor által amúgy is bírt terület határain, vagy azokon a vármegyéken, amelyeknek az ispáni címét is viselte. Ekkor tehát a tisztség viselöi - bár jogkörük de iure még mindig az egész országra kiterjedt, de facto csak egy adott terület nádorai voltak. Mindezek visszatükröződtek abban, hogy a 13. század legvégén III. András már tudatosan is megosztotta az intézményt, és később szövetségeseinek egy körét örökös nádori címmel is jutalmazta - a gyakorlatban ugyanis semmiféle jogütközést vagy konfliktust nem eredményezett az sem, hogy az országban egyszerre heten is palatinusnak címezték magukat (feltehetően királyi jóváhagyással). 1310-től kezdve, mikor I. Károly már a saját kezébe kívánta venni a tisztség betöltését, a saját kinevezett nádorai is mind egy-egy szükebb régióhoz kötődtek. A változás az 1320-as évek elejétől, a Druget-nádorok hatalomgyakorlásával állt be. Druget Fülöp 1323-tól szintén a saját territóriumának székhelyen, regionális nádorként müködött, ám utódja, János már nem a Drugetek területén, 
hanem Óbudán tartotta székhelyét, és az ország egyre több régiója számára tartott nádori közgyülést. Ezzel jelentősen kitágult az a terület, amely felett a nádor bírói hatalommal bírt. Mondhatjuk, hogy hosszú idő után Druget János volt az első olyan méltóságviselő, akinek egyszerre volt tényleges kapcsolata az ország keleti és nyugati felével. Fia, Vilmos követte példáját, alatta terjedt el igazán a nádori közgyülés intézménye (az országnak szinte a teljes északi régióját lefedték a változó időközzel tartott nádori congregatioi). Vilmos alatt következett be az a (korábbi szakirodalomban tévesen az 1342-es évhez és Nagy Lajos reformjához kötött) változás, hogy a nádori bíróság szép lassan a Visegrádon székelő országbírói bíróság mellé költözött, és ott lett a mindenkori nádor egyetlen kúriája. Vilmos utódja, Zsámboki (Gilétfi) Miklós 1342-től már nagyrészt készen kapta azt a rendszert, amely aztán a nádor elnevezésében is elkezdett tükröződni, és a nádor regni Hungarie palatinus, vagyis „Magyarország nádora” lett. Bár a cím felvétele valószínűleg nem áll a fenti folyamattal összefüggésben, de jelképesen is kifejezi egy fejlődési vonalnak a lezárultát. Az alábbiakban ezt a „vonalat” mutatjuk be részletesebben, természetesen kitérve a nádori intézmény egyéb, itt nem említett változásaira is.

\section{1 - A tatárjárásig terjedő időszak: a „mobilis nádorok”}

Mog 1192. évi nádorsága és Barc fia Miklós 1219. évvel kezdődő hivatalviselése közötti időszakról intézménytörténeti értelemben igen keveset lehet mondani. A nádorok legtöbbször az aktuálpolitika fontosabb figuráiként bukkannak föl. Mivel az uralkodók eleve a híveiket igyekeztek beültetni eme pozícióba, így gyakran cserélődött a nádor személye Imre és II. András alatt is, és nem egyszer a nádor valamilyen más politikai vagy nem politikai esemény következtében került a figyelem és a kútfők középpontjába. ${ }^{232}$ Mindezek nem tartoznak a hivataltörténethez, így a korabeli nádori ítélkezés folyamata részleteiben nem elemezhető. Annyi mondható el, hogy a nádor ekkor még szorosabb kapcsolatot tartott fent a királlyal és a királyi udvarral, erről árulkodik, hogy több esetben iktatott király által adományozott földet, vagy állapította meg annak határait, esetleg valamilyen más módon hajtott végre egy királyi ítéletet. ${ }^{233}$ Szentföldre indulása előtt a vasvári egyház népeinek a védelmét is a nádorára bízta

\footnotetext{
${ }^{232}$ A nádorok listáját lásd Archont. 1000-1301. 16-18. A kor hatalmi elitjének, és ezen belül egyes pozíciók előkelőségének elemzésére lásd Fügedi 1986. 87-102.; Nógrády 1995. 163. 1209-ben Csépán nádor gyilkosság áldozata lett, de valószínűleg nem politikai okból (lásd legújabban Szabó 2009, különösen 386-390.).

${ }^{233}$ 1206-1209 k.: RV 103. sz.; 1212: RA 271. sz.; 1209-1212 k.: CD VII/1. 235.; 1217: RA 315. sz. Tegyük hozzá: a nádor személyes közremüködésére később is találunk példákat, de arányaiban nem olyan nagy számban,
} 
rá András. ${ }^{234}$ Szintén András küldte ki Pot nádort és Tamás kancellárt, hogy írják össze a tihanyi monostor népeinek szolgáltatásait, hogy ő aztán megerősíthesse azokat. ${ }^{235}$ Mindezek azt illusztrálják, hogy a nádor ekkor sokszor tartózkodott a király udvarában, még ha önálló hatóságnak minősült is. Szerencsére részben ezt a korszakot fedi le a váradi káptalan ítéletjegyzőkönyve, az ún. Váradi Regesztrum, amely - ha töredékesen is maradt ránk - számos 1205 és 1235 közé eső jogesetet ír le. Ezekből kiderül, hogy a nádorok ekkor már mindenféle - királynak alávetett és szabad státuszú - emberek felett bíráskodtak, és a jogesetek között éppúgy találunk klasszikus státuszpereket, mint lopás, károkozás, vagy éppen emberölés ügyében indított eljárásokat. ${ }^{236}$ A korszak általános jellemzője volt, hogy bár az írásbeliséget már használták a belső hivatali ügyintézés során, az ítéleteket vagy szóban hozták, ha pedig a felek írásos bizonyítékot szerettek volna, akkor még mindig valamilyen más hatóság foglalta azt írásba. Mindezt jól illusztrálja az a néhány példa, amikor nádori levél kibocsátásáról van tudomásunk. A Váradi Regesztrum bejegyzéseiben 1214-ből még olyan esetet olvashatunk, hogy Miklós nádor szabályszerüen lezárt egy ítéletet, ám a felek oklevelet is szerettek volna minderről, ezért keresték föl a váradi káptalant - ekkor tehát még fel sem merült bennük, hogy a nádortól is kérhetnének oklevelet. ${ }^{237}$ Két évvel később Kán nembéli Gyula nádor egyenesen levélben kérte a káptalant, hogy a pernyertes fél részére állítsanak ki oklevelet. A parancslevél szabályos formulákat tartalmazott („,Gyula [!], Dei gratia comes palatinus cuncto capitulo Varadinensis ecclesię salutem et dilectionem. Notificamus vobis, quod...”), így ez az első teljes szövegében ismert nádori oklevél. ${ }^{238}$ Feltűnő, hogy a végső ítéletlevél kibocsátását a nádor itt is a káptalanra bízta rá, még ha az ítéletet a bünösök felett ő is mondta ki. Ugyanilyen tartalmú az ezen a téren később változást hozó Barc fia Miklós 1219 júniusa után kiállított oklevele. ${ }^{239}$ A korai nádori ítélkezésre tehát még nem volt jellemző, hogy a saját nevükben kiállított oklevéllel zárják le ügyeiket, inkább egy másik hatóságot kértek meg rá (ha kellett, levélben leírva a jogesetet). ${ }^{240}$

Az intézményi fejlődés egyik fontos mérföldköve volt Szák nembéli Barc fia Miklós nádorsága. A korábbi archontológiákban három nádori ciklusával is számoltak (1213-1214,

\footnotetext{
mint ezekből az időkből. Lásd pl. 1245: RA 805. (RP 69. sz.) (az oklevél hamis, de a nádori közremüködésnek lehet valóságalapja, vö. Weisz-Zsoldos 2010. 476.); 1247: RA 856. sz.; 1270: MES I. 576. (RP 155. sz.)

${ }^{234}$ 1217: RA 322. sz.

235 1211: RA 262. sz.

${ }^{236}$ RV 9., 15., 19., 27., 62., 64., 89., 95., 97., 103., 105., 116., 148., 153., 162. sz. esetek

${ }^{237}$ RV 103. sz.

${ }^{238}$ RV 162. sz. (RP 4. sz.)

${ }^{239}$ RV 217. sz. (RP 5. sz.)

${ }^{240}$ Minderre összefoglalóan lásd Szőcs 2010. 429-431.
} 
1219-1222 és 1226), vélhetően az ezen nézetet képviselő Wertner Mór és Pauler Gyula tekintélye folytán. ${ }^{241}$ Legutóbb Zsoldos Attila választotta szét a középkorban igen gyakori nevet viselő, 1213-1214 folyamán nádori tisztet viselő Miklóst és a csak 1219-től nádor Barc fia Miklóst. ${ }^{242}$ Annyi mindenesetre bizonyos, hogy az itt említett reformok 1219-től mutathatók csak ki, és két területet érintenek. Egyrészt a nádori ítéletlevél-adás megindulását, másrészt a helyettesi rendszer megszervezését, amelyből a későbbi alnádori és albírói posztok nőttek ki. Mint fentebb is láthattuk, Miklós előtt is bocsátottak ki a nádorok okleveleket, ám ezek vagy magánoklevélnek számítottak, ${ }^{243}$ nádori hivataluktól függetlenül, vagy pedig a belső hivatali ügyintézésben játszottak szerepet. Az első ismert nádori ítéletlevél 1219-re keltezhető, és utána Barc fia Miklósnak 1220-1221 folyamán 6 saját nevében kiállított ítéletlevelét is ismerjük. ${ }^{244} \mathrm{Az}$ oklevelek nagyobbik hányada pannonhalmi vonatkozású és Uros apát kérésére állították ki, de Miklós saját pecsétje alatt adott ki oklevelet a Ják nemzetség egyik birtokosztályáról is, illetve arról döntéséről, amely az esztergomi udvarnokok és az esztergomi káptalan közötti birtokvitát zárta le. ${ }^{245}$ Ilyesfajta esetekben korábban is eljártak nádorok. Maga Uros apát is járt ügyeivel Miklós hivatali elődjeinek ítélőszéke előtt, de semmi nyoma nincs annak, hogy erről ők oklevelet adtak volna ki. ${ }^{246}$ Miklós oklevéladó gyakorlata 1226-ra eső, nem egészen egy évnyi nádorsága alatt sem csökkent, összesen (az említésekkel és tartalmi átírásokkal együtt) 19 oklevelet köthetünk hozzá, igaz ezek közül nem mind volt ítéletlevél. ${ }^{247}$

\footnotetext{
${ }^{241}$ Wertner 1898. 77-78., Pauler 1899. II. 53.; MTK IV. 1143., Szentpétery 1985. 97., KMTL 474. Egy korábbi tanulmányban magam is így jártam el: Szöcs 2010. 430.

${ }^{242}$ Archont. 1000-1301. 333.

${ }^{243}$ Radó nádor 1057. évi, interpolált oklevele: DHA I. 161-162. (RP 1. sz.)

${ }^{244}$ 1219: PRT I. 645-646.; 1220: PRT I. 647., 647-648.; 1221: PRT I. 652-653., UB I. 84-85., MES I. 231-232. (RP 6-11. sz.). Bizonnyal Barc fia Miklóshoz köthető az az ítéletlevél is, amelyet a Pannonhalmi Regisztrum említ O jelzet alatt (PRT II. 255.). A regisztrum nem nevezi meg, hogy melyik Miklós nádor okleveléről van szó, de II. András egy 1221. évi oklevele alapján, amelyben említette Barc fia Miklós ugyanezen tárgyú ítéletét (PRT I. 652.), összekapcsolhatjuk a két esetet. Lásd erröl Szőcs 2009. 431. 22. jz. (RP 13. sz. és kommentárja)

${ }^{245}$ UB I. 84-85., MES I. 231-232. (RP 10-11. sz.)

${ }^{246}$ Pot és Bánk nádorok (1209-1212 és 1212-1213) előtt már biztos pereskedett Uros, mint ez Tomaj nb. Dénes egy 1236. évi okleveléből kiderül, és ezekről oklevelet is kiállítottak, de valószínü, hogy nem maguk a nádorok, hanem - ahogy ez korábban is szokás volt - valamilyen más hatóság foglalta azokat írásba. Lásd minderről Szöcs 2009. 429-430.

247 2009-ben még csak 17 oklevelet tudtam hozzá kötni (Szöcs 2009. 431.). Teljes szövegében fennmaradt okleveleinek (11) felsorolását lásd Solymosi 2004. 229. 52. jz. Tartalmi átírásban és említésben fennmaradt oklevelei: RV 217. sz., HO VIII. 19., PRT II. 255. (a Pannonhalmi Regisztrum említése, lásd fentebb is), Ampod fia Dénes 1227. évi oklevelében Miklós két korábbi diplomáját is említette: ÁÚO VI. 442-443. II. András adománylevelének említése: ÁÚO XI. 226. Balog Miklós asztalnokmester 1254. évi levelében szintén említést tesz Barc fia Miklós egy ítéletleveléről (PRT II. 291-292.). Az említés elvileg azonosítható lenne Miklós egy meglévő oklevelével is (PRT I. 677.), ám a helynevek nem egyeznek teljesen, így valószínű, hogy két külön oklevélről van szó. Végül szintén a Pannonhalmi Regisztrum említi Miklós nádor Ronka (Renge) faluval
} 
A másik Barc fia Miklóshoz köthető újítás a helyettesi rendszer megszervezése volt. A helyzet annyiban hasonló az oklevéladási gyakorlathoz, hogy a folyamat hirtelen, és láthatóan különösebb átmenet nélküli megindulásról van szó, és biztos, hogy nem a forráshiánynak tudhatjuk azt be, hogy nem találkozunk azelőtt nádorhelyettessel. Erre a bizonyítékot szintén a Váradi Regesztrum szolgáltatja, amelynek 1220 előtti bejegyzéseiben egyszer sem említenek ilyesfajta tisztséget, ám utána hirtelen 4 különböző nevet is regisztrálni tudunk. Másrészt látni, hogy a tisztségnek ebben az időben még nincs kikristályosodott neve, hanem alkalomszerủ megnevezésekkel illetik őket a források. ${ }^{248}$ Úgy tünik, hogy Miklós egy olyan helyettesi rendszert dolgozott ki, amely szerint a segédjei az ország azon részein bíráskodtak a nevében, ahol ő éppen nem tartózkodott. Legalábbis ez sejlik ki a Váradi Regesztrum azon 1220. évi adataiból, hogy ekkor Barc fia Miklós összes esete kelet-magyarországi vonatkozású (ebben nincsen semmi furcsa, hiszen erre a területre esett a váradi káptalan fö vonzáskörzete), ám ezzel párhuzamosan a helyettes bíráinak minden (konkrétan négy) ítélete dunántúli vonzáskörzettel bírt, ami viszont igen ritka. ${ }^{249}$

Barc fia Miklós újításai felemásan mentek át a gyakorlatba. A nádorhelyettesítés ezen rendszere nem nyerte el az országlakosok tetszését, legalábbis erre utal, hogy az 1222. évi Aranybullába belefoglalták azt is, hogy a nádor csak egy helyettes bírát tarthat, és azt is a saját kúriájában. ${ }^{250} \mathrm{Az}$ Aranybulla 1231. évi változata pedig a korábbi „unum” (egyet) kifejezést a hangsúlyosabb „unicum” (egyetlen egyet) változatra cserélete le, gondosan intve utána a nádort, hogy nehogy a fenti, és más egyéb tilalmak ellenében cselekedjen. ${ }^{251} \mathrm{~A}$ nádorhelyettesi rendszer ugyan nem szünt meg, de a forrásokból ítélve tényleg visszaszorult, és a Miklós által kialakított helyetteshalmozásnak vége szakadt. ${ }^{252}$ Sokkal sikeresebb volt a másik újítás: ekkortól ugyanis szinte minden nádor ügyelt arra, hogy a saját nevében és

\footnotetext{
kapcsolatos, S jelzet alatt őrzött oklevelét (PRT II. 255.). A jegyzék nem árulja el, hogy melyik Miklós nádorról van szó, de mivel egyrészt a falu neve a 13. század második felétől inkább már Ásványtő volt (Csánki III. 511.), másrészt a Regisztrum kizárólag Árpád-kori nádorok, és a Miklós nevűek közül csak Barc fia Miklós okleveleit említi, továbbá Barc fia Miklós más, beazonosítható oklevelét szintén S jelzet alatt ôrizték, mint ezt a Miklósoklevelet, így a legvalószínübben ezen oklevelet is Barc fia Miklós diplomái közé sorolhatjuk (okleveleit lásd még RP 5., 12-13., 22-23., 25-27. sz.).

${ }^{248}$ Vicarius palatini (comitis) (1220: RV 248-249. sz., 266. sz.; 1221: RV 289. sz.); vicecomes palatini comitis (1221: RV 282. sz.); viceiudex palaini comitis (1221: ÁÚO I. 182-183., PRT I. 652. (RP 9. sz. reg.]); vicepalatinus (1220: RV 271. sz.; 1221: 318. sz., 321. sz.); iudex vicarius (1222: DRMH I/1. 35.). Hogy itt nem ennyi különféle nevü tisztségről van szó, hanem arról, hogy még nem volt megszokott, hogyan is kell nevezni a nádor nevében eljáró embert, azt jól mutatja, hogy pl. Móric alnádort mind a négy elnevezéssel illették 12201221 folyamán.

${ }^{249}$ Szőcs 2012. 417.

${ }^{250}$ DRMH I/1. 35.

${ }^{251} \mathrm{DRMH}$ I/1. 40.

${ }^{252}$ Az alnádorra lásd még a „8.1 - A nádort helyettesítő tisztségek: alnádor, nádori albíró” c. alfejezetet.
} 
pecsétje alatt bocsásson ki ítéletlevelet. ${ }^{253}$ Ezzel a nádori hivatal is egy fontos lépcsőfokot lépett át.

A Barc fia Miklós utáni következő nagyobb időszak záró határát Türje nembéli Dénes második nádorsága, illetve Rátót nembéli Roland hivatalviselésének a kezdete (1248) táján húzhatjuk meg. Az itteni bő negyed évszázadot egymástól teljesen eltérő politikai és bíráskodási szerepet betöltő nádorok fémjelzik, amelyek közül a két leghíresebb a II. András hủ emberének számító Ampod fia Dénes (1227-1128; 1231-1234/1235), illetve a IV. Béla bizalmát is elnyerő Tomaj nembéli Dénes $(1234 / 1235-1240){ }^{254}$ Ám ami összeköti ezt a korszakot, az az, hogy a nádori bíráskodás ebben az időben - úgy tünik - nem alapvetően helyhez kötötten zajlott. A nádor az országban vándorolt a királyi udvarhoz hasonlóan, és intézte az elébe járulók ügyeit - úgy is mondhatnánk, hogy ez az időszak a „mozgó nádorok” korszaka volt. A nádorispán természtesen a későbbiek folyamán is mozoghatott, ám az 1250es évektől kezdődő időszak arculatát mégis inkább a helyhez kötött, partikuláris nádori intézkedések fémjelezték, azaz a tisztség viselője általában egy adott helyen tartózkodott, jól körülírható ítélkezési vonzáskörzettel. Ilyen vonzáskörzeteket 1248 előtt egy nádor esetében sem lehet kimutatni, és, mint látni fogjuk, ez nem írható pusztán a forráshiány számlájára.

A fenti tendenciák már kimutathatóak Barc fia Miklós idején, illetve az előtt is. A nádori ítélkezés eme vonatkozásait Szovák Kornél elemezte Roland esetében, az előzményeket is figyelembe véve. ${ }^{255}$ Pontosítani igyekezett azt az addigi álláspontot, hogy a nádor az 1230-as évektől kezdve a saját birtokán ítélkezett, ahol két alnádort tartott. Mindezt a 13. század első felére kivetítve a következőképpen igyekezett ellenőrizni: egyrészt hol működtek ebben az időben az alnádorok, másrészt a nádori oklevelekbe foglalt ügyek területi illetékessége hová esik, harmadrészt hol keltezték a nádori okleveleket. Szovák a forráshiány miatt az első és a harmadik kérdésre csak hiányos feleletet tudott adni, míg a másodikat (az egyes nádori ítéletek területi hovatartozását) nem elemezte ki részletesen 1248 előtt. Viszont Rátót nembéli Roland első nádori ciklusa (1248-1260) alkalmasnak látszott egy részletesebb vizsgálatra, mivel tőle nemcsak a legtöbb oklevél maradt fönt az Árpád-kori nádorok közül, de abban gyakran kitette a pontos keltezés mellett a kelethelyet is. Az oklevelek elemzése során Szovák megállapította, hogy a pozsonyi ispáni címet is viselő Roland legtöbbször Pozsonyban keltezte oklevelét, és vélhetően ott tartotta a saját kúriáját is, és a többi ítélete is zömében az

\footnotetext{
${ }^{253}$ A Miklóst követő nádorok oklevéladási gyakolatára lásd Szőcs 2009. 431-433.

${ }^{254}$ A hivatalviselési időre: Archont. 1000-1301. 18-19. Ampod fia Dénesre lásd: Wertner 1895. 92-93., Weisz 2003. Tomaj nb. Dénesre: Wertner 1898. 113-114.; lásd mindkettejükre: Archont. 1000-1301. 295.

255 Szovák 1989
} 
északnyugati régióba esett. Ez egy kölcsönös folyamat volt, ugyanis a nádort eleve azok kereshették föl, akik a közelben voltak, és így nem kellett nagy költségeket fordítani az utazásra. $^{256}$ Itt most ugyanezt a teljességre törekvő elemzést végeznénk el a Roland előtti nádorok esetében. Természetesen némileg módosítani kell a módszertanon, hiszen a nádori oklevelek kelethelyét 1248 előtt - mint azt Szovák Kornél is megállapította - direkt módon mindössze két alkalommal tették ki (mindkétszer Tomaj nembéli Dénes). ${ }^{257}$ Így hát a nádori intézkedések területi vonatkozásait kell vizsgálni, hogy Rolandhoz hasonlóan megállapíthatóe valamelyiküknél valamilyen területi súlypont, és ha igen, akkor az összefüggésben áll-e a nádor által viselt ispáni címmel. 1213 és 1248 között biztosan 73 nádori és 4 nádorhelyettesi oklevelet tudunk regisztrálni teljes szövegében vagy tartalmi átírásban, esetleg említésben. ${ }^{258}$ Természetesen nem minden oklevél esetében tudunk területi vonatkozásokat megállapítani, és van, ahol nem is érdemes ilyet keresni. Az oklevelek mellett ugyanakkor több mint 70 olyan nádori vagy alnádori intézkedésről tudunk, amelyeket más írószerv foglalt írásba. Többségében az ún. Váradi Regisztrumban maradtak fent ilyenek, de jó pár egyéb hiteleshelyi és királyi oklevél is említ nádori ítéleteket.

Ez a két csoport együtt már viszonylag reprezentatív mennyiséget képez egy vizsgálathoz. Ám ha abból indulunk ki, hogy a partikuláris ügyek esetében a nádort főként olyanok keresték fel, akik a közelében tartózkodtak, akkor az intézkedések közül néhányat nem szabad figyelembe venni. Ilyenek egyrészt a pannonhalmi vonatkozású ítéletek. Uros pannonhalmi apát mindig ügyelt arra, hogy a legmagasabb világi és egyházi bírói fórumok előtt tárgyalják az apátság ügyeit, ezért nem a területileg legközelebbi bírákat kereste, hanem a rangban magasabbakat. Így sokszor a király elé állt, aki nem egyszer a nádori törvényszék elé utalta ügyét, máskor egyenesen a nádort kereste föl. Ezen ítéletek területi vonatkozása a monostor birtokállományának elhelyezkedésétől függ, és nem biztos, hogy az eljáró nádorok feltétlen a közelben tartották volna a székhelyüket. Ugyancsak ki kell zárni az azon népelemek fölötti intézkedéseket, akik hivatalból a nádori ítélőszék alá tartoztak (udvarnokok, besenyők). Itt ők nem választhattak, hogy magasabb szintű bírói fórumként kit keressenek fel. ${ }^{259}$ Szintén ki kell zárni azokat az eseteket, amikor a nádor külön királyi parancsra járt el egy ügyben, hiszen itt sem a gyakori tartózkodási helye (ha volt ilyen) dominált a

\footnotetext{
${ }^{256}$ Szovák 1989. 299-303.

${ }^{257}$ 1236: PRT I. 751. (RP 45. sz.), 1239: PRT I. 768-769. (RP 62. sz.); vö. Szovák 1989. 301.

${ }^{258}$ A nádori és helyettesi okleveleket lásd: RP 3-78. sz.

${ }^{259}$ Ilyen eset pl. az árpási besenyők ügye, akik 1224-ben a saját közvetlen elöljárójuk, az ún. besenyőispán ellen emeltek panaszt (Györffy 1990. 127., RP 16. sz.), amit a nádornál kellett megtenniük, bárhol is tartotta az a székhelyét. Tegyük hozzá: az Árpád-kori Sopron és Győr megyék határán található Árpáson lakó besenyők nádorhoz való fellebbezését biztosan segítette az, hogy 1224-ben Gyula nádor soproni ispán is volt egyben.
} 
személyének kiválasztásakor. Összességében csak azon eseteket érdemes figyelembe venni, ahol egyáltalán feltehető, hogy a nádori ítélőszék kiválasztását nem indokolta semmilyen különösebb ok, a felek valószínüleg azért álltak elé, mert ő volt a legkönnyebben elérhető (nagy)bíró. Bár a tévedés lehetősége itt is fennáll, de a Váradi Regesztrum kisebb jelentőségü (lopással, testi sértéssel) foglalkozó ügyei, vagy a nem országos jelentőségű személyek közti perek ilyeneknek látszanak. Ha ezek földrajzi vonatkozásait összevetjük az adott nádor ispánságával, akkor a következő táblázatot kapjuk:

\begin{tabular}{|c|c|c|c|}
\hline nádor neve & ispánsága & az ítélet területi vonatkozása & forrás \\
\hline Mog & bihari & 1206: Gyán, Bihar (Bihar m.) & RV 97. sz. \\
\hline \multirow{2}{*}{ Bánk } & \multirow{2}{*}{ pozsonyi } & 1213: Szatmár, Malca (Szatmár m.) & RV 9. sz. \\
\hline & & 1213: Nyüved (Bihar m.) & RV 19. sz. \\
\hline \multirow{3}{*}{ Miklós } & \multirow{2}{*}{ csanádi } & 1213: Besenyő (Arad m.) & RV 64. sz. \\
\hline & & 1213: Lazdi, Seusci (Bihar m.) & RV 103. sz \\
\hline & bodrogi & 1214: Szoboszló (Szabolcs m.) & RV 103. sz. \\
\hline Kán nb. Gyula & soproni & 1215: Békés (Békés m.) & RV 116. sz. \\
\hline Kán nb. Gyula & - & 1216: Szabolcs (Szabolcs m.) & RV 162.sz. \\
\hline \multirow{19}{*}{ Barc f. Miklós } & \multirow{19}{*}{ soproni } & 1219: Széplak, Szerep (Abaúj m.) & RV 175. sz. \\
\hline & & 1219: Széplak, Medgyaszó (Abaúj, Zemplén m.) & RV 180. sz. \\
\hline & & 1219: Folt, Bágya (Heves m.) & RV 189. sz. \\
\hline & & 1219: Vasvári, Zsadány, stb. (Csanád, Arad, Temes m.) & RV 213. sz. \\
\hline & & 1219: Körü (Heves m.) & RV 217. sz. \\
\hline & & 1219: Nyír (Közép-Szolnok m.) & RV 220.sz. \\
\hline & & 1219: Tiván, Tót (Heves m.) & RV 226. sz. \\
\hline & & 1220: Körü (Heves m.) & RV 244. sz. \\
\hline & & 1220: Körü, Peles (Heves m.) & RV 245. sz. \\
\hline & & 1220: Pó (Külsö-Szolnok m.) & RV 269. sz. \\
\hline & & 1220: Ság (Szabolcs m.) & RV 275. sz. \\
\hline & & 1221: Márok (Baranya) & RV 281. sz. \\
\hline & & 1221: Arad (Arad m.) & RV 290. sz. \\
\hline & & 1221: Gyad, Tata (Fejér, Komárom m.) & RV 308. sz. \\
\hline & & 1221: Káta, Dengeleg (Pest, Nógrád m.) & RV 309. sz. \\
\hline & & 1221: Vasvár, Tozár, Ják, Ság (Vas m.) & RV 313. sz. \\
\hline & & 1221: Tozár, Zsedény (Vas m.) & RV 314. sz. \\
\hline & & 1221: Köröselő (Vas m.) & $\begin{array}{l}\text { UB I. }{ }^{84-85 . ~(R P ~} \\
\text { 10. sz.) }\end{array}$ \\
\hline & & 1221 körül: Boglár (Fejér m.) & $\begin{array}{l}\text { HO VIII. 19. (RP } \\
\text { 12. sz.) }\end{array}$ \\
\hline \multirow{7}{*}{ Kán nb. Gyula } & \multirow{7}{*}{ soproni } & 1223: Bart (Esztergom m.) & MES I. 241-242. \\
\hline & & 1224: Menyhárt, stb. (Sopron m.) & $\begin{array}{l}\text { UB I. 95. (RP } 15 . \\
\text { sz.) }\end{array}$ \\
\hline & & 1224-25: Csecstó (Bodrog m.) & $\begin{array}{l}\text { MES I. 247. (RP } \\
\text { 17. sz.) }\end{array}$ \\
\hline & & 1225: ${ }^{260}$ Ság (Csongrád m.) & MES I. 254-255. \\
\hline & & 1222-25: Herman, Vald (Vas m.) & ÁÚO VI. 435. \\
\hline & & 1222-25: Szilvás (Baranya m.) & ÁÚO XI. 225. \\
\hline & & 1222-25: Kecsen (Békés m.) & RV 358. sz. \\
\hline
\end{tabular}

${ }^{260}$ A nádori ítéletet a garamszentbenedeki apát foglalta írásba 1225. dec. 24-én, így valószínủ, hogy az ítélet is ugyanerre az évre esett. 


\begin{tabular}{|c|c|c|c|}
\hline nádor neve & ispánsága & az ítélet területi vonatkozása & forrás \\
\hline Barc f. Miklós & soproni & 1226?: Csurgó, Zákány (Somogy m.) & $\begin{array}{l}\text { ÁÚO VI. 442-443. } \\
\text { (RP 22-23. sz.) }\end{array}$ \\
\hline \multirow{11}{*}{$\begin{array}{l}\text { Ampod f. } \\
\text { Dénes }\end{array}$} & \multirow{11}{*}{-} & 1227: Csurgó, Zákány (Somogy m.) & $\begin{array}{l}\text { ÁÚO VI. 442-443. } \\
\text { (RP 28. sz.) }\end{array}$ \\
\hline & & 1227: Hartyán (Nógrád m.) & $\begin{array}{l}\text { ÁÚO VI. } 445-446 . \\
\text { (RP 29. sz.) }\end{array}$ \\
\hline & & 1227: Vég, Bán, Rékas (Baranya m.) & DSAd 28. \\
\hline & & 1228: Tapolca, Pukor (Pozsega m.) & $\begin{array}{l}\text { CDCr III. 293- } \\
\text { 295. (RP 30. sz.) }\end{array}$ \\
\hline & & 1227-28: Zselic (Somogy m.) & $\begin{array}{l}\text { CDCr III. 347- } \\
\text { 350. (RP 31. sz.) } \\
\end{array}$ \\
\hline & & $1231:^{.261}$ Lévna (Nyitra m.) & $\begin{array}{l}\text { DL 95539. (RP } 36 . \\
\text { sz.) }\end{array}$ \\
\hline & & 1227-28, 1231-32: Pest-Kelenföld (Pest m.) & RA 492. sz. \\
\hline & & 1227-28, 1231-32: Ényed (Sopron m.) & ÁÚO VI. 511-512. \\
\hline & & 1232: Pordány (Sopron m.) & $\begin{array}{l}\text { UB I. 139-140. } \\
\text { (RP 33. sz.) }\end{array}$ \\
\hline & & 1233: Hof, Menyhárt (Moson m.) & $\begin{array}{l}\text { UB I. 152. (RP } 34 . \\
\text { sz.) }\end{array}$ \\
\hline & & 1227-28, 1231-34: Kapornok, Lanch (Zala m.) & $\begin{array}{l}\text { Veszprém: } \\
\text { pótkötet 94-95. }\end{array}$ \\
\hline \multirow{6}{*}{$\begin{array}{l}\text { Tomaj nb. } \\
\text { Dénes }\end{array}$} & - & 1235 körül: Tumban (Bihar m.) & RV 387. sz. ${ }^{262}$ \\
\hline & bihari & 1236: Csepel (Hont m.) & $\begin{array}{l}\text { CDS II. 11-12. } \\
(\mathrm{RP} 44 . \text { sz. })\end{array}$ \\
\hline & \multirow{4}{*}{ szolnoki } & 1236: Szántó (Zala m.) & $\begin{array}{l}\text { HO VI. 30-34. (RP } \\
\text { 43. sz.) }\end{array}$ \\
\hline & & 1236: Kapornok, Lanch (Zala m.) & $\begin{array}{l}\text { Veszprém: } \\
\text { pótkötet 94-95. } \\
\text { (RP 46. sz.) }\end{array}$ \\
\hline & & 1237: Süly (Pozsony m.) & $\begin{array}{l}\text { CDS II. 21. (RP } \\
\text { 54. sz.) }\end{array}$ \\
\hline & & 1239: Csenger (Szatmár m.) & $\begin{array}{l}\text { ÁÚO VII. } 77-78 . \\
\text { és ÁÚO XI. 309- } \\
310 . \quad \text { (RP 63-64. } \\
\text { sz.) }\end{array}$ \\
\hline \multirow{3}{*}{ Kán nb. László } & \multirow{3}{*}{ somogyi } & 1244: Szentiván (Veszprém m.) & $\begin{array}{l}\text { Szovák 1996. 456- } \\
\text { 457. (RP 68. sz.) }\end{array}$ \\
\hline & & 1243-45: Érd (Pest m.) & $\begin{array}{l}\text { Zichy I. 27. (RP } \\
\text { 70. sz.) }\end{array}$ \\
\hline & & 1242-45: Szántó (Zala m.) & $\begin{array}{l}\text { CD IX/7. 662-665. } \\
\text { (RP 71. sz.) }\end{array}$ \\
\hline \multirow{2}{*}{$\begin{array}{l}\text { Türje nb. } \\
\text { Dénes }\end{array}$} & \multirow{2}{*}{ somogyi } & 1245-46: Szántó (Zala m.) & $\begin{array}{l}\text { CD IX/7. 662-665. } \\
\text { (RP 76. sz.) }\end{array}$ \\
\hline & & 1245-46: Ládony (Sopron m.) & $\begin{array}{l}\text { HO VIII. } 174-175 . \\
\text { (RP 73. sz.) }\end{array}$ \\
\hline \multirow{3}{*}{$\begin{array}{l}\text { Gutkeled nb. } \\
\text { István }\end{array}$} & \multirow{3}{*}{-} & 1247: Bela (Zala m.) & $\begin{array}{l}\text { Zala II. 285. (RP } \\
\text { 75. sz.) }\end{array}$ \\
\hline & & 1246-47: Baksa (Baranya m.) & $\begin{array}{lll}\text { CD } & \text { VII/1. 293- } \\
294 . & & \\
\end{array}$ \\
\hline & & 1246-47: Szántó (Zala m.) & $\begin{array}{l}\text { CD IX/7. 662-665. } \\
\text { (RP 76. sz.) }\end{array}$ \\
\hline
\end{tabular}

${ }^{261}$ Dénes 1234. évi oklevelében eladta az egyik ítélete után reá szállott Levna nevü földet, amit 3 év után sem akartak megvenni a rokonok és határosok. Így az ítéletnek 1231-re kellett esnie.

${ }^{262}$ Nem lehet eldönteni, hogy az ítéletet Ampod fia Dénes, vagy Tomaj nembéli Dénes hozta. A kérdésnek annyiból nincs jelentősége, hogy kezdetben Tomaj nembéli Dénes sem tüntet fel semmilyen ispánságot okleveleiben. 


\begin{tabular}{|c|l|l|l|}
\hline nádor neve & \multicolumn{1}{c}{ ispánsága } & \multicolumn{1}{c|}{ az ítélet területi vonatkozása } & \multicolumn{1}{c|}{ forrás } \\
\hline \multirow{2}{*}{$\begin{array}{c}\text { Türje nb. } \\
\text { Dénes }\end{array}$} & \multirow{2}{*}{ pozsonyi } & 1248: Szántó (Zala m.) & $\begin{array}{l}\text { CD IX/7. 662-665. } \\
\text { (RP 76. sz.) }\end{array}$ \\
\cline { 3 - 4 } & & 1248: Karcsa (Pozsony m.) & $\begin{array}{l}\text { CDS II. 217-218. } \\
\text { (RP 77. sz.) }\end{array}$ \\
\hline
\end{tabular}

1. táblázat: az 1206-1248 közötti nádori ítéletek földrajzi vonatkozásai

A táblázaton végigtekintve szembetünő, hogy a nádorok ispánsága és az általuk hozott itéletek földrajzi megoszlása között semmilyen különösebb összefüggést nem fedezhetünk fel. Még jobban kidomborodik ez, ha megvizsgáljuk azokat az eseteket, amikor az intézkedés éppen az ispáni megyéjükbe esett. Rögtön az első esetben Mog nádor és bihari ispán a Váradi Regesztrum egy későbbi bejegyzésének visszatekintése alapján a bihari várnépek és várjobbágyok, illetve egy klerikus közötti ügyben ítél. Itt Mog jól láthatóan bihari ispánként hozott ítéletet Magnus klerikus javára, amit az is támogat, hogy a regisztrum bejegyzése ebben az esetben kiemelte, hogy a nádor ispán is volt egyben, mivel a lejegyző is lényegesnek vélte ezt. ${ }^{263}$ A következő ilyen eset, amikor Gyula nádor és soproni ispán a soproni csöböradók ügyében megparancsolta az adók beszedőinek, hogy a borsmonostori egyház népeinek soproni falvaiban ne szedjék be a csöböradót. Gyula szintén ispánként hozta meg az ítéletet, még ha oklevelében elsősorban nádornak is címezte magát, hiszen egy királyt illető, de a megyésispán által beszedett jövedelemről ${ }^{264}$ intézkedett Imre király privilégiuma alapján. Türje nembéli Dénes nádor és pozsonyi ispán 1248-ban egy pozsonyi várjobbágynak csereföldet adott a régi földje ellenében. Ez is egyértelműen ispáni feladatkör, azaz itt sem nádorként intézkedett, hanem a másik hivatalához kötődő teendőit látta el. Furcsa mód tehát az összes olyan esetről ki lehet mutatni, ahol az ispánság és az ítélet egy megyébe esett, hogy ott nem nádori mivoltában intézkedett a tisztség viselője.

Éppen a Váradi Regesztrum kínál néhány további érdekes példát a területi vonatkozások szempontjából. Mivel Kálmán törvénye alapján az ország összes székeskáptalanjában tarthattak istenítéletet, ezért az esetek többsége helyből került ki - az ország más pontjain élők a hozzájuk közel eső helyeket keresték föl. ${ }^{265}$ Viszont Várad esetében van néhány megmagyarázhatatlanul távoli megkeresés is. Ha a beazonosítható dunántúli és nyugatfelvidéki jogeseteket vesszük szemügyre, akkor azt tapasztaljuk, hogy ott mindig valamilyen főméltóság ítél: királynéi udvarispán vagy országbíró, ${ }^{266}$ esetleg valamilyen megyésispán, aki

\footnotetext{
${ }^{263}$ RV 97. sz. Általában nem írták oda a nádor ispáni címét, ha említik őt a bejegyzésekben.

${ }^{264}$ A csöböradóról legújabban: Weisz 2012. 52-54.

${ }^{265}$ A regisztrum helyneveit K. Fábián Ilona vitte térképre, azon jól lemérhető a káptalan vonzáskörzete, lásd K. Fábián 1997.

${ }^{266}$ RV 312. sz. (1221): Nyitra és Bars m.; 339. sz. (1222): Somogy m.
} 
a király környezetében tartózkodik, és a szöveg külön kiemeli, hogy királyi parancsra lett az eset bírája. ${ }^{267}$ Nem említenek külön királyi parancsot egy trencséni vonatkozású ügyben, ahol Márton bolondóci ispán volt a bíró, sem egy Győr megyei esetnél, amikor Miklós győri ispán ítélt. $^{268}$ A legtöbb nyugat-magyarországi vonatkozású ügyben viszont a nádor ${ }^{269}$ vagy a helyettese $^{270}$ volt a bíró. Kézenfekvő magyarázatnak tünik, hogy a pl. Vas vagy Somogy megyei emberek elkezdték a pert a környékükön járó nádor vagy a helyettese előtt, és amikor az egyik kitüzött határnapra eljutott az ügymenet odáig, hogy már csak az istenítélet dönthetett, akkor a bíró az éppen aktuális tartózkodási helyéhez közel eső káptalanhoz küldte a feleket. A fenti esetekben pedig éppen a váradi káptalan volt ez a legközelebbi hely, így kerülhettek az ország másik feléröl származó emberek Váradra. Más bírák esetében is ez lehetett a magyarázat: az országbíró ugyanúgy a királlyal együtt mozgott az országban, ahogy a többi ispán is, aki a király környezetében tartózkodhatott (ez a királyi parancs emlegetése esetében egyértelmü, a bolondóci és a győri ispán esetén csak feltételezhetjük ugyanezt). Így a per egyes állomásának a helyszíne mindig változott, és kiszámíthatatlan volt, hogy hol fejeződik be. Ráadásul látható, hogy a Regesztrum egymás után következö bejegyzéseiben többnyire közel esnek egymáshoz azok az esetek, amikor a nádort jelölik meg eredeti bíróként. ${ }^{271}$ Ezek szintén arra utalnak, hogy csak bizonyos időközönként szaporodtak meg a váradi káptalan azon ügyei, amikor a nádor küldte a feleket hozzájuk: nyilván, amikor éppen a közelben tartózkodott.

Feltehetjük, hogy a nádor mozgásának valamiféle rendszert kellett követnie. Ezt egyfelől az a szükségszerüség is diktálja, hogy azok, akik az ítélőszéke előtt elkezdték a pert, és egy későbbi határnapra történő halasztás történt, megtalálhassák őt akkor is, amikor már nem a közelükben tartózkodik. Hogy mindez a felvetés a gyakorlatban is múködött, arról a legrészletesebben Tomaj nembéli Dénes 1236. évi oklevele tájékoztat. ${ }^{272}$ A felperes Zlaudus

\footnotetext{
${ }^{267}$ RV 100. sz. (1214): Zala megyei ügyben királyi parancsra Salamon bácsi ispán ítél; 274. sz. (1220): Zala és Somogy megyei ügyben Mika bihari ispán ítél András parancsára; 327. sz. (1222): a pozsonyi ispán perlekedik Fejér megyeiekkel, a király által delegált bíró Oguz ispán; 268. sz. (1220): a zalai királyi lovászok és királyi tárnokok közti perben Demeter mestert bízta meg a király.

${ }^{268}$ RV 371. sz. (1229); 270. sz. (1220)

${ }^{269}$ RV 281. sz. (1221): Miklós nádor, Baranya m.; 308. sz. (1221): Miklós nádor, Fejér és Komárom m.; 313. sz. (1221): Miklós nádor, Vas m.; 314. sz. (1221): Miklós nádor, Vas m.

${ }^{270}$ RV 248. sz. (1220): Fila vicarius palatini, Somogy m.; 266. sz. (1220): Fila vicarius palatini, Tolna m.; 271. sz. (1220): Mór vicepalatinus, Komárom m.; 321. sz. (1221): Mór vicepalatinus, Bars (?) m.

${ }^{271}$ Pl.: 1213: 9., 15., 19., 27., 62., 64. sz.; 1214: 89., 95., 97., 103., 105. sz.; 1219: 175., 180., 189., 213., 217. , 220., 226. sz.; 1220: 244-245. sz. (ugyanekkor két alnádori eset: 248-249. sz.); 269. (alnádori: 271. sz.), 275. , 277. sz.; 1221: 280-281. (alnádori: 282. sz.), 285., 288. (alnádori: 289. sz.), 290. sz.; 308-309., 313-314. sz. (alnádoriak: 318., 321. sz.); 1222: 333., 337. sz. Ezeken kívül néhány eset „magányosan”áll.

${ }^{272}$ HO VI. 30-34. (RP 43. sz.)
} 
mester (a későbbi veszprémi püspök és királyi kancellár) egy birtokhatár-perben megidézte a nádori ítélőszék elé a Zala megyei Szántó birtok ügyében a zalai udvarnokokat. 1236. június 24-én csak ő jelent meg a nádor előtt, az udvarnokok nem. A nádor egyre újabb és újabb határnapokat jelölt ki a peres felek részére, ahol rendre csak a felperes jelent meg, az udvarnokok nem, sőt, azok az őket megidéző nádori poroszlóra támadtak. Az oklevélből kiderül, hogy Dénes nádor június 24. és július 21. között a Heves megyei Poroszlón volt, majd július 21-én Esztergomban, augusztus 27-én a Nógrád megyei Losonc közelében lévő Gálcson, ${ }^{273}$ míg szeptember 21 -én a Baranya megyei Cselejen (lásd 1. sz. ábra).

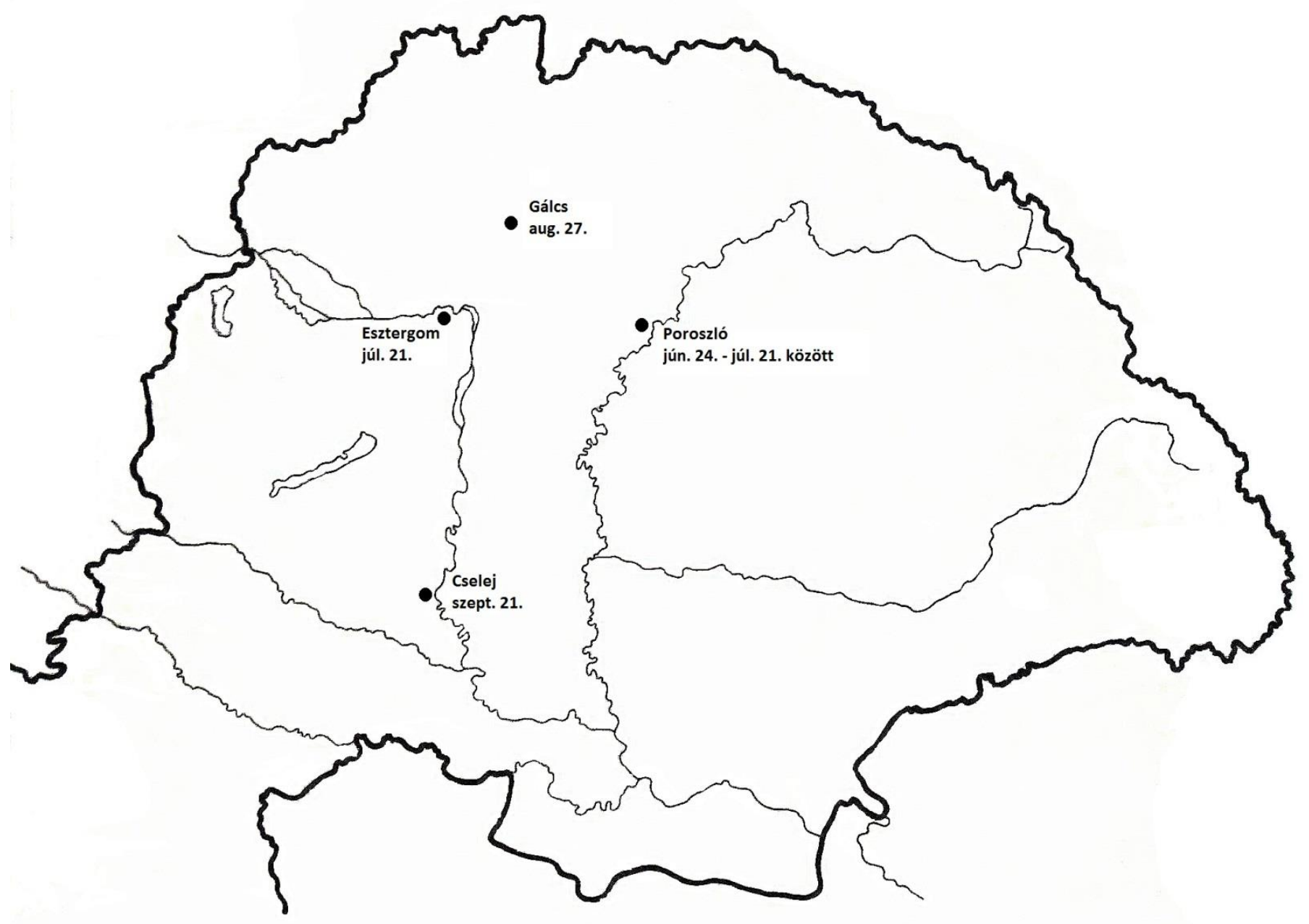

1. ábra: Tomaj nembéli Dénes tartózkodási helyei (1236)

Zlaudusnak nem okozott gondot, hogy minden alkalommal megtalálja a nádort, sőt, az oklevél szerint a köztes időben hazament birtokára, Zala megyébe (tehát nem a nádor

\footnotetext{
${ }^{273}$ A 15. századi másolatban fennmaradt oklevél szövegében ,inlulunch in Galch” szerepel. A szöveg a másolás során romlott, az ,inlulunch" valójában: in Lusunch lehetett, hiszen az $l$ betü könnyen összekeverhető a hosszított $s$-sel, ha a másoló nem érti a szöveget. Gálcs (Gács) település Nógrád megyében volt, közvetlenül Losonc mellett.
} 
kíséretével együtt utazott ő is). Figyelemre méltó, hogy Dénes nádor és a felperes Nógrád megyében volt augusztus 27-én, és szeptember 8-án Dénes azt rendelte el Zlaudus számára, hogy igazolja poroszlója szavahihetőségét. Szeptember 21-re Dénes már Baranya megyében, a Duna mellett tartózkodott, amikor Zlaudus felkereste őt a poroszlót igazoló Zala megyei és környékbeli tanúkkal és oklevelekkel. Ha az időpontok közti különbséget nézzük (13 nap), és azt, hogy a tanúk és oklevelek összegyüjtése is némi időbe telhetett, akkor mindenképpen arra kell gondolnunk, hogy a felperes tudta, hogy nagyjából merre induljon, hogy a kitüzött határnapra megtalálja a nádort. Ezt csak úgy lehetett megvalósítani, ha a nádor legalábbis egy rövid időre (legalább 2-3 hétre) előre megtervezi az útvonalát, és ha valami sürgős királyi parancs el nem téríti ettől, akkor tartotta is magát ahhoz. Valószínü (sőt, szükségszerü), hogy idézések esetén a nádori poroszló nem csak a határnapot mondta meg a beidézett félnek, hanem a helyet is, bár erre az oklevelek nem tesznek utalást, vagy ha ő maga állította a feleket az ura elé, akkor tudta, hogy nagyjából hova kell vezetni őket.

Megjegyzendő, hogy erre az időszakra, az 1220-1230-as évekre esik a pannonhalmi vonatkozású nádori ítéletek fénykora. Ennek fő mozgatója az akkori pannonhalmi apát, Uros volt. Az apát hosszú hivatali ideje alatt (1207-1242) hatalmas igyekezettel védte és gyarapította egyháza birtokállományát. A legmagasabb világi és egyházi hatóságoknál járt közbe, és bárkivel perre ment az apátság vagyonáért. Ennek a „stratégiának” a részét képezte, hogy az ítéletekről okleveleket állíttatott ki magának, amelyek őrzéséről, sőt, másolatok készítéséről is gondoskodott, és ezeket az okleveleket ügyesen használta későbbi pereiben. ${ }^{274}$ Uros idején olyan megszokottá vált, hogy az apátság ügyei a legnagyobb világi és egyházi föméltóságok előtt rendeződnek, hogy IV. Béla 1257-ben már egy szokásjogból fakadó kiváltságként erősítette meg azt, hogy az apát és a népei csak a király vagy a nádor előtt foghatók perbe. ${ }^{275}$ Összesen 37 pannonhalmi vonatkozású nádori vagy albírói ítéletet, intézkedést vagy oklevelet tudunk regisztrálni 1248-ig bezárólag, amelyek egy kivételével mind Uros apátságának idejére esnek. ${ }^{276}$ Egyetlen nagyobb „lyukat” találunk: 1226-tól, Barc

\footnotetext{
${ }^{274}$ KMTL 701-72.; Szovák 1989. 301.

${ }^{275}$ RA 1149. sz.

${ }^{276}$ PRT I. 645-646. (RP 6. sz.); PRT I. 647. (RP 7. sz.); PRT I. 647-648. (RP 8. sz.); PRT I. 652-653. (RP 9. sz.) (egy nádori és egy albírói intézkedést is említ); PRT I. 651-652. (vö. RP 13. sz.); PRT I. 625. (két nádori ítéletet is említ); PRT I. 661.; RP 14. sz.; PRT I. 675. (RP 18. sz.); PRT I. 675-676. (RP 19. sz.); PRT I. 676677. (RP 20. sz.); PRT I. 677. (RP 21. sz.); PRT I. 678-679. (RP 24. sz.); PRT II. 291-292. (RP 26. sz.); PRT I. 751. (RP 45. sz.) (saját magán kívül korábbi 4 nádori ítéletet is említ); PRT I. 755-756. (RP 47. sz.); PRT I. 753754. (RP 48. sz.); PRT I. 756-757. (RP 49. sz.); PRT I. 752-753. (RP 50. sz.); PRT I. 754.; PRT I. 761-762. (RP 56. sz.); PRT I. 759-760. (RP 57-58. sz.) (két nádori intézkedést is említ); PRT I. 762. (RP 59. sz.); PRT I. 763764. (RP 60. sz.); Solymosi 1998. 210-211. (RP 61. sz.); PRT I. 768-769. (RP 62. sz.); PRT I. 760-761. (RP 65.
} 
fia Miklós nádorságának végétől egészen 1236-ig, Tomaj nembéli Dénes nádorig nincs egyetlen olyan ismert nádori ítélet sem, amely pannonhalmi vonatkozású lenne. A kérdéses időszakban hangsúlyosan Ampod fia Dénes volt a nádor (illetve 1228 és 1231 között Mojs, de az ö hivatali müködése láthatatlan: egyetlen hozzá köthető oklevél vagy ítélet sem maradt ránk!). Apod fia Dénest többször támadták egyházellenes tevékenysége miatt, és úgy tünik, hogy Uros apát sem bízott meg benne. Egyébként pedig két „kedvenc” nádora Barc fia Miklós és Tomaj nembéli Dénes volt. Uros 35 éven át volt apát, de ennek a két nádornak összesen 14 évnyi hivatali idejére esik majd minden olyan ítélet (a 37-ből 32), amelyben a nádor is szerepet kapott. Az első ítéleteket már Pot (1209-1212) és Bánk (1212-1213) idejéből regisztrálni tudjuk, ${ }^{277}$ ám a Szentföldről visszatérve, 1219-től kezdődnek nagyobb számban. A legelső ránk maradt, 1219-re keltezhető ilyen oklevél elárulja, hogy az apát a király elé vitt egy (egyébként nem túl jelentős) ügyet, és András adta tovább a nádorának. Itt tehát Uros még nem a nádori ítélőszéktől várta igazát, de Barc fia Miklós már teljesen önállóan, a maga nevében zárta le az esetet. ${ }^{278} 1220$ folyamán az apát újra a nádort kereste fel, amikor egy olyan perben kellett ítélkeznie, ahol a királyi udvarnokokkal és várnépekkel támadt konfliktusa. Bár az udvarnokok szereplése indokolhatja a nádori ítélőszéket, ${ }^{279}$ lehetséges, hogy az apát itt is András királyt kereste föl először, mivel az eset kapcsán egyszerre tünik föl a nádor és a király poroszlója. ${ }^{280}$ Ám látszólag semmi nem indokolja azt, hogy ugyanebben az évben (1220) Uros egy olyan pert is Miklós nádor előtt tárgyalt meg, amelynek semmilyen udvarnoki vonatkozása nem volt, és András király közbenjárását sem említették. ${ }^{281}$ Úgy tünik tehát, hogy Uros apát „rászokott” a nádori ítélőszékre. Egy szintén nem alávetett népek elleni pert (a nádor valószínüsíthető távolléte miatt) Márton nádori albíró előtt kezdeményezett 1220-1221 folyamán, majd Márton döntésének áthágói ellen már magánál Barc fia Miklósnál keresett jogorvoslatot, aki 1221-ben ezt a döntését is egy oklevéllel zárta le. ${ }^{282}$ Miklós valamikor 1219 és 1221 között (gyaníthatóan inkább 1220-1221 folyamán) egy teljesen egyházi vonatkozású tizedperről is döntött és oklevelet adott Urosnak. ${ }^{283}$ Az apát a fehérvári latinokkal és a nagyhalomi besenyőkkel folytatott tizedperben is Miklós nádor döntésére bízta

\footnotetext{
sz.); A Pannonhalmi Regisztrum három olyan nádori oklevelet is említ (PRT II. 255-256.) (RP 27., 66. és 78. sz.), amely önálló, mára elveszett oklevelet takar.

${ }^{277}$ Vö. PRT I. 751. (RP 45. sz.)

${ }^{278}$ PRT I. 645-646. (RP 6. sz.)

279 A királyi udvarnokok hivatalból a nádori ítélőszék alá tartoztak, lásd a „7.1 - Az udvarnokok feletti joghatóság" c. alfejezetet.

${ }^{280}$ PRT I. 647-648. (RP 8. sz.)

${ }^{281}$ PRT I. 647. (RP 7. sz.)

${ }^{282}$ PRT I. 652-653. (RP 9. sz.)

${ }^{283}$ A Pannonhalmi Regisztrum említi ezt az oklevelét (PRT II. 255.), lásd RP 13. sz.
} 
magát (a besenyők kapcsán ez természetes, hiszen a besenyők is a nádori joghatóság alá tartoztak, ${ }^{284}$ a szabad státuszú fehérvári „latinok” viszont nem), csakúgy, mint egy két szolga hovatartozását érintő perben. Hogy ezekről Miklós adott-e okleveleket az apátnak, nem tudjuk. ${ }^{285}$ A nádori ítélőszék mellett azonban később is előfordult, hogy az apát a királyt kereste fel panaszával, aki áttette az ügyet a nádorhoz. Az ügyek többsége birtokvita volt akár világi személyek, akár más egyházak, akár a királynak alávetett népek között. ${ }^{286}$ Tizedvitában is sokszor döntött a nádor, csakúgy mint státuszperekben. ${ }^{287}$ Egyedi csoportot alkotnak azok a perek, amikor a monostornak alávetett népek szolgáltatásainak a milyenségében döntött egyszer Miklós (a híres „,pannonhalmi per” első állomásaként), egyszer pedig Tomaj nembéli Dénes. ${ }^{288}$ Mindkét ügy a király (II. András és IV. Béla) előtt indult, és a király tette át a nádori ítélőszék elé, talán mert az udvarnokok miatt illetékesebbnek ítélte azt a fórumot. Uros halála után (1242) a nádor gyakorlatilag már nem ítélt Pannonhalma kapcsán. Az Árpád-kor végéig bezárólag összesen két vonatkozó nádori ítéletlevelet ismerünk (mindkettőt Roland adta ki, 1254-ben ill. 1255-ben). ${ }^{289}$ Roland után nincsen már nádor, akinek színe elé pannonhalmi vonatkozású perek kerültek volna, sőt, 1335-ben Druget Vilmos nádor előtt a monostor már arra a kiváltságára hivatkozott, hogy ök a királyon kívül semmilyen bírói fórum elé nem állíthatóak, és az apátság ezen privilégiumát Vilmos nádor is elismerte. ${ }^{290}$

\section{2 - A regionális nádorság kezdete}

A nádori hivatal jellemzőiben Rátót nembéli Domonkos fia Roland első nádorsága alatt (1248-1260) következett be fontos változás. Ezzel a ciklussal Roland az általunk vizsgált (1342-ig terjedő) korszak leghosszabb összefüggő nádori hivatalát töltötte, ám nem ez teszi egyedivé működését. Nádorságának főbb jellemzőit Szovák Kornél elemezte ki. ${ }^{291}$

\footnotetext{
${ }^{284}$ Lásd a „7.2 - A besenyők” c. alfejezetet.

${ }^{285}$ PRT I. 651-652.

${ }^{286}$ PRT I. 647., 647-648., 652-653. (RP 7-9. sz.); DL 44031. (a vonatkozó rész kiadása: RP 14. sz.); PRT I. 675., 676-677., 677., 751., 753-754., 755-756., 756-757., 760-761., 763-764., 768-769. (RP 18., 20-21., 45., 47-49., 60., 62., 65. sz.) A Pannonhalmi Regisztrum említésében: PRT II. 255., 256., vö. RP 66., 78. sz.); ill. PRT I. 754.

${ }^{287}$ Tizedper: PRT I. 632., 759-760., 762. (RP 56-59. sz.), PRT I. 651-652., ill. a Pannonhalmi regisztrum említésében: PRT II. 255. (vö. RP 13. sz.); státuszper: PRT I. 645-646., 675-676., 752-753. (RP 6., 19., 50. sz.), PRT I. 661.

${ }^{288}$ PRT I. 678-679., 768-769. (RP 24., 61. sz.)

${ }^{289}$ PRT II. 290-291. és 293. (RP 98. és 100. sz.)

${ }^{290}$ AOkl XIX. 444. sz. A nádor és az egyházak közötti kapcsolatra lásd még az „5.2 - A nádorral szembeni jogi immunitás" c. alfejezetet.

${ }^{291}$ Szovák 1989
} 
Megállapítása szerint a pozsonyi ispáni címet is viselő Roland legtöbbször Pozsonyban keltezte oklevelét, és vélhetően ott tartotta a saját kúriáját is, és a többi ítélete is zömében az északnyugati régióba esik. Ez egy kölcsönös folyamat volt, ugyanis a nádort eleve azok kereshették föl, akik a közelben voltak, és így nem kellett nagy költségeket fordítani az utazásra. ${ }^{292}$ Úgy tünik, hogy Roland teljesen fehagyott az „utazó nádor” szokásával. Ebben szerepet játszott az a tény is, hogy Roland már 1242-ben Frigyes osztrák herceg ellenében is megerősítette és védte Sopron és Pozsony várát, így alkalmasnak látszott arra, hogy az ötvenes években, a Babenberg-háborúk időszakában is védje a nyugati határszélt. ${ }^{293}$ Roland intézkedéseinek nagy része tényleg Pozsony megyébe esett, illetve a környező vidékre (lásd a 2. sz. térképet, ahol csak a nem Pozsony megyei vonatkozású intézkedéseit tüntettük fel.).

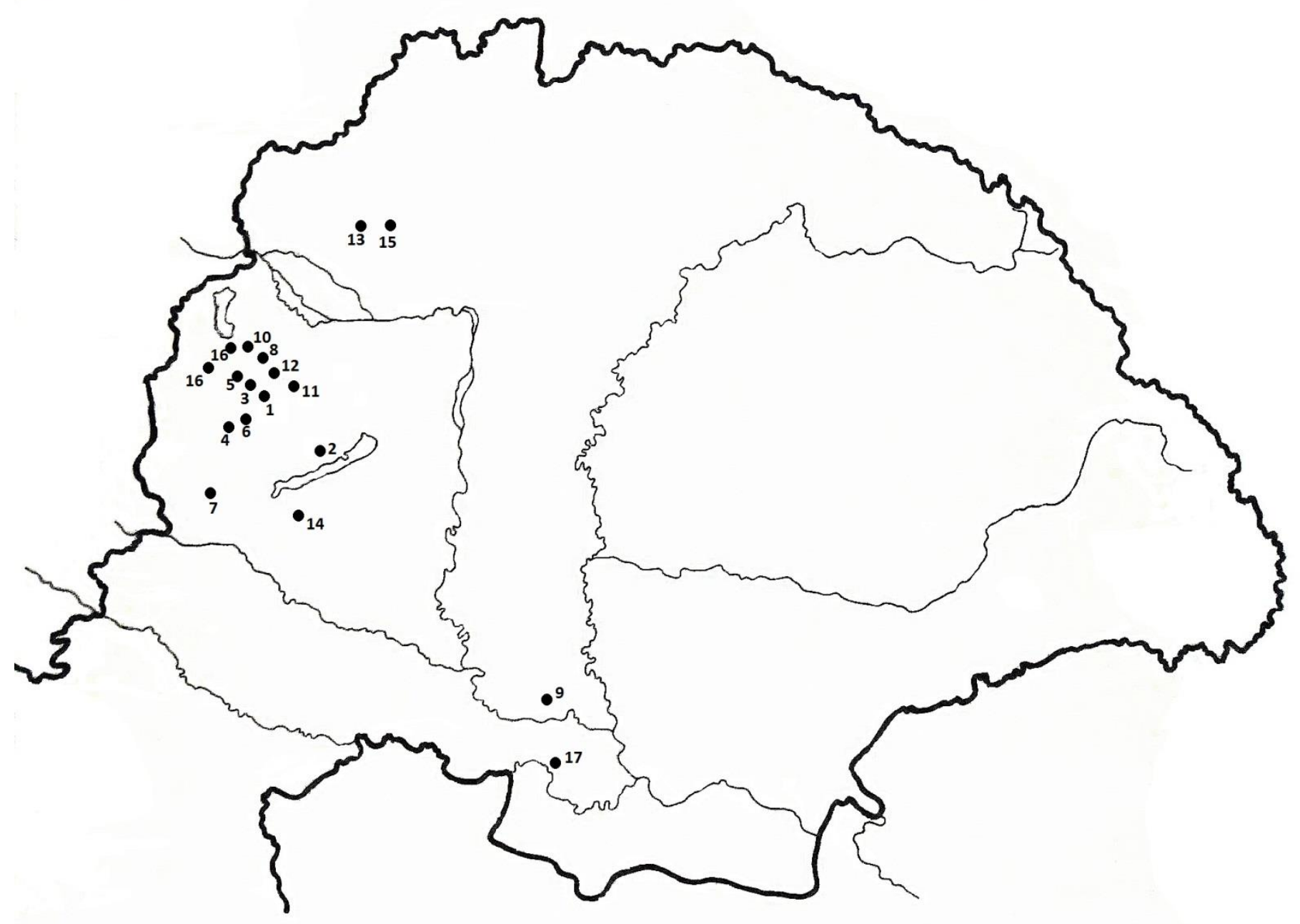

2. ábra: Roland nádor 1248-1260 közötti nem Pozsony megyei intézkedései

A számok a következö helyeket jelölik (zárójelben a forrás) - 1: Kamond, Veszprém m. (PRT XII/A 437-438., RP 82. sz.); 2: Nevegy, Zala m. (Sörös 1908. 162-163., RP 84-85. sz.); 3: Tokorcs, Vas m. (UB I. 231-232., RP 92.

\footnotetext{
${ }^{292}$ Szovák 1989. 299-303.

${ }^{293}$ RA 1928. sz., vö. Szovák 1989. 303.
} 
sz.); 4: Vasvár, Vas m. (UB I. 235., RP 95. sz.); 5: Urai, Vas m. (UB I. 235-236., RP 96. sz.); 6: Balozsaj, Vas m. (UB I. 243-244., RP 102. sz.); 7: Nova, Zala m. (Zala I. 28., RP 108. sz.); 8: Kisfalud, Sopron m. (UB I. $326-$ 327., RP 109. sz.); 9: Szolnok, Bács m. (CDS II. 393.); 10: Agyagos, Sopron m. (UB I. 252-253., RP 110. sz.); 11: Gyimolt, Veszprém m. (RP 111. sz.); 12: Család, Sopron m. (UB I. 237-238., RP 114. sz.); 13: Csekej, Nyitra m. (CDS II. 434.); 14: Terebez, Somogy m. (HO VII. 74., RP 118. sz.); 15: Macskaszarm, Bars m. (CDS II. 241., RP 121. sz.); 16: Csáva, Széplak, Sopron m. (UB I. 240-241., Függelék, A-reg.); 17: Szerémvár, ${ }^{294}$ Szerém m. (CDCr V. 623-624.). Nincs feltüntetve bizonytalan lokalizációja miatt Sebes birtok (talán Tolna megye?) (RP 120. sz.); egy Rábca mentén fekvő malom (Vas m.) (UB I. 239-240., RP 99. sz.)

Az itt feltüntetett 16 esettel szemben áll 22 biztosan Pozsony megyei ügy, ${ }^{295}$ további néhány esetben vagy nem állapítható meg a területi vonatkozás, vagy felesleges is olyat keresni. ${ }^{296}$ A két Dél-Magyarországra eső helyszín Szolnok (a település nem a Tisza melletti Szolnokkal, hanem a bodrogi várhoz tartozó Bács megyei Szolnok földdel azonosítható), illetve Feketenép, amely a szerémi vár tartozéka volt. ${ }^{297}$ Roland ekkor is Béla király külön parancsára (ex speciali mandato domini Bele, illustris regis Ungarie) intézkedett, a várföldek visszavételének ügyében. ${ }^{298}$

Mindez átvezet minket egy olyan szerepkörbe, amely az országbárók, így a nádor esetében is egyre markánsabb gyakorlattá válik, és amely a nádorok esetében az 1260-as években tetőződik, ti. hogy a külön királyi megbízás alapján adott egyéni, sokszor politikai jellegü feladatok egyre inkább háttérbe szorítják a „hagyományos” nádori funkciót. Végül az 1262-től kezdődő országmegosztás rendkívüli helyzete teremtette meg azt, hogy a nádor már elsősorban a király éppen aktuális parancsait és igényeit végrehajtó báró lett, aki mellesleg a nádori címet viselte. Külön felhatalmazás alapján már a tatárjárás előtt is intézkedtek nádorok, föként Ampod fia Dénesnek ismerjük jó néhány ilyen megbízását. 1227-ben II. Aszen bolgár cárnál járt, nyilván diplomáciai úton, és tagja volt annak a követségnek is, amelyet II. András király a pápához menesztett, amikor 1232-ben kiközösítették őt. ${ }^{299}$ 1239-ben Tomaj nembéli

\footnotetext{
${ }^{294}$ Az intézkedés a szerémi várhoz tartozó Szerém megyei Feketenép (Feketevnep) nevű földet érintette, ám mivel a föld elhelyezkedése a megyén belül nem ismert, ezért a várat vittük föl a térképre.

${ }^{295}$ CDS II. 222. (RP 79. sz.); CDS II. 246-247. (RP 80. sz.); CDS II. 265. (RP 81. sz.), az eset két intézkedésröl is szól; CDS II. 269. (RP 83. sz.); CDS II. 284-285. (RP 86. sz.), két külön intézkedésről is szól; CDS II. 286. (RP 87. sz.); CDS II. 289-290. (RP 88. sz.); CDS II. 292-294. (RP 89. sz.); CDS II. 290. (RP 90. sz.); CDS II. 352. (RP 103. sz.); CDS II. 353. (RP 104. sz.); RP 105. sz.; CDS II. 353-354. (RP 106. sz.); CDS II. 354-355. (RP 107. sz.); RP 112. sz.; CDS II. 394. (RP 117. sz.); CDS II. 461-462. (RP 119. sz.); AO VII. 30-31. (RP 124. sz.); MES I. 404.; RA 1102. sz.

${ }^{296} \mathrm{Pl}$. egy alkalommal kötelezi Péter ispánt, hogy Osl bán özvegyének fizessen a megadott határnapra 12 márkát (RP 123. sz.), máskor jóváhagy egy előtte lezajlott pénzbeli adósság-kiegyenlítést (RP 122. sz.).

${ }^{297}$ Szolnok földre lásd ÁMTF I. 235.

${ }^{298}$ CDS II. 393.; CDCr V. 623-624.

${ }^{299}$ A váci káptalan 1227. évi okleveléből derül ki, hogy Henche ispán megváltott Dénes nádortól egy birtokot, aki „ab Asceno rege Bulgarorum est reversus” („Aszen bolgár királytól volt visszatérőben”), lásd ÁÚO VI. 446. (vö. RP 29. sz.). A pápai követségre lásd RA 485. sz.
} 
Dénes nádor is „az Alpokon túl” (ultra Alpes) időzött Béla király megbízásából. ${ }^{300}$ Amikor pedig megindult Béla herceg első birtokvisszavételi programja, amely 1229 és 1231 között érte el a csúcspontját, abban András nádora, Ampod fia Dénes is részt vett - ő irányította a besenyő földek restitúcióját. A Magyarországra telepített besenyők egy részének feje a nádor volt, így Dénes - II. András politikájának elkötelezett híveként - nyilván csak kényszerü hivatali kötelességének tett eleget, amikor ,a király parancsára az összes elidegenített besenyő földet" visszavette. ${ }^{301}$ Ám a tatárjárás után egyre gyakoribbá lettek a különféle nádort érintő „bizottsági” megbízások. 1247-ben István nádor Csák soporoni ispánnal közösen vizsgálta meg és távolította el a Rába folyón épült „káros malmokat”, amelyek malomgátjaikkal elzárták a folyó folyását. ${ }^{302}$ Ám az igazi nagy felülvizsgálat-sorozat az elidegenített várföldek és egyéb királyi népek földjeinek visszavétele ügyében indult meg. Béla a legkülönfélébb tisztségviselőit bízta meg mind a várföldek, mind az udvarnokföldek felülvizsgálatára. ${ }^{303}$ Roland nádor már 1252. november 25-én arról írt, hogy „királyi parancsra az összes, pozsonyi vártól elidegenített földet mindenkitől visszakértük és a pozsonyi várnak visszaadtuk Béla király regisztruma alapján, amelyet a mondott vár földjeiről készítettek”. ${ }^{304} 1255$ végén egy újabb felülvizsgálat-sorozat kezdődött Pozsony megyében, amelyet a nádor Vince nyitrai püspökkel közösen bonyolított le. ${ }^{305}$ Ám még 1254 kora őszén került sor egy Vas megyei birtokfelülvizsgálatra. Első ilyen tárgyú oklevele 1254. szeptember 29-én kelt. ${ }^{306}$ Egy, csak tartalmi átírásban fennmaradt Vas megyei felülvizsgálatokkal kapcsolatos levelét egyenesen úgy vezették be, hogy „a király úr Roland nádorra bízta, hogy az ő nevében az egész országában vizsgálja felül a vártól illetéktelenül elidegenített földeket és azokat a váraknak juttassa vissza". ${ }^{307}$ Mivel Roland a teljes szövegben fennmaradt okleveleiben sehol nem ír általános, országos megbízásról, ezért könnyen lehet, hogy ez a bevezető inkább az átírás interpretációja, de az is lehet, hogy tényleg ott szerepelt. Az viszont bizonyos, hogy a

\footnotetext{
${ }^{300}$ HO VI. 37.

301 „de mandato domini regis omnes terras Byssenorum alienatas revocaremus” UB I. 161-162. (RP 32. sz.) A nádor besenyők feletti joghatóságáról lásd a „7.2 - A besenyők” c. alfejezetet.

${ }^{302}$ UB I. 218-219. (RP 74. sz.)

${ }^{303}$ A birtokvisszavételekröl általában lásd Rákos 1974. 21-27. Az udvarnokföldek restitúciójával kapcsolatban legújabban lásd Kis 2010. 152-207.

304 „ex precepto regio omnes terras a castro Posoniensi alienatas ad ipsum castrum per registrum domini Bele regis, super terras dicti castri confectum, ab omnibus revocassemus et castro Posoniensi restituissemus" CDS II. 284. vö. RP 86. sz. Hasonló módon említi a visszavételeket és a regisztrumot egy tartalmi átírásban fennmaradt oklevelében: CDS II. 290. (RP 90. sz.)

${ }^{305}$ CDS II. 352., 353., 353-354., 354-355.; DL 3965. (RP 103-107. sz.)

${ }^{306}$ UB I. 235. (RP 95. sz.). Lásd még UB I. 235-236., 239-240., 247. (RP 96-97. és 99. sz.)

307 „cum dominus rex ipsum dominum Rolandum palatinum per totum regnum suum vice sui ad revocandas terras a castro indebite alienatas et castris restituendas delegasset” HO VIII. 57. vö. RP 97. sz.
} 
gyakorlatban nem járta végig Roland az ország megyéit ilyen funkcióval, hiszen az 1254. évi Vas megyei, és az azt követő 1255. év végi Pozsony megyi „akció” kivételével egyetlen más megye kapcsán sem maradt fent a nádortól ilyen tárgyú oklevél. Tudjuk ugyanakkor, hogy a bodrogi és szerémi vár kapcsán is végzett ilyen feladatot, amint erről Tamás kalocsai érsek 1256. évi, illetve V. István 1272. évi levele tájékoztat. ${ }^{308}$ A két vár nagyon messze esik Roland hagyományos müködési területétől, de ez megmagyarázható (lásd alább).

Máskor a megyéből való kimozdulást nem „bizottsági” megbízások, hanem más jellegü politikai okok indokolták. 1254 tavaszán Buda mellett találjuk, ott társaival a cseh királlyal kötendő béke részleteit dolgozta ki. ${ }^{309}$ A végül május 1-jén megkötött béke értelmében Stájerország délnyugati fele a magyar királyhoz került, és Béla a közigazgatás beindításában is igényelte Roland részvételét. 1254 második felében Roland ugyan Vas megyében tartózkodott a királyi várföldek visszavételét végző bizottság irányítójaként, ám 1255. február 15-én már a stájerországi Regede várában találjuk. ${ }^{310}$ Valószínüleg itt, vagy a közelében adhatta ki azt a február 9-i oklevelet is, amelyen szakadás miatt épp nem látszik a kelethely. ${ }^{311}$ A vár környékén találkozhatott IV. Bélával, erre utal legalábbis, hogy a február 15-én Regedében lezárt ügyet a király bízta rá megtárgyalásra. Ezután Roland követte a királyt a Dráva folyó mentén keletnek, mivel 1255. március 11-én már Vaskán keltezett oklevelet, és ugyanebben az időben IV. Béla is a településen tartózkodott és több egyházi tizedperrel kapcsolatos ügyet letárgyalt. Roland is részt vállalt ebből az ítélkezés-sorozatból, mert az ő vaskai oklevele is tizedperrel kapcsolatos (semmilyen más ilyen jellegü oklevele nincs egyébként). ${ }^{312}$ Ebből kiderül, hogy a királlyal párhuzamosan, de vele egyeztetve tárgyalta az ügyeket, mert eredetileg párbajt ítélt az óbudai és pannonhalmi egyház között, végül a király kérésére a párbajt visszavonta. Vaska pedig nincs olyan nagyon messze Bodrog és Szerém megyéktől, könnyen lehet tehát, hogy ekkor bízta meg Béla azzal, hogy folytassa le ezeket a vizsgálatokat is. A vaskai ítélkezések (és a szerémi és bodrogi restitúciós tevékenység) után a király és a nádor egyaránt nyugatnak indult, Bélát 1255 áprilisában a Somogy megyei, Dráva közelében fekvő Csurgón találjuk, Roland pedig május közepén ismét Regedében tartózkodott - talán még mindig együtt volt a királlyal, hogy a stájerországi magyar közigazgatás

\footnotetext{
${ }^{308}$ CDS II. 393.; Szerémvár kapcsán a következőket írta V. István: „olim ... Rolandus banus, tunc palatinus et comes Posoniensis ab ipso patre nostro [ti. IV. Béla] pro revocandis iuribus castrorum iudex deputatus, quamdam terram eorum hereditariam Feketevnep vocatam nomine iuris castri Sirmiensis, ad suggestionem quorumdam emulorum suorum fecisset impediri, et annotari in registro" CDCr V. 623-624. (RA 2184.)

${ }^{309}$ CDS II. 306. (RP 94. sz.)

${ }^{310}$ Regedei oklevele (1255. febr. 15.): UB I. 240-241. (Damus pro memoria, lásd Függelék, A-regeszta).

${ }^{311}$ UB I. 239-240. (RP 99. sz.)

${ }^{312}$ Roland vaskai levele: PRT II. 293. Béla ott kiadott, tizedperekkel kapcsolatos oklevelei: RA 1036-1038. sz.
} 
kiépítésében és megszilárdításában segítsen. ${ }^{313}$ Ám az északnyugati régió ügyeitől itt sem szakadt el: Vas megyeiek keresték fel, hogy intézkedjen egy föld hovatartozásának ügyében, és Roland az emberével utasításokat adott a vasvári káptalannak, majd májusban (az említett Regede melletti oklevelében) zárta le a kérdést. Hogy meddig maradt stájer területeken, nem tudni, ám az itt időzéséhez köthetjük azt a napi kelet nélküli, a Regedevártól nem túl távoli Muraszombaton kiadott oklevelét, amelyben egy Zala megyei föld perét zárta le. ${ }^{314} 1255$ decemberében már ismét Pozsony megyében találjuk Rolandot az említett Pozsony megyei felülvizsgálatok céljából. Mivel ekkor, 1255 első felében tudjuk egyedül kimutatni azt, hogy Roland a frissiben Magyarországhoz került stájer országrész és egyéb ügyek miatt az ország déli, délkeleti részén tartózkodott, így a bodrogi és szerémi felülvizsgálatokat is ehhez az időponthoz, 1255 tavaszához köthetjük (láttuk, hogy a bodrogiról 1256-ban már említés történt). Ez mellesleg jól beleillik abba, ami Béla egy 1255. évi okleveléböl derül ki, hogy korábban egy ,általános gyülést” (generalis congregatio) tartott Vácott Nógrád, Hont és Gömör megyék számára a tatárjárás utáni gazdátlan birtokok rendezése céljából, amely gyűlést 1254 februárja utáni időpontra tehetjük, de minden bizonnyal még az 1254. évre. ${ }^{315}$ Ezután indulnak meg a felülvizsgálatok: Roland részéről 1254 őszén Vas megyében, 1255 tavaszán Bodrog és Szerém, 1255 decemberében pedig Pozsony megye számára. Balog (Sinister) Miklós asztalnokmestert szintén 1254-ben bízta meg Béla, speciálisan az udvarnokföldek felülvizsgálatával és helyreállításával. Balog Miklós is 1254-1255 folyamán tevékenykedett. ${ }^{316}$ Valószínű egyébként, hogy a várföldekkel kapcsolatos restitúció nem terjedt ki sokkal több megyére Roland részéről, mint amiről itt tudunk, hiszen Miklós udvarnokföldekkel kapcsolatos munkája is csak néhány nyugat-magyarországi megyében folyt. $^{317}$

E rövid időszak részletesebb áttekintése is jól mutatja azt, hogy Roland nádorként már egy konkrét régió bírája volt (Északnyugat-Magyarországé), ${ }^{318}$ ám ha Bélának szüksége volt egy megbízható emberre, azonnal kimozdította, vagy éppen elmozditotta onnan, mint azt Roland leváltásának a körülményei mutatják. Béla király hüséges embere ugyanis nem meghalt, vagy politikailag megbukott. Ahogy hivatali utóda, Héder nembéli Henrik írta

\footnotetext{
${ }^{313}$ Béla csurgói oklevele: RA 1040. sz. Roland regedei oklevele (1255. máj. 13.): UB I. 243-244. (RP 102. sz.)

${ }^{314}$ Zala I. 28. (RP 108. sz.)

${ }^{315}$ S. Kiss 1971. 13-15.

${ }^{316}$ Kis 2010. 158-160., 184.

${ }^{317}$ Somogy, Zala, Vas és Veszprém megyékben, lásd Kis 2010. 159-160.

${ }^{318}$ Tegyük hozzá: az ország más részei sem nélkülözték teljesen a magasabb szintü bíráskodást, ui. ebben az időben már vlsz. fennállt a Pesten majd Budán székelő alnádor intézménye. Lásd erről részletesen a „8.1 - A nádort helyettesítő tisztségek: alnádor, nádori albíró" c. alfejezetet.
} 
legelső ismert nádori oklevelében 1260 őszén: „Roland nádort időközben másik méltóságba helyezték át”. ${ }^{319}$ Ez a „másik méltóság” nem volt más, mint a szlavón báni tisztség. ${ }^{320}$ Roland első ismert felbukkanása szlavón bánként csak 1261. augusztus 21. utánra tehető, de nádorságát már 1260 augusztusa után elvesztette, valamikor 1260. november 30-a előtt, amikor is Henrik nádor első ismert oklevelét kiadta. Henrik ebben az oklevélben egy Roland által elkezdett, de már be nem fejezett ügyet zárt le, és mivel már említette azt, hogy Rolandnak más méltósága van, ezért nem kételkedhetünk abban, hogy a báni tisztet valamikor 1260 októbere, novembere folyamán kapta meg. A méltóságváltás közvetlen kiváltó oka az volt, hogy a régi szlavón bán, Gutkeled nembéli István ekkortájt tűnt el a forrásokból: nyilván meghalt. ${ }^{321}$ Halálának pontos ideje ugyan nem ismert, de semmi nem zárja ki, hogy ne az 1260-as évek ezen időszakára tegyük. Ám a bán halála egy elég kényes politikai helyzetben következett be. Ezidőtájt történt ugyanis, hogy a szlavón hercegi címre Béla a fiatalabb fiát, Béla herceget nevezte ki, pedig ez a poszt hagyományosan a mindenkori trónörököst illette. Az idősebb fiú, István joggal sérelmezhette mindezt, és nem kevesen az 1260-as éveket fémjelző apa és fiú közti ellenségeskedés egyik kiváltó okának tekintik Béla ezen húzását (bár könnyen lehet, hogy nem ez volt a viszály fó oka). ${ }^{322}$ Ám Roland áthelyezése és a fiatal, 10 11 éves $^{323}$ Béla herceg szlavón herceggé való kinevezése eléggé egybeesik ahhoz, hogy valami összefüggést keressünk: ha István hercegnek valamennyire meg is lehetett magyarázni a döntést, némi „tüske” azért maradhatott benne. Csak ez indokolhatja, hogy a király egy szintén tapasztalt és hű emberét helyezte támaszul fiatalabb fia mellé, akinek ekkor még nyilván nem sok rálátása volt a nagypolitika sötétebb bugyraira. Béla így egy olyan embert választott új szlavón bánnak, aki egyébként jól teljesített a nádori poszton, és biztosak lehetünk benne (és ezt páratlan hivatali potenciálja is megerősíti), hogy a 12 év rutinja után ekkor már igen hatékonyan müködtette hivatalát. Ám a megüresedő szlavón báni poszt élére ő látszott a legalkalmasabbnak, hiszen kisebbik fia mellé egy olyan embert kellett találnia Bélának, aki egyszerre volt tapasztalt és hüséges, és - mivel az ilyen emberek már nyilván mind beépültek az államkormányzatba - elmozdítása a legkisebb politikai kárral járt. És az 1260 nyárutóján megkötött pozsonyi fegyverszünet után (amiben Béla véglegesen lemondott minden stájerországi birtokáról a cseh király javára) már nem volt szükség Roland nyugati

\footnotetext{
319 „Rolandus palatinus medio tempore ad aliam est dignitatem transmutatus” CDS II. 462. (vö. RP 125. sz.)

${ }^{320}$ Archont. 1000-1301. 46.

${ }^{321}$ Karácsonyi 1900. 513.; Engel 2003. Gutkeled nem 5. Sárvármonostori ág 1. tábla: elágazás

${ }^{322}$ Az álláspontokat és a köztörténeti hátteret lásd Zsoldos 2007. 12-18.

${ }^{323}$ Béla herceg születési idejének pontosabb meghatározását lásd Zsoldos 2007. 13-15.
} 
határbiztosítására. Béla lépése jól mutatja, hogy a nádori hivatal hatékony müködtetése mennyire eltörpült az egyéb politikai prioritások mellett.

A Rolandot követő következő időszak fő háttérjellemzője Béla és idősebb fia ellentéte volt. A növekvő feszültség végül 1262 novemberében lobbant lángra, és ekkor vonult fel először fegyveresen egymás ellen Béla király és István herceg - talán még összecsapásra is sor került. A konfliktust mindenesetre gyorsan lezárta egy pozsonyi megegyezés 1262 novemberének végén, amely során István felvehette az „ifjabb királyi” címet. Úgy tünik, hogy István uralma már 1260-tól kezdve kiterjedt a keleti országrész bizonyos Erdélyen kívüli területeire is, ám az ,ifjabb király” posztja teljesen más minőségü újításokat is lehetővé tett a számára. Mintegy megkettőzve apja kormányzati rendszerét, egyedülálló módon saját nádort is állított országrésze élére.

Az addig sem ellenkezett a korabeli gyakorlattal, hogy a királyné és a hercegek a királyhoz hasonló udvartartást építsenek ki maguknak, saját udvari tisztségekkel. Ezen udvari tisztségek a iudex curie névvel illetett udvarispánokból, illetve tárnok-, asztalnok-, lovász- és pohárnokmesterekből álltak. ${ }^{324}$ Ám az önálló nádor állítása egy teljesen más helyzet volt. A nádor ugyanis legkésőbb III. Béla korától kezdve nem az „udvar” részét képezte, hanem egy a felett álló kormányzati pozíciónak minősült, így nem is lehetett a külön udvartartások magától értetődő hozadéka. Ezért nem állított, állíthatott senki a királyon kívül nádort, még annyira sem, amennyire az aktuális helyzettől függően befolyása lehetett a saját udvarának összetételére. A 13. században egyedül a világi államigazgatással sok mindenben párhuzamosan kiépülő egyházi igazgatás számára engedélyezte a király, hogy egy saját palatinust állítsanak. Ott is csak a hierarchia csúcsán álló esztergomi érsek tehette meg ezt, a püspökök csak a hercegi udvar személyzetének egyházi megfelelőiét állíthatták saját népeik fölé. $^{325}$ A tisztség az 1260-as években bukkant fel először, és erősen valószínü, hogy mindez királyi engedéllyel, vagy legalábbis jóváhagyással történt. Béla az egyházi kormányzat ilyetén való párhuzamosságában nem látta világi hatalmának csorbulását. Látszólag ugyan egy hasonló rendszert láthatunk a 11. századi dukátus kapcsán is, hiszen akkor szintén létezett külön királyi és külön hercegi nádor. Sajnos a hercegi nádorispánról - a 11. század forrásviszonyainak ismeretében nem meglepő módon - szinte semmit nem tudunk, csak a létezését tudjuk konstatálni. Arra is csak egyetlen forrás utal egyértelműen, a korábbi

\footnotetext{
${ }^{324}$ A királynéi udvartartásra lásd Zsoldos 2005. 93-95., 97-100., ill. Archont. 1000-1301. 64-69. A hercegire: Archont. 1000-1301. 69-76. Tegyük hozzá: a királyné és a hercegek nem minden esetben nevezhették ki saját maguk az udvari embereiket, alapesetben az ö udvaruk összeállitása is királyi jog volt (lásd Zsoldos 2005. 103106.).

${ }^{325}$ Az érseki palatinus tisztségére lásd részletesebben az 1.1 - Az elnevezés c. fejezetet.
} 
fejezetekben már többször idézett dekrétumfejezet: az ún. László-féle III. törvénykönyv 3. cikkelye. Ez szól arról, hogy ha a nádorispán hazamenne, akkor az udvar pecsétjét tartsa a helyettesénél, és az udvaron kívül ne küldhessen másra pecsétet, csak azokra, akiket udvarnokoknak neveznek, ellenkező esetben 55 penzát fizessen. A cikkely utolsó mondata a következőképpen hangzik: „Hasonlóképp a herceg ispánját is, ha az övéi fölött úgy ítélkeznék, mint mások fölött, ugyanezen ítélettel sújtsák” (ti. 55 penzát fizessen). ${ }^{326}$ A comes elnevezés alatt biztosan a palatinus comest értették, hiszen az egész fejezet róla szól, és a királyi palatinust is csak az első mondatban nevezték teljes nevén (palatinus comes), utána már őrá is csak comesként utaltak. A rendelkezésnek mellesleg akkor van értelme, ha fordítva képzeljük el, mint amit a szórend sugall: ha a herceg (nádor)ispánja mások felett is úgy bíráskodik, mint az ő joghatósága alá tartozók felett, akkor ítéljék el. Talán a külön hercegi nádor halvány nyoma, hogy az 1075. évi garamszentbenedeki alapítólevélben a hercegséget a királysággal frissen felcserélő I. Géza Gyula nádort „Jula comite meo palatino”, vagyis „,az én nádorispánom" formában emlegette. ${ }^{327}$ A birtokos jelző biztosan nem arra utalt, hogy ő nevezte ki, és azért az ő nádorispánja, hiszen ez a korban természetes volt, és semmilyen más esetben nem utaltak rá külön. Talán a Gézával párhuzamos hercegi udvartartás (Lászlóé, aki megkapta a dukátust) ${ }^{328}$ nádorispánja lehetett a másik, de az is lehet, hogy pusztán csak arra utalt, hogy az ekkor nyugati országrészeken tanyázó Salamon királytól megszerezve a hatalmat, itt az ö nádora (és nem Salamon királyé) volt jelen. ${ }^{329}$ Ezt a példát azonban nem állíthatjuk teljes egészében párhuzamba az István ifjabb király alatt létrejött rendszerrel, hiszen a nádorispán funkciója ekkor még teljesen más volt. Udvari tisztségnek minősült, nem külön államkormányzatinak, tulajdonképpen a későbbi udvarispán intézményére hasonlított leginkább. ${ }^{330}$ Így ez a példa csak a párhuzamos királyi és hercegi udvartartásra világít rá. Bár intézménytörténeti szempontból mindenképpen indokolt ekkoriban kettős nádorságról beszélni, funkcionálisan valójában ez nem volt több, mint amikor a 13. századi hercegi udvarok önálló udvarispánnal rendelkeztek.

\footnotetext{
326 „Similiter et ducis comes, qui super suos, quam alios iudicaverit, eadem sentencia corrigatur.” Závodszky 1904. 174. Magyarul: ÍFMT 89. (Körmendi Tamás ford.)

${ }^{327}$ DHA I. 218.

${ }^{328}$ Kristó 1974. 88.

${ }^{329}$ Ez utóbbi értelmezés mellett szól, hogy az alapítólevél szerint jelen voltak még „ceterisque regni mei principibus”, „és az országom egyéb fóemberei” is (DHA I. 218.). Itt biztosan nem a királyi és hercegi „regnumot” állította szembe egymással, hanem inkább azt hangsúlyozta, hogy ez az ő országa, és nem Salamoné. (Más a helyzet, ha a „regnum” szó alatt a király szükebb környezetét, udvarát értette. A szó ilyentén való értelmezésének az ún. Intelmek egy sokat vitatott cikkelye miatt hatalmas irodalma született, de ebbe a kérdésbe itt most nem kíváunk belemenni.) A hercegi nádorispánról lásd még Kristó 1999a. 45-46.

${ }^{330}$ Lásd a „3 - A nádori hivatal elemei és kifejlődése a 11-12. században” c. fejezetet.
} 
Érdemes leszögezni, hogy a címét hivatalosan az 1262. december 5-i poroszlói egyezség értelmében elnyerő ifjabb király már ekkor tisztában volt azzal, hogy saját nádora lesz, esetleg már volt is. István ugyanis az egyezményben kötelezte magát arra, hogy személyesen vizsgálja ki azt, ha a nádorát, udvarbíróját vagy más bíráját apja bárói vagy serviensei bepanaszolják, hogy súlyosan ítélték meg birtokügyeiket vagy mást. ${ }^{331}$ A passzus nyilván arra vonatkozik, hogy ha apja híveinek birtokai éppen a keleti országrészébe esnek, akkor ott ne önkényeskedhessenek István bírái. Ennek ellenére az első ifjabb királyi nádort csak 1263 májusából ismerjük, és 1270-ig bezárólag összesen három nádoráról tudunk. ${ }^{332}$ A nádorváltásokat mindig az indokolta, hogy politikai értelemben Istvánnak nem volt szerencséje az embereivel: a gyorsan változó helyzetben a háromból ketten is átálltak Bélához. Az első ismert ifjabb királyi nádor Péc nembéli Dénes volt, akit még hercegi udvartartásából „örökölt”. Dénes 1259-ben István herceg asztalnokmestere volt, emellett zalai ispán, ami egyértelmüen mutatja, hogy Béla király nevezte ki erre a posztra. ${ }^{333}$ Ennek ellenére az országfelosztás után megmaradt az ifjabb király hüségén, és talán 1264 folyamán (amikor Béla a fia több hívét is átcsábította magához) állt át az idősebb király oldalára, és (ifjabb) Béla szlavón herceg udvarispánjai között találjuk. ${ }^{334}$ István új nádora Csák nembéli Domonkos lett. Amennyire életpályáját ismerjük, „homo novus” volt, és István környezetében jutott először pozícióhoz 1263-ban (ekkor zempléni ispán és ifjabb királyi pohárnokmester. A megye alapján biztosra vehetjük, hogy Istvántól kapta mindkét tisztségét.). Fiatalon jutott ebbe a magasnak mondható pozícióba, hiszen még 1300-ban is élt. A későbbi adománylevelek alapján úgy tünik, hogy ura mellett harcolta végig az 1265-ös belháborút, amiböl katonailag István került ki győztesen. Ennek ellenére 1266 legvégén ő is átszökött Bélához. 1266. december 25-én még nádorként adott ki oklevelet, de utódjának ugyanebböl az évből ismerjük egy említését. ${ }^{335}$ István viszonylag gyorsan választott új nádort Balog nembéli Benedek

\footnotetext{
331 „Item promittimus, quod si comes palatinus noster sive iudex curie nostre, vel alii iudices nostri, barronibus seu servientibus karissimi patris nostri in causis possessionum et aliis conquererentur ex causa probabili se gravari, nos ad insinuationem et requisitionum venerabilis patris Sm[aragdi] archiepiscopi Colochensis personaliter predictorum iudicum sententias et processus audire et emendare tenebimur, iuxta modum prestiti super hoc specialiter sacramenti." MES I. 487.

${ }^{332}$ Archont. 1000-1301. 25-26.

${ }^{333}$ Archont. 1000-1301. 71.

${ }^{334}$ Wertner 1897. 607-608.; Zsoldos 2007. 38.

${ }^{335}$ Archont. 1000-1301. 26., 298.; Zsoldos 2007. 100. Tegyük hozzá: az is elképzelhető, hogy Domonkos 1266. december 25-re datált oklevele valójában 1265. december 25-én kelt. Ebben az időben mind a dec. 25-i (karácsonyi), mind a jan. 1-ji (római) évkezdetet használták a királyi kancelláriákon (Szentpétery Imre szerint a karácsonyi évkezdet sokkal gyakoribb volt. Az évkezdetekre, példákkal, lásd Szentpétery 1985. 33-35.). Amennyiben Domonkos nádor íródeákja a karácsonyi évkezdetet használta, úgy december 25-e esetén az 1266ra írt évszám a mai fogalmaink szerint valójában 1265 . Ez esetben a nádorváltás az év folyamán hamarabb is
} 
személyében, aki szintén teljesen neki köszönhette karrierjét. Azelött István udvarispánja volt, és ezt a tisztségét is megtarthatta, így egyedülálló módon egyszerre lett iudex curie és palatinus. Kétségtelenül igaza lehet Zsoldos Attilának abban, hogy „a szokatlan méltósághalmozás rendkívüli helyzetet sejtet”, ${ }^{336}$ mert tényleg úgy tünik, hogy Istvánnak egyrészt hirtelen kellett valakit találnia erre a posztra, másrészt kezdett kifogyni azokból, akikben maradéktalanul megbízott.

Ha megvizsgáljuk e nádorok müködését, akkor azt látjuk, hogy az 1250-es években kialakult tendenciákat örökítették tovább. Az ifjabb és idősebb királyi nádorok intézkedéseit térképre vetítve a 3. sz. ábrán találjuk.

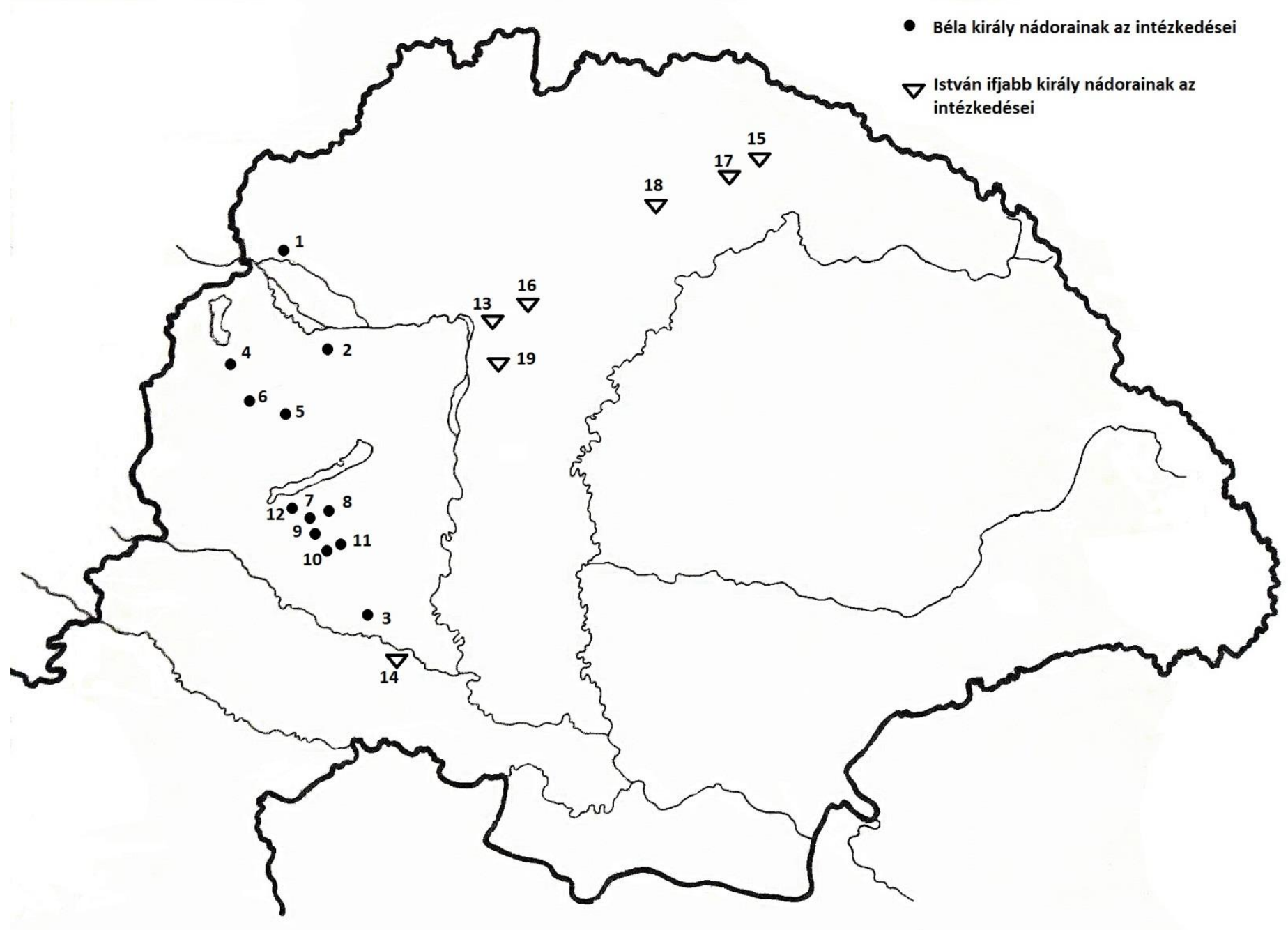

3. ábra: Az idősebb és az ifjabb királyi nádorok intézkedéseinek területi vonatkozásai

lehetett. Ha viszont a római évkezdetet, akkor a nádorváltás valóban az év legvégén kellett, hogy történjen. Ám az 1266. év legvégén lezajlott nádorváltás mellett szól az, hogy Csák nb. Domonkost Lampert egri püspök 1266. november 28-i oklevele még nádornak nevezi (Száray I. 10., vö. RP 135. sz.). Magunk Domonkos kérdéses oklevelét az 1266. év alá vettük föl (RP 136. sz.).

${ }^{336}$ Zsoldos 2007. 100. 
A számok a következö helyeket jelölik (zárójelben a forrás) - 1: Velk, Pozsony m. (CDS II. 461-462., RP 125. sz.); 2: Barát, Györ m. (HOkl. 40., RP 127. sz.); 3: Bagota, Baranya m. (ÁÚO VIII. 44-45.); 4: Hobaj, Sopron m. (UB I. 321., RP 130. sz.); 5: Sár, Veszprém m. (ÁÚO III. 180., RP 137. sz.); 6: Battyán, Vas m. (HO VII. 112113.); 7: Pat, Somogy m. (HO VIII. 115-116., RP 146. sz.); 8: Lápa, Somogy m. (ÁÚO III. 186-187., RP 147. sz.); 9: Bárd, Somogy m. (ÁÚO III. 191-192., RP 148. sz.); 10: Denna, Somogy m. (ÁÚO VIII. 206-207., RP 149. sz.); 11: Szentgyörgy, Somogy m. (ÁÚO III. 184-185., RP 150. sz.); 12: Léta, Somogy m. (ÁÚO III. 188189., RP 151. sz.); 13: Szántó, Nógrád m. (RP 129. sz.); 14: Geréc, Baranya m. (HO VI. 163., RP 131. sz.); 15 : Nagymezö, Zemplén m. (RP 136. sz.); 16: Guta, Nógrád m. (HOkl. 53-55., RP 144. sz.); 17: Csany, Gönyü, Újvár m. (ÁÚO VIII. 211-212., RP 145. sz.); 18: Laponya, Gömör m. (HO VIII. 117-118., RP 154. sz.); 19: Oszlár, Pest m. (ÁUUO VIII. 276.) ${ }^{337}$. Nincs feltüntetve bizonytalan lokalizációja miatt Nádasd és Sár (Vas vagy Zala megye) (HO VIII. 86-87., RP 128. sz.)

Mindenekelőtt látható, hogy - nem túl megelepő módon - az idősebb és ifjabb királyi nádorok tevékenysége nem keresztezte egymást. Az idősebb király két nádora, Henrik és Lőrinc csak a rájuk eső nyugati országrészben tevékenykedtek (itt egyébként az összes 1260 utánra eső hely fel van tüntetve, bár az országmegosztás csak 1262-ben következett be). A Somogy megyei „tömörülést” (7-12. szám a térképen) az a birtokfelülvizsgálat-sorozat okozza, amelyben Lőrinc nádor és somogyi ispán vett részt 1268-ban, minden bizonnyal nem nádori, hanem ispáni tisztségéből fakadóan. Az egyetlen eset, amelyben látszólag területi ütközés van, a térképen 14-es számmal jelölt Geréc birtok ügye. Ennek kapcsán szögezzük le, hogy az oklevél kelethelye Pétervárad (Peterwarad), amely az ifjabb királyi orszégrészbe esett. ${ }^{338}$ A diplomát kiadó D. nádor egy olyan birtok adásvételét hagyta jóvá, ahol Demen fia Sándor ispán eladta Geréc nevü földjét Lőrinc mosoni ispánnak, az idősebb király országbírájának. A föld még éppen az azt megvásároló Lőrinctől jutott Sándor kezére, ahogy azt a kői káptalan oklevele is tartalmazta. A szerződő felek egyike tehát az idősebb király bárója volt, ám az ügylet előzményét már az ifjabb király országrészébe eső káptalan tárgyalta. Az ügyet nem lehetett tisztán az egyik vagy másik fél bíráihoz sorolni, mint ahogy a gyakorlatban több ilyen eset is lehetett. A D-sziglával feltüntetett nádort Péc nembéli Dénessel és Csák nembéli Domonkossal egyaránt azonosíthatjuk. ${ }^{339}$ Inkább utalhatna Dénesre az, hogy a Bács megyei Péterváradon keltezte az oklevelét, és ismerünk egy másik oklevelet is, amelyben ugyanúgy egy D-sziglával jelölt nádor és bácsi ispán a bácsi és kői káptalannal levelez - nyilván ugyanazon személyröl van szó. ${ }^{340}$ A nádor tehát huzamosabb ideig is ott tartózkodott a déli országrészben. Péc nembéli Dénesről pedig tudjuk, hogy köpönyegforgatása után az első tisztség, amit Bélától kapott, az a szerémi ispánság volt (akkor

\footnotetext{
${ }^{337}$ Nádori oklevél, lásd az eredetit: DL 577., ill. Függelék, C-reg.

${ }^{338}$ HO VI. 163. (RP 131. sz.)

${ }^{339}$ Lásd ezzel kapcsolatban az RP 131. sz. reg. kommentárját.

${ }^{340}$ A bácsi káptalan oklevelét lásd Kubinyi 1867. 99-100. (RP 134. sz.) Ez utóbbi oklevelet azért nem vittük fel a térképre, mert nincs ,pontszerü” területi vonatkozása.
} 
Szerém megye már Béla országrészébe esett). ${ }^{341}$ Úgy tünik tehát, hogy ezen a területen volt érdekelt. Utódja, Domonkos szintén viselte a bácsi ispáni címet, de itt csak arról lehetett szó, hogy mintegy „megörökölte” hütlenné lett elődje pozícióit. Domonkosnak egészen máshol, Északkelet-Magyarországon, a Zemplén megyei Perecsén volt a családi birtoka, és inkább ott tartózkodott. Két ismert oklevele közül legalábbis az egyiket ott keltezte, a másik pedig egy Perecsével határos föld eladásához való beleegyezés volt, amit az egri püspök részére állított ki - nyilván akkor is azon a környéken tartózkodott. ${ }^{342}$ Domonkos ráadásul nem jelölte Dsziglával a nevét az oklevelében. Mindez ugyan nem perdöntő teljesen, de úgy tünik, hogy az egyik ifjabb királyi nádor (talán Dénes) inkább a déli területeken volt érdekelt, és zömében ott is időzött. Talán szintén ennek a jele, hogy 1264-ben Dénes alnádora, Gotárd Hatvanban székelt. ${ }^{343}$ Szükség volt valakire abban a régióban is, amíg a nádor huzamosabb ideig délen tartózkodott. Utódai esetében azonban az ítélkezések súlypontja egyértelműen áttevődött Észak-Magyarországra, mint ez a térképen is látszik. Ugyanezt tapasztaljuk, ha az okleveleik kelethelyét vizsgáljuk meg (amennyiben kitették). Az említett D. nádor a Bács megyei Péterváradon keltezett. Domonkos egyetlen ismert kelethelye viszont már a Zemplén megyei Perecse, a családi birtoka. ${ }^{344}$ Nyilván az sem véletlen, hogy Domonkos egyik servitora borsodi várjobbágy volt, és Borsod megyében volt földje. ${ }^{345}$ Tombold fia Benedektől három kelethellyel ellátott oklevelet ismerünk: Forró (Újvár megye), Bereg (Bereg megye) és Patak (Nógrád vagy Zemplén megye). Az első oklevélből tudjuk, hogy a per egy korábbi állomásakor a nádor a Pest megyei Besenyő faluban volt. ${ }^{346}$ A 3. sz. térképről látható, hogy az ítéleteik földrajzi vonatkozásai is ezt a tágabb régiót fedték le. Az egyedi ítélkezések mellett Benedeknél olvashatunk külön királyi megbízásokról is. 1268-ban István ifjabb király több báróját csoportos ítélkezésre küldte, Benedek így írt erről: ,,amikor Besenyő faluban voltunk a Szüz Mária sziget [Margitsziget] mellett Szent Mihály arkangyal tizenötöd napján [okt. 13.], és más társaimmal, ti. Gergely esztergomi préposttal, Scela fia Mihállyal, Szakállas Lörinccel, Ethenad fia Benedekkel, Ruhman fia Jánossal és az ország más nemeseivel, akiket urunk, István király és az ő országa csoportos ítélkezésre a mondott szigetre rendelt az egész ország

\footnotetext{
${ }^{341}$ Archont. 1000-1301. 207. Arról, hogy 1265 után Szerém és Valkó megye már a Szlavón hercegséghez került, és ezáltal Béla felségterülete lett, lásd Zsoldos 2007. 84.

${ }^{342}$ Az okleveleket lásd: DL 67402. (kiadása: RP 136. sz.); ill. Száray I. 10. (RP 135. sz.)

${ }^{343}$ DF 278431. (= DF 280264.), kiadása: RP 129. sz.

${ }^{344}$ HO VI. 163. (RP 131. sz.); DL 67402. (kiadása: RP 136. sz.)

${ }^{345}$ RA 1858. sz.

${ }^{346}$ HOkl. 53-55. (RP 144. sz.); ÁÚO VIII. 211-212. (RP 145. sz.); ill. a Bereg kelethellyel ellátott oklevél: DL 63602. Kiadását lásd: Függelék, B-regeszta. Benedek ebben az oklevélben nem tüntette fel a nádori címét, de viselte, lásd a regeszta utáni kommentárt.
} 
ügyei kapcsán, törvényt ültünk". 347 Benedek egyedi megbízásokat is végzett: valamikor 1267-1269 folyamán Pest megyébe szállt ki a „gonosztevők kihírdetésére és a tulajdonosaitól jogtalanul elidegenített földek számbavételére", ${ }^{348}$ talán szintén István utasítására. ${ }^{349}$

Mindeközben Béla országrészének a két nádorára, Héder nembéli Henrikre és Kemény fia Lörincre a belháborúk alatt fontos feladatok hárultak, Béla magas rangú hadvezérei voltak (az ifjabb királyi nádorok talán részt vettek egyik-másik összecsapásban, és egyéb külföldi hadjáratokban, de igazán fontos pozíció e téren nem jutott nekik). ${ }^{350}$ Héder nembéli Henrik, megörökölve Roland nádori tisztségét és pozsonyi ispánságát, egy hozzá hasonló stílusú hivatali gyakorlatot kezdett folytatni az északnyugati régió bírájaként. A Pozsony megyei Velk föld ügyében ítélt 1260-ban, illetve a Győr megyei Baráti és a Zala megyei Örs falu udvarnokai és helyi birtokosok ügyében 1261-ben. ${ }^{351}$ Ezt a „hagyományos” hivatali pályát törte meg az ellenségeskedés. 1261 utántól 1267-ig Henriknek összesen csak 4 oklevelét tudjuk azonosítani (ebből kettő csak későbbi tartalmi átírásban maradt fent), és egyik sem köthető konkrét évhez. ${ }^{352}$ Annál több információnk van arról, hogy Henrik 1264-1265 folyamán Béla egyik seregtestének a tényleges vezére volt (a sereget névlegesen Anna macsói hercegnő vezette). A Feketehalom ostroma után megforduló hadiszerencse következtében az ország közepe felé nyomuló Istvánnak Isaszegnél állta útját Béla maradék serege, amit Henrik nádor vezetett. Az 1265. március elején megvívott csata István győzelmét hozta, a nádor két fiával együtt fogságba esett. ${ }^{353}$ Bár erről a források külön nem szólnak, nyilván az apa és fia közötti béke következményeként került sor a szabadon bocsátásukra.

Kemény fia Lőrinc 1267 legelején váltotta Henriket a nádori poszton. Az elmozdítás oka nem teljesen világos. Mivel Henrik ugyanebben az évben szlavón bán lett a király szemében

\footnotetext{
347 „cum nos essemus in villa Beseneu iuxta insulam beatissime virginis Marie, in quindenis sancti Michaelis archangeli, et cum ceteris sociis nostris, qui a domino nostro rege Stephano et a regno suo ad commune iudicium ad predictam insulam super facto tocius regni fuerant deputati, videlicet magistro Gregorio preposito Strigoniensi, Nycholao comite filio Scela, Laurencio barbato, Benedicto filio Ethenad, et Johanne filio Ruhman, ac aliis nobilibus regni, pro tribunali sedissemus” HOkl. 54. (vö. RP 144. sz.)

348 ,ad indicandos malefactores et cognoscendas causas terrarum indebite alienatarum a suis possessoribus" ÁÚO VIII. 276. (Az oklevél nádori oklevél, ám a kiadásában rosszul oldották fel az intituláció plts rövidítését, és „,prelatus”-t írtak palatinus helyett, lásd Függelék, C-regeszta).

${ }^{349}$ A kérdés részletes tárgyalását lásd a „6.1 - A nádori közgyülés intézményének kialakulása” c. alfejezetben.

${ }^{350}$ Domonkos vlsz. ott volt Feketehalom várában ura mellett, a vár 1264-1265 fordulóján zajló ostromakor, de ezt inkább a kényszer szülhette, az 1265-i isaszegi csatában is csak bátyja vitézségét emelte ki István adománylevele (Zsoldos 2007. 61-62.). Ráadásul azt sem tudjuk, hogy ekkor már nádor volt-e, bár a kérdésnek nincs sok jelentősége. Tombold fia Benedek biztosan nem volt még nádor, csak udvarispán, amikor részt vett István 1266 nyarán zajló bolgár hadjáratában (Zsoldos 2007. 96.).

${ }^{351}$ CDS II. 461-462. (RP 125. sz.); HOkl. 40. (RP 127. sz.); HO VIII. 86-87. (RP 128. sz.)

${ }^{352}$ UB I. 321. (RP 130. sz.); PRT X. 523. (RP 132. sz.); PRT X. 524. (RP 133. sZ.); ÁÚO III. 180. (RP 137. sz.)

${ }^{353}$ Minderre részletesen lásd Zsoldos 2007. 47-51., 55-74.
} 
hütlenné vált Roland helyett, ezért kézenfekvő lenne ezt az okot keresni a háttérben. Ám Lőrincet már egy 1267 februárjában kelt oklevélben nádorként említik, Henrik pedig egy, csak évet tartalmazó 1267-i oklevél szerint még nádor, tehát a hivatalcsere 1267 legelején történt. Roland viszont ez év május 21-én még szlavón bán, és a bizalom csak a nyáron ingott meg benne. ${ }^{354}$ Lőrinc nádori pályaképét - a ránk maradt információk alapján legalábbis szintén úgy határozhatjuk meg leginkább, hogy alapvetően Béla bárója, aki éppen ekkor a nádori címet viselte. Azaz fóként olyan király által elrendelt feladatokat hajtott végre, amelyek nem voltak különösebb összefüggésben nádori címével. 1267 augusztusában (amikor a király fia ellen készülődött) jelen volt ura környezetében, és részt vett 1267 szeptemberében az 1267. évi dekrétum kiadását követő törvénykezéseken is. ${ }^{355} 1267$ decemberében már szintén Béla király külön parancsára és királyi hatáskörrel (auctoritate regia) felruházva - a tihanyi monostor lovas jobbágyainak a helyzetét intézte. ${ }^{356}$ 1268-ban (néhány kisebb ügy mellett) $^{357}$ került sor a Somogy megyei birtokfelülvizsgálatok lefolytatására. Ezen felülvizsgálatok háttere az 1267. évi törvény azon cikkelye, amely elrendelte, hogy „a nemesek földjeit, melyeket a mi vagy a királynéasszony szabad falvainak a népei, avagy az udvarnokok, vagy pedig a várnépek bármilyen ürüggyel elfoglaltak vagy elfoglalva tartanak, e nemeseknek vissza kell adni”. ${ }^{358}$ 1267-1268 folyamán több ilyen felülvizsgálatról is tudunk. $^{359}$ Lőrinc azért kaphatta Somogy megyét, mert nádori címe mellett somogyi ispán is volt egyben, így is mindig kihangsúlyozta a külön királyi megbízást. A részleteket minden ez ügyben kiadott oklevele elején taglalta, amelyek a következőek voltak: ,amikor minket Béla, Magyarország jeles királya Somogy megyébe küldött az udvarnokok, várnépek, királynéi népek és más szolgáltatónépek által elfoglalt nemesi birtokok és jogok visszavételére, öt, ezen megye összes nemese által választott nemes embert ... rendelt nekünk ítélőtársul, és ugyanezen öt nemes, a mi ítélőtársaink, az Úr életadó szent keresztfáját megérintvén esküvel esküdvén megfogadták, hogy nem mást, csak a szolgáltatónépek által illetéktelenül elfoglalt nemesi jogokat állítják helyre. Másodjára nekünk is megesküdtek a szentséges ereklyéket és az Evangéliumot megérintvén a fiaik fiaira ugyanerről, és ezen biztosítékkal indultunk el a

\footnotetext{
${ }^{354}$ Archont. 1000-1301. 20., 46.; Zsoldos 2007. 98-99.

${ }^{355}$ Lörinc jelenlétére a közös törvénykezésen lásd Béla 1267. szept. 15-e körül (RA 1532. sz.) kiadott oklevelét, ill. RA 1551. sz. (vélhetően szintén ekkortájt kelt)

${ }^{356}$ PRT X. 528-529. és 529-530. (RP 138-140. sz.)

${ }^{357}$ CD VII/5. 349-353. (RP 143. sz.); A Vas megyei Battyán föld kapcsán szintén előtte kezdődött per, a felek végül a vasvári káptalan előtt egyeztek ki: HO VII. 112-113.

358 „quod terre nobilium, quas populi liberarum villarum nostrarum vel domine regine seu udvornici seu castrenses quacunque occasione occupaverunt et detinent, restituantur ipsis nobilibus". DRMH I/1. 42. Magyarul: Szöveggyüjtemény 279.

${ }^{359}$ Adatolva: Szücs 1984. 376-378.
} 
király mondott parancsára." ${ }^{, 60}$ A birtokvisszavételekről összesen 6 oklevél szövege maradt fent. $^{361}$ Valamikor 1269 júniusa és októbere között Lőrinc megint Béla környezetében tartózkodott és vele ítélkezett egy Pozsony megyei vonatkozású ügyben. Egy másik Pozsony megyei per szintén előtte kezdődött, ám a király elé utalta. ${ }^{362}$ Még két olyan, a királytól teljesen független oklevelét ismerjük, amelyet nem tudunk évhez kötni. ${ }^{363}$ Henriket és Lőrincet nem lehet olyan markáns módon területhez kötni, mint Rolandot, és amennyire látszik, mindketten többet tartózkodtak a király környezetében, mint az ország egy adott pontján. Így tehát a zavaros „hatvanas évek” tetőzték be azt a már lassan a tatárjárástól meginduló folyamatot, hogy a nádor kissé visszaszorult a királytól független bírói szerv szerepköréből (bár jogilag sohasem szünt meg annak lenni, és mindvégig gyakorolta is ezt a funkcióját), de a politikai helyzet kívánalmainak megfelelően inkább egy, a király környezetében tartózkodó, és az ő egyedi kívánalmait ellátó báró lett. Mindez hangsúlyozzuk - a tatárjárás előtt is előfordult, ám Rolandon át egészen Henrikig és Lőrincig bezárólag markánsan ebbe a szerepbe billent át a mérleg nyelve.

\section{3 - Az ,oligarcha-nádorok" ${ }^{364}$ kora}

A korszak egyik fö jellemzőjének tekinthető, hogy a nádori müködés súlypontja szinte teljesen a családi birtokra és annak szükebb vonzáskörzetére szorult vissza. Mindez nem

\footnotetext{
360 „cum nos dominus noster illustris Bela rex Hungarie ad revocandas terras ac alia iura nobilium per udvornicos, castrenses, populos domine regine ac alios cuiuslibet condicionis homines occupata, ad comitatum Symigiensem transmisisset, et quinque homines de nobilibus ipsius comitatus electos per omnes nobiles de eodem comitatum [!] (...) nobis in socios deputasset, et iidem quinque nobiles socii nostri iure iurando, tacto sancto vivifice crucis ligno Domini, domino regi promisissent, quod non aliud nisi iura nobilium indebite per condicionarios occupata restituerent, et etiam secundario nobis tactis sacrosanctis reliquis et evangelio, supra filios filiorum suorum iurassent illud idem, et recepta tali caucione processissemus ad preceptum domini regis supradictum" HO VIII. 115. (RP 146. sz.). A többi, alább jelzett oklevél is ugyanezt a bevezetöt tartalmazza.

${ }^{361}$ HO VIII. 115-116., ÁÚO III. 184-185., 186-187., 188-189., 190-192., ÁÚO VIII. 206-207. (RP 146-151. sz.). Lőrinc somogyi bizottsági müködését, és a mellé rendelt bizottság összetételét részletesen elemezte Szücs Jenő: Szücs 1984. 376-380.

${ }^{362}$ RA 1614., 1645. sz.

${ }^{363}$ DL 93879. és DL 98880. (kiadásuk: RP 152-153. sz.)

364 Az „oligarcha” kifejezés használatában a disszertáció során Zsoldos Attila legújabban kifejtett meghatározását követjük, amely elkülöníti az „oligarcha” és a „tartományúr” kifejezéseket, és nem szinonímaként kezeli azokat. Az „oligarcha az a tartományúr, aki a királyi hatalmat kizárja a tartományából és funkcióit önkényesen gyakorolja". (Zsoldos 2012e. 352.). Ez nem zárja ki, hogy egy ideig, vagy akár - ha érdekei úgy kívánják - folyamatosan hüséges legyen a királyhoz, de a tartományának irányítását alapvetően ő tartja a kezében, és halála utáni felosztásáról is ő gondoskodik. Zsoldos e kritériumok alapján az oligarchák közé sorolta pl. Csák Mátét, a Köszegieket, Aba Amadét, Ákos nb. Istvánt vagy Kán nb. Lászlót és Borsa Kopaszt is. Ellenben az ország déli részén hatalmat birtokló Csák nb. Ugrin, vagy Debreceni Dózsa és később a Drugetek csak „tartományurak” voltak. Lásd Zsoldos 2012e.
} 
előzmények nélküli (hiszen láthattuk István ifjabb király esetében is, hogy nem egy nádora a müködése helyszínén volt birtokos, vagy legalábbis földrajzilag érdekelt), és nem is egyik pillanatról a másikra történt. A folyamat relatíve „,vegytisztán” az 1280-as évektől kezdett megvalósulni és egészen a „kiskirályok” I. Károly által történő leveréséig tartott, ám a későbbi nádorok müködésében is éreztette hatását.

1270-től véglegesen István lett az ország ura, az új király pedig egyfajta konszolidációs politika eredményeképpen nemcsak hogy nem állt bosszút apja korábbi hívein, de néhányukat egyenesen magas államkormányzati posztokba emelte. Így történt a nádori méltósággal is: István nem tartotta meg a hozzá végig hüségesnek bizonyuló Tombold fia Benedeket. Benedek egyébként 1269-ben véglegesen eltünik a forrásokból: lehet, hogy meg is halt. ${ }^{365} \mathrm{Az}$ új nádor az addig az ifjabb Béla herceg szolgálatóban álló Mojs fia Mojs lett. Kiválasztásában (az általános konszolidációs politika keretein túl, természetesen) szerepet játszhatott az, hogy egyrészt az anyja a Monoszló nemzetségből került ki, akik István fő bizalmasának számítottak, és még ennél is többet nyomhatott a latban az, hogy részt vett az egyik bolgár hadjáratban, vélhetően az 1266. éviben, István oldalán. ${ }^{366}$

Mojs ugyan majdnem végig megmaradt nádornak István uralkodása alatt, de ez csak bő két évet jelentett, ami kissé kevés ahhoz, hogy nádorságának profilját részletesebben meg tudjuk rajzolni. Bár a nádori poszt mellett a soproni ispáni címet is megkapta, kezdetben nem sok adat van arról, hogy megyéje közelében tartózkodott volna. Egyik első intézkedése, még István koronázása előtt, az volt, hogy ura parancsára beiktatta az esztergomi érseket a neki adományozott Esztergom megyébe. Valamikor ezután visszament családi birtokaira, Somogy megyébe, és rendezte kazsoki hospeseinek a jogállását (ekkor a Somogy megyei Igalon állított ki oklevelet erről). ${ }^{367} 1271$ késő tavaszán, mikor háború tört ki István és II. Ottokár cseh király között, elkísérte urát a harcmezöre, addig is a soproni vár védelmére mást kellett kirendelnie Istvánnak - pedig a vár védelme a mindenkori megyésispán feladata lett volna, de úgy tünik, hogy a király inkább a seregben igényelte Mojs szolgálatait. ${ }^{368}$ A harc végeztével, 1271 szeptemberében ismét a családi birtokok közelében találjuk - egy előtte zajló megegyezést legalábbis a Tolna megyei Kurdon hagyott jóvá. ${ }^{369} 1272$ folyamán azonban visszavonult Sopron megyébe. Kétszer is Babóton keltezett oklevelet, megyei vonatkozású

\footnotetext{
365 Archont. 1000-1301. 289.

${ }^{366}$ Zsoldos 2007. 116-117.

${ }^{367}$ MES I. 576.; Solymosi 1998. 225-226. (RP 155-156. sz.)

${ }^{368}$ Zsoldos 2007. 130.

${ }^{369}$ HO VIII. 126. (RP 157. sz.)
} 
ügyekben intézkedve. ${ }^{370}$ Ugyanebből az évből ismerjük még két magánügyben kiadott diplomáját, amelyben a lányai helyzetét rendezte és az ábrahámi monostor számára tett többedmagával adományokat. ${ }^{371}$ Bár ilyen kevés adatból nehezen lehet messzemenő következtetéseket levonni, de azért mégis feltünő, hogy a hét fennmaradt, és biztosan hozzá köthető oklevélből hármat teljesen magánügyben adott ki, egyben külön királyi parancsra hajtott végre, és csak a maradék három „klasszikus” ítéletlevél. Az ehhez az időszakhoz köthető legfontosabb intézménytörténeti újítás, hogy Mojs volt az első olyan nádor, aki viselte a „kunok bírája” (iudex Cumanorum) titulust. A tisztséget István egyesítette a nádori poszttal, és akár alkalmi méltóságösszevonásnak szánta, akár nem, végül állandósult, és még évszázadok múlva is a nádor viselte a „kunok bírája” címet. Arról egyébként semmilyen adatunk nincs a korszakunkból, hogy a mindenkori nádor valaha is ítélkezett, vagy más módon rendelkezett volna a kunok ügyében. ${ }^{372}$

Mojs leváltása még V. István egyik utolsó rendelkezése volt, és az esemény már elörevetítette annak a korszaknak a nyitányát, amelyet a különféle méltóságok gyors, az aktuálpolitika érdekében tett cseréi jellemeztek. Mojs helyébe Kemény fia Lörinc került a király akaratából, ám az ő nádorsága sem tartott néhány hónapnál tovább. ${ }^{373}$ A IV. László uralkodása alatti 18 évre (1272 augusztusától 1290 júliusáig) minimum 25 nádorváltás jutott, de lehet, hogy 27 is - és akkor a hamis oklevelek adatait még ide sem számoltuk, nem vizsgálva, hogy az abban emlegetett új nádoroknak lehet-e valóságalapja. ${ }^{374}$ Ez természetesen nem jelent 25 (27) különböző személyt. Összesen 12 ember viselte a nádori posztot, akik között voltak olyanok, akik csak egyszer-egyszer kapták meg egy rövid időre. Ilyenek az 1280-as években az Aba nemzetségből kikerülő nádorok: Finta, Makján és a később oly nagy karriert befutó Amadé. Egyikük nádorságát sem lehet egy évnél hosszabban kimutatni. Ilyen továbbá IV. László hü emberének számító Básztély nembéli Rénold és Mizse - mindketten László uralmának legvégén nyerték el ezt a méltóságot egy rövid időre. ${ }^{375}$ A nádori pozíción

\footnotetext{
${ }^{370}$ UB II. 14-15., UB III. 279-280. (RP 158-159. sz.)

${ }^{371}$ Mon. Bp. I. 125. (RP 160. sz.); MES III. 707-708. (RP 161. sz.)

${ }^{372}$ A kunbírói tisztségre részletesen lásd a ,7.3 - A kunok” c. alfejezetet.

373 Mojs leváltását az indokolta, hogy be kellett töltenie a hütlenné lett Gutkeled nembéli Joachim helyett a szlavón báni tisztet: Zsoldos 2003. 783-784.

${ }^{374}$ Lásd Archont. 1000-1301. 20-23. Az archontológia csak lábjegyzetben utal rá, hogy 1279 szeptemberében Mátét egy rövid időre leváltották és egy új, nem ismert nádort neveztek ki helyette, hogy aztán nem sokkal később újra visszatérjen Máté. Erről részletesen lásd Zsoldos 1997b. 83-84. A 25 vagy 27 nádorváltás körüli bizonytalanságot az okozza, hogy - véleményünk szerint - nem egyértelmü, hogy Péc nb. Dénes 1284 nyarán egy rövid időre felváltotta-e Héder nb. Miklóst a nádori tisztségben, vagy sem. Lásd erről az RP 217. sz. reg. kommentárját.

${ }^{375}$ Archont. 1000-1301. 22-23.
} 
egyébként a Csák nembéliek (Péter és Máté) és a Héder nembéliek (Henrik fia Miklós és János) osztoztak Péc nembéli Dénessel, aki már István ifjabb király nádoraként is szerepet kapott. László uralmának kezdetét (1272 augusztusától 1273 késő őszéig) pedig Kemény fia Lőrinc és Rátót nembéli Roland nádorok egymást váltása jellemezte - mindketten kétszerkétszer viselték a posztot néhány hónap erejéig. A kuszának tủnő helyzet valójában mindig jól megmagyarázható az aktuálpolitika éppen akkori állásával. IV. László uralkodásának a nádori intézmény szemszögéből nézett első nagyobb korszakát egy hárompólusú uralmi rendszer jellemezte: az egymással szemben álló Kőszegi-Gutkeled párt és a Csákok, illetve sajátos harmadik szereplőként Erzsébet anyakirályné és köre. A kezdeti korszakra jellemző volt az is, hogy az egyes foúri csoportok saját magukkal töltették be ugyan a legfontosabb föméltóságokat, egyetlen kivétellel. A nádori székbe ugyanis mindig egy velük szövetséges (valójában inkább általuk irányított) harmadik személyt emeltek. Ahogy Szűcs Jenő találóan megfogalmazta: „Amíg éltek [ti. IV. Béla idősebb bárói, Kemény fia Lőrinc, Rátót nembéli Roland, Péc nembéli Dénes], arra voltak jók, hogy az egymást sűrün követő kormányzati válságok kezdeti szakaszában (1272-75) felváltva nádorrá tegyék meg őket. A nádori méltóság mintegy szépségflastrom volt a kialakuló "pártkormányzatokon«."376 Kezdetben Kemény fia Lőrinc volt Erzsébet anyakirályné körének az embere, Rátót nembéli Roland pedig az „ellenzéké” (amely 1272-1273 folyamán még nem vált élesen szét Kőszegiekre és Csákokra). Lörinc és Roland mindig akkor volt néhány hónapra hatalmon, amikor a mögöttük álló politikai erők felülkerekedtek. ${ }^{377}$ Ezt a képet törte meg 1273 októberében az akkor kiformálódó Kőszegi-Gutkeled csoport, akik a saját embereikkel töltötték meg a föméltóságokat, nádorként pedig Péc nembéli Dénest állították. Bár Dénes sem volt több, mint a Kőszegiek kirakatfigurája, azok a reformok, amelyeket még 1273 tavaszán indítottak el a Dráván túl, a nádoroknál is utat találtak maguknak. Fő céljuk bizonnyal az lehetett, hogy eltávolítsák a hatalom közeléből a király kiskorúságának idején magát kéretlen régensi szereppel felruházó Erzsébet anyakirálynét. Ennek a bíráskodási „reformcsomagnak” a részeként megszületett a 14. században oly nagy karriert befutó nádori „általános gyülés” (generalis congregatio) intézménye, amelyet kezdetben külön felhatalmazással, királyi jogként, később, III. András idejétől kezdve saját jogukon gyakoroltak a nádorok. ${ }^{378} \mathrm{~A}$ konszolidáció kezdetét jelzi az is, hogy Dénes volt az első olyan nádor a királyváltás óta, akihez bizonyosan szabályos nádori ítéletleveleket tudunk kötni (1274 áprilisa és június eleje

\footnotetext{
376 Szücs 1993. 282.

${ }^{377}$ Ezen néhány hónap pártküzdelmeire részletesen lásd Szűcs 1993. 282-284.

${ }^{378}$ Minderről részletesen lásd a „6.1 - A nádori közgyülés intézményének kialakulása” c. alfejezetet.
} 
között a Zala megyei Mándon tartózkodott, és helyi ügyekben bíráskodott). ${ }^{379} \mathrm{Nem}$ kizárt persze, hogy Rátót nembéli Roland nádor néhány keltezetlen oklevele még az 1272-1273 közötti két nádorsága valamelyikére, és nem az 1274-1275-ös utolsó hivatalára tehető, de erősen valószínű, hogy az 1272-1273-as időszak zavaros, és nem egyszer háborús viszonyai közepette nem folyt szokványos nádori ítélkezés az országban. ${ }^{380}$ Dénes olyan ügyesen helyezkedett, hogy még az őt nádorrá tevő Kőszegi-Gutkeled csoport bukását is túlélte. Ahogy annak idején elhagyta István ifjabb királyt, és IV. Bélához pártolt, úgy csatlakozott jó ütemérzékkel a Csákok hatalomátvételéhez 1273-1274 fordulóján, és amikor lépésről lépésre, 1274 nyarára kibuktatták a hatalomból a Gutkeledeket is, ő ezután is megmaradhatott tisztségében. A bosszúból ellenkirályt állítani akaró Kőszegi-Gutkeled párt teljes vereségét hozta az 1274 szeptemberében lezajlott fövényi csata, amelyben maga Köszegi Henrik, az addigi szlavón bán is holtan maradt a csatatéren - ez még jobban bebetonozta a Csákokat az uralomba. A nádori méltóságban mégis cserét hajtottak végre: Péc nembéli Dénes a megüresedő szlavón báni posztot kapta meg, így újra nádorrá lépett elő Rátót nembéli Roland. ${ }^{381}$ Legkésőbb erre az időszakra tehetőek Roland fentebb már idézett oklevelei, melyek bizonyítják, hogy újraindult a nádori hivatalgyakorlás az országban. A Kőszegi párt visszatérésével és ezáltal Roland bukásával azonban véglegesen véget ért a korábbi politikai szereplőkből verbuvált „dísznádorok” kora.

A következő nagyobb korszakot az fémjelzi, hogy a két nagy párt szereplői immár saját magukat helyezték e méltóságba (a kinevezés formálisan természetesen a királyt illette, de sejthetően többnyire nem ő volt a kezdeményező fél). A Kőszegiek 1275 júniusában tértek vissza, miután a Csákok nem tudtak katonailag végezni velük. Az, hogy az eddigiektől eltérően az országbárói tisztségek betöltésekor maga a csoport feje, Köszegi Henrik fia Miklós lett az új nádor, újszerü, de magyarázható lépés. Az eddig jól bevált rendszer régi szereplőiből ugyanis senki nem maradt, aki számba jöhetett volna. Kemény fia Lörinc 1273 körül meghalt, Péc nembéli Dénes és Rátót nembéli Roland pedig (ekkor) a Csákok embere volt, így Miklós maga foglalta el a kérdéses méltóságot. A lépést a Csákok is leutánozták, és

\footnotetext{
379 Bándi 1979. 364-365.; ÁÚO IX. 111-112. (RP 163-164. sz.); lásd még UB II. 68-69. (RP 166. sz.)

${ }^{380}$ Roland ezen oklevelei: DL 93884. (vö. az alnádorának ugyanekkor kiadott levelével, DL 93896.) (kiadásuk: RP 167-168. sz.); HO I. 67. (RP 169. sz.); esetleg a pozsonyi káptalan 1423-i oklevelében említett Rolanddiploma is szóba jöhet (ZsO X. 77.), de az valószínúbben keltezhető az 1248-1260 közötti nádorsága idejére, lásd RP 171. sz. reg. kommentárját. Kérdéses, hogy egy zavaros átírásban említett oklevele (CD IV/3. 250-251.; RP 170. sz.) mikorra keltezhető, mert pozsonyi ispáni címe biztosan az első, 1260 előtti nádorságára utal, ám egyéb érvek a későbbi időszakokra is utalhatnak (lásd Thoroczkay 2012. 421., ill. az RP 170. sz. reg. kommentárját).

${ }^{381}$ Szücs 1993. 283-285.
} 
1275 és 1277 között Héder nembéli Miklós és Csák nembéli Péter váltogatta egymást a nádori méltóságban, mikor melyikük pártja volt éppen hatalmon. ${ }^{382}$ Ezt a tendenciát szakította meg 1277 tavaszán IV. László nagykorúsítása, és az 1277 májusában lezajlott Rákos mezei általános gyűlés, amelyen már a nemesség és föpapság mellett a köznemesek és a kunok képviselői is részt vettek, így joggal nevezhetjük az első országgyülésnek. ${ }^{383}$ Ezen egy báróktól független kör igyekezett megvalósítani egyfajta konszolidációs programot. A rákosi országgyülés idején éppen a Héder nembéliek voltak hatalmon, akiket aztán még nyáron kibuktattak a Csákok (így Héder nembéli Miklóst ismét Csák nembéli Péter váltotta a nádorságban, ahogy ez már korábban megszokott volt). Ezek után viszont a királynak egy nagyon komoly válsággal kellett szembenéznie - az ország számos pontján lázadás ütötte fel a fejét, a Kőszegiek pedig ismét ellenkirály állításával próbálkoztak. ${ }^{384}$ Ebben a sajátos helyzetben Péc nembéli Dénes ismét elérte, hogy megkapja a nádori méltóságot. Az 1278-ban kezdődő konszolidációs programot jelzi, hogy 1273 után először a nádorok ismét elkezdtek generalis congregatiot tartani egyes megyék számára, a rend helyreállítása céljából. Az első ilyen ismert közgyülést ugyanaz a Péc nembéli Dénes tartotta Somogy megyében, akihez az első dokumentálható nádori közgyülés is köthető 1273-ból. Ezen kívül Dénes egyéb Somogy megyei ügyekben is ítélkezett. ${ }^{385}$ Majd amikor 1278 nyarán a Dénest felváltó Csák Péter néhány hónapos nádorságát testvére: Csák Máté követte (aki természetesen nem azonos az elhíresült tartományúrral, hanem annak a nagybátyja volt), ez a konszolidációs program új lendületet vett. Máté is tartott generalis congregatiokat Somogy és Sopron megyéknek, és, ami fontosabb, sokkal nagyobb lendületet kapott alatta a nádori ítélkezés. Összesen 18 biztosan hozzá köthető oklevelét ismerjük az 1278 és 1280 közötti két évből, amely alig kevesebb, mint az 1272 és 1278 közöttről ismert összes nádori oklevél száma (20). ${ }^{386}$ Bár valamennyi forráspusztulással számolni lehet az 1272-1278 közötti időkből, de ez az aránytalanság mégsem lehet a véletlen müve, különösen, hogy a rendelkezések jellege is

\footnotetext{
${ }^{382}$ Szűcs 1993. 285-291.; Archont. 1000-1301. 21.

${ }^{383}$ Gerics 1987. 279-280. Gerics József meghatározása szerint az a gyűlés nevezhető országos gyülésnek ( országgyülésnek), amelyen a föpapok és bárók mellett a serviensek is együttesen lépnek fel és tevékenyen részt vesznek.

${ }^{384}$ Szücs 1993. 296-298.

${ }^{385}$ ÁÚO IX. 48-49. (RP 185. sz.), amelyben a közgyülését is említi.

${ }^{386}$ Mindkét részröl csak a biztosan erre az időszakra keltezhető nádori okleveleket számoltuk ide. Az 1272 és 1278 közötti okleveleket lásd RP 162-164., 165. (hamis!), 166-167., 169., 172-175., 177., 180-187. sz. (a nem jelült regeszták vagy alnádori okleveleket, vagy 1272 elé is keltezhető diplomákat takarnak). Máté nádor oklevelei: UB II. 24-25., 118-119., 125-126. (benne egy korábbi oklevelét is említve), 126., 129-130., 130131., 131.; ÁÚO IV. 203.; ÁÚO XII. 490., 701-703.; CD V/2. 477-478.; HO VI. 238-239.; Kubinyi 1867. $113-$ 114., 125.; DL 38669. (benne egy másik oklevelét is említve) (RP 188-196.; 198-199., 201-202., 204-207. sz.); Juck 1984. 66., lásd itt: Függelék, D-regeszta.
} 
szélesebb körü tevékenységet mutat. A szokásos perhalasztó és ítéleteket lezáró oklevelek mellett a nádor részt vett az udvarnokföldek és egyéb szolgáltatónépek földjeit felülvizsgáló programban. A programot László 1278 öszén hírdette meg, és eredményeképpen a nádor emberei Sopron, Somogy és Vas megyében tevékenykedtek 1279 folyamán. ${ }^{387}$ A felülvizsgálatokat a nádor megbízott emberei folytatták le, az egyes ügyek csak akkor kerültek Máté elé, ha valami probléma merült volna fel - például a visszavenni kívánt föld tulajdonosai oklevéllel rendelkeztek arról, hogy jogosan tartják maguknál. ${ }^{388}$ A Somogy megyei bizottságnak még az összetételét is ismerjük. Háromtagú volt, és a nádor embere, egy bizonyos Barcs (Barch) mellett részt vett benne Kelemen somogyi udvarnokispán, és Menzau fia Pál comes. Mivel máshol külön kiemelték, hogy ezekben a felülvizsgálatokban a király és a nádor embere vett részt, és itt is emlegették, hogy öket a király és a nádor állította és küldte ki a felülvizsgálatokra (a domino rege et M. palatino deputati et transmissi), ${ }^{389}$ ezért Pál lehetett a király embere. A Vas megyei vizsgálatok kapcsán is ismerjük a nádor emberét, István comest. Öt a nádor egy levéllel bocsátotta a Vas megyei udvarnokokhoz, hogy azok emeljék ezt az Istvánt „kapitányuknak és bírónak” (pro capitaneo et iudice), hogy a birtokaikat visszaszerezhessék. ${ }^{390}$ Mivel a vépi és szőlősi udvarnokok nem akarták végrehajtani ezt a parancsot, ezért Máté ismételt nyomásgyakorlására volt szükség. Az ilyen vizsgálatok általános jellemzőjeként itt is elmonthajuk, hogy elvileg a felhatalmazás országos jellegű volt, ám a valóságban csak bizonyos, összességében nem is túl nagy számú dunántúli megyét érintett.

Nádori részről tehát mindenképpen Csák Mátét tarthatjuk a konszolidációs korszak emberének, aki ekkor még minden tekintetben együttmüködött az uralkodóval. Máté hüségét, és az egész konszolidációs kísérletet végül az országba érkezett pápai legátus, Fülöp ténykedése söpörte el. Bár nem ezért érkezett Magyarországra, végül hozzákezdett a kunok térítéséhez, és olyan feltételek elé állította az ifjú királyt, amelyet az nem akart végrehajtani. A kun kérdés 1279 nyarától mérgezte a politikai közéletet, végül a király ellenállása odáig fajult, hogy Fülöp pápai interdiktum alá helyezte az uralkodót és az országot. ${ }^{391}$ Mindez nyílt szakítást eredményezett a király és a bárók egy csoportja között, felborítva az addigi kényes egyensúlyt. Az első, 1279 szeptembere körüli hatalomátrendeződést Máté még éppen túlélte

\footnotetext{
${ }^{387}$ A háttérre: Szücs 1993. 300.; lásd még Kis 2010. 162.

388 Sopron megyei visszavételekre lásd: UB II. 129-130., 130-131. (RP 198-199. sz.); a Somogy megyeire: Kubinyi 1867. 113-114. (RP 201. sz.); Vas megyeire: UB II. 125-126. (RP 205-206. sz.)

${ }^{389}$ A nádor és király embereinek emlegetése más oklevelekben: UB II. 129-130., 130-131. Itt: ÁÚO IV. 213.

${ }^{390}$ UB II. 125-126. (RP 206. sz.)

${ }^{391}$ Szücs 1993. 301-308.; Zsoldos 1997b. 81-82.
} 
(egy nagyon rövid időre leváltották, majd visszahelyezték. Hogy ki töltötte be a méltóságot, nem tudni). ${ }^{392}$ Ám 1279-1280 fordulóján, miután a király fogságba vetette a pápai legátust, egyes bárók magát IV. Lászlót fogták el. Az esemény irányítóinak a személye nem ismert, de egyes feltételezések alapján akár Csák Máté nádort is feltételezhetjük. ${ }^{393}$ A kiszabaduló király végül 1280 nyarán távolította el Máté nádort, és helyébe Aba nembéli Finta, az addigi erdélyi vajda került. ${ }^{394}$ Finta bő fél éves nádorsága nem önmagáért volt jelentős (összesen két ügyét ismerjük, mintkettő rutinesetnek mondható), ${ }^{395}$ hanem mert elöször töltötte be egy Aba nemzetségbeli ezt a méltóságot (a 11. századi Sámuelt nem számítva, természetesen). Bár gyorsnak mondható, és végül a király részéről az Abák elleni hadjáratba torkolló ${ }^{396}$ bukása után évekig újra a Csákok és Kőszegiek váltották egymást e poszton, néha Péc nembéli Dénessel színesítve, előrevetítette azt, hogy az Aba nemzetség tagjai is részt kértek és kaptak a nádorság betöltésekor. Mindez majd a késő Árpád-kor egyik legmeghatározóbbnak mondható, és több hivatali újítást is bevezető nádorának, Aba nembéli Amadénak a müködésében csúcsosodott ki a 13-14. század fordulóján.

Miután a „kun kérdés” az 1282 őszén lezajlott Hód-tavi csatával lezárult, Lodomér érsek és köre újabb konszolidációs kísérleteket próbált keresztülvinni, amelyek végül szintén elbuktak. ${ }^{397}$ Ám új színként jelentkezett az, hogy a rivális csoportok mellett maga a király önálló erőként kapcsolódott be a küzdelembe. Intézménytörténeti hozadéka ennek annyi lett, hogy immár IV. László saját emberei is megjelentek a nádori poszton. Ilyen saját embernek mondható Aba nembéli Makján, aki 1286 szeptemberében kapta meg e pozíciót, amikor László a Kőszegieket menesztve kísérletet tett arra, hogy hangsúlyosan a saját embereivel töltesse be a legföbb méltóságokat. ${ }^{398}$ Makjám királyi parancsra hozzá is kezdett egy generalis congregatio tartásához Északkelet-Magyarországon, az Abák tágabb értelemben vett családi birtokain, ${ }^{399}$ de a király önállósodási kísérlete katonailag fulladt kudarcba. László hiába próbálta megtörni a Kőszegiek nyugati hatalmát, az 1287 márciusában lezajlott zsitvai csatában végül alulmaradt. Májusban már kénytelen volt amnesztiát hírdetni, és nem sokkal később ismét a Kőszegieket találjuk a nádori tisztségben. Feltehetően a király embere volt Básztély nembéli Rénold is, aki 1289 augusztusában viselte a nádorságot. Az ő személye

\footnotetext{
392 Zsoldos 1997b. 83-84.

${ }^{393}$ Zsoldos 1997b. 84-85.

${ }^{394}$ Archont. 1000-1301. 22.; Zsoldos 1997b. 86.

395 ÁÚO XII. 704. (RP 208. és 334. sz.); DL 57472. = DL 48271. (RP 209. sz.), vö. még DL 57214. (RP 210. sz.)

${ }^{396}$ Aba nb. Finta bukásának okait és következményeit részletesen tárgyalja: Zsoldos 1997b. 90-93.

${ }^{397}$ Szücs 1993. 312-314.

${ }^{398}$ Szücs 1993. 316.

${ }^{399}$ CD V/3. 333-334. (RP 226. sz.)
} 
kapcsán terjedt el a korábbi szakirodalomban az az elmélet, hogy ekkor az országnak kettő nádora volt, amely elgondolással kicsit részletesebben is foglalkoznunk kell.

A kettős nádorságról szóló elmélet alapját Pauler Gyula vetette meg. ${ }^{400}$ Pauler ezt arra alapozta, hogy a király 1289. szeptember 9-i oklevelében (és az azt átíró szepesi káptalan szeptember 30-i levelében) említés esik Rénold nádorról, ugyanakkor 1289. szeptember 8-án maga Héder nembéli Miklós nádor állított ki egy oklevelet. Pauler az adatokat úgy magyarázta, hogy - a III. András idején, 1298-ban kétségtelenül fennálló eset mintájára Miklós volt a dunántúli nádor, Rénoldot pedig a „keleti országrész számára” állította a király. ${ }^{401}$ A gyorsan elterjedt elgondolást azonban legutóbb Zsoldos Attila részesítette kritikában, egyúttal leszámolva az egész elmélettel. Rámutatott, hogy a Rénold nádort említő szeptemberi oklevelek - a királyi oklevelek kritikai jegyzéke alapján - hamisnak tekinthetőek. Rénold nádorságát azonban 1289. augusztusi adatok alátámasztják, ám olyan adataink nincsenek, amelyekben a nádorok „kereszteznék” egymást. Így valószínűbb, hogy Rénold 1289. augusztus 21-e utáni leváltását követően szeptember elején Héder nembéli Miklós követte őt, kettős nádorságról tehát nem beszélhetünk. ${ }^{402}$

Az Árpád-házi királyok okleveleinek kritikai jegyzékében azon az alapon nyilvánította Borsa Iván hamisnak a Rénoldot is említő szeptemberi okleveleket, hogy a „formulái és az átíró oklevél írása későbbi korból való származásra mutatnak, s így hamisnak kell tekinteni”. ${ }^{403}$ Hogy IV. László levele, és az azt átíró szepesi káptalan oklevele hamis, abban Borsa Ivánnak kétségtelenül igaza van. Magunk még azt is hozzátennénk, hogy az állítólagos „eredeti” szepesi káptalani oklevél hátulján lévő pecsétfolt mérete egyáltalán nem egyezik annak a pecsétnek a méretével, amelyet a szepesi káptalan ebben az időben használt ${ }^{404}$ tévedésről tehát szó sem lehet. Kérdés viszont, hogy tartalmaz-e az oklevél mégis hiteles elemeket? Bár mindenképpen elkerülendőnek tartjuk az „,irányított forráskezelést” (vagyis hogy egy prekoncepció, jelen esetben a kettős nádorság bizonyítása érdekében addig „elemezgetjük” a forrásokat, amíg a kívánt eredményt valahogy el nem érjük), mégis, úgy gondoljuk, hogy a kettős nádorságnak lehet alapja ebben az időben, csak éppen nem úgy, ahogyan Pauler Gyula nyomán eddig feltételezték. A kérdés kiindulópontja a Rénoldot említő

\footnotetext{
${ }^{400}$ Pauler 1899. II. 406., 571. 302.jz.

${ }^{401}$ Pauler II. 406.

${ }^{402}$ Zsoldos 2010a. 306-310.

${ }^{403}$ RA 3531. sz.

${ }^{404}$ A pecsétfészekben fekvő hiteles pecsét mérete kb. 36 mm. Lásd pl. DL 71616. (1289. ápr. 8.); DL 63616. (1289. okt. 18.). Az 1289. szept. 30-ra keltezett hamis oklevélen lévő pecsétfolt átmérője pontosan nem meghatározható, de egyértelműen nagyobb ennél. Elvileg feltehetnénk, hogy egy átlagosnál sokkal szélesebb pecsétfészket használtak, de ez nem volt jellemző a káptalan többi oklevelére.
} 
két hamis oklevél. Ezekben hiteles és felhasználható részekre utal az, hogy egyáltalán említik benne Rénold nádort, aki 1289 augusztusában biztosan viselte ezt a tisztséget. ${ }^{405}$ Pedig az ő maximum egy éves hivatalviselése legfeljebb az 1290-es évek elején lehetett köztudott, a későbbi korokban semmiképp. Tovább növeli az oklevél tartalmi részei iránti bizalmat még két elem. Az egyik, hogy IV. László szeptember 9-re keltezett hamis oklevele szerint Rénold nádor egy bizonyos Miklós fia Jánost nem véd meg (szavatol) egy Zemplén megyei birtokban, amelyet János egy Újvár megyei birtokért adott cserébe, pedig Rénold erre a király oklevele alapján kötelezte magát. ${ }^{406}$ E szerint tehát Rénold egy Újvár és Zemplén megyék területét érintő birtokcserét felügyelt volna. Ismerünk ugyanakkor egy másik adatot is. Az egri káptalan 1336. évi oklevele említi Rénold mára már elveszett levelét, amelyben leírta az Újvár megyei Egyházasszalánc és a Szabolcs megyei Tuzsér földek határait. ${ }^{407}$ Igen valószínű, hogy itt is egy birtokcseréröl volt szó, ha egy oklevélben két távolabbi föld határait írta le egyszerre. Rénold tehát pontosan ebben a régióban birtokcseréket hajtott végre - amely arra utal, hogy a hamis oklevél tartalma nem teljesen légből kapott. A másik bizalomkeltő elem a hamis királyi oklevél kelethelye: Poroszlóban (in Poruslo) adták ki. Szerencsére ebből az időből Lászlónak több kelethellyel ellátott oklevelét is ismerjük. Az Árpád-házi királyok okleveleinek kritikai jegyzéke alapján augusztus 21-én Tiszalúc (Lyuch) mellett keltezett, augusztus 27-én egy bizonyos Seble nevü hely közelében (ennek azonosítására alább visszatérünk), egy szeptember 1-jén kelt hamis oklevél kelethelye Alsóapold (Apoldya), az említett szeptember 9-i hamis oklevél kelethelye valószínűleg a Szabolcs megyéhez tartozó Poroszló, ${ }^{408}$ szeptember 13-án pedig két oklevelet is kiadott Túrkevén (Kewe). ${ }^{409}$ A kritikai jegyzék névmutatója a Seble helynevet a Bács megyei, mai Szerbia területén található Zsablyával azonosította, ahol László máskor is keltezett oklevelet. ${ }^{410} \mathrm{Ez}$ az azonosítás azonban igen valószínűtlen lenne a többi helynév fényében, hiszen a király végig a FelsőTiszta-vidéken mozgott ekkor, nem csak valószínütlen, de fizikálisan is lehetetlen lenne egy ilyen hirtelen kitérő, hogy aztán nem sokkal azután visszatérjen a kiindulási régióba. Feltehetjük tehát, hogy egy nem ismert helynévvel van dolgunk, de véleményünk szerint kevésbe spekulatív megoldás is elképzelhető: az oklevél valójában „kakukktojás” a sorban, nem is 1289-ben kelt. A datáció nem tartalmaz évet, ám a kiadások egyöntetüen 1289-re

\footnotetext{
${ }^{405}$ Lásd Zsoldos 2010a. 307.; Archont. 1000-1301. 23.

${ }^{406}$ Kiadása: ÁÚO XII. 479. (RA 3531. sz.)

${ }^{407}$ AO III. 303-304. (RP 243. sz.)

408 Csánki I. 524.

${ }^{409}$ RA 3527-3533. sz.

${ }^{410}$ RA II/2-3. füzet 527. old.
} 
helyezték Szabó Károly alapján. ${ }^{411}$ Szabó Károly Kun Lászlóról írott életrajzi kötetében viszont a következő indokkal helyezte 1289-re a levelet: „Egy hét mulva aug. 27-én [IV. László] Szathmárban Gebe mellett mentette föl Mihály fiait, Istvánt és Pált, embereikkel együtt a szathmári föispán és más birák hatósága alól ... E levelek kelte «prope Fyred» és «prope Geble» (WENZELnél Ceble) táborozásra mutat, s biztosan határozható 1289-re.»412 Szabó itt vélhetően arra utalt, hogy 1289-ben László hadban volt, és mivel a helynevek mellé kitette a „prope” jelzőt (vagyis hogy „mellett”), az akkor katonai „táborozásra mutat” és ez „biztosan” datál erre az évre. Már ez a logika is erősen kétséges, ráadásul Szabó félreolvasta a helynevet, amely nem Geble (így nem is azonosítható a Szatmár megyei Gebével), hanem Seble. Semmi okunk sincsen tehát, hogy 1289-re helyezzük ezt az oklevelet. Mivel László oklevele Zsablyát már máskor is írta Seble alakban, ${ }^{413}$ ezért a helynevet ezzel a településsel azonosíthatjuk, csak a kiadási évet kell máshová tenni. Ez az oklevél tehát nem számít bele László mostani itineráriumába. A szeptember 1-ji hamis oklevéllel szintén nem számolva azt látjuk, hogy László augusztus 21-én Tiszalúcon volt, szeptember 13-án pedig Túrkevén. Déli irányba indult tehát, a mai Nagykunság területére. Ebbe az útirányba tökéletesen beleillik egy Szabolcs megyei poroszlói kelethely, amely a két település között található, és ezzel harmonizál a szeptember 9-i keltezési idő is. Megjegyzendő, hogy a szeptember 1-jére datált hamis oklevél kelethelye (a szászföldi Apold) ugyanúgy kiesik ebből a sorból, mint Zsablya. Mivel teljesen elképzelhetetlen, hogy a hamisító ismerte volna László korabeli itineráriumát, ahogy annak is kicsi a valószínüsége, hogy véletlenül „beletalált” volna egy fiktív kelethellyel, kimondhatjuk: a hamis oklevelet egy valódi alapján szövegezhették meg, amelynek mind a tartalmi részeiből (Rénold nádor Újvár megyei birtokcserék ügyében intézkedik), mind a datációjából felhasználtak részeket, ez utóbbiból a kelethelyet. Azt is nehéz lenne elképzelni, hogy ha a kelethelyet átvették, akkor a keltezési időt eltorzították volna néhány nappal, hiszen az oklevél tartalmát a keltezési idő nem befolyásolja semmilyen módon. Mindez - hangsúlyozzuk - egyelöre csak feltevés, a kettős nádorság kérdését meg kell vizsgálni egy másik szempontból is, nevezetesen a másik feltételezett nádor, Héder nembéli Miklós oldaláról nézve.

A kettős nádorságra abból következtetett Pauler Gyula, hogy Rénold szeptember 9-i szereplése mellett egy bizonyos Miklós nádor, somogyi ispán és a kunok bírája (Nos Nicolaus palatinus, comes Simigiensis et iudex Cumanorum) egy nappal korábban, szeptember 8-án

\footnotetext{
${ }^{411}$ Kállay I. 13.; RA 3528. sz.

412 Szabó 1886. 168. 4. jz.

${ }^{413}$ RA 3280. sz.
} 
Kapornokon adott ki oklevelet (Datum in Kopornuk, in festo nativitatis Beate Virginis, anno Domini millesimo ducentesimo octuagesimo nono). ${ }^{414}$ Miklós nádort egységesen Héder nembéli Henrik fia Miklóssal azonosítják, vélhetően a nyugati kelethely miatt (Kapornok Zala megyében található), és azért, mert Miklós már többször is volt nádor, ráadásul amikor legközelebb, 1291-ben szintén kinevezték nádorrá, ugyanúgy viselte a somogyi ispáni címet, mint ezen 1289. évi oklevél Miklós nádora. ${ }^{415}$ Az azonosítást ugyanakkor bonyolítja, hogy az oklevél mára már elveszett, csak Fejér György 1830. és 1841. évi kiadásaiból ismert (a későbbi kiadás is Fejér szövegét vette át). ${ }^{416}$ Az 1841. évi kiadás, amely az eredeti alapján (ex originale membrana) készült, tartalmazza az oklevélen függő pecsét leírását is, amely nem hasonlít a Héder nemzetség, és közelebbről Miklós nádor pecsétjére. ${ }^{417} \mathrm{Ez}$ azonban nem feltétlenül zárja ki Héder nembéli Miklós személyét, hiszen kopott ábra esetén összetéveszthetőek a pajzs mellé helyezett mellékalakok, ráadásul a leírt pecsét egyetlen ekkor számbajöhető bárói család címerére sem hasonlít. Ha pedig László a saját bizalmi emberét nevezte volna ki nádorrá, az sokkal inkább a környezetében tartózkodott volna, ahogy Rénold nádor is, főleg a kinevezése utáni hetekben (1289. augusztus 21 -én még Rénold a nádor!), és nem a távoli Dunántúlon. Arról sem lehet szó, hogy Fejér véletlenül elírta volna az oklevél keltezését a kiadásban, ugyanis kétszer is leközölte, 1830-ban Hevenessi György 17-18. század fordulóján keletkezett kézirata alapján, 1841-ben pedig az eredetiről. Nem valószínü, hogy a két személy szük 150 eltéréssel ugyanúgy olvasta volna félre a dátumot. Ugyanakkor Miklós nádornak ezen oklevele után egyetlen más felbukkanása sincsen. Legközelebb csak III. András jóvoltából viseli a nádori hivatalt, 1291-től. Hogy tehát 1289 szeptemberét követően meddig volt nádor, és IV. László egyáltalán elismerte-e nádorságát, nem tudjuk ellenőrizni.

A tisztánlátás végett egy harmadik szemszögből is meg kell vizsgálni a helyzetet: az aktuálpolitika oldaláról. Héder nembéli Kőszegi Miklós és családjának befolyása ellen László mindig küzdött, és 1286 novemberében már az ötödik hadjáratát indította meg ellenük, amely ismételten kudarccal végződött, nem sikerült megtörni ellenállásukat. Amit László nem tudott elérni, azt majdnem megtette helyette Habsburg Albert osztrák herceg. Egyes nyugati határvárakat (pl. Pozsonyt) már évek óta a kezén tartó Albert 1289 áprilisában támadást

\footnotetext{
${ }^{414}$ Az oklevelet lásd CD V/3. 481-482.; CD VII/5. 484. (RP 244. sz.)

${ }^{415}$ UB III. 287-288. (RP 246. sz.)

${ }^{416}$ Cselenkó 2006. 98-99. 260. jz.

${ }^{417}$ A pecsét „,formam scuti refert cum tribus virgultis decussatis” (pajzsformát mutat három egymást keresztező ággal). CD VII/5. 484. Héder nb. Miklós nádor pecsétjén cölöpök vannak, ahogy a Héder nemzetség címerein általában, lásd Körmendi 2009. 405.
} 
intézett Nyugat-Magyarország ellen. A támadás Kun László hallgatólagos beleegyezésével történt, aki így akarta gyengíteni a legföbb ellenfeleit. ${ }^{418}$ A harcok Albert diadalával elcsendesedtek a nyárra, majd szeptember végétől újra folytatódtak. Lászlónak esze ágában sem volt beavatkozni, még úgy sem, hogy Albert győzelmei valójában az ország területi integritásának a rovására mentek. ${ }^{419}$ Ilyen helyzetben igen nehéz lenne elképzelni, hogy a Felső-Tisza-vidéken tartózkodó király miért akarta volna éppen Köszegi Miklóst kinevezni nádornak. A kinevezések, mint fentebb is láthattuk, mindig akkor történtek, amikor a Kőszegiek politikai befolyása aránytalanul megnőtt, ám ez az időszak éppen nem ilyen volt. Pedig a kibékülés László és a Héder nembéliek közt nem történt meg 1289 nyarának a végére, amit jól mutat, hogy a király továbbra sem avatkozott be Albert nyugati hadjárataiba (pedig Lodomér esztergomi érsek és mások részéről igen erős nyomás nehezedett rá ez ügyben). ${ }^{420}$ Összességében úgy véljük, hogy László ezidőtájt semmiképpen nem volt olyasfajta kényszerhelyzetben, ami indokoltá tette volna, hogy a Héder nembéliek egyik fejét nádorrá emelje, és úgy tünik, hogy a viszony is ellenséges volt a király és a nagybirtokos família között, tehát azt sem valószínü, hogy saját akaratából döntsön így.

Magunk a következőképpen rekonstruálnánk az eseményeket. Egyrészt, olyasfajta tudatos kettős nádorságról, amely majd III. András uralma alatt kiépül, semmiképpen nem beszélhetünk. Ebből a szempontból tehát félrevezető a korábbi archontológiák azon beosztása, hogy Básztély nembéli Rénoldot „dunáninneni nádornak” nevezték. ${ }^{421}$ Ez ugyanis egy király részéről is jóváhagyott rendszert sejtetne, de hogy erről szó sem volt, jól mutatja, hogy Kőszegi Miklós a „kunok bírája” címet is szerepeltette a titulusai között, pedig az már csak földrajzilag is a kelet-magyarországi nádort illette volna. ${ }^{422}$ Miklós tehát saját magát éppúgy a teljes ország nádorának vélte, ahogy valószínüleg Rénold is. De iure értelemben tehát nem létezett kettős nádorság, viszont 1289 szeptemberében az egyetlen törvényes, király által kinevezett nádor - úgy véljük - nem Héder nembéli Kőszegi Miklós, hanem Básztély nembéli Rénold volt. Tény, hogy szeptemberi hivatalviselésének emlékét csak hamis oklevelek tartották fent, a szeptember utáni időszakról pedig semmilyen biztos adatunk nincs, de gyanítható, hogy ezek a hamis oklevelek eredeti felhasználásával készültek, hiszen a bennük olvasható információk földrajzilag és tartalmilag is összecsengenek Rénold más

\footnotetext{
${ }^{418}$ Szücs 1993. 319.

${ }^{419}$ Szücs 1993. 319.

${ }^{420}$ Szücs 1993. 319-320.

${ }^{421}$ Szentpétery 1985. 98.; KMTL 475.

${ }^{422}$ III. András idején, ha felosztva volt a méltóság, mindig a kelet-magyarországi nádor viselte a „kunok bírája” címet, lásd Zsoldos 2010a. 317.
} 
intézkedéseivel, a László-oklevél kelethelye pedig beilleszthető a király akkori itineráriumába. Kőszegi Miklós nádorságát egy királyi akarattól független titulusnak tekinthetjük. Azt talán sosem fogjuk megtudni, hogy a László ellen ekkor már együttes erővel és akarattal fellépő klérus és országbárók ,ellen-nádora” volt, vagy egyszerűen önhatalmúlag, korábbi nádorságaira visszautalva adta ki ilyen cím alatt az oklevelét. Magunk inkább ez utóbbi lehetőséget tartjuk a valószínűbbnek. A királyi tekintély ekkor már végleg elenyészett. Ahogy az Osztrák Rímes Krónika fogalmazott: „úgy látták [az ország főpapjai és főurai], hogy az ifjú László király ... semmiféle javulásra nem hajlandó, s ezért haragra gerjedtek iránta. Tartották magukat a jogukhoz: ő [ti. László] ugyanis azt fogadta a pápának, a magyarok közül pedig a grófoknak és főpapoknak, hogy amennyiben az eddiginél is rosszabb útra tér, akkor senki se nevezze őt tovább urának. Ehhez kezdték tartani magukat valamennyien a magyarok". ${ }^{423}$ Egy ilyen helyzetben elvileg elképzelhető némi önkény a királlyal amúgy is rossz viszonyt ápoló Kőszegiek részéröl.

László halála (1290) után az ellenkirályként már korábban is felléptetett Andrást választották meg uralkodónak. A III. András alatti kormányzati reformok komoly változásokat hoztak a nádori intézmény történetében is, amelyek még a király halálát követő évtizedben (1310-ig) is éreztették hatásukat. Az 1290-es évektől kezdve a Druget-nádorokig bezárólag az intézmény számtalan kérdését és problémáját tisztázta Zsoldos Attila, aki az elkövetkező 20 év (1290-1310) nádorokkal kapcsolatos történetét két tanulmányban dolgozta fel, sokat pontosítva az addigi beidegződéseken. ${ }^{424}$ Mivel mintaszerű elemzéséhez magunk sem tudunk érdemben mit hozzátenni, ezért a továbbiakban főként az ő kutatásai mentén összegezzük a nádori tisztség változásait.

$\mathrm{Az}$ 1290-es évek kuszának tünő nádorváltásai valójában nem a IV. László alatti kormányzati anarchia továbbélését tükrözik. Egy föpapokból álló (ma úgy mondanánk: „értelmiségi”) kör, amelynek Lodomér esztergomi érsek volt a szellemi irányítója, már IV. László idején is próbálkozott azzal, hogy határt szabjon a néhány akkor meghatározó bárói család (Kőszegiek, Gutkeledek, Csákok) politikai túlsúlyának. Az egymással szembeni hatalmi küzdelmeik, amelybe később a király már önálló tényezőként kapcsolódott be, roppant károsak voltak a magyar közállapotokra. A IV. László nagykorúsítása utáni konszolidáció megtervezése, amelyet fentebb ismertettünk, már Lodomérék nevéhez volt köthető, ahogy később is próbálkoztak, pl. 1289 nyarán a fövényi országos gyülésen az ország

\footnotetext{
${ }^{423}$ Kun László 244.

${ }^{424}$ Zsoldos 2010a.; Zsoldos 2011a.
} 
közállapotának rendezésével. ${ }^{425}$ Ám ebben az időben a legfőbb akadályozó tényezőnek már nem a bárói csoportokat tekinthetjük, hanem a klérussal teljesen szembeforduló, és a problémák elől egyre inkább a kunok közé menekülő királyt. III. András trónra léptével azonban újra megnyílt a lehetőség a politikai rendezésre. A sajátos politikai rendszert kidolgozó főpapi csoport egy nyugati-típusú rendiséget kívánt kiépíteni az országban. ${ }^{426}$ Lodomérék ugyanakkor nem tudták teljesen kikerülni a bárókat, így beletörődtek abba is, hogy a királyt támogató bárói csoportok szabályosan felosszák egymás között a főméltóságokat. Ezen felosztás szabályos volta leginkább a nádori tisztség betöltésében mutatkozott meg. A nádorokat ugyanis „koalíciós” alapon nevezte ki András az akkori két legnagyobb őt támogató fơuri család tagjai közül: Aba nembéli Amadé és Héder nembéli Miklós viselték a tisztségeket. 1290 nyarán Amadé kezdte meg nádori müködését, aki 1291ben átadta tisztségét Kőszegi Miklósnak. A rendszer alapja ez az évenkéti cserélődés lehetett, mivel a fenti szabályosság később is megfigyelhető 1296-ig, és egyszer mutatkozott csak benne törés, amikor a Kőszegiek fellázadtak a király ellen 1291 végén. ${ }^{427}$ A lázadás okát abban kereshetjük, hogy az 1291. évi osztrák hadjáratot követő békében előírták váraik lerombolását, amelyet András el is kezdett végrehajtani. Az ellentétek átnyúltak a következő évre is, végül Kőszegi Miklós a királyt fogságba ejtő fivérével, Jánossal (más néven Ivánnal) is ellentétbe került. Miklós részt vett az ellentétek elsimításában is: III. András kiszabadulásakor a cserébe adott túszok között ott találjuk Kőszegi Miklós egyik familiárisát, ami jól mutatja, hogy ebben a kérdésben Jánossal ellentétes oldalon foglalt helyet. ${ }^{428}$ Miklós így visszakerülhetett András bárói közé, és folytathatta azt a „nádori váltógazdálkodást”, ami kezdettől fogva elindult. A szabályosság 1296-ban tört meg ismét (amikor éppen Kőszegi Miklós volt a nádor), és szintén a király és a Kőszegiek konfliktusa miatt, ám úgy tűnik, hogy ezúttal maga András volt a támadó fél, aki Albert osztrák herceg lányával kötött házassága után így akart megszabadulni a számára és apósa számára is kényelmetlen famíliától. A harcok értelemszerüen Miklós nádorságának megszünését és a struktúra átszervezését is magukkal hozták. Ám a rendszernek volt egy másik - vélhetően Lodomérék köréhez köthető - eleme is. Amikor a király egy olyan famíliával került ellentétbe, amelyik az éppen aktuális nádort is adta, akkor az nem csak tisztségváltást eredményezett, hanem a konfliktus idejére a tisztség megkettőzését is. 1291 végén, Kőszegi Miklós lázadása után annak „váltótársa”, Aba

\footnotetext{
${ }^{425}$ Szücs 1993. 320.

${ }^{426}$ A III. András alatti reformsorozat tudatosítása a modern történettudományban, és a hátterének, müködésének pontos feltárása Gerics József érdeme, lásd Gerics 1987. passim, főként 283-309.

${ }^{427}$ Zsoldos 2010a. 318.

${ }^{428}$ Minderre: Zsoldos 2010a. 319-321.
} 
Amadé került a helyébe, ám kinevezték mellé Szentemágocs nembéli Mihályt is. 1296-ban, ismét Miklós leváltásával Amadé mellett Csák nembéli Péter fia Máté lett a nádor. Máté később önállóan is megkapta ezt a tisztséget, de miután 1297-ben ő is a király ellen fordult, ismét két nádora lett az országnak: a megbízható Aba Amadé mellett az akkor már a királlyal kibékült Kőszegi Miklós kapta meg a tisztet. ${ }^{429}$ Az ellenséges viszony tartósan fennmaradt III. András, és a később oly hírhedté vált „trencsényi föúr”, Máté között, így - valószínüleg szintén biztonsági okokból - a kettős nádorság rendszerét továbbvitték Amadé és Miklós leváltása utánra is: 1298-1299 nyara között, egy évig Péc nembéli Apor és Rátót nembéli Roland kapta meg a méltóságot. Az ő címüket pontosan le is írta egy 1298. évi oklevél, amelynek kibocsátói között egyedülálló módon egyszerre volt jelen mindkét nádor: Opour palatinus Citradanubialis, Rolandus palatinus Ultradanubialis (Apor dunáninneni nádor, Roland dunántúli nádor). ${ }^{430}$ Ezen kívül csak Amadé egy 1295. évi oklevele utal arra, hogy ő a nádori tiszte mellett a „király úr által valamennyi ügy megítélésére kiküldött dunáninneni bíró” is volt. ${ }^{431}$ Ez utóbbi arra utal, hogy ő rendesen csak a „dunántúli” (korabeli tájszemlélet szerint: kelet-magyarországi) ügyekben volt kompetens. Bár ilyesfajta megkülönböztetés sehol máshol nem jelent meg (és a nádorok saját okleveleikben sem jelezték, hogy csak az ország egy része felett bírnának fennhatósággal), a Duna mentén osztott határvonal lehetett mindig az irányadó, mert megfigyelhető, hogy a kettős nádorság idején az egyik csak nyugatmagyarországi, a másik csak kelet-magyarországi esetekkel foglalkozott. Ezen kívül a „kunok bírája" címet mindig csak a kelet-magyarországi nádor viselte. ${ }^{432}$ Jellemző volt egyébként, hogy a méltóság megosztása esetén az adott nádor mindig azt az országrészt kapta, ahová családi birtokai is estek. ${ }^{433}$ Mint már fentebb utaltunk rá, a kétféle (kettős és osztatlan) nádori címet Zsoldos Attila a politikát irányító kétféle csoportnak tulajdonította. A hagyományos, osztatlan nádorság, amely szabályosan cserélődött a legfőbb föúri családok között, nyilván a bárói oligarchák rendszere volt. (Más főméltóságok esetében egyébként nem mutatható ki ilyesfajta szabályosság: nyilván csak a legmagasabb presztízsü intézményről nem tudtak megegyezni egymás között az Abák és Köszegiek, azért találták ki ezt a kompromisszumos megoldást.) Ám a válságok ideji kettős nádorságot Zsoldos a III. Andrást támogató főpapi kör ötletének tartja, amely jól beleillik báróellenes irányvonalukba. „, [A]z egymás mellett müködő két nádor szükségképpen kisebb politikai súlyt képvisel, mint egyetlen -, másfelől valóban

\footnotetext{
${ }^{429}$ Zsoldos 2010a. 323-324.

${ }^{430}$ UDS I. 192. (RP 281. sz.)

431 ,iudex citradanobialis ad omnes causas decernandas per dominum regem deputatus” HOkl 145. (RP 267. sz.)

${ }^{432}$ Zsoldos 2010a. 317.

${ }^{433}$ Zsoldos 2010a. 317., 323.
} 
célszerünek tűnhetett a válság idejére szorosabb ellenőrzés alá vonni az ország területét." ${ }^{434}$ Ez utóbbi azért fontos, hogy megelőzzék azt, hogy az ország több pontján egyszerre robbanjon ki királyellenes felkelés a föúri érdekcsoportok összefogásával. „Az ilyen esetek megelőzése érdekében megint csak a nádori hatáskör területi megosztása tünhetett a legjobb megoldásnak, hiszen így mind a keleti, mind a nyugati országrészben rendelkezésre áll a királyi hatalom képviselője, aki azonnal elfoljthatja a lázadást (vagy legalábbis megpróbálkozhat azzal)." ${ }^{435}$ Ezen okok miatt - Zsoldos szerint - Lodomérék nemcsak a válságok idejére, hanem hosszabb távon is kívánatosnak tartották volna a tisztség megosztását, amire az is utal, hogy 1298-ban, amikor éppen nem zajlott fegyveres konfliktus Csák Mátéval, akkor is megtartották egy ideig a kettős nádorságot. „Végül is azonban, összegzett Zsoldos Attila - ezen egyetlen esetet leszámítva, csak a válságok idején müködött két nádor egyidejűleg, ami arra vall, hogy a kormányzat többi tényezője, a király és a vele éppen együttműködő előkelők elismerték ugyan annak célszerüségét a lázadásokkal fenyegető idők feszült viszonyai közepette, ám ragaszkodtak a nádori méltóság betöltésének hagyományos rendjéhez, s a püspöki kar reformjainak ezen elemét csak rendkívüli körülmények esetén voltak hajlandók támogatni." ${ }^{436}$

A korszak két legjelentősebb nádora Héder nembéli Kőszegi Miklós és Aba nembéli Dávid fia Amadé volt. Mindkettejük hivatali müködése jól dokumentálható, jelentős számú oklevelet hagytak ránk. Köszegi Miklós egy aktív, de hagyományosnak mondható nádori müködést folytatott, ám Amadé több, addig nem jellemző reformot is bevezetett, amelyek közül egyik-másik túlélte őt magát is, és nyomot hagyott az I. Károly alatt müködő Drugetnádorok között (mindez annak köszönhető, hogy a Drugetek központja ugyanoda esett, mint az Abáké, a Druget-tartomány ugyanis, bár nem volt teljesen azonos vele, de az Amadétartományra épült rá). ${ }^{437}$ Általánosságban mindkettejükről elmondható, hogy bár névleg vagy az egész ország (máskor csak a fél ország) nádorai voltak, müködésük valójában az ország egyetlen régiójára korlátozódott: a tágabb értelemben vett családi „territóriumukra”. Kőszegi Miklós esetében ez a nyugati határszélt jelentette, Vas, Zala és Sopron megyékkel. ${ }^{438}$ Gyakran megfordult és intézkedett emellett Somogy ritkábban a szomszédos Baranya megyében is - ez

\footnotetext{
${ }^{434}$ Zsoldos 2010a. 326.

${ }^{435}$ Zsoldos 2010a. 326.

${ }^{436}$ Zsoldos 2010a. 326.

${ }^{437}$ Engel 1982. 905.; Zsoldos 2001b. 60.; Zsoldos 2012a. 581.

${ }^{438}$ Köszegi Miklós szükebben vett családi birtokai nem voltak azonosak testvérei birtokaival, és inkább csak Vas és Zala megye bizonyos részeire terjedtek ki (Zsoldos 2010b. 657.), de nádori működése természetesen túllépte ennek a határait, ezért beszélhetünk a tágabb értelemben vett „Kőszegiek” territóriumairól.
} 
a somogyi ispáni címnek is köszönhető, amit 1289-1295 között viselt. ${ }^{439}$ Pozsonyi ispánsága alatt (1284-1285) megfordult Pozsonyban is, és más, megyét érintő okleveleket is kiadott. ${ }^{440}$ Ettől a területtől keletebbre csak ritkábban „merészkedett”, csak pl. a Fehérvári törvénynapok kapcsán, ${ }^{441}$ hadjárat alkalmával, ${ }^{442}$ vagy amikor országos gyűlést tartottak Pest környékén, amin ő is jelen volt. ${ }^{443}$ A legtöbb oklevele mindazonáltal Vas vagy Zala megyében kelt, ahogy ügyeinek többsége is oda (esetleg Sopron megyéhez) tartozott. ${ }^{444}$

Amadé regionális értelemben ugyanúgy a saját territóriumán tartózkodott, és nádori vonzáskörzetének az Újvár megyei Gönc volt a központja, ahol a kúriáját tartotta, illetve Zemplén, Szabolcs, Sáros és Ung megyékre terjedt ki, amely nagyjából lefedte saját uralmi körzetét is. ${ }^{445}$ Bár címeiben nem tüntette fel, biztosan viselte Ung megye ispánságát, illetve más megyék ispánságát is, amelyet többnyire comes címet viselő alispánjai irányítottak (ilyen megye volt még Bereg, Szepes és Újvár). ${ }^{446}$ Amadé 1288-ban volt először nádor, és sohasem veszítette el III. András bizalmát, így a fent vázolt „váltógazdaság” stabil emberének számított. Címét egészen haláláig, 1311-ig viselte, amelyet 1310-ig I. Károly is elismert (az 1301-1310 közötti nádorokról lásd alább). Ebből a (megszakításokat nem számolva) bő húsz évből több mint 70 oklevelét ismerjük teljes szövegében vagy tartalmi átírás és említés formájában, ${ }^{447}$ amely elegendő arra, hogy az ottani sajátosságokat ne a véletlen számlájára

\footnotetext{
${ }^{439}$ Somogy megyei kelethelye: Váty, 1295. márc. 22. (ÁÚO XII. 512-513., RP 260. sz.); Baranya megyei kelethelye: Segesd, 1295. jún. 6. (ÁÚO X. 191., RP 261. sz.). Ezeken kívül egyértelműen e két megyét érintő esetei: 1291. dec. 6: ÁÚO X. 424-425. (RP 249. sz.); 1294. nov. 25.: ÁÚO X. 162-165. (RP 258. sz.); valószínűleg erre az időszakra tehető két másik oklevele is: ÁÚO XII. 671. és ÁÚO X. 434. (RP 264., 277. sz.). Korábbi évei alatt két Somogy megyei vonatkozású ügye volt, (1275-1277 k.): HO VI. 214. (RP 183. sz.); 1284. aug. 20.: DL 1175. (RP 219. sz.), ez utóbbi a fehérvári törvénynapon kelt, és a király kérésére erősítette meg annak egy korábbi adományát, nem ,tipikus” megyei per tehát.

${ }^{440}$ 1284. júl. 6.: MES II. 181-182. (RP 216. sz.); (1284-1285): HO I. 84. (RP 224. sz.)

${ }^{441}$ 1284. aug. 20.: DL 1175. (RP 219. sz.). Valószínü egyébként, hogy ennél több fehérvári gyülésen volt jelen.

442 1291. jún. 12.: UB II. 234. (RP 247. sz.): kelethely a Fejér megyei Fövényen.

${ }^{443} \mathrm{Pl}$. az 1277 májusában Rákoson tartott, a szakirodalom által első országgyülésnek nyilvánított eseményen, amelyen „valamennyi föpap és báró” (omnium prelatorum et baronum) részt vett, bizonyosan jelen volt az éppen nádor Miklós (Szücs 1993. 293.).

${ }^{444}$ Sopron I. 51.; Zala I. 112.; UB II. 80., 94-95., 187-188., 190-192.; UB III. 290-291.; ÁÚO X. 421-422., 436.; CD VII/5. 484.; DL 93885.; DF 283094. (RP 177., 180-182., 220-223., 244., 257., 259., 263., 270. sz. - a kiadási hivatkozások sorrendje nem egyezik az RP-számok emelkedő sorrendjével)

${ }^{445}$ Kristó 1973. 75. Hogy a Szabolcs megye feletti fennhatóság 1310-ig Amadéhoz és nem a Borsákhoz tartozott, mint az a szakirodalomban felmerült, lásd alább.

${ }^{446}$ Zsoldos 2011b. 62-63., lásd még adatokkal 63. 122.jz.

447 1288-1300 közötti oklevelei (okmánytárak szerinti bontásban): CD VI/2. 290., VIII/3. 497. (mindkettő említés); HO VII. 262-263., 281-282., 288., 288-289. (tartalmi átírás), 289., 292-293., 293. (mindhárom damus pro memoria), VIII. 263-264., 397-398.; ÁÚO IX. 481-482., X. 217., 218. (említés), 377.; HOkl. 145-147.; UB II. 327-328.; Zichy I. 80., 82. (mindkettő tartalmi átírás), 95-96., 97., 101. (mindhárom damus pro memoria), 124.; Károlyi I. 26-27., 28., 28-29. (utóbbi kettő damus pro memoria); kiadatlan Árpád-kori oklevelei: DL 75208., 75209. (mindkettő damus pr memoria), 75151., 84192., 105754., 96039., 40366., 57228., 96042. (utóbbi
} 
írjuk. Amadé majdnem összes ügye Újvár, Zemplén, Szabolcs, Ung és Sáros megyék területére esett, akár az egész ország nádora volt, akár csak a keleti országrészé, akár csak címzetes nádorként viselte titulusát a 14. század első évtizedében. Hivatalának különféle szükebb-tágabb határai semmilyen gyakorlati különbséget nem jelentettek. A több mint 70 esetből összesen két kivétel akadt, mindkettő 1299 nyarára esett, és azzal függött össze, hogy ez év nyarán Amadé a rákosi országgyülésen volt, majd továbbra is a királlyal tartott az augusztus 20-i fehérvári törvénynapra. Feltünő azonban, hogy ezt a két (Sopron és Veszprém megyei vonatkozású) esetet sem tisztán nádori mivoltában folytatta le, hanem kiemelten a király külön megbízásából. Az egyik oklevelet nem is egymaga adta ki, hanem 16 másik egyházi és világi előkelővel együtt, és közösen erősítették meg III. András király egy adományát. ${ }^{448}$ Amadé jól láthatóan nem nádori, hanem országbárói minőségben volt jelen. A másik alkalommal - bár az oklevél már csak Amadé nevében kelt - szintén a király bízta az ő, és más bárói, és a királyi tanácsosai döntésére (nostro et aliorum baronum ac consiliariorum suorum iudicio) a Veszprém megyei királynéi népek földjének az ügyét. ${ }^{449}$ Amadé a többi felsorolt báróval együtt szintén a király felhatalmazásából bíráskodott, nem kifejezetten nádori jogköréből kifolyólag. Mindez azért érdekes, mert Amadé ezen nyugat-magyarországi „kimozdulásain” letárgyalt néhány más esetet is, külön királyi parancsot nem említve, és ezek kivétel nélkül ahhoz az északkelet-magyarországi régióhoz köthetők, ahonnan Amadé ügyei egyébként is kikerültek. ${ }^{450}$ Úgy tűnik tehát, hogy a territóriumától távol is az ottani esetekkel foglalkozott. Olyan intézkedése, amely nem kifejezetten külön királyi utasításra történt volna, és nem a fentebb felsorolt régiót érintette, a több mint 70 ismert ügye közül egy sem akadt. Amadé tehát - bármi is volt elméletben a címe - csak a saját közvetlen territóriumán folytatott bíráskodást, ott viszont szakadatlanul, vélhetően akkor is, amikor a nádori címet éppen más

kettő damus pro memoria), 96043., 75150., említésben fennmaradt: DL 83974.; DF 265430., 285768. Ezen oklevelek kiadását, és a fenti, kiadott oklevelek regesztáját (illetve a damus pro memoria oklevelek esetében az Amadéhoz kapcsolás érveit) lásd RP 239-241., 245., 250-256., 266-269., 271., 273., 275-276., 279-280., 297312., 314-316., 319-320., 322-323. sz. Az Anjou-kori okleveleit lásd: AOkl I. 460., 485., 558., 607., $618 ., 644$. sz. reg.; AOkl II. 14., 122., 161., 243., 712., 938., 960. sz. reg. Azon keltezetlen oklevelei, amelyek az Árpád- és az Anjou-korból is szármathatnak: HO VII. 351.; Károlyi I. 32-33.; Zichy I. 83., 116. (damus pro memoria); RDES I. 521-522.; DL 84191., 75152., 57996., 75216., 75228., 75232. (az utóbbi négy damus pro memoria); DF 220809. (említés). A keltezetlen oklevelek regesztáit, a kiadatlanok szövegét, és a damus pro memoria oklevelek Amadé nádorhoz tartozásának érveit lásd RP 324-326., 328-331., 338., 340-344. sz.

${ }^{448}$ UB II. 327-328. (RP 297. sz.)

${ }^{449}$ HO VII. 281. (RP 300. sz.)

4501299 (a kelethely: Rákos): Zichy I. 95-96.; Zichy I. 97. (RP 298-299. sz. Mindkét oklevél damus pro memoria. Hogy Amadé lenne a kibocsátó, lásd ue. regeszták utáni kommentárt.). 1300 (a kelthely): Rákosmező: HO VII. 292-293. (RP 314. sz. Az oklevél damus pro memoria, a kibocsátó melletti érveket lásd a kommentárban) 
viselte. Amadé még IV. Lászlótól megkapta Ung megyét örökbirtokként, amiben III. András is megerősítette, és haláláig meg is tartotta. ${ }^{451}$ Emellett a korban Újvár megye ispánságát is végig az Aba nembéliek tartották kezükben, ahogy Amadé viselte egy időben a zempléni ispáni címet is. ${ }^{452}$ Így erősen valószínü, hogy Amadé lényegében akkor is folytatta ebben a régióban a megszokott bíráskodási gyakorlatát, amikor az országos nádori címet éppen más viselte. Talán a keltezetlen damus pro memoriák egy része az ilyen időszakokhoz köthető, bár erre egyértelmű bizonyíték nincs. ${ }^{453}$ Ennek a permanens joggyakorlásnak az lett az eredménye, hogy Amadé egy, a kor viszonyaihoz képest komolynak mondható hivatali szervezetet épített ki magának. Ezen szervezet „komolyságát” egyfelől a kibocsátott oklevelek nagy száma mutatja: egyetlen századfordulós nádornak sem maradt ránk annyi diplomája, mint neki. Bár ennek lehetnek provenienciális okai is (nagyon sok oklevél maradt fent a Zichy és a Vay család levéltárában, amelyeket a törökdúlás megkímélt), nem lehet pusztán csak ezzel magyarázni. Amadé volt az, aki állandó helyettesi rendszert épített ki maga mellé. Bár már korábban is jellemző volt, hogy a hagyományosan Pesten, majd Budán székelő alnádor (vicepalatinus) mellett egy nádor környezetében tartózkodó albíró (viceiudex) is a nádor segítségére volt, Amadé egy állandó székhelyet jelölt ki az albírái számára, amely nem volt azonos az ő személyes székhelyével. Amadé az Újvár megyei Göncön, míg az albírái a szintén megyebeli Vizsolyon tartották kúriájukat. ${ }^{454}$ Vizsoly és Gönc mellett Amadé ítélkezési rendszerének harmadik fontos pillére Eger volt, azon belül is az egri káptalan. A korban az egyházi hiteleshelyeknek fontos szerepük volt, nem csak az egyes ügyek írásba foglalása miatt, de számtalan eljáráshoz is nélkülözhetetlenek voltak (pl. eskütétel általi bizonyításkor, vagy egy világi mellett hagyományosan egy egyházi ember tanúskodott a birtokba iktatás, határjárás során, stb.). Amadé legtöbbször az egri káptalannal müködött együtt, ha hiteleshelyre volt szüksége, és az együttmüködés kölcsönös volt. Kimutatható ugyanis, hogy az egri káptalan okleveles gyakorlata hatással volt Amadé oklevéladására is. A 13. század közepén megjelenő, és az utolsó harmadában elterjedő kiadót fel nem tüntető (a kezdősorairól damus pro memoria oklevélnek nevezett) okleveles gyakorlatot a hiteleshelyek közül az egri káptalan kedvelte a legjobban. ${ }^{455}$ Az első ilyen típusú oklevelük 1293-ban kelt, és erre az évre

\footnotetext{
${ }^{451}$ Engel 1998. 41.; Zsoldos 2010a. 325.

${ }^{452}$ Archont. 1000-1301. 218., 235.

${ }^{453}$ Lásd Zichy I. 116.; DL 75216., 75232., 57996., 75228. (RP 338., 340-344. sz.)

${ }^{454}$ Az albírákról részletesebben a „8.1 - A nádort helyettesítő tisztségek: alnádor, nádori albíró” c. fejezetben esik szó.

${ }^{455}$ Minderre számszerü statisztika (egyelöre még) nincs, de magam átnéztem az összes ilyen típusú oklevelet (amelyet a DL-DF 5.1. elektronikus adatbázisban feltüntettek), és ha be tudtam azonosítani a kibocsátót, az ott
} 
datálható Amadé első két damus pro memoriaja is. ${ }^{456}$ Ezután mindkét intézmény viszonylag nagy számú intituláció nélküli oklevelet kezdett kibocsátani. Bár az egri káptalan és Amadé ilyen típusú 1293. évi okleveleinek az írásképe nem azonosítható egyértelműen, de apró igaz, önmagában nem nagy forrásértékkel bíró - formulás hasonlóság ${ }^{457}$ és az időpontok egyezése mégis megengedi azt a feltételezést, hogy Amadé kancellári személyzetét (részben legalábbis) az egri káptalan adta. Ez a „három pillér” (Gönc, Vizsoly, Eger) a 14. század első évtizedében is fennállt, amikor Amadé használhatta ugyan a nádori címet, de az ekkor már ténylegesen csak a saját territóriuma felett jelentett neki joghatóságot.

Aba Amadé bíráskodási gyakorlatát áttekintve azt mondhatjuk, hogy a fent vázolt szervezet kiépítése összességében ugyan egyedinek volt mondható a „kiskirályok” között, ami részben (pl. az albírák állítása kapcsán) a nádori tisztséggel is összefüggésben állt, de alapvetően mégis a saját uralmi területén végzett bírói joggyakorlás volt. Úgy tünik, hogy sem Amadénak, sem más, a 13. század végén hivatalt viselő társának nem volt különösebb igénye arra, hogy a nádori címét az egész ország fölött gyakorolja. Mindez nagyban megkönnyíthette a tisztség megosztását is, hiszen Amadét vagy Köszegi Miklóst azzal semmilyen gyakorlati hátrány nem érte, hogy egy olyan országrész fölé is állítottak még egy nádort, amely felett ők formálisan sem akarták gyakorolni hivatalukat.

Több szó esett már a III. András halála utáni évtizedről. Régi észrevétel, hogy az évtized folyamán többen (összesen heten) viselték a méltóságot 1301 és 1310 között. A hét előkelő közül négyen már III. András alatt is betöltötték e posztot: Csák Máté, Aba Amadé, illetve az 1298-1299-es évek nádorai: Péc nembéli Apor és Rátót nembéli Roland. A Kőszegi famíliát az addigra valószínüleg már elhunyt Miklós helyett fivére, János képviselte a nádorok között. Nádori címet viselt még az András utolsó éveiben országbírói posztot betöltő Ákos nembéli István is, végül 1306-tól bukkan fel e tisztséggel Borsa Kopasz. ${ }^{458} \mathrm{Az}$ adatokat többféleképpen értelmezték, ám többnyire az érintettek által önkényesen felvett címviselésnek tartották. $^{459}$ Zsoldos Attila nemrég felállított új elmélete szerint azonban rendszert lehet találni

összegyült adatokból a fenti következtetésre jutottam. Mindez még pontosításra szorul, amit egyébként szándékomban is áll elvégezni.

${ }^{456}$ Az egri káptalan oklevelei (1293. júl. 15.): DL 56823., 56824. Regesztájuk, a kibocsátó megjelölésével: Hanvay 13-14. sz. Szintén az egri káptalan oklevele (1293. okt. 19.): DL 76169. (Zichy I. 80.). Amadé oklevelei ([1293]. szept. 7. és szept. 14.): DL 75208. és 75209. (RP 251-252. sz. A kibocsátás évére vonatkozó érveket lásd uo.)

${ }^{457}$ A damus pro memoria elnevezés egy összefoglaló név, valójában több ilyen típusú beveztő formula létezett. A vizsgált 1293. évi oklevelek mindegyike egységesen a datum pro memoria formulát használta. Tegyük hozzá: ez is elég gyakorinak számított, így ez inkább csak kiegészítő érvként használható.

${ }^{458}$ Archont. 1301-1457. 1-2.; Zsoldos 2011a. 289-291.

${ }^{459}$ A különféle értelmezéseket és hivatkozásukat lásd Zsoldos 2011a. 289. 3-5. jz. 
a látszólagos kuszaságban. Feltűnt neki, hogy miért pont ez a hét előkelő viselt csak nádori címet, hiszen társadalmi státuszukat tekintve csak az Abák és a Kőszegiek, esetleg a Borsák számítottak az „első vonalba”, hogyan került oda a „másodvonalas” Ákos nembéli István, vagy főként a még oda sem tartozó Rátót nembéli Roland és főleg Péc nembéli Apor. Másrészt szintén nagy hatalmú előkelők (pl. Csák nembéli Ugrin), vagy az Aporhoz hasonló „közepes” és kisebb nemesek miért nem követték a példájukat? Ráadásul látható, hogy e nádorok nem csak magukat tartották a hivatal (szerintük) egyetlen „törvényes” viselőjének, hanem okleveleikben - ha a szövegkörnyezet ezt megkívánta - társaiknak is elismerték e címét, emelett külső hatóságok, sőt, maga I. Károly király is ugyanígy tett. ${ }^{460}$ Mivel a fenti kör egyszer sem tágult (leszámítva, hogy Borsa Kopasz csak 1306-tól jelent meg), ezért gyanítható, hogy valamilyen összekötő kapocs volt a csoport tagjai között, csak észre kell venni. Zsoldos Attila ezen összekötő kapocs létrejöttét még III. András idejére vezette vissza. 1299-ben a király ellen forduló előkelők egy csoportja (Kőszegiek, Csák nembéli Ugrin, és a Csákok egy másik ágáról származó Máté, Borsa nembéli Roland) a pápától kért ellenkirályt, végül támogatásával Anjou Károlyt küldték Magyarországra, aki 1300 augusztusában partra is szállt Spalatóban. De ekkorra András - jó politikai érzékkel - kiegyezett legfontosabb ellenfeleivel, a Csákokkal és a Köszegiekkel. ${ }^{461}$ A források csak a kiegyezés tényét rögzítették, azt, hogy a király mit kínált fel a vele szembenállóknak cserébe, nem. Zsoldos véleménye szerint ez nem volt más, mint hogy elismerte őket az általuk kormányzott tartomány tényleges urává, amelynek eszköze az örökös nádori cím volt. A meghódolt Kőszegi János és Csák Máté valóban szerepelt a 14. század nádorai között. Emellett ellensúlyként - András négy olyan személyt is ebben a tisztségben részesített, akik már eleve az ö hívének számítottak: a posztot éppen betöltő Aba Amadét, az előtte nádorságot viselő Péc nembéli Aport és Rátót nembéli Rolandot, továbbá addigi országbíróját, Ákos nembéli Istvánt. Azért pont ezt a négy személyt, mert ők többé-kevésbé beletartoztak abba a körbe, akikkel a király szabályos szerződést kötött még 1298-ban (más báróival is szerződést kötött, ám ők „szálkának” számítottak a Csákok és Kőszegiek szemében, így András „feláldozta” őket a velük való megegyezés oltárán). ${ }^{462}$ A megegyezés valamikor 1300 augusztusa környékén jött létre, erre utal, hogy Amadé augusztus 1-jén nevezte magát utoljára a „kunok bírájának" is, amely az osztatlan hivatalviselésre utalna, másrészt az István országbíróról szóló adatok is megszakadnak augusztus 17-ével. Van ezen felül egy 1304. évi oklevél, amely

\footnotetext{
${ }^{460}$ Zsoldos 2011a. 291-293.

${ }^{461}$ Zsoldos 2011a. 294-295.

${ }^{462}$ Zsoldos 2011a. 296-297.
} 
szerint I. Károly azt a kiváltságot adta egy hívének, hogy „egyetlen országunkban állított bíró: nádor, vagy bárki más, legyen az ideiglenes vagy örökös" (nullus iudex in regno nostro constitutus, palatinus vel quilibet alius, temporalis vel perpetuus) sem ítélkezhet fölötte. Mindez arra utal, hogy Károly a nádort is azon bírói joghatóságok közé sorolta, amelynek volt „,ideiglenesen állított” és „örökös” változata is. ${ }^{463}$ Az egyetlen személy, aki kilógott a sorból, Borsa Kopasz. Ő abban a tekintetben is különbözött a többiektől, hogy viselte a „kunok bírája” címet, illetve I. Károly őt 1310 után is nádornak tartotta. Mivel Kopasz csak 1306-ban bukkan föl elsőként ilyen méltósággal, sejthető, hogy ő volt Károly tényleges nádora, míg a többieknek a király éppen csak elismerte a címét. Mindez 1310-ig tartott, onnantól kezdve Károly csak Kopaszt fogadta el egyedüli nádornak (bár ez nem akadályozta a még élő másik három előkelőt, hogy magukat továbbra is annak címezzék). ${ }^{464}$ A méltóság el nem ismerése nem feltétlen politikai szakítás eredménye volt, Károly egyszerüen csak a harmadik, mindenben törvényes koronázása után elérkezettnek láthatta arra az időt, hogy új alapokra helyezze a nádori tisztséget is. Ahogy Zsoldos Attila megfogalmazta: „a nádori méltóság története szempontjából az Árpád-kor 1310 nyarán ért véget", 465

Érdemes egy gyors körképet adni arról, hogy hogyan viselkedtek az örökös nádorok. Aba Amadéról fentebb már esett szó: lényegében ugyanazt a hivatali stílust folytatta, ami III. András alatt is jellemző volt rá: a saját uralmi körzetének az ügyeit intézte csak. A közelében, a Borsod megyei Diósgyőrött, a családi birtokának központjában tartotta székhelyét Ákos nembéli Ernye fia István. ${ }^{466}$ Egyetlen olyan intézkedése sem ismert, amely túlmutatna a megye határain, klasszikus nádori feladatokat egyébként sem végzett. Oklevelei közül összesen kettő olyan maradt fent, amelyben bírói feladatokat látott el: egy ízben utasította a feleket, hogy tegyenek esküt az egri káptalan színe előtt, másik alkalommal pedig megerősített egy előtte lezajlott földeladást. ${ }^{467}$ A nádori címét 1310 után is használta, akárcsak Amadé. Ezt a király elvileg nem ismerte el, pl. amikor jelen volt, az 1313 nyarán, Budán rendezett országos gyülésen, akkor a királyhoz közel álló országbírói oklevél csak

\footnotetext{
${ }^{463}$ Zsoldos 2011a. 297. Az idézett oklevél: DL 91155. (AOkl I. 603. sz.). Véleményünk szerint a fenti oklevél nem bizonyítja teljesen egyértelműen, hogy a nádori posztot is ideiglenes és örökös kategóriákra választották szét, mivel a szöveget úgy is értelmezhetjük, hogy a két jelző (temporalis vel perpetuus) csak az alius (ti.: iudex) szóhoz értendő, így a megfogalmazás éppen hogy elválasztja a nádori tisztséget a „másfajta” bírói posztoktól, amelyek lehetnek ideiglenesek vagy örökösek. Mindez azonban nem teszi semmissé az egyéb érveket, amelyek véleményünk szerint - az oklevél másfajta értelmezése esetében is megállnak a lábukon.

${ }^{464}$ Zsoldos 2011a. 298-299.

${ }^{465}$ Zsoldos 2011a. 299.

${ }^{466}$ Kristó 2001. 39.

${ }^{467}$ AOkl II. 141., 295. sz.
} 
„volt nádornak” címezte. ${ }^{468}$ A saját magának megtartott nádori címhasználat mégsem jelentett szembefordulást Károllyal, mert az ilyen titulus alatt kiadott oklevelei „ártalmatlan” birtokadományok voltak a családi birtokaiból a híve, vagy éppen a diósgyőri pálos egyház számára. $^{469}$

A nagy nyugat-magyarországi oligarcha, Köszegi János intézkedései Sopron, Vas és Zala megyék területére estek. ${ }^{470}$ Igaz, itt találunk olyanokat, amelyek egészen kinyúltak a mai Közép-Dunántúlra: több ízben is intézkedett a veszprémi káptalannak a Balaton északkeleti partján található földjei ügyében (az esetekre alább visszatérünk). ${ }^{471}$ Feltủnő emellett, hogy a szükebb családi fészkének számító Vas megyén túlmenően ${ }^{472}$ többször is keltezett Veszprém megyében. ${ }^{473}$ Ügyei többnyire az ekkor klasszikusnak számító intézkedéseket tartalmazták: jóváhagyott a színe előtt lezajlott elzálogosítást, engedélyt adott erre, földbirtoklási ügyekben, vagy éppen famíliárisának, Geregye nembéli Kalmerius comesnek az érdekében intézkedett. ${ }^{474}$ Ám volt néhány olyan ismert esete is, amely túlmutatott saját territóriumának határain. A tihanyi konventhez címzett, 1303. június 19-én kelt levele szerint csopaki (de Chopak) Buzma fia István és fivérei erővel el akartak foglalni egy telket (sessio) a veszprémi káptalantól. A telket nem nevezte meg sem a nádor levele, sem a tihanyi konvent válaszlevele, de az oklevél hátuljára írt de valle Chupak feljegyzésből, továbbá abból, hogy a Zala megyei Csopak a veszprémi káptalan tulajdona volt, ${ }^{475}$ és a foglalók is onnan származtak, biztosan azonosíthatjuk Csopakkal. A nádor tehát utasította a tihanyi konventet, hogy a nádori emberrel együtt küldjék ki saját emberüket, és titltsák el Istvánékat a telektől. Továbbá egy, már korábban elfoglalt földet, amit még a magyar királyok adományoztak a káptalannak, és amit Istvánék Márk fia István hatalma révén maguknál tartottak, szintén állítsanak vissza a káptalan tulajdonába. ${ }^{476} \mathrm{~A}$ nádori oklevél kelethelye Rátót (Rathold), amely bizonyára a Veszprém megyei településsel azonosítható. Ebből, és az oklevél megfogalmazásából ítélve

\footnotetext{
${ }^{468}$ AOkl III. 577. sz.

469 1311: AOkl III. 207. sz.; 1313: AOkl III. 586. sz.; 1315: AOkl IV. 216. sz. Az egyháznak szóló korábbi adománya: AOkl I. 584. sz.

${ }^{470}$ AOkl I. 197., 256., 409., 424., 493., 645. sz.; AOkl II. 151. sz.; UB II. 148. (RP 324-325. sz. reg. közötti reg. A szövegkiadás az Árpád-korra keltezte az oklevelet, de valószínübb, hogy Anjou-kori. Az erre vonatkozó érveket lásd a regeszta utáni kommentárban.)

${ }^{471}$ AOkl I. 409., 714-715. sz.

472 Kőszeg: AOkl I. 197. sz.; Gencsapáti: AOkl I. 493. Maga Kőszeg Jánosnak és ágának a tulajdona lett a Henrik-fiak közötti birtokfelosztást követően: Zsoldos 2010b. 654.

${ }^{473}$ Rátót: AOkl I. 409. sz.; Csesznek: AOkl I. 424. sz. és UB II. 148. (RP 324-325. sz. közötti reg.)

${ }^{474}$ Kalmerius és a Köszegiek kapcsolatára lásd Karácsonyi 1900. 467. és RP 324-325. sz. reg. közötti regeszta kommentárját. Kalmerius érdekében kibocsátott oklevelek: UB II. 148., AOkl I. 256. sz.

${ }^{475}$ Csánki III. 44.

${ }^{476}$ HO IV. 105-106. (AOkl I. 409. sz., vö. 423. sz.)
} 
([sessio] .... quam ... capitulum Vesprimiensis ... dicit velle occupari) úgy tűnik, hogy János éppen a Veszprém közelében fekvő településen tartózkodott, amikor a káptalan beszámolt neki az esetről, erre ő azonnal intézkedett is, utasítva egy közel fekvő egyházi intézményt. Csopakhoz pedig Tihany esett a legközelebb. Mindez annyiból érdekes, hogy Kőszegi János itt biztosan nem a territóriumán „kiskirálykodott”, hanem a szó klasszikus értelmében véve nádorként járt el, hiszen az elfoglalt föld ugyan Zala megyéhez tartozott, de a tihanyi félszigettől nyugatra eső fekvésével semmiképpen nem volt a Kőszegi János családi birtoka. ${ }^{477} \mathrm{Az}$ eset nem egyedi. Ismerünk két másik pert is 1305-ből, amely a veszprémi egyház paloznaki jobbágyai és Herbord meg fia: János közt folyt különféle hatalmaskodások miatt, amit a jobbágyok követtek el. ${ }^{478}$ A perek még III. András idejében kezdődtek a király és országbírája színe előtt, ahol a jobbágyokat el is marasztalták, majd Herbord János nádor színe előtt is felújította az ügyet. A pernek ugyan volt egy olyan kapcsolódása a Kőszegiekhez, hogy a büntetés elől elszökő paloznaki jobbágyok a Baranya megyei Siklósra (in provinciam Barana videlicet in Suklous) ${ }^{479}$ menekültek, ám János nádor fia Gergely visszaküldte őket Paloznakra. Baranya megye János testvérének, Henriknek a „felségterülete” volt ekkor (a megye ispáni címét is betöltötte), ${ }^{480}$ de gyaníthatóan ez nem játszott abban szerepet, hogy János nádor elé került a per. Azt ugyanis a Veszprém megyei Herbord és fia kezdeményezte János előtt, a Baranya megyei szál ebben nem volt lényeges, emellett Kőszegi János és testvére: Henrik uralmi körzete elég jól elkülönült egymástól, ekkor már nem lehet egyetlen közös „Kőszegi-tartományról” beszélni. ${ }^{481}$ Az ügyekben végül nem a nádor döntött, hanem a felek fogott bírák ítélete nyomán egyeztek ki, amely egyezségeket a tihanyi káptalan foglalta írásba 1305 márciusában. A nádor előtti perek így legvalószínübben 1304 folyamán kezdődtek. Minehhez hozzávéve, hogy János - mint fentebb utaltunk rá - viszonylag sokszor keltezett oklevelet Veszprém megyében, ezt a megyét is a „felségterületéhez” sorolhatjuk, amely így egyértelműen túlmutatott családi territóriuma határain. A Dunántúl felett ebben az időben a Csehországból érkezett Vencel és hívei uralkodtak. Úgy tünik, hogy Vencel - jól felfogott érdekében - szintén elismerte azoknak a nádori címét, akik hívéül szegődtek. Így tett

\footnotetext{
${ }^{477}$ Köszegi János uralmi körzetére lásd Zsoldos 2010b. 655-657.

${ }^{478}$ AOkl I. 714-715. sz.

${ }^{479}$ DF 200770. (AOkl I. 715. sz.). Az oklevél jelzete egyébként bizonytalan, mert a DL-DF 5.1. adatbázisban DF 200769. jelzet alatt található az AOkl I. 714. sz. reg. alatti oklevél fekete-fehér fényképe, és a 715. sz. reg. alatti (tehát az itt is idézett) oklevél színes fotója, míg a DF 200770. jelzet alatt pont fordítva (azaz a fekete-fehér mikrofilm-másolatokat és az ugyanezen oklevelekröl készült későbbi színes digitális fotókat rosszul párosították össze). Valószínüleg az eredeti, fekete-fehér fotók tartalmazzák a helyes jelzeteket, így az idézett oklevél jelzete a hivatkozott DF 200770., ám az internetes adatbázisban a színes fotója a DF 200769. jelzet alatt található meg.

${ }^{480}$ Archont. 1301-1457. 102.

${ }^{481}$ Zsoldos 2010b. 658.
} 
Ákos nembéli István és Csák Máté esetében is. ${ }^{482}$ Olyan oklevelet éppen nem ismerünk, amiben Vencel Köszegi Jánosnak is megadta volna ezt a címet, de János biztosan az ő hívének, és I. Károly ellenségének számított, hiszen 1301-ben ő foglalta el a Károly-pártiak székhelyének számító Esztergomot, és 1302 szeptemberében csapataival felmentette a Károly és hívei által megtámadott Budát, ahol Vencel tartózkodott. ${ }^{483}$ Nem valószínü, hogy akkor is biztosította volna ezt a fegyveres támogatást, ha Vencel nem adja meg neki ugyanazt a legitimitást, amit hasonló fajsúlyú (sőt, Ákos nembéli István személyében nálánál kisebb) társainak megadott. Hogy János az egyetlen „valódi” nádora lett volna Vencelnek (ahogyan pl. Borsa Kopasz 1306-tól Károlynak), nem valószínü.

Az utolsó nagy hatalommal bíró örökös nádor Csák nembéli Máté volt. Címét Vencel és később Károly is elismerte. ${ }^{484} 1310$-ben, amikor a koronázása után Károly megpróbálta megszüntetni a számára nyilván mindig is kellemetlen örökös nádorság intézményét, akkor egy alkuval Csák Mátét is sikerült maga mellé állítania. Az immár teljesen legitim király kormányában Máté a tárnokmesteri címet kapta, amit egy rövid ideig használt is. ${ }^{485}$ Máté azonban kezdettől fogva bizalmatlanul viszonyult Károlyhoz (meg sem jelent a koronázásán), végül a király 1311 tavaszán hivatalosan is megfosztotta tárnokmesteri címétől, később Gentilis bíboros is kiközösítette. ${ }^{486}$ Károly oklevelei így 1310-től fogva nem nevezik Mátét sem nádornak (az a néhány eset, amikor mégis, biztosan fogalmazási „hiba” a királyi kancellária részéről), ${ }^{487}$ „volt nádornak” is csak ritkán. ${ }^{488}$ Máté azonban - szándékosan dacolva Károllyal - magát a haláláig következetesen nádornak titulálta okleveleiben, kivétel nélkül, ${ }^{489}$ és a territóriumán működő szervektől ugyanezt a megszólítást várta el. ${ }^{490}$ A „Máté

\footnotetext{
${ }^{482}$ AOkl I. 94., 377. sz; AOkl I. 184-186. sz.

${ }^{483}$ Magy. Tört. II. 44. (a vonatkozó rész Hóman Bálint munkája); MTK I. 188-189. (a vonatkozó rész Solymosi László munkája); vö. AOkl I. 756. sz.; lásd még Csukovits 2012. 57.

${ }^{484}$ Zsoldos 2011a. 290.

${ }^{485}$ Engel 1988. 94-95.; Kristó 1999b. 43-44.

${ }^{486}$ Engel 1988. 95-96.; Kristó 2003c. 301. A király és Csák Máté 1310 körüli viszonyát Gentilis már idézett kiközösítő oklevelének a narrációja beszéli el részletesen, lásd Károly emlékezete 86-92. (AOkl III. 102. sz.)

${ }^{487}$ AOkl III. 323. sz. (1312. jún. 29.); 327. sz. (1312. júl. 1.); 542. sz. (1313. jún. 24.) Mindegyik oklevél a rozgonyi csata kapcsán említi a királyhoz hütlen Mátét, és szövegében illeszkedik azon oklevelek sorába, amelyekben egyszerüen csak „mesternek” titulálják, vagy pusztán „hütlen” Mátéként emlegetik. Tehát biztosan nem egy rövid életü politikai fordulatról, és az azt leképező szóhasználatról van szó.

${ }^{488}$ Ez utóbbira: AOkl IV. 10., 195., 385., 578., 585. sz.

${ }^{489}$ AOkl III. 298., 354., 564., 811. sz.; AOkl IV. 243., 326-331., 499. sz.; AOkl V. 301., 478., 571. sz.; RP 332. sz.; DL 49018. Egyetlen kivétel egy 1320-ra keltezett oklevele, amelynek intitulációjában Mathaes de Trenchinio szerepel (Zsilinszky 1872. 43. vö. AOkl V. 989. sz.), ám az oklevél csak egy 1490. évi átírás újkori másolataként maradt fent. Az oklevél formulás részei teljesen elütnek Máté egyéb okleveleitől, így gyaníthatóan egy hamisítvánnyal van dolgunk, amelynek a célja az volt, hogy az oklevelet 1490-ben bemutató Franko de Longo Campo elődjének soltészjogait bizonyítsa.

${ }^{490}$ AOkl III. 299., 355. sz., AOkl V. 572. sz. (nyitrai káptalan); AOkl V. 807. sz. (garamszentbenedeki apát)
} 
nádor" cím annyira beleivódott a környező vidék szóhasználatába, hogy az onnan kikerülő politikai ellenfelei (pl. a nyitrai püspök és az esztergomi érsek) 1310 után is is gyakorta így emlegette őt okleveleiben, bár folyamatosan hangoztatták hütlenségét. ${ }^{491}$ A palatinus nem puszta cím volt Máté számára, hanem akként is viselkedett: az egyetlen olyan örökös nádor volt, akiröl tudjuk, hogy generalis congregatiokat is tartott az uralma alatti területeknek. Az első ismert eset még a nádori címének legális használata idején történt, 1309-ben. A congregatio 1309. október 18-ra volt kitüzve, Tapolcsányba. Másodjára 1314 augusztusában tartott közgyülést, szintén a Nyitra megyei Tapolcsányban. ${ }^{492}$ A település Máté egyik fó tartózkodási helyének számított, ahol várat épített, és vadaskertet is berendezett magának. ${ }^{493}$ Intézkedései egyszer sem lépték túl territóriumának határait, 1310 előtt sem. Egyébként a hagyományosnak mondható ügyek fordultak meg előtte: birtokperek, iktatások, birtokfelosztás engedélyezése, előtte lezajlott megegyezések igazolása.

Az utolsó két örökös nádorról, Rátót nembéli Rolandról és Péc nembéli Aporról nem sokat mondhatunk. Rolandnak kizárólag olyan felbukkanásait ismerjük, amikor más bárók társaságában jelent meg politikai ügyekben. ${ }^{494}$ Aporral pedig összesen kétszer találkozunk a ránk maradt forrásokban, Rolandhoz hasonló szerepkörben. ${ }^{495} 1307$ után egyikük sem bukkan fel többet: 1310-re vélhetően mindketten meghaltak már. ${ }^{496}$ Abból, hogy mindig Károly bárói között találkozunk velük, és a király a tanácsukra is hivatkozott egy-egy adomány kapcsán, gyanítható, hogy e két nádor a király közvetlenebb környezetében tartózkodott, nem az ország egy adott pontján székeltek. Ennek ellenére egyikük sem tartozott az „első vonalba”. ${ }^{497}$

\section{4. - I. Károly első nádorai - az, „oligarchikus nádorság” öröksége}

A 14. század első évtizedében, mint láttuk, a nádori főméltóság többnyire egy saját uralmi körzete élén hatalmát gyakorló bárót takart. Nem csoda hát, hogy a magyar viszonyokba egyébként sem beleszülető I. Károly szemében a tisztség nem feltétlen tünt az ország első és legfontosabb posztjának. A Közép-Kelet-Európát bemutató, 1308. februármárcius körül keletkezett Descriptio Europae Orientalis (Kelet-Európa leírása) címü mü

\footnotetext{
${ }^{491}$ Pl. AOkl III. 244-245., 247., 251. sz. (az összes oklevél az esztergomi érsek kérésére íródott); AOkl IV. 560561. sz. (nyitrai püspök és az esztergomi érsek); AOkl V. 48-50. sz. (nyitrai püspök)

${ }^{492}$ AOkl II. 758. sz.; AOkl III. 811. sz.

${ }^{493}$ AOkl V. 48. sz. vö. ÁMTF IV. 474.

${ }^{494}$ AOkl I. 358., 644. sz.; AOkl II. 232., 243., 272. sz.

${ }^{495}$ AOkl I. 644. sz.; AOkl II. 272. sz.

${ }^{496}$ Zsoldos 2011a. 291.

${ }^{497}$ Lásd Kristó 1999b. 45., 47.
} 
szerzője szerint (aki elég tájékozott volt a magyarországi ügyekben, és leginkább egy, az ország délnyugati melléktartományában alkotó, szláv anyanyelvü domonkos szerzetessel, talán egy bizonyos Andreas Hungarusszal azonosítható) $)^{498}$ a nádor számított az első, a tárnokmester az ország második méltóságának. ${ }^{499}$ Maga Károly azonban már a hatalmi konszolidációjának megkezdése, 1310 után kísérletet tett arra, hogy az ország legfőbb méltóságává a tárnokmesteri hivatalt tegye (abból valóban csak egy volt). ${ }^{500}$ Ennek fényében nem is lebecsülendő, hogy amikor harmadik koronázása előtt megkísérelt kiegyezni a legnagyobb foúrral, Csák Mátéval, akkor ezt a posztot ajánlotta fel neki. Miként Gentilis bíboros egy nem sokkal későbbi oklevele is írta: „a király pedig tárnokmesterségre emelte őt [ti.: Mátét], amely tisztség az elsőnek számított az országban” ${ }^{501}$ Hogy Gentilis értékelése a tárnokmesteri posztról nem puszta propagandisztikus szófordulat volt, és nem is a korabeli viszonyok hiányos ismeretéből fakadt, mutatja, hogy ekkor már egy ideje Károly okleveleinek a méltóságsorában vagy a bárók egyéb felsorolásakor a tárnokmester a világi méltóságok között többnyire az első helyen állt, a nádort ezzel a második helyre szorítva. ${ }^{502} \mathrm{~A}$ tendencia Domonkos nádor hivatalviselése során (1315-1320) végig így maradt, ${ }^{503}$ csak Dózsa nádor esetében fordult meg a rangsor 1322-ben, ${ }^{504}$ hogy aztán a Druget-nádorok idején már stabilan ők álljanak az első helyen. A nádori funkció devalválódásának további jele, hogy az örökös nádorság felszámolása után Károly az 1310-1330-as évek folyamán többször is felruházott embereket, hogy egy-egy régió „kiküldött bírái” legyenek. Ezen bírák joga sok átfedést mutatott a nádori jogkörrel, ${ }^{505}$ így ha maguk intézménytörténeti értelemben nem is tekinthetőek „,kis nádoroknak”, a nádori funkciók gyakorlása később sem az ország egyetlen kinevezett palatinusának a privilégiuma volt. A kiküldött bírák aztán (néhány kivétellel) az 1320-as évek közepétől a macsói báni különtartományt leszámítva inkább csak akkor jelentek

\footnotetext{
${ }^{498}$ A mü keletkezési idejét már kiadója, a lengyel Olgierd Górka kikövetkeztette különféle utalások alapján: Descriptio VIII-IX. Lásd még Nacsa 1985. 8-9. A szerző kiléte körül vita folyik, Andreas Hungaricus személyére lásd Borzákné Nacsa Mária doktori értekezését: Nacsa 1985. 86-97.

${ }^{499}$ Károly emlékezete 75. (Descriptio 51.)

${ }^{500}$ A tárnokmesteri rang első helyre emelésére szintén felfigyelö Kristó Gyula azzal magyarázta mindezt, hogy a század legelején a királyhoz mindvégig hüséges Csák Ugrin töltötte be ezt a méltóságot, így a nádori poszt devalválódása idején ez volt a legalkalmasabb az első báró szerepének a lefedésére, „így a rendíthetetlenül Károlyhoz hü Csák Ugrin méltósága, a tárnokmesterség emelkedett időlegesen a hierarchia élére”. Kristó 1999 b. 43-44.

${ }^{501}$ Károly emlékezete 87. (Kristó Gyula ford.) vö.: AOk1 III. 102. sz.

${ }^{502}$ AOkl II. 232., 272. sz. (1307), 459., 494. sz. (1308).

${ }^{503}$ AOkl IV. 131. sz. (1315), 604., 615., 624., 633-634. sz. (1317); AOkl V. 18., 248. sz. (1318), 884. sz. (1320). Hogy Domonkos nádort a méltóságsorokban majdnem mindig megelőzte Demeter tárnokmester, C. Tóth Norbertnek is feltünt: C. Tóth 2012b. 442.

${ }^{504}$ AOkl VI. 496., 801. sz. (1322)

${ }^{505}$ A kiküldött bírák intézményére lásd Zsoldos 2011 b
} 
meg, ha a nádori méltóság éppen üresedésben volt. ${ }^{506}$ A poszt aztán meg is szűnt, a nádori hatalom presztízsének emelkedésével (és persze a sok kis külön tartomány megszünésével párhuzamosan, amelyek időleges továbbigazgatására hívták életre az intézményt). ${ }^{507} \mathrm{Az} 1320$ ig tartó időszak tehát intézménytörténeti értelemben is az oligarcha-nádorok örökségének lassú felszámolásáról szólt, vagyis annak a regionális nádorságnak a megszüntetéséről, amit ők folytattak. Ez nem feltétlenül tudatos megszüntetés volt, inkább egy lassú átalakulás. Részben még Druget Fülöp alatt sem szünt meg az ottani hatalomgyakorlási mód, másrészt viszont jelentősen megváltoztak és kitágultak a nádori joggyakorlás határai.

I. Károly első saját nádorát, Borsa nembéli Kopaszt még az örökös nádorok általa is elfogadott időszakában nevezte ki, és címét a király 1310 után is elismerte. ${ }^{508}$ Kopasz 1304 augusztusában még bánnak címezte önmagát, ${ }^{509}$ nádorként elő ízben 1306 februárjában bukkant fel, amikor a kunok bírája és a szatmári ispáni címet is viselte (genitivusban: Kopoz palatini, iudicis Cumanorum et comitis Zatmariensis). ${ }^{510}$ Bár 1314-ig ezen kívül összesen csak egyszer nevezik meg egyéb titulusait ${ }^{511}$ (az összes többi említése és saját oklevele is csak palatinusként emlegette), nincs okunk kételkedni abban, hogy folyamatosan viselte e címeket is, és valószínűleg - a korabeli gyakorlatnak megfelelően - a zarándi ispánságot is. ${ }^{512}$ Ám Szabolcs megye, mint alább szó lesz róla, valószínüleg csak 1312 után került a fennhatósága alá. Székhelyét a Bihar megyei Adorján várában tartotta, nem egy oklevelét ott keltezte. ${ }^{513}$ Ügyei is ezt a vidéket fedték le: leginkább Bihar és Zaránd megyék területére terjedt ki fennhatósága, és természetesen Szatmár megyére, amelynek ispánságát külön kiemelten is viselte. ${ }^{514}$ Nem meglepő módon szinte mindig a területileg illetékes váradi káptalannal vette fel a kapcsolatot, ha valamilyen hiteleshelyi közremüködésre volt szüksége. Területi joghatósága azonban 1312 után egyértelmüen bővült. Aba Amadé halála után Károly megkezdte a tartományának lassú felbomlasztását, amely során a királynak kapóra jött az Amadé-fiak szorult helyzete: abban a kassai konfliktusban, amelyben a tartományúr is életét vesztette, foglyul ejtették Amadé két fiát is a Kassaiak. A király közvetítésével kiszabaduló fiúk komoly árat fizettek: át kellett adniuk több várost és várat, továbbá Zemplén és Újvár

\footnotetext{
${ }^{506}$ Zsoldos 2011b. 61-62. A macsói bánra lásd még az „5.1 - A földrajzi határok” c. alfejezetet.

${ }^{507}$ Zsoldos 2011b. 62.

${ }^{508}$ Zsoldos 2011a. 298-299.

${ }^{509}$ AOkl I. 644. sz.

${ }^{510}$ AO I. 107.; ispáni címére lásd még Szatmár megye 27.

511 1308. szept. 15.: AOkl II. 442. sz.

${ }^{512}$ Zsoldos 2011b. 63. 122. jz.

${ }^{513}$ AOkl III. 221., 456., 849. sz.; lásd még Kristó 2001. 38.

${ }^{514}$ Lásd pl. AOkl II. 13., 164., 442., 925., 992. sz.; AOkl III. 1., 221., 529., 849. sz.
} 
megyéket minden tartozékukkal, és sok egyéb engedményt kellett tenniük Károlynak. ${ }^{515} \mathrm{Az}$ Amadé-fiak mindezt teljesítették is. Többminden is mutat arra, hogy 1312 elejétöl kezdve Károly elkezdte politikailag birtokba venni a tartományt. ${ }^{516}$ Ennek egyik jeleként 1312 áprilismájusának fordulóján Kopasz külön királyi parancsra előbb Kassa alatt Újvár, majd Sáros alatt Zemplén megye számára generalis congregatiot tartott, és a másodikon Kopasz mellett jelen voltak a király, a királynéi kancellár és Amadé fiai is. ${ }^{517}$ Kopasz jelenlétére látszólag tehát csak azért volt szükség, mert nádorként neki kellett celebrálnia ezen közgyüléseket (a király személyesen ekkor már csak országos gyüléseket hírdetett, megyei szintủeket nem nagyon). Valójában Kopaszt nem csak „legitimitási dísznek” hívták meg az Amadé-tartomány közgyüléseire, ezidőtájt más környékbeli ügyek is jártak elötte: május 28-án a jászói konvent már Kopasz nekik címzett levelére hivatkozva idézte színe elé a peres feleket a Borsod megyei Lak és Abod földek kapcsán. ${ }^{518}$ Ezen földek ügyét biztosan nem a jelzett közgyüléseken tárgyalta Kopasz, hiszen nem az ott érintett megyékben feküdtek.

Úgy tünik, hogy ugyanekkor, 1312 után bővült ki Kopasz fennhatósága Szabolcs és Ung megyékkel, bár a kérdés kissé hosszabb kifejtést igényel. A szakirodalomban felmerült, hogy a szabolcsi ispánságot már a század kezdetétől fogva Borsa nembéli Beke tartotta a kezében, és az 1308-1310 között felbukkanó Sándor comes Borsa Kopasz alispánja volt. ${ }^{519}$ Borsa Beke első felbukkanása valójában 1313-ra esett, ${ }^{520}$ és Sándor alispán kapcsán, bár 7 oklevelét is ismerjük, ${ }^{521}$ semmi olyan kifejezett adatunk nincs, ami Kopaszhoz kötné őt. Tudjuk viszont, hogy olyan emberek ügyét tárgyalta 1308 és 1310 között, akik Aba Amadé ítélőszéke előtt is megfordultak, ${ }^{522}$ ráadásul Amadé halála környékén eltünik a forrásokból, és többé nem bukkan föl. Mindez inkább arra utal, hogy Sándor Amadé alispánja volt, és a megye az Abák fennhatósága alá tartozott. Erre utal az is, hogy 1310 elött Amadénak több szabolcsi

\footnotetext{
${ }^{515}$ Engel 1988. 98-99;; Kristó 2003. 303.

${ }^{516}$ Engel 1988. 99-100; Kristó 2003. 303.

517 AOkl III. 287. sz. Az erről tudósító királyi oklevél 1312. máj. 9-én Sáros vára alatt kelt, így a sárosi congregatio ezen időpont körül lehetett. A kassai így április végére, esetleg május legelejére eshetett.

${ }^{518}$ AOkl III. 300-301. sz.

${ }^{519}$ Archont. 1301-1457. 183.; Zsoldos 2011b. 63. 122. jz.

${ }^{520}$ Archont. 1301-1457. 183.

${ }^{521}$ AOkl II. 324., 776., 778., 833., 843-844., 856. sz.

522 Aladár fia László Sándor oklevelében: AOkl II. 324., 843. sz. Amadé okleveleiben: Zichy I. 97., HO VII. 288-289., HO VII. 289., HO VII. 292-293. (RP 299., 307-308., 314. sz.). Keld fia István fia György Sándor oklevelében: AOkl II. 844. sz. Apja, Keld fia István Amadé okleveleiben: Zichy I. 82., DL 96042. (RP $279 ., 302$. sz.). Elképzelhető, hogy Roland fia Sándor (Sándor okleveleiben: AOkl II. 324., 843. sz.) is azonos az Amadé oklevelében felbukkanó Roland fia Sándorral (Zichy I. 124., vö. RP 271. sz.). Tegyük hozzá: ilyen kevés adatból ekkora menyiségű egyezés önmagában is feltünő.
} 
vonatkozású esete is volt, ${ }^{523}$ míg Borsa Kopasznak csak 1313-tól kezdődtek a szabolcsi perei. ${ }^{524}$ Szabolcs megye tehát az Amadé-fiak tartományának bukása után került át Kopasz érdekszférájába. Ennél összetettebb Ung megye kérdése, ami átvezet a kiküldött királyi bírákkal kapcsolatos kérdéshez is.

Mindenekelőtt lássuk, hogy mi indokolja Kopasz Ung megye feletti fennhatóságát. László, Kopasz nádor albírája (vicepalatinus, de valójában nem alnádorról, hanem nádori albíróról volt szó) ${ }^{525}$ 1314. június 2. előtti oklevelében kötelezte az Ung megyei Valkajáról (de Volkouya) való Miklóst, hogy jelenjen meg a színe elött Kopasz kúriájában, Adorjánban. Miklós - László albíró június 8-i oklevele szerint - megjelenvén bevádolta emberöléssel, csonkítással Jakó fia Istvánt, és azzal, hogy Valkaja nevü birtokát I. Károly bírájával, Tamás munkácsi várnaggyal leromboltatta (idem Stephanus possessionem suam Volkouya vocatam cum iudice domini K. regis Ungarie scilicet castellano de Munkach magistro Thoma destrui fecisset). Ennek bizonyságául bemutatta Loránd ungi curialis comes és a négy szolgabíró oklevelét (litteras Lourandi curialis comitis de Vng et quatuor iudiciis nobilium de eodem), illetve a leleszi konvent oklevelét. ${ }^{526}$ László albíró a megvádolt Istvánt is bizonyítékai bemutatására kötelezte a leleszi konvent előtt augusztus 1-jére, továbbá előírta a feleknek, hogy augusztus 15 -én jelenjenek meg a színe előtt. ${ }^{527}$ Ugyanezen perhez kapcsolódhatott László albíró azon okleveles parancsa, amelyben Botiznak írta elő, hogy tegyen esküt a leleszi konvent előtt 1314. július 1-jén valkajai Miklóssal szemben. ${ }^{528} \mathrm{Az}$ albíró augusztus 24-én, Mérken kelt levelében nyugtázta is, hogy a Botiz nevében megjelenő helmeci (de Helmech) István bemutatta a leleszi konvent esküt bizonyító oklevelét. ${ }^{529}$ Hogy az eseteket miért nem Kopasz tárgyalta, hanem a székhelyén tartózkodó helyettese, arra kézenfekvő magyarázatnak tünik, hogy Kopasz 1314 nyarán a délvidéken időzött, ${ }^{530}$ így nem kételkedhetünk abban, hogy az eset egyébként az ő fennhatósága alá tartozott volna. Az ügybe beavatkozott ugyan Tamás, I. Károly bírája és munkácsi várnagya is, és - amennyiben igaza van Zsoldos Attilának -

\footnotetext{
${ }^{523}$ Zichy I. 80. (RP 250. sz.), 82. (RP 279. sz.), 101. (RP 311. sz.); HO VII. 293. (RP 315. sz.); DL 96039. (RP 266. sz.); AOk1 II. 938. sz.

${ }^{524}$ AOkl III. 456., 512. sz.

${ }^{525}$ László viceiudex néven is megjelenik (AOkl III. 782., 823. sz.), így következetlen terminológiai használatról beszélhetünk. Az alnádor és a nádori albíró közötti különbséget lásd a „,8.1 - A nádort helyettesítő tisztségek: alnádor, nádori albíró" c. alfejezetben.

${ }^{526}$ Az idézetek: DL 69660.

${ }^{527}$ AOkl III. 759. sz.

${ }^{528}$ AOkl III. 782. sz.

${ }^{529}$ AOkl III.823. sz.

${ }^{530}$ Lásd AOk1 III. 793. sz.
} 
ezzel a kissé pontatlan fogalmazással a „kiküldött bíró” intézményére utalhattak ekkor. ${ }^{531}$ Anélkül, hogy itt ennek a lényegébe részletesebben belemennénk, csak utalunk arra, hogy a „kiküldött bíró” ugyan nádori jellegü jogkört látott el a rábízott terület felett, ám jellemző volt, hogy ö maga volt az adott megyék ispánja, ez egyben megmutatta joghatóságának határait is. ${ }^{532}$ Tamás azonban nem volt ungi ispán. A „főispáni” cím ekkor Amadé fia Lászlót illette, az ő nevében kormányzó comes (funkcionálisan: alispán) Pányoki Jakab volt, a curialis comes (akit funkcionálisan az alispán helyettesével azonosíthatunk), mint láttuk, Loránd. ${ }^{533}$ Így ha Tamás bírói címében tényleg ezt az intézményt is keressük, jogköre biztosan nem terjedt ki Ung megyére. Ellentétben Kopasszal, akinek az alnádora több ügyben is eljárt. A nádor tehát Szabolcs és Ung megyék feletti fennhatóságot megkapta, de jól láthatóan csak azt. I. Károly, úgy tünik, tartott attól, hogy az akkor még hivatalosan szövetségesnek számító Amadé-fiak valahogyan újjászervezik a tartományt, ezért „túlbiztosítva” elaprózta a közigazgatását. A központnak számító Újvár és Szepes megyék élére külön bírót állított, ahogy Sáros és - Tamás munkácsi várnagy és beregi ispán személyében - Bereg megye élére is. ${ }^{534}$ Szabolcs és Ung megyéket pedig megkapta Kopasz nádor - így vált teljessé az Amadétartomány közigazgatása.

Kopasz uralmi körzetének nyugati-délnyugati határait mutatja az is, hogy 1314 novemberében Bihar és Kraszna mellett Békés és Szolnok megyék számára is generalis congregatiot tartott. ${ }^{535}$ Szolnok megye ekkor közigazgatásilag még kettő, és nem három részből állt, így ez egyszerre jelentette a későbbi Külső-Szolnok és Közép-Szolnok feletti fennhatóságot. ${ }^{536}$ Nádorként valószínűleg az ország többi részén is lett volna ítélkezési joga, de az „oligarcha-nádorság” örökségén még ő sem lépett túl, sőt, azok minden jellemzőjét képviselte. $^{537}$

A hütlenné vált Kopasz leváltása közelebbről nem ismert időpontban, valószínüleg 1315 első felében következett be. ${ }^{538}$ Helyére a politikai élet „kipróbált” és tapasztalt figurája, Rátót

\footnotetext{
${ }^{531}$ Zsoldos 2011b. 60.

532 Összefoglalóan, példákkal: Zsoldos 2011b. 56-65.

${ }^{533}$ Archont. 1301-1457. 219.

${ }^{534}$ Zsoldos 2011b. 59-60.

${ }^{535}$ AOk1 III. 849. sz. Az oklevél kibocsátója nem látható, de mivel Adorjánban, Kopasz székhelyén kelt, továbbá kiadója nádori jogkört gyakorolt (általános közgyülés tartása) egy olyan területen, amely amúgy is Kopasz körzete volt, így a kiadót biztonsággal azonosíthatjuk ővele.

${ }^{536}$ A kérdéssel részletesen foglalkozunk a „5.1 - A földrajzi határok” c. alfejezetben.

${ }^{537}$ Lásd Zsoldos 2012e. 353.

538 Engel Pál 1314 augusztus-szeptemberére keltezte Kopasz leváltását (és általában a bárók szinte teljes cseréjét), lásd Engel 1988. 105-106. Ezzel szemben Kristó Gyula jogosan hivatkozott olyan, Engel által még nem ismert (részben DL-DF-jelzettel sem rendelkező) oklevelekre, amelyek szerint 1314 őszén, egészen
} 
nembéli Domonkos került. Öt éven át viselte méltóságát, mégis a kor egyik legkevésbé kiismerhető nádora, mivel egyetlen oklevele sem maradt ránk (összesen egy kiadványa ismert tartalmi átírásban). ${ }^{539}$ A Domonkos által nádorként kormányzott megyéket Zsoldos Attila azonosította be az alapján, hogy Domonkos halála után a visegrádi várnagy és a budavári bíró I. Károly által állított, és helyette ideiglenesen eljáró bírói címmel volt felruházva Pest, Fejér és Esztergom megyék és a besenyők ispánsága kapcsán (in comitatu Pestiensi, Albensi, Strigoniensi et Byssenorum per dominum Karolum ... regem Ungarie vice et nomine persone sue maiestatis pro tempore iudices deputati). Mivel ez az intézmény a már többször említett nádori jogkörrel eljáró bírókat takarta, ezért szerinte Domonkos ezen megyék felett gyakorolt hatalmat (Pest megye felett alnádora révén). A megyék - köztük Esztergom megye is Zsoldos szerint a honorjához tartoztak. ${ }^{540}$

Ezen kívül úgy tünik, hogy Domonkos sokat tartózkodott Károly környezetében. A király több adománylevele említi tanácsát vagy jelenlétét olyan kontextusban, hogy azt biztosan nem lehet puszta formulának betudni. ${ }^{541}$ Ezen kívül egyetlen ismert oklevele (amely nem hivatali jellegü, a Gömör és Borsod megyei birtokának eladásáról szólt) 1320. február 1-jén Temesvárott kelt, Károly székhelyén, ahol ekkor a király is jelen volt. ${ }^{542}$ Ez talán nem sok adat, de figyelembe kell venni azt is, hogy egyetlen olyan forrásunk sincs, amiből biztosan következne, hogy Domonkos nem a király kíséretében tartózkodott, míg a korábbi és későbbi nádortársairól mindig találni ilyen adatokat. Mindezek fényében nem véletlen, hogy nem maradt ránk egyetlen ítéletlevele sem (holott a Fejér-Esztergom-Pest régió az ország központi területe volt, és elég sok forrással rendelkezünk e vidékről). Vélhetően Károly udvarának egyik stabil szereplője volt, és alig tartózkodott megyéiben, amely inkább csak jövedelemforrásul szolgált a számára. Domonkos mégis kivételnek mondható a kor nádorai között, mert az őt követő rövid üresedés után kinevezett Debreceni Dózsa még mindig Borsa

\footnotetext{
novemberig még biztosan Kopasz volt a nádor. Kristó szerint, mivel 1315 nyarán Károly még nádornak nevezte, de már hütlennek mondta, Kopasz 1315. júl. 1-je előtt „kevéssel, legfeljebb két-három hónappal” azelőtt fordult királyával szembe, így leváltása is ekkorra tehető (Kristó 2003. 321.). Legutóbb Bárány Attila tekintette át a kérdést, ő - a bizonytalanság kihangsúlyozása mellett - úgy vélte, hogy Kopasz 1315 tavaszán fordult szembe a királlyal (Bárány 2011. 77-79.).

${ }^{539}$ AOkl V. 689. sz. Vö. C. Tóth 2012b. 442.

${ }^{540}$ Zsoldos 2012b. Esztergom megye a korabeli források szerint mindvégig az esztergomi érsek alá tartozott, Zsoldos Attila szerint a megye katonai védelme miatt adta át Károly a nádornak, de a látszat kedvéért az érseket továbbra is a megye örökös ispánjaként tüntették fel. Ha így is volt, legkésőbb Druget Vilmos már biztosan nem gyakorolt fennhatóságot Esztergom megye felett, mert a nádori közgyülései sorozatából csak a környező megyékben állt meg, és ezt a vármegyét mindig kihagyta. Esztergom megye „fehér foltként” kezelését nem magyarázhatjuk mással, mint hogy az érsek megyéjében a nádor nem tarthatott közgyülést.

${ }^{541}$ AOkl IV. 143. (1315. aug. 12.), 604. sz. (1317. okt. 23.); AOkl V. 884. sz. (1320. aug. 27.)

${ }^{542}$ AOkl V. 689. sz. vö. 692. sz.
} 
Kopasz és a többiek hivatali stílusát folytatta. Károly egyébként nem sietett az új nádor kinevezésével, hiszen 1321. január 13-án Domonkos már biztosan nem élt (utoljára 1320 augusztusában említik), legalábbis ez következik abból, hogy a megyéiben kiküldött bírók jártak el. ${ }^{543}$ Ennek ellenére következő ismert utódját, Dózsát, az addigi erdélyi vajdát csak 1321 legvégén nevezte ki e posztra. ${ }^{544}$ Dózsa uralmi körzete részben a már legyőzött Borsa Kopasz megyéit fedte le. Ezen terület felett már eddig is volt befolyása, mint király által kirendelt bírónak, ami lényegében nádori jellegü jogkört (és ispáni címet) jelentett Szabolcs, Szatmár, Bihar, Kraszna és Szolnok (Külső-Szolnok) megyék felett. Nádorként is ugyanebben a régióban maradt. Az életét elsőként feldolgozó Komáromy András még furcsaságként említette, hogy szinte állandóan Debrecenben székelt, és alig mozdult ki innen, ${ }^{545}$ de a korszak gyakorlatának a fényében éppen ez tekinthető tipikusnak. Nádorsága jellemzőit összefoglaló Zsoldos Attila megállapítása szerint is csak a felsorolt néhány megye ügyeivel foglalkozott személyesen. ${ }^{546}$ Ezen kívül Dózsa esetében bizonyítható elsőként az a Druget Vilmos nádorságától már általánosnak mondható jelenség, hogy már a nádor távollétében is adtak ki okleveleket az ő nevében. Azt tapasztaljuk ugyanis, hogy 1322. május 21-én és 22-én is kelt Debrecenben egy-egy nádori oklevél. ${ }^{547}$ Ezzel párhuzamosan, május 22-én a közgyülései szokásos helyszínén, Kállósemjénben nyitotta meg a congregatioját Szatmár, Szabolcs, Szolnok és Kraszna megyék számára. A közgyülésen május 24-én és 25-én további okleveleket is kiadott. ${ }^{548} \mathrm{Az}$ oklevelek kivétel nélkül eredetiben maradtak ránk (igaz, a két debreceni oklevél a Vay család anyagában, amely azóta megsemmisült, csak fényképeit ismerjük), a keltezések elírása tehát nem valószínü. Kállósemjén és Debrecen között kb. 55$60 \mathrm{~km}$ a távolság, így az sem valószínü, hogy a nádor ide-oda mozgott volna a helyszínek között, tehát valahol biztosan nem ő volt jelen. Ugyanezzel az esettel találkozunk néhány héttel később: június 6-án szintén Kállósemjénben nyitotta meg a közgyülését (ezúttal Bihar, Szabolcs és Szatmár megyéket sorolva fel), és az egyik ügyben 7-én adott ki oklevelet ottani kelettel. ${ }^{549}$ Ezzel párhuzamosan június 6-án, majd 9-én is kelt egy-egy nádori oklevél

\footnotetext{
${ }^{543}$ Zsoldos 2012b. 48., 50.

544 Dózsa kinevezésének időpontja és politikai körülményei szintén zavarosak, és többféle rekonstrukciót is megengednek. A kérdéssel legutóbb foglalkozó Zsoldos Attila és Bárány Attila egyarán 1321 végére tette az időpontot, és idézik a korábbi, helynként eltérő álláspontot közvetító szakirodalmat is: Bárány 2011. 108-110.; Zsoldos 2011b. 54. 53. jz.

${ }^{545}$ Komáromy 1891. 67-68.

${ }^{546}$ Zsoldos 2011b. 65-66.

${ }^{547}$ AOkl VI. 579., 582. sz.

${ }^{548}$ AOkl VI. 581., 587-588. sz.

${ }^{549}$ AOkl VI. 620. sz.
} 
Debrecenben is. ${ }^{550}$ Ezek után jogos kérdés, hogy melyik helyszínen tartózkodott személyesen a nádor? Ha analógiákat keresve előretekintünk az időben, akkor a szakirodalom régi megállapítása, hogy a 14. század második felétől, végétől a nádori közgyűléseket nem személyesen a hivatalviselő celebrálta, hanem annak helyettese. ${ }^{551}$ Ám ha nem ennyire tekintünk elöre, csak az 1330-40-es évekig, akkor éppen az ellenkezőjét tapasztaljuk: Druget Vilmos hivatalviselése (1334-1342) idején az volt a tendencia, hogy ő a közgyüléseken volt jelen személyesen, és a nádori kúriában addig a személyzete folytatta a müködést. Mindennek (egyebek mellett) az az egyik bizonyítéka, hogy amíg a közgyűlésein a személyes használatú nádori nagypecsétet vagy gyürüspecsétet használták, addig ezen párhuzamos időpontokban Vilmos óbudai kúriája sosem azzal, hanem egy középpecséttel hitelesített. ${ }^{552}$ Analógia tehát mindkét változatra akad, ám Dózsa esetében sajnos nem olyan könnyü megállapítani a pecsételési módokat a párhuzamos oklevéladás esetében. Ám az bizonyos, hogy a Dózsa nagypecsétjének tekinthető, kb. 57-58 mm átmérőjü sigillummal ${ }^{553}$ hitelesítették két, kállósemjéni közgyűlési oklevelét május 22-én és május 25-én. ${ }^{554}$ A debreceni oklevelek, mint említettük, a Vay család levéltárából valók, és már csak fekete-fehét fényképüket ismerjük (és kizárólag az előoldalukat), így azok pecsétjei nem állapíthatóak meg világosan. Annyi biztos, hogy azok is viszonylag nagyobb méretűek voltak, mert az oklevelek előlapjára átütött pecsétfoltok az egyik esetben kb. 8 sornyi, a másik esetben 10 sornyi helyet foglalnak el $^{555}$ - igaz, ez utóbbi oklevél kevésbé „,szellős” sorközökkel íródott, egyébként nyilván ugyanarról a pecsétről lehetett szó mindkét esetben. Ennek mérete nem állapítható meg, de valamiféle „középpecsétről” lehet szó. ${ }^{556}$ A közgyülésen felbukkanó nádori nagypecsét szintén amellett szól, hogy Dózsa személyes jelenlétét a congregation valószínűsítsük, míg a debreceni kúriában a hátrahagyott személyzet folytatta a müködését a nádor nevében. Ez a „hátrahagyott személyzet” talán ,általános bíráját” (iudex generalis), Péter fia Miklóst jelentette, esetleg annak albíráját (viceiudex ... iudicis generalis), Péter comest. Mindketten

\footnotetext{
${ }^{550}$ AOkl VI. 617., 623. sz.

${ }^{551}$ Legutóbb Lackfi István nádorsága idejéből (1387-1392) C. Tóth Norbert hozott erre konkrét példákat: C. Tóth 2009. 96-97. A nádor személyes jelenlétének a hiányát taglaló szakirodalmat szintén idézi: C. Tóth 2009. 88. 18. jz.

${ }^{552}$ Lásd erről a „4.6 - A nádori kúria Visegrádra költözése” c. alfejezetet.

${ }^{553}$ Egyetlen viszonylag ép példánya: DL 2122. (AOkl VI. 752. sz.). Ugyanezen pecsét töredékei azonosíthatóak a következő oklevelein: DL 50707., 50716., 50717., 76303., 50722., 50726., 50730. (AOkl VI. 411., 581., 588., 687., 714., 728., 909. sz.)

${ }^{554}$ DL 50716., 50717. (AOkl VI. 581., 588. sz.)

${ }^{555}$ DL 96084, 96079. (AOkl VI. 579., 582. sz.)

${ }^{556}$ Dózsának egyébként egyetlen olyan oklevelét sem ismerjük, amelyen egyértelmüen azonosítható lenne egy 57-58 mm-nél kisebb, kb. középpecsétnek megfeleltethető nyomat vagy folt. Ezen kívül csak gyürüspecsétes oklevelek maradtak fent tőle: DL 50710., 50711. (AOkl VI. 456-457. sz.). Mindkét oklevél Debrecenben kelt.
} 
Debrecenben tartották székhelyüket. ${ }^{557}$ A júniusi párhuzamos oklevéladást nem lehet biztos módon kielemezni ilyen szempontból, mert a két debreceni oklevélnek hiányzik a hátuljáról a pecsétje, csak bizonytalan, nehezen mérhető foltokat találunk. A közgyülésen kelt nádori oklevél pedig nem eredetiben maradt ránk.

Annyi bizonyos, hogy igazolhatóan Dózsa idején szakadt el először a nádori „hivatal” müködése a nádor személyétől, és ez mindenképpen egy intézményesülési folyamat kezdetét jelzi.

\section{5 - A Druget-nádorok}

A már többször emlegetett „Druget-nádorok” három személyt takarnak, Druget Fülöpöt (nádor 1323-1327 között), testvérét, Jánost (nádor 1328-1333 között) és János fiát, Vilmost (nádor 1334-1342 között). A család az egyetlen olyan itáliai família volt, amely komolyabb karriert futott be. A karrier megalapozója Fülöp volt, aki - legalábbis egyes oklevelek homályos utalásaiból ez tetszik ki - még ifjú korában érkezett I. Károly kíséretében az országba. ${ }^{558}$ János és fia, Vilmos már jóval később érkeztek, amikor Károly uralma már megszilárdult, és Fülöp halála után János lényegében politikai előzmények nélkül, célzatosan rá szabva kapta meg fivére nádori címét, fia pedig a Druget-tartomány igazgatását. Majd amikor János Nápolyba kísérte a királyt, a fia nádorhelyettes lett (vicegerens palatini), és atyja halála után nem sokkal később nádor. ${ }^{559}$ Az alábbi részfejezetben nem célunk ezen szük 20 év nádori müködését pontosan felvázolni, egyrészt mert a ránk maradt sok adat miatt az egyébként is túlmutatna egy alfejezet keretein, másrészt felesleges is volna, hiszen a Drugetfamília és tartomány (ezáltal a Druget-nádorok) történetét részletesen feldolgozza Zsoldos Attila. ${ }^{560}$ Egyetlen kivételként azt a folyamatot mutatjuk csak be részletesen (a következő alfejezetben), amely során a nádori kúria átkerült Visegrádra, majd megszilárdult ott. Egyébként inkább csak utalnánk azon tendenciákra, amelyek odáig vezettek, hogy Druget János és Vilmos ismét az ország „vándorló nádora” lett. A „tendencia” pedig nem volt más, mint a megyék számára tartott általános gyülés (generalis congregatio) intézményének jelentős kibővítése. Mindez nem azt jelenti, hogy a nádorok ne rendelkeztek volna állandó

\footnotetext{
${ }^{557}$ Személyükre lásd a „8.1 - A nádort helyettesítő tisztségek: alnádor, nádori albíró” c. alfejezetet.

${ }^{558}$ Csukovits 2009. 29.; Zsoldos 2012d. 35.

${ }^{559}$ Zsoldos 2012c. 527-529., 533-535. A Drugetekre általában lásd még: Hampel 1881; Wertner 1891b; Engel 1982. 904-907.; Kurcz 1988. 140-146.; Engel 1998. 42-44.

${ }^{560}$ Ez idáig csak résztanulmányok jelentek meg: Zsoldos 2012a; Zsoldos 2012c, 2012d.; illetve az előzményekre vonatkozóan: Zsoldos 2011b, Zsoldos 2012b. E tanulmányok vélhetően hamarosan újakkal bővülnek, és - a maradék hézagok kitöltésével - könyv formában is napvilágot látnak.
} 
kúriával is. Ez Fülöp esetében az Abaúj megyei Vizsolyban volt, a Druget-tartomány központjában, míg János Óbudán székelt. ${ }^{561}$ Az óbudai székhely fö oka bizonyára az lehetett, hogy - talán Károly ötletéből fakadóan - szétválasztották és megosztották Fülöp tartományának igazgatását és a nádori cím viselését apa és fia között. Mivel a tartományt megöröklő Vilmosnak jutott a korábbi nádori székhely, Vizsoly, ezért János másik székhelyet kapott. Bár kronológiai értelemben óbudai várnagynak valamivel hamarabb nevezte ki öt Károly, mint nádornak, ${ }^{562}$ a néhány hét különbségnek sok jelentőséget nem kell tulajdonítanunk, mindent egybevetve azt mondhatjuk, hogy nagyjából egyszerre kapta meg a két posztot (azaz: óbudai nádori székhelyét nem lehet egyértelmüen levezetni óbudai várnagyságából). A harmadik Druget-nádor, Vilmos székhelye (pontosabban: székhelyei) már bonyolultabb kérdést jelentenek, és egy külön alfejezetben foglalkozunk vele. A nádorok gyakran tartózkodtak a székhelyükön, már amennyiben nem mentek közgyülésre. Fülöp esetében további jellemző volt, hogy mind ottléte, mind távolléte alatt működött a kúriájában egy albíró, aki folyamatosan helyettesítette őt, így a nádori kúriai bíráskodás lényegében soha nem szünetelt. Ezen kívül egy másik helyettes Budán székelt. Ezt a rendszert nem a Drugetek találták ki, már az Árpád-korban is létezett, de a kúriai albírói bíráskodás Aba Amadé mellett Druget Fülöp alatt élte a csúcspontját. A folyamatos helyettesi rendszer aztán János és Vilmos alatt már megváltozott. Druget Vilmos alatt állandósult ugyanis, hogy a távollévő nádort nem az albírái helyettesítették, hanem az ítélőmestere, aki nem a saját maga, hanem a nádor nevében adta ki az okleveleket, vagyis a nádori hivatal és a nádor személye véglegesen szétvált (mint láttuk, ez már Dózsa alatt is előfordult alkalmanként, de Vilmos idején állandósult gyakorlat lett).

Druget Fülöp alapvetően még csak a saját régiójában tevékenykedett, amit már nádorrá való kinevezése előtt is jól ismert. Fülöp szepesi és újvári ispánként, egy ízben (1318-ban) kiküldött bírói jogkörét is feltüntetve már korábban is igazgatta ezt a területet, és ekkor már mellette találjuk alispánként, majd vizsolyi udvarbíróként (iudex curie) azt a Perényi Miklóst, aki később vizsolyi albírája lesz, és halála után Vilmosnak is a szolgálatába állt, amíg az a Druget-tartományt igazgatta. Bár Fülöp királyi bírói felhatalmazása megengedte volna, nem tudunk arról, hogy valaha is tartott közgyülést az uralma alatt álló megyéknek. Ám kinevezése után nem sokkal (amely kinevezés talán 1322 decemberének második felére esett), ${ }^{563}$ január

\footnotetext{
561 Jánosra: Zsoldos 2012c. 531.

${ }^{562}$ Zsoldos 2012c. 529.

563 Engel Pál az archontológiában a nádori tisztséget 1323. jan. 14-ére még üresedésben lévőnek mondja (Archont. 1301-1457. 2.). Ám a hivatkozott oklevél (DL 40417.) csak annyit mond, hogy nem tudják I. Károly parancsát kihírdetni Pest megyének, mert az alnádori tisztség üresedésben van éppen. Hogy a nádori tisztség is
} 
18-án már generalis congregatiot celebrált Szabolcs megyének Gáva faluban. ${ }^{564}$ Szabolcs megye addig Dózsa nádor fennhatósága alá tartozott, aki utoljára 1322 januárjában tartott közgyülést 4 megye, köztük a szabolcsi számára. ${ }^{565}$ Az ezévben tartott többi közgyülés is arra utal, hogy Dózsa addigi nádori régióját is fennhatósága alá vette a sajátjával egyetemben. Május 10-én Abaúj megye nemességének tartott közgyűlést Vizsolyon, június 14-én ismét Szabolcs megyének, megint csak Gáván. ${ }^{566}$ Kora-ősszel a nádor új lendületet vett, és szeptember 26-án Beregszászon celebrált congregatiot Bereg és Ugocsa megyék számára, szeptember 30-án már Szatmár megyének tartotta Vetésen, amely október 8-án még mindig zajlott, mert ekkor a megye hatóságának egy oklevele ,in congregatione palatini” kelt a közgyülés helyszínén, Vetésen. ${ }^{567}$ Október 26. és 30. között Bihar megyének tartotta Micskén. ${ }^{568}$ Szatmár megye november 2-i oklevele „,in congregatione Philippi palatini” kelt, amely arra utalhatna, hogy a nádor visszatért a megyébe egy ,pótközgyülést” tartani. ${ }^{569}$ Továbbá vizsolyi albírájának, Perényi Miklósnak egy napi keletet fel nem tüntető 1323. évi oklevele Boldván, „secundo die congregationis” kelt. ${ }^{570}$ Alapvetően egyedülállónak nevezhetjük, hogy Miklós kimozdult Vizsolyból, mert egyébként sohasem kísérte el az urát sehová. Így arra gyanakodhatunk, hogy ez a bizonyos közgyülés Fülöp nádor távollétében zajlott le, és helyettese vezényelte le - ezért adott ki az ügyben ő oklevelet. Boldva Borsod

üresedésben lett volna, az azért nehezen elképzelhető, mert Fülöp 4 nappal az oklevél kelte után, január 18-án már közgyülést tartott Szabolcs megye számára (lásd a következő lábjegyzet). Semmi nem indokol egy olyan feszített kronológiát, hogy Fülöp rögtön a kinevezése után - mintha csak erre várt volna - azonnal Szabolcs megyébe siessen közgyülést tartani, ráadásul figyelembe kell venni azt is, hogy egy ilyen gyülést már hetekkel elötte meg kell hírdetni a megye lakosai számára. Valószínűbb, hogy a már nádorrá kinevezett Fülöp egy ideig még nem gondoskodott a budai alnádori szék betöltéséröl, így ő január 14-én már hivatalban volt. Dózsa budai alnádora 1322. november 27 -én még oklevelet adott ki (AOkl VI. 848. sz.), de ez az utolsó olyan adat, amely Dózsa müködését sejteti. Fülöp azonban dec. 6-án még királynéi tárnokmester volt (AOkl VI. 857. sz.). Mivel Károly ekkortájt a térségtől távol, Temesvárott tartózkodott (AOkl VI. 863. sz.), mindenképpen kellett némi idö, amíg Dózsa halálának a híre eljutott hozzá, illetve a kinevezés Fülöphöz. Beszédes ugyanakkor, hogy Károly 1322. dec. 27-én már levelében arra utasította a budai káptalant, hogy egy parancsát mutassák be a pesti ispánnak (azaz az alnádornak). Erre válaszolt a káptalan jan. 14-én a hivatkozott oklevélben, hogy az alnádori tisztség nincsen betöltve. Bár lehet, hogy Károly éppen nem gondolt arra, hogy a pesti ispáni cím össze van kötve az alnádorival, ám valószínübb, hogy éppen azzal számolt, hogy a tisztség a levele Budára érkezésekor már nem lesz üresedésben, vagyis a nádori kinevezést már maga mögött tudta. Ez esetben Fülöpöt valamikor december 6 és 27 között tette meg nádorrá Károly.

${ }^{564}$ A Szabolcs megyei közgyülésre lásd AOkl VII. 13., 14., 19. sz.

${ }^{565}$ Zsoldos 2011b. 65.

${ }^{566}$ AOkl VII. 181-182.; 271., 273-274. sz.

${ }^{567}$ AOkl VII. 482.; 485., 488. sz.

${ }^{568}$ AOkl VII. 526-527., 545. sz.

${ }^{569}$ DL 50747. (AOkl 556. sz.)

${ }^{570}$ Zichy I. 249. (AOkl VII. 704. sz.) 
megyében található, ${ }^{571}$ viszont az oklevélben egy Gömör megyei birtokról intézkedtek, így valószínü, hogy ez is egy páros congregatio lehetett. Összegezve tehát az említett megyéket (Abaúj, Borsod, Gömör, Szabolcs, Bereg, Ugocsa, Szatmár és Bihar), hozzátehetünk még néhány olyan megyét, amelyről ugyan nem tudjuk, hogy Fülöp tartott volna congregatiot, ám maga, vagy albírája révén biztosan eljárt ottani esetekben is. Ilyen megye Zemplén, ${ }^{572}$ Szepes ${ }^{573}$ és Sáros, ${ }^{574}$ ezek egyike sem tartozott korábban Dózsa érdekszférájába. Ugyanakkor nyáron Fülöp Budán tartózkodott szeptember elejéig, ${ }^{575}$ hogy aztán a hónap végén az őszi közgyülések tartására induljon. Ez a tendencia (a nyári budai tartózkodásokat leszámítva) egész nádorságára érvényes volt. Megyei közgyüléseket kizárólag ebben a régióban tartott később is, 1324-ben Szabolcs, Ung és Bereg megyéknek, ${ }^{576}$ és talán egy ezévi Szatmár megyei congregatiora utalt vissza egy 1325 májusában kiadott oklevelében. ${ }^{577}$ 1325-ből csak egy újabb Szatmár megyei gyűlésről van tudomásunk, ám egyedülálló módon budai alnádora, Tamás Zala megyének tartott egyet hasonló időpontban. ${ }^{578}$ Mint láttuk, már korábban is volt arra példa, hogy albírája vezényeljen le egy ilyen nemesi gyülést, és az eset azt is megmutatta, hogy Fülöpnek nem nagyon állt szándékában személyesen átmenni a Dunántúlra bíráskodni. 1326-ból Zemplén, Szabolcs és Szatmár megyei gyülésekről tudunk a megszokott őszi időpontban, október-november folyamán. ${ }^{579}$ Nyilvánvaló, hogy ennél több megyében fordult meg a nádor, valószínűsíthetjük, hogy amikor az őszi hónapokban megindult, akkor végigjárta nádori territóriumának jelentős részét.

A Fülöp előtt megforduló egyéb ügyek is mind ezt a régiót fedik le. Csak néhány személyesen intézett kivétel volt, de ezeket is meg lehet magyarázni. Az egyiket az 1324. évi hadbaszállással, amikor a királlyal együtt a Küküllö-menti táborban tartózkodott, és a hozzá forduló feleket a győri káptalanhoz küldte eskütételre. ${ }^{500}$ A másik esetben is a király és más bárók környezetében tartózkodott, amikor Miklós pozsonyi ispán pert indított a színe elött Szentemágocs nembéli János ellen, amelyben Fülöp párbajt ítélt, de a király magához vonta

\footnotetext{
571 ÁMTF I. 760.

572 AOkl VII. 603.

${ }^{573}$ AOkl VII. 573-574., 594. sz.

${ }^{574}$ AOkl VII. 495. sz.

${ }^{575}$ AOkl VII. 350. (1323. júl. 8.). Szintén budai tartózkodására utal az, hogy Lampert országbíró előtt a peres felek egyike Fülöp nádor ügyvédvalló levelével jelent meg Budafelhévízen júl. 9-én (AOkl VII. 352. sz.); AOkl VII. 435. sz. (szept. 1.)

${ }^{576}$ AOkl VIII. 264., 273., 280. sz.; 404. sz.; 409. sz.

${ }^{577}$ AOkl IX. 183. sz.

${ }^{578}$ AOkl IX. 442. sz.; 490-492. sz.

${ }^{579}$ AOkl X. 406. sz.; 428., 430-431., 435. sz.; 448., 453. sz. (a Szatmár megyeire lásd még: AOkl X. 544. sz., XI. 300. sz.)

${ }^{580}$ AOkl VIII. 349. sz. (1324. júl. 16.)
} 
az esetet, és a felek végül a párbaj helyszínén a felsorolt országbárók közbenjárásával kiegyeztek. $^{581}$

A nyugat-magyarországi területekkel a kapcsolatot alapvetően budai albírája, Tamás révén tartotta. Tamás kimutathatóan Fejér, Tolna, Baranya, Somogy és Zala megyei perekben járt el, és persze környékbeli, Pilis megyei ügyekben intézkedett. ${ }^{582}$ Az előtte megfordult kevés ügyből azonban nyilvánvaló, hogy a budai alnádor nem töltött be komoly szerepet a nyugat-magyarországi bíráskodásban. Így Fülöpöt nem mondhatjuk ténylegesen országos hatáskört gyakorló nádornak, tevékenysége sokkal inkább rokonítható az őt megelőző Debreceni Dózsáéval, mint az utána következő Druget Jánossal.

Fülöp halála után egy hosszabb, több mint 1 éves üresedés után követte öt fivére, János. Könnyen helytálló lehet Zsoldos Attila azon feltételezése, hogy Károly azért várt ilyen hosszú időt a méltóság betöltésével, mert azt direkt Jánosnak tartotta fenn. És mivel ő ekkor csak nemrég érkezett fiával Magyarországra, és sokkal inkább kötődött régi hazájához, így ahhoz, hogy átvegye elhunyt testvére hivatalát (ami egyet jelent a tartós magyarországi berendezkedéssel), „el kellett varrni” az itáliai szálakat. Így elképzelhető, hogy Fülöp halála után nem sokkal visszatért Itáliába, majd újra, immár hosszabb időre Magyarországra. ${ }^{583}$ Hogy Károly már Fülöp halálát követően számolt a Drugetekkel, mutatja, hogy János ittmaradt fiának, Vilmosnak már 1327 augusztusában átörökítette a királyra háramlott Drugettartományt, amit Vilmos rögtön birtokba is vett. Károly kezdeményezésére megkezdték az egyes birtokok számbavételét, megvizsgálták határait, és beiktatták Vilmost az örökségébe. A vizsgálatok során szerepet kapott Fülöp bizalmi embere, vizsolyi albírája, Perényi Miklós is. ${ }^{584}$ Vilmos emellett bírói értelemben is igazgatni kezdte a tartományát. A Károly által ráruházott „öt megyében a király által kiküldött általános bíró” (iudex generalis in quinque comitatibus per dominum regem deputatus ${ }^{585}$ tisztsége folytán már 1328 tavaszán generalis congregatiokat tartott a terület számára. ${ }^{586}$ (Vilmos egyébként később is tartott gyüléseket ezen megyéknek, amikor János nádort már beiktatták.) ${ }^{587}$ Vilmos ezen kívül - ha a ránk maradt oklevelek tanúsága szerint nem is olyan nagy intenzitással, mint Fülöp - egyéb bírói

\footnotetext{
${ }^{581}$ AOkl IX. 113-116. sz. (1325. márc. 25-26.)

582 AOk1 VII. 269., 275., 351. sz.; 411., 433. sz.; 563., 567. sz.; 592. sz.; AOkl VIII. 530., 547. sz.; AOk1 IX. 442. sz.; 538. sz.; 551. sz.; AOkl X. 137., 169., 272. sz.; 280. sz.; AOkl XI. 16., 33. sz.; 142., 261. sz.

${ }^{583}$ Zsoldos 2012c. 529.

${ }^{584}$ A tartományi birtokok számbavételére, birtokbavételére és a vizsgálatokra utaló oklevelek: AOk1 XI. 411. sz.; AOkl XII. 45-46., 67., 126-127., 218., 421., 424. sz.

${ }^{585}$ DL 57104. (AOkl XII. 115. sz.)

${ }^{586}$ AOkl XII. 115-118., 157. sz. Hogy Vilmos fennhatósága mely megyékre terjedt ki, lásd Zsoldos 2012a

${ }^{587}$ Lásd erről Zsoldos $2012 \mathrm{a}$
} 
és igazgatási teendőket is ellátott. ${ }^{588}$ Így amikor apja, János 1328 őszén elkezdte megkapni Károlytól a különböző tisztségeket (óbudai várnagyság, ungi ispánság, ${ }^{589}$ majd maga a nádori tiszt), a fia már alaposan berendezkedett a tartományában. Apja székhelyéül Óbudát jelölte ki Károly. Bár a motivációk lényegében ismeretlenek, igen valószínünek kell tartanunk, hogy ezt a felosztást maga a király találta ki, ezért is adta az óbudai várnagyságot Jánosnak, és ezért tette a tartomány örökösévé a fiát az apa helyett.

Azzal, hogy hosszú idő után János volt az első olyan nem nádor, aki hivatalosan nem kötődött a családi birtokaihoz, a nádori „hatósugár” jelentős kibővülését hozta magával. 1329 tavaszától ismertek az első nádori kiadványai, ekkor Óbudáról elindult és közgyülést tartott Somogy és Baranya megyében. Augusztusban a fia megyéit járta végig, előbb Abaúj, Borsod és Gömör, majd Zemplén és Ung megyéknek celebrált congregatiot. Szeptemberben Szabolcs megye következett, és valószínüleg egy Arad megyei gyülés emlékét takarhatta az az oklevele, amely 1329. október 6-án Aradon kelt egy átlagosnak tünő birtokügyben. Egy későbbi levele egy Nógrád megyei gyülést is említett. ${ }^{590}$ Feltételezhetjük, hogy Bereg és Ugocsa megyék számára is tartott közgyülést ekkor, de az is lehet, hogy mindez - más megyékkel együtt - már 1330 legelején volt. ${ }^{591}$ Egy 1330 februári oklevél egy Pest megyei közgyülésről szól, és 1331-ben Zala, Veszprém és Sopron megyéknek tartott ilyet. ${ }^{592}$ A közgyüléseken nem csak az számított újdonságnak, hogy (elöször a nádori intézmény fennállása során!) Kelet-Magyarországtól kezdve Nyugat-Magyarországig több régiót is lefedtek, hanem János egy másik téren is szakított a korábbi hagyományokkal. A közgyülés addig az adott megye vagy megyék (esetleg régió) ügyeinek a fóruma volt. János idején többször is előfordult, hogy egy megyei gyülésen nem az oda eső kérdésekben is ítélkezett.

\footnotetext{
${ }^{588}$ AOkl XI. 369., 509., 583. sz.; AOkl XII. 337., 365.

${ }^{589}$ AOkl XII. 442. (1328. okt. 9.)

${ }^{590}$ A források felsorolását lásd Zsoldos 2012c. 531. Talán - miként Zsoldos Attila vélte - ezen Arad megyei gyülésre utal az az 1331. máj. 1-jén kelt levele (AOkl XV. 167. sz.), amelynek ügyét egy korábbi aradi generalis congregatioról tette át óbudára a színe elé (Zsoldos 2011c. 531. 35. jz.). Ám az, hogy a per közgyülés utáni következő állomása 1331 tavaszára esett, elvileg egy 1330. esetleg 1331. évi aradi közgyülést is feltételezhetne, bár ezekről konkrét adat nem maradt fent.

591 János egy 1330. március 26-án (az oklevél datálására lásd az Anjou-kori Oklevéltár megjegyzését a regeszta után: AOkl XIV. 171. sz.) kelt levelében az Újvár, Gömör, Borsod, Zemplén, Ung, Bereg és Ugocsa megyék számára tartott közgyülésen (in congregatione nostra comitatibus Wyuar, Gumer, Borsod, Zemlen, Hung, Bereg et Vgocha celebrata - DL 2596.) kiszabott bírságok behajtásáról beszélt. Mivel Bereg és Ugocsa megyéken kívül az összes többi megye congregatioja azonosítható az előző évből, feltehetjük, hogy az előző ősszel kiszabott bírságokat hajtatta be 1330 tavaszán. Tegyük hozzá: elvileg az is lehetséges, hogy még 1330 januárjamárciusa között tartotta ezeket, hiszen 1330. febr. 26-án Pest megyében rendezett közgyülést, ahol egy Gömör megyei elhalasztott pert is elövettek (lásd alább) - ami feltételezhet egy nem sokkal korábbi Gömör megyei congregatiot.

${ }^{592}$ Zsoldos 2012c. 531.
} 
Már 1329-ből találunk erre példát. Az Aradon (in Orod) kelt oklevele (amely esetleg egy aradi közgyülésre utalhat) egy olyan idézésről szól, amelynek a helynevei (Szalócháza, Melléte, Mala) mind Gömör megyére mutatnak. ${ }^{593} \mathrm{Az}$ 1331. évi oklevele, amely konkrétan egy Arad városa mellett tartott közgyülésről számolt be (in congregatione nostra generali apud ciuitatem Arad celebrata), ${ }^{594}$ a Zemplén megyei Ompud és Bodrogszerdahely birtokok közti határvitát rendezte a leleszi konvent közbenjárásával. ${ }^{595}$ Ez esetben azt is feltehetnénk, hogy ez az aradi gyülés valójában az Ung megyei Arad településen ${ }^{596}$ volt, hiszen az oklevél nem nevezte meg a megyé(ke)t, csak a helyszínt. Mivel már 1329-ben is Zemplén megyével párosan tartott János közgyülést Ung megyének, így az megmagyarázná, hogy mit keresne egy Aradon rendezett congregation egy zempléni birtokvita. Ez esetben az 1331-es oklevél egy ismeretlen Zemplén-Ung megyei közgyülésről szólna. A feltételezést azonban gyengíti, hogy a szöveg ,apud civitatem Arad”-ról beszél, míg az Ung megyei településről nem tudjuk, hogy város lett volna, így ez mindenképpen az Arad megyei településre utal. Az oklevél szövegét sajnos csak Fejér György hiányokkal tarkított kiadása tartotta fenn, ${ }^{597}$ az eredeti elveszett, így teljes biztonsággal nem tudhatjuk, hogy mi állt ott eredetileg. Ám az 1330-ban Pestnek tartott közgyülés esete segíthet dönteni. Több Gömör megyei birtokot érintő vita kapcsán a felek - János saját korábbi oklevele értelmében - a Pest városában, a megye nemesei számára tartott február 26-i közgyülésen jelentek meg. ${ }^{598}$ János tehát nem a kúrájába való megjelenést írt elö a feleknek (mint ez pl. Fülöp esetében szokott volt), hanem egy megyei generalis congregatiora rendelte be őket maga elé. Feltehetjük, hogy az Arad megyei közgyülés(ek?) esetében is ez történt: a gömöri és zempléni vitáknál egy közgyülésen felmerülő pert nem a kúriájába, hanem egy másik közgyülésre halasztott.

János követte Károlyt itáliai útjára, amely időre fia kapta meg a nádorhelyettesi címet. ${ }^{599}$ Bár feltehetjük, hogy János még élve érkezett vissza Magyarországra (mint ahogy azt is, hogy soha nem ért vissza, hanem hátramaradva szülöföldjén ott végezte be életét), nádorként többet már nem játszott szerepet. ${ }^{600}$ Utódja fia, Vilmos lett, akit 1334. május 17-e előtt neveztek ki

\footnotetext{
${ }^{593}$ AOkl XIII. 545. vö. 566. sz. A helynevek: ÁMTF II. 524., 526., 549.

${ }^{594} \mathrm{CD}$ VIII/5. 201.

${ }^{595}$ AOkl XV. 167. sz.

${ }^{596}$ Csánki I. 388.

${ }^{597}$ CD VIII/5. 200-204.

598 AO II. 474. (AOkl XIV. 104., 107. sz.)

${ }^{599}$ Ennek részletes tárgyalását lásd Zsoldos 2012c. 532-540.

${ }^{600}$ Zsoldos 2012c. 534.
} 
nádornak, és valamikor 1342. szeptember elején vagy végén hunyt el, ${ }^{601}$ néhány hónappal élve túl I. Károlyt. Ezen bő nyolcévnyi nádorsága alatt komoly változások zajlottak le a nádori hivatalban is, amelyek részben már János alatt megkezdődtek (itt elsősorban a nádori hatókör országos szintüre bővülésére kell gondolnunk). Egy másik viszont teljesen Vilmoshoz köthető: alatta ment végbe a nádori székhely Visegrádra, az országbírói kúria mellé való költözése. A folyamatot a korábbi szakirodalom egy jelentős része nem teljesen helyes módon az 1342-es évhez, és Nagy Lajos reformjához kötötte. A kérdéssel a következő alfejezetben részletesen foglalkozunk, itt most csak a nádori hatósugár Vilmos alatti kitágulását vázoljuk fel.

A hatókör kiszélesedését legfőképpen az egyes megyék számára tartott generalis congregatiokból lehet lemérni. A Druget Vilmos alatti közgyüléseket Kruták Anita tekintette át. Látható, hogy 1334-ben, nádorságának első évében még csak a saját szűkebb tartományát járta végig (Bihar, Szabolcs, Bereg, Zemplén, Ung, Abaúj és Sáros megyék), ${ }^{602}$ dunántúli közgyülésre csak egy halvány nyom utal. ${ }^{603}$ Ám a következő év késő-tavaszán, nyarán a nyugat-felvidéki és néhány nyugati megye került sorra (Nógrád, Hont, Bars, Pozsony, Moson, Sopron, Gömör, Zala és Veszprém megyék). Összel pedig ismét a tágabb értelemben vett tartományi vonzáskörzete következett (Bihar, Kraszna, Szatmár, Ugocsa, Szabolcs, Bereg, Zemplén, Ung, Hevesújvár, Torna és Borsod megyék). ${ }^{604}$ Tegyük hozzá: a Gömör megyei

\footnotetext{
${ }^{601}$ Archont. 1301-1457. 3. Vilmos halálának időpontjára lásd még Piti 2006. 435-436.; C. Tóth 2012. 443-444. (föként 444. 53. jz.)

${ }^{602}$ Kruták 2012. 427-428.

${ }^{603}$ Ez a „halvány nyom” egy Budán, 1334. jún. 28-án kelt nádori oklevél (DF 283264.), amelyben megparancsolja a földvári konventnek, hogy idézzék meg színe elé a besenyők 4 esküdtjét és Besenyő Jakab két fiát, akiket elöző napi, számukra rendezett közgyülésén kellett volna proscribálnia, ám halasztást rendelt el (nos proscriptionem Gregorii et Mathey filii Jacobi Bysseni predie in congregationem nostram factam eisdem duxerimus indulgendum eosdem iudicio et iustitii committendo). Az oklevél helynevei egyértelmüen a keletdunántúli Besenyőispánság területére utalnak (Györffy 1991. 141-142.). Ha szó szerint vesszük az oklevélben foglaltakat, akkor a jún. 28-i Budán keltezett nádori diplomához mért „predie” egy jún. 27-i közgyülést takarna. Vilmos első biztosan behatárolható congregatioja júl. 5-től kezdődött, Bihar megye számára (Kruták 2012. 427.). Elvileg sem a közgyüléshez képest másnapi budai kelethely, sem az egy héttel későbbi keleti megjelenés nem kizáró ok, de azért összességében valószínütlen. A magyarázat az lehet, hogy a budai nádori oklevél nem Vilmos személyes jelenlétében, csak a nevében kelt, mint erre több példát is láthatunk a következő fejezetben. A nádori iroda vlsz. egy nekik küldött nádori parancslevélben szereplő „piszkozatot” írt át, így az abban szereplö elöző napot nem a budán keltezett parancslevélhez kell mérni. Ez persze hiteles nyoma egy nem keletmagyarországi közgyülésnek, amelynek a helyszínét a Besenyőispánság megyéinek valamelyikére (Tolna, Fejér) tehetjük, esetleg magának a Besenyőispánságnak a területére, amely számára külön is rendeztek congregatiot. Az időpontot viszont valamivel korábbra is kitolhatjuk. Arra, hogy az óbudai kúria a nádor távollétében bocsátott ki okleveleket már 1334-től kezdve, lásd a „4.6 - A nádori kúria Visegrádra költözése” c. alfejezetet. A 14. századi Besenyőispánság és a nádor kapcsolatáról lásd bővebben a „7.2 - A besenyők” c. alfejezetet.

${ }^{604}$ Kruták 2012. 428.
} 
gyülést nem ö, hanem az alnádora tartotta. ${ }^{605} \mathrm{Ez}$ a tempó természetesen nem volt egyenletes: ezután sokkal kevesebb gyülésről tudunk egészen 1340-ig, és azok is főként a saját tartományára koncentrálódtak. 1341-ben volt még egy nagy közgyűlés-sorozat, amely során Vilmos előbb a keleti országrész megyéit járta végig, majd a Felvidéken keresztül ismét a nyugati megyéket látogatta meg e célból (Zala, Veszprém, Győr, Komárom, Pozsony és Moson). ${ }^{606} \mathrm{Az}$ itt elősorolt megyék az ország északi felét fedték le, a déli régióból összesen egy Somogy megyei, Somogyban tartott congregatiojáról tudunk, Nagy Lajos 1343. évi oklevelének említése alapján. ${ }^{607}$ Ha emellett megvizsgáljuk Vilmos egyéb nádori működését, akkor látható, hogy olyan területekre is elért a „keze”, ahol egyébként nem tartott közgyülést, legalábbis nem maradt fent erre utaló adat. Több a Nyugat-Dunántúlra vonatkozó (Somogy, Baranya, Tolna, Fejér és Vas megyei) ügye is volt. ${ }^{608}$ A margitszigeti domonkos apácák 1336-1338 között zajló Esztergom megyei birtokpere is elötte zajlott, ${ }^{609}$ illetve egyszer még egy Bodrog megyei birtokügyben is intézkedett. ${ }^{610}$ Ha ezeket a területeket is hozzávesszük azokhoz a megyékhez, ahol Vilmos közgyülést tartott (és természetesen azokat az eseteket is, amelyek az adott megyékből közgyülésen kívül kerültek a színe elé), akkor azt látjuk, hogy Vilmos joghatósága a teljes Nyugat-Magyarországot a gyakorlatban is lefedte a Dráva vonaláig. Kelet-Magyarországon a Temes megyei intézkedése mellett ${ }^{611}$ Zaránd megyei birtokügyéről tudunk. ${ }^{612}$ Így Kelet-Magyarország déli régiója meglehetősen foghíjas volt, de ez könnyen magyarázható azzal, hogy az északi központokban (Óbudán ${ }^{613}$ és Vizsolyban, majd Visegrádon és Nagymaroson) nádori kúriát tartó Vilmostól meglehetősen távol estek e megyék, így az ottani perek nem is tudtak a nádori ítélőszék elé kerülni. Tegyük hozzá:

\footnotetext{
${ }^{605}$ Kruták 2012. 428.

${ }^{606}$ Kruták 2012. 429-433.

607 „Wylhelmi Drugeth palatini et iudicis Cumanorum ... in quadam sua congregatione universitatis nobilium comitatus Simigiensis, Symigii celebrata" (C. Tóth 2002. 152., vö. AOkl XXVII. 11. sz.). Kruták Anita az érintett megyék térképre vitelekor Somogy megyét kihagyta, ám feltüntette a szomszédos Baranya megyét (Kruták 2012. 434. 6. térkép), forráshelyet viszot erre az adatra nem adott. Magam nem találtam Baranya megyére vonatkozó adatot, ettől természetesen még lehet ilyen forrás. A másik lehetőség, hogy a szerző véletlenül eltévesztette, és Baranyát vette fel Somogy megye helyett.

${ }^{608}$ 1335: AOkl XIX. 166., 279. sz.; 1337: AOkl XXI. 113., 261., 326-327., 412., 632. sz.; 1338: AOkl XXII. 90., 130., 167., 256., sz.; 1339: AOkl XXIII. 48., 141., 379., 381., 428. sz.; 1340: AOkl XXIV. 159., $638 ., 699$. sz.; 1341: AOkl XXV. 14., 20., 80. sz.; 1342: AOkl XXVI. 18., 97., 241. sz.

${ }^{609}$ AOkl XX. 392., 402. sz.; AOkl XXI. 229., 376., 409., 415., 653., 660. sz.; AOk1 XXII. 89., 145., 160. sz.

${ }^{610}$ 1337: AOkl XXI. 102., 111. sz.

${ }^{611}$ 1334. okt. 4.: DL 40688. (vö. 1335. márc. 29.: AOk1 XIX. 155. sz.)

612 1339: AOkl XXIII. 9., 16. sz.

${ }^{613}$ Hogy az oklevelei kelethelyeként csak „Buda” néven feltüntetet település ténylegesen is Óbudát takarja, lásd AO III. 91. (1334. júl. 22.); AOkl XIX. 479. sz. (1335. aug. 7.)
} 
Vilmos legtöbb intézkedése még mindig a Druget-tartomány területére esett, amely megyék zömének ispáni címét is viselte. ${ }^{614}$

Vilmos albírái nem jutottak olyan hangsúlyos szerephez, mint pl. Druget Fülöp alatt. Környezetében két albírót ismerünk: Dénes fia Jakabot, aki csak 1335-ben töltötte be tisztségét, és egy bizonyos Bertalant 1339-ből. Jakab gömöri alispán is volt egyben, és Gömör mellett talán Budán is székelt. Bertalannal Visegrádon találkozunk, amikor fogott bíróként döntött az országbíró ítélkezésének helyszínén, azaz Visegrádon. ${ }^{615}$

Valamivel hosszabb karriert futott be Vilmos vizsolyi albírája, Izsép mester. 1339-1341 folyamán bukkan fel, utoljára biztos módon 1341 augusztusában említi őt a váradelőhegyi konvent, miszerint az ő oklevele utasítására küldték ki tanúságukat egy Bihar megyei birtok felosztására. ${ }^{616}$ Ezen kívül Zsámboki Miklós nádor 1342. december 2-án kelt oklevele tartalmilag átírta Izsép egy keltezetlen oklevelét, és ebből - ha nem is teljesen biztosan - arra következtetethetünk, hogy október 13 -án is hivatalban volt még. ${ }^{617}$ Kinevezése valóban az

${ }^{614}$ Nádorsága mellett szepesi, abaúji, hevesi, gömöri, borsodi, tornai, sárosi, zempléni és ungi ispán volt, lásd Archont. 1301-1457. 3.

${ }^{615}$ Jakab és Bertalan tevékenységéről részletesebben lásd a „,8.1 - A nádort helyettesítő tisztségek: alnádor, nádori albíró" c. alfejezetet.

${ }^{616}$ 1339. aug. 19.: AOkl XXIII. 503. sz. 1341. aug. 5.: AOkl XXV. 546. Engel Pál archontológiájában tévesen szerepel Izsép első felbukkanásának a dátuma (1337. okt. 6.), a megadott forrás egy 1340. évi oklevelet takar (AO IV. 44.). Ezen kívül az archontológia szerint „,volt” albíróként említik 1341. jan. 13-án. Ez szoros értelemben véve tényleg igaz (,,iuxta continenciam literarum magistri Isep quondam viceiudicis eiusdem Vilermi palatini de Visul" - Károlyi I. 192.), ám az említés Zsámboki Miklós nádor 1351. évi okleveléből származik, és mindenkit, pl. Druget Fülöpöt, vagy éppen magát Druget Vilmos nádort is néhainak említik benne („Philippi quondam palatini”; „Vilermi Drugeth quondam palatini bone memorie predecessoris nostri”), így mindezt az átíró oklevél megfogalmazásának kell tartanunk.

${ }^{617}$ Az oklevél: MES III. 475-480. (AOk1 XXVI. 622. sz.). Izsép oklevelének tartalmi átírása: MES III. 476-478. A nehézséget az okozza, hogy a tartalmi átírás szerint a felek bemutatták Izsép nádori albíró nyílt oklevelét, amelyben elrendelte a szepesi káptalan számára, hogy 1341. június 3-ra becsüljenek fel és iktassanak egy birtokot, illetve ha azt nem tudják, akkor egy másikkal tegyék ugyanezt, ám ez utóbbit a megjelölt személy visszavásárolhatja. Az ellentmondókat idézzék a nádor színe elé. (Eddig regesztázta ki az oklevelet: AOk1 XXIV. 724. sz.). A tartalmi átírás szövege ezután úgy folytatódik, hogy a jún. 3-i időpontot el kellett halasztani, és a becslésre végül okt. 6-án került sor, amely a leírt részletek szerint lezajlott, és okt. 13-án a felek vissza is vitték az erről szóló káptalani oklevelet. A szövegből nem világos, hogy kinek vitték vissza ezt az okt. 6-i káptalani oklevelet okt. 13-án, mert a tartalmi átírás a káptalani oklevél tartalmának ismertetésekor véget ér. Ha azt gondoljuk, hogy Izsép albíróhoz vitték vissza, akkor ő feltehetőleg átírta egy külön oklevelében a saját korábbi parancslevelét, illetve a káptalani oklevelet, és ebből az következik, hogy okt. 13-án még hivatalban volt. Ez esetben viszont az 1342. évi oklevél a tartalmi átírásba nem vette át azt a részt, hogy az albíró nyugtázza a káptalani oklevél szövegét, és ez alapján mit ítél a végső ügyben. Ha viszont azt feltételezzük, hogy Izsép bemutatott oklevele csak odáig terjedt, hogy elrendelte a káptalani intézkedést, és a szepesi káptalan levele külön került tartalmi átírásra, akkor nem világos, hogy az 1342. évi oklevél szövege ezt a káptalani oklevelet miért nem említette a bemutatott diplomák között. Mivel az ottani szöveg világosan csak Izsép albíró nyílt okleveléről beszélt, ezért valószínű, hogy az egészet ő írta át okt. 13 körül. Zsámboki Miklós 1342-ben azért nem írta át tartalmilag Izsép levelének záró részét, mert abban a perben, ami akkor előtte zajlott, főként a birtokbecslést 
első felbukkanása környékén történhetett. 1339 nyarán maga Vilmos is Vizsolyban tartózkodott éppen, ${ }^{618}$ és kezdetben csak néhány ügyet bízott Izsépre alkalmilag, mert az albíró több korai oklevelének az intitulációja is kiemelte, hogy ő éppen ennek az esetnek a nádor által állított bírája. ${ }^{619} \mathrm{~A}$ nádor augusztus végén otthagyta Vizsolyt, és nekiállt közgyüléseket tartani a környező megyék számára (augusztus 25-i kezdettel Újvár és Sáros megyékben, majd augusztus 31-től Gömör, szeptember 7-től Borsod és Torna, szeptember 18tól Zemplén és Ung megyéknek). ${ }^{620}$ Ezek után október végére újra visszatért Vizsolyba és a Szepességbe. ${ }^{621}$ Mindezalatt Izsép mester is intézkedett a régió ügyeiben, továbbra is kiemelve, hogy a ráruházott nádori hatáskörénél fogva tette mindezt. ${ }^{622}$ Novembertől kezdve Izsép okleveleiben elmaradt a külön nádori legitimációra való hivatkozás, amely azt mutatja, hogy megszilárdult a helyzete. Vilmos ezek után egészen 1341 nyaráig fel sem kereste a családi birtok bírói központjaként szolgáló vizsolyi kúriát, főként Visegrádon tartózkodott. Az 1339 novemberétől 1340 decemberéig bezárólag terjedő bő egy évből Izsépnek 22 oklevelét ismerjük, amely (a forráspusztulással is számolva) igen aktív bírói tevékenységre utal. ${ }^{623}$ 1341-ben viszont - bár közvetett, elszórt adatokból úgy tünik, hogy Izsép még hivatalában volt, az oklevéladás mértéke drasztikus csökkenésen ment keresztül. Már ennek sem tudjuk a biztos magyarázatát, mint ahogy annak sem, hogy mi volt az oka, hogy Vilmosnak pont ekkor jutott eszébe az, hogy egy ilyen aktív helyettest hagyjon hátra Vizsolyban, korábban miért nem. A válasz véleményünk szerint a nádori kúriák átrendeződésében keresendő, amelyről a következő alfejezetben lesz részletesen szó. Most csak annyit előlegeznénk meg, hogy Vilmos ekkor már tudatosan készülhetett a saját központjának Visegrádra helyezésére, és az addig viszonylag sürün látogatott vizsolyi kúria háttérbe szorítására. Emellett azt már mások is megfigyelték, hogy Vilmos föként a páratlan években tartott tömeges közgyüléseket, ${ }^{624}$ így

végző szepesi káptalani oklevélben foglaltak számítottak lényegesnek, így mikor Izsép leveléből azt átírta, be is fejezték az ő oklevelének további ismertetését.

${ }^{618}$ Vilmos Vizsolyi tartózkodására lásd AOk1 XXIII. 478., 510-512. sz. (1339. aug. 10., 1339. aug. 23. Ezek pont közrefogják Izsép első oklevelének aug. 19-i keltét).

619 1339. aug. 19.: „Magister Isep viceiudex magnifici viri domini Villermi Druget palatini et iudicis Comanorum, in eiusdem terminis et tenutis constitutus”. 1339. szept. 29. „Nos magister Isyp viceiudex magnifici viri domini Villermi Druget palatini et iudicis Comanorum in tenutis eiusdem deputatus" Mindkét oklevél jelzete: DL 56894. 1339. okt. 20.: „Nos magister Iseyp viceiudex magnifici viri domini Wyllermi Drugetter palatini et iudicis Comanorum, in eiusdem terminis et tenutis constitutus” DL 40814.

${ }^{620}$ AOkl XXIII. 518., 525., 527-529., 540-541., 557-558., 567-568. sz.

${ }^{621}$ AOkl XXIII. 646., 655., 676. sz.

${ }^{622}$ AOkl XXIII. 643., 644. sz.

${ }^{623} 1339$ novemberétől: AOkl XXIII. 678., 679., 694., 708., 715., 738. sz. AOkl XXIV. 92., 129., 227., 230., 293., 494., 517., 545., 567., 578-580., 595., 596., 610., 724. sz. Ezen kívül még egy 1341. febr. 28-án kiadott oklevelét említette Vilmos: AOkl XXV. 820. sz.

${ }^{624}$ Nyers 1934. 56.; Kruták 2012. 433. 
1339-ben, Izsép kinevezésekor már eleve tervezhette azt, hogy 1341-ig, amíg a közgyülések amúgy is ide nem szólítják, már nem fog többé Vizsolyba visszatérni. Ez viszont indokoltá tette akkor még egy helyettes hátrahagyását, hiszen nem szüntethette meg teljesen azt a vizsolyi kúriát, amely akkor már évtizedek óta a térség bírósági központja volt. Ezért hosszabb kihagyás után ismét kinevezett ide egy albírót, így „kísérletezett” a Drugettartomány igazgatásával. A jelek szerint nem volt megelégedve ezzel a módszerrel sem, mert 1341-től kezdve már az összes tartományi ügyét ő intézte Visegrádról (vagy Nagymarosról). Izsép müködését már hivatalos leváltása elött is visszafogta, csak ez lehet az egyetlen magyarázat arra, hogy 1340 decemberéig majdnemhogy „tömeges” oklevélkibocsátásáról beszélhetünk, ám 1341 folyamán már egyetlen oklevele sem ismert, holott 1341 őszéig még biztosan hivatalában volt - pusztán forráspusztulással nem magyarázhatunk egy ilyen hirtelen váltást. Valószínü, hogy sokaknak (talán magának Vilmos nádornak is) sértette az érdekét egy ilyen „túl aktív” nádorhelyettes.

\section{6 - A nádori kúria Visegrádra költözése}

A disszertációban vizsgált korszak végpontjául azt az eseményt választottuk, amelynek eredményeképpen a nádori ítélőszék a királyi udvarba, Visegrádra költözött, és így tulajdonképpen a nádori bíróság egy lett az udvari bíróságok közül - legalábbis ami a helyszínt illeti. Az esemény időpontját Hajnik Imre a következőképpen határozta meg nagyszabású jogtörténeti müvében: „Nagy Lajos mindjárt uralkodása kezdetén a nádori biróságot a királyi kuriába ismét beillesztette. A nádornak ezóta nincs többé külön kuriája, hanem ő a királyi kuriának csak egyik birája.” Mindehhez lábjegyzetben még azt is hozzáfüzte, hogy „,[a]z utolsó nádor, kinek külön kuriája volt, Drugeth Vilmos Károly király uralkodása végén." ${ }^{625}$ Hajnik tehát Lajos uralkodásának elejére tette mindezt, vélhetően arra utalva, hogy a változás Zsámboki Miklós 1342 szeptemberétől kezdődő nádorságától mutatható ki. Hajnik közelebbről nem igazolta ezen állítását, amely már a kérdéssel részletesen foglalkozó Nyers Lajosnak is feltűnt. Ö az alnádorokra alapozva próbálta megállapítani az önálló nádori kúria megszüntének az időpontját. Szerinte ugyanis a „két alnádor közül ... az egyik állandóan a nádor vidéki székhelyén tartózkodott. Drugeth Vilmos alatt a nádor vidéki kúriája Vizsolyon állandósult. Az itt lévő alnádor működését a nevében

\footnotetext{
${ }^{625}$ Hajnik 1899. 22. (7. jz.)
} 
kiadott oklevelek bizonyítják. Viszont, amikor megszakadnak a vidéki kúria székhelyén megjelenő alnádori kiadványok, ebből egyszersmind következtetést vonhatunk a nádor vidéki kúriájának megszűnésére is." ${ }^{626}$ Nyers ezek után számba vette Izsép vizsolyi albíró okleveleit, megállapítva, hogy az utolsó ismert oklevele 1341. február 28-án kelt. A következtetését úgy vonta le, hogy „,a nádor vidéki kúriájának megszűnését 1341. febr. 28 és 1342. aug. 29 [ti. Druget Vilmos utolsó ismert kiadványa] közé tehetjük. S talán megengedik azt a föltevést, hogy a vizsolyi kúria csak Drugeth Vilmos halálával szűnik meg. Megszűnése időben összeesik az I. Károly megindította és Nagy Lajostól tovább folytatott bíráskodási központosítással. Mégis azt kell mondanunk, hogy a vidéki kúria megszűnése okozatilag nem függ össze a központosítással, hanem csak azzal párhuzamosan haladó tény. A nádori kúria fönnállása inkább Drugeth Vilmos személyével volt kapcsolatban s halálával magától megszünik. Nagy Lajos azután már nem támasztotta életre, hanem a nádori vidéki bíráskodást és bíróságot is központosította s beillesztette a királyi kúriába. Ez pedig mindjárt Nagy Lajos uralkodása kezdetén (1343. elején) végbement s bizonyára ezzel van összefüggésben a regni

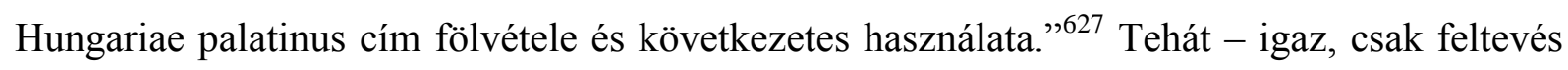
útján! - de Nyers Lajos is Nagy Lajos idejére, 1343 elejére tette a nádor „vidéki” bíráskodásának megszünését, véleménykülönbség legfeljebb csak annyi volt Hajnikkal szemben, hogy egy „önmagától fejlődő” folyamatnak tekintette az önálló nádori központ megszünését. A későbbi szakirodalom a Hajnik és Nyers által kitaposott úton haladt tovább, és ha említették a kérdést, akkor többnyire az 1342-es évhez és Nagy Lajos nevéhez kötötték az önálló nádori kúria megszüntét. ${ }^{628}$ Bónis György még annyit finomított ezen az elméleten (az 1342-es datálást elfogadva), hogy szerinte „Hajnik ... túlságosan kiélezte azt, hogy »a nádornak azóta nincs többé külön kúriája«. Az oklevelek az 1370-80-as években a jegyzőket »curie nostre (vestre) notarius « néven említik aszerint, hogy a nádor, vagy a jelentéstevő hiteleshely adja ki azokat. A nádornak tehát továbbra is volt külön kúriája, csakhogy ez a királyi udvarban, a presentia regiától (az országbíró jelenlététől) elkülönítve, önálló segédszemélyzettel müködött."629

Véleményünk szerint azonban a kérdést máshogyan kell megközelíteni. A kronológiát egyedül bizonyítani igyekvő Nyers Lajos ugyanis - úgy véljük - több hibát is vétett gondolatmenetében. Egyrészt feltételezte, hogy a „két alnádor közül ... az egyik állandóan a

\footnotetext{
${ }^{626}$ Nyers 1934. 10.

${ }^{627}$ Nyers 1934. 12.

${ }^{628}$ Pl. Holub 1929. 167.; Bónis 1963. 201., 230.; Gerics 1966. 290.; Bertényi 1976. 42., 45.; MTK I. 207. (Körmendy Adrienne munkája); Korm. redsz. 71. (Fedeles Tamás munkája); Csukovits 2012. 85. vö. uo. 52. jz.

${ }^{629}$ Bónis 1963. 230-231. Bertényi Iván is ezt tartja a legvalószínűbbnek (Bertényi 1976. 45. 61. jz.)
} 
nádor vidéki székhelyén tartózkodott”, másrészt „Drugeth Vilmos alatt a nádor vidéki kúriája Vizsolyon állandósult” ${ }^{\text {"630 }}$ Ezek az állítások Druget Fülöp nádorságára még minden további nélkül igaznak bizonyulnak, ám Vilmos alatt már teljesen átalakult a nádorhelyettesi rendszer, ráadásul neki Vizsoly csak az egyik kúriája volt, és, mint látni fogjuk, 1339 után lényegében meg is szünt. Mint az előző fejezetben szó esett erről, Izsépet nem az egyetlen kúrián ítélkező alnádornak tartjuk, hanem a Druget-tartomány igazgatására állított személynek, mivel a nádor ekkor már egyre kevésbé volt jelen ott. Nyers emellett elkövette azt a bizonyítási hibát is, hogy bár regisztrálta, hogy a vizsolyi „kúria” 1341 februárja után nem mutatható ki, pusztán feltevésszerüen mégis kitolta annak meglétét a nádor haláláig.

Magunk a kérdést úgy közelítenénk meg, hogy először is megvizsgáljuk Druget Vilmos ránk maradt okleveleinek a kelethelyét. Vilmos neve alatt kb. 360 oklevélről tudunk 1334 és 1342 között, ${ }^{631}$ amely bőségesen elegendő statisztikailag releváns következtetések levonására. $\mathrm{Az}$ oklevelek jelentős részében kelethely is található. Ezeket az alábbi táblázatban rendszereztük, a leggyakoribb kelethelyeket külön kiemelve. Mivel a generalis congregatio esetében a kelethely az aktuális helyszín függvényében változott, és amúgy sem vonható le semmilyen következtetés belölük az állandó kúriára nézve, ezért azokat összevontuk. Az „egyéb” kategóriába azok a helyszínek kerültek, amelyek nem azonosak a négy leggyakoribb kelethellyel, de nem is közgyülés alkalmával tartózkodott ott a nádor.

\begin{tabular}{|l|l|l|l|l|l|l|}
\hline $\mathbf{E} \mathbf{v}$ & (Ó)Buda & Vizsoly & Visegrád & Nagymaros & congregatio & egyéb \\
\hline $\mathbf{1 3 3 4}$ & 8 & 3 & & & 18 & \\
\hline $\mathbf{1 3 3 5}$ & 25 & 1 & 2 & & 19 & 2 \\
\hline $\mathbf{1 3 3 6}$ & 7 & 11 & 2 & & & 1 \\
\hline $\mathbf{1 3 3 7}$ & 12 & 8 & 17 & & 15 & 1 \\
\hline $\mathbf{1 3 3 8}$ & 8 & & 12 & & & \\
\hline $\mathbf{1 3 3 9}$ & 12 & 10 & 6 & & 12 & 1 \\
\hline $\mathbf{1 3 4 0}$ & 3 & & 6 & 1 & 1 & \\
\hline $\mathbf{1 3 4 1}$ & & $(3)$ & 12 & 17 & $(35) 38$ & \\
\hline $\mathbf{1 3 4 2}$ & & & 30 & 1 & 1 & 2 \\
\hline
\end{tabular}

2. táblázat: Druget Vilmos okleveleinek a kelethelyei (hány oklevél kelt az adott helyen)

\footnotetext{
${ }^{630}$ Nyers 1934. 10.

${ }^{631}$ Az Anjou-kori oklevéltár vonatkozó kötetei, illetve az 1334-es év esetében a DL-DF 5.1 adatbázis adatai alapján.
} 
A táblázat alapján látható, hogy Vilmos, ha éppen nem közgyülést tartott, alig mozdult ki „vidékre”. Az „,egyéb” kategória alacsony számát még inkább kiemeli, ha megvizsgáljuk ezeket az eseteket. 1335-ben egy ízben Pannonhalmán adott ki oklevelet a monostor meglátogatása apropóján, ám néhány nappal később már Pozsonyban keltezett a megye számára tartandó közgyülésen, és ezután kezdődtek a nyugati megyék számára tartandó congregatiok. ${ }^{632}$ Vagyis Pannonhalma éppen a közelben volt, nem kizárólag külön ennek a kedvéért mozdult ki Vilmos a székhelyéről. Az 1336., 1337. és 1339. év „egyéb” kategóriába sorolt egy-egy kelethelye tulajdonképpen egy szintén tipikusnak tekinthető helyszín, amely nem kapott külön oszlopot: Szepesvár. A megye ispánságát Vilmos már kezdettől fogva viselte, és még nádorsága alatt is megfordult néha-néha ott, rendszerint az év elején vagy végén. ${ }^{633}$ Így a több mint 320 ismert kelethelyből összesen három olyat találhatunk, amely a nádor „nem tipikus” kimozdulását jelezte. Ezek közül az egyik a Visegrádtól nem messze fekvő Damásd, királyi vadászhely (in Damas, venacionis loco regio), amelyre kézenfekvő magyarázatot ad, hogy ekkor Károly is ott keltezett - együtt volt tehát a királyával. ${ }^{634}$ Egy ízben, 1335 márciusában a Zemplén megyei Terebesen keltezett, ahol utasítást adott az ungi alispánnak, hogy vizsgálja ki egy Ung folyó melletti malom ügyét. ${ }^{635}$ Bár egy Ung megyei ügyet intézett egy Zemplén megyei helyszínen, és ez egy nádori közgyülést is sejtethet (hiszen Ung és Zemplén megye rendszeresen „,párban álltak” a közgyülések tartásakor), itt biztosan nem arról volt szó, mert egy Ung-Zemplén megyei közgyülésen hivatalból jelen kellett volna lennie a megyei alispánnak, nem lett volna szükség arra, hogy Vilmos levélben keresse meg őt. A másik ,atipikus” helyszín egy ugyanilyen eset: 1342 áprilisában Sáros kelethellyel írt a Zemplén megyei alispánnak és a 4 szolgabírónak egy hatalmaskodás kivizsgálása ürügyén. ${ }^{636}$ Bár Sáros és Zemplén megye is szomszédos volt egymással, a nem dokumentált közgyülés feltételezését a fentiek miatt itt is elvethetjük. Ugyanakkor elmondható: Druget Vilmos alapvetően csak akkor mozdult ki a kúriájából, ha közgyűléseket tartott, egyébként a székhelyén tartózkodott. Kérdés, hogy hol volt ez a székhely.

Ha ismét a fenti táblázatot nézzük, akkor a Nyers Lajos által feltételezett vizsolyi helyszín csak az 1336-os és az 1339-es évben mutat komolyabb gyakoriságot, 1339 után viszont lényegében megszünt. 1341-ben ugyan ismerünk három ott kiadott oklevelet

\footnotetext{
${ }^{632}$ AOkl XIX. 444., 455. sz.

${ }^{633}$ AOkl XX. 47. sz.; AOkl XXI. 671. sz.; AOkl XXIII. 60. sz.

${ }^{634}$ A nádori oklevél (1342. jún. 2.): AOkl XXVI. 275. sz. A királyi oklevelek (1342. máj. 31.): AOkl XXVI. 264. sz., (1342. jún. 6.): 293. sz.

${ }^{635}$ AOkl XIX. 100. sz.

${ }^{636}$ AOkl XXVI. 153.
} 
Vilmostól, ám ezek az Abaúj megye részére tartott nádori közgyüléshez kapcsolódnak. Feltehetjük persze, hogy nem véletlenül tartotta itt Vilmos a közgyülést, nyilván ezzel „két legyet ütött egy csapásra”, hiszen a Druget-tartomány központját is meglátogatta egyben (a táblázatban ezért szerepel zárójelben az 1341. évnél a vizsolyi kelethelyek száma, illetve a közgyülések esetén egy másik szám. A vizsolyi kelethelyeket a közgyülésekhez soroltuk, ám ha azt a hármat külön vesszük, akkor a congregatiokon kelt oklevelek száma csak 25 és nem 28). Ám akárhová is soroljuk az 1341-es év vizsolyi kelethelyeit, tény, hogy akkor Vilmos már nem célzatosan, kizárólagos módon kereste fel a helyszínt. Így elmondhatjuk, hogy Vizsoly 1339 után megszünt számára kúria lenni, azelőtt is csak időszakonként tartózkodott ott. További feltünő jelenség, hogy míg nádorsága első idejében a kelethelyek súlypontja Óbudára esett, addig az 1340-es évekre ez szintén megszűnt, és áttolódott Visegrádra. Ez alól az 1341. év a kivétel, amikor a várossal átellenben lévő, a Duna másik partján található Nagymaros a domináns. Ám a kelethelyek puszta hozzárendelése a kiadási évhez csak néhány fő tendenciát jelez, egyébként nem segít abban, hogy a kúria, kúriák pontos helyét és időbeli megoszlását tisztázzuk.

Ha ugyanis nem éves, hanem napi szinten ütköztetjük az egyes kelethelyeket, akkor nem egy alkalommal párhuzamosságokat találunk. 1335 májusában Vilmos közgyüléseket tartott a keleti megyék számára. Május 17-én (Balassa)gyarmaton adott ki oklevelet a Nógrád és Hont megyei congregation, május 19-én Budán utasította a fehérvári káptalant egy Fejér megyei hatalmaskodás kivizsgálására. Ám május végén folytatta a közgyűlések tartását Bars megyének. ${ }^{637}$ Elvileg nem lenne lehetetlen, hogy a Gyarmat és Óbuda közötti mintegy (légvonalban) $80 \mathrm{~km}$-es távolságot kép nap alatt letudja a nádor, ám arra nincs ésszesrü magyarázat, hogy miért tette volna ilyen gyorsan a kitérőt. Más adatok azonban meggyőznek arról, hogy itt sem erröl volt szó. Ugyanebben az évben szeptember 18-án Bihar és Kraszna megyék számára kezdett közgyülés tartásába Vilmos, amely még szeptember 21 -én is zajlott, amikor oklevelet adott ki. Másnap, szeptember 22-én azonban Budán keltezett oklevelet, amelyben a jászói konventet utasította, hogy intézkedjen egy Gömör megyei birtokügyben. ${ }^{638}$ A közgyülések a keleti megyéknek tovább folytak, és szeptember 27-én Szatmárnémetiben nyitotta meg a következőt Szatmár és Ugocsa megyék számára, amelynek 4. napján, szeptember 30-án bocsátotta ki oklevelét. Mindezalatt szeptember 29-én Vilmos ismét oklevelet keltezett Budán, jóváhagyva egy színe előtt lezajlott birtokosztályt. ${ }^{639}$ Világos, hogy

\footnotetext{
${ }^{637}$ AOkl XIX. 271., 279., 302., 308-309. sz.

${ }^{638}$ AOkl XIX. 572., 577. sz.

${ }^{639}$ AOkl XIX. 586., 588. sz.
} 
itt ugyanazzal a jelenséggel állunk szemben, amelyet már Dózsa nádorsága alatt is regisztrálni lehetett 1322-ben: az egyik színhely csak a nádor nevében, de távollétében bocsátotta ki az okleveleket. Mindez nem csak az 1335-ös évre volt jellemző, hanem az összes olyan időszakra, amikor Vilmos hosszabb ideig távol volt a csoportos közgyülések tartása miatt. 1337-ben május 15-én Vizsolyban adott ki oklevelet, majd megkezdte a keleti megyék számára tartott körútját (május 27-án nyitotta meg Újvár, Sáros és Zemplén megyéknek a közgyülést Középnémetiben). A vizsolyi oklevelével azonos napon, május 15-én azonban budai kelettel két oklevelet is kiadott. ${ }^{640} 1339$-ben szeptember 18-án nyitotta meg Vilmos Sárospatakon Zemplén és Ung megyék közgyülését, amelynek ügyében szeptember 22-én adott ki több oklevelet is. Ugyancsak szeptember 22-én kelt az a budai oklevele, amelyben egy pert Károly színe elé utalt át a király külön parancsára. ${ }^{641}$ A budai kúria 1340-ben véglegesen megszünt, megjelent viszont egy új helyszín: Nagymaros. Az 1341. évi nagyszabású közgyülés-sorozat idején a párhuzamos oklevelek immár nagymarosi, illetve részben visegrádi kelethellyel lettek kibocsátva. 1341. június 25-én kezdődött Mikcsén Bihar és Kraszna megyék közgyülése, és június 27-én bocsátott ki Vilmos ott oklevelet, ám június 26-án Visegrádon is keltezett egy nádori diplomát. ${ }^{642}$ Július 30-án Sáros faluban Sáros megyének a közgyülését nyitották meg, Vilmos augusztus 2-án és 3-án bocsátott ki ott oklevelet. Augusztus 1-jén Nagymaroson is kelt egy nádori diploma. ${ }^{643}$ Az augusztus 13-án Abaúj megyének tartott vizsolyi közgyülés, és a 18-án ott kiadott oklevelei Vilmos augusztus 14-i visegrádi oklevelét fogják közre. ${ }^{644}$ Aztán augusztus végén és szeptember folyamán a nádor töretlenül folytatta közgyüléseit Torna, Borsod, Hevesújvár, Hont és Bars megyék számára, és ezalatt szintén töretlenül üzemelt a nagymarosi nádori kúria is, 4 további oklevelet kiadva. ${ }^{645}$ Amikor október-november folyamán Vilmos az északi és nyugati megyékbe ért (Trencsény, Nyitra, Zala, Veszprém, majd Győr és Pozsony), a nagymarosi kúria akkor sem állt le. ${ }^{646}$

Egy korábbi alfejezetben, Debreceni Dózsa kapcsán már utaltunk arra, hogy úgy véljük: a közgyüléseken volt jelen a nádor személyesen, és a kúriai bíróság csak a nevében adta ki az okleveleket. ${ }^{647}$ Akkor azonban elmaradt ennek részletesebb indoklása. A kétségtelen választ

\footnotetext{
${ }^{640}$ AOkl XXI. 263-265. sz. (a közgyülésekre lásd uo. 291-292., 294-297. sz.)

${ }^{641}$ AOkl XXIII. 566-568. sz.

${ }^{642}$ AOkl XXV. 427., 429. sz.

${ }^{643}$ AOkl XXV. 535., 539., 544. sz.

${ }^{644}$ AOkl XXV. 569-570., 577-578. sz.

${ }^{645}$ AOkl XXV. 580., 584-585., 589., 601., 621-622., 658., 663., 669., 670., 672., 677-678., 684., 686. sz.

${ }^{646}$ AOkl XXV. 693-694., 730., 733., 752-753., 759., 762., 776-777., 785., 798. sz.

${ }^{647}$ A , 4.4. - I. Károly első nádorai - az »oligarchikus nádorság« öröksége” c. fejezetben.
} 
az eredetiben fennmaradt okleveleken található pecsétek vizsgálata adja meg. ${ }^{648}$ Most egyelőre még csak arra a néhány időszakra koncentrálunk, amikor biztosan párhuzamos oklevélkibocsátásra került sor. Azt a szabályosságot tapasztaljuk, hogy a budai, illetve 1341ben a nagymarosi kúriában kiadott oklevelek hátuljára kivétel nélkül mindig egy 47-48 mmes pecsétet nyomtak. ${ }^{649} \mathrm{Ez}$ Vilmos egy régtől fogva használt, ún. „nádorhelyettesi pecsétjével” azonosítható. Egyetlen viszonylag ép példányát egy 1341. június 26-án, Visegrádon kelt oklevelén láthatjuk, ${ }^{650}$ illetve más okleveleken is megtalálható a töredékes pecsétábra, de zömében csak a „foltját” ismerjük. A közgyülések során ezt a pecsétet soha nem használták. 1335, 1337, 1339 és 1341 folyamán vagy a 70 mm-es nádori nagypecséttel, ${ }^{651}$ vagy gyürüspecséttel ${ }^{652}$ pecsételtek. $^{653}$ Nem csak a fent külön kiemelt

${ }^{648}$ Felismerhető pecsétábra kevés oklevélen maradt fent, ám a pecsétfolt sok eredeti oklevélen jól látszik. Ezek
méretét a DL-DL 5.1 adatbázisban megtalálható színesben befényképezett oklevelek mellé helyezett mérce
alapján lehet megállapítani. A Magyar Nemzeti Levéltár Középkori Gyüjteményében eredetiben megtalálható
(DL-jelzetes) oklevelek nagy többségét és néhány nem ottani (DF-jelzetes) oklevelet lehetett így lemérni.
Összesen 149 esetben sikerült beazonosítani a pecsétábrát vagy pecsétfoltot, és ez alapján magát a pecsétet
Vilmos oklevelein. Vilmos pecsétjeinek leírását lásd alább.
${ }^{649}$ Ezen, , ,párhuzamos időpontokban” kiadott oklevelek: 1335: DL 2950. (AOkl XIX. 586. sz.); 1337: DL
31234 . (AOkl XXI. 264. sz.); 1341: DL 72525., DL 51152. (AOkl XXV. 427., 730. sz.)
${ }_{650}$ DL 72525. (AOkl XXV. 427. sz.) Leírása: „Természetes okker színủ viasz, kb. 48 mm, függőpecsét. Ábra: pajzs, jobb felső sarkánál lovagsisak, kétoldalt ágaskodó oroszlán. Felirata: S MGRI VYLLERMI DRUGETH COMITIS ---. Kissé sérült: széle kitöredezett, kb. 10 \%." (DL-DF 5.1 DL 72525.). A körirat folytatásában a további, töredékes ábrák alapján a „vicesgerentis palatini” található (DL 31238.: 1338. szept. 27., AOkl XXII. 474. sz.; DL 87094.: 1339. márc. 27., AOkl XXIII. 141. sz.; DL 76613.: 1340. szept. 11., AOkl XXIV. 532. sz.), vagyis ez a nádorhelyettesi korszakból való pecsétje. Nyers Lajos még csak a töredékes változatait ismerte, így az ő pecsétleírása hiányos és hibás (Nyers 1934. 64-65.).

${ }^{651}$ A pecsét leírása: Nyers 1934. 64. Nagyjából vagy teljesen ép példányait lásd: DL 99956. (1336. márc. 4., AOkl XX. 94. sz.); DL 40724. (1336. ápr. 16., AOkl XX. 191. sz.); DL 99960. (1336. okt. 13., AOk1 XX. 381. sz.); DL 63663. (1338. jan. 29., AOkl XXII. 35. sz.)

${ }^{652}$ Nyers Lajos a nádori pecsétek számbavételekor Vilmos kapcsán is megjegyezte, hogy „elég gyakori nála a gyürüspecsét használata”, de közelebbi leírást nem adott (Nyers 1934. 65.). Tény, hogy a pontos pecsétábrát, de még a méretet is roppant nehéz a gyürüspecsétek kapcsán megállapítani, hiszen szinte mindg töredékesen maradtak fent, és a pecsétfoltok nagysága is folyamatosan változó. Ugyanis a levélre nyomott kevés viaszba nyomták bele a gyürüt, amely rendszerint nem ,vágta körül” a viaszt, mint a nagypecsétek, amelyek ezáltal szabályos kerek, és a tipárium nagyságát hitelesen közvetítő foltot hagytak, hanem a gyürü csak „,széttolta” a viaszt, pecsétfészket kialakítva. Így a gyürüspecsétes pecsétfoltok sokszor szabálytalan alakúak és ugyanazon gyürü esetében is változóak. Mindamellett számomra úgy tünik, hogy legalább kétféle gyürüspecsétet használt, méghozzá párhuzamosan. Egy alkalommal ugyanis ki lehet venni a szabályos kerek foltot is, amelynek átméröje 16-17 mm (DL 57309., AOkl XXIII. 518. sz. Ugyanez lehet rajta a következő okleveleken: DL 51023., AOkl XIX. 689.; DL 102905., AOkl XXIII. 529. sz.; DL 76650., AOkl XXV. 678. sz.). Más esetben a pecsétfoltok és szabálytalan pecsétfészkek ennél egyértelmüen kisebbek, 12-13 mm körüliek (DL 57075., AOkl XXIII. 540.; DL 51147., AOkl XXV. 413.; DL 64022. sz., AOkl XXV. 418. sz.; DL 40840., AOkl XXV. 584. sz.; DL 66121., AOkl XXV. 759. sz.). Ezek semmiképpen nem lehetnek egy 16 mm-es gyürü lenyomatai. A DL 50987. jelzetü oklevélen (1335. jan. 13., AOkl XIX. 27. sz.) két gyürüspecsét viszonylag ép lenyomata látható, de nem egyértelmü, melyik a nádoré (az oklevélen eredetileg három pecsét is volt, és mivel Druget Vilmos elengedi benne egy bírságból a neki és az albírájának járó részt, talán a nádor mellett az albíró pecsétjét is sejthetjük rajta). 
„párhuzamos” időpontok során volt ez így, hanem mindig. Emellett több, átírásban vagy említésben fennmaradt oklevél, amely a nádori közgyüléseken kiadott parancslevelekre hivatkozott, kiemelte, hogy a nádor ottani levele a gyürüspecsétjével volt hitelesítve. ${ }^{654}$ Ezek után logikailag elég nehezen lenne elképzelhető, hogy a nádor egy emberére bízta volna rá a nádori nagypecsét és a személyéhez leginkább kötődő gyürüspecsét(ek) használatát a közgyüléseken, amíg ő maga az óbudai, később a nagymarosi kúriában azzal a középpecséttel erősítette meg okleveleit, amely még csak nádorhelyettesi címére utalt. Hasonló következtetésre juthatunk, ha megvizsgáljuk a közgyülések folyamán a kúriában kiadott nádori oklevelek tartalmát. Szinte mindig rutinesetekről volt szó: a „nádor” egy per indításakor utasítást adott a területileg illetékes hiteleshelynek, hogy vizsgálják ki az esetet és tegyenek jelentést, nyugtázta a színe előtt megtörtént megegyezéseket vagy a hiteleshelyi jelentéseket, illetve pert halasztott - ez utóbbit igen sokszor. Nem egyszer az indok hiánya is feltűnő az ilyen perhalasztó okleveleken. 1341. szeptember 15-én, amikor Vilmos nádor a Felvidéket járta, egy hatalmaskodási ügyben a peres felek (a garamszentbenedeki konvent és ohaji Jakab fiai) a számukra kitűzött időpontban meg is jelentek Nagymaroson a nádori kúriában, végül „Vilmos nádor” egy hét várakozás után a „felek akaratából” (de voluntate partium) elhalasztotta a pert november $18-$ ra. ${ }^{65}$ Ugyanez történt akkor is, amikor János fia Miklósnak Ubul fia Miklós ellen október 6-án kellett megjelennie a nádor előtt egy Sáros megyei földbirtok hovatartozása miatt. A felek (személyesen illetve képviselő útján) meg is érkeztek, a pert végül a nádori oklevél szintén de voluntate partium, vagyis a felek akaratából halasztotta el a következő év januárjára. ${ }^{656}$ Mindkét esetben megjelent mindkét fél a helyszínen, jól látszott tehát, hogy meg akarták volna kezdeni a pert. Mivel a de voluntate partium egy elég megszokott és semmitmondó formula volt a perhalasztó oklevelekben, gyaníthatjuk, hogy ez esetben arról lehetett szó, hogy a résztvevők nem akartak maguktól kiegyezni, viszont a nádor távollétében a kúriai személyzet sem akarta megkezdeni a pert, mivel itt már nem egy olyan rutinügyről volt szó, amire automatikus és a szokásjog által jól bejáratott választ lehetett adni. Ezért a felek kénytelenek voltak „azt akarni”, hogy a pert

\footnotetext{
653 Azok a fent idézett, „párhuzamos” időpontban kiadott oklevelek, amelyeket a congregatiokon nádori nagypecséttel pecsételtek: 1335: DL 39105., DL 38151., DL 51014-51015. (AOkl XIX. 271., 572., 588. sz.); 1337: DL 68835., DL 60223., DL 76557., DL 3067. (AOkl XXI. 291., 295-297. sz.); 1341: DL 3392., DL 86575., DL 57077., DL 3417. (AOkl XXV. 429., 589., 621-622. sz.); amelyeket gyürüspecséttel: 1341: DL 40840., DL 76650., DL 87124., DL 66121. (AOkl XXV. 584., 678., 686., 759. sz.).

${ }^{654}$ Az egri káptalan oklevele (1339. szept. 7.): AOkl XIX. 537. sz., (1339. nov. 12.): AOkl XIX. 689. sz.; a pannonhalmi konvent oklevele (1341. nov. 17.): AOkl XXI. 802. sz.

${ }^{655}$ MES III. 396. (AOkl XXV. 663. sz.)

${ }^{656}$ DF 228446. (AOkl XXV. 733. sz.)
} 
tegyék át egy későbbi időpontra, amikorra Vilmos nádor már személyesen is jelen lehet. Mindezek alapján tehát biztosra vehetjük, hogy a közgyüléseken volt jelen a nádor, és a kúriai ügyintézést addig mások látták el az ő nevében. Ezek a „mások” ekkor már a nádori protonotáriusok, vagyis ítélőmesterek lehettek, akiknek a feladata később is a nádori oklevelek kibocsátása és a kúriai ügyintézés volt. ${ }^{657}$ Vilmosnak két ítélőmesterét ismerjük név szerint: az óbudai kúriában múködött - kimutathatóan - 1338-ig Péter mester, aki már Druget Jánost is szolgálta ilyen minőségben. ${ }^{658}$ 1340-től bukkan fel Mátyás mester, aki füzéri várnagy is volt egyben. Ez utóbbi tisztsége, továbbá az, hogy őt a nádor vizsolyi albírája említette két alkalommal, ${ }^{659}$ valószínủvé teszi, hogy ő a vizsolyi kúriában tevékenykedett Izsép nádori albíró müködése alatt. Mátyásnak a vizsolyi kúriához kötését tovább erősíti, hogy 1342-ben, amikor Vilmos már véglegesen felszámolta ezt a központját és leváltotta Izsépet, Mátyás mestert is csak volt protonotáriusként említette két ízben az egri káptalan. ${ }^{660}$ A korai, ingadozó terminológiára jellemző, hogy mindkettejüket egyszer notariusnak, máskor protonotariusnak címezték, továbbá egyiküket sem nádori oklevelek említik, hanem különféle káptalani, konventi vagy éppen nádori albírói oklevelek, amelyekben magánszemélyként vagy peres félként bukkanak fel.

Az tehát, hogy az óbudai kúria a nádor távollétében is müködött és kibocsátott okleveleket, magával hozza azt a feltevést, hogy ez akkor is megtörténhetett, amikor nincs egyértelmű bizonyíték arra nézve, hogy Vilmos nádor éppen máshol tartózkodott, de valószínűsíthetjük azt. Így például amikor azt látjuk, hogy 1335. február 17-én Budán keltezett oklevelet, február 23-án Vizsolyon, majd március 11-én a Zemplén megyei Terebesen, ${ }^{661}$ talán feltehetjük, hogy már előbb megérkezett Vizsolyba. És mivel május elején Nógrád és Hont megyék számára kezdett közgyülést tartani, elképzelhető, hogy eleve ki sem mozdult onnan, és az összes budai oklevele ${ }^{662}$ távollétében került kiadásra. Ezen oklevelek az olyan szokásos rutineseteket tartalmazzák csak (hiteleshelyi tanúság kérése, nyugtatvány egy bírság megfizetéséről, perhalasztás), amelyek belefértek egy akkori ítélőmester hatáskörébe is. Ennél jóval biztosabb, hogy 1336 elején nem kell budai tartózkodással számolni. A nádori oklevelek kelethelyei ekkor a következőképpen alakultak: január 27.: Buda, február 9.: Szepesváralja, február 27-28.: Vizsoly, március 4., 11.: Vizsoly, március 20.: Buda, március

\footnotetext{
${ }^{657}$ Az ítélőmesterekre lásd a „8.2 - A nádori »iroda« belső munkatársai: jegyzők, ítélőmesterek” c. alfejezetet.

${ }^{658}$ AOkl XIX. 391. sz. (1335. júl. 7.); AOkl XXI. 253-254. (mindkettő 1337. máj. 8.); AOkl XXII. 357. (1338. júl. 15.). Lásd még Archont. 1301-1457. 2-3.

${ }^{659}$ 1340. aug. 18.: AOkl XXIV. 494. sz., 1340. okt. 13.: AOkl XXIV. 595. sz.

${ }^{660}$ 1342. jún. 5-6.: AOkl XXVI. 292., 295. sz.

${ }^{661}$ AOkl XIX. 79., 81., 100. sz.

${ }^{662}$ Összesen hat ilyen oklevél maradt ránk: AOkl XIX. 154-155., 175-177., 220. sz.
} 
23.: Visegrád, április 6.: Vizsoly, április 16-17.: Vizsoly, május 8.: Buda, május 10.: Vizsoly, június 2.: Buda. ${ }^{663}$ Bár az időpontok közötti távolság megengedi azt is, hogy Vilmos ide-oda utazgasson a feltüntetett helyszínek között (egyedül talán a május 8-10-i Buda-Vizsoly táv tűnik kicsit szüknek), de erősen valószínü, hogy az első és utolsó kivételével összes budai oklevél a távollétében kelt (és talán még azok is). Egyébként itt is felbukkan az a kettősség, hogy az eredetiben fennmaradt vizsolyi kelethelyü oklevelek hátuljára a 70 mm-es nagypecsét került, míg a Budán kiadottakéra a $47 \mathrm{~mm}$-es „,nádorhelyettesi” középpecsét. ${ }^{664}$ Vilmos tehát az év első felében Vizsolyban székelt, míg az apjától megörökölt óbudai kúriában a szintén az apjától „megörökölt” Péter ítélömester bocsátotta ki az okleveleket.

Kérdéses, hogy ez mióta volt így. Mint fentebb szó esett róla, Vilmos úgy vette át apja helyét a nádori poszton, hogy egy ideig csak helyettes nádor volt. ${ }^{665}$ Ezen idő alatt igen kevés saját oklevele maradt ránk, összesen három diplomáját ismerjük. Ezek közül az egyiket egy kb. 13 mm-es gyürüspecséttel hitelesítette (nem kizárt, hogy ez azonos a későbbi, hasonló méretű gyürüspecsétjével), kettőt pedig egy $60 \mathrm{~mm}$-es pecséttel. ${ }^{666}$ Hogy az 1334-es év első felében Vilmos hol tartózkodott, arról semmilyen adatunk nincsen. Aztán 1334. május 17-én már nádorként adott ki oklevelet Budán. Az oklevél azért érdekes, mert a megerősítési záradékába belefoglalták azt is, hogy Vilmos a levelet addig visszatartja, amíg nem hozzák neki vissza a nádori pecsétet, amely akkor nem állt a rendelkezésére. ${ }^{667}$ A hátulján a korábban is felbukkanó $60 \mathrm{~mm}$-es pecsét foltja áll. Zsoldos Attila ebből azt a következtetést vonta le, hogy Vilmosnak ekkor még nem volt nádori pecsétje. ${ }^{668}$ Mivel az oklevelet egy olyan pecséttel hitelesítették, amely egyértelműen rendelkezésére állt már Vilmosnak korábban is, és a későbbi nádori okleveleit is ezzel a $60 \mathrm{~mm}$-es pecséttel erősítette meg, egészen 1334 szeptemberéig $^{669}$ (tehát úgy általában létezett egy akkor nádoriként használt pecsét), továbbá a

\footnotetext{
${ }^{663}$ AOkl XX. 36., 47., 80., 82. 94., 107., 126-127., 139., 167., 191-192., 231., 241., 265. sz.

${ }^{664}$ A 70 mm-es nagypecsét a vizsolyi kelethelyü okleveleken: DL 76527., DL 31231., DL 99956., DL 99957., DL 63661., DL 40724. (AOkl XX. 80., 82., 94., 107., 167., 191. sz.); a 47 mm-es középpecsét a budai kelethelyü okleveleken: DL 2988., 56846., DL 3003. (AOkl XX. 36., 126., 231. sz.)

${ }^{665}$ Zsoldos 2012c. 533-540.

${ }^{666}$ A gyürüspecsétes: DL 47854. (1333. szept. 10.); a 60 mm-esek: DL 57299., DL 87036. (AOkl XVII. 383., 510. sz.)

${ }^{667}$ „Presentes autem dum nobis fuerint reportate sigillo nostri palatinatus quo nunc caremus, faciemus contineri” AO III. 77. (a kiadásban az utolsó szó hibásan „communiri”, de az oklevélben „contineri”, vagyis „visszatart” áll, vö. DL 2827.)

${ }^{668}$ Zsoldos 2012c. 533.

${ }^{669}$ Vilmos következő 1334. évi oklevelein volt ez a 60 mm-es pecsét: DL 89271. (jún. 11.), DL 38149. (júl. 9.! a DL-DF 5.1-es adatbázisban hibás keltezés szerepel!), DL 50976-50977., 50979. (júl. 22.), DL 76489. (júl. 23.), DL 99409. (júl. 29.), DL 40675. (júl. 30.), DL 58479. (aug. 7.), DL 2802. (aug. 8.), DL 50983. (aug. 27.), DL 2849. (szept. 8.). Ez az utolsó adat a $60 \mathrm{~mm}$-es pecsét használatára.
} 
záradékban a reporto (visszahoz) ige szerepel, magunk úgy véljük, hogy volt Vilmosnak nádori pecsétje, csak éppen az nem volt akkor elérhető. Mégpedig - véleményünk szerint azért nem volt Budán elérhető, mert maga Vilmos nádor (és persze a pecsétje) valahol máshol tartózkodott, ezért kellett az oklevél átadását addig visszatartani, amíg rá nem kerülhet a nádori sigillum. Azaz az óbudai kúria már kezdettől fogva folytatta a „távolléti” működést. Június 11-én is ezen $60 \mathrm{~mm}$-es pecsét alatt adott ki Vilmos oklevelet Budán, majd amikor megkezdte a keleti megyék számára a közgyüléseket, szintén ezt vitte magával. Gyorsan észrevehették, hogy a nádori kúria müködése lényegében lehetetlenné válik, ha nincsen egy saját, külön pecsétjük. Éppen ezért kapta meg a budai kúria a $47 \mathrm{~mm}$-es ,nádorhelyettesi” pecsétnyomót, amelyet egy 1334. augusztus 29-i oklevelükön tudunk először regisztrálni. ${ }^{670}$ Két nappal korábban, augusztus 27-én Vizsolyban is kelt egy nádori oklevél - a $60 \mathrm{~mm}$-es nádori pecséttel. ${ }^{671}$ Ez évben a vizsolyi és budai kelethelyű oklevelek váltogatták egymást, mivel Vilmos Vizsolyban maradt, megszokott székhelyén, és apja kúriájában innentől kezdve már csak a 47 mm-es pecsétet kezdték el használni.

1336 végétől 1337 elejéig ismét a budai és vizsolyi kelethelyek váltakoztak, ugyanazzal a szabályossággal, hogy Vizsolyban pecsételtek az akkor már $70 \mathrm{~mm}$-es új nagypecséttel, Budán a középpecséttel. ${ }^{672}$ Ezután 1337 márciusában és áprilisában csak Visegrádi kelethelyü oklevelek maradtak ránk. Visegrádon már azelőtt is felbukkant a nádor, de tartósan ekkor állapodott meg ott először adatolható módon. A visegrádi diplomáit zömében a $70 \mathrm{~mm}$-es nagypecséttel hitelesítették, ám egyik alkalommal egy érdekes jelenséggel találkozunk. 1337. április 1-jén a felek megegyeztek a színe előtt egy hatalmaskodási ügyben, amiről a nádor mindkettejük számára kiállított egy-egy oklevelet ugyanazzal a szöveggel. Mindkét oklevél ránk is maradt eredetiben, és az egyiknek egy azidáig nem dokumentált, (talán) $50 \mathrm{~mm}$-es pecsétfoltot találunk a hátulján, a másiknak pedig a $47 \mathrm{~mm}$-es „,nádorhelyettesi” pecsét töredékét, amelyet jól láthatóan egy gyürüs „ellenpecséttel” hitelesítettek. ${ }^{673}$ (Tegyük hozzá: nem lehetetlen, hogy csak ,érzéki csalódásról” van szó az 50 mm-es folt esetében, hiszen alig különbözik a $47 \mathrm{~mm}$-es pecsét nagyságától. ${ }^{674}$ Ezen pecsételési módra nem tudunk biztos

\footnotetext{
${ }^{670}$ DL 50984. (AO III. 99-101.)

${ }^{671}$ DL 50983.

${ }^{672}$ AOkl XX. 392., 438., 467., 499.; AOkl XXI. 48-49., 60., 70. sz.

${ }^{673}$ DL 51052. és 51053. (AOkl XXI. 153. sz.)

${ }^{674}$ Ennek ugyanakkor nem csak a pecsétfoltok nagysága közötti apró különbség mond ellent, hanem az is, hogy a $47 \mathrm{~mm}$-es középpecsét esetében jól láthatóan ott van egy külön kis befüzött hártyaszalagon egy hitelesítő kispecsét, amely nyilván azt jelezte, hogy ez az oklevél nem pusztán a nádori irodában kelt, hanem a nádor személyes közreműködésével. Azon az oklevélen, amelyen az $50 \mathrm{~mm}$-es pecsét(folt) látható, ilyen hitelesítésnek semmi nyoma nincsen, és nem csak folt formájában hiányzik, de az „ellenpecsét” hártyaszalagjának való kivágás
} 
magyarázatot adni. Ez előtt utoljára (a ránk maradt oklevelek alapján) március 18-án használta Visegrádon a $70 \mathrm{~mm}$-es nagypecsétet, majd április 9-től kezdve újra visszatért a használatához. ${ }^{675}$ Csak feltételezhetjük, hogy a nagypecsét valami miatt ekkor nem volt elérhető vagy használható, és ezért Vilmos felkérette Budáról Visegrádra a protonotáriusa által használt tipáriumot.

Az 1337-es év további részében Vilmos Vizsolyba ment, majd megkezdte a közgyülések tartását. Így tehát Vilmos föbb tartózkodási helyeit 1337-ig javarészt Vizsolyban és kisebb részt Visegrádban jelölhetjük meg. Arra, hogy nádorsága alatt valamikor huzamosabb ideig Óbudán is székelt volna, nincs egyértelmü bizonyíték - igaz, konzekvensen ellene szóló adat sem. Júliusban, a közgyülések első szakaszának lezárultával ismét Visegrádra tért vissza, ahol a nagypecsét mellett egy ízben ismét felbukkan a $47 \mathrm{~mm}$-es „,nádorhelyettesi” középpecsét. ${ }^{676}$ 1337 decemberében pedig azzal találkozunk, hogy egy Budán kelt nádori oklevelet (egy szimpla kérelem a vasvári káptalanhoz) a szokásos középpecsét mellett egy kispecséttel is ellenjegyeztek. ${ }^{677}$ Lehet, hogy ez Vilmos éppen akkori budai tartózkodására utal?

1338-ban Vilmos nem tartott közgyülést, és okleveleinek a kelethelyei össze-vissza váltakoztak Visegrád és Buda között (ezen kívül az év elején oklevelet adott ki Szepesváralján). Sajnos igen kevés 1338. évi oklevelén maradt fent beazonosítható pecsétábra, de a visegrádi oklevelek vagy a 70 mm-es nagypecséttel, vagy egy gyürüspecséttel voltak megerősítve, a budaiak a szokásos $47 \mathrm{~mm}$-essel. ${ }^{678}$ A nagypecsét és a gyürüspecsét tartózkodási helye alapján feltehetjük, hogy ebben az évben Vilmos már nagyrészt Visegrádon székelt, és nem is igen mozdult ki onnan.

1339 első felében Vilmos Visegrádról Szepesvárra, majd Vizsolyba ment. Biztosan vitte magával a nagypecsétet is, hiszen február 19-én azt használta. ${ }^{679}$ Vilmos tudhatta, hogy ez az év ismét nagyobb szabású közgyülésekkel fog telni, amelyeket a keleti és északkeleti megyék számára rendszerint mindig Vizsolyból indított. Ennek ellenére 1339 februárjának a vége és május vége között ismét a budai és visegrádi kelethelyek váltakoznak, hogy aztán június

sincs ott. Ennek az $50 \mathrm{~mm}$-es pecsétnek a kérdését egyébként nem sikerült megfejtenem. Vilmos későbbi oklevelein is felbukkan néha egy-egy olyan folt, amely inkább $50 \mathrm{~mm}$ nagyságú, de nem találtam rá egyértelmü bizonyítékot, hogy ez tényleg egy önálló pecsétnyomó lett volna. Az önállóság ellen szól, hogy van olyan látszólag $50 \mathrm{~mm}$ nagyságú pecsét, amelynek az ábrája egyértelmüen a $47 \mathrm{~mm}$-es nádorhelyettesi középpecséttel azonos (DL 87094.) Így valószínübb, hogy a pecsétnyomó peremén kissé túlnyúlt viasz, vagy egészen apró mérési hibák okozzák a méretbeli ingadozást.

${ }^{675}$ 1337. márc 18.: DL 48548. Ápr. 9.: DL 31233. és DL 3055. (AOkl XXI. 117., 174-175. sz.)

${ }^{676}$ 1337. júl. 25.: DL 87069. (AOkl XXI. 429. sz.)

${ }^{677}$ 1337. dec. 2.: DL 40757. (AOkl XXI. 632. sz.)

${ }^{678}$ DL 63663., DL 49668., DL 48361., DL 28058., DL 31238. (AOkl XXII. 35., 234., 292., 424., 474. sz.)

${ }^{679}$ AOkl XXIII. 60., 91. sz. 
elején Vilmos újra Vizsolyban bukkanjon fel. Ami szokatlan, hogy úgy a visegrádi, mint a budai okleveleken a „nádorhelyettesi” középpecséttel találkozunk! Sajnos a szerencse ezúttal nem siet a segítségünkre, mert e három hónap alatt összesen 2 oklevélen tudunk használható pecsétfoltot beazonosítani, de a március 27-én Visegrádon, és a május 8-án Budán kelt diplomán is a „helyettesi” pecsétnyomóval találkozhatunk. ${ }^{680}$ Nem teljesen biztos, de elképzelhető, hogy Vilmos a budai kúria mellett immár Visegrádon is hátrahagyott helyettesítő személyzetet, amely Buda mellett Visegrádra is kimozdult. Ez a visegrádi helyettesítés ugyanakkor nem tekinthető teljesen biztosnak, mivel a nyári-öszi közgyülések alatt ismét csak a budai kúria párhuzamos müködését tudjuk adatolni. Ekkor történt az is, hogy Vilmos a közgyülések után ugyan egy időre még visszament Vizsolyba, és ekkor állította Izsép albírót maga helyett, de ezzel már véleményünk szerint a vizsolyi kúria háttérbe szorítását készítette elő. Amikor legközelebb, 1341-ben ott járt, akkor már csak a megyei közgyülések egyik helyszíneként időzött ott egy rövid ideig, és már vonult is tovább. Az 1340-es év pedig a vizsolyi után a budai kúria megszüntetését is magával hozta. Ekkor ismét szüneteltek a nagy közgyülések. Januárban még kelt Budán egy oklevél, de ezután márciustól egészen szeptemberig sorozatban csak visegrádi kelethelyekkel találkozunk, ${ }^{681}$ amelyet egy Hont és Nógrád megyék számára Gyarmaton az év első felében tartott tartott nádori közgyülés szakított csak meg. ${ }^{682}$ A pecsételés szempontjából hasonlókat tapasztalunk, mint az előző évben. Januárban a budai kúrián a $47 \mathrm{~mm}$-es pecsétet használták, és aztán Visegrádon egész nyár folyamán ugyanezt. ${ }^{683}$ A gyarmati közgyülésen kiadott oklevél sajnos nem maradt fent eredetiben, így azt nem tudjuk ellenőrizni ebből a szempontból. Ezután szeptember 11-én a Visegráddal átellenben található Nagymaroson keltezett Vilmos egy oklevelet, szintén a 47 mm-es pecsétjével megerősítve. ${ }^{684}$ Ezután a budai kúria adott ki két oklevelet (szeptember 22., október 20.), majd az évet egy Visegrádon, december 1-jén kelt diploma zárja. ${ }^{685}$ Mindhárom oklevél eredetiben maradt ránk, és mindhármon ugyanaz a $47 \mathrm{~mm}$-es pecsét volt. Vagyis az év folyamán akárhol is adott ki Vilmos oklevelet (vagy adtak ki a nevében), látszólag ugyanazt az egy pecsétnyomót használták. Ha az oklevelek kiadása közti időt nézzük, akkor elvileg elképzelhető is lenne, hogy az az egy tipárium vándoroljon ide-oda, mert egyik oklevélpár között sem telt el annyi idő, amennyi ne tette volna lehetővé az

\footnotetext{
${ }^{680}$ DL 87094., DL 48362. (AOk1 XXIII. 141., 257. sz.).

${ }^{681}$ AOkl XXIV. 47., 128., 159., 226., 289., 396. sz.

${ }^{682}$ AOkl XXIV. 384. sz.

${ }^{683}$ DL 73646., DL 65751., DL 3285., DL 87106. (AOkl XXIV. 47., 159., 289., 396. sz.)

${ }^{684}$ DL 76613. (AOkl XXIV. 532. sz.)

${ }^{685}$ AOkl XXIV. 556., 609., 699. sz.
} 
odaérkezését (mellesleg Visegrád és Óbuda elég közel feküdt egymáshoz, középkori viszonyok között is kényelmes egynapos útnak számított a táv). Ez a „vándorlás” ugyanakkor az eddig megszokott rendszer alapján elég nehezen lenne logikailag elképzelhető. Még furcsábbá teszi a helyzetet, hogy 1341 első felében, amikor a visegrádi és a nagymarosi kelethelyek váltakoztak, akkor is ezt a középpecsétet használták az összes nádori oklevélen, sőt, amikor Vilmos 1341. április 26-án közgyülést tartott Újbécsen Pest és Pilis megyéknek, az ott kiadott oklevelét is a $47 \mathrm{~mm}$-es pecsétnyomóval hitelesítette. ${ }^{686}$ Ezután, egészen júniusig szintén Visegrád és Nagymaros volt a két kelethely, amely okleveleken ugyanezt a pecsétnyomót használták. ${ }^{67}$ Már-már arra gyanakodhatnánk, hogy a nádori nagypecsét elveszett, de aztán júniustól, amikor Vilmos belekezdett az azévi csoportos közgyülések tartásába, újra „előkerült”. A június 10-i, Nagymaroson kelt 47 mm-es pecséttel megerősített oklevelet már biztosan a kúriája adta ki a távollétében, hiszen másnap, június 11-én már Záhonyban nyitotta meg a Szabolcs és Szatmár megyei nemeseknek tartandó congregatiot. ${ }^{688}$ A záhonyi közgyülés oklevelein már vagy a gyürüspecsétjét, vagy a 70 mm-es nagypecsétjét használta. ${ }^{689}$

A fenti helyzet magyarázatát csak találgatni tudjuk. Mivel 1340-ben egyébként is igen kevés nádori oklevél maradt ránk, ezért talán azt, hogy ebben az évben Visegrádon is a középpecséttel pecsételtek, azzal magyarázhatjuk, hogy a nádor királyi parancsra hadba szállt. 1340. május 8-án már biztosan készülődött egy ruténiai hadjáratra, amely vélhetően a Lengyelországba betörő tatár csapatok ellen irányult volna. ${ }^{690}$ A hadjárat valószínűleg nem indult el, mert erről egyetlen oklevél vagy narratív forrás sem szól, ám a nádori nagypecsét ilyen hosszú idejü eltünése mégis Vilmos hivatali távolmaradását feltételezi. A távolmaradás persze nem egy ténylegesen Lengyelországba vezetett hadjárat miatt volt, a nádor csak folyamatos készenlétben állt a határokon a honorkontingense élén. 1340-ben a nyár folyamán is végig szó volt a tatár veszélyről, és még Károly tervezett dalmáciai hadjáratát is lefújták emiatt. A magyarországi haderő végig készenlétben állhatott, amely az északkeleti határvidéken honorbirtokos Druget Vilmosra is kiemelt feladatot rótt. ${ }^{691}$ Mindez részben magyarázatot adhat az 1340. év bizonyos eseményeire, de a nádori nagypecsét ilyen hosszú

\footnotetext{
${ }^{686}$ A visegrádi és nagymarosi kelethelyü, azonosítható pecséttel rendelkező oklevelek: DL 99990., DL 3353. , DL99991. (AOkl XXV. 20., 72., 80. sz.). Az Újbécsen, április 27 -én kiadott oklevele: DL 3374. (AOkl XXV. 237. sz.)

${ }^{687}$ DL 3381., DF 200875., DL 3388. (AOkl XXV. 323., 345., 386. sz.)

${ }^{688}$ AOkl XXV. 386., 397. sz.

${ }^{689}$ DL 51146., DL 76638., DL 31240., 76639., DL 76640. (AOk1 XXV. 397., 400-401., 405-406. sz.)

${ }^{690}$ Piti 2001. 48-50.

${ }^{691}$ Piti 2001. 50-52.
} 
hiányát kizárólag a hadbaszállással nem magyarázhatjuk. Vilmos ugyanis bizonyíthatóan 1339. február 24-én, Vizsolyban használta utoljára a nagypecsétet. ${ }^{692}$ Ezek után még több oklevelet is kiadott Vizsolyban, de ezek sajnos vagy másolatban és tartalmi átírásban maradtak fent, vagy ha eredetiben is, de nem vehető ki rajtuk tisztán a megerősítő pecsét mérete. Ezek után legközelebb, mint láttuk, csak a keleti megyék számára tartott közgyülésekkor, 1341 júniusában került elő a 70 mm-es tipárium. A nagypecsét távollétére sajnos nem tudunk bizonyítható magyarázatokat adni. Feltűnő, hogy Vilmos az 1339 augusztusában, a keleti megyéknek tartott közgyülésein kiadott (és eredetiben ránk maradt) okleveleken kizárólag gyürüspecsétet használt. ${ }^{693} \mathrm{Ez}$, hacsak nem a szelektív forráspusztulás furcsa véletlenjével állunk szemben, szintén a nagypecsét tényleges távollétére utal. Nem kizárt, hogy Vilmosnak valójában a pecsételési szokásai változtak meg. 1339-től már tudatosan készült a vizsolyi és budai kúria megszüntetésére, és visegrádi székhelyének egyszerübb ügyeit az oda vont nádori középpecséttel intézte. Minderre az 1341-1342. év pecséthasználta utalna, amely arra a szisztémára épült, hogy az oklevelei többségét Vilmos a középpecséttel pecsételte, akkor is, amikor igazolható a személyes jelenléte, és a $70 \mathrm{~mm}$-es tipáriumot meghagyta az ünnepélyes, függőpecsétes okleveleire és a generalis congregatiok idejére. A budai kúria 1340. évi teljes megszüntetése kapcsolatba hozható lehet az év hadi eseményeivel, legalábbis felgyorsított egy folyamatot. Vilmos tartósabb visegrádi távolléte ugyanis többes helyettesítési feladatot rótt az óbudai személyzetre. A nádor mindezt úgy rendezhette el, hogy teljesen oda helyezte át a helyettesi személyzetet. Ennek a jele, hogy 1340 tavaszán az óbudai kúria pecsétje hosszabb időre is átkerült Visegrádra (márciustól szeptemberig terjedő időszak). Összel mutatható ki először a Visegráddal átellenben fekvő nagymarosi kelethely. Nagymaros mindenképpen a Vilmost helyettesítő személyzet helyszíne volt, és ezt jól mutatja, hogy 1341 folyamán, amikor a nádor ismét elvonult tömeges közgyülések tartására, főként onnan adták ki távollétében az okleveleket. Ez már az óbudai székhely teljes felszámolásának a szándékára utal, hiszen Vilmos arra készült, hogy a maga közelében állandósítsa ítélőmestereit. Mindez nem ment az egyik pillanatról a másikra, szeptember végétől a kúriai személyzetet egy rövid időre ismét Óbudán találjuk. 1340. október 20-án kelt utoljára Budán nádori oklevél, innentől kezdve 1341. január 10-ig Visegrádon, aztán vegyesen Visegrádon és Nagymaroson adtak ki nádori okleveleket. Immár ez a két helyszín lett a nádori kúria, amennyiben Vilmos nem vonult ki a megyékbe. Az apja nádorságáig visszavezethető, és akkor már relatíve megszokottnak számító óbudai székhely

\footnotetext{
${ }^{692}$ DL 3215. (AOkl XXIII. 91. sz.)

${ }^{693}$ DL 57309., 89287., 102905., 57075. (AOkl XXIII. 518., 527., 529, 540. sz.)
} 
felszámolása és Nagymarosra (részben Visegrádra) költöztetése jól jelzi, hogy Vilmos nádor ekkor már tudatosan csak a visegrádi orientációval számolt, fontosabb volt neki, hogy ott, közvetlen szomszédságában helyettesítsék a távollétében is.

Az 1341. évi közgyülések nyártól egészen novemberig elhúzódtak. A nádori kúria ezalatt föként Nagymaroson üzemelt, ám volt két nádori oklevél, amelyet mindenképpen a nádor távollétében, ám Visegrádon adtak ki. Ennek okát nem tudjuk biztosan, az egyik ilyen egy függőpecsétes diploma volt, amelyben a „,nádor” a nyitrai káptalan jelentése alapján, azt törvényesnek találva Töre birtokot Lökösnek és Pálnak ítélte. ${ }^{694}$ Elvileg gondolhatnánk arra, hogy a döntést a nádori ítélőmester jóvá akarta hagyatni valakivel, és ezért kelt át a túlpartra, a visegrádi kúriába, ám az eset egyszerü rutinügy volt: Lökös és Pál csak egy határjárást kért a saját földjéhez a káptalantól, amely ellentmondók nélkül rendben lezajlott, a nádori kúriának csak ezt a bonyodalom nélküli helyzetet kellett volna nyugtázni. A másik Visegrádon kelt oklevél még inkább „rutinügy” volt: egy Szepes megyei birtoknál akartak határjárást végezni, ezért megparancsolta a jászói konventnek, hogy adják tanúságukat a két megjelölt nádori ember valamelyike mellé. ${ }^{695}$ Ezekből látszik, hogy bár az ítélőmesterek nádori kúriája Budáról alapvetően inkább Nagymarosra került át, a visegrádi kúria is használatban maradt. Aztán 1342-ben a súlypont már teljesen Visegrádra tevődött át. Ebben az évben nem voltak komolyabb közgyülések, így a nádor főként a királyi udvar színhelyén időzött. Nagymaroson csak egyszer, az év legelején, 1342. január 25-én kelt nádori oklevél, ${ }^{696} 30$ alkalommal pedig Visegrádon. Ezek az oklevelek egy kivétellel mind a 47 mm-es középpecséttel voltak megerősítve. ${ }^{697}$ Az egy kivétel egy 1342. augusztus 1-jén kiadott ítéletlevél volt, amelyben Vilmos egy hosszabban húzódó per végső döntéseként két Gömör megyei birtok hovatartozásáról döntött. Az oklevélen a 70 mm-es nádori nagypecsétje szerepelt, függőpecsétként. ${ }^{698}$ Hogy a $47 \mathrm{~mm}$-es pecsét is Vilmos saját használatú, személyes tipáriuma lett, jól mutatja, hogy amikor Damásdon, a Visegrádhoz közeli királyi vadászóhelyen tartózkodott I. Károly, Lajos herceg és a veszprémi püspök társaságában, az ott kiadott oklevelét (amelyben Lajos herceg kérésére a veszprémi püspöknek elengedett bizonyos

\footnotetext{
${ }^{694}$ 1341. jún. 26.: AOkl XXV. 427. sz. (ezen ugyanúgy a 47 mm-es középpecsétet használták, lásd DL 72525.)

695 1341. aug. 14.: AOkl XXV. 570. sz.

${ }^{696}$ AOkl XXVI. 33. sz.

${ }^{697}$ Azok a visegrádi oklevelek, amelyen a 47 mm-es pecsét volt: DL 56853., DL 3459., DL 56854., DL 76658., DL 3467., DL 91325., DL 51161., DL 51165., DL 51169., DL 87131., DL 68844., DL 3502., DL 51179., DL 3511. (AOkl XXVI. 13., 25., 72., 85., 97-98., 112-113., 224., 283., 363-364., 426., 460. sz.)

${ }^{698}$ DL 74803. (AOkl XXVI. 407. sz.)
} 
bírságokat), szintén ezzel a középpecsétjével erősítette meg. ${ }^{699}$ Ezen a helyen pedig biztosan a nádor volt személyesen jelen, nem az ítélőmestere.

Vilmos nádor kúriáinak az alakulását tehát a következőképpen foglalhatjuk össze. Amikor az apja, János viselte a nádori címet, akkor János kúriája Óbudán volt, míg Vilmos a Druget-tartományt igazgatta, Vizsoly központtal. Amikor János I. Károly kíséretében elhagyta az országot, és Vilmost nádorhelyettessé nevezték ki, akkor is föként a keleti országrészben tartózkodott, nincs arra adatunk, hogy az országos politikai ügyekbe beavatkozott volna. ${ }^{700}$ Aztán János halála után, valamikor 1334 tavaszán Vilmos megkapta a nádori titulust, ekkor egyrészt átvette apja óbudai kúriáját a személyzettel (Péter ítélőmesterrel) együtt. Vilmos megtartotta az óbudai kúriát, de neki magának esze ágában sem volt ott tartósan berendezkedni, inkább a saját, tágabb értelemben vett tartományi ügyeivel foglalkozott továbbra is (legalábbis erre utal, hogy kezdetben csak azoknak a megyéknek tartotta a nádori közgyüléseket). ${ }^{701} 1334$ nyarán a budai kúria önálló pecsétet kapott, ezzel megkezdődött a párhuzamos nádori oklevéladás. A kezdeti időszakban Vilmos sokszor időzött Vizsolyban, emellett Visegrádon és nyilván Óbudán is többször megfordult. Az, hogy a mindenkori nádor Visegrádon is eltöltsön némi időt, nem újkeletű dolog. Már Druget Fülöp ${ }^{702}$ és János ${ }^{703}$ is többször időzött alkalmilag ott, ekkor többször emlegették őket az országbíró megbízott bírótársaként, vagy csak alkalmi politikai ügyek szólították őket oda. Nyilván nem volt elhanyagolandó szempont a nádor és a királya közötti kapcsolattartás sem. Valószínü, hogy Vilmos visegrádi tartózkodásai kezdetben szintén ilyen alkalmi látogatások voltak csupán. 1337-ig a fó tartózkodási helye leginkább Vizsoly volt. A változás 1338-tól állt be. Ekkor a nádor az év eleji rövid szepességi tartózkodása után Visegrádra tért vissza, és javarészt ott is maradt. Ezt tekinthetjük a „fordulat évének”, mert 1339-ben, amikor a szokásos közgyülések előtt meglátogatta a vizsolyi kúriát és ismét hosszabban időzött ott, akkor már egy helyettes albírót hagyott ott hátra maga helyett - nyilván tudatosan arra készülve, hogy egy jó ideig már nem tér oda vissza. 1340-ben aztán a budai kúriát is megszüntette, amely némi ingadozás után végül Nagymaroson állapodott meg. A kúria megszűnését elősegítette, hogy ebben az évben a nádor Visegrádtól is sokszor távol volt a tatárok elleni hadi készültség miatt, és az állandó helyettesítést inkább Visegrádra és közelébe helyezte. 1341 során, amikor a nádor javarészt távol volt, föként a nagymarosi kúria üzemelt, de 1342-re, amikor Vilmos az ideje nagy részét

\footnotetext{
${ }^{699}$ DF 200883. (AOkl XXVI. 275. sz.)

${ }^{700}$ Zsoldos 2012c. 536.

${ }^{701}$ Kruták 2012. 427.

702 1327: AOkl XI. 226., 270. sz.

${ }^{703}$ 1330: AOkl XIV. 82., 100-102., 254., 280., 288. sz.; 1331: AOkl XV. 173. sz.
} 
ismét Visegrádon töltötte, eljelentéktelenedett. Mivel Vilmos 1342 szeptemberében elhunyt, már nem tudjuk meg, hogy 1342-ben véglegesen is sor került a nagymarosi kúria beolvasztására, vagy 1343-ban, az újabb tömeges közgyülések évében ismét előtérbe került volna. A nádori kúria Visegrádra költözése tehát nem egy hirtelen reform eredménye volt, amelyet Lajos valósított volna meg 1342-ben, hanem egy folyamat végállomása. Ez a folyamat még Vilmos előtt, a nádor alkalmi visegrádi időzésével kezdődött, és főképpen Vilmos alatt ment végbe 1338 és 1340 között.

Ezek után még annyit érdemes tisztázni, hogy történt-e valamilyen érdemi változás az új nádor, Zsámboki (Gilétfi) Miklós korai hivatali müködésében Vilmos kései éveihez képest. Azaz: ha a kúria Visegrádra helyezését nem is, de valami mást írhatunk-e I. Lajos és az 13421343-as év „,számlájára” a nádori intézmény kapcsán?

Az egyik régóta közismert és látványos változás a nádori titulusban következett be, igaz, nem azonnal. Miklós először a Vilmostól „megörökölt” intitulációt használta egészen 1342. december 22-ig, amikor önmagát regni Hungarie palatinus címmel látta el. 1343 elején még egy ideig visszatért a régi forma, március 10-től már konzekvensen ez a címe élt tovább. ${ }^{704}$ Nyers Lajos a címváltozást a nádori kúria Lajos alatt végbemenő központosításával hozta kapcsolatba. ${ }^{705}$ Mivel ez a „központosítás” nem a címváltozás idején ment végbe, ezért C. Tóth Norbert magyarázatát kell inkább elfogadni, aki a nádor és országbíró politikai szerepének megváltozását sejtette emögött. Míg ugyanis az országbíró címe innentől kezdve „Lajos király országbírója” lett, vagyis jobban kihangsúlyozták a királytól való függést, addig a nádori tisztség inkább ,távolodott” a király befolyása alól, amelynek nyilvánvaló jeleként a nádorok kinevezése innentől kezdve az országgyülésekhez (vagyis az ország akaratának egyetértéséhez) kötődött. ${ }^{706}$

Ha a nádori hatalomgyakorlást nézzük, akkor azt tapasztaljuk, hogy egyrészt Miklós teljesen felszámolta a nagymarosi kúriát, és amennyiben nem megyei közgyüléseken, vagy más, alkalmi helyen adott ki oklevelet, akkor az mindig Visegrádon történt. Nádorsága kezdeti szakaszában még főként az elődje által „ráhagyott” eseteket folytatta, és közgyülést tartott néhány megye számára. Ekkor már kimutatható a visegrádi kúria párhuzamos

\footnotetext{
${ }^{704}$ C. Tóth 2012. 444-445. Tegyük hozzá: a dec. 22-i oklevél, amelyben „enklávéként” feltűnik új címe, csak többszörös másolatban maradt ránk (lásd DL 3537., AOkl XXVI. 664. sz.), így az is elképzelhető, hogy csak a későbbi átírások változtatták meg titulusát az 1343 márciusától kizárólagos, és számukra is megszokott formára - bár erre így, önmagában semmilyen bizonyíték nincs a decemberi intituláció „rendszeren kívüli” voltán túl. ${ }^{705}$ Nyers 1934. 48.

${ }^{706}$ C. Tóth 2012. 442-447. A konstrukció ugyan nem nélkülöz bizonyos feltételezéseket (pl. az 1342. évi nádorválasztó országgyủlés létét inkább csak sejthetjük, de konkrét forrás nem szól róla), de egyelőre ez tünik a legelfogadhatóbb magyarázatnak.
} 
müködése: Miklós 1342. október 25-én Hídvég faluban a Hont megyei nemeseknek tartott congregatiot, amely kapcsán 29-én bocsátott ki oklevelet. Ezalatt október 26-án visegrádi keltezéssel utasította a veszprémi káptalant, hogy adják tanúságukat egy Zala megyei birtokhoz. ${ }^{707}$ Ezután október 31-én Nyitra és Trencsény megyéknek tartott közgyülést, majd Pozsonyban adott ki oklevelet november 10-én. November 17-re visszatért Visegrádra. ${ }^{708}$ Hogy a kúriába ő tért vissza, onnan tudjuk, hogy a november 17-i visegrádi oklevelet már ugyanazzal a kb. 72 mm-es nagypecséttel pecsételték meg, amelyet nádorsága kezdetén használni kezdett. ${ }^{709}$ Ugyanakkor létezett már ekkor is egy másik nagypecsétje, amely egy december 2-i oklevelén található, valamivel kisebb méretü volt (kb. $68 \mathrm{~mm})$, és ábrája is teljesen más. ${ }^{710} 1343$ áprilisáig tartó visegrádi tartózkodása után, május első felétől aztán ismét közgyülésekre indult Miklós, betartva azt a Vilmos alatt kikristályosodott szabályszerüséget, hogy kétévente kerül sor a tömeges „láncgyülésekre”. Május 12-én Fejér megyének, május 19-én Somogy megyének, majd 26-án Tolna megyének tartott közgyülést. Június 9-én Bodrog, majd június 30-án Valkó megyében nyitotta meg a congregatiot. ${ }^{711}$ Ezalatt a visegrádi kúria is üzemelt, és ekkor kiadott okleveleik megerősítési záradékához rendre odaírták, hogy a nagyobbik pecsét távolléte miatt a nádor kisebbik pecsétjével erősítik meg az oklevelet. ${ }^{712}$ Ezek az oklevelek tényleg egy kb. 29 mm-es kisebb pecséttel voltak megerősítve, amelynek az első okleveles felbukkanása egyébként még május 10-re tehető, amikor Miklós nádor még Visegrádon volt. ${ }^{713}$ A közgyülések oklevelein mindig a 72 mm-es nagypecsét volt. Visegrádon augusztus végén egészen szeptember 3-ig még csak perhalasztó oklevelek keltek a nádor nevében, a 29 mm-es tipáriummal hitelesítve, aztán szeptember 10én kiadtak egy hosszú oklevelet egy bonyolult, még Vilmos nádor alatt kezdődő birtokperről, amelyet Miklós ekkor véglegesen le is zárt. ${ }^{714}$ Ítélőmesterek rendszerint nem szoktak ilyen típusú okleveleket jegyezni a nádor távollétében még ekkortájt, így azt gondolhatnánk, hogy Miklós visszatért Visegrádra. Ám más okleveleiből tudjuk, hogy ezzel egyidőben, szeptember 1-jén nyitotta meg Várad mellett a Bihar és Kraszna megyéknek tartandó közgyülést,

\footnotetext{
${ }^{707}$ AOkl XXVI. 559., 562. sz.

${ }^{708}$ AOkl XXVI. 567., 569-571., 576., 593. sz.

${ }^{709}$ A pecsétre lásd Nyers 1934. 65.; Mủvészet 1342-1382. 349. 241. sz. (a pecsétet 70 mm-esnek írja, de ennél egyértelmüen nagyobb, Nyers is 72 mm-es méretet ad meg). Néhány megközelítőleg ép példányát lásd DL 3535. és DL 2871. jelzetek alatt.

${ }^{710}$ DL 68847. (AOkl XXVI. 622. sz.)

${ }^{711}$ AOkl XXVII. 307., 310., 319., 350-351., 398., 453-454., 459. sz.

${ }^{712}$ AOkl XXVII. 306., 311., 466-467., 577., 584. sz.

713 DL 51226. (AOkl XXVII. 279. sz.) Onnan lehet tudni, hogy Miklós ekkor még ott volt, mert két nappal később használta a 72 mm-es nagypecsétet, amelyet aztán magával vitt a közgyülésekre.

${ }^{714}$ AOkl XXVII. 601. sz.
} 
szeptember 8-án pedig Szabolcs és Bereg megyének. ${ }^{715}$ A magyarázatot ismét a pecsétek adják meg: a visegrádi oklevélen a 72 mm-es nádori nagypecsét volt, míg a Szabolcs és Bereg megyei közgyülés diplomáin egy - először ekkor megjelenő - kb. 25 mm-es pecsét. ${ }^{716} \mathrm{~A}$ nádor tehát valóban visszatért Visegrádra, a keleti megyéknek a közgyülést pedig valaki más folytatta a nevében. Ezek után azt tapasztaljuk, hogy a rövid visegrádi kitérő után Miklós is odament a kérdéses régióba, és a $25 \mathrm{~mm}$-es pecsétet birtokló megbízottjával (aki Tamás fia László alnádor lehetett) ${ }^{717}$ párhuzamosan kezdték tartani a congregatiokat. Szeptember 15-én Sárospatakon Zemplén és Ung megyék számára nyílt meg a közgyűlés, az itt kiadott okleveleken a $25 \mathrm{~mm}$-es pecséttel találkozunk. ${ }^{718}$ Ugyancsak szeptember 15-én kezdődött Muhin egy ugyanilyen esemény, Borsod megye nemesei számára. Az itteni okleveleken viszont a $72 \mathrm{~mm}$-es pecsétet találjuk. ${ }^{719}$ A szeptember 22-től Gömörön, Gömör és Torna megyéknek tartott ítélkező gyülés oklevelén megint csak a kispecséttel találkozunk, míg a nádor ugyanekkor Kassán volt, az Abaúj és Sáros megyei congregation. ${ }^{720}$ László alnádor ezután Kompolton, Hevesújvár megye általános gyülésén elnökölt ura nevében, míg Miklós vélhetően Szepes megyében járt, Szepesváralján - bár az itt kiadott oklevél nem maradt fent eredetiben, így csak logikailag sejthetjük, hogy ezen a párhuzamos helyszínen a „valódi” nádor volt jelen. ${ }^{721}$ Ezután az időben párhuzamos közgyülések megszüntek (legalábbis nincs róluk információnk), annyit tudunk csak, hogy október 13-án Gyarmaton Nógrád megyében, október 17-én és még 24-én is Hídvég faluban Hont megyében tartottak nádori közgyülést. ${ }^{722}$ Mivel ezekről eredeti oklevél nem maradt fent, ezért nem tudjuk megmondani, hogy melyik pecséttel pecsételtek, de talán a nádor ottlétének a jele lehet, hogy a Nógrád megyei gyüléssel

\footnotetext{
715 AOkl XXVII. 707., 605., 609-610. sz.

${ }^{716}$ Ez utóbbira: DL 51248., DL 76709-76710.

${ }^{717}$ Tamás fia László alnádorra: Archont. 1301-1457. 3. Azért azonosíthatjuk az itteni személlyel, mert 1344-ben László alnádor szintén a nádor nevében, de már saját neve alatt kiadott oklevelekkel tartott közgyüléseket nyugat-magyarországi megyéknek, és az egyik ott kiadott oklevelének a hátulján egy nagypecsét, és egy mellé illesztett 25 mm-es kispecsét foltja látható (DL 3657., AOkl XXVIII. 709. sz.) - ez utóbbi azonos lehet az itteni 25 mm-es pecsétnyomóval. Lászlótól ezen kívül még 1347-ből maradtak fent oklevelek, de akkor már egy 29 mm-es pecsétet használt (DL 51425., DL 51426., DL 41053., DL 103270.), ám ez nem zárja ki, hogy 1343 és 1344 folyamán egy 25 mm-es tipáriuma legyen.

${ }^{718}$ DL 87152. (AOkl XXVII. 614. sz.) vö. még 613. sz.

${ }^{719}$ DF 210465., DL 70163. (AOkl XXVII. 620-621. sz.)

${ }^{720}$ Gömör: DL 56856. (AOkl XXVII. 631. sz.); Kassa: DF 269295. (AOkl XXVII. 636. sz.)

${ }^{721}$ Kompolt: DL 3614. (AOkl XXVII. 655. sz.) Hogy ez a helyszín Hevesújvár megye közgyülése volt, lásd AOkl XXVII. 654. sz. Szepesváralja: AOkl XXVII. 657. sz. Hogy ez a Szepes megyei közgyülésen lett kiadva, lásd AOkl XXVII. 663. sz.

${ }^{722}$ AOkl XXVII. 689., 696., 728. sz.
} 
egy időben, október 13-án a visegrádi kúriában még mindig azon 29 mm-es pecsét alatt adtak ki okleveleket, amelyeket a nádori nagypecsét hiányában a nyár kezdetén is használtak. ${ }^{723}$

Miklós tehát jellegében a Vilmos által kitaposott szokásjogi normát folytatta (páratlan években közgyülések, ezalatt a visegrádi kúria a távollétében is folytatja müködését), ám már kezdetben újított annyit, hogy a congregatiok tartását bizonyos esetekben másra bízta. Igaz, már e téren is számolhatunk Vilmos-kori előzményekkel, ${ }^{724}$ de tény, hogy akkor nem fordultak elő ennyire konzekvensen, hogy egy teljes párhuzamos láncot folytasson le a nádor és a megbízottja. 1344-ben egyébként ugyanezen László alnádor tartott közgyülést Veszprém, Sopron és Zala (és talán más nyugat-magyarországi) megyéknek, de ott már a saját, és nem a nádor nevében bocsátott ki oklevelet. ${ }^{725} \mathrm{~A}$ másokra bízott közgyülés folyamatának végállomása egyébként az lett, hogy a 14. század végére a nádor már egyáltalán nem vett részt a generalis congregatiokon, hanem azt vagy az alnádora, vagy az ítélőmestere tartotta. ${ }^{726}$

Összefoglalásképpen azt mondhatjuk, hogy Miklós idejében méginkább előrehaladt a nádori hivatal elválása a nádor személyétől azzal, hogy már nem csak a kúriában, de a közgyüléseken is adhattak ki a nevében, de távollétében oklevelet. A kúria teljes egészében Visegrádra költözött ekkor már, viszont egy jó ideig - ezt hangsúlyoznunk kell! - még különálló egység maradt. Félrevezető tehát az olyasfajta megfogalmazás, hogy „Nagy Lajos ... a nádori vidéki bíráskodást és bíróságot is központosította $\mathrm{s}$ beillesztette a királyi

\footnotetext{
723 1343. okt. 13.: DL 51251-51254. (AOk1 XXVII. 684-686. sz.)
}

${ }^{724}$ 1335. aug. 7-i Gömör megyei közgyülését Jakab albíró (mellesleg gömöri alispán) tartotta, de ő a saját neve alatt bocsátott ki ott oklevelet, nem a nádor nevében: AOkl XIX. 479. sz. Ezen kívül volt Vilmosnak néhány „gyanúsan” közel eső közgyülése. Már Kruták Anitának is feltünt, hogy 1335-ben szept. 27-én Szatmárnémetiben nyitott közgyülést szept. 28-án egy Gelénesen tartott követte, az előbbi Szatmár és Ugocsa, az utóbbi csak Szatmár megye számára. Ugyanakkor ezek szomszédos települések voltak, és ezért „elképzelhető, hogy a kettő között volt a közgyülés helyszíne, így az oklevelek szövegébe hol az egyik, hol a másik település került" (Kruták 2012. 428.). Eredeti oklevél csak a Szatmárnémetit emlegető gyülésről maradt fent (már ha tényleg kettő volt egyáltalán, és nem egyet kevertek össze), azon a 70 mm-es nádori nagypecsét volt (DL 51014., DL 51015.). Ugyancsak párhuzamos congregatio lehetett 1341-ben, amelyeket november 5-én Győrben (Győr és Komárom megyének), nov. 6-án Pozsonyban nyitották meg (Pozsony és Moson megyének). Kruták Anita szerint „ekkora távolságot egy nap alatt is megtehetett a nádor, így valószínü, hogy az alnádor maradt helyette Győrben, aki lefolytatta a közgyülést” (Kruták 2012. 432-433.). A győri és pozsonyi gyüléseken kelt oklevelek közül egy sem maradt fent eredetiben, így azoknak a pecsétjeit sem tudjuk ellenőrizni.

${ }^{725}$ AOkl XXVIII. 685., 699., 709-710., 722. sz.

${ }^{726}$ Lackfi István nádorsága idejéből (1387-1392) jó példákat idézett C. Tóth Norbert, összehasonlítva a nádori itineráriumot az egyes megyei közgyülések időpontjával, és ebben olyan párhuzamosságokat mutatott ki, hogy a közgyüléseken mindenképpen a nádori ítélőmester, Uzsai Márton részvételét kell feltételeznünk: C. Tóth 2009. 96-97. Arra, hogy a 14. század második felében már nem a nádor tartotta a közgyüléseket, lásd még C. Tóth 2009. 88. 18. jz-ben idézett szakirodalmat. Eddig egyébként még senki nem vállalkozott ennek a tendenciának a részletes bemutatására, a korábbi irodalom csak a „végeredményt” és a hozzávetőleges időpontot (a 14. század második felét, végét) emlegette, holott a század első felében, mint láttuk, éppen az volt a jellemző, hogy a közgyülést a kúriájától távollévő nádor tartotta személyesen. 
kúriába", ${ }^{727}$ Ahogy Bónis György is utalt rá, a nádori külön kúriát még az 1380-as években is megkülönböztették a királyi udvaron belül. ${ }^{728}$ A nádori bíráskodás tehát szervezetileg nem a királyi kúria része lett, hanem csak azonos helyszínen volt megtalálható mindkettő. Az átlagember számára természetesen ezek a szervezeti különbségek nem számíthattak sokat, ők a nádort éppúgy a királyi udvarral köthették össze, ahogy az országbírót, és a későbbi többi bíróságot is. Aztán a Zsigmond-kor elején már a nádort az országbíróval együtt a királyi kúria „rendes bírájának” tekintették, ${ }^{729}$ a betagozódási folyamat ekkorra már befejeződött. Mindezzel lezárult az a 150 (tágabb értelemben 200) éves folyamat, amely során a királyi udvarból kiváló, és országjáró nádorispántól elvezetett a királyi udvarba visszaköltöző nádorig.

\footnotetext{
${ }^{727}$ Nyers 1934. 12.; ehhez nagyon hasonló: MTK I. 207.

${ }^{728}$ Bónis 1963. 230-231.

${ }^{729}$ Legalábbis ez következik abból, hogy a korábbi szakirodalom által 1300 körülre (vö. Gerics 1969) keltezett tanácsi határozat 2. cikkelye a nádort és az országbírót egyaránt a királyi kúria részének tekintette. A határozatokat Engel Pál a 14-15. század fordulójának a környékére keltezte az ott felbukkanó jogi terminusok alapján: Engel 2000. 125-132.
} 


\section{5 - A NÁDORI JOGHATÓSÁG KORLÁTAI}

$\mathrm{Az}$ 1222. évi Aranybulla már idézett, nádorokra vonatkozó cikkelye (amelyet más szavakkal az 1231. évi megújítás is megismételt) a következő mondattal kezdődik: „A nádor országunk minden embere felett különbség nélkül ítélkezzék."730 Az 1308-ban keletkezett Descriptio Europae Orientalis (Kelet-Európa leírása) címü munka magyar viszonyokban relatíve járatos szerzője szintén úgy vélte, hogy a nádor ,,az egész országban (in toto regno) az igazságszolgáltatás feje.”731 Ez az elv azonban már az első Aranybulla kiadásának idején sem volt teljesen igaznak tekinthető, a nádori joghatóságnak valójában több korlátja is volt. A földrajzi értelemben vett „horizontális” korlátok szerint bizonyos országrészek felett nem érvényesült a nádori joghatóság. Bár az országrészek alapvetően állandónak tekinthetőek, a pontos határok képlékenynek mutatkoztak az idők folyamán. Emellett számolni kell „vertikális” korlátokkal is, amelyek a társadalom egyes csoportjai esetében jelentkeztek, akik királyi előjoguk értelmében ki voltak véve a nádori joghatóság alól. Az alábbiakban ezeket tekintjük át.

\section{1 - A földrajzi határok}

A szakirodalom régi megállapítása, hogy azon régiókban, amely felett territoriális nagybírák álltak (itt elsősorban Erdélyre és Szlavóniára kell gondolnunk), a nádor fennhatósága nem terjedt ki. Az erdélyi vajdákat illetően egyöntetü volt a korábbi szakirodalom állásfoglalása: a nádor nem avatkozott be az erdélyi vajda jogkörébe, amit az is kiválóan mutat, hogy Erdély területén nem a nádor, hanem a vajda tartotta az igazságszolgáltatás egyik klasszikus fórumát, az ,általános gyüléseket” (generalis congregatiokat). ${ }^{732}$ Azt a néhány esetet, ami ennek ellentmondott, joggal tarthatjuk nem jellemző kivételnek. A 15. századból pl. vannak rá adataink, amikor egy erdélyi birtokiktatásra a nádor vagy országbíró szólított föl egy hiteleshelyet, holott ez a vajda feladata lett volna. ${ }^{733}$ Ám ez éppúgy nem volt jellemző, ahogy az olyan oklevélformuláknak

\footnotetext{
730 „Palatinus omnes homines regni nostri indifferenter discutiat” DRMH I/1. 35. Magyarul: Szöveggyüjtemény 270.

731 „palatinus ... est iusticiarus in toto regno.” Descriptio 51. Magyarul: Károly emlékezete 75. (Borzákné Nacsa Mária ford.)

${ }^{732}$ Lásd pl. Nyers 1934. 13.; Istványi 1940-1941. 192.; Kristó 1979. 120-121.; Kristó 2003b. 182.; Kruták 2012. 434.

${ }^{733}$ Janits 1940. 30.
} 
sincsen komoly forrásértéke, mint pl. I. Károly 1331-ben vagy 1340-ben adott kiváltságai, amelyekben a megadományozott felek és erdélyi birtokai ki lettek véve egyszerre a nádori, országbírói, vajdai és alvajdai joghatóság alól. ${ }^{734}$ Mindezek inkább a kancelláriai toposzokra, mintsem a gyakorlatban is élő területi átfedésekre mutatnak rá. A probléma nem is a „klasszikus” erdélyi területek feletti joghatóság kérdésében volt, hanem a „peremvidék” kapcsán - bizonyos megyék hovatartozása ugyanis ingadozott. Ezen „,vegyes” területet Jakó Zsigmond a következöképpen írta le, amikor meghatározta a történelmi Erdély foglamát: „Ide [ti. a történelmi Erdélyhez] számítjuk a Partiumból Közép-Szolnok és Kraszna vármegyét, de Zarándot már nem. A két előbbi vármegye ugyanis a XV. századig a nádor és a vajda egyelöre tisztázatlan, vegyes joghatósága alatt állott, de később Belső-Erdéllyel alkotott egységet”. 735 Jakó ezen megállapítását nemrég Hegyi Géza vette górcső alá, és aprólékos elemzéssel kimutatta, hogy földrajzi és társadalomtörténeti értelemben a két megye sokkal inkább kötődött a szükebb értelemben vett Magyarországhoz, mint Erdélyhez (a megyei birtokosok eredete, egyéb birtokaik fekvése és családi kapcsolataik alapján, illetve a hiteleshelyi vonzáskörzetek tekintetében). ${ }^{736}$ Lássuk mi a helyzet, ha nem a megyei lakosok oldala felől közelítjük meg a kérdést (társadalomtörténetileg), hanem a megye feletti hatóságok szemszögéből (politikai oldalról). A Közép-Szolnok megyei vegyes joghatóságról valójában csak azzal a megszorítással beszélhetünk, hogy előtte leszögezzük: a megye ilyen formán csak a 15. század húszas éveitől kezdve létezett. ${ }^{737}$ Kezdetben csak egy Szolnok megye volt, ám két, egymással nem összefüggő területcsoportot formájában (vitatott, hogy egy ősi „óriásmegyét” vágtak két részre a később szerveződő megyék, vagy a két fél között soha nem is volt közvetlen területi kapcsolat). ${ }^{738}$ A megyefeleket már a 13. század első felétől igyekeztek megkülönböztetni, és a 13. század második felében és a 14. század folyamán is ingadozott a névhasználat: az Erdély felőli rész a Belső- és a Külső-Szolnok nevet egyaránt viselte. Ám a megyék egységére a bizonyíték, hogy a 15. század első harmadáig bezárólag sosem létezett két szolnoki ispán, a cím birtokosa mindkét megyerésznek egyaránt az ura

\footnotetext{
734 1331: EO II. 710. sz. (AOkl XV. 267. sz.); 1340: EO III. 2-3. sz. (AOkl XXIV. 15-16. sz.)

735 EO I. 30. (Jakó Zsigmond bevezetője). Korábban is ezt vette alapul Kristó Gyula (Kristó 1979. 105-107., 109-110.), és az egyetértése mellett hangsúlyozta e megyék egyszerre különálló voltát is (Kristó 2002. 27-28., 106-107., 112-113.)

${ }^{736}$ Hegyi 2012. 27-45.

737 Ezt már hangsúlyozta Hegyi Géza is, aki csak praktikus okokból tartotta fent a megnevezést a 15. század előtti időszakra is (Hegyi 2012. 25.)

${ }^{738}$ Az eltérö álláspontok ismertetését lásd Kristó 1988. 434-438.; ill. legutóbb: W. Kovács 2012. 46-47.
} 
volt. $^{739}$ A megyefelek területének nagy része kívül esett Erdélyen, ám azzal, hogy legkésőbb 1262-től kezdve egységesítették a szolnoki ispáni és erdélyi vajdai címet, ${ }^{740}$ Szolnok megye megindult az Erdélybe való integrálódás útján. A 15. század első felétől aztán az Erdélyhez közelebb eső (akkor már megállapodott nevén: Belső-) Szolnok megye ismét ketté vált, és létrejött Közép-Szolnok megye. ${ }^{741}$ 1426-tól már külön beszélhetünk Közép-Szolnok megye és Külső-Szolnok megye ispánjairól, az erdélyi vajda pedig megszakításokkal 1441-ig viselte a szolnoki ispáni címet - bár ennek ekkor Külső-Szolnok megyére nézve már nem volt realitása. ${ }^{742}$ Szolnok megye különleges helyzete tehát ebböl következett: egyszerre tartozott az erdélyi vajdához (kissé benyúlva Erdély területére), és feküdt azon kívül. Mindezek fényében nincs is azon csodálkozni való, hogy a kezdeti időkben valóban a nádor hatalma érvényesült a terület felett. A Váradi Regesztrum tanúsága szerint a nádor többször is ítélkezett Szolnok megyei ügyekben (az Erdélyhez közelebb eső és a Tisza melletti megyefeleket egyaránt beleértve). ${ }^{743}$ A korai vajdai joghatóság hiányára utal az is, hogy Tomaj nembéli Dénes 1235 től egészen 1241 táján bekövetkező haláláig végig viselte a szolnoki ispáni címet is. ${ }^{744} \mathrm{~A}$ későbbi vajdai joghatóság bizonyítékaként szokás felhozni azt az általunk is idézett szakirodalmi tételt, hogy Külső-Szolnok megyének is a vajda tartott általános közgyüléseket, és nem a nádor. ${ }^{745} \mathrm{Ez}$ tényleg így is volt, azonban nem kezdettől, a közgyülések megjelenésének idejétől fogva. Azt látjuk ugyanis, hogy 1314-ben Borsa Kopasz nádor tartott generalis congregatiot Bihar, Békés, Kraszna és Szolnok megyék számára. ${ }^{746}$ 1317-ben Debreceni Dózsa „király személye helyetti bíróként” kétszer is közgyülést rendezett öt keleti megyének, köztük Szolnoknak is. ${ }^{747}$ Dózsa aztán 1318 és 1320 között megkapta az erdélyi vajdai címet, és 1320. március 12-én már erdélyi vajdai és szolnoki ispáni intitulációval

\footnotetext{
${ }^{739}$ Szolnok megyék elnevezésére lásd: W. Kovács 2012. 48-49. A szolnoki ispánokat: Archont. 1000-1301. 209-211.

${ }^{740}$ Archont. 1000-1301. 209.; ill. a kronológia bizonytalanságára lásd még: W. Kovács 2012. 47. 14. jz.

${ }^{741}$ Kristó 1988. 439.; W. Kovács 2012. 47-49.

${ }^{742}$ Archont. 1301-1457. 201.; Janits 1940. 27.; W. Kovács 2012. 48.

${ }^{743}$ 1219: RV 220. sz.; 1220: RV 269. sz., lásd még RV 277. sz. eset, amikor Barc fia Miklós nádor beszámolt arról, hogy környezetében Szolnok megyei ,jó emberek” (boni homines) tartózkodtak, köztük egy comes, és segítségükkel teremtett békét.

${ }^{744}$ Archont. 1000-1301. 210. Ennek oka az lehetett, hogy Dénes már tárnokmesterként, II. András alatt is volt egy ideig szolnoki ispán (1228 és 1230 között, lásd uo.), és talán szerette volna visszakapni ezt a megyét a bihari ispánsága helyett, amit kezdetben a nádori címe mellett viselt.

${ }^{745}$ Gábor 1908. 12-14.; Istványi 1940-1941. 194-196.; Janits 1940. 28. - további példákkal is alátámasztva, hogy a vajda joghatósága milyen szorosan érvényesült Külső-Szolnok megyében is.

${ }^{746}$ AOkl III. 849. sz. Az oklevél kiadója és a közgyülés celebrálója nem ismert, ám ezekben az időkben Borsa Kopasz más keleti megyék számára is tartott közgyüléseket (Kristó 2003b. 176.), így valószínüleg ezt is az ö nevéhez köthetjük.

${ }^{747}$ Zsoldos 2011b. 53-54.
} 
számolt be egy Szabolcs, Szatmár és Szolnok megyének tartott közgyülésről. ${ }^{748}$ Viszont - ha ezen oklevelekben nem is tüntette fel - továbbra is viselte a „király által kirendelt bíró” titulust. És miután 1322 januárjában kinevezték nádorrá, akkor is megtartotta joghatóságát e terület felett, és már ez év májusában közgyülést tartott négy megye, többek között Szolnok és Kraszna számára. ${ }^{749}$ Mint már arról a korábbi fejezetekben szó esettt, Zsoldos Attila megállapítása szerint ezen a „kirendelt bíró” egyfajta nádori jogkört gyakorolhatott a király által meghatározott és keze alá juttatott területek fölött. ${ }^{750}$ Így tehát, bár 1320-ból van az első adat arra, hogy az erdélyi vajda (és szolnoki ispán) tartja a generalis congregatiot Szolnok megye lakosainak, nagyon úgy tünik, hogy ezt Dózsa nem vajdai minőségben tette. Hiszen egyrészt láttuk, hogy mind Kopasz nádor 1314-ben, mind Dózsa - utóbbi először csak regionális, később országos nádori jogkörrel bírván - 1317 és 1322 között magától értetődően a saját felségterületének tekintette azt, hogy Szolnok megye számára is ő celebrálja a közgyülést. Másrészt azért sem tarthatott Dózsa vajdai jogkörénél fogva congregatiot Szolnok megyének, mert az - a korban szokásos módon - csoportos gyülés volt: egyszerre Szabolcs, Szatmár és Szolnok megye számára. Az előbbi két megye felett pedig soha semmilyen joghatósággal nem bírt a vajda. Így azt mondhatjuk, hogy az 1320-as évek első feléig Szolnok megye inkább a nádor, mintsem a vajda joghatósága alá tartozott ebböl a szempontból. A fordulat azonban nem sokkal később már bekövetkezett Szécsényi Tamás vajdasága (13211342) alatt. A fordulatban szerepet játszott az is, hogy Debreceni Dózsa 1322 végén meghalt, és a nádori méltóságot elnyerő Druget Fülöp kiterjesztette ugyan fennhatóságát Dózsa körzetére is, de uralmi súlypontja mindenképpen északabbra tolódott, a korábbi Amadétartomány területére. ${ }^{751}$ A nádori közgyűlések ezek után valóban „kikerülték” Szolnok megyét. Különösen szembetűnő ez Druget Vilmos nádorsága alatt, aki igen sok generalis congregatiot tartott, és szinte minden Szolnokkal szomszédos (nem erdélyi) megye számára celebrált ilyet, így a két Szolnok kihagyását nem tekinthetjük véletlennek. ${ }^{752} 1342$ után I. Lajos uralma alatt is igen sok nádori közgyűlést tartottak, de Szolnokot ezek sem érintették. ${ }^{753}$ Mindezzel egyidőben, 1333 áprilisában Szécsényi Tamás erdélyi vajda már Külső-Szolnok (de Zonuk exteriori) vármegyét utasította congregatio tartására a saját emberének színe

\footnotetext{
${ }^{748}$ AOkl V. 721-722. sz.

${ }^{749}$ Zsoldos 2011b. 65.

${ }^{750}$ Zsoldos 2011b. 56-65. Lásd még a „4.4. - I. Károly első nádorai - az »oligarchikus nádorság« öröksége” c. alfejezetet.

${ }^{751}$ A Drugetek uralmi körzetére lásd Zsoldos 2012a; ill. a „4.5 - A Druget-nádorok” c. alfejezetet.

${ }^{752}$ Lásd Kruták Anita térképét: Kruták 2012. 426-434. (különösen 434. old. 6. sz. térkép)

753 A Lajos-kori közgyülések felsorolását lásd Gábor 1908. 127-139.; Szolnok megyeieket: W. Kovács 2012. 50-51.
} 
előtt. $^{754}$ 1334-ben és 1335-ben és 1337-ben ugyancsak vajdai parancsra tartottak közgyülést. ${ }^{755}$ Szolnok megye (megyék) tehát politikai szempontból az 1320-as évek második felétől váltak teljesen vajdai joghatóságúvá.

A másik, Jakó Zsigmond által vegyes joghatóságúnak ítélt megye Kraszna. Kraszna határos volt Belső- (a későbbi Közép-) Szolnok vármegyével, és Erdélybe való teljes integrálódása már a tárgyalt korszakunkon túl, a 16. század folyamán ment csak végbe. ${ }^{756} \mathrm{~A}$ megye hozzátartozott ahhoz az öt vármegyéhez, amely felett Debreceni Dózsa király által állított bíróként nádori jellegü jogkört gyakorolhatott. ${ }^{757}$ Ám - Szolnokkal ellentétben - a megye ezután még nem került ki a nádori fennhatóság alól, és a Drugetek többször is tartottak ott közgyülést. Ekkoriban már kezdtek kialakulni azok a megyepárok (esetleg megyehármasságok), amelyek számára rendszerint együtt celebrálták a congregatiokat. Kraszna többnyire Bihar megyével került párba, és mivel Bihar volt a „nagyobb testvér”, ezért a közgyülések központja mindig ott, rendszerint Nagyvárad közelében volt. ${ }^{758}$ Ez a párosítás később is fennállt (pl. 1343, 1349, 1360, 1370, 1381 folyamán szintén Bihar és Kraszna megyék részére tartotta a congregatiot a mindenkori nádor). ${ }^{759} \mathrm{~A}$ szakirodalomban ugyan felmerült, hogy a Zsigmond-korban már már nem találkozunk a szokásos Bihar-Kraszna megyepárosítással, ${ }^{760}$ de valójában még 1435 -ben is tartottak a nádor nevében közös biharikrasznai közgyülést. ${ }^{761} \mathrm{Az}$ általunk tárgyalt korban így Kraszna megyét nem vegyes jogállásúnak, hanem tisztán nádori fennhatóság alatt állónak mondhatjuk politikai értelemben is. Külső-Szolnok megye helyzete ebből a szempontból más volt. Ez nyilván összefüggésben áll azzal, hogy a megye ispánságát a vajda viselte, de fontos leszögezni: a megyék feletti joghatósága túlmutatott a megyésispáni jogkörnél azáltal, hogy a közgyüléseket is ő nevében tartották ott. Alább szó lesz róla, hogy a macsói bán ispánságai felett nem a bán, hanem a nádor bírt ilyen típusú joghatósággal, és, mint láttuk, az 1320-as évekig ugyanez a helyzet állt fenn Külső-Szolnok esetében is. Szolnok ezután politikailag vajdai fennhatóság alá került, ám ez biztosan nem a terület „határvidék” jellegével hoszható összefüggésbe - már ha beszélhetünk egyáltalán „határvidék” jelenségről e megyék esetében.

\footnotetext{
${ }^{754}$ EO II. 772. sz. (AOkl XVII. 175. sz.). Egy 1326-ra keltezett (AOkl X. 153. sz.) hasonló tárgyú oklevél valójában 1333-ban vagy 1334-ben kelt, lásd EO II. 773. sz.

${ }^{755}$ EO II. 813., 815-816. sz.; ill. EO II. 855-856., 859. sz.; ill. EO II. 934-936. sz.

${ }^{756}$ W. Kovács 2012. 61.

${ }^{757}$ Zsoldos 2011b. 53-55.

${ }^{758}$ Kruták 2012. 428-429., 432.

${ }^{759}$ 1343, 1349: EO III. 166. és 521. sz.; 1360, 1370, 1381: Gábor 1908. 132., 136, 138.; W. Kovács 2012. 57.

${ }^{760}$ Kristó 2003b. 181.

${ }^{761}$ C. Tóth 2008. 120. (a közgyülést az alnádor tartotta az ura nevében)
} 
A délvidéki joghatóság tekintetében már eleve megosztottabb volt a szakirodalom. Nyers Lajos szerint Szerém, Valkó, Pozsega és Verőce megyék felett a 15. század végéig joghatóságot gyakorolt a nádor, mivel nem tartoztak Szlavóniához. ${ }^{762}$ Bár földrajzi értelemben tényleg van abban igazság, hogy az adott megyéket nem számolták Szlavóniához, viszont azt látjuk, hogy 13. században a szlavón bán mégis gyakorolt joghatóságot a felsorolt megyék felett is. A szlavón bán tényleges hatalma sokszor a Dráva folyóig kiterjedt, és a szorosabb értelemben Szlavóniához nem tartozó, de a Drávától délre eső („drávántúli”) megyékben a bán adót szedett és bírói joghatósággal is bírt. Ez érvényes volt a folyón átnyúló megyék (Somogy, Zala) drávántúli részeire is. ${ }^{763}$ Mindez nem egyszer értelmezési zavarokhoz és hatásköri súrlódásokhoz is vezetett, amit az idők folyamán igyekeztek mérsékelni. ${ }^{764}$ Ha a korai időszakra koncentrálunk, akkor az 1250-ig terjedő nádori ítéleteket és intézkedéseket számba véve ${ }^{765}$ három olyan esettel találkozhatunk, amely átnyúlt a Dráván túlra. Az egyik eset Bebek Detre nádor 1398. évi oklevelének említésében maradt fönt. Bemutatták Garai Miklós 1383. évi oklevelét, amiben többek között átírták a hajdani István nádor 1247. évi, a Dráva és a Mura között fekvő Béla birtok ügyében kiadott oklevelét. ${ }^{766}$ Mivel a per során ennek nem volt lényeges szerepe, ezért nem is részletezték bővebben. Bár nem tudjuk, hogy István szerepe miben merült ki (birtokba iktatott, avagy döntött egy peres ügyben), de az oklevél hitelét nincs okunk megkérdőjelezni. Más a helyzet Vízközzel, melyet IV. Béla adományozott, és parancsára László nádor iktatta birtokba az új tulajdonosokat. A birtok Somogy megyébe esik, de a Dráván túlra. Az adományt fenntartó oklevél hitelessége ugyan vitatható, de az adomány megtörténte is bizonyítható, így talán a nádori közremüködést sem kell semmisnek venni. ${ }^{767}$ Viszont az iktatást az a László nádor hajtotta végre, aki somogyi ispán is volt egy személyben, így akár ebben a minőségében is végezhette ezt a feladatot. ${ }^{768}$ Az egyetlen, teljes egészében drávántúli vonatkozású terület a Pozsega megyei Tapolca és Pukor közti föld. Az ezt fenntartó 1228. évi oklevél viszont hamis, vagy legalábbis interpolált, és a nádori intézkedéseket tárgyaló részei egy másik, pannonhalmi vonatkozású nádori oklevélből lettek átemelve - hogy a birtok kapcsán valaha is ítélt volna bármelyik nádor, nem bizonyítható. $^{769} \mathrm{~A}$ forrásokban viszonylag gazdag délnyugati területeken tehát összesen

\footnotetext{
${ }^{762}$ Nyers 1934. 13.

${ }^{763}$ Minderre lásd Weisz-Zsoldos 2010.

${ }^{764}$ Weisz-Zsoldos 2010. 478-480.

${ }^{765}$ Ezeket térképre vetítve lásd Szőcs 2012. 420-421.

${ }^{766}$ Zala II. 285. (RP 75. sz.)

${ }^{767}$ Weisz-Zsoldos 2010. 476; lásd még az RP 69. sz. reg. kommentárját.

768 ÁÚO XI. 337-340. (RP 69. sz.)

${ }^{769}$ CDCr III. 293-295. (RP 30. sz. reg.). Hamis vagy interpolált voltára lásd az RP 30. sz. reg. kommentárját.
} 
három nádori joghatósági jelenlét mutatható ki, ebből egy biztosan hamis, egy bizonytalan, egyről (Béla birtok kapcsán) pedig nem lehet eldönteni - jobb híján hitelesnek kell tartanunk. Ez egyfelől egy minimális ütközést jelent ugyan a báni joghatósággal, ám úgy véljük, hogy a hitelesnek tekinthető jelenlét csekély száma mindenképpen arra utal, hogy a nádor alapvetően nem intézkedett a Dráván túl, már a 13. század első felében sem. Feltűnő egyébként, hogy az említett Pozsega megyei föld ügyében egy hitelesnek tekinthető oklevél szerint már Gyula szlavón bán hozott ítéletet 1232-ben, néhány évvel az állítólagos 1228-as nádori ítélet után. ${ }^{770}$ Így a nádori joghatóság Dráva folyóig való terjedését a 13. század első felére már megszilárdultnak tekinthetjük és a nádorok később is betartották a határokat. Szemléletes példa erre az az 1255 júliusában, a pécsi káptalan által kiadott oklevél, amely elárulja, hogy Máté özvegye, Zsófia pert indított egy Kudmen nevü, Verőce megyei (tehát szintén teljesen Dráván túli) birtok leánynegyede ügyében a nádor előtt. ${ }^{771}$ Ám a nádor továbbadta az egész ügyet bizonyos nemeseknek, hogy vagy teremtsenek megegyezést, vagy tüzzenek ki határnapot a perre. Azok le is folytatták az ügyet, az esküt is ők rendelték el, a felek végül a pécsi káptalan előtt tettek bevallást. Úgy tűnik tehát, hogy Roland sem érezte magát illetékesnek egy teljesen Dráván túlra eső birtok esetében.

Ám a déli megyék kapcsán nem mehetünk el szó nélkül egy másik sajátos „,peremvidék” mellett, ez pedig a macsói bán joghatósága alá tartozó megyék kérdése. A macsói tartomány még a 13. század elején került magyar fennhatóság alá, majd Rasztiszlav fia, „macsói” Béla 1272. évi meggyilkolása után Béla tartományait a bárók felosztották egymás között és a szlavón és szörényi bánságok mintájára azokból is „,bánságokat” szerveztek. Így jött létre a macsói bánság is, amelyet 1279-től a boszniai bánsággal egyetemben Erzsébet anyakirályné kapott meg, végül 1284-ben Dragutin István kezébe került - amennyire tudjuk, nem katonai úton, hanem házassági hozományként. ${ }^{772}$ István egészen 1316. évi haláláig kormányozta Macsót, halála után pedig II. Uroš szerb uralkodó a saját országához csatolta a tartományt. Bár I. Károly ekkor éppen igen nehéz katonai helyzetben volt, 1317-ben mégis hadjáratot vezetett Szerbia ellen, elfoglalta Macsó várát, hadi sikerét két évvel később, 1319-ben szilárdította meg. Károly 1319 végén vagy 1320-ban újjászervezte a macsói báni tisztséget,

\footnotetext{
${ }^{770}$ DL 100201., CDCr III. 367-368.

${ }^{771}$ CD IV/2. 345-347. Az oklevél eredeti (DL 396.). Kudmen birtok fekvésére lásd Karácsonyi 1900. 295.

${ }^{772}$ A bánság korai történetére lásd KMTL 421. (Rokay Péter és Takács Miklós munkája); Archont. 1000-1301. 50-51.
} 
amely ezek után egészen a 15 . század végéig, a török hódításig fennállt. ${ }^{773}$ Az első macsói bán Garai Pál lett, aki egyúttal a valkói és bodrogi ispáni tisztet is megkapta. Károly később más megyéket is a macsói bánhoz kötött: a tisztség viselője 1323-tól szerémi, 1328-tól baranyai, 1333-tól bácsi ispán is volt egyben, és ezek után a mondott öt megye ispánságát több mint egy évszázadig állandóan a mindenkori macsói bán töltötte be. ${ }^{774}$ Bár bizonyos értelemben a macsói bán „tartományának” is tekinthetjük e megyéket, ${ }^{775}$ az azok feletti joghatóság mégsem tartozott teljes egészében a macsói bánsághoz. Egyrészt, Valkó megye területén 1351-ig a szlavón bánt illette a nyestbőradó ${ }^{776}$ (amely elég kellemetlen jogátfedést jelentett a macsói bán szempontjából, hiszen a megyét „honorként”, azaz többek között a jövedelmei miatt kapta meg). Emellett a „csatolt” megyék felett a nádor is jogi fennhatóságot gyakorolt. Ezáltal viszont az a helyzet állt elő, hogy néhány, a 13. század első felében még „drávántúlinak” számító megye mégis bekerült a nádori érdekszférába. Mindennek az előzményeit már a macsói bánság újjászervezése előtt is tapasztaljuk. Károly 1304. május 6-án kiadott oklevelében figyelmeztette az ország összes bíráját, kiváltképp a Valkó megyeieket (universis iudicibus in regno suo constitutis, et specialiter iudicibus in Wlko [!] constitutis), hogy Miklós fia Gergely comest kivette minden bíró, így a nádor joghatósága alól is. ${ }^{777}$ Mivel az oklevél leginkább a Valkó megyei bírákat hangsúlyozta ki, nyilvánvalóan Gergely ott lehetett érdekelt, és talán azonos lehetett azzal a pacsintai Gergellyel, akit Károly ezidőtájt több kiváltságban is részesített. ${ }^{778}$ A szöveg külön is kiemelte, hogy a drávántúli Valkó megye területére eső birtokkal rendelkező Gergely felett a nádor sem ítélhet, természetesnek tekintve, hogy a tisztség viselöje azon a területen is eljárhatott, ellenben a szlavón bánról külön nem esett szó. Bár az Árpád-kor folyamán ezt a megyét inkább a mindenkori szlavón bán felségterületének tekintették, a váltás azzal magyarázható, hogy a báni posztot ekkor a Károllyal szemben álló, és Vencelt (majd 1306-tól Ottót) támogató ${ }^{779}$ Kőszegi Henrik töltötte be. ${ }^{780}$ Erre a vidékre amúgy sem terjesztette ki Henrik a fennhatóságát, hiszen Valkó, Szerém, Pozsega és Bács megyék a Károlyhoz hűséges Csák Ugrin tartományához tartoztak. ${ }^{781}$ Az ifjú

\footnotetext{
${ }^{773}$ A bánság későbbi történetére röviden és általában: KMTL 421.; Archont. 1301-1457. 27. Engel Pál érdeme volt egyébként annak a tisztázása, hogy I. Károly nem 1319-ben, hanem 1317-ben vezetett elöször hadjáratot Uroš ellen: Engel 1988. 115. 123. jz., ill. lásd még uo. 127.

${ }^{774}$ Archont. 1301-1457. 27.; Engel 1982. 914.

${ }^{775}$ Vö. Zsoldos 2012e. 351.

${ }^{776}$ Weisz-Zsoldos 2010. 469-470.

${ }^{777}$ DL 91155. (AOkl I. 603. sz.); vö. Zsoldos 2011a. 17.

${ }^{778}$ Tóth 2001. 26-27.

${ }^{779}$ Kristó 1999b. 55.

${ }^{780}$ Archont. 1301-1457. 16.

${ }^{781}$ Tóth 2001. 26.
} 
király így magától értetődő módon vonta politikai ellenőrzése alá azokat a megyéket, amelyek a későbbi macsói bán honorjait képezték, természetesnek tekintve, hogy ott (akkor még macsói bán hiányában) a nádor is eljárhatott. Így ez a terület az Anjou-korra véglegesen „kicsúszott” a szlavón bán ellenőrzése alól. A nádori fennhatóság 1314 nyarán is biztosan fennállt, amikor is Scemteu fia Gergely Kopasz nádor elött perbe fogta Gergely bánt (Gregorius banus filius Endre, nobilis de comitatu Syrimiensi) a Szerém megyei Réva (Ryua) birtok ügyében. Végül párbajra került sor a nádor színe előtt, aki ennek eredménye alapján együtt a vele ülésező Szerém, Bács és Valkó megyei nemesekkel (cum universis nobilibus Syrimiensis, Bachiensis et de Wolko comitatuum) halálra ítélte Gergelyt. ${ }^{782}$ Tulajdonképpen rejtély, hogy az északkelet-magyarországi nádori territóriumának határait hivatali értelemben soha át nem lépö ${ }^{783}$ Kopasz nádor előtt mit keresett egy ilyen távoli ügy. Bár Kopasz oklevele csak egy 1314. július 20-i tartalmi átírásban maradt ránk, abból, hogy ítélőtársai a szerémi, bácsi és valkói nemesek voltak, arra következtethetünk, hogy itt ő egy csoportos közgyülést tartott a három megyének. Az átíró oklevél tartalmából (a nádor által halálra ítélt Gergely gyerekei megváltják apjuk életét azzal, hogy szóban forgó Réva birtokot eladják Gergely bánnak) arra következtethetünk, hogy ez a közgyülés nem sokkal azelőtt zajlott le. Hogy Kopasz 1314 nyarán valóban nem tartózkodott a Bihar megyei Adorjánban tartott kúriáján, az is mutatja, hogy 1314 júniusa és júliusa folyamán hirtelen több ügyet is László nevű alnádora tárgyalt le, míg a nádornak ezen időszakból nem maradt fent ottani oklevele. ${ }^{784}$ Kopasz nyilvánvalóan nem saját elhatározásából és a maga kezdeményezésére, hanem királyi ráhatásra tarthatta ezeket a közgyüléseket. Később, amikor a macsói bán megkapta ezeket a megyéket az 1320-as évektől kezdve, a nádorok továbbra is fennhatósággal bírtak a megyék felett. Hiába csatolták a báni méltósághoz 1328-ban Baranya megyét, egy évvel később már Druget János nádor tartott a megyének közgyülést, 1330-ban pedig szintén az ő parancsára tartottak a Valkó megyei nemesek congregatiot, és hamarosan a nádor is a körükbe érkezett. ${ }^{785}$ Még 1343-ban is Zsámboki Miklós tartotta a közgyüléseket Bodrog és Valkó megyéknek. ${ }^{786}$ Arról pedig már esett szó fentebb, hogy Druget Vilmos nádornak több, közgyüléseken kívüli Baranya megyei esete volt. ${ }^{787}$ Ugyanez a macsói bán oldaláról is igazolható. Az első bán, Garai Pál a kinevezése után nem sokkal hangsúlyozottan a király

\footnotetext{
${ }^{782}$ AO I. 351. (AOkl III. 793. sz., az eset folytatását lásd uo. 794-795. sz.)

${ }^{783}$ Lásd erre a „4.4. - I. Károly első nádorai - az »oligarchikus nádorság« öröksége” c. alfejezetet.

${ }^{784}$ AOkl III. 759., 782. sz.

${ }^{785}$ AOkl XIII. 252. sz.; AOkl XIV. 370., 381. sz.

${ }^{786}$ AOkl XXVII. 398., 453-454., 459. sz.

${ }^{787}$ Pl. AOkl XIX. 166. sz.; XXI. 113.; XXVI. 18., 97. sz.
} 
nevében (vice et nomine regio) tartott közgyülést 1320-ban a Bodrog megyei Hajszentlőrincen. ${ }^{788}$ Ostfi Miklós 1338-ban a „macsói bán, szerémi, bácsi, valkói, bodrogi és baranyai ispán, valamint a király személyében kiküldött bíró ugyanezekben” címet viselte. A kiküldött bírói titulus, mint már erről többször is szó volt, egyfajta „nádori jellegü” jogkört jelentett a megjelölt megyék felett, amely többnyire a közgyülések tartásában realizálódott. ${ }^{789}$ A macsói bánok azonban ilyen cím birtokában még azt is külön kihangsúlyozták, hogy ők akkor egy nádori jogkört gyakoroltak: Miklós bán az 1338. október 22-i valkói közgyülésen már nádori jogon (iura palatinalia) bíráskodott, és egy másik oklevélben a „király és a nádor személyében kiküldött” (in persona sua regia et palatini deputatus) bíró címével élt. Ezt a titulusát 1339-ben is megtartotta. ${ }^{790}$ Utódja, Ostfi Domonkos 1339. november 28-án ugyancsak az elődje által használt „király és a nádor személyében kiküldött” bíróként tartott közgyülést Baranya megyének. ${ }^{791}$ Itt még azt is kiemelték, hogy a bán mellé itélőtársként kirendelt esküdeket „a nádori közgyülés szokása szerint” (iuxta more congregationis palatinatus) $^{792}$ jelölték ki. A Zsámboki Miklóst követő nádorok is rendszeresen tartottak közgyüléseket a macsói bánsághoz csatolt megyékben, ${ }^{793}$ bár ekkor már felbukkan az is, hogy a macsói bán a saját jogán hívhatja össze a congregatiot. Véglegesen ugyanakkor csak Lajos kora után kerülnek át ezek a megyék a báni fennhatóság alá. ${ }^{794}$ Mindez azért hansúlyozandó, mert a szlavón bán pl. saját maga jogán rendezhetett közgyüléseket a Szlavón bánság szorosabb értelemben vett határain kívül eső drávántúli „,csatolt” megyéknek. ${ }^{795}$ Ez a jog a macsói bánt nem illette meg, ő a „csatolt” megyékben (köztük pl. a drávántúlinak számító Valkóban is) a 14. század elejétől az általunk vizsgált korszak végéig csak megyésispáni jogokkal bírt. A terület feletti átfogóbb joghatóság a nádort illette meg, és ha éppen a macsói bán gyakorolta is azt, akkor is mindig kihangsúlyozták, hogy ő most a ráruházott nádori jogkörével él.

Emellett a macsói bán honorjához nem tartozó Pozsega megye területe kapcsán is felbukkan a nádor neve a különféle bíráskodási immunitást biztosító kiváltságokban. A pécsi

\footnotetext{
${ }^{788}$ Zichy I. 183. (AOkl V. 811. sz. vö. 850. sz.)

${ }^{789}$ A titulusra vonatkozó adatokat és a kiküldött bírói intézmény részletes tárgyalását lásd Zsoldos 2011b. 6061.; ill. passim.

${ }^{790}$ Az adatokat lásd Zsoldos 2011b. 61.

791 A titulációja: „banus de Machou, comes Syrmiensis, Bachyensis, de Wolkou et de Baranya, ac per excellentissimum principem dominum Karolum Dei gratia illustrem regem Hungarorum iudex in eisdem in persona sua regia et palatini deputatus” DF 261637. (AOkl XXIII. 717. sz.)

792 DF 261637.

${ }^{793}$ Az adatokat lásd Gábor 1908. 127-139.

${ }^{794}$ Istványi 1940-1941. 203.

${ }^{795}$ Istványi 1940-1941. 200-202.
} 
egyházmegyéhez tartozó és Pozsega megye területén lévő pozsegai káptalan népeit nemcsak a hagyományosan báni járadéknak tekinthető nyestbőradó alól mentesítette (IV.?) László és I. Károly kiváltságlevele, de az országbírói és nádori bíráskodás alól is, semmilyen bánt nem említve. ${ }^{796}$ A kiváltságokat egy 1528. évi (azóta már szintén elveszett) oklevélben említették és írták át tartalmilag, és nem tudjuk pontosan elválasztani a László és Károly által adott előjogokat. ${ }^{797}$ Erzsébet királyné 1342-ben pedig három „,világi” tulajdonú falut mentesített a részletesen felsorolt „báni-jellegü” adók (pl. a Nestalia nevü marturina és submarturina) alól, továbbá nem kell az ott lakó népeknek a nádor vagy a mindenkori megyésispán közgyülésére elmenniük (ad congregationem domini palatini, vel comitis parochyalis, aut vicecomitis de eodem comitatu Posaga pro tempore constitutorum). ${ }^{798}$ A királyné az adók beszedése kapcsán is a nádort és az országbírót, illetve a megyésispánokat utasította, hogy a felsorolt adófajtákat ne szedjék be az ott lakóktól, és a falvak népeit közvetlen királynéi fennhatóság alá rendelte. Bár a fenti rendelkezések erősen formula-jellegüek, mégis feltűnő, hogy a szlavón báni titulust egyik oklevélben sem említették (még a nyestbőradó beszedése kapcsán sem!). Emellett, mint fentebb már utaltunk rá, Pozsega megye is azok közé tartozott, amelyek a 14. század elején Csák Ugrin „tartományát” képezték, és amelyek felett már a korai időktől kezdve érvényesült I. Károly, és ezáltal a nádor fennhatósága. ${ }^{799}$ Erzsébet királyné oklevele egyenesen a nádori congregatio tartását tekintette alapnak a megye területén. Így - a 14. század első felétől kezdve - Pozsega megyét is (részben) nádori joghatóságú megyének tekinthetjük, bár a gyakorlatban nem tudunk semmilyen megyei vonatkozású nádori ítéletről vagy intézkedésről 1342-ig bezárólag. Ez a „lokális nádorok” esetében természetes is, ám Druget János és Vilmos müködése sem érintette Pozsega megyét - ez természetesen nem zárja ki egy elméletben lehetséges fennhatóság meglétét.

\section{2 - A nádorral szembeni jogi immunitás}

A területi értelemben vett joghatóság határai mellett létezett egy olyasfajta korlát is, amely bizonyos külön jogokkal bíró társadalmi csoportokra terjedt ki. Az 1222. évi Aranybulla 1231. évi megújítása már rögtön tartalmazott egy megszorítást: „A nádor pedig minden ember felett különbség nélkül ítélkezzék, kivéve az egyházi személyeket és

\footnotetext{
796 CD VIII/7. 158-159.

${ }^{797}$ Koszta 2009. 239-240.

${ }^{798}$ DF 233338. (AOkl XXVI. 71. sz.)

${ }^{799}$ Tóth 2001. 26., ill. lásd fentebb.
} 
klerikusokat, valamint a házassági és hitbérügyeket és más egyházi [vonatkozású] ügyeket, amelyek bármely címen egyházi vizsgálat alá tartozónak látszanak." ${ }^{\circledR 00}$ Az egyháziak belső pereiben világi bíróságok egyébként sem voltak illetékesek. A 13. század első felében bizonyos egyházi státuszpereket ${ }^{801}$ és egyházi intézmények közti tizedpereket ${ }^{802}$ is tárgyalt a nádor - ám ezek többnyire Pannonhalmával kapcsolatos perek voltak, és általában az egyház részéről keresték meg a nádort, tehát nem „hivatalból” tartoztak elé az ilyen ügyek, hanem felkért („,fogott”) bíróként működött. Az egyházi személyek világi bíróságokkal szembeni jogi immunitása ugyanakkor nem érintette automatikusan az egyházi birtokon élő népeket, ám a 13. század közepétől szokássá vált, hogy maguk a birtokokat és lakóikat is kivették a világi bíráskodás alól, általában a királyt, vagy valamilyen más magasabb rendủ személyt vagy hatóságot jelölve meg közvetlen fórumnak. ${ }^{803}$ Érdekes látni, hogy a 13. század második felétől a nádori bírói székhez azelőtt ezer szállal kötődő pannonhalmi apátság is „kihátrált” a joghatóság alól. 1257-ben IV. Béla a kérésükre még azt a kiváltságukat erősítette meg, hogy az apát és népei csak a király és a nádor előtt vonhatóak perbe, ám 1335-ben már azon kiváltságukat ismertették el Druget Vilmos nádorral, hogy a királyon kívül más bírói fórum elé nem citálhatók. ${ }^{804}$ Egyedül az egyháziak világiakkal való birtokvitái kerülhettek továbbra is állandó jelleggel a nádori ítélőszék elé (hogy ez világi hatóságok elé tartozik, arra már az 1233. évi beregi egyezmény is utalt). ${ }^{805}$

Ezen kívül mentességet élvezett a nádori joghatóság alól az a világi személy vagy közösség vagy falu, aki vagy amely ilyesfajta kiváltságot kapott a királytól. A kiváltságot megkaphatták egyszerü magánemberek vagy azok birtokai is, ${ }^{806}$ ám ennél fontosabbak és időben hosszabban hatóak voltak a különféle saját joggal bíró csoportoknak adományozott jogok. A hospesközösségek és az ő jogaikból kinövő „szabad királyi városok” sokszor

\footnotetext{
800 „Palatinus vero omnes homines indifferenter discuciet, preter personas ecclesiasticas et clericos, et preter causas matrimoniales et dotis, et alias ecclesiasticas, quacumque ratione videntur ad ecclesiasticum examen pertinere.” DRMH I/1. 40. Magyarul: Szöveggyüjtemény 276.

${ }^{801}$ PRT I. 645-646., 675-676., 752-753. (RP 6., 19., 50. sz.), PRT I. 661.

${ }^{802}$ 1219-1221: PRT I. 651-652. vö: RA 368. sz., ill. RP 13. sz.; 1238: PRT I. 759-760., 761-762. (RP 56-59. sz.); 1238-1241: lásd RP 66. sz. reg. kommentárját; 1255: PRT II. 293. (RP 100. sz.)

${ }^{803}$ Lásd pl. az esztergomi érseki népek immunitását: MES I. 436-438., 474. Vö. még az „1.1 - Az elnevezés” c. alfejezetben az érseki nádorról írtakkal. A garamszentbenedeki apátság népeit elöször, IV. Béla korától kezdve, csak a megyésispánok joghatósága alól vették ki, ám 1326-ban és 1328-ban már közvetlen királynéi illetve királyi fennhatóság alá kerültek: Keglevich 2012. 63-64. A veszprémi püspökség népei kiváltságát I. Károly 1324-ben erősítette meg: AOkl VIII. 401. sz. A pozsegai káptalan kiváltságáról az előző alfejezet végén esett szó (lásd Koszta 2009. 239-240.), stb. Általában véve lásd még Bónis 2003. 144-147.

${ }^{804}$ 1257: RA 1157. sz.; 1335: AOkl XIX. 444. sz.

${ }^{805}$ MES I. 295. (Szöveggyüjtemény 404.)

${ }^{806}$ Pl. 1270: RA 1929. sz.; 1304: AOkl I. 603. sz.; 1335: AOkl XIX. 427. sz.; 1339: AOkl XXIII. 183., 273., 721. sz.; 1340: AOk1 XXIV. 624. sz.; 1342: AOkl XXVI. 71. sz.
} 
egymást másoló kiváltságai között pedig szinte kötelező elemként jelent meg a bíróválasztás joga, és hogy ezzel párhuzamosan kivették őket a megyésispán, és adott esetben más bírók joghatósága alól. Az első ilyen városi jellegű kiváltságolásnak a pataki hospesek 1201. évi kiváltságlevele tekinthető, ${ }^{807}$ ám az abban olvasható bírósági immunitás még csak a megyésispánra vonatkozott, és a király mellett a nádorispán joghatóságát is meghagyta (tkp.: közvetlenné tette) a közösség felett. ${ }^{808}$ Ám már rögtön a második ismert hospeskiváltság, amelyet az Erdély területén fekvő három közösség, Karakó, Igen és Romosz lakói nyertek el 1206-ban, mentesítette a közösséget az erdélyi vajda (vagyis a király utáni legmagasabb rangú területileg illetékes bíró) joghatósága alól is ${ }^{809}$ - ezzel megnyílt az út a közvetlenül a király alá tartozó városok felé. Aztán 1230-tól, a Szatmárnémetinek adott kiváltságtól kezdve szinte valamennyi városi kiváltságlevélben meghatározták a fellebbezés útját, kiemelve, hogy a királyi szék, esetleg a tárnokmester szerepét. ${ }^{810}$ Nyitra részére 1248-ban adott kiváltságlevél külön is kiemelte, hogy „,a nyitrai polgárok senki kívülről jött bíró, tudniillik a nádor vagy megyésispán ítélkezésének nem kell, hogy alávessék magukat. Ha azonban valamely nehéz ügyben netán nem tudnának dönteni, úgy rendelkezünk, hogy saját személyünk, vagy a tárnokmester elé hívassanak". ${ }^{811}$ Mivel IV. Béla a kiváltság megadásakor külön leszögezte, hogy a nyitraiak a fehérvári polgárok kiváltságait kapták meg, ${ }^{812}$ ezért joggal feltételezte a kutatás, hogy már az először 1237-ben említett fehérvári kiváltságok is tartalmazhattak ilyen mentességet - bár hogy ez részleteiben hogyan hangzott, azt nem lehet megállapítani. ${ }^{813}$ Ám az egyes hospesközösségek részére kiadott városprivilégiumok - kimondva vagy kimondatlanul - mentesítették a nádori joghatóság alól ezeket a közösségeket. A nagyszombatiaknak adott 1238. évi kiváltság értelmében a lakosok csak a király, illetve az általa kijelölt bíró joghatósága alá tartozhatnak. ${ }^{814}$ Zólyom 1243. évi kiváltsága is biztosította, hogy csak az ő bírájuk ítélhessen közöttük, és ha valamilyen ügyben nem tudna dönteni,

\footnotetext{
${ }^{807}$ Vö. Szende 2011. 33-34.

${ }^{808}$,ab electo inter se iudicentur preposito, quo propter negotiorum dificultatem non sufficiente, palatini comitis sive regis subeant iudiciumm[!], nec in secularibus alios habeant” Elenchus III/2. 22.

${ }^{809}$ Szende 2011. 34-35.

${ }^{810}$ Fügedi 1961. 64.

811 „,nec ipsi cives Nitrienses aliquorum extraneorum iudicium, palatinorum videlicet, et comitum provincialium adstare iudicio teneantur; sed si super arduis negociis diffinire forsitan ignorarent, volumus, ut ad nostram presentiam, vel magistri tavernicorum nostrorum ... convocentur” CDS II. 209. Magyarul: Tatárjárás emlékezete 332. (Gy. Ruitz Izabella ford.)

812 ,ipsis et ipsorum successoribus perpetuo Albensium civium dedimus libertatem” CDS II. 209.

${ }^{813}$ Zsoldos-Neumann 29-30., 32.

814 „Solius etiam regis iudicio, vel quem ipse ville in villicum prefecerint, astare debeant.” CDS II. 31.
} 
akkor csak a királyi ítélet dönthet. ${ }^{815}$ Ez a séma aztán nagyon gyakori lett, és a választott bíró után a királyi jelenlétet vagy személyét jelölte meg fellebbezési fórumnak Körmend és Pest 1244. évi kiváltságlevele (az utóbbi esetében kiegészítve azzal, hogy a király más bírót is kijelölhetett), ${ }^{816}$ és ezt találjuk Korpona (1244), ${ }^{817}$ Bábaszék és Dobronya (1254), ${ }^{818}$ Komár (1263), ${ }^{819}$ Györ (1271), ${ }^{820}$ Sopron (1277), ${ }^{821}$ Pozsony (1291), ${ }^{822}$ Körmöcbánya $(1328)^{823}$ és Komárom (1331) privilégiumaiban is. ${ }^{824}$ A komáromi kiváltságlevélben is ott találjuk a tárnokmestert a király mellett fellebbezési fórum gyanánt. Sátoraljaújhely hasonló szellemü kiváltságát István királyfi (rex primogenitus, nem azonos a későbbi „ifjabb királyi” címével!) adta 1261-ben, a saját személyét jelölve meg magasabb bíróként. ${ }^{825}$ Besztercebánya kiváltsága (1255) nem jelölte meg a fellebbezés helyét, de kiemelte, hogy az ország semmilyen más bírája nem illetékes a közösség felett, csak a sajátjuk, ${ }^{826}$ és tartalmilag ezt olvashatjuk a nagyszőllősiek részére István ifjabb király által adott oklevélben (1262), ${ }^{827}$ továbbá Németlipcse (1263), ${ }^{828}$ Hibbe (1265), ${ }^{829}$ Szatmár (1271), ${ }^{830}$ Vasvár (1279), ${ }^{831}$ Gölnicbánya (1287), ${ }^{832}$ Sárvár (1328) ${ }^{833}$ és Köszeg $(1328)^{834}$ kiváltságlevelében. A már idézett 1248. évi nyitrai oklevél mellett külön csak IV. László budaiaknak adott kiváltságlevele (1287), és I. Károly Nagymarosnak juttatott adománylevele (1324) nevesítette a nádori ítélőszék alóli immunitást. ${ }^{835}$ Emellett Szina 1249. évi kiváltsága hivatkozott a kassai

\footnotetext{
815 „Nullus vero iudex vel comes de Zoulum ipsos iudicet preterquam eorum iudex, qui eos ... iudicabit. Et si forte talis causa inter eos emergeret, quam dictus iudex iudicare non posset, examini iudicii regii et non alii reservetur." CDS II. 94.

${ }^{816}$ Elenchus III/2. 38., 40.

${ }^{817}$ CDS II. 113.

${ }^{818}$ CDS II. 313.

${ }^{819}$ Solymosi 1998. 221.

${ }^{820}$ Elenchus III/2. 61-62.

${ }^{821}$ Elenchus III/2. 69.

${ }^{822} \mathrm{M}-\mathrm{Zs}$ Okl I. 57.

${ }^{823}$ AOkl XII. 473. sz.

${ }^{824}$ AOkl XV. 403. sz.

${ }^{825}$ Elenchus III/2. 52.

${ }^{826}$ CDS II. 341.

${ }^{827}$ ÁÚO VIII. 31.

${ }^{828}$ Juck 1984. 44-45.

${ }^{829}$ Juck 1984. 48-50.

${ }^{830}$ CD IV/3. 207. (a keltezésére lásd RA 2133. sz.)

${ }^{831}$ Elenchus III/2. 71.

832 Juck 1984. 67-68. (a keltezéséhez lásd még RA 3464. sz.)

${ }^{833}$ AOkl XII. 253. sz.

${ }^{834}$ AOkl XII. 304. sz.

${ }^{835}$ Buda: „exemptam a iurisdictione regni nostri palatini ... aliorumque omnium universaliter nostrorum regni magnatum et baronum et specialiter magistri tawernicorum nostrorum ac iudicis curie nostre" Elenchus III/2. 83. (RA 3449. sz., jelezve, hogy az oklevél hitelessége nem áll szilárd lábakon, igaz, nem is feltétlenül hamis, vö.
} 
kiváltságokra bíráskodási téren is. ${ }^{836}$ Kassa korai kiváltságát sajnos nem ismerjük, bár amikor I. Lajos 1347-ben megújította a város szabadságát, akkor abban szintén nevesítve szerepelt a nádori joghatóság alóli kivétel, ${ }^{837}$ de nem biztos, hogy ez a száz évvel korábbi kiváltságlevélben is ott volt. Léteztek azonban ezeknél kevésbé egyértelmü kiváltságolások is. Bars 1240. évi privilégiuma csak az udvarispán, Szepesolaszi 1243. évi kiváltsága pedig az ispán joghatósága alól mentesítette a lakosokat egyértelmü módon ${ }^{838}$ (Eperjes, Kisszeben és Sáros a szepesi hospesek kiváltságát kapta meg 1299-ben, és az ő adományleveleük is csak az ispán joghatósága alóli mentességet említi). ${ }^{839}$ A berényi hospesek bírája is csak a kisebb ügyekben (in minutis causis) ítélhetett, ${ }^{840}$ ahogy a beregszászi és késmárki bírónak is meg kellett osztania hivatalát egy király által külön állított bíróval (ezen oklevelek az országos nagybírák alóli mentességről külön nem ejtenek szót). ${ }^{841}$ Emellett gyakran visszatérő elem volt, hogy nem csak az ispánok és egyéb bírák joghatósága alól vették ki a fenti városokat, de tiltották az ún. „megszállás” (descensus) jogát is, amely szerint a körükbe érkező tisztségviselő ellátásáról nem kell gondoskodniuk. ${ }^{842}$

Mindezek ellenére a „szabad királyi városok” bírói kiváltságait nyugodtan értelmezhetjük úgy, hogy a város általában véve mentesült a nádori főség alól, akkor is, ha ezt nem jelezték külön. Hogy a kortársak is így gondolták, arra jó példa I. Károly 1331. évi oklevele, amelyben ismételten megújította Sopron város kiváltságait. Az apropót az adta, hogy 1331-ben Druget János nádor, elödeihez képest alaposan kitágítva müködésének határait, megjelent Sopron megyében, hogy ott (1279 óta először!) közgyülést tartson. ${ }^{843}$ A megyei tisztikar pedig (talán a szokásjog ki nem forrott volta miatt, talán szándékos túlkapásként) a várostól is behajtotta a nádor ellátására vonatkozó pénzjáradékot, hiába mentesültek a descensus alól. Így a királynál panaszt tevő soproni polgárok részére I. Károly ismét kiadott egy oklevelet, amelyben megerősítette azt, hogy „a [soproni] hospeseink, ahogy más városaink hospesei is, a nádori

még Györffy 1997. 189.); Nagymaros: „nullus palatinorum, baronum, et quolibet titulo dignitatis prefulgentium in regno nostro pro tempore constitutorum descensum super illos facere audeat violentum, vel ius, et iudicandi iurisdictionem super ipsos sibi vendicare" CD VIII/2. 514. (AOkl VIII. 269. sz.)

${ }^{836}$ „omni libertate gaudeant, qua ex concessione nostra hospites nostri de Kassa perfruuntur ... quam in iudiciis” CDS II. 223.

${ }^{837}$ AOkl XXXI. 739. sz.

${ }^{838}$ CDS II. 56-57., 84.

${ }^{839}$ Juck 1984. 82-83.

${ }^{840}$ Solymosi 1998. 222.

${ }^{841}$ CD IV/1. 455-457.; Juck 1984. 51-52.

${ }^{842}$ Példákkal: Fügedi 1961. 54.

${ }^{843}$ Az 1279. évi közgyülés: UB II. 126; RP 195. sz. Mivel a generalis congregatio intézményének gyakorivá válása után egy nádor működésének a súlypontja sem esett erre a vidékre, így gyaníthatóan nem csak a forráshiány miatt nem tudunk több soproni közgyülésről. Ezzel kapcsolatban lásd a következő fejezetet. 
joghatóság és bíráskodás alól teljes mentességet élveznek”. ${ }^{844}$ Az oklevélben említett „más városaink" (alia nostra civitas) a szabad királyi városok összességét jelentette, amelyek a fenti bírói kiváltságolások révén a király értelmezése szerint is egységesen ki voltak véve a nádori iurisdictio alól.

Bár az egységes bírói mentességre a legjobb példát a városprivilégiumok szolgáltatják, tulajdonképpen más népcsoport is rendelkezhetett hasonló immunitással, ha megadta nekik a király. A városok mellett gyakran egyéb etnikumok is kaptak ilyen típusú kiváltságot. Az Erdély területén élő kiváltságolt népelemek (székelyek, erdélyi szászok) előjogai értelemszerüen a vajdára vonatkoztak, de más etnikumok előjogai elvileg érinthették a nádori joghatóságot is. A fehérvári „latinok” vagy az esztergomi örmények kiváltságairól azonban alig tudunk valamit, ${ }^{845}$ a szepesi szászok 1271. évi kiváltságlevelében pedig csak korlátozott mértékben érvényesült a bíráskodási autonómia. ${ }^{846} \mathrm{IV}$. Béla zsidóknak juttatott 1251 . évi kiváltságlevele (amely egyébként Frigyes osztrák herceg hasonló tartalmú privilégiumára épült) viszont csak a zsidók közti zsidóbíró helyzetét szabályozta részletesen, a zsidókeresztény perek fórumáról nem ejtett szót. ${ }^{847}$ Tegyük hozzá: nincs arról tudomásunk, hogy (a már idézett fehérvári latinokat érintő tizedper kivételével) a mindenkori nádor bármilyen kiváltságolt etnikum felett bíráskodott volna. Ez alól természetesen kivételt jelentenek azok a keleti etnikumok (besenyők és kunok), akik felett a nádor kifejezett joghatósággal bírt. Róluk egy másik fejezetben esik szó.

\footnotetext{
${ }^{844}$,ipsi hospites nostri, ut aliarum nostrarum civitatum a iurisdictione seu iudicio palatinatus penitus sint exempti” Házi I. 59. (AOkl XV. 348. sz.)

${ }^{845}$ Fehérvári latinok: Zsoldos-Neumann 35-41., további irodalommal (mellesleg a fehérvári latinok felett egy tizedperben Ampod fia Dénes nádor ítélkezett 1219-1221 között: PRT I. 651-652. Ez persze nem zárja ki egy későbbi immunitás megadását). Az esztergomi örmények kiváltságlevelének egy részét tartalmilag átírták 15. századi oklevelek, lásd Elenchus III/2. 36. (RA 735. sz.).

${ }^{846}$ Juck 1984. 55-56.

${ }^{847}$ M-Zs Okl I. 27-30.
} 


\section{6 - A generalis CONGREgatio}

A nádori „vidéki” bíráskodás egyik külön fóruma a dolgozatban már számtalan alkalommal említett ún. „általános gyülés”, latinul congregatio generalis volt, amelyet kezdetben egyszerre csak egy-egy, majd a 13. század végétől kezdve hol egy, hol kettő, vagy akár több megye nemessége számára tartottak. Fontos leszögezni, hogy generalis congregatiot nem csak a nádor tarthatott, hanem a király, vagy más, a király által megbízott személy, territoriális különkormányzatuk élén pedig az erdélyi vajda és a szlavón bán is. ${ }^{848} \mathrm{Az}$ Anjou-korban már az is előfordult, hogy egy adott megye nemessége külön királyi, esetleg nádori parancsra saját magának tartotta a közgyülését - ez esetben az ispán vagy alispán elnökölt a 4 szolgabíróval, és néha egy közeli hiteleshely is elküldte a tanúságát, hogy szentesítse az ott elhangzottakat. ${ }^{849}$ Az első ismert és hitelesnek tekinthető nádori gyűlés Péc nembéli György fia Dénes nádor nevéhez köthető, aki az 1273 legvégén kiadott oklevelében arról beszélt, hogy a király és az ország báróinak tanácsára a Zala megyei gonosztevők elítélésébe fogott (ex precepto domini nostri Ladizlai serenissimi regis Vugarie ex consilio baronum tocius regni ad condempnandos malefactores fuissemus ingressi), és konkrétan a Zala megyei közgyülésen (in comitatu Zaladiensi in congregationis collegio) ítélkezett. ${ }^{850} \mathrm{Ez}$ előtt csak biztosan hamis oklevelekben jelenik meg az intézmény. ${ }^{851}$

\section{1 - A nádori közgyủlés intézményének kialakulása}

Az intézmény elöképe és létrejötte vitatott. Arra, hogy a nádor egy megyébe érve bíráskodjon a színe előtt összeseregletteknek, már a Váradi Regesztrumban is találunk példát. Egy 1219-re datálható bejegyzés szerint „egy királyi szolgáló Tiván faluból és Tót faluból és az egész kemeji terület tolvajokat hirdetett ki Miklós nádorispán színe előtt." ${ }^{\text {852 }}$ Bár az itt

\footnotetext{
${ }^{848}$ A generalis congregatio intézménye általában: Hajnik 1899. 67-77.; Istványi 1939-41.; Tringli 1997. A macsói bán által tartott közgyülések speciális voltára lásd a „5.1 - A földrajzi határok” c. alfejezetet.

${ }^{849}$ Pl. 1312: AOkl III. 410. sz.; 1313: AOkl III. 593-594. sz.; 1314: AOkl III. 751., 765., 771-772. sz.; 1321: AOkl VI. 282-283. sz.; 1322: VI. 531., 555., 703. sz.; 1330: AOkl XIV. 370., 381. sz.; 1331: AOkl XV. 374. sz.; 1335: AOk1 XIX. 154. sz. stb. Lásd még Istványi 1939. 70.

${ }^{850}$ ÁÚO IX. 38. (RP 162. sz.)

${ }^{851}$ Pl. III. Béla 1190. évre datált oklevele (csak a generalis congregatiora vonatkozó adat): Elenchus III/2. 18. (RA 151. sz.), hamis voltára lásd Pauler II. 591-592.; Belus nádori alispán 1201-re datált oklevele: CD VII/4. 71. (vö. RP 2/3. sz. - hamis voltára vonatkozó érveket lásd uo.); IV. Béla 1254-re datált fehérvári kiváltságlevele: $\mathrm{CD} I V / 2$. 232. (RA 1012. sz. - a hamis voltára vonatkozó érveket lásd uo.)

852 „Minister regis de villa Tiuan et de villa Tot et tota provincia de Quemey vociferati sunt coram Nicolao, palatino comite contra fures” RV 226. sz. Érdekes, hogy Kemejt (ami Heves megye tiszántúli része) a
} 
olvasottak teljesen rímelnek a 13. század második felében tartott nádori közgyülések gyakorlatára, nem egyértelmü, hogy a fenti eljárást a közgyülések előképének tekinthetjük-e. Istványi Géza a generalis congregatio elöképét kutatva már utalt arra, hogy itt csak az alávetett udvarnokréteg feletti bíráskodási gyakorlatról volt szó, és „,a XIII. századi társadalmi viszonyokat mérlegelve, nem is gondolhatjuk, hogy éppen a megnövekedett önérzetü nemesek kéredzkedjenek egy alacsonyabb rangú néposztály [ti. az udvarnokok] törvényszéke elé." ${ }^{, 53}$ Istványi itt azt sugallta (de sem itt, sem később nem bizonyította), hogy a nádori közgyülés intézménye egy alulról szerveződő, spontán jelenség volt, ahol a bírói fórum mibenléte kizárólag azon múlott volna, hogy a nemesek ki elé akartak „kéredzkedni”. Abban azonban egyet kell érteni, hogy a későbbi nádori közgyülések elözményeit nem feltétlenül ebben kell keresni. A szakirodalom egy vonulata a Váradi Regesztrum azon bejegyzéseiben véli megtalálni az előképet, amelyek szerint egy bizonyos Benedek bán és Bánk udvarispán egy-egy megye „lakosai” (conprovinciales) számára tartott bírói gyüléseket 1221-1222 folyamán. ${ }^{854} \mathrm{Az}$ alapgondolatot Bolla Ilona vetette fel egy 1957. évi tanulmányában, ${ }^{855}$ és 40 évvel később Tringli István és Zsoldos Attila is Bánk ezen Újvár, Szabolcs és Borsod megyéket érintő körútjában kereste a későbbi generalis congregatio csíráját. ${ }^{856}$ Zsoldos Attila felvetette, hogy Bánk királyi udvarispán ítélőtársa, Benedek talán az ekkor hivatalban lévő Benedek alországbíróval lehet azonos. Továbbá „nagy biztonsággal megállapítható, hogy Bánk 1221-ben és 1222-ben az északkeleti országrész egyes megyéiben olyasféle bírói körutat tett, mint amilyenek a későbbi nádori közgyülések (generalis congregatio) megtartására adtak alkalmat, s az elé tárt ügyeket speciális uralkodói felhatalmazás nélkül, a királyi udvarispáni méltóságából fakadó joghatósága alapján ítélte meg." ${ }^{857}$ Ezen kívül Zsoldos a Váradi Regesztrum adatai és az első tényleges nádori közgyülések közötti fél évszázados szakadékot is igyekezett áthidalni egy 2003-ban megjelent tanulmányában. ${ }^{858}$ Abban kifejtette, hogy a Regesztrumban olvasható 1221-1222. évi adatok a kúriai bíráskodás vidékre telepítéséről hosszabb távon nem bizonyultak tartósnak, hiszen az Aranybulla nem sokkal később már a királyi udvarhoz kötötte az udvarispán bíráskodását, így a megyéket járó országbíró képe nem tudott gyökeret verni. „Az 1260-as évek végéről ugyanakkor nyoma maradt annak, hogy az

\footnotetext{
„provincia” szóval illette a bejegyzés, amely többnyire a vármegyék megnevezése volt. Ennek ellenére Kemej megyéről nem tudunk, itt is minden bizonnyal terület vagy körzet jelentésben áll, vö. ÁMTF III. 106.

${ }^{853}$ Istványi 1939. 53. 7. jz.

${ }^{854}$ RV 292-306., 326., 329-332., 334-335. sz.

855 Bolla 1957. 99. (vö. 103. 56. jz.)

${ }^{856}$ Tringli 1997. 392-393.; Zsoldos 1997c. 9-10.

${ }^{857}$ Zsoldos 1997c. 10.

${ }^{858}$ Zsoldos 2003
} 
efféle bírói gyűlések tartásának szokása nem enyészett el teljesen: István ifjabb király udvarispánja ugyanis 1268-ban Pest megyében a gonosztevők felkutatása és a birtokosaiktól jogtalanul elidegenített földek ügyében ... kiküldött bíróként ítélkezett. Az a körülmény, hogy 1268-ban még a II. András-kori helyzethez hasonlóan az udvarispán tartott bírói gyülést, mindössze öt év múlva viszont Dénes nádor [1273. évi, az elsö ismert nádori congregatiot jelentő] Zala megyei fóruma már a nádori gyűlés kifejlett, $\mathrm{s}$ utóbb állandósuló formája szerint zajlott, valószínüsíti - bár bizonyossá, természetesen, nem teszi -, hogy a zalai lehetett ténylegesen is az első nádori gyülés." ${ }^{859}$

Magunk úgy véljük, hogy a Váradi Regesztrum kérdéses, 1221-1222. évi bejegyzései még úgy sem hozhatóak összefüggésbe a későbbi nádori generalis congregatioval, hogy jellegét és funkcióját tekintve nagyon hasonló volt a kettő (ti.: egy adott megye elsősorban szabad státuszú lakosai számára egy utazó nagybíró által celebrált ítélkező gyülés). Az összekapcsolásukat azonban az akadályozza meg, hogy nagyon úgy néz ki: a II. András-kori ítélkezési sorozat egy ideiglenes eset volt, és semmi nyom nincs arra nézve, hogy túlélte volna az Aranybulla kibocsátását. Ehhez egy kicsit közelebbről is meg kell vizsgálni a Bánk országbíró által folytatott „gyüléseket”.

Mindenekelőtt azt kell leszögezni, hogy ebben az időben nem csak Bánk országbíró (és a talán az alországbíróval azonosítható Benedek) tartott egy adott megye conprovincialisnak nevezett lakosai számára ilyen bírói fórumot. A conprovincialis kifejezés alatt egyébként ebben az esetben nem a megye összes lakosát, hanem egy meghatározott társadalmi csoportot, a királyi servienseket kell értenünk. ${ }^{860}$ Már Bánk ténykedése előtt, 1220-ból is találunk olyan adatot, amely szerint a bihari serviensek (comprovinciales de Bichor) tolvajokat hírdettek ki az András király által delegált Mika, bihari ispán színe előtt (coram Mica, comite Bichoriensi iudice a rege Andrea delegato). ${ }^{861}$ Feltűnő, hogy a megyéjében elvileg illetékes bihari ispánt András külön állította bíróként. Hogy itt tényleg valami más megbízatásról volt szó, mutatja, hogy ugyanebben az évben a Kolozs megyei serviensek (comprovinciales de Dus, ez utóbbi elírás Clus helyett) ${ }^{862}$ is Mika bihari ispán előtt végezték a tolvajok kikiáltását, ahogy 1221 ben a Békes megyeiek (comprovinciales de Bekes) is. Itt ugyancsak megemlítette a bejegyzés, hogy Mika a rege delegatis, vagyis ,a király által megbízott” volt. ${ }^{863}$ Szintén 1220-ból való az az eset, amely szerint a Szolnok megyei serviensek (comprovincialibus Zounoc) Pál csanádi

\footnotetext{
${ }^{859}$ Zsoldos 2003. 798.

${ }^{860}$ Zsoldos 1997c. 9.

${ }^{861}$ RV 235. sz.

${ }^{862}$ Vö. K. Fábián 1997. 51. (129. sz.)

${ }^{863}$ RV 263., 286. sz.
} 
ispán (iudice Paulo comite de Chenadu) bírói színe előtt vádolták be lopással Farkas szolgáját. ${ }^{864}$ Azért kerülhetett az ügy a csanádi ispán színe elé, mert - Mikához hasonlóan - a megbízott bírói illetékessége Szolnok megye területére is kiterjedt. Ugyanilyen gyülést sejthetünk azon 1220. évi bejegyzés mögött is, amely szerint a nem beazonosítható Cheuz ${ }^{865}$ faluból való Péter és conprovincialisai által bevádolt tolvaj ügyét Demeter curialis comes folytatta le, szintén királyi utasításra (precepto regis). ${ }^{866}$ Könnyen lehet, hogy a conprovinciales itt sem általános értelemben vett megyei társat, hanem servienseket jelent, csak ez magyarázná, hogy miért foglalkoztak volna külön királyi utasításra egy amúgy jelentéktelen üggyel. Demeter curialis comes talán az 1215-ben felbukkanó bihari udvarispánnal lehet azonos, ${ }^{867}$ és talán az éppen más megyékben tevékenykedő Mika bihari ispánt helyettesítette.

Amíg tehát Bánk Újvár, Borsod és Szabolcs megyékben tartott ítélkező fórumot, Mika (már korábban is megkezdve müködését) Bihar, Kolozs és Békés megyéknek, Pál pedig többek között - Szolnok megyének (valószínű egyébként, hogy csanádi ispán révén, megbízása a saját vármegyéjére is kiterjedt Mikához hasonlóan). Bánk ténykedésével egy időben még Barc fia Miklós nádornak is volt egy hasonló esete. Gottfried aradi prépost emelt panaszt egy, a pályi egyház birtokán megölt ember ügyében, ám a bevádolt Bodon serviens, amikor a nádorispán színe elé idézték, az „ő megyebelieivel együtt” (cum comprovincialibus suis) tagadta mindezt. ${ }^{868} \mathrm{~A}$ váradi tüzesvas-próba is öt igazolta végül, de ami számunkra most érdekes, az annak a ténye, hogy ha egy adott serviens a nádor előtt a conprovinciales, vagyis a serviens-társaival karöltve védekezett, akkor ennek is ugyanolyan gyülésnek kellett lennie, mint a többinek. Mivel a jogesetet a Regesztrumban teljesen körülölelik Bánk országbíró kérdéses esetei, ${ }^{869}$ biztosak lehetünk benne, hogy a nádor és az országbíró jogszolgáltatása teljesen egy időben zajlott. Természetesen felveti a kérdést, hogy a nádor esetében miért csak ezt az egy ilyen típusú regesztát ismerjük, miközben Bánktól sorozatban többet is. Erre nem tudunk biztos választ adni, csak feltevéseket: talán azért, mert Miklós kevésbé aktívan kapcsolódott be ebbe a bíráskodási sorozatba, vagy egyszerüen csak olyan megyékben járt alapvetően, amelyek kívül estek a váradi káptalan vonzáskörzetén, így ebben a forrásban hiába is keresnénk az őrá vonatkozó tömeges adatokat. Az azonban bizonyos, hogy ezt a

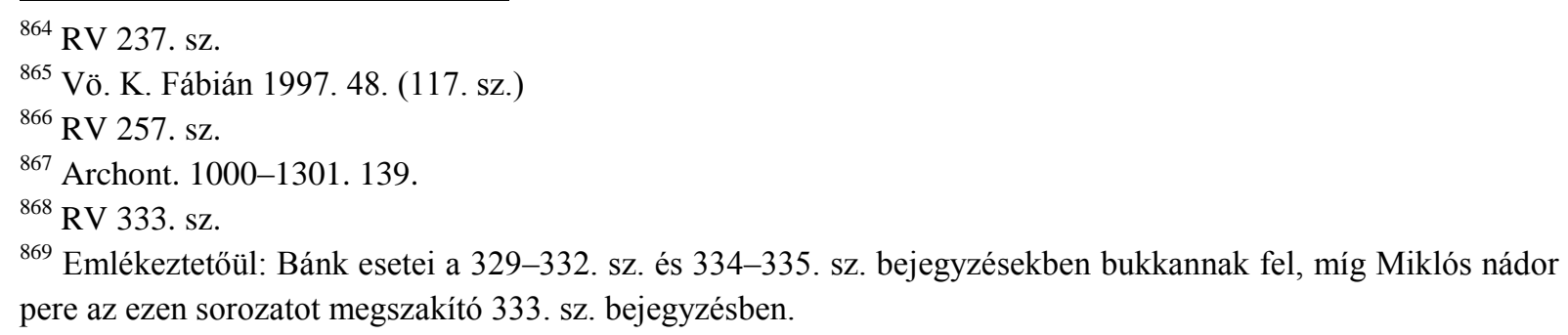


megyei serviensek számára 1221-1222 során folytatott ítélkezés-sorozatot nem csak az országbíró végezte. Mindez persze azt is jelenti, hogy az itteni bírák - ahogy a regeszták rendszerint jelezték is - külön királyi megbízást teljesítettek. Ez alól vélhetően Bánk sem volt kivétel, még akkor is, ha az őrá vonatkozó bejegyzések ezt nem jelezték külön. Ám ugyanígy nem jelezték pl. Pál csanádi ispán esetében sem, és mivel mind Bánk és Pál, mind pedig a többiek lényegében hasonló feladatokat láttak el, ezért a királyi megbízás is ugyanaz lehetett.

Feltűnő jelenség, hogy míg az 1220-1222 közötti évekből, csak a váradi káptalan vonzáskörzetéből legalább 4 olyan személyt tudunk kimutatni, akik a serviensek számára tartottak ítélkező fórumokat egyes megyékben (a Mika helyetteseként állított Demeter udvarispánnal nem számolva), addig 1220 előtt, vagy éppen 1222 után egyetlen ilyen adatunk sincs sem a Váradi Regesztrumban, sem más forrásban. ${ }^{870}$ Ezek alapján magunk - Tringli Istvánnal ellentétben ${ }^{871}$ - úgy véljük, hogy itt nem egy megszlárdult, állandó jellegü, hanem egy ideiglenes intézkedés-sorozatról volt szó, talán II. András már említett, 1219-1220. évi kormányzati reformjainak részeként. ${ }^{872}$ Akármi is motiválta Andrást, az biztos, hogy ebben a néhány évben megyésispánokat és egyéb méltóságviselőket bízott meg azzal, hogy a kijelölt körzetüket végigjárva bíráskodjanak a serviensek felett. Még akár az is elképzelhető, hogy a király végül az országbírót szemelte ki arra a feladatra, hogy hivatala alatt állandósuljon e funkció, de az biztos, hogy az ilyen típusú ítélkezésekből végül hosszú távon semmi nem lett. Az 1222. évi Aranybulla az országbírói hivatalt a királyi udvarhoz kötötte, külön kiemelve, hogy azon kívül ne indítson pert. ${ }^{873} \mathrm{Az} 1220-1222$ közötti intézmény teljesen elhalt, és bár, mint láttuk, a nádor ugyan vándorolt az országban, de semmilyen adat nincs arra nézve, hogy egy adott megyébe érve szisztematikusan összegyültek volna elé a helyi lakosok a későbbi generalis congregatio mintájára. Így tehát a Váradi Regesztrumban olvasható serviensek számára tartott gyüléseket, bár kétségtelenül csábító párhuzamot kínálnak, véleményünk szerint törölni kell a nádori közgyülések előképei közül. Csak abban az esetben lehetne mégis számba venni azokat, ha bizonyítani tudnánk ezen ítélkező megyei gyülések továbbélését 1222 után. Ám erre sem az országbíró, sem más méltóságviselő részéről nincs semmilyen forrás. $^{874}$ (A Zsoldos Attila által felhozott 1268. évi példa az udvarispáni gyülésre

\footnotetext{
${ }^{870}$ A conprovinciales szó ugyan korábban és később is felbukkan a regisztrumkönyv lapjain (RV 116., 166., 317., 385. sz.), de egyértelmúen más kontextusban.

${ }^{871}$ Tringli 2009. 493.

${ }^{872}$ A reformokra lásd Nógrády 1995. 180.; ill. a „3 - A nádori hivatal elemei és kifejlődése a 11-12. században” c. fejezet végét.

${ }^{873}$ DRMH I/1. 35.

${ }^{874}$ Az egyetlen ellenpélda talán az lehetne, hogy a tatárjárás után, 1242-ben Pál országbíró „az ország többi nemesei közül elsőnek kelt át a Dunán, mind ezen, mind az erdélyi vidéken kiirtotta és igazságos ítélkezéssel
} 
véleményünk szerint egy egészen más tendenciába illeszkedik bele, erről alább részletesen szó lesz.) Annak az esélye pedig, hogy az 1270-es évek elején még élénken emlékeztek volna ezen néhány év intézkedéseire, és tudatosan akartak volna visszanyúlni hozzá, nyugodtan elvethető. A generalis congregatio előzményeit mi máshol keressük, mégpedig két olyan párhuzamos „,szálban”, amelyek végül 1273-ban értek össze.

Az egyik ilyen „szál” már kezdetektől fogva kimutatható, de a tatárjárás után új lendületet vett: a külön királyi megbízásra bizonyos megyékbe kiküldött, és ott valamilyen speciális feladatot végrehajtó megbízottakról van szó. Ök egyformán lehettek egyházi és világi személyek, és feladatuk az 1240-1250-es években többnyire a királyi vagyon revíziójára irányult. A nádorokat is sokszor megbízták ilyen külön feladatokkal, és sokszor éppen a saját, ispánságként is viselt megyéjükben jártak el, ám ez nem volt kötelező. ${ }^{875}$ Mindez az 1260-as években, az országmegosztás idején az ifjabb király országrészére is érvényes volt. István ugyanis valamikor 1267 és 1269 között, de legvalószínűbben 1268-ban nádorát és udvarbíráját, Benedeket ${ }^{876}$ is bíráskodási és birtokrevíziós feladatokkal bízta meg. Mindezt Benedek egy kelet nélküli okleveléből tudjuk, amelyben jelentette István (ifjabb) királynak, hogy „tudja meg felséged, hogy kimentem Pest megyébe a gonosztevők kihírdetése és a tulajdonosaitól jogtalanul elidegenített földek számbavétele céljából”. ${ }^{877}$ Az oklevél elején ez a rutinszerü formula vezette be azt a konkrét esetet, amely szerint Benedek megtudta, hogy a Pest megyei Oszlár (Ozlar) föld Kristóf, Péter és egyéb péteri (de Patery) rokonaiknak a tulajdona, ám a föld nem másnak, mint István húgának, a később szentté avatott Margit apácának a tulajdonában van (nunc possidet karissima soror vestra domina Margareta). Mivel a földet Benedek nem merte visszavenni, ezért István elé utalta az ügyet. $^{878}$ Valószínű, hogy ezen kívül a birtokvizsgálatok nagyjából rendben lezajlottak a megyében, és ezt a nádor számára kissé kellemetlen epizódot leszámítva nem sok egyéb

\footnotetext{
felszámolta a tolvajokat és rablókat, akik e tájon a szokottnál nagyobb számban szaporodtak el”. (ipse prius pre ceteris nobilibus regni ultra Danubium veniens, tam in eisdem, quam in Transsilvanis partibus fures et latrones, qui tunc in eisdem locis plures solito surrexerant, extirpando, et iusto medianteijudicio condemnando) ÁÚO VII. 283. Magyarul: Tatárjárás emlékezete 335. (Gy. Ruitz Izabella ford.) Itt azonban világos, hogy egy rendkívüli helyzetről volt szó, és az országbíró nem a szokott hivatali kötelességét teljesítette.

${ }^{875}$ A nádor általában a királyi udvarszervezet és a helyi nemesek földjei ügyében járt el, lásd pl. 1254-55: UB I. 235., 235-236., 247. (RP 95-97. sz.); CDS II. 352., 353., 353-354., 354-355. (RP 103-107. sz.).; CDS II. 393.; 1257: CDS II. 394. (RP 117. sz.); 1268: HO VIII. 115-116., ÁÚO III. 186-187., 190-192., ÁÚO VIII. 206207., ÁÚO III. 184-185., 188-189. (RP 146-151. sz.) Lásd még a „4.2 - A regionális nádorság kezdete” c. alfejezetet.

${ }^{876}$ Archont. 1000-1301. 26.

877 „Noverit excellencia vestra me in comitatu Pestiensi ad indicandos malefactores et cognoscendas causas terrarum indebite alienatarum a suis possessoribus accessisse”. ÁÚO VIII. 276.

${ }^{878}$ DL 577. (ÁÚO VIII. 276.); vö. Függelék, C-regeszta
} 
oklevél született ekkor. Zsoldos Attila a fentebb idézett gondolatmenetében ezt az esetet is a nádori közgyülések előképének tulajdonította, ${ }^{879}$ és tényleg tény, hogy egyfajta átmenetet képez a későbbi nádori közgyülések és az 1240-60-as évek egyedi királyi megbízásra történő kiküldetései között. A Pest megyei elidegenített földek felülvizsgálata kapcsán, az eset teljesen párhuzamba állítható az olyan típusú intézkedésekkel, amelyre már korábban is bőségesen találtunk példát, és amelynek egy állomása az idősebb király országrészében éppen ekkortájt, 1268-ban zajlott. ${ }^{880}$ Bár az oklevélben tárgyalt tényleges ügy is ezzel a megbízással állt összefüggésben, Benedek a narrációban megemlített még egy feladatkört: a ,gonosztevők kihírdetését”, amellyel viszont a korai nádori közgyülések egyik klasszikus funkciója jelenik meg. A megyék számára tartott általános értelemben vett igazságszolgáltatás ugyanis sosem képezte részét a királyi kiküldetéseknek, azok mindig egy konkrét feladatra irányultak csak.

Mindez elvezet minket a nádori közgyülések másik előképéhez, a királyi általános gyülésekhez. Önmagában már az is feltűnő, ha csak az elnevezést vizsgáljuk meg. Generalis congregatiot az országban először csak a király tartott az 1250-es évektől kezdve. Majd az 1270-es évek elejétől fogva a nádor és a szlavón bán, később az erdélyi vajda is, míg a 14. század első felére - igaz, külön királyi, esetleg nádori parancsra - már a megyék is tarthattak saját maguk részére ilyen gyülést. Mindez azt sugalja, hogy az intézmény „lefelé tágult”, vagyis ezen fórum lefolytatásának a joga és szokása az évek előrehaladtával egyre inkább lehetővé vált az alsóbb közigazgatási szinteken is, és így az „ősforrást” a királynál kell keresnünk, de a kérdés természetesen nem ilyen egyszerü. Az elnevezés azonossága ugyanis még nem garantálja az intézményi kontinuitást is egyben. Ha azonban megvizsgáljuk a korai királyi generalis congregatiok funkcióját, egy érdekes dolgot fedezhetünk fel. IV. Béla először 1254-1255 folyamán hírdette meg közgyülését Vácra három megye (Nógrád, Hont és Gömör) számára. A közgyülés tárgya a megyei birtokügyek rendezése volt. ${ }^{881}$ Ezen congregatio tehát érdemben nem különbözött azoktól a bárókra ruházott feladatoktól, amelyek többnyire szintén a tatárjárás után összekuszálódott birtokviszonyokat rendezték. Az 1260-as években István ifjabb király is tartott generalis congregatiot az országrésze számára,

\footnotetext{
${ }^{879}$ Zsoldos 2003. 798. Igaz, ő még inkább a Váradi Regesztrumban olvasható udvarbírói (országbírói) ítélkezési sorozattal tekintette inkább rokonnak az oklevél szövegének hibás kiadása miatt, amely a „prelatus et iudex curie” formában írta le Benedek intitulációját, miközben az eredetiben „palatinus et iudex curie” áll, lásd DL 577., ill. Függelék, C-regeszta.

${ }^{880} \mathrm{Az}$ 1267-1268. évi birtokfelülvizsgálatokra részletesen lásd Szücs 1984. 376-378.; ill. itt a „4.2 - A regionális nádorság kezdete" c. alfejezetet. Az természetesen nem biztos teljesen, hogy Benedek tevékenysége része is volt ennek az 1268. évi birtokfelülvizsgálatnak, amelynek hatása az idősebb király országrészéből így István országfelébe is átszivárgott volna, mert ez ellen fel lehetne hozni érveket (lásd a 4.2-es fejezetet), csak arra az általánosabb párhuzamra utaltunk, hogy egy báró király általi „kiküldése” bevett szokás volt a korban.

${ }^{881}$ S. Kiss 1971. 13-15.
} 
ám annak fő témája már teljesen más volt: a gonosztevők elítélése. Az eset 1263-ban történt, amikor István Borsod, Újvár, Zemplén, Heves és Gömör megyék nemesei és mindenféle állapotú lakosai részvételével (per nobiles ... et alios cuiuslibet condicionis homines de parochia de Borsod, de Novo Castro, de Zemlyn, de Heves et de Gumur) rendezett congregatiot, amelyen a megyék lakosai (többek között) Marcell fiait törvénybe idézték lopás vétségében. ${ }^{882} \mathrm{~A}$ gyűlés a későbbi nádori közgyülések ismert sajátosságait mutatta. De István nem csak maga rendezett igazságszolgáltató közgyüléseket, hanem báróit is megbízta ugyanezzel 1268 októberében. Az itt oklevelet kiadó Benedek nádor a következőképpen írta le az előzményeket: „amikor Besenyő faluban voltunk a Szűz Mária sziget [Margitsziget] mellett Szent Mihály arkangyal tizenötöd napján [okt. 13.], és más társaimmal, ti. Gergely esztergomi préposttal, Scela fia Mihállyal, Szakállas Lőrinccel, Ethenad fia Benedekkel, Ruhman fia Jánossal és az ország más nemeseivel, akiket urunk, István király és az ő országa közös ítélkezésre a mondott szigetre rendelt az egész ország ügyei kapcsán, törvényt ültünk". ${ }^{883}$ A szöveg megfogalmazásából egyértelműen kitetszik, hogy István maga nem volt jelen, csak egyes nemeseket bízott meg azzal, hogy a nevében „közös ítélkezést” (commune iudicium) tartsanak. Ebbe a tendenciába kapcsolódhatott bele Benedek már tárgyalt Pest megyei megbízása is, aki a birtokviszonyok rendezése mellett a gonosztevők elítélését is feladatául kapta. Az ilyen típusú felülvizsgálatok és törvénykezések gyakori jellemzője volt, hogy a kiküldött kihangsúlyozta, hogy ö a király parancsára, vagy egyenesen a nevében (vice $s u i)^{884}$ jár el, vagyis a végrehajtott intézkedések nem az éppen akkor viselt hivatali jogköréhez tartoztak. Ennek a hangsúlyozása ugyan Benedek Pest megyei kiküldetéséről szóló oklevelében elmaradt, de arra semmiképpen nem gondolhatunk, hogy az elidegenített földek számbavétele az udvarbírói vagy a nádori jogkör szerves része lett volna, így itt is biztosan egy eseti megbízásról volt szó. Az 1270-es évek legelejére tehát már megjelent mindaz, ami a nádori közgyűléseket jellemzi majd 1273 után: egyfelől a király által vezetett intézmény elnevezése és keretei (ítélkező gyülés egyes megyék, régiók részére), másfelől az, hogy a nádor és más bárók is tarthattak ítélkező gyüléseket a király külön parancsára. 1273-ig még nem futott össze e két szál, azaz ezeket a bárói ítélkező gyüléseket addig nem nevezték congregationak, közgyülésnek. Elviekben nem zárhatjuk ki, hogy nem királyi közgyülést már

\footnotetext{
${ }^{882}$ HO VIII. 93-94., S. Kiss 1971. 18-19.

883 „cum nos essemus in villa Beseneu iuxta insulam beatissime virginis Marie, in quindenis sancti Michaelis archangeli, et cum ceteris sociis nostris, qui a domino nostro rege Stephano et a regno suo ad commune iudicium ad predictam insulam super facto tocius regni fuerant deputati, videlicet magistro Gregorio preposito Strigoniensi, Nycholao comite filio Scela, Laurencio barbato, Benedicto filio Ethenad, et Johanne filio Ruhman, ac aliis nobilibus regni, pro tribunali sedissemus" HOkl. 54. (vö. RP 144. sz.)

${ }^{884}$ 1254: UB I. 247. (RP 97. sz.)
} 
korábban is tartottak. Amikor V. István egy 1270. évi oklevelében arról írt, hogy a királyi jogok helyreállítása céljából Vas megyének congregatiot tartott, és másokat az ország más részeire küldött ugyanezen célból, ${ }^{885}$ akkor azok az emberei a kiadott okleveleikben (ha voltak ilyenek) szintén használhatták a maguk gyülésére ezt a szót. Akár Mojs nádor is köztük lehetett, de egyrészt ezt forrásszerűen nem lehet igazolni, másrészt pedig itt nem a későbbi nádori közgyülések klasszikus témájával, a megyei igazságszolgáltatással találkozunk, hanem a várföldek helyzetének átvizsgálásával, amelyre már számtalan példát láthattunk korábbról is. ${ }^{886}$ Mivel jó okunk van feltételezni, hogy az ítélkező nádori és báni közgyülések tartását egy konkrét esemény váltotta ki 1272 után, így erősen valószínü, hogy tényleg nem csak a forráshiány az oka, hogy 1273 előtt nem ismerünk egyetlen ilyen alkalmat sem.

Ezt a konkrét kiváltó eseményt Zsoldos Attila rekonstruálta. Észrevette, hogy a megyei szolgabírói intézmény, a nádori, továbbá a báni közgyülések tartása egyaránt 1273-ból mutatható ki biztos érvénnyel elsőként, és mindez egybeesett azzal az időszakkal, amikor fia kiskorúságának idején Erzsébet anyakirályné szinte „régensi” hatalmat gyakorolt. Elképzelése szerint a királyné hatalmát csökkentő törekvések hozták létre a vidéki bíráskodás eme fórumait, amit ugyan ideiglenesnek szántak, ám végül állandósult. Erzsébet előtt pedig azzal legitimálták mindezt, hogy volt férje, V. István király politikai örökségének állították be az újításokat. ${ }^{887}$ Ezek után került sor arra, hogy V. István megbízható embere, Péc nembéli Dénes a Zala megyei gonosztevők elítélésébe fogjon László király parancsára.

Hogy ezt az intézményt kezdetben ideiglenesnek szánták, megerősíti az is, amelyre már Tringli István is felfigyelt. Nevezetesen, hogy a közgyülések említésekor mindig kiemelték, hogy a nádor királyi parancsra, az ő felhatalmazásából járt el. Tringli szerint csak a 14. század első felében alakult ki az a szokás, hogy a nádor (és vele párhuzamosan a bán és a vajda) saját elhatározásból is tarthatott közgyülést. ${ }^{888}$ A 14. század helyett ugyan az 1290-es évek elejére lehet tenni a saját jogkörüknél fogva tartott nádori congregatiok kezdetét, ${ }^{889}$ de ez Tringli

\footnotetext{
885 ,peragratis quibusdam partibus regni nostri, ad alias vero propter iurium regalium reformationem iudicibus transmissis, ad Castrum Ferreum venissemus, in congregacione, quam ibidem de nobilibus jobagionibus castri, castrensibus, et aliis incolis eiusdem provincie, facta primitus proclamatione, preceperamus convocari” UB I. 383. (RA 2048. sz.)

${ }^{886}$ Ezen 1270. évi (és későbbi, V. István alatti) birtokrestaurációs gyülésekre lásd még Kis 2010. 166-167.

${ }^{887}$ Zsoldos 2003. 791-803.

${ }^{888}$ Tringli 1997. 390.

${ }^{889}$ Ahol kiemelik a királyi felhatalmazást: 1273: ÁÚO IX. 38-40. (RP 162. sz.), 1278: CD V/2. 477-478. (RP 192. sz.), 1279: UB II. 126. (RP 195. sz.), 1286: CD V/3. 333-334. (RP 226. sz.). Az átmenetre utal, hogy Henrik fia János nádor 1288. évi Vas megyének tartott közgyülését egyik oklevelében a király akaratából megtartottnak mondta (Bándi 1987. 124., RP 234. sz.), másik oklevele szerint „,minden Vas megyei nemes és más állapotú ember akaratából” (de voluntate omnium nobilium et aliorum cuiuslibet condicionis hominum
} 
megállapításának lényegén mit sem változtat. A kezdetekre nézve beszédes Máté fia Máté 1278. évi oklevele, amelyben leírta, hogy amikor őt a király a báróinak egyetértésével és tanácsára nádorrá, illetve somogyi, soproni és bányai ispánná emelte, helyettesévé rendelvén (vices suas committens) elküldte öt az ország megyéibe (districtus), hogy fellépjen a tolvajok, latrok és más gonosztevők ellen, és intézkedjen a nemesek, várjobbágyok, egyházak, udvarnokok és más emberek elidegenített, elpusztított, vagy csak jogtalanul birtokolt földjei ügyében, hogy visszaállítsa azokat mindenkinek a saját jogába. ${ }^{890}$ A szöveg külön kiemeli, hogy a király nem nádori, vagy éppen megyésispáni minőségben küldte el öt a megyékbe (pedig az oklevél közelebbről egy Somogy megyei congragatioról szól, és ő somogyi ispán is volt!), hanem vice sui, vagyis a maga képében. Mindez arra utal, hogy ezen congregatiokra nem úgy tekintettek a kortársak, mint amelyek egy korábbi nádori vagy akár udvarispáni jogkör szerves részét képezték, és annak folytatásai. Egy olyan, eredendően királyi intézményként tekintettek rá, amelyet ott és akkor éppen a nádor gyakorolt.

Az 1273. évi első nádori közgyüléssel (amit esetleg néhány másik, ma már nem dokumentálható közgyülés követett vagy megelőzött) még nem szilárdult meg a nádori generalis congregatio intézménye. Mindezt jól illusztrálja, és vélhetően nem pusztán a forráshiánynak kell betudnunk, hogy 1273 után öt évig egyáltalán nincs tudomásunk nádori közgyülésröl, aztán 1278-1279 folyamán rögtön hármat is ismerünk. Az elsőt az a Péc nembéli Dénes tartotta, akihez a legelső, 1273. évi közgyűlést is köthetjük, míg a másik kettőt Csák nembéli Máté, és okleveleinek narrációjából kiderül, hogy a közgyülések az akkor meginduló országos konszolidációs program részét képezték, amelynek éppen Máté nádor volt az egyik fontos oszlopa. ${ }^{891}$ A konszolidációs kísérlet kudarca után ismét hosszabb szünet állt be, majd 1286-ban Aba nembéli Makjám, IV. László híve ${ }^{892}$ a király utasítására tartott Zemplén megyében közgyülést. ${ }^{893}$ Mindezekkel párhuzamosan IV. László is tartott még ítélkező congregatiokat kisebb régiók számára (pl. a konszolidációs program részeként 1278 vagy 1279 folyamán bizonyos kelet-magyarországi hét megye számára, vagy 1282-ben

comitatus de Castri Ferrei UB II. 207., RP 231. sz.) tartotta. Innentől kezdve a királyra nem történik utalás, lásd 1295: DL 96039., RP 266. sz.; 1298: Zichy I. 89., RP 282. sz.; 1299: ÁÚO XII. 635-637., RP 292. sz.; DL 96042-96043., HO VIII. 397-398., RP 302-304. sz. Egy 1278. évi nádori közgyülés esetén (ÁÚO IX. 48-49., RP 185. sz.) ugyan szintén nincs utalás a királyra, ám ott a szövegkörnyezet sem kívánta ezt meg, mert csak mellékesen említették az eseményt az oklevélben, nem egy ott kiadott ítéletlevélről van szó. Az 1290 körüli határvonalat III. András 1290. évi dekrétuma szentesítette (14. tc., DRMH I/1. 45.), amely már magától értetődőnek vette a nádor megyékbe kivonuló bíráskodását.

${ }^{890} \mathrm{CD} \mathrm{V/2.} \mathrm{477.} \mathrm{(RP} \mathrm{192.} \mathrm{sz.)}$

${ }^{891}$ 1278: ÁÚO IX. 48-49. (RP 185. sz.); CD V/2. 477-47. (RP 192. sz.); 1279: UB II. 126. (RP 195. sz.)

892 Szücs 1993. 316.

${ }^{893}$ CD V/3. 333-334. (RP 226. sz.) 
Szeged mellett), ${ }^{894}$ ám a királyi gyűlések egyre inkább országos szintű ügyeket kezdtek tárgyalni, amelyeket már joggal nevezhetünk az első országgyüléseknek. ${ }^{895}$ László király uralmának utolsó szakaszában, 1288 júniusában Héder nembéli János Vas megyei közgyüléseiről maradtak még fent adatok (rövid idő alatt hármat is tartott a megyében). Ekkor már megtörtént a véglegesnek mondható szakítás a király és az egyházi, meg javarészt a világi elitje között. ${ }^{896}$ A nádor és a király közti politikai távolság egyik szembetűnő jelének mondhatjuk, hogy a Vas megyei közgyülésekről szóló okleveleinek az egyikén a megszokott királyi parancsra történő hivatkozás szerepel, ám egy másikon már „minden Vas megyei nemes és más állapotú ember" akaratára hivatkozott. ${ }^{897}$ (A harmadik közgyülésekről tudósító oklevélben a nádor nem nevezte meg a kezdeményező félt.) ${ }^{898}$ Ez az első olyan ismert példa még ha az uralkodóval szembeni politikai dac szülte is -, amikor már a saját jogán közgyülést tartó nádorral szembesülünk. Az, hogy ugyanazon eseményt az egyik nádori oklevél a király akaratának, a másik oklevél viszont már egy, a megyei lakosok kérésén nyugvó nádori kezdeményezésnek tudja be, jól mutatja, hogy ekkor még korántsem volt magától értetődő a királyi akarattól független generalis congregatio szokása. De ezt a IV. László-kori állapotot aztán gyorsan szentesítette III. András uralma, aki az uralkodása kezdetén törvényeröre emelte az 1273. évi közigazgatási „reformcsomag” mindkét részét. Egyfelől ugyanis előírta az 1273-ban megjelenő szolgabírói intézmény létét a megyékben, ${ }^{899}$ másrészt törvénycikk szólt a nádori megyei közgyülésekről is. Ez utóbbi kimondta: „ha a nádor az országunkban az igazság szolgáltatására indul, minden megyében négy kiküldött bíró és a megyei ispán tartoznak vele menni és bíráskodni”. ${ }^{900}$ Inenntől kezdve a generalis congragatiok kapcsán már nem esik többet szó arról, hogy a király parancsára vagy engedélyével történt volna. Vagyis a nádori közgyülés kialakulását itt, az 1290. évi törvényekkel tekinthetjük lezártnak, amikor az 1273 utáni átmeneti korszak után (amikor a nádor „hivatalosan” még csak a királyi jogkört kapta meg egy-egy konkrét alkalomra) a közgyüléseket saját jogán, a nádori intézmény részeként celebrálhatta.

Összefoglalva tehát: úgy véljük, hogy a nádori (és báni, később a vajdai) általános gyülések előképét nem kell a 13. század első feléig, a Váradi Regesztrumban előforduló

\footnotetext{
${ }^{894}$ S. Kiss 1971. 33-34., 39-40.

${ }^{895}$ Gerics 1987. 279-281.

${ }^{896}$ Szücs 1993. 318-320.

${ }^{897}$ „,de voluntate omnium nobilium et aliorum cuiuslibet condicionis hominum comitatus de Castri Ferrei” (UB II. 207., RP 231. sz.). A királyi akaratra történő hivatkozás: Bándi 1987. 124. (RP 234. sz.)

${ }^{898}$ UB III. 285. (RP 230. sz.)

${ }^{899}$ Zsoldos 2003. 805-807., vö. DRMH I/1. 44.

${ }^{900}$ DRMH I/1. 45. Magyarul: Szöveggyüjtemény 286.
} 
1220-1222. évi, a serviensek számára tartott ítélkezés-sorozatig visszavezetni. Tény, hogy az ottani modell igen hasonló a későbbi nádori generalis congregatio intézményéhez, ám az egy rövid életü, gyorsan elhaló újító próbálkozás volt csak II. András részéről, és nem mutatható ki, hogy lett volna bármiféle kontinuitás a húszas évek, és az ötven évvel későbbi időszak között. A gyülések előképét a magunk részéről egyfelől egy olyan szokásban keressük, amely már korábban is előfordult, de az 1240-es évektől terjedt el igazán. Eszerint a király különféle feladatokkal küldte ki a báróit bizonyos megyékbe, hogy az ő nevében intézkedjenek. Ezek a feladatok rendszerint a királyi vagyon (várbirtokok, udvarnokföldek, udvarnokok hovatartozásának) felülvizsgálatát jelentették, és kezdetben sosem volt általános értelemben vett igazságszolgáltatási funkciójuk. István ifjabb király esetében jelent meg speciális feladatként az ítélkezésre kiküldött bíró. Benedek ifjabb királyi nádor és udvarbíró - azzal, hogy a Pest megyei gonosztevők kihírdetése volt az egyik feladata 1268 körül - már egészen közel került a nádori közgyülések modelljéhez, bár a kérdéses terminus technicust még nem használta. Ezzel párhuzamosan alakult ki a király által tartott generalis congregatio szokása is az 1250-es évektől kezdve. Ezek feladatköre tulajdonképpen azonos volt a kiküldött bárók feladataival, csak éppen több megye, vagy egy nagyobb régió számára tartották a király és a helyi lakosok részvételével. IV. Béla alatt így birtokrevíziós kérdéseket intéztek, míg István ifjabb király alatt megjelent az első ítélkező congregatio is. A három territoriális nagybíró (nádor, szlavón bán, erdélyi vajda) által tartott közgyülés elnevezése a királyi congregatiok intézményéből származott. A nagybírói közgyűlések létrejötte egy konkrét időponthoz, 1273hoz köthető, és bizonyára igaza lehet Zsoldos Attilának abban, hogy azért adták át ideiglenesen a generalis congregatio tartásának jogát a nádornak és a bánnak, hogy ezzel is gyengítsék Erzsébet királyné régensi hatalmát. Hogy a nádor és a bán (majd valamivel később a vajda) nem egy saját jogán folytatott intézményt „örökölt meg” korábbról, hanem a királyi congregatiok jogát ruházták át rájuk, azt nem csak a latin terminológiai egyezés mutatja, hanem az is, hogy kezdetben mindig külön kiemelték, hogy a közgyülést királyi parancsra, királyi jogon, vagy egyenesen a király nevében tartják. Ez a saját jogon folytatott közgyülések esetében nem így lett volna. Így a nádori generalis congregatio véleményünk szerint kezdetben nem volt más, mint a király által folytatott közgyülés intézményének ideiglenes, kifejezetten néhány konkrét alkalomra szóló átruházása a nagybírára, amely átruházást az tette lehetővé, hogy a nádor már az 1260-as években is ellátott hasonló feladatokat királyi parancsra. A IV. László alatt ideiglenesnek szánt újítást aztán később is megtartották, és az 1290-es évek legelejére beépült a nádori jogkörbe. 


\section{2 - A nádori generalis congregatio intézménye 1290-1343 között}

A megelőző fejezetekben már elég részletesen tárgyaltuk a nádori közgyülések egyes nádorok alatti jellemzőit, illetve azon területeket, amelyekre kiterjedt a nádori jogkör ebből a szempontból, így most csak egy rövid összefoglalást adunk a korábbi fejezetek alapján, néhány általános jellemzővel kiegészítve.

Törvényben elöször a már fentebb említett 1290. évi szabályozásban szóltak a nádori közgyülésről, ebben kimondták, hogy a megyébe érkező nádor mellé a megyésispán és a 4 szolgabíró csatlakozzon bírótársként. ${ }^{901}$ Ezt egészítette ki az 1298. évi törvény a következővel: „Azt is elrendeltük, hogy a nádor táborban megszállván, a mezőkön és gyüléseken, nem pedig falvakban és városokban ítélkezzék, [éspedig] ... tavaszi, nyári és őszi, nem pedig téli [időszakban]". ${ }^{902}$ A törvény tehát attól tiltotta el a nádort (és kíséretét), hogy a gyüléseket tartva egy adott településen megszálljon, nem kevés vagyont felélve. A törvénynek lassan lehetett foganatja, mert már 1298. október 6-án Roland nádor „Gáva falu közelében” (prope villam Gewa) tartotta közgyülését. Emellett Roland Borsod megyei és Amadé Zemplén megyei közgyülései szintén a nyári és őszi hónapokra estek, igaz, ezeket a nádorok „,in villa Edelin” és „,in villa Lelez” celebrálták. ${ }^{903}$ A 14. században aztán hol kitették a település határában való táborozást jelentő apud vagy prope prepozíciókat a településnév mellé, hol nem (csak a keltezéskor megszokott in prepozíciót használva), de erősen valószínű, hogy a legtöbbször valójában a határában tartották az eseményt. A téli hónapok tilalmának betartására már biztosabb adataink vannak. Kopasz esetében még csak az éppen határesetet jelentő november végi nádori közgyülésekre vannak adatok, ${ }^{904}$ de Debreceni Dózsa ${ }^{905}$ és Druget Fülöp ${ }^{906}$ esetében egyszer-egyszer előfordultak januári gyülések is. Druget János pedig egy alkalommal a Pest megyei gyülést február hónapban tartotta. ${ }^{907}$ Ezen ritkának és egyedinek nevezhető esetek kivételével azonban a nádori közgyülések március és május közötti hónapokban indultak, és októberben, vagy legkésőbb november első felében lezárultak. Mindebben nyilván nem az 1298. évi törvény szövegének, hanem a praktikumnak volt nagyobb szerepe. Az 1320-as évekre alakult ki az a szokás is, hogy a nádor, a megyei

\footnotetext{
${ }^{901}$ DRMH I/1. 45. Magyarul: Szöveggyüjtemény 286.

${ }^{902}$ DRMH I/1. 52. Magyarul:Szöveggyüjtemény 296.

${ }^{903}$ Gáva: Zichy I. 89. (RP 282. sz.); Edelény: ÁÚO XII. 637-638. (RP 293. sz.); Lelesz: DL 96042. (kiadása: RP 302. sz.)

${ }^{904}$ Pl.: Kopasz nádor (1313. nov. 18.): AOkl III. 631., (1314. nov. 22.): AOkl III. 849.

905 1322. jan. 9-16.: AOkl VI. 406-408., 411. sz.

${ }^{906}$ 1323. jan. 18-21.: AOkl VII. 13-14., 19. sz.

${ }^{907}$ 1330. febr. 26-27.: AOkl XIV. 107. sz.
} 
alispán vagy ispán és a szolgabírák mellé a helyi nemesek közül 12 esküdtet rendeltek ítélőtársul, akiknek a kiválasztása a megyei nemesség joga volt. ${ }^{908}$

Bár, mint az előző fejezetben szó volt róla, a nádori közgyülések intézménye 1273-tól már létezett, és celebrálásuk 1290 után hivatalosan is nádori jognak számított, jelentősége az Árpád-kor folyamán egyáltalán nem mondható nagynak. Ugyanez igaz a 14. század első évtizedére is. Az 1273 és 1313 közötti 40 évből összesen 13 nádori közgyülésről van csak tudomásunk. ${ }^{909}$ Hogy ez mennyire kevés, jól érzékelteti, hogy például alig huszonnyolc évvel később, 1341-ben Druget Vilmos nádor csak abban az egyetlen évben 18 közgyülést tartott. ${ }^{910}$ 1343-ban az utódja, Zsámboki Miklós 17-et. ${ }^{911}$ Az említett Árpád-kori törvények (1290, 1298), és az egyes oklevélnarrációk is azt sugallják, hogy egy rendszeres, sorozatban akár több megyére is kiterjedő módon mehetett a közgyülések tartása. A konkrét források viszont akkor is eltérő képet sugallnak, ha azok jelentős pusztulásával is kell számolni. Az 1273 utáni negyven év congregatioinak száma már önmagában is kevés ahhoz, hogy rendszeres gyakorlatnak véljük, de külön feltünő, hogy a nádor legtöbbször olyan megyékben tünt fel, amelyekhez valamilyen más módon is köze volt. 1278-ban Dénes úgy tartott Somogy megyének közgyülést, hogy a megye ispánja is volt egyben. ${ }^{912}$ Csák nembéli Máté 1278-ban Somogyban, 1279-ben Sopronban hívott össze ilyen gyülést, és mindkét oklevelében

\footnotetext{
${ }^{908}$ A 12 esküdtre az első adat: 1324. máj. 23.: AOkl VIII. 273. sz. A kiválasztásuk módjáról Domonkos macsói bán 1339. nov. 28-i oklevele (AOkl XXIII. 717. sz.) tájékoztat, miszerint az ö Baranya megyei közgyülésének esküdtjeit „a nádori közgyülés szokása szeint” a megyei nemesek jelölték ki mellé bírótársként (cum ... iuratis assessoribus per universitatem nobilium eiusdem comitatus pro causis quibuslibet iudicario deliberandis nobis in socios, iuxta morem congregationis palatinatus, deputatis): DF 261637. Az esküdtekre lásd még Istványi 1939. 69.

909 1273: Zala megye számára Péc nb. Dénes (ÁÚO IX. 38-40.; RP 162. sz.); 1278: Kaposon, Somogy megyének szintén Péc nb. Dénes (ÁÚO IX. 48-49.; RP 185. sz.); 1278: Somogy megyének Csák nb. Máté fia Máté (CD V/2. 477-478.; RP 192. sz.); 1279: Sopronban, Sopron megyének szintén Csák nb. Máté (UB II. 126.; RP 195. sz.); 1286: Zemplén megyének Aba nb. Makján (CD V/3. 333-334.; RP 226. sz.); 1288. jún. 19.: Szombathelyen Vas megyének Héder nb. János (UB III. 285., UB II. 207-208., Bándi 1987. 124.; RP 230., 231., 234. sz.); 1295. szept. 7.: Szatmár és Szabolcs megyének a Szatmár megyei Szalkán Aba nb. Amadé (DL 96039.; RP 266. sz.); 1298. okt. 6.: Gáván, Szabolcs megyének Rátót nb. Leusták fia Roland (Zichy I. 89.; RP 282. sz.); 1299: Borsod megye számára szintén Rátót nb. Roland (ÁÚO XII. 635-637., 637-638.; RP 292-293. sz.); 1299. nov. 4.: Leleszen, Zemplén megyének Aba nb. Amadé (DL 96042-96043., HO VIII. 397-398.; RP 302-304. sz.); 1306. febr. 7.: Zaránd megyének Zarándon Borsa nb. Kopasz (AOkl II. 13. sz.); 1309. okt. 18 -án Tapolcsányban Csák Máté - vélhetően nem egy megye, hanem az egész tartománya számára (AOkl II. 758. sz.); 1313. nov. 18-án Bihar megyének Váradelőhegyen Borsa nb. Kopasz (AOkl III. 631. sz.)

${ }^{910}$ Felsorolásukat lásd Kruták 2012. 432.

${ }^{911}$ Igaz, ezek egy részét az alnádora tartotta a nádor nevében, vele párhuzamosan. A következő megyékről tudunk: Fejér, Somogy, Tolna, Bodrog, Valkó, Bihar és Kraszna, Szabolcs és Bereg, Zemplén és Ung, Bodrog, Gömör és Torna, Abaújvár és Sáros, Hevesújvár, Szepes, Nógrád, Hont, Pozsony, Komárom. Tételesen lásd: AOk1 XXVII. 307., 310., 319., 350-351., 398., 453-454., 459., 605., 609-610., 613-614., 620-621., 631., 636., 654-655., 657., 663., 689., 696., 707., 728., 739., 776. sz.

${ }^{912}$ Archont. 1000-1301. 21.
} 
általánosságban is szólt arról, hogy a király az egész országra (per totum suum regnum) ${ }^{913}$ kiterjesztette fennhatóságát, és most éppen Somogy vagy Sopron megyébe ért. ${ }^{914}$ Mindebből akár az 1330-as évektől jellemzővé váló ,láncközgyülésekre” is következtethetnénk, ám a megfogalmazás formulaszerüségének gyanúját veti fel, hogy Máté somogyi és soproni (és bányai) ispán volt ekkor, ${ }^{915}$ és pont erről a két megyéről maradt fent oklevél is, semmi másról. A későbbiek folyamán pedig az „oligarcha-nádorok” generalis congregatioi a saját territóriumukra terjedt csak ki. Az Aba nemzetséghez tartozó nádorok esetében ez az ország északkeleti megyéit jelentette. ${ }^{916}$ Héder nb. János egyetlen nádori közgyülése szintén abban a Vas megyében volt 1288-ban, amely a nemzetségük közpotja volt. ${ }^{917}$ Tegyük hozzá: sem az Abák, sem a Kőszegiek (Héder nembéliek) esetében nem a legszükebb nemzetségi központban volt a közgyülés, ebből a szempontból tehát tényleg „vidéki” bíráskodás volt még ha nem is kellett túl messzire menniük. Rátót nb. Leusták fia Roland famíliája szintén birtokos volt Borsod és Szaboles megyékben, ahol Roland congregatiokat tartott, ${ }^{918}$ de befolyásuk korántsem volt akkora a területre, mint amekkora az Abák vagy a Kőszegiek esetében fennállt. Borsa nembéli Kopasz Zaránd és Bihar megyei gyülései éppúgy a nádor legszükebb hatalmi körzetében voltak, ${ }^{919}$ mint az örökös nádori címet viselő Csák Máté congregatioja, aki a tartományi ügyeit rendezte ilyen módon. ${ }^{920}$ Bár az, hogy a közgyüléseik határa nem lépte túl a nádorok szűkebb uralmi körzeteinek határait, önmagában nem meglepő, de hogy ebből az időszakból ennyire kevés ilyen bíráskodó gyülésről tudunk, mindenképpen arra utal, hogy ez az intézmény nem képviselt komoly súlyt az Árpád-korban és az azt követő évtizedben, amely időszak egyébként is az Árpád-kor öröksége volt a nádorság története szempontjából.

\footnotetext{
${ }^{913}$ UB II. 126. (RP 195. sz.)

914 „cum... praesertim in Comitatu Symighiensi essemus” CD V/2. 477. (RP 192. sz.); „cum ad comitatum Suprvniensem accessissemus" UB II. 126. (RP 195. sz.)

${ }^{915}$ Archont. 1000-1301. 21.

${ }^{916}$ Aba nb. Makján Zemplén megyének, Amadé Zemplén, Szabolcs és Szatmár megyéknek. Az Abák hatalma 1311-ben Szabolcs és Zemplén megyéket biztosan magába foglalta (Kristó 1973. 75.), Szatmár megye már kissé kiesik ebböl, de azt a congregatiot Szabolcs megyével közösen, „páros” közgyülésként tartotta Amadé, akinek a szükebb nádori vonzáskörzete biztosan kiterjedt erre a megyére is, mint ez ítéletleveleiből látszik.

${ }^{917}$ Lásd pl. Karácsonyi 1900. 598-605.; Zsoldos 201b. 653-654.

${ }^{918}$ Karácsonyi 1900. 926-927.

${ }^{919}$ Kopasz uralmi körzete leginkább e két megyére terjedt ki, lásd példákkal a „4.4. - I. Károly első nádorai - az »oligarchikus nádorság« öröksége” c. alfejezetet. Egyébként valószínü, hogy Zaránd megye ispánja is volt, lásd Zsoldos 2011b. 63. 122. jz.

${ }^{920}$ Minderre az utal, hogy Máté később is ezen a településen tartott közgyülést, ahol egyébként Trencsény mellett szintén egy jelentősebb rezidenciát épített ki magának (Kristó 2001. 36.), és a Trencsén megyei Trencsényböl halasztott egy ügyet a Nyitra megyei tapolcsányi congregatiora (AOkl II. 758. sz.), amely eszerint nem csak a szükebb megye ügyeivel foglalkozott.
} 
Az 1310-es évek második felétől kezdett a közgyülés intézménye fontosabb bíráskodási és döntéshozói fórummá válni. Ez nem jelentette automatikusan a nádori gyülések számának hirtelen emelkedését (bár egy idő múlva természetesen ez is a folyamat egyik eredménye lett), inkább csak a közgyüléseket tartók körének a bővülését. Az 1310-1320-as évek hozták el a nádor nélküli közgyülések virágkorát. Egyrészt ekkortól kezdődtek a kizárólagosan a megyei személyzet által lefolytatott congregatiok. Ezeket Kristó Gyula az ekkor fennálló „feudális anarchia” egyik jelének tekintette, mivel szerinte a megyésispánok királyi felhatalmazás nélkül rendezték meg ezeket, és miután Károly konszolidálta hatalmát, visszaálltak a nádori közgyülések. ${ }^{921}$ Bár Kristó végkövetkeztetése mindenképpen helyes (ti. hogy a károlyi konszolidáció idején egyre inkább előtérbe kerültek a nádori gyülések), magunk úgy véljük, hogy a megye által rendezett közgyüléseket a király felhatalmazásából tartották, és legalább két csoportját különíthetjük el. Az egyik esetben egy konkrét királyi parancsra összehívott gyűlésről volt szó. Például 1313-ban Károly egy földbirtoklási eset kivizsgálását kérte Bereg megye négy szolgabírájától, a megye összes nemesétől és várjobbágyától (quatuor iudicibus nobilium, ac universis nobilibus et iobagionibus castri de comitatu de Bereg). ${ }^{922}$ A megye ennek a vizsgálatnak a lebonyolítására hívta össze az általuk congregatio generalisnak nevezett megyei gyülést, végül jelentették a királynak az eredményt. ${ }^{923}$ Ennél jóval érdekesebbek azok az esetek, amikor - látszólag - nem volt szó külön királyi kérésről. Mihály újvári ispán és a megye 4 szolgabírája a megyének 1312. december 21-én Forrón congregatio generalist tartott, és nem említették a királyi meghatalmazást. ${ }^{924} 1314$ májusában ugyancsak a négy megyei szolgabíróval tartott Mihály ispán közgyülést, királyi parancsot itt sem említve. ${ }^{925}$ Ugyanakkor nehezen lenne elképzelhető, hogy egy 1311 óta már stabilan a király ellenőrzése alatt lévő megyében egy, a király által odahelyezett ispán ${ }^{926}$ Károly ellenében rendezett volna ilyen gyüléseket. Az 1310-es évek második felétől jelentek meg a király által megbízott bírák is, akik egy adott régió felett átfogóbb uralommal is rendelkeztek, amely rendszerint szintén a közgyülések tartásában nyilvánult meg. ${ }^{927}$ Az Újvár megyei esetek leginkább ezen kiküldött bírói intézmény egyfajta „előfutárát” jelentik, hiszen - Zsoldos

\footnotetext{
${ }^{921}$ Kristó 2003b. 173.

${ }^{922}$ DL 105777. (AOkl III. 593. sz.)

${ }^{923}$ AOkl III. 594. sz.

${ }^{924}$ HO VII. 369. (AOkl III. 410. sz.)

${ }^{925}$ AO I. 344. (AOkl III. 751. sz.)

${ }^{926}$ Engel 1988. 99-100. Mihály egyébként 1312-ben tünt fel elöször, és 1315-ben még hivatalában volt (Archont. 1301-1457. 94.) - Károly tehát jól láthatóan nem tekintette „renitens” vidéknek ezt a megyét és tisztikarát.

${ }^{927}$ Zsoldos 2011b. 53-64.
} 
Attila kutatásai szerint - ezek a kiküldött bírák rendszerint egy-egy volt tartományúr territóriuma feletti igazgatási jogokat kapták meg, hogy azt a területi egységet még egy ideig együtt kormányozhassák. Abaúj megye pedig Amadé halála után, 1311-ben került Károly kezére. ${ }^{928}$ Ekkor még nem létezett a „kiküldött bíró” intézménye, de egy 1314 augusztusában kiadott oklevélben már úgy írták körül Mihály titulusát, hogy abból arra is következtethetnénk, hogy valamikor 1314 nyarán megkapta ezt a címet. ${ }^{929}$ Így Mihály 1314 előtti felhatalmazása a kiküldött bírói tisztség megszületése előtti időszakra világít rá, amikor Károly a megye ispánját már felruházta olyan jogokkal, amelyek a közgyülések összehívását és lefolytatását is magában foglalták, hasonlóan a vármegye előző urának, Amadé nádornak a jogaihoz.

Az említett kiküldött bírák mellett mások is tartottak közgyüléseket a megyéknek ebben az időben. Zólyomi Doncs mester 1317. április 29-i liptói congregatioja például biztosan nem illeszthető be a kiküldött bírói intézmény keretei közé (Doncs sem használta magára e titulust). ${ }^{930}$ Emellett úgy tűnik, hogy a soproni, vasi és zalai ispánságot kezében tartó Kőszegi András 1314 júniusában meghírdetett Vas és Zala megyei generalis congregatioi ${ }^{931}$ tényleg csak egy uralkodójával dacoló tartományúr megnyilvánulásai voltak, hiszen a viszony éppen ez év első felében mérgesedett el alaposabban a király és a Kőszegiek között. ${ }^{932} 1321-1322$ folyamán is előfordult, hogy a király a megyésispánt bízza meg azzal, hogy a megyében közgyülést folytasson le. ${ }^{933}$ Mivel ezek a példák nyugat-felvidéki és dunántúli megyék esetében jelentkeztek, életre hívásukat nyugodtan magyarázhatjuk azzal, hogy a keleti súlyponttal, vagy éppen semmilyen konkrét vonzáskörzettel nem rendelkező nádorok (Domonkos, Dózsa) fennhatósága nem terjedt ki erre a vidékre.

A kiküldött bírók intézménye kissé visszább szorult azzal, hogy Druget Fülöp nádori vonzáskörzete teljesen lefedte Abák, és részben a Borsák tartományát, így ott már maga a nádor hívhatta össze a megyéknek a gyűléseket. ${ }^{934}$ Ám ha kellett, speciális esetben szintén

\footnotetext{
${ }^{928}$ Engel 1988. 99-100.

${ }^{929}$ Lásd Zsoldos 2011b. 60. ill. uo. 101. jz.

${ }^{930}$ AOkl IV. 446. sz. Doncs biztosan nem a király ellenében tartotta, mert nem sokkal később az itt magát még csak magisternek tituláló Doncsot Károly Liptó megye ispánjává nevezte ki (Archont. 1301-1457. 150.).

${ }^{931}$ AOkl III. 765., 771-772. sz.

${ }^{932}$ Engel 1988. 107-108.

933 1321. máj. 2.: Veszprém m. (AOkl VI. 113. sz.); 1322. ápr. 19.: Trencsény m. (AOkl VI. 531. sz.); 1322 májusa után Kőszegi András is közgyülést tartott Vas megyének (AOkl VI. 555. sz.), ekkor már vlsz. királyi jóváhagyással tette, hiszen 1321-ben Károly személyesen tette meg őt vasi ispánnak rokona, Kőszegi „Kakas” Miklós ellenében (Engel 1988. 130.; Zsoldos 2010b. 661.); 1322. júl. 24.: Somogy m. (AOkl VI. 703. sz.).

934 Fülöp a következő megyéknek tartott congregatiot: Abaúj, Borsod, Gömör, Szabolcs, Bereg, Ugocsa, Szatmár, Ung és Bihar. A részletese adatokat lásd a „4.5 - A Druget-nádorok” c. alfejezetben.
} 
„elővették” e hivatalt. Ilyen alkalom adódott akkor, amikor a nádori szék éppen üresedésben volt, vagy amikor Druget Vilmos kormányozta a Druget-tartományt, amíg apja a nádori címet viselte. Ekkor Vilmost szintén felruházták annak a jogával, hogy a tartományi megyékben közgyüléseket tarthasson. ${ }^{935} \mathrm{~A}$ harmadik speciális eset a macsói bánok által honorként bírt megyék kérdése volt. Itt alapvetően a nádornak volt joga közgyüléseket tartani, ám ha a bánra akarták ezt átruházni, akkor ő is megkaphatta a kiküldött bírói címet. ${ }^{936}$ Ezek után azonban lényegében megszünt ez az ideiglenes felhatalmazás. Helyette a nádori generalis congregatiok határai tágultak ki. A budai alnádora révén már Druget Fülöp is rendezett közgyülést a nádori körzetének határain túl. ${ }^{937}$ Ám az első olyan nádor, aki személyesen is tartott egyszerre a keleti és nyugati megyék számára ítélkező gyülést, Druget János volt. ${ }^{938}$ Fia, Druget Vilmos alatt pedig az ország északi felének jelentős részét lefedték már a nádori közgyülések. ${ }^{939}$ Ekkor alakul ki az a Zsámboki Miklós alatt is jellemző szokás, hogy a nádor föként kétévente, páratlan években indul a generalis congregatio tartására. Druget Vilmos alatt megfigyelhető az is, hogy a nádori kúriában már a nádor távollétében is adtak ki oklevelet az ő nevében, ám a közgyüléseket Vilmos mindig személyesen celebrálta (vagy albírája révén, de akkor az albíró oklevele nem a nádor, hanem a saját nevében került kiadásra). ${ }^{940}$ Ugyan felmerülhet néhány szorosabb időpont kapcsán, hogy Vilmos nádor nem mindenhol lehetett személyesen jelen, de rendszerszerü módon először Zsámboki Miklós 1343. évi közgyülés-sorozata alatt mutatható ki az, hogy ő és alnádora párhuzamosan rendezték a generalis congregatiokat egy adott régióban a megyéknek, és mindketten a nádor nevében kibocsátott okleveleket adtak ki (László alnádor azonban a saját pecsétjével pecsételte meg azokat). ${ }^{941}$ Ekkor találkozunk először azzal, hogy már nem csak a nádori kúria müködése, de a megyei közgyülések intézménye is elszakadt a nádor kötelező személyes jelenlététől. Mindemellett I. Lajos korát nyugodtan nevezhetjük a nádori generalis congregatiok fénykornak is.

\footnotetext{
${ }^{935}$ Az üresedésre lásd: Zsoldos 2011b. 61-62. Druget Vilmos ezen speciális felhatalmazására a János nádorsága alatti időszakból: Zsoldos $2012 \mathrm{a}$.

${ }^{936}$ Zsoldos 2011b. 60-61.; ill. lásd még az „,5.1 - A földrajzi határok” c. alfejezetet.

937 1325: AOkl IX. 442. sz.; 490-492. sz.

${ }^{938}$ Közgyüléseinek felsorolását lásd Zsoldos 2012c. 531.; ill. itt, a „4.5 - A Druget-nádorok” c. alfejezetben.

${ }^{939}$ Ezek felsorolását lásd Kruták 2012.; ill. itt, a „4.5 - A Druget-nádorok” c. alfejezetben.

${ }^{940}$ Erre a példát lásd 1335: AOkl XIX. 479. sz.

${ }^{941}$ Minderre, részletesen adatolva, lásd a „4.6 - A nádori kúria Visegrádra költözése” c. alfejezetet.
} 


\section{7 - A NÁdOR MINT AZ ALÁVETETT NÉPELEMEK BÍRÁJA}

Ebben a fejezetben a nádori intézmény egy igen archaikusnak mondható elemével foglalkozunk. Bizonyos jogi és etnikai csoportokat ugyanis már az Árpád-kor legkorábbi szakaszától kezdve a nádorispán fősége alá rendeltek. Egyrészt a királyi udvarszervezet népei, az udvarnokok tartoztak ide, másrészt a besenyők. A 13. század 70-es éveitől kezdve aztán a nádor elkezdte viselni a „kunok bírája” titulust is. Az udvarnokok feletti főhatalma már a királyi udvarszervezet felbomlását megelőző időkben megszűnt, és a 14. században már semmilyen kapcsolat nem mutatható ki a nádor és az udvarnokok között. A besenyők feletti hatalomnak vannak ugyan nyomai az Anjou-kor idején, amely aztán éppúgy elenyészett, mint különálló etnikumként maguk a besenyők. Egyedül a „kunok bírája” cím viselése élte túl a középkort a nádorok esetében (kibővülve a ,jászok bírája” címmel), ám, mint látni fogjuk, ennek a titulusnak már kezdettől fogva kicsi volt gyakorlati jelentősége - a vizsgált korszakban lényegében semmilyen kapcsolatot nem lehet kimutatni a kunok és a mindenkori nádorispán között.

\section{1 - Az udvarnokok feletti joghatóság}

A tisztség kialakulását tárgyaló fejezetben már történtek utalások arra, hogy a királyi udvarszervezethez tartozó udvarnokoknak ${ }^{942}$ a főbírája a nádor volt. A nádor és az udvarnokok kapcsolatáról már a legelső nádorispánra vonatkozó szabályozás, az ún. Lászlóféle III. törvénykönyv 3. cikkelye is szót ejt, a következőket írva: „Ameddig pedig ugyanez az ispán [ti. a nádorispán] odahaza marad, senkire se küldjön pecsétet, kizárólag csak azokra, akiket udvornic-nak neveznek, és akik saját akaratukból mennek hozzá: az ilyen fölött legyen szabad bíráskodnia." ${ }^{943}$ A törvényből világosan kitetszik, hogy a nádor királyi udvaron kívüli bírói hatalma csak az azt önként felvállalókra, és az udvarnokokra terjedt ki, tehát az udvarszervezet népei feletti főhatalom nem a király személyének helyettesítéséből, hanem közvetlenül nádorispáni mivoltából eredt. Bár mindebből látszik, hogy egy igen archaikus eleme ez a nádori hivatalnak, nem teljesen egyértelmü, hogy pontosan mikortól eredeztethetjük. Az egyetlen olyan középkori hagyomány, amely szól erről, Kézai Simon

\footnotetext{
${ }^{942}$ A királyi udvarszervezet átfogó történetére lásd legújabban: Kis 2010. (a korábbi szakirodalmat is feltüntetve) 943 „Domi vero comes idem quamdiu manserit, super neminem sigillum mittat, nisi super eos dumtaxat, qui vocantur udornic et qui spontanea voluntate iverint ad eum, illi ei liceat iudicare.” Závodszky 1904. 174. Magyarul: ÍFMT 89. (Körmendi Tamás ford.)
} 
gestája, biztosan téved. Kézai az alávetett népelemek eredetére is választ akart találni. Szerinte az udvarnokok eredetileg idegen foglyok voltak, akiket az ország előkelöi a saját szolgálatukra rendeltek. Ám Kálmán eltörölte ezt a fajta szolgálatot, mert azt akarta, hogy csak neki és a püspököknek legyenek udvarnokai. „És hogy a nemesek közössége - írta Kézai - ne nehezményezze az ilyesféle tilalmat, az ország nádorának, akit a nemesek érdekében

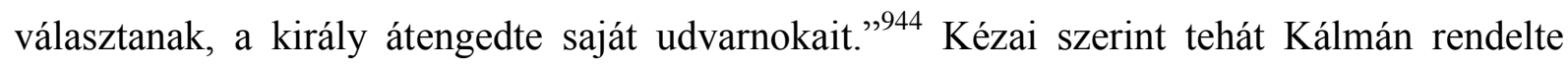
volna nádori hatáskörbe az udvarnokokat, ezáltal a felettük való bíráskodást. Ennek hamis voltát László törvénye igazolja: már akkor is a nádor volt az udvarnokok bírája. A királyi szolgálónépi szervezetet legújabban áttekintő Kis Péter úgy véli, hogy „ha a történetnek nem is adhatunk hitelt, Könyves Kálmán uralkodásának kora és László törvényének keletkezése nincs távol egymástól, legalábbis az 1280-as évekből nézve, ezért lehetségesnek tartjuk, hogy a nádor nem Szent István alatt, hanem csak később lett az udvarnokok főbírája."945 Kis itt vélhetően arra célzott, hogy ha a nádorispán László korában kapta meg ezt a jogkört, akkor ez Kézai idejében már összemosódhatott Kálmán uralkodásával. A gond ezzel nem csak az, hogy László III. törvénykönyve (vagy annak egyes részei) talán nem is László alatt keletkeztek, hanem korábban, ${ }^{946}$ de föként, hogy e cikkely nem arra volt „kihegyezve”, hogy az udvarnokok föbírája ezentúl legyen a nádorispán, hanem a királyi pecsétnek a királyi udvarban tartására. Az udvarnokok feletti bíráskodási jogkör csak egy mellékes és - úgy tünik - magától értetődő elemként szerepel. Abban viszont biztosan igaza van Kisnek, hogy az udvarnok réteg feletti jogkört nem feltétlen datálhatjuk Istvántól. A szent király második törvénykönyvének utolsó cikkelye (amely a lopást elkövető udvarnokok feletti bíráskodásról szól) sajnos nem mérvadó ez ügyben. ${ }^{947}$ Ennek ellenére természetesen lehet, és logikusan is hangzana, hogy a királyi udvarszervezet már István korától fogva a nádor alá volt rendelve, ám erre, mint hangsúlyoztuk, semmilyen konkrét bizonyíték nincsen.

\footnotetext{
944 „Et ne communitas nobilium reprobationem huiusmodi grave ferret, palatino regni, qui pro utilitate nobilium praeficitur, rex suos udvornicos úti dedit.” SRH I. 193. Magyarul: MCS 123. (Bollók János ford.)

${ }^{945}$ Kis 2010. 28. 98. jz.

${ }^{946}$ Lásd ÍFMT 85.

${ }^{947}$ Györffy György utalt rá, hogy az udvarnokok kivételezett helyzetéről még ebben a cikkelyben (Istv. II/21.) nincs szó, de a század végén László törvénye alapján már a nádor ítélkezett felettük (Györffy 1977. 204.). István eme törvénycikkelyében az áll, hogy a lopást elkövető udvarnokokat a ,szabadok törvénye szerint ítéljék el” (Závodszky 1904. 156. vö: ÁKÍF 77.). Eszerint tehát még nem a nádori bíráskodás vonatkozott volna az udvarnokokra. Ám - mint arra Gerics József rámutatott Bolla Ilona nyomán - ez a szövegváltozat csak a későközépkori kódexekben maradt fent, az István törvényeit megőrző legkorábbi, 12. századi Admonti-kódexben csak annyi található: „törvény szerint ítéljék el” („lege diiudicentur”): Gerics 1988. 91., ill. 94. 5. jz. A cikkely tehát csak azt mondta ki, hogy az udvarnokokra is a törvénykönyvben már korábban lefektetett szabályozás vonatkozik lopás esetén. Ezekben nem esik szó a bírói fórumról, csak a büntetésről, így ez a törvény a nádor udvarnokok feletti joghatóságának a kérdésében közvetve sem mérvadó.
} 
Az viszont bizonyos, hogy ez a jogkör egészen a 13. századig fennmaradt. Barc fia Miklós 1221-ben kiadott, eredetiben ránk maradt egyik oklevele a következő alapvetéssel kezdődik: „Jóllehet a hivatalunkhoz a királyi udvarnokok földjének bárminemü jogtalanságtól való megvédése és az [illő] helyzetébe való visszahelyezése tartozik, mégis, a király parancsára" az esztergomi udvarnokok és az esztergomi káptalan közti peres üggyel foglalkozik. ${ }^{948}$ Ezt a bevezetőt akként értelmezhetjük, hogy csak a királyi udvarnokokkal kapcsolatos ügyek tartoztak a nádorispán hivatalához, az egyháziaké nem, de külön királyi parancsra mégis az esztergomi egyház és az egyházi udvarnokok közti vitában döntött. Arra már a 12. századból is találunk példákat, hogy a nádor egy adott egyházi intézmény és a szolgálatára rendelt udvarnokok közti perben bíráskodjon. ${ }^{949}$ Ezekben az esetekben is mindig kiemelték, hogy a király akaratából került a per a nádor színe elé, ám ennek vélhetően nem az volt az oka, hogy a királyi udvarnokok feletti joghatósága miatt az egyházi udvarnokok perét is a nádornak utalta ki az uralkodó. Ezekben az esetekben ugyanis a nádor mindig bírótársakkal ítélt (a bakonybéli monostor perénél 5 másik előkelővel egyetemben, amelyek közül nem is a nádor volt a főbíró, a veszprémi egyház 1152. évi perénél pedig - a nádorral együtt - öt, az 1184. évinél pedig három kijelölt bíró járt el). Ezen ügyeket tehát a nádor mint a királyi udvar egyik főembere kapta meg. ${ }^{950}$ A 13 . században azonban több olyan adatunk is van, amely a nádor és a királyi udvarnokok kapcsolatát világítja meg. ${ }^{951}$ Bár az ismert nádori ítéletek és esetek többségében nem szerepelnek udvarnokok semmilyen formában, ennek az is lehetett az oka, hogy az ilyen perekről ritkábban születtek oklevelek. A 14. században aztán már nem rendelkezünk olyan forrással, amely közvetlenül igazolhatná a nádorispán udvarnokok feletti főségét ${ }^{952}$ - az „oligarcha-nádorok” idején ez a funkció érthető módon háttérbe szorult, és később sem támasztották fel.

A nádor és az udvarnokok feletti joghatóság annyira összefonódott, hogy nem egyszer az egyházak és a nekik alávetett szolgáltatónépek közötti perben is a nádort kérték föl az ítélkezésre, vagy a felkért király a nádorhoz továbbította az esetet. ${ }^{953}$

\footnotetext{
948 „Licet ad nostrum pertineret officium odornicorum regis terram, quocumque iniusto modo distractam, in statum reformare; de mandato tamen domini regis...” MES I. 231. (RP 11. sz.)

${ }^{949}$ A bakonybéli monostor és Opus udvarnokispán közötti per (1131 k.): CAH 48. (RA 57. sz.); a veszprémi egyház és Somogy megyei szolgái közti per (1152): CAH 61. (RA 81. sz.); az esztergomi királyi udvarnokok és a tihanyi egyház közötti per (1184): CAH 90.

${ }^{950}$ Kis 2010. 29.

${ }^{951}$ Ezeket részletesen felsorolja: Kis 2010. 30-35.

${ }^{952} \mathrm{Kis} 2010.35$.

${ }^{953}$ Ilyen az első ismert nádori ítéletlevél is: PRT I. 645-646. (RP 6. sz.).
} 
Hogy a nádor a királyi várszervezet egyes elemei felett is bírt joghatósággal, arra csak egy nagyon bizonytalan adatból lehetne következtetni. Imre király 1204-ben kiváltságokat adott az erdélyi szászok között élő „latin” (minden bizonnyal: itáliai) Jánosnak, többek között „azt is megengedjük neki, hogy senkinek ne legyen köteles a színe elé állani, kivéve minket és azt, aki a mi jobbágyainknak fiait ítéli meg". ${ }^{954}$ II. András 1206-ban megújította bátyja két évvel korábban tett adományát, köztük azt is, hogy „a pereskedésekkor semmilyen bíró színe elé ne kelljen járulniuk, kivéve a királyi felség és a nádorispán [színe elé]" ${ }^{955}$ Hogy András e téren nem változtatott a kiváltság milyenségén, azt azon sorai mutatják, amely szerint „ugyanazt a szabadságot” (eandem libertatem) adta Jánosnak, amit az Imrétől is kapott. Mivel 1204 és 1206 között nem telt el olyan sok idö, hogy a viszonyok teljesen megváltozzanak, ezért Váczy Péter joggal feltételezhette, hogy a 13. század legelején a nádor volt a királyi jobbágyok (fiainak) bírája. ${ }^{956}$ Tegyük hozzá: Váczy a ,jobbágyok fiai” kifejezést félreértelmezve előkelőket értett alatta, azt feltételezve, hogy a nádor a megyésispánok bírája volt. A ,jobbágy” szónak tényleg volt „elökelő" értelme is a korban, ${ }^{957}$ de a ,jobbágyfiú” kifejezést sosem az előkelők, hanem a királyi várszervezet várjobbágyai kapcsán használták. A ,jobbágyfiú” pontos viszonya a ,jobbágyi” réteghez bizonytalan, a várjobbágyság korai kutatói egy külön társadalmi státuszt láttak benne, míg legújabban Zsoldos Attila arra jutott, hogy ,a iobagio és a filius iobagionum kifejezések között a lényeget érintő jelentésbeli különbség nem volt." ${ }^{958}$ Az oklevélszöveg helyes értelmezése szerint tehát a várjobbágyok bírája lett volna a nádor a 13. század legelején, ám ennek feltételezése annyiból furcsa, hogy (13. századi adatok alapján) a várjobbágyok fölött a várispánnak is volt joghatósága, sőt, ez a joghatóság olyan erős volt, hogy amikor a király vagy a nádor előtt vonták a jobbágyokat perbe, ők sokszor továbbadták a pereket az általuk illetékesebbnek tartott ispánoknak. ${ }^{959}$ Ennek ellenére vannak adataink arra, hogy a várjobbágyok ügyében a nádor bíráskodott, úgy a Váradi Regesztrumbó1, ${ }^{960}$ mint más forrásokból, ${ }^{961}$ de ez önmagában még nem kellene, hogy valami kiemelt joghatóságra utaljon, hiszen a nádor általános bírói jogkörének a kereteibe is belefért az, hogy néha a várjobbágyok ügyében is ítélkezzen. Könnyen lehet, hogy a két

\footnotetext{
954 „Concessimus eciam ei, ut ante alium iudicem preter nos, vel illum qui iudicat filios hyobagionum nostrorum nullatenus cogatur in aliquo respondere.” ÁÚO I. 92. (RA 210. sz.)

955 „in placito ad nullius iudicis adstet presensiam preter Regie Maiestatis et Comitis Palatini” ÁÚO XI. 84. (RA 223. sz.)

${ }^{956}$ Váczy 1938. 59.

${ }^{957}$ Szilágyi 1937. 19-20. (böségesen adatolva); KMTL 304. (Engel Pál szócikke)

${ }^{958}$ Zsoldos 1999. 36-37.

${ }^{959}$ Zsoldos 1999. 15-16.

${ }^{960}$ RV 62. sz. (1213); 97., 103. sz. (1214); 275. sz. (1220)

${ }^{961}$ Ezeket lásd Zsoldos 1999. 16. 32. jz.
} 
idézett kiváltság mégsem pont ugyanazt takarja, és az első inkább azt jelenti: János csak a király és az ispánok (vagyis akik a jobbágyok fiait megítélik) előtt köteles megjelenni (pl. a gyakran ispánok helyett ítélkező udvarispán előtt nem), míg II. András emelt ezen a kiváltságon. Az is lehet, hogy a nádori hivatalnak a 12-13. század fordulóján mégis volt valami laza köze a várjobbágysághoz, de az tény, hogy a 13. századra ennek nem maradt olyan egyértelmü nyoma, mint az udvarnokok esetében.

\section{2 - A besenyők}

A nádornak egészen biztosan volt különhatalma egyes etnikai csoportok felett is. Az egyik ilyen etnikum a besenyő volt. A kulcsadat, amelyből a nádori hivatal besenyők feletti joghatóságára szokás következtetni, Kán nembéli Gyula nádor 1224. évi oklevele, amelyben szabályozta az árpási besenyők jogait. Az oklevél szerint „,az árpási besenyők hozzánk, azaz a nádorhoz tartozván színünk elé járultak...". ${ }^{962}$ Tegyük hozzá: az oklevélben a nádor kifejezetten csak az árpási besenyőket (Bisseni de Arpas) mondta hozzá tartozónak, amely Árpás település az Árpád-korban Sopron megyébe esett, ${ }^{963}$ és Gyula nádor soproni ispán is volt egyben, ${ }^{964}$ így mindez akár egy adott ispánnak a megyéjében lakó besenyők feletti joghatóságára is utalhatna. Ám a szöveg egyrészt a nádori hivatalt emlete ki (ad nos, videlicet ad palatinum jogába tartoztak a besenyők), ráadásul az Árpád-korból több adatot is találunk, amely a nádor és a besenyők közti kapcsolatra utal, ha nem is ennyire egyértelmű módon. Kérdéses azonban, hogy a nádor fősége az összes magyarországi besenyőre kiterjedt-e. Többen is felhívták arra a figyelmet, hogy a besenyők már a 11. századtól kezdve eltérő jogállással rendelkeztek, ${ }^{965}$ és az 1060-as évek végére, 1070-es évek elejére tehető (hagyományosan 1067-re keltezett) százdi oklevélben is azt találjuk, hogy a monostor alapítója, Péter comes 30 lovasszolgát: 20 magyart és 10 besenyőt adományozott a százdi monostornak. ${ }^{966}$ Mivel ezekkel a besenyőkkel egy magánember rendelkezett, ezek a nem szabad státuszú besenyők biztosan nem álltak a nádor fősége alatt. Pálóczi Horvát András egyenesen úgy vélte, hogy csak a „királyi birtokon letelepített, kollektív szabadságot (libertas

\footnotetext{
962 „Bisseni de Arpas ad nos, videlicet ad palatinum pertinentes, ad nostrum accedentes presentiam...”. Györffy 1990. 127. (RP 16. sz.)

${ }^{963}$ Györffy 1990. 127. vö. Kniezsa 1937. 331. 14. jz., aki külön kiemelte, hogy Árpás Győr megyébe esett.

${ }^{964}$ Archont. 1000-1301. 18.

${ }^{965}$ Kniezsa 1937. 328. 12.jz.; Kordé 1990. 10-16.; Pálóczi 1996. 16.

966 „XXX equites: XX Vngari et [X] Bisseni” DHA I. 184. Az oklevél keltezési idejére lásd DHA I. 182. 1.jz.
} 
Bissenorum) élvező besenyők" tartoztak közvetlenül a nádor fennhatósága alá. ${ }^{967}$ Tegyük hozzá: úgy tünik, hogy még az ilyesfajta kiváltságokat birtokló az árpási besenyők sem közvetlenül voltak a nádor alá rendelve, hiszen az 1224. évi oklevélből az is kiderül, hogy a nádor a besenyők ispánját nevezi ki, és ő a közvetlen vezetőjük. Az ítélkezést pedig a besenyőispán udvarispánja (curialis comes) végzi, évente egyszer a körükben. ${ }^{968} \mathrm{Az}$ ö „szabadságuk” tehát nem rokonítható azokkal a 13. század eleji kiváltságokkal, amikor egy személyt vagy csoportot a király közvetlenül a saját és a nádor fennhatósága alá rendelt, kivéve őket a megyésispánok és udvarispánok bírói széke alól. ${ }^{969}$ A besenyők 1224-ben úgy hivatkoztak kiváltságaikra, mint amiket régtől fogva viselnek (libertas ab antiquo instituta), és bár vitattak egyes módosításokat, a nádor vagy a besenyőispán főségét nem.

A szakirodalomban az is felmerült, hogy a nádor nem csak strukturálisan, de katonai értelemben is a besenyők feje volt, és erre már egy, az árpási kiváltságlevélnél jóval régebbi adat is utalna. Az 1116. évi olšavai magyar-cseh összecsapás emléke mind a magyar krónikás hagyományban, mind Prágai Kozmánál megtalálható (és mindkét fél magának tudta be a győzelmet). A magyar krónika szerint a magyar sereg első vonalát képviselő székelyek és besenyők visszafutottak a királyi táborig, mire a királyi haderőben is pánik tört ki, ezért az ifjú király, II. István is menekülni kezdett. A csehek fosztogatni kezdték a tábort. „János azonban, Uros fia, a nádorispán a királytól messze táborozott. Ez, amikor meghallotta, hogy mi történt, csendben és feltünés nélkül fölfegyverezte a katonáit, és rajtuk ütött a cseheken, akik a tábort dúlták. És »összetörte az Úr« a cseheket a magyarok »kardja élén«, és szörnyü halálra sebezte őket. János hírnököt küldött a király után, és tudatta vele a győzelmet, amit az Úr adott neki. " ${ }^{970}$ A cseh krónikás szerint viszont a magyarok vereséget szenvedtek, és ő nem tudott a nádori (és semmilyen más egyéb) beavatkozásról. Szerinte mikor a cseh seregek István táborát dúlták, akkor a magyar sereg első részét alkotó „hospesek” ugyan megközelítették őket, de nem mertek támadni, és Istvánnal együtt közösen megfutottak. ${ }^{971}$ A küzdelmet leginkább a székelyek első írott forrásban való megjelenése miatt tartja számon a szakirodalom, emellett általánosnak mondható a vélemény, hogy itt a magyarok vereséget

\footnotetext{
${ }^{967}$ Pálóczi 1996. 16.

${ }^{968}$ A besenyőkiváltságok részletes elemzését lásd Kordé 1990. 17-20.

${ }^{969}$ Ilyen kiváltságokat kaptak pl. a pataki hospesek (1201): RA 194.; János (1204): RA 210. sz. (vö. 223. sz.); Adolf prépost (1209): RA 243. sz.

970 „Ianus vero filius Vrosa, palatinus comes longe descenderant [!] de rege. Qui cum audissent [!] silenter ac suaviter suos armaverunt [!] et impetum super Bohemos, qui castra devastabant, fecit. 'Contravitque Dominus' eos 'in ore gladii' Hungarorum et dire morti [!] sauciavit. Misitque Ianus post regem nuncium et manifestavit illi victoriam, quam Dominus sibi dederat.” SRH I. 436-437. Magyarul: Képes Krónika 100. (Bollók János ford.) ${ }^{971}$ CFH I. 807.
} 
szenvedtek, és János nádor beavatkozása csak utólagos szépítés. ${ }^{972}$ János nádorispán viszont kétségtelenül valós személy volt. ${ }^{973}$ Kordé Zoltán szerint az ellentmondás úgy oldható fel, hogy János valójában a besenyő és székely előhadak élén állott, amely had valóban sikereket ért el a csata első felében, így ő veretlenül hagyta el a csatateret. Ám a krónikás a székely és besenyő előhad nyakába akarta varrni a vereséget, ezért úgy állította be, mintha az ő megfutamodásuk vezetett volna II. István meneküléséhez. Az elégtételt a részsikereket elérō János nádor győzelmének felnagyításával adta meg a magyaroknak, a nádor mellett nem is említve a besenyő és székely csapatokat. Emellett - Kordé feltételezése szerint - a besenyők katonai vezetője általában véve is a nádor volt. ${ }^{974}$ A csata részletese története kapcsán sajnos csak történetírói kombinációkra vagyunk utalva, és a valóságot nem állapíthatjuk meg. Így tehát a nádor és a besenyők kapcsolatát sejtető legkorábbi adat számtalan nehézséggel terhelt, és véleményünk szerint még az sem egyértelmü, hogy János nádor ekkor tényleg a besenyő és székely csapatokat vezette volna hadba. Hiszen ehhez egyrészt az kell, hogy a magyar krónikás hagyományban olvasható esemény a magyar tábort dúló cseheken rajtaütő János nádorról, és a Prágai Kozmánál szereplő mozzanat a tábor dúlása közben a cseheket megközelítő (de végül meg nem támadó) hospesekről azonos eseményt takarjon. Továbbá, hogy ezek a hospesek a magyar krónikás hagyományban szereplő székelyekkel és besenyőkkel legyenek azonosak, miközben maga a krónika nem vont összefüggést ezen etnikumok és a János nádor vezette csapattest között. Azt a feltételezést, hogy a besenyők katonai feje általában véve a nádor, a véleményünk szerint ezen forrás alapján nem igazolhatjuk. Sőt, összesen egyetlen olyan adatunk van, amely egy ilyen kapcsolatra utalna. Az esztergomi káptalan 1291. évi okleveléből arról értesülünk, hogy Csák nembéli Máté fia Péter nádor erőszakkal elvette a csallóközi padányi nemes besenyők kiváltságlevelét, amelyet IV. Béla király adott nekik, és mások más okleveleiket, ezért a káptalan ezen nemesek kérésére újra átírta azokat. ${ }^{975} \mathrm{Az}$ eset valamikor 1275 és 1281 között történt, ${ }^{976}$ és a későbbi átírásból tudjuk, hogy Béla kiváltsága azt tartalmazta, hogy a felsorolt besenyőket, ,akiket

\footnotetext{
${ }^{972}$ A csatát elemzi és a szakirodalmat ismerteti: Kordé 1991. 18-21. Nemrég Szabados György ellentétes véleményt fogalmazott meg, magyar győzelemnek tekintve az eseményeket: Szabados 2007b. 484-486.

${ }^{973}$ Lásd hiteles oklevelek tanúnévsoraiból: DHA I. 357. (1108), 383. (1111), 396. (1113); Archont. 1000-1301. 15.

${ }^{974}$ Kordé 1990. 17.; Kordé 1991. 20-21.

975 „cum privilegium domini Belae regis per Petrum palatinum filium magistri Mathaei de generatione Chaak ... ipsis nobilibus invitis per violentiam sint recepta ..." CD VI/1. 172-173. (vö. DF 285429.)

976 Péter hivatali évei alapján, amelyet ezen idő alatt megszakításokkal viselt: Archont. 1000-1301. 21-22. Belitzky János 1275-re datálta mindezt, Karácsonyi János szövegének félreértelmezése alapján (ti. Karácsonyi Péter nádor hivatalba léptének első évét említette, majd kitért erre az ügyre is a szövegében. Ám ő nem utalt arra, hogy a kettő ugyanabban az évben történt volna, ez már Belitzky értelmezése volt): Belitzky 1937. 84-85.
} 
besenyőfiaknak neveznek" (qui filii Bissenorum dicuntur) az ország nemesei közé emelte a király, és senki mással, csak a királlyal tartoztak hadba vonulni (et nobiscum, et non cum aliquo exercituare teneantur). ${ }^{977}$ Felvethetnénk, hogy a hatalmaskodó Péter nádor ezt a hadbavonulási kiváltságot akarta semmissé tenni az oklevél elvételével, és visszaterelni a padányi besenyőket a saját katonai fösége alá. Ugyanakkor tegyük hozzá: a privilégium, amely országos nemessé tette a padányi besenyőket, minden más értelemben is kivette azokat a nádori fennhatóság alól a nádor-besenyő viszonylatban, amely önmagában is érthetővé tenné a jogaik lerontását, ebből az esetből nem kell feltétlen a katonai főséget kiolvasni. Emellett beszédes, hogy az Árpád-kor folyamán ezen az egyetlen, többféle magyarázatot is megengedő forráson kívül semmilyen nyom nincs arra nézve, hogy a nádor besenyő csapatokkal rendelkezett volna. A besenyők felől megközelítve, azt látjuk, hogy az olšavai csatához időben közeli 1146. évi Fischa menti csatában az elővédet alkotó besenyők és székelyek csapatának élén, Freisingi Ottó leírása szerint, egy-egy comes állt (hogy ők a besenyő- és székelyispánok voltak, vagy csak a külföldi krónikás általánosító szóhasználatával állunk szemben, nem tudni). A megfutó besenyőktől és székelyektől a magyar krónikás hagyomány határozottan megkülönböztette a magyarok csapatait, amelyek egyikét „a király úr nagybátyja, név szerint Belus bán” vezetett, nagy mészárlást víve véghez. ${ }^{978}$ Belos bán pedig ekkor már biztosan viselte a nádori címet is. ${ }^{979}$ Hadakozó nádor később is felbukkan a forrásokban. ${ }^{980}$ Ám az adatok ritka számából és esetlegességükből jól látható, hogy a nádornak általában véve nem voltak hivatalból adódó katonai feladatai, csak amennyire bárói mivoltából fakadó kötelessége és hadvezéri habitusa ezt megkívánta. A

\footnotetext{
${ }^{977}$ CD IV/3. 262. (RA 1464. sz.)

978 „avunculus domini regis, Bele ban nominatus” A csata leírása: SRH I. 456-457. A csatához lásd még Kordé 1991. 21-22.

${ }^{979}$ Archont. 1000-1301. 16., vö. RA 72. sz.

980 Belos bán és nádor máskor is vezetett hadat II. Géza idején. Egy bizonytalan kronológiájú, de legvalószínübben 1150 végére helyezhető hadjáratról Kinnamos írt (ÁMTBF 207-208. A hadjárat idejét Makk Ferenc tisztázta: Makk 1980. 45-48.). Ampod bán és nádor 1166-ban (esetleg 1167 elején) több seregtesttel is betört Dalmáciába, amelyröl szintén Kinnamos tudósított (ÁMTBF 240.). Ampod ezen kívül Leusták vajdával közösen harcolt bizánci csapatokkal együtt egy 1230. évi oklevél tudósítása szerint (HO VII. 20-21.) - a hadjáratot azzal az 1176-ban lezajlott szeldzsuk-törökök ellen vezetett hadjárattal szokás azonosítani, amelynek magyar segédcsapatairól Kinnamos is beszámolt (ÁMTBF 247.). Az orosz évkönyvek tanúsága szerint 1211-ben II. András Pot nádor vezetésével küldte hadait Halicsba (Hodinka 1916. 317.; ill. C. Tóth 2001. 66. vö. uo. 57.). A 13. századra a nádorispán katonai részvételéről szóló adatok megritkulnak. Az első ismert „hadakozó” nádor 1211 után Rogerius tudósítása arról a meg nem nevezett, de vélhetően Tomaj nb. Dénessel azonosítható nádorról, akit IV. Béla küldött az Orosz-kapu védelmére 1241-ben, hogy feltartóztassa a betörni készülő tatárokat (SRH II. 560-561.). Ezen kívül tudjuk még, hogy Roland nádor a teljes magyar nemességgel együtt részt vett az 1260. évi kroissenbrunni csatában (Pauler 1899. II. 235.), és az 1260-as évek belharcaiban is komoly szerep jutott a Bélát képviselő Héder nb. Henrik nádornak (Zsoldos 2007. 50-51., 69-70.). Az ez után következő időszak harcaiban résztvevő nádorok már inkább az oligarchikus ellentétek krónikájához tartoznak.
} 
nádor és a besenyők katonai jellegü közvetlen kapcsolatáról pedig egyik forrás sem szól. Ellenben tudjuk, hogy 1210 körül a besenyők egy részét a szebeni ispán vezette hadba. ${ }^{981}$ Véleményünk szerint tehát elviekben elképzelhető, hogy a nádor alá rendelt hadakozó besenyők a nádorispán katonai fösége alá is tartoztak, de arra nem találunk példát, hogy a nádor ténylegesen is hadba vezette volna öket - az 1116. évi olšavai csata kapcsán is csak feltételezésekre épített rekonstrukciók vezettek erre az eredményre.

A nádor besenyők feletti joghatósága viszont a 13. század folyamán még néhány alkalommal kimutatható. Uros pannonhalmi apátnak konfliktusa támadt a nagyhalomi besenyőkkel, miután azok megtagadták a monostornak járó bortizedet. Az apát egyenesen a pápánál tett panaszt, és III. Honorius 1218. november 23-i levelében arra szólította fel az esztergomi és a győri prépostot, továbbá a győri főesperest, hogy vizsgálják ki az ügyet. ${ }^{982}$ Ám az ítéletet nem a nevezett felek, hanem Barc fia Miklós nádor mondta ki, és II. András király erősítette meg 1221-ben. ${ }^{983}$ Hogy az ügy végül elötte kötött ki, talán nem volt független a nádori címétől, bár a nagyhalomi besenyők mellett a fehérvári latinok ügyében is ítélt Barc fia Miklós. Így könnyen lehet, hogy ez az eset csak általános nádori tekintélye folytán került hozzá, hiszen Uros apát előszeretettel vitt pannonhalmi pereket a nádor ítélőszéke elé. Tíz évvel később a besenyő földek ügyében Ampod fia Dénes nádor járt el akkor, amikor II. András fia hozzálátott az apja által tett, szerinte igazságtalan adományok felülvizsgálatához. A nádorral végeztették az elidegenített besenyő földek visszavételét (omnes terras Byssenorum alienatas revocaremus), ${ }^{984}$ és ez már inkább utal a nádori hivatal besenyők feletti joghatóságára, mint a pannonhalmi tizedper. Fentebb már említettük azt az 1275-1281 közé keltezhető esetet, amely szerint Csák nembéli Péter nádor erőszakkal elvette a padányi nemes besenyők kiváltságlevelét. Amennyiben nem egy más motivációjú hatalmaskodásról volt szó, a nádor itt is a besenyők feletti hatalmának helyreállítását remélhette ettől, hiszen a privilégiumuk szerint az országos nemessé emelkedett besenyők kikerültek ilyen jellegü fósége alól.

Ezen néhány gyér adaton kívül azonban nem sokat tudunk a nádor és a besenyők kapcsolatáról. Valószínű, hogy a fennhatóság mértéke egyébként is hullámzó lehetett a gyakorlatban, hiszen az „oligarcha-nádorok” fennhatósága a saját szükebb territóriumukra terjedt ki, nem valószínű, hogy pl. egy Aba nembéli Amadé sokat törődött volna a nyugat-

\footnotetext{
${ }^{981}$ Kordé 1990. 17. 51. jz.; Györffy 1990. 166.

${ }^{982}$ PRT I. 175. és 645.

${ }^{983}$ PRT I. 651-652.

${ }^{984}$ UB I. 161-162. (RP 32. sz.)
} 
magyarországi besenyő tömbökkel. A joghatóság azonban nem ment feledésbe az Anjoukorban sem. 1324-ben Druget Fülöp nádort kétszer is ,a kunok és besenyők bírája” (iudex Cumanorum et Byssenorum) címmel illették I. Károly oklevelének méltóságsorában. ${ }^{985}$ Érdekes, hogy e titulusa a királyi méltóságsorban csak ebben a kettő, március 23-i és május 14-i oklevélben tünik fel, sem az ezen időszak előtti, sem utáni, de még a két dátum közötti méltóságsorokban sem, ${ }^{986}$ és maga Fülöp nádor sem rakta ki intitulációjában soha. A két oklevélnek semmilyen közelebbi besenyő vonatkozása nincsen. A címet, úgy tűnik, a „kunok bírája” titulus mintájára alkották meg a kancellárián, mintegy annak bővítményeként. Emellett könnyen lehet, hogy Fülöp egyik hivatali elődje, Rátót nembéli Domonkos nádor is viselte ezt a titulust. Legalábbis ez következik abból, hogy Domonkos halála után, 1321-ben bizonyos ideiglenesen állított kiküldött bírák Pest, Esztergom és Fejér megyék mellett a besenyőispánság feletti jogkört is megkapták, és ez a terület lefedhette Domonkos honorjait. $^{987}$ Ekkor, 1321-ben hallunk először világos módon a „,besenyőispánságról” (comitatus Byssenorum). Hogy pontosan mikor jött létre, nem egyértelmü, így nem tudjuk, hogy mennyiben számolhatunk Árpád-kori előzményekkel. Az ispánság a Fejér és részben Tolna megye területére eső sármelléki besenyőket fogta össze. ${ }^{988}$ Egy 1300. évi oklevél fogott bírák között említi a Tolna megyei Kérről származó besenyők közé tartozó Theber comest, ám itt szinte biztosan csak általános rangjelző címről volt szó, nem a besenyőispánról. ${ }^{989} \mathrm{~A}$ besenyőispáni cím ráadásul korábban is létezett (mint láttuk, már 1224-ben, az árpási besenyők oklevelében is adatolható), ez nem feltételezi egy külön besenyőispánság meglétét. A 14. század folyamán mindenesetre csak az általa lefedett vidéken éltek besenyők nagyobb tömbben, ${ }^{990}$ és a besenyőispánság létrehozásának okát is leginkább ebben a tényben kereshetjük. A besenyőispánságról a legtöbbet az 1345 és 1352 közötti évekből tudunk, részben annak köszönhetően, hogy a besenyő eredetü Fáncsy család oklevelei ezen időszakból fennmaradtak a Seilern család levéltárában, Morvaországban. ${ }^{991}$ Ugyanakkor más forrásokban

\footnotetext{
985 AO II. 117., CD VIII/2. 511. (AOkl VIII. 123., 252. sz.).

${ }^{986}$ Lásd AOkl VIII. 317. p. Hatházi Gábor szerint 1328-ban Druget Vilmos nádor is viselte ugyanezt a címet (Hatházi 1996. 46.), de ezt biztosan elírásnak tudhatjuk be, egyébként ekkor nem is ő volt a nádor.

${ }^{987}$ Zsoldos 2012b. 48-49.

988 ÁMTF II. 337.; Györffy 1990. 123.; Hatházi 1990. 35-41.; Pálóczi 1996. 16.; Hatházi 1996. 45-46.; Kristó 2003a. 77-78.

989 A perben a veszprémi püspök és Demeter mester ,„per arbitrium proborum virorum, videlicet ... comitum Dominici de Saar, Petri filii Egus de Jutos et Theber de Keer in Bissenis...” egyeztek meg (CD IX/7. 729.). Kér falu azonosítása: Györffy 1990. 137.

${ }^{990}$ Lásd erről Györffy György gyüjtését, aki régiók szerint kilistázta a magyarországi besenyőkre vonatkozó okleveles adatokat: Györffy 1990. 123-167.

${ }^{991}$ Lásd ÁMTF II. 337.
} 
is előtérbe került a vidék és ispánja, így ezt az időszakot joggal tarthatjuk a megye „virágkorának”. 1346-tól egy bizonyos „Besenyő” Gergely (Georgius Byssenus), másként zsadányi János fia Gergely volt a besenyőispán. ${ }^{992}$ Gergely I. Károly hívének számított, a király többször is adományban részesítette hűséges szolgálatai miatt, máskor meg a király színe előtt pereskedett. ${ }^{993}$ 1344-ben még csak királyi emberként szerepel I. Lajos oklevelében, bármiféle titulus említése nélkül, 1345 decemberében azonban azt kérte Lajos királytól, hogy néhány Csanád megyei földet (amelyek történetesen Csanád esztergomi érsek öröklött birtokának számítottak), csatoljanak a besenyő földekhez, mivel azok „ősi szokás szerint hadakozni tartozó besenyőknek" (Byssenorum antiquo more exercituare debentium) a földjei. ${ }^{994}$ Csanád érsek rögtön panaszt tett a bácsi káptalan előtt, és a káptalani oklevél sem említette még Gergelynek semmilyen címét, de ő ekkor már a besenyők nevében járt el a király előtt, így nem lehetetlen, hogy kapott olyan rangot, amit a panaszt tevő érsek esetleg még nem ismert. 1346 februárjában már rector seu capitaneusnak, márciusban és májusban pusztán rectornak címezte önmagát egy-egy oklevelében. ${ }^{995}$ Végül 1346 november körüli levelében megjelent a comes Byssenorum titulusa, amely aztán egészen 1352. évi utolsó felbukkanásáig állandósult (illetve egy ízben a király a comes universorum Bissenorum, ,az összes besenyő ispánja" címmel látta el). ${ }^{996}$ Az 1346 folyamán ingadozó, majd megszilárduló terminológia sejtetni engedi, hogy tényleg ezen időpont körül kapta rangját. Az egy Csanád megyei vonatkozású eset kivételével saját jogán mindig a besenyőispánság területén járt el, és rendszerint 3 vagy 4 szolgabírával ítélkezett a megyei besenyők felett, továbbá a szolgabírákkal karöltve (tehát megyei hatóságként) adott ki oklevelet, sőt, még generalis congregatiot is tartott ,az összes besenyő közbenjárásával”. 997 A besenyőispánság tehát ekkor egy szabályos etnikai „nemesi megyeként” funkcionált. De hogyan viszonyult mindehhez a látszólagos önállósághoz a nádor? Kristó Gyula azt emelte ki, hogy a iudex Byssenorum titulus 1324. évi felbukkanását követően ,a nádor a besenyők elöljárójaként nem szerepel”. 998 Ez szoros értelemben véve igaz, mert erre utaló címzés tényleg nem bukkan fel sehol.

\footnotetext{
992 Gergelyre vonatkozó adatok: Györffy 1990. 131., 146-149., 157., 163.

993 1331: AOkl XV. 391. sz.; 1334: Györffy 1990. 140-141.; 1341: AOkl XXV. 412. sz.

${ }^{994}$ AO IV. 554.

${ }^{995}$ Györffy 1990. 131., 146-147.

996 Györffy 1990. 147-149., 157. A comes Byssenorum titulus valójában már Gergely egyik május 1-ji oklevelének tartalmi átírásában megjelenik (Zichy II. 245-246.), de ezt a megjelölést inkább annak kell betudnunk, hogy az oklevelet 1347 májusában átíró Miklós nádor már az akkor megszilárdult ispáni címén emlegette őt. Az átíró oklevél Gergely 1346. évi intitulációját nem tartalmazza szó szerint.

997 A megyei közgyűlésre lásd Gergely ispán egyik 1346. évi oklevelének tartalmi átírását: „in congregatione generali ipsius magistri Georgii Bysseni, de medio universorum Byssenorum exsurgendo” Zichy II. 245-246.

${ }^{998}$ Kristó 2003a. 78.
} 
Ugyanakkor azt is tapasztaljuk, hogy Gergely besenyőispán egyik ügye az ekkor hivatalban lévő Zsámboki Miklós nádor előtt kötött ki felsőbb hatóságként, igaz, nem automatikusan, hanem királyi parancsra. ${ }^{999}$ A per egyik résztvevője, Becsei Töttös királyi ajtónállómester (akit besenyő földek elfoglalásával vádoltak) Lajos belsőbb hívének számított, így több halasztást is kieszközölt a királytól, aki végül a nádor elé utalta a pert. Másfajta kapcsolat is kimutatható a besenyőispán és Miklós nádor között. Gergely 1349-ben többször is a nádor különféle nyugat-magyarországi közgyülésein bukkant fel, ahol egyfajta „társbíróként” volt jelen, külön besenyő vonatkozás nélkül. 1349. május 14-én Zsámboki Miklós Somogy megyei közgyülésén az egyházi ember mellé kiküldött embert ő delegálta, és itt a nádor oklevele öt „külön ehhez, a király helyébe rendelt királyi embernek” nevezte. ${ }^{1000}$ Jelenlétét, és az általa delegált besenyő származású kiküldöttet indokolhatná az, hogy a peres birtok (Telki, Somogy megye) szintén besenyő vonatkozású volt, és Gergelyt a király ezért állította társbíraként, ám ezen a közvetett forráson kívül besenyő lakóira nincs adat. ${ }^{1001}$ Bár Miklós nádor ugyanezen a közgyülésen kiadott másik oklevele nem tett Gergelyről említést, ${ }^{1002}$ annak külön megbízása nem csak erre az egyetlen esetre szólt. Nem sokkal később a nádor Pozsony megyei congregatioján is feltünt társbíróként, mert június 21-én Miklós Sáp birtokot „együtt Treutelnek mondott Miklós mester pozsonyi ispánnal, Gergely besenyőispánnal, nemkülönben az alispánnal, a Pozsony megyei szolgabírákkal és esküdtekkel, ülnökökkel és a többi nemessel” erősítette meg tulajdonosai birtokában. ${ }^{1003}$ Gergely jelenléte itt is „kakukktojásnak” tünik, mert Sáp birtok kapcsán sem ismerünk besenyőket, bár a tágabb régióban van róluk tudomásunk. ${ }^{1004}$ 1351-ben, egy Tolna megyei nádori közgyülésen pedig Gergely már az egyik peres, sőt, pervesztes félként jelent meg, aki felett a nádor ítélkezett. ${ }^{1005}$ Azzal pedig, hogy Gergely a besenyőknek saját maga tartott generalis congregatiot, elvileg egy nádori felségjogot gyakorolt, vele párhuzamosan. Igaz, ezt megtehette a nádor alárendeltjeként is, az ő külön parancsára.

Az adatokból úgy tünik, hogy zsadányi Gergely idején a besenyőispánság magasabb jogállást kapott. A már I. Károlyhoz is „bejáratos” Gergely 1345 decemberében is

\footnotetext{
999 Zichy II. 245-246. (AOk1 XXXI. 393. sz.)

1000 A fehérvári egyház rektora, Péter mester „cum Johanne Bysseno, per magistrum Gregorium comitem Byssenorum, hominem regium vice sue persone adhoc specialiter deputato" szállt ki a Somogy megyei Telki birtokra. DL 4040.

${ }^{1001}$ Györffy 1990. 148.

1002 1349. máj. 16.: DL 4041.

${ }^{1003}$ DL 3965. (vö. Györffy 1990. 148.)

${ }^{1004}$ Györffy 1990. 148., 155-158. Belitzky János a csallóközi Karcsa településeket is besenyő eredetűnek vélte (Belitzky 1937), ám ez a feltevés nem bizonyítható.

${ }^{1005}$ CD IX/2. 121-123. (vö. Györffy 1990. 148-149.)
} 
személyesen Lajos királynál próbálta kijárni egyes földek besenyő tulajdonba helyezését, ${ }^{1006}$ így elképzelhető, hogy az ő hivatali ideje alatt a besenyőispánság tényleg élvezett egyfajta autonómiát. De még ezen forrásokon keresztül is úgy tünik, hogy a nádor bizonyos főségétől nem tudott szabadulni. Mivel a nádor „besenyőbírói” szerepe leginkább egy fellebbezési fórum, illetve a besenyők és a magyarok közti konfliktus bírósága lehetett, Gergely ezért volt jelen a nádor közgyülésein, hogy az adott régió besenyőket érintő ügyeit rendezze (még ha az egyes esetek külön besenyő vonatkozásairól nem is tudunk), és Lajos is ezért tette át a nádor elé azt a pert, amit a besenyők még Gergely ispán színe előtt indítottak Becsei Töttös ellen.

Hogy nem csak az adatok téves interpretációjáról van szó, és a nádornak tényleg volt besenyőbírói szerepe 1324 után is, Druget Vilmos egy 1334. évi esete mutatja. Vilmos június 28-án kelt oklevelében megírta, hogy az előző napi közgyülésére rendelte el Besenyő Jakab két fiának proscribálását, ám elengedvén a bírságokat halasztász rendelt el, ezért felszólította a földvári konventet, hogy embere a konvent tanúságával idézze a színe elé a besenyők 4 nevezett esküdtjét (iuratos Byssenorum), akik a maguk és az összes besenyő nevében (tam pro se, quam pro omnibus Byssenis) kötelesek megjelenni a nádor elött besenyő Jakab fiai feletti ítélethozatalra. A július 5-i válaszlevelében a konvent közölte a nádorral, hogy az esküdteket egy kivételével megidézték a július 5-től számított tizenötödnapra. ${ }^{1007} \mathrm{~A}$ nádor tehát itt egy besenyő ügyet akart lezárni azok törvényes képviselőivel az oldalán, amely elég jól megfeleltethető egy magasabb szintü besenyőbírói tevékenységnek. Ugyan ezen kívül az egyébként igen sok oklevelet ránk hagyományozó Vilmostól nem ismerünk besenyő vonatkozású esetet, ám ezek a foghíjas adatok is elegendőek annak igazolására, hogy a nádor besenyők feletti joghatósága az 1320-as évektől kezve az 1350-es évekig végig fennállt. A kevés számú esetet leginkább azzal magyarázhatjuk, hogy a besenyő belügyeket a saját maguk közül megválasztott tisztviselőik rendezték el, és a nádor csak a legfőbb, vélhetően igen ritkán igénybe vett bírói fórum volt.

Bár már kívül esik az általunk tárgyalt korszak határain, még annyit érdemes megemlíteni, hogy a besenyők feletti joghatóság nem tartott sokáig. I. Lajos 1352 januárjában az összes Fejér megyei nemes besenyőt egyszerre országos nemesi rangra emelte, és a Fejér megyei ispán joghatósága alá helyezte őket. ${ }^{1008}$ Ezt a mozzanatot a besenyőispánság elsorvasztásának is tekinthetjük egyben, hiszen ha a nemes lakói a Fejér megyei hatóság alá

\footnotetext{
1006 AO IV. 554.

1007 DF 283264. Az okleveleket Györffy György is kiregesztázta (Györffy 1990. 141.), ám ott a konvent oklevelének keltezése, jelzete, továbbá a megadott határnap hibás.

${ }^{1008}$ Az oklevelet Zsigmond is megerősítette 1399-ben, innen ismerjük: ZsO I. 6208. sz., vö. Györffy 1990. 149.
} 
tartoznak, akkor a besenyőispánság mint „,nemesi megye” értelmét veszti. Zsigmond pedig 1399. december 23-i oklevelében (amelyben Lajos kiváltságát is megerősítette a Fejér megyei besenyők országos nemessé emeléséről) ugyanezt a kiváltságot megadta a Tolna megye területén élő besenyőknek is, a tolnai ispán alá rendelve őket. ${ }^{1009}$ Ezek voltak a fontosabb lépései annak a folyamatnak, amely részben már az 1350-es évek elött megkezdődött, és amelynek a végállomásaként a kiváltságolt besenyők nemesi címet elnyert tagjai lassan beolvadtak az országos nemességbe, más tagjai pedig az alávetettek közé kerültek. ${ }^{1010}$ Bár a besenyőispánság felett, mint láttuk, már zsadányi Gergely ispánsága alatt (1346-1352) is lazulni kezdett a nádor fösége (de véleményünk szerint azért még kimutatható a kapcsolat), a besenyők országos nemessé emelésével véglegesen értelmét vesztette az etnikai alapú fennhatóság. Ezzel természetesen egy másfajta jellegű főség fennállt, amelynek a kereteit az országos nemesekkel kapcsolatos jogok és szokásjogok adták. Ilyennel találkozunk pl. Lajos 1369. évi privilégiumában, amelyben a Csanád megyei Besenyőn élő nemes besenyők (fideles nostri Bisseni nobiles de Bessenew) birtokait kivette a nádor, az országbíró, ezek helyettesei és a megye joghatósága alól (palatino regni nostri, et iudici curie nostre, ... vices gerentibus ..., item comiti vel vicecomiti et iudicibus nobilium dicti comitatus Chanadiensis), saját személyes törvénykezése elé rendelve azokat. ${ }^{1011}$ Mindez már a korabeli általános nemesi jogok mintáját követi, és jól láthatóan semmilyen köze nincsen a nádor besenyők feletti különhatalmához.

\section{3 - A kunok}

A nádor legismertebbnek mondható etnikai-bírói jogköre a „kunok bírája” (iudex Cumanorum) cím, de csak azért, mert az állandósulni is tudott a nádori intitulációkban az egész középkor folyamán. Eredete homályos. István ifjabb király (akinek a felesége mellesleg egy kun előkelő - talán Szaján kun fejedelem - lánya volt) ${ }^{1012}$ 1262-ben, ifjabb királyi címével együtt vette föl a „kunok ura” (dominus Cumanorum) címet is. ${ }^{1013}$ Ezzel természetszerüleg ő lett az országrészében letelepített kunok főbírája is. Talán hozzá köthető ezen bírói cím „kiszervezése”, talán már hamarabb, a kunok beköltözésekor megjelent,

\footnotetext{
${ }^{1009}$ ZsO I. 6208. sz., vö. Györffy 1990. 151.

${ }^{1010}$ Hatházi 1996. 46.

${ }^{1011}$ DF 282545. (hibás kiadása: Gyárfás III. 504-505.)

1012 RA 1054. sz. oklevélben IV. Béla rokonának nevezi Szaján kun herceget (dux), ebből szokás erre következtetni.

${ }^{1013}$ Szentpétery 1921. 82-87., kimutatva az ennél korábbi adatok nem hiteles voltát.
} 
mindenesetre az első alkalommal, amikor a iudex Cumanorum titulussal találkozunk (1269 nyarán), akkor még nem az aktuális nádor viselte, hanem az ifjabb király hívének és rokonának számító Monoszló nembéli Gergely. ${ }^{1014}$ A 19. századi szakirodalomban - egy levéltári jegyzékre hivatkozva - felbukkant, hogy (egy 1269. évi oklevél alapján) először Kemény fia Lőrinc kapta meg nádorként ezt a titulust. A jegyzék adata azonban félreértésen alapul, mint azt Gyárfás István tisztázta. ${ }^{1015}$ Az első olyan nádor, aki biztosan viselte e címet így V. István tisztviselője, Mojs. Egy 1270. május 13-án kelt oklevélben említik először nádornak, akkor még csak „fidelem nostrum Moys palatinum” titulussal látta el V. István, és május 18-án ő is csak soproni és szebeni ispánnak címezte önmagát. ${ }^{1016} \mathrm{~V}$. István 1270 . június 13-i oklevelében még szintén csak nádor és soproni ispán, ám a király augusztus 27-i okmányában már találkozunk a kérdéses titulussal. ${ }^{1017} \mathrm{Ez}$ a tisztségnév legkorábbi kronológiailag meghatározható felbukkanása nála, ám korántsem biztos, hogy Mojs ezen két nyári időpont között kapta meg a „kunok bírája” címet, mert szük két héttel később, egy szeptember 8-i oklevélben ismét csak „Mois palatino et comite Supruniensi” található. ${ }^{1018}$ Így könnyen lehet, hogy már június 13-án is viselte a tisztséget, csak ugyanúgy nem tették ki, mint szeptemberben. Mellesleg, annak dacára, hogy ez a cím megszilárdult a nádorok mellett, az Árpád-kor folyamán a kitétele vagy elhagyása még teljesen esetleges volt mind a nádori intitulációkban, mind más oklevelek említéseiben, stabilan csak az 1320-as évektől tapadt hozzá a nádori méltóság megnevezéséhez.

A cím létrejöttét és a nádorokhoz való kapcsolatát vizsgálva nem mehetünk el szó nélkül az ún. II. kun törvény egyik rendelkezése mellett, amely azt mondta ki, hogy a kun előkelők és a kunok egész közössége „országunk mindenkori nádorának bíráskodása alá fognak tartozni, miként ez Bélának, a mi nagyapánknak idejében elrendeltetett, aki [ti. a nádor] országunk lakóival együtt bárki fölött minden ügyben ítélkezni fog, mellette ülvén az a bíró vagy föember, akit minden [kun] nemzetségben kirendelnek, amint ez a mi nagyapánk ideje óta szokásban van; azzal a kivétellel csupán, hogy ha a per két kun nemes között keletkezik vérontás ügyében vagy valamely [más] ügyben, akkor afölött [a vétkes fölött] csupán annak a nemzetségnek a bírája fog ítélkezni, ki a vádlott részéről ott lesz, és az ilyen két kun

\footnotetext{
1014 Archont. 1000-1301. 240. Monoszló Gergely személye az apát és azonos nevű fiát is takarhatja, ezzel kapcsolatban lásd Zsoldos 2009. 544. 207. jz.

1015 Gyárfás II. 424-425.

${ }^{1016}$ CD V/1. 21. (RA 1919. sz); MES I. 576. (RP 155. sz.)

${ }^{1017}$ RA 1928. sz.; RA 1959. sz.

1018 ÁÚO VIII. 286. (RA 1963. sz.)
} 
nemesnek a perében a nádor semmit sem rendelhet el”. ${ }^{1019}$ IV. László neve alatt két „kun törvény" is fennmaradt, amelyek közül csak ez utóbbi szól a nádor kunok feletti joghatóságáról, részletesen is szabályozva azt. Emellett a nádor és a kunok összekapcsolását IV. Béla idejére keltezte a szöveg. A csak 18. századi átiratokból ismert törvény hitelességével kapcsolatban már az 1930-as években kétségek merültek fel. Kring Miklós 1932-ben erősen gyanúsnak, sorok közötti utalásaival majdnemhogy hamisnak bélyegezte, és a hamisítást a 18. századi jászkun redempcióval vonta összefüggésbe, ti. hogy a kunok bizonyítsák: ők is ugyanazt a nemesi szabadságot élvezik, amelyet az országos nemesek. ${ }^{1020}$ Lényegében elfogadhatónak vélte Kring érveit az Árpád-házi királyok okleveleinek kritikai jegyzéke c. kiadvány is. Értékelése szerint az oklevelet ,jelenleg ismert formájában az eredetinek jóval későbben interpolált átdolgozásának kell tartanunk, s hogy az interpolálás éppen az una ac eadem cum regni nobilibus libertas [egy és ugyanazon nemesi szabadság] bizonyításának érdekében történt”. ${ }^{1021}$ A törvényszöveg interpolált voltát mások is elfogadták, míg egyesek a teljes hitelességét hangoztatták, sőt, például Szücs Jenő egyenesen odáig ment, hogy csak ezt a bővebb változatot tekintette valódi törvénynek, míg az első szerinte csak a pápai legátus diktátuma volt. ${ }^{1022}$ A törvény hitelét legutóbb és legátfogóbb módon Berend Nóra támadta meg. Kring Miklós érvei mellett felhívta a figyelmet arra is, hogy az „I. kun törvény” oklevelén, amelynek a szövegét a pápai kancellária 1339. évi másolata tartotta fent, a pápai átíró oklevél szerint IV. László hiteles kettőspecsétje függött. Mivel 1339-ben Johannes de Amelio főesperest azért küldte a pápa az assisi levéltárba, hogy másolja át a legfontosabb iratokat, ezért úgy tünik: a pápai megbízott a magyarországi „kun törvények” leghitelesebb szövegét ezzel tekintette azonosnak. Emellett Berend felhívta a figyelmet III. Miklós pápa 1279. december 9-i levelére is, amelyben leírta a Magyarországra küldött pápai legátus ténykedésének eredményeit. Ebben a pápa röviden ismertette az elfogadott kun cikkelyeket, és felsorolása az „I. kun törvény” tartalmának felel meg. Ha augusztus 10-én elfogadták volna a második, bővebb szövegezésü törvényt - érvelt Berend Nóra -, akkor a pápa decemberi levelében már az bukkanna fel. Így, Kring Miklóshoz és a véleményét elfogadókhoz hasonlóan a „törvényt” ő is az 1745. évi jászkun redempciót megelőző időszak

\footnotetext{
${ }^{1019}$ DRMH I/1. 71. magyarul: Kun László 137. (Szilágyi Loránd ford.)

${ }^{1020}$ Kring 1932. 39-41.

1021 RA 3000. sz. A kötetet Szentpétery Imre kéziratának felhasználásával Borsa Iván szerkesztette. Hogy az oklevélhez füzött kommentár pontosan melyik szerzőtől származik, nem derül ki. Berend Nóra és Langó Péter egyaránt Borsa Iván véleményének tartotta (Berend 2002. 148.; Langó 2006. 68.). Annyi bizonyos, ha Borsa ezt a kommentárt így megjelentette, akkor ő is egyetértett vele, függetlenül attól, hogy még Szentpétery fogalmaztae meg, vagy sem.

${ }^{1022}$ A kérdés historiográfiáját részletesen ismerteti: Berend 2002. 148.; Langó 2006. 61-62.
} 
egyik bizonyítási eszözének tartotta, amelynek hivatkozott eredetijét azóta sem találta senki, szövegét pedig az egyetlen hiteles „I. kun törvény” alapján alkották volna meg. ${ }^{1023}$ Minderre Langó Péter válaszolt részletesen. Sorra véve az érveket, úgy vélte, hogy a törvény 18. századi feltünésének önmagában nézve nincsen cáfolati értéke, ha a szöveg egyébként maradéktalanul beilleszthető a kor viszonyai közé. A vitatott szövegezés pedig komoly eltéréseket tartalmaz az „I. kun törvény” textusához képest, olyan formulás vagy egyéb részekben (pl. tanúk felsorolásánál) is, amelynek semmilyen jelentősége nem volt a törvény tartalmi részét tekintve. Ha a mintát kizárólag a rövidebb szövegezésü kun cikkelyek jelentették volna, miért nem másolták át egyszerüen az ottani keretszövegeket? A változások, bővítmények, elhagyások ráadásul mind jól illeszkednek a korba (pl. az egyik megváltozott személyü tanú kimutatható más forrásokban is, a kunok ismertetett szállásterülete valóban egybevág az akkori viszonyokkal, ám a későbbi, 14. századtól állandósuló szállásterületekkel már nem, stb.), és nem valószínű, hogy 1730 körül, a szöveg első feltünése idején ilyen hibátlan másféle keretet tudtak volna adni egy hamisítványnak. Az oklevél egésze tehát nem lehet hamisítvány. Emellett az a vélekedés sem állja meg a helyét, hogy 18. századi betoldásokkal egészítettek volna ki egy korabeli szöveget annak igazolására, hogy a kunok egységes és kollektív nemességet élveznek. A vitatott szövegrészek ugyanis Langó Péter értelmezése szerint nem a kunok egészéről, csak bizonyos csoportjairól szólnak, és az ott használt universitas-fogalom jól beilleszthető a 13. század második felének eszmetörténetébe. „Az okirat - érvelt Langó - nem szól a kunok nemesi jogállásáról, hanem csak a nemes kunokról”. A törvényt azonban, amelynek a kunok a sok egyéb szabályozás miatt nem igazán örültek, maga IV. László sem akarta betartani. László halála után pedig egyetlen királynak sem állt érdekében keresztülvinni az ott foglaltakat. ${ }^{1024}$

Azért tértünk ki hosszabban is a kun törvények körüli hitelességi vitára, mert az egyetlen korszakunkra vonatkozó leírását adják a nádor kunok feletti főségének, részletesebb szabályozással. Mint látni fogjuk, a nádor kunok feletti bírói hatalmáról az 1350-es évekig bezárólag $\mathrm{kb}$. annyit mondhatunk, amennyit ez a törvény is elmond, nem lényegtelen hát, hogy megbízhatónak tekinthetjük-e. Elöre bocsátjuk, hogy a kun törvények szövegezése körüli vitát mi sem tudjuk eldönteni, ám a nádorokra vonatkozó rész nem feltétlen a hitelét erösíti. Az, hogy a törvényszöveg a nádor kunok feletti bírói hatalmát markánsan kétszer is Béla király rendelkezésének állította be, biztosan nem lehet igaz. Hiszen ha el is fogadnánk, hogy a nádor már 1270 előtt is megkapta e címet, az országmegosztás miatt IV. Béla akkor

\footnotetext{
${ }^{1023}$ Berend 2002.

${ }^{1024}$ Langó 2006.
} 
sem rendelkezhetett a kunokról, azok ugyanis területileg az ifjabb király fennhatósága alá tartoztak, aki - mint láttuk - gondoskodott is a iudex Cumanorum titulus betöltéséröl. Ha mégis elfogadjuk a forrás hitelességét, akkor az ellentmondást kétféleképpen lehet feloldani. Vagy azt feltételezzük, hogy a címet tényleg IV. Béla rendelte a nádorokhoz, ám még az országmegosztás előtt, amikor a kunok az ő felségterületéhez tartoztak. Ezzel viszont nem tudjuk azt megmagyarázni, hogy miért nem tették ki Mojs előtt a nádorok ezt az intitulációikban, 1270-től pedig miért igen, ha csak egy továbbélő tisztségről lett volna szó. Ennél is súlyosabb probléma, hogy a törvényszöveg ,amint ez a mi nagyapánk ideje óta szokásban van" kitétele azt sugallja, hogy az ott leírt modell tényleg müködött a gyakorlatban, ha szokásjogként hivatkoztak rá. Viszont 1262 előtt bármelyik tisztségviselő jobban megfelelt volna a „kunok bírája” titulus gyakorlására, mint a markánsan a nyugati határszélen, Pozsonyban székelő, és csak az ottani ügyekkel foglalkozó Roland nádor, és utódja, Henrik, aki szintén pozsonyi ispán lett, és onnan keltezett oklevelet. Az tehát, hogy a „kunok bírája” címet ténylegesen Béla kapcsolta volna össze a nádorokkal 1262 előtt, véleményünk szerint nem valószínü. ${ }^{1025}$ A másik lehetőség, hogy itt egy tévedésről volt szó, és két elemet mosott össze az emlékezet. Az egyik elem a „kunok bírája” tisztség létrehozása IV. Béla regnálása idején (de könnyen lehet, hogy nem öáltala), amely bíró az 1279-es törvényben leírt módon ítélkezett a kunok között, ám mivel - másrészt - ezt a tisztet 1270 óta a mindenkori nádor viselte, ezért írhatták azt, hogy a nádor még Béla király alatt lett a kunok bírája. Kérdés persze, hogy mennyire reális feltételezni azt, hogy kevesebb, mint egy évtized alatt ennyire markánsan torzított volna a kollektív emlékezet. Arra, hogy Béla szerepeltetésének valamiféle szándékos, ideológiai jellegü oka lett volna, magunk nem találunk semmilyen indokot. Bármi is volt az oka annak, hogy a törvénycikkbe Béla neve került, nem tekinthetjük hitelesnek, és továbbra is Mojsot kell tartanunk az első olyan nádornak, aki a „kunok bírája” volt.

Lényeges kérdés, hogy milyen tartalommal bírt a fenti cím. A törvényszöveg alapján (amennyiben elfogadjuk hitelesnek az ott leírtakat) a kunok közti ügyeket a saját, választott bíráik is elintézhetik, a kunbíró illetékessége a kvázi magasabb szintű, kun-magyar perek kapcsán lépne életbe, ahol együtt ítélne a kun nemzetség saját, belső bírájával. Még a törvény szövegét teljesen eredetinek tartó Langó Péter is kihangsúlyozta, hogy egyetlen király sem akarta betartani az 1279. évi kun cikkelyeket, és azok sosem jutattak érvényre. ${ }^{1026}$ Így még ha

\footnotetext{
1025 Gyárfás István több helyütt is írta, hogy az 1243-1244 folyamán visszatért kunokat IV. Béla a nádor bíráskodása alá rendelte (Gyárfás II. 281., Gyárfás III. 144., 157.), ám forrásként csak az 1279. aug. 10-i kun törvényre hivatkozott (Gyárfás II. 281. 1. jz.), így ez korántsem tekinthető biztosnak. ${ }^{1026}$ Langó 2006. 71.
} 
hitelesenek is fogadjuk el a szöveg nádori bíráskodásra vonatkozó leírását, akkor sem biztos, hogy mindez átkerült volna a gyakorlatba. A források pedig egyenesen az ellenkezőjét sejtetik. A nádoroknak ugyanis 1342-ig bezárólag egyetlen kunokkal kapcsolatba hozható esetéről sincsen tudomásunk. ${ }^{1027}$ Hogy nem volt minden gyakorlatot nélkülöző titulus, arra csak abból a szabályosságból következtethetünk, hogy a nádori hivatal megosztása esetén kizárólag a „dunántúli” (tehát kelet-magyarországi) nádor viselte a iudex Cumanorum címet, a 14. század első évtizedében pedig csak I. Károly kinevezett nádora, Borsa Kopasz. ${ }^{1028}$ Ám érdemes figyelembe venni Engel Pál megjegyzését, miszerint a ,jászkunok korszakunkban [1301-1457 között] még nem álltak egységes irányítás alatt, egyidejileg több hatóság címezte magát a jászok, a kunok vagy mindkét nép bírájának avagy ispánjának, valószínileg azért, mert egyes székek felett gyakoroltak fennhatóságot ... a »kunok bírája« címet 1322-től ... a mindenkori nádor is viselte [kiemelés a szerzőtől!], kivéve Jolsvai Leustákot (1392-97) és nádorsága elején Bebek Detrét (1397-98)". ${ }^{1029}$ Így az egyes nádorokkal párhuzamosan az elöször 1319-ben felbukkanó iudex Cumanorumok lehettek az ,igazi” kunbírók, akik a gyakorlatban csak egy kisebb terület felett bírtak fennhatósággal, ${ }^{1030}$ és nem úgy tünik, hogy a nádor alárendeltjei lettek volna. Az összes kunt elméletileg átfogó „tiszteletbeli” kunbíró pedig a nádor volt, de a színe elé csak igen ritkán kerültek ezzel az etnikummal kapcsolatos ügyek. Másként nem tudjuk feloldani azt az ellentmondást, amely az intitulációban állandósuló cím, és az ezt gyakorlati oldalról is igazoló esetek hiánya között feszül. Talán erre a bírói fennhatósági rangsorra utal I. Lajos 1344. február 12-i oklevele, amelyben a király kinyilvánította, hogy a valószínűsíthetően kun etnikumú Berő fia Balázs és Pál fia Komár 1031 pereiben csak ő ítélkezhet, sem a nádor, sem az Olás nemzetségbeli kunok kapitánya (nec

\footnotetext{
${ }^{1027}$ Borsa Kopasz egy ízben a vele szemben elkövetett hatalmaskodások körébe soroltatta sok más mellett azt is, hogy a nádorhoz tartozó kunokat is kiraboltak (1306: „Cumanis ad ipsum Kopoz palatinum pertinentibus” AO I. 107-108., AOkl II. 9. sz.), ám ez a fellépése nem tünik bírói feladatkörnek, inkább csak a személye ellen elkövetett sérelmek számát emelte meg. Mindenesetre ez az első olyan halvány nyom, hogy a iudex Cumanorum cím viselöjének tényleg van valami köze a kunokhoz! Tegyük hozzá: kunokat akkor is találunk Kopasz oldalán, amikor már nem viselte a nádori méltóságot (Györffy 1953. 262.), ráadásul Kopaszt összefüggésbe hozták a IV. László elleni merénylettel is, amit a kunok követtek el (Kun László 40. - Kristó Gyula előszava). Mivel Kopasz birtokai eleve a kun szállásterületek mellett feküdtek, ezért könnyen lehet, hogy a kunokkal való kapcsolata nem is elsősorban a nádori címével állt összefüggésben.

${ }^{1028}$ Lásd a „4.3 - Az »oligarcha-nádorok« kora” és a „4.4. - I. Károly első nádorai - az »oligarchikus nádorság« öröksége" c. alfejezeteket.

${ }^{1029}$ Archont. 1301-1457. 147.

${ }^{1030}$ Felsorolásukat lásd Archont. 1301-1457. 147-149. Ám az ott feltüntetett „Besenyő Gergely mg., a kunok rectora v. kapitánya 1346-02-27 (Dl. 69965)" adat félreértésen alapszik, az oklevélben Gergely a besenyök rektorának vagy kapitányának mondja magát, lásd még az előző, besenyőkre vonatkozó fejezetet.

${ }^{1031}$ Györffy 1953. 273.
} 
palatinus, nec capitaneus Comanorum generationis Olas), sem a király más bírája. ${ }^{1032} \mathrm{Az}$ exempció ugyan kissé formulaszerü a „más bírák” emlegetése miatt, de az Olás nemzetségi (a későbbi kun Kolbáz-szék elődje) ${ }^{1033}$ kun kapitány mellett feltűnő nádori fennhatóság említése talán mégis a realitásokat tükrözi. A nemzetségbeli Balázs és Komár tehát elsősorban a nemzetségi kun vezetők alá tartozott, és másodsorban a nádor fennhatósága alá. Tudjuk egyébként, hogy az Olás nemzetségnek is volt egy külön kunbírója, 1328 decemberében pl. Nekcsei Demeter tárnokmester, mellesleg körösszegi várnagy töltötte be ezt a pozíciót (iudex Cumanorum de genere Olaas). ${ }^{1034}$ Nem valószínủ egyébként, hogy Nekcsei Demetert az éppen ekkor nádor Druget János nevezte volna ki erre a pozícióra, címe sokkal inkább következett a királytól elnyert körösszegi várnagyságából, vagyis a nemzetségi kunbíró (ebben az esetben legalábbis) nem a nádor alárendeltje volt, hanem tőle független személy.

Hogy a nádor nem közvetlen módon volt a kunok bírája, azt az 1340-es évektől kezdve más források is igazolják. Zsámboki Miklós nádor 1343. április 12-i oklevele az első olyan ismert oklevél, amelyben a nádori hivatal viselője a kunokról intézkedik. A következőket írta: „Lajosnak, Isten kegyelméből Magyarország királyának a kegyelme a kun kapitányok minden szolgálata alól mentesítve a mi szolgálatunkba helyezte át az Ilunchuk nembéli Buthemer comest a rokonaival, és a szállásán meg a kapitánysága alatt lévő kunokkal együtt, akik a megboldogult ... Tamás erdélyi vajdához és szolnoki ispánhoz tartoztak, hogy mi őt az összes szállásán lévő és kapitányságához tartozó kunjaival együtt megvédelmezzük olyan módon, hogy senki másnak, csak nekünk ... vannak alárendelve, és a zsoldpénzt (stipendia) tölünk veszik át”. Ezért a nádor arra utasította az ispánokat, várnagyokat, nemeseket és a kunok kapitányait, hogy a királyi kegy révén neki szolgáló (per regiam benignitatem nobis servituros) Buthemert és kunjait ne zaklassák, mert az ő védelme alatt áll. ${ }^{1035} \mathrm{Az}$ oklevél kiemelte, hogy Buthmer és a kapitánysága alatti kunok Tamás erdélyi vajdához tartoztak azelőtt. Szécsényi Tamás 1342 októberében, fél évvel ezen oklevél kiadása előtt elhunyt, ${ }^{1036}$ ezért kerülhetett sor az ,átruházásra”. Abból, hogy a stipendiumot az új uruk, a nádor fizette a Buthmer alá tartozó kunoknak, katonai jellegü főségre is következtethetünk, vélhetően a

\footnotetext{
${ }^{1032}$ MES III. 532. (AOkl XXVIII. 75. sz.)

1033 Györffy 1953. 273.

1034 Archont. 1301-1457. 147.

1035 „Lodovici Dei gratia illustris regis Hungarie benignitas comitem Buthemer de genere Ilunchuck cum suis proximis et Cumanis in suo descensu, et sub suo capitaneatu existentibus, condam ad magnificum virum Thomam woyvodam Transylvaniensem et comitem de Zolnok pertinentibus, ab omnique capitaneorum Cumanorum iudicatu exemtum nobis transmisit servieudum, et per nos ipsum cum suis Comanis in suo descensu existentibus, et suo capitaneatui pertinentibus protegendum, ita, ut a modo nemini alteri, nisi nobis subesse...teneantur, a nobis stipendia recepturi”. Gyárfás III. 482-483. (AOkl XXVII. 170. sz.)

${ }^{1036}$ Archont. 1301-1457. 11.
} 
nádori sereggel kellett hadba vonulniuk. ${ }^{1037}$ Az oklevél ugyanakkor jól mutatja, hogy egy kisebb kun közösség nem tartozott magától értetődő módon közvetlenül a nádor katonai és bírói hatalma alá. Buthmer is a nálánál magasabb rangú, oklevélben említett „kun kapitányok” fősége alatt állt, és a közvetlen nádori fennhatóság elérése külön királyi kegyből történt. Lajos ugyanezt a kiváltságot adta 1371-ben a Kuncheg nemzetséghez tartozó Fekete Miklós fia kun Lászlónak, a madarászának, és az ő összes kapitánysága alá tartozó kunnak (Ladislaum Cumanum aucupem nostrum filium Nicolai nigri, generationis Kuncheg, nec non Comanos sub suo capitaneatu existentes), hogy öket csak a király vagy a nádor, vagy egy nádori bíró bírói széke elött (nostrorum aut domini palatini vel eiusdem palatini iudicis in presentia) vonhatják perbe. ${ }^{1038}$ Mindez azt erősíti, hogy a nádor nem gyakorolt közvetlen bírói hatáskört a kunok felett, és már ahhoz is királyi privilégiumra volt szükség, ha egy csoportjuk közvetlenül a nádor bíráskodása alá akart tartozni. Hogy helyesen értelmezzük az oklevélben foglaltakat, érdemes még egyszer elővenni a „II. kun törvény” vonatkozó rendelkezését: „a kunok közül való eme urak és nemesek és a kunok egész közössége (universitas) országunk mindenkori nádorának bíráskodása" alá fognak tartozni. ${ }^{1039}$ A szokásjogra hivatkozó törvény szó szerint tehát csak a nemes kunokat rendelte a nádor bírói széke alá (az universitas a nemesek politikai közösségét jelentheti ebben a kontextusban). Lajos fenti okleveleit azonban még sem foghatjuk fel úgy, hogy az addig nem nemes kunokat a király magasabb státuszra emelte, és ezáltal a nádori föség alá helyezte őket. Egyrészt, a nemesítésükről nem esik szó a szövegben, pedig azt meg szokták említeni az erről szóló oklevelek. Másrészt, az ott említett kunok egyike sem tünik egyszerü, alávetett státuszúnak. Mindketten saját „kapitánysággal” (capitaneatus) és az alájuk tartozó emberekkel rendelkeztek, amely rang biztosan kimerítheti az 1279-ben jelzett kun universitas fogalmát. Az 1343. és 1371. évi oklevelek azt árulják el, hogy még ezen kunok sem tartoztak közvetlenül a nádori ítélőszék alá. Akár hitelesek tehát a „II. kun törvény” rendelkezései, akár nem, a gyakorlatba nem mentek át az ott foglaltak. Valószínű persze, hogy az egyes kun kapitányok és területi kunbírók ítélőszékétől lehetett a nádori törvényszékhez fellebbezni, de az általunk vizsgált korszakból (1342-ig bezárólag) erre egyetlen ismert példa sem akadt. Hasonló folyamatok játszódtak le egyébként a jászok esetében is. Tudjuk, hogy 1370-ben a királyi jászok bíráját (iudex Jasonum) Oppelni László

\footnotetext{
${ }^{1037}$ A hadba szálló kunoknak járó zsold fizetése már a 13. század vége óta szokásban volt, lásd Györffy 1953. 261-263.

1038 Gyárfás III. 506-507.

1039 „,iidem domini de Comanis et nobiles et universitas Comanorum iudicio palatini regni nostri, qui fuerit pro tempore constitutus” DRMH I/1. 71. Magyarul: Kun László 137. (Szilágyi Loránd ford.)
} 
nádor állította erre a posztra. ${ }^{1040}$ Ezen jászbíró ellen egy bizonyos Sceuke nevű jász tett panaszt Lajos király előtt, hogy a bíró és társa illetéktelenül akar az ő birtokára és házába behatolni és ott zálogot venni (ad domum et possessionem ... potenti manu venire, et vagia et pignora in eisdem domo et possessione suis recipere). ${ }^{1041}$ Úgy tünik, hogy Sceuke királyi jász egy általa illegitimnek tartott törvénykezései eljárás ellen fellebbezett a nádor által állított jászbírótól a király színe elé. Itt ugyanazt a kettősséget látjuk, amelyet fentebb Miklós fia László királyi madarász esetében is, hogy a bíráskodási fóruma a király vagy a nádor volt, egyenrangú módon.

Az 1370-es évektől egyébként már találunk arra példát, hogy a nádor egy kunok és magyarok közti ügyben mondjon ítéletet, sőt, tisztán kunok közti ügyben is, ahogy a jászok feletti joghatósága is igazolható. ${ }^{1042}$ Ennek ellenére a nádor kunok feletti gyakorlati fennhatósága a 15. század második felében is ingadozó volt, és a 16. században, bár emlékeztek rá, még akkor is alig volt jelentősége, amikor a nádori poszt éppen be volt töltve. ${ }^{1043}$ Ekkorra egyébként a nádor már az intitulációban is gyakran feltüntette a kunok mellett a jászokat iudex Comanorum et Philisteorum formában. A tisztség azonban nem azt az utat járta be, ami a besenyők feletti joghatóság esetében történt, vagyis a lassú elsorvadást. A 17. század első fele, amikor hosszabb idő után ismét betöltötték a nádori hivatalt (és elkezdték rekonstruálni, hogy mi is tartozik a jogköréhez tulajdonképpen), a nádoroknak a Jászkun kerületek feletti minden addiginál erőteljesebb hatalmi befolyását hozta el. Akkor már egyértelműen nádori jognak tekintették a jászkun főkapitány állítását, amely jogot a király csak a nádori szék üresedése esetén gyakorolhatta, továbbá a nádor a vidék jövedelmeit is élvezte (a török miatti területi korlátok figyelembe vételével, természetesen). ${ }^{1044}$ A 13. században megjelenő, majd állandósuló kunbírói titulus „gyümölcse” így igazán tartósan és erőteljes módon csak a 17. századra „ért be”.

\footnotetext{
${ }^{1040}$ I. Lajos hozzá írt oklevelének a címzése a következö: „fideli suo Stephano dicto Izopos, iudici Jazonum nostrorum per dominum ducem palatinum constituto” DL 28088. (vö. Gyárfás III. 505. - hibás kelettel) ${ }^{1041}$ Gyárfás III. 505.

${ }^{1042}$ Gyárfás III. 99-100., 105-108., 173-178.

${ }^{1043}$ Kocsis 2005. 31-32.

${ }^{1044}$ Erre az időszakra lásd Ember 1946. 579-581.; Kocsis 2005. 32-33. A jászkun kerületek jövedelmével addig közvetlenül a királyi kincstár rendelkezett, miként ezt az 1514. évi decr. 3. cikkelye és az 1518. évi decr. 14. cikkelye is megerősítette (CJH I. 708-709., 760-761.). Az 1485/86. évi „nádori cikkelyek” ugyan nádori jövedelemnek tekintik a kunok után járó 3000 aranyat, és mindezt I. Lajos korára vezetik vissza (DRH II. 317.), ám a cikkelyek hitelességével kapcsolatban újabban igen komoly kritikák merültek fel. C. Tóth Norbert 2012ben két előadást is tartott ezzel kapcsolatban (2012. febr. 22.: „Az 1486. évi nádori cikkelyek hitelessége” az SZTE BTK „Mühelyszemináriumi előadások” sorozatának keretein belül, ill. 2012. nov. 15.: „A nádori cikkelyek keletkezése” az ELTE BTK-án rendezett „Rendiség és parlamentarizmus Magyarországon” c. konferencián). Ezekben a cikkelyeket 16. sz. közepi hamisítványoknak tekintette.
} 


\section{8 - A NÁDORI HIVATAL MUNKATÁRSAI}

Bár gyakran beszélünk elvont módon nádori „intézményről” vagy „hivatalról”, azt nem tudjuk kimutatni az Árpád-kor folyamán, hogy létezett volna a nádor személyétől függetlenül, a távollétében is működő, és az ő nevében oklevelet kibocsátó „hivatal”. Így tehát a nádor személyes jelenléte és a nádori hivatal müködése ekkor még elválaszthatatlanul összetartozott. Ennek ellenére már egészen korán, a 13. század elejétől kezdve megjelent az igény a nádort adott esetben nélkülözni tudó, ám nádori szintü bíráskodásra. Mindezt kezdetben helyettesek állításával oldották meg a nádorok, de ők, ha a nádor képében intézkedtek is, a saját nevükben bocsátottak ki oklevelet, és ítéleteiket jóvá kellett hagyatni a nádorral (ez nem vonatkozott a 13. század közepétől a nádori intézménytől távolabb kerülő alnádori hivatalra). Így csak a nádori „iroda” munkatársainak száma nőtt meg, de a nádori intézmény ezáltal nem függetlenedett a nádor személyétől. Az első olyan nyom, amely a távollévő tisztviselő idején is az ő nevében müködő hivatalra utal, Debreceni Dózsa tisztségviselése (1322) alatt következett be. Dózsa Kállósemjénben tartott közgyülései idején a debreceni nádori kúriában is keltek személyes nádori intitulációval oklevelek. ${ }^{1045}$ Az önállósodó hivatal ekkor még nem tudott állandósulni, mert Dózsa utódja, Druget Fülöp idején a távollévő (vagy csak éppen nem bíráskodó) nádort az albírája, Perényi Miklós mindig a saját nevében helyettesítette. Igaz, hogy halvány nyomok azért vannak arra, hogy a „hivatal” müködése kettejük távolléte esetén sem állt le. Az egri káptalan 1324. december 13-án kiadott levelében igazolta, hogy a színük előtt Fülöp nádor ügyvédvalló oklevelével megjelenő Miklós albíró Margit asszonyt, a nádor feleségét képviselte. Másnap, december 14-én Miklós (legalább) három oklevelet is kibocsátott Vizsolyban. ${ }^{1046}$ Eger és Vizsoly között a távolság légvonalban is kb. $85 \mathrm{~km}$, ám mivel meg kell kerülni a teljes Bükk hegységet, ezért az út terepen jóval hosszabb (vagy átvágva a hegységen nehezebb), és nem túl valószínü, hogy a december 13-án még Egerben tartózkodó Miklós visszatérhetett volna december 14-re Vizsolyba. Mivel az egri káptalan oklevele csak átírásban maradt ránk, elvileg elképzelhető, hogy a keltezését elírták, ${ }^{1047}$ bár erre egyértelmü bizonyíték nincs. Így - hacsak hipotetikusan is - de azt is feltételezhetjük, hogy a december 14-i oklevelek Perényi Miklós albíró nevében, de a távollétében kerültek kiadásra. Akármi is az igazság, Fülöp alatt még biztosan nem lett rendszer belőle, és nála csak

\footnotetext{
${ }^{1045}$ Lásd a „4.4. - I. Károly első nádorai - az »oligarchikus nádorság« öröksége” c. alfejezetet.

${ }^{1046}$ AOkl VIII. 545., 548-550. sz.

${ }^{1047}$ Tegyük hozzá, hogy az Anjou-kori oklevéltár regesztája véletlenül tényleg elírta a keltezést, mert bár dec. 13. alá vették fel az oklevelet, a regesztában „D. in fe. B. Nicolai conf.” szerepel. Az oklevélben „,in octavis beati Nicolai confessoris" áll (DL 75391.).
} 
kivételes esetben fordult elő, hogy az albíró távollétében az ő nevében is kiadhattak oklevelet (már amennyiben a fenti esetet tényleg így kell értelmezni).

Mindezek arra utalnak, hogy a 14. század elején már megjelent az igény egy folyamatosan működő hivatalra, amely nem függ senki jelenlététől, és a hivatalviselő személye csak a legitimitást adja. A folyamat aztán Druget Vilmos nádorsága alatt ért be véglegesen. Vilmos egyrészt megtartotta az apjától öröklött óbudai nádori kúriát az ottani személyzettel, de nem mondott le a vizsolyi kúriájáról sem. Az óbudai kúria pedig folyamatosan folytatta a nádor nevében történő oklevéladást, miközben Vilmos nádori közgyüléseket tartott, vagy Vizsolyban, később Visegrádon székelt. ${ }^{1048}$ Vilmos újítása a korábbi gyakorlathoz képest az volt, hogy a távollétében müködő kuriális bíráskodást nem egy helyettes állításával rendezte el, mint ez gyakorlat volt korábban, hanem az ,irodai személyzetet" hagyta a távollétében müködni. Érdekes egyébként, hogy a nádori kúria és a közgyüléseket tartó nádor oklevelei közötti időbeli párhuzamosság már Nyers Lajosnak is feltűnt, ám ő mindezt csak 1343-tól, Zsámboki Miklóstól kezdte el adatolni. ${ }^{1049}$ A gyakorlat tényleg folytatódott Vilmos halála után is, Zsámboki Miklós nádorsága idején, így elmondható, hogy ekkortájt született meg elvont értelemben is a „nádori hivatal”, amelynek folyamatos müködése már nem a nádor vagy nádori albíró jelenlétén múlott. Az alábbi alfejezetekben ezt a hivatali segítő személyzetet elemezzük részletesebben, kezdve az alnádori és a nádori albírói intézmény történetétől, az iroda belső munkatársainak számító írnoki, majd később protonotáriusi (ítélőmesteri) személyzeten keresztül a nádori intézmény müködését biztosító „külső segítőkig” bezárólag. Ezen külső, sokszor alkalmi segítséget az egyes ítélőtársak, illetve a gyakorlati végrehajtásban segédkező poroszlók, majd nádori emberek, jelentették.

\section{1 - A nádort helyettesítő tisztségek: alnádor, nádori albíró}

A korábbi szakirodalomban többnyire egységesen „alnádor” elnevezéssel illették a különféle nádorhelyettesi szerepet betöltőket. Véleményünk szerint itt differenciáltabban kell eljárni, és legalább kétféle nádorhelyettesi funkciót kell megkülönböztetnünk a 13. század közepétől fogva. Az egyik az ,alnádor”, amelyet a latin terminológiában többnyire vicepalatinus névvel illettek, és a jelzett időhatártól kezdve a feladata nem csak a nádor személyének helyettesítése volt, hanem az, hogy Pesten, később Budán székelve ellássa a

\footnotetext{
1048 Minderre részletesen lásd a „4.6 - A nádori kúria Visegrádra költözése” c. fejezetet. ${ }^{1049}$ Nyers 1934. 55-56.
} 
pesti ispáni teendőket, illetve a régióban bíráskodjon. Az alnádor személye az idők folyamán távolodott a nádori hivataltól, bár kinevezése valószínüleg mindvégig a nádor joga volt. A másik fő nádorhelyettesi funkciót az „albíró” (teljesebb nevén: „nádori albíró”) hivatala jelentette, amelyet a latinban többnyire a viceiudex (viceiudex palatini) szóval adtak vissza. Ö közvetlenül a nádor személyes munkatársa volt, többnyire a környezetében tartózkodott, és a nádor személyét helyettesítette. A 13. század végétől kezdve - éppen a nádor környezetében való tartózkodása miatt - az albírók számítottak az adott nádori tartomány másik fő bírájának. Fontos azonban jelezni, hogy az itt felvázolt terminológia és feladatkör sokkal esetlegesebb volt a gyakorlatban. Mint alább részletesen kifejtjük, a terminológiai szétválasztás nem mindig állt fent (a Druget-nádorok idején pl. a Budán székelő helyettest is viceiudex névvel illették), és nem mindig töltötték be mindkét hivatalt. Így inkább csak tendenciákról beszélhetünk az egyes nádorhelyettesi funkciók szétválasztásakor, a gyakorlatot valójában a nádor személyes igényei szabták meg. Ráadásul az 1240-es évek előtti időszakra a fent elmondottak egyáltalán nem érvényesek, sem terminológiai, sem funkcionális téren.

A nádor helyettesítése már akkor is napirenden volt, amikor még csak a király képében bíráskodott a királyi kúriában. Szent László III. törvénykönyve is szót ejtett arról, hogy „ha valamikor a nádorispán hazamenne, a király és az udvar pecsétjét, aki helyetteseként hátramarad, annak adja át”. ${ }^{1050}$ Nem valószínű, hogy emögött intézményesített keretek álltak volna, valószínű, hogy inkább csak a király megbízott egy éppen udvarban tartózkodó előkelőt, hogy átmenetileg vegye át a nádorispán helyét. ${ }^{1051} \mathrm{Az}$ első ismert nádorhelyettesek megjelenése az 1219-1220-as igazgatási reformokhoz köthető. Az első hiteles említések a Váradi Regesztrumban találhatóak 1220-ból. ${ }^{1052}$ Hogy az intézmény csak ekkortájt jelent meg, mutatja, hogy nincsen még kikristályosodott neve a tisztségnek. 1220-ban Fila kétszer és Petus egyszer vicarius palatini. ${ }^{1053}$ A névváltozatosságot Móric alnádor 1220-1221-es említésein lehet jól lemérni. Egy esetben (1221) ő is vicarius palatini comitis. Egyszer (1221) vicecomes palatini comitis, három alkalommal (1220-1221) egyszerüen csak vicepalatinus, míg egyszer (1221) vice iudex palatini comitis. ${ }^{1054}$ Az utolsó kivételével mindegyik a Váradi Regesztrum bejegyzéseiből való (az utolsó Benedek, tatai apát oklevele, amely több ponton is eltér a megszokott formuláktól). Barc fia Miklós nádor egy 1221. évi oklevelében Mártont az

\footnotetext{
1050 „si aliquando palatinus comes domum ierit, regis et curie sigillum, qui in vice eius remanserit, illi dimittat” Závodszky 1904. 174. Magyarul: ÍFMT 89. (Körmendi Tamás ford.)

${ }^{1051}$ Vö. Zsoldos 1998. 27. 156. jz.

1052 Hamis oklevélben már 1201-ből találkozunk Belos nádori alispánnal (Belus, vice comes D[omini] Palatini): CD VII/4. 70-71. (RP 2. és 3. sz. közötti reg.) Az oklevél egy újkori, Kemény József-féle hamisítvány.

${ }^{1053}$ RV 248. és 266. sz. (Fila); RV 249. sz. (Petus)

${ }^{1054}$ RV 289. sz.; 282. sz.; 271., 318., 321. sz.; ÁÚO I. 182-183.
} 
ő vice iudexének nevezte. ${ }^{1055}$ Az 1222. évi Aranybulla a nádor kapcsán „helyettes bírákat” (iudices vicarios) emlegetett. ${ }^{1056}$ A különféle megnevezések itt még biztosan nem annak tudhatók be, hogy ennyi, funciójában hasonló, ám különféle tisztség létezett volna a nádor helyettesítésére, hanem hogy a frissen megszervezett hivatalnak még nem szilárdult meg a neve. Ezalatt a két év alatt összesen négy alnádorról van tudomásunk (Fila, Petus, Móric, Márton), akik nem egymást váltva, hanem - legalábbis részben - párhuzamosan működtek, mint az a Váradi Regesztrum regesztáinak egymásutániságából következik. A nádori helyettesek halmozásának az Aranybulla szabott gátat: a már sokszor idézett részében kimondta, hogy a nádor „,helyettes bírákat ne tartson, csak egyet a saját udvarában”. ${ }^{1057} \mathrm{Az}$ alnádorok elnevezése az Aranybulla rendelkezése után sem egységesült. Köbölkúti Péter 1234-ben egyszerre vicepalatinus és viceiudex néven jelent meg, Endri (az Endre elírása?) 1235-ben vice palatini, Albert pedig 1237-ben és 1239-ben viceiudex palatini. ${ }^{1058}$ A tatárjárás után az Árpád-korban a viceiudex ${ }^{1059}$ és a vicepalatinus ${ }^{1060}$ elnevezéssel egyaránt találkozunk, nagyjából ugyanolyan arányban. Gotárd, István ifjabb király alnádora csak a „vice Dyonisio palatino" megnevezést használta önmagára, és ez akár alkalmi helyettesítést is sejtethetne, ám a teljes intituláció (Nos comes Gothardus vice Dyonisio palatino in Hotwan residens) ${ }^{1061}$ a Budán vagy Pesten székelő alnádorok szokásos formulája, amely arra utal, hogy itt az idősebb király budai alnádorát másoló hatvani alnádorról van szó. Viszont a tatárjárás után már egyszer sem fordult elő az, hogy egy személyt kétféle elnevezéssel illessenek. Ha a nádorhelyettesnek több említése (vagy saját intitulációja) is akadt, akkor a kettő közül mindig ugyanazt a terminust használta. Ezen kívül megfigyelhető az is, hogy a bizonytalan személyü és datálású „F.” alnádor kivételével ${ }^{1062}$ a Budán (Pesten) székelők neve következetesen a vicepalatinus, míg a viceiudex bárhol a nádor környezetében felbukkanhatott. Ez már sejtet egyfajta különbségtételt, miszerint itt már nem pont ugyanazt a funkciót fedte a két tisztségnév. Az Anjou-korban már egyértelmű bizonyítékaink vannak a kettős alnádori

\footnotetext{
${ }^{1055}$ PRT I. 652. (RP 9. sz.)

${ }^{1056}$ DRMH I/1. 35.

1057 „,iudices vicarios non habeat, nisi unum in curia sua.” DRMH I/1. 35. Magyarul: Szöveggyüjtemény 270.

1058 Péter: HO VIII. 31-32. (RP 37-38. sz.); DF 200920. (kiadása: RP 39-40. sz.). Endri: DL 70387. (kiadása: RP 41. sz.). Albert: DL 96256. és DL 41010. (vonatkozó részek kiadása: RP 52-53. sz.); HO VI. 37.

1059 DL 93896. (kiadása: RP 168. sz.); Zala I. 118-119. (RP 203. sz.); DL 57228. (kiadása: RP 301. sz.); DL 75155. (kiadása: RP 317. sz.); DL 75156. (kiadása: RP 321. sz.); HO VII. 360. (RP 327. sz.); ÁÚO III. 172.

1060 Zichy I. 79. (RP 179. sz.); Heves 51. (RP 197. sz.); DL 90791. (kiadása: RP 238. sz.); DL 58436. (pecsétfelirat, lásd RP 289. sz., ill.. Majláth 1883.), ÁÚO X. 388. (RP 313. sz.); ÁÚO VIII. 394.; ÁÚO IX. 194.; HO VI. 435.; Elenchus III/2. 40.; Zichy I. 98.

${ }^{1061}$ DF 280264. (kiadása: RP 129. sz.)

${ }^{1062}$ Zala I. 118-119. (RP 203. sz. Az oklevél datálási nehézségeit lásd a regeszta utáni kommentárban.)
} 
rendszerre, még ha a terminológia használata zavarosabb is lett kissé. László, Borsa Kopasz helyettese egyszerre mindkét fő névvel (vicepalatinus és viceiudex) említette saját magát, tehát nem egy másik hivatali szerv következetlen névhasználatáról volt szó. ${ }^{1063}$ Debreceni Dózsa István nevű alnádora egy oklevélben ,viceiudex ... palatini ... Bude residens” néven bukkant fel, de egy abban átírt oklevél őt „vicepalatinus Bude residens”-nek hívta. Egy hónappal később már saját oklevélben is „,vicepalatinus Bude residens” lett, és később már következetesen ezt a nevet alkalmazta magára. ${ }^{1064}$ Ezzel párhuzamosan volt Dózsának egy „általános bírája” (iudex generalis ... palatini) is. ${ }^{1065}$ Ő nem Budán, hanem - amikor van rá adatunk - Debrecenben, Dózsa székhelyén keltezte okleveleit. A párhuzamos kettős alnádorság Druget Fülöp alatt is folytatódott, ugyanilyen alapon. Az egyikük, Tamás, Budán keltezte okleveleit, és titulusában is ott szerepelt a „Bude residens” („Budán székelő”) kitétel. ${ }^{1066}$ A másik helyettes, Perényi Miklós egy kivétellel mindig Vizsolyban, Fülöp kúriájában. ${ }^{1067}$ Miklós a már megszokott viceiudex ... palatini elnevezést használta, ${ }^{1068}$ viszont Tamásnál 1324-ig úgyszintén a viceiudex megnevezés élt, aztán 1325-től következetesen a iudex ... palatini Bude residens titulussal illették, ${ }^{1069}$ ami némi rangemelkedést (de legalábbis terminológiai megkülönböztetést) jelent a Vizsolyban ítélkező Miklóssal szemben, hiszen ő mindvégig viceiudex maradt.

De mikori időpontban jelölhetjük a meg a folyamat végét, amikor már szétvált az alnádor és az albíró hivatala? Hajnik Imre a 14. századi viszonyokból kiindulva, azt az egész Árpádkorra visszavetítette, Szovák Kornél ezt úgy pontosította, hogy a nádornak kezdettől fogva volt egy, többnyira a környezetében müködő albírája, és ezzel párhuzamosan a 13. század

\footnotetext{
1063 1314: DL 69660., 69661. (AOk1 III. 759. sz., 823. sz.)

${ }^{1064}$ HO VIII. 411-412., DL 3652. (AOkl VI. 571. sz., 629. sz.); DF 200110. (AOkl VI. 775-776. sz.); Zichy I. 216-217. (AOkl VI. 830., 838. sz.); DL 86950. (AOkl VI. 848. sz.)

${ }^{1065}$ DL 96082., 96083., 50718. (AOkl VI. 508., 517., 600. sz.)

1066 AOkl VII. 275. sz., 351. sz., 395. sz., 411. sz., stb. VIII. 349. sz., 547. sz., IX. 538. sz., 551. sz., X. 137. sz., 169. sz., 272. sz. stb., XI. 33. sz., 261. sz. Egy alkalommal, 1325-ben nem Budán keltezett, hanem a Zala megyei Újudvaron, de akkor okt. 7-én a nádor parancsára közgyülést tartott Zala megyének, ez a magyarázat (AOkl IX. 442. sz.).

${ }^{1067}$ AOkl VII. 63. sz., 337. sz., 428-429. sz., 505. sz., stb., VIII. 24. sz., 70. sz., 99. sz., 106. sz., 141. sz., stb., IX. 20. sz., 49. sz., 51. sz., 83. sz., 98. sz., 117. sz., stb., X. 15. sz., 21. sz., 111. sz., 150. sz., 171. sz., stb., XI. 85-86. sz., 185. sz., 206. sz., 283. sz., 289. sz. stb. Egy ismert alkalommal keltezett máshol, a Borsod megyei Boldván: AOkl VII. 704. sz.

1068 Egy-egy egyedi titulus előfordul: vices ... palatini a legelső ismert levelében (nyilván még nem szilárdult meg a terminológia: AOkl VII. 63.); vicecomes ... palatini - saját intituláció, ám ez az oklevél csak másolatban maradt fönt, és valószínüleg elírás (AOkl XI. 206. sz.); a leleszi konvent egy alkalommal csak comes-nek, Valter föesperes pedig egyszer vicepalatinus-nak említette (AOkl X. 529. sz., XI. 202. sz.).

${ }^{1069}$ Egy kivétellel, a csatári konvent említésében ugyanis még a régi sablon szerepel (AOk1 IX. 551. sz.)
} 
második felében „megjelenik egy hol Pesten, hol pedig Budán rezideáló alnádor”. ${ }^{1070}$ Tringli István a 13. század végével számolt: a „nádornak a [13.] század végére két kúriája jött létre, az egyik [alnádor] többnyire a nádorral együtt annak vidéki kúriájában ítélt, a másik azonban a királyi székhely közelében tevékenykedett." ${ }^{\text {"1071 }}$ A kettős alnádori rendszert tehát legalább a 13. század végéig visszavezette a szakirodalom. Magunk abból az alább részletesen tárgyalt tényből indulnánk ki, hogy a Pesten, majd Budán székelő alnádor már az 1240-es évektől, de talán már a tatárjárás előtt is Pest megye ispáni jogkörét is gyakorolta. ${ }^{1072}$ Ennek kapcsán gyakran idézik azt az oklevelet, amelyet 1323. január 14-én ${ }^{1073}$ küldött a budai káptalan I. Károly királyhoz. Eszerint Károly Pest megye ispánjának és szolgabíráinak küldött levelét nem tudják átadni, mivel az alnádori (vicepalatinus) hivatal éppen üresedésben van. Ez az adat nem csak azt bizonyítja, hogy a pesti ispán feladatait az alnádor látta el, hanem azt is, hogy a hivatala általában véve be lehetett töltve, hiszen a megyének müködnie kellett. Az Árpád-korból csak nagyon elszórt adatunk van a Pesten vagy Budán székelő alnádorra, az Anjou-korból pedig 1322-ig egyet sem ismerünk. ${ }^{1074}$ A 14. század eleji hiátust vélhetően nem csak forráshiánynak kell betudnunk, hiszen egy jó darabig maga a király sem tudta szilárdan kezében tartani Budát, nem valószínű, hogy nádorai ott folyamatos alnádort tartottak volna. Ezt leszámítva azonban valószínüsíthetjük, hogy a tisztet relatíve folyamatosan betöltötték, különben nem maradt volna meg az alnádori tisztség Pest megyével való összekapcsolódása a

${ }^{1070}$ Hajnik 1899. 66.; Szovák 1989. 300.
${ }^{1071}$ Tringli 2010. 381.
${ }^{1072}$ Zsoldos 1998. 26-27.; Tringli 2001. 154-155.
${ }^{1073}$ Az oklevelet 1333. évi kelettel is szokták idézni (lásd Archont. 1301-1457. 163. 177. jz.; Zsoldos 1998. 25.; Tringli 2001. 154.; Tringli 2010. 380-381.), sőt, az Anjou-kori Oklevéltár köteteiben kétszer is regesztázták, egyszer az 1323. (AOkl VII. 7. sz.), egyszer az 1333. év alatt (AOkl XVII. 23. sz.). Az oklevélben (DL 40417.) az év leírása tényleg 1333-nak néz ki $\left(\mathrm{M}^{\mathrm{o}} \mathrm{CCCX} \mathrm{XX}^{\mathrm{o}}\right.$ tertio, jól láthatóan három, és nem kettő X-szel), ám tartalmilag csak az 1323. év jöhet szóba. A levél szerint ui. Károly király Temesvárott, dec. 27-én kelt (in Themesvar, in festo beati Johannis apostoli et evangeliste), Pest megyének küldött levelét nem tudják bemutatni, mert az alnádori hivatal éppen üresedésben van. Az oklevél kelte: post octavas Ephiphanie die prenotato, vagyis 1323 esetén jan. 14., 1333 esetén jan. 16. Világos tehát, hogy Károly átírt parancslevelének az előző évben kellett kelnie. Károly itineráriuma pedig csak az 1322. év esetén egyeztethető össze a temesvári kelethellyel, mert az év decemberében valóban ott tartózkodott (AOkl VI. 880. sz., a város mellesleg ekkor még a székhelyének számított), míg 1332. dec. 20-21-én Visegrádon volt (DL 99943., DL 99944., DF 277277.), ahogy 1333. jan. 2-án is (AOkl XVII. 2-3. sz.), nem valószínü, hogy a két időpont között, dec. 27-re „leszaladt” volna Temesvárra, hogy rögtön vissza is térjen Visegrádra. Inkább az 1322/1323. évi keletek mellett szól az is, hogy január 14-én az alnádori hivatalt üresedésben lévőnek mondták. Debreceni Dózsa 1322. nov. 27-i utolsó, és Druget Fülöp 1323. jan. 20-i első feltünése között a nádori (és ezáltal az alnádori) hivatal minden kétséget kizáróan üresedésben volt (Archont. 1301-1457. 2.). 1333 januárjában a nádori hivatal biztosan be volt töltve (Druget János). Az alnádorra ebből a hónapból valóban nincs adat, tehát elvileg lehetett üresedésben, de márciusból már ismejük János Budán székelő alnádorát (AOkl XVII. 142. sz.).

10741267 és 1299 között összesen 5 személyröl van tudomásunk úgy, hogy egyikük hivatalviselését sem lehet egy évnél hosszabb időre kimutatni. Listájukat lásd Archont. 1000-1301. 20-24. Az Anjou-korra: Archont. 1301-1457. 2-3. vö. AOkl VI. 571. sz. 
14. századra is. ${ }^{1075}$ Egy viszonylagos folyamatossággal létező, latinul többnyire vicepalatinus névvel illetett Budán székelő alnádorral tehát számolhatunk. Ezzel párhuzamosan Aba Amadé nádorsága idején előfordultak olyan viceiudexek is, akiknek a müködését semmiképpen nem lehet a pesti ispáni címet is viselő budai alnádorral összeegyeztetni - legfőképpen azért, mert sosem Budán kelteztek, hanem Vizsolyban (a „Bude residens” alnádorok az Árpád-korban, amennyiben ismerjük a kelethelyüket, többnyire Budán vagy Pesten keltezték a levelüket, tehát nem csak üres formula volt az ott tartózkodásra való utalás). ${ }^{1076}$ Bár előfordult, hogy a budai alnádor elhagyta székhelyét (fentebb már utaltunk Druget Fülöp Tamás nevü alnádorára, aki Zala megyének tartott közgyülést az ura parancsára, és Pósa alnádor kérdésére is), ${ }^{1077}$ mivel Amadé viceiudexei következetesen ugyanazt a települést jelölték meg, Vizsolyt, ezért kimondhatjuk, hogy ott tartották kúriájukat, nem csak ideiglenes ott tartózkodásról volt szó. A kettős alnádori rendszer tehát a 13. század utolsó évtizedében, Aba Amadé alatt már biztosan müködött. Amadé albirája tehát a nádori székhely (Gönc) közelében, Vizsolyban tartotta hivatalát. ${ }^{1078}$ A vizsolyi viceiudexek mellett, ha nem is ugyanazon időből, de ismerjük Amadé vicepalatinus Bude residensét is, tehát ez a méltóság is be volt töltve. ${ }^{1079}$

\footnotetext{
${ }^{1075}$ Ennek látszólag ellentmond az a tény, hogy amikor már az alnádor pesti ispáni jogkörét is megszüntették, teljesen ispán nélküli volt a megye, ám az ispán feladatait a 4 szolgabíró is el tudta látni (Tringli 2001. 155156.), azaz létezhetett megye ispáni jogkört gyakorló személy nélkül is. Ám ez a szolgabírói rendszer az 1270-es években jött létre (Zsoldos 2003. 791-797.), és a korai időkben még biztosan nem lehetett olyan fejlett, hogy önmagában el tudja müködtetni a megye hatóságát.

${ }^{1076}$ Heves 51., Zala I. 118-119. (RP 197., 203. sz.). A statisztikailag nem túl jelentős két Árpád-kori adatot (más esetben nincs kitéve a kelethely) erösíti, hogy mind Debreceni Dózsa, mind Druget Fülöp budai alnádorára igaz volt ugyanez. Miklós fia Péter „vicepalatinus Bude residens” (Zichy I. 98.) egy damus pro memoria-jában Pesten keltez: HO VIII. 383-384. (RP 289. sz.). Kérdéses, hogy a „Budán székelővel” azonosíthatjuk-e Pósa alnádort (vicepalatinus), aki Fehérvárott keltezett egy damus pro memoria oklevelet (Zichy I. 77., RP 176. sz.). Hogy ö esetleg a budai alnádorok közé tartozott, arra nem csak egy másik oklevélben említett vicepalatinus elnevezése utal (a nádor környezetében tartózkodókat ekkor többnyire viceiudex névvel illették), hanem a per területi vonatkozása is, mivel a Pest megyei Berkiből származó Csom perelt a szintén Pest megyei Negyed faluval. Mivel az eset biztosan az aug. 20-i éves fehérvári törvénynapon történt (az oklevél szerint a felperes Szent István ünnepétől, vagyis aug. 20-tól várakozott az alnádor színe előtt, aki levelét Fehérvárott keltezte), ezért talán arra gondolhatunk, hogy itt a budai ítélkező fórumok ideiglenes Fehérvárra településéről volt szó. Persze az sem biztos, hogy Pósa tényleg a Budán székelő alnádorok közé tartozott, hiszen a vicepalatinus titulusa mellett ez nincs kitéve.

${ }^{1077}$ AOkl IX. 442. sz., ill. Pósára lásd az előző jz.

${ }^{1078}$ Zichy I. 121. (RP 272. sz.); DL 75155. és 75215. (kiadásuk: RP 317-318. sz.); DL 75156. (kiadása: RP 321. sz.). Teljes bizonyossággal ugyan csak János albíró esetén találkozunk a vizsolyi székhellyel, mert Amadé másik név szerint is ismert viceiudexe, Pál oklevelének nem ismerjük a kelethelyét (HO VII. 360., RP 327. sz.). Ismerünk azonban egy Vizsolyban kiadott damus pro memoria oklevelet, amelyet 1296-ra keltezhetünk, és amely Amadé nádor egyik ügyét folytatja, tehát az ö albírája adta ki (Zichy I. 121., RP 272. sz., lásd még az RP 271. sz. reg. kommentárját). Az oklevél hátulján lévő pecsétfolt mérete pedig nem azonos János nádori albíró pecsétjének méretével (lásd az RP 272. sz. reg. kommentárját), így úgy tűnik, hogy több vizsolyi albírája is volt Amadénak.

${ }^{1079}$ DL 90791. (kiadása: RP 238. sz.)
} 
Nem egyértelmü, hogy a kettősség létrejöttét mikortól számíthatjuk. Az Aranybulla csak egy, a nádor kúriáján ítélkező helyettest írt elő. És mivel az alnádorok minimum a tatárjárás óta Pest megyéhez, és azokhoz a részekhez kötődtek, ezért logikus lenne, hogy ez már életre hívta egy másik, valóban a nádor melletti helyettes meglétét, ahogy ezt többé-kevésbé Szovák Kornél is feltételezte. ${ }^{1080}$ A források elégtelen volta ugyan nem teszi lehetővé ennek egyértelmű kimondását, de azért apró jelek szólnak mellette. Halvány nyom, hogy az első ismert tatárjárás utáni albíró (viceiudex), Pósa fia Bodur 1267-ben magánemberként a pécsváradi konvent előtt tett bevallást egy föld adásvételéről. ${ }^{1081}$ Az oklevél szerint ő annak a Kemény fia Lőrincnek az albírája volt, aki a somogyi ispánságot is viselte ez időben, így valószínűsíthetjük, hogy Bodur inkább Lőrinc környezetében tartózkodott, semmint Budán székelt volna. Sándor pedig, aki (Domokos fia) Roland albírájának (viceiudex) nevezte magát, egy Kanad (Kányád?) nevű településen keltezett 1272-ben vagy 1274-ben. ${ }^{1082}$ A település nem azonosítható egyértelmüen, de az ügy a Vas megyei Káld falu feldúlása kapcsán robbant ki, így talán itt sem a budai alnádor járt el. Ha a logika helyes, akkor 1267-től már adatolni lehet a kettős alnádorság rendszerét, de megalapozottan csak Aba Amadé idejéből állíthatjuk, hogy létezett. Valószínű egyébként, hogy nem minden nádor élt albírák választásával, csak aki igényelte azt, míg a pesti ispánsággal összekapcsolódó tisztséget a legtöbben betölthették.

Mint láttuk, az Anjou-kor korai szakaszában, amikor ismét elkezdtek helyetteseket állítani, Debreceni Dózsa és Druget Fülöp idejéből megmaradt az a szokás, hogy a kettős helyettesi rendszert az Árpád-kori szisztémához hasonlóan müködtessék. Druget Fülöp halálát követően azonban a nádorhelyettesi posztok visszább szorultak. Druget János Óbudán rendezte be székhelyét, amely már önmagában is feleslegessé tette a budai és a kúriai albírói tisztség szátválasztását. Jánosnak 3 helyetteséről is tudunk. Gekemen óbudai alvárnagy régóta hüséges emberének számított, ám őt csak ideiglenes jelleggel nevezte ki az albírói posztra 1329-ben. ${ }^{1083}$ Gekemen egyébként megmaradt óbudai alvárnagynak, és bő fél évvel később már csak ilyen minőségben adott ki oklevelet az új albíróval, Péterrel együtt (comitis Petri viceiudicis et comitis Gyekmeni vicecastellani domini Johannis palatini de Veteribuda). ${ }^{1084}$ Péter még egyszer bukkant fel az év folyamán, ${ }^{1085}$ többször nem hallunk róla (hacsak nem

\footnotetext{
${ }^{1080}$ Szovák 1989. 300.

1081 ÁÚO III. 171-172.

1082 DL 93896. (kiadása: RP 168. sz.)

1083 Oklevelének intitulációja: „,comes Jekuminus castellanus de Veteri Buda, viceiudex ... Johannis palatini pro tempore constitutus” Zichy XII. 7. (AOk1 XIII. 222. sz.). Személyére: Zsoldos 2012c. 528., 531.

1084 1330. jan. 21.: DL 376. (AOkl XIV. 52. sz.)

1085 A leleszi konvent 1330. júl. 24-i oklevele említette (comitis Petri vice iudicis ... Johannis Drugeth ... palatini): DF 265526. (AOk1 XIV. 430. sz.)
} 
volt azonos az 1333-tól az óbudai kúriában müködő Péter mesterrel, nádori protonotáriussal, ${ }^{1086}$ de ez nem valószínü). 1333-ban Gergely albíró bukkant fel kétszer is, szintén viceiudex titulussal említve. ${ }^{1087}$ Mindhárom albíró Óbudához kötődött, és nem egyértelmü, hogy tisztségük az egyébként is (Ó)Budán székelő alnádorhoz, vagy a nádor környezetében tartózkodó albíróhoz állt közelebb, már ha van értelme különbséget tenni egy ilyen speciális esetben. Eközben az elhunyt Fülöp vizsolyi albírája, Perényi Miklós is tovább folytatta ott müködését, csak ekkor már a Druget-tartományt megkapó Vilmos égisze alatt. 1328-ban segített átvenni a tartományt, közremüködött abban, hogy Vilmost beiktassák az egyes várakba, és a hozzájuk tartozó birtokokba. ${ }^{1088}$ Később ugyanazt a bíráskodási gyakorlatot vitte tovább, amit Fülöp alatt is képviselt, még a megszokott titulusában is csak az uraként megjelölt személy változott (comes Nicolaus viceiudex magistri Wyllermi). ${ }^{1089}$ Mikor Vilmos nádorhelyettesi címet kapott, akkor is Perényi Miklós maradt a vizsolyi albírája, ám nádorrá emelkedése után nem tartotta meg, pedig biztosan nem halt meg. ${ }^{1090}$

Vilmosnak szintén három helyettesét ismerjük. Dénes fia Jakabot I. Károly egy ízben vicepalatinusnak nevezte, ${ }^{1091}$ egyébként Vilmos és a saját okleveleiben is az ekkor általánosnak számító viceiudex megnevezéssel illették. Jakab még dédesi várnagy volt Druget Fülöp idején, és akkor került Vilmos szolgálatába, amikor az a tartomány mellett annak „,Személyzetét” is átvette. ${ }^{1092} \mathrm{Az}$ időleges albírói titulus mellett Gömör megyei alispán volt, és sokszor a megye ügyei kapcsán bukkant fel. ${ }^{1093}$ Esetleges óbudai tartózkodására is utalhat a budai alnádornak kijáró vicepalatinus név mellett az a Budán, Vilmos nádor nevében kelt oklevél, amely szerint egy békebírságot a nádornak és Jakab alnádorának is megfizettek ott. ${ }^{1094} \mathrm{Ha}$ ez így is volt, biztosan nem ő volt Vilmos állandó jelleggel Budán székelő alnádora, már ha Vilmos betöltötte egyáltalán ezt a posztot. Jakab összes albírói megjelenése az 1335-ös évhez köthető, és 1336-ban már csak gömöri alispánságát említik az oklevelek. ${ }^{1095}$ 1339-ben egy bizonyos Bertalan a viceiudex, aki fogott bíróként döntött az országbíró

\footnotetext{
1086 1333. okt. 18.: AOkl XVII. 469. sz.

1087 AOkl XVII. 121., 142. sz. Gergely személyére lásd Zsoldos 2012c. 532. 47. jz.

1088 AOkl XII. 45-46. sz.

${ }^{1089}$ Ez az intituláció Miklós 1330. febr. 7-i oklevelében található (átírása: DL 60199.), de máskor is ugyanez volt.

${ }^{1090}$ Perényi Miklós további sorsára lásd AOk1 XIX. 43. sz., 479. sz., 575. sz., 698. sz.

1091 1335. márc. 2.: AOkl XIX. 84. sz.

1092 Zsoldos 2012d. 36., 39.

1093 AOkl XIX. 283., 479. Szintén Gömör megyei vonatkozásúnak tekinthető az az oklevele, amelyben a nádori bíróság előtt való megjelenésre szólította fel Benedek fia Lászlót (AOkl XIX. 574., vö. 586. sz.), mivel Lászlót csetneki származása (lásd AOkl XIX. 303. és 306. sz.) ehhez a megyéhez köti.

${ }^{1094}$ AOkl XIX. 352. sz.

1095 AOkl XX. 426., 429., 447. sz.
} 
ítélkezésének helyszínén, Visegrádon. ${ }^{1096}$ Az egyéb fogott bírák (az országbírói albíró és protonotárius) az országbírói kúriához kötődtek. Az oklevelek szerint a bírók a döntést április 25-re ígérték, végül május 8-án számoltak be róla Pál országbírónak. Bertalan tehát a nádor környezetében, Visegrádon tartózkodó albíró volt, ám az 1339-es év kivételével nem hallunk róla. Mint említettük, nem tudunk arról, hogy Vilmos a vizsolyi kúriában betöltötte volna az albírói tisztséget nádorrá választása után. Perényi Miklóst valamiért leváltotta, és ő utána legközelebb csak „Ruszkai” Benedek fia Izsép mester viceiudexet nevezte ki, aki 1339 és 1341 között viselte ezt a tisztséget. Izsép akkor igen aktív helyettesi tevékenységet kezdett folytatni. Fentebb már említettük, hogy véleményünk szerint kinevezése azzal függött össze, hogy Vilmos 1339-ben már tudatosan készült arra, hogy a generalis congregatiok következő nagy időszakáig, 1341-ig nem tér vissza Vizsolyba. Hogy a tartománya ne maradjon bírói központ nélkül, a vizsolyi kúriájában hátrahagyta a nevében ítélkező Izsépet. ${ }^{1097}$ Mind János, mind Vilmos alatt feltűnő, hogy a helyettes bírákkal csak egy-egy rövidebb, meghatározott időtartamra találkozunk. Mivel ezt a tendenciát nem tekinthetjük a forráspusztulásból adódó véletlennek, így arra kell gondolnunk, hogy az albírói tisztség nem volt állandó jelleggel betöltve Druget János és Vilmos nádorsága alatt. Többnyire a saját környezetükben müködő helyetteseket állítottak, és a poszt betöltését nagyban befolyásolták a pillanatnyi igények is. Így általánosságban elmondható, hogy az Árpád-kor folyamán többé-kevésbé megszilárdulni látszó rendszer a budai alnádorral és a kúriai albíróval funkcionálisan tovább élt az Anjou-kor elején Dózsa és Druget Fülöp nádorsága alatt (bár az Árpád-kori terminológia csak Dózsa alatt mutatható ki). Azzal, hogy Druget János a kúriáját Óbudára, az egyik alnádor kijelölt székhelyére helyezte, értelmetlenné is tette a kettős helyettesi szisztémát, és ez fia idején sem állt igazán helyre. Tudunk ugyan Vilmos környezetében müködő albíróról, és vizsolyi albíróról is, de őrájuk már nem alkalmazható a „klasszikus” kettős rendszer, hiszen a vizsolyi helyettes, Izsép kinevezése idején a hely már nem tekinthető Vilmos igazi kúriájának, a BudaVisegrád vonzáskörzetben feltünő viceiudexek pedig csak rövid időre kerültek hivatalukba. Az állandó budai albíró (alnádor) szerepét Vilmos idején már a távollétében működő óbudai nádori kúria vette át (Pest megye ispáni feladatait, ami a budai alnádorsághoz kötődött, aligha a nádori kúria látta el, erre lentebb még visszatérünk). A vizsolyi albírót pedig szintén egy alkalmi igény, a nádornak a honorbirtokaitól való tudatos és tartós távolléte generálta. 1342-re a nádori hivatal számtalan eleme professzionalizálódott és megszilárdult, ám a nádorhelyettesek állítását pont nem szabályozta semmilyen kiforrott szokásjog.

\footnotetext{
${ }^{1096}$ AOkl XXIII. 204., 260., 556. sz.

${ }^{1097}$ Lásd a „4.5 - A Druget-nádorok” c. fejezetet.
} 
Fentebb már többször említettük, hogy az alnádor látta el Pest megyei ispáni teendőit. A tisztség ezen megyéhez kapcsolása az 1230-1240-es években mehetett végbe. Itt le kell szögezni: ez nem azt jelenti, hogy az alnádor pesti ispán is lett volna egyben. Ezen titulusát sosem említik, még akkor sem, amikor indokoltan várnánk. Az az 1323 januári oklevél, amit a budai káptalan címzett Károly királyhoz, Pest megye hatóságához címzett levelének ki nem hírdetését nem azzal indokolta, hogy az ispánság nincs betöltve, hanem hogy az alnádori hivatal van üresedésben. ${ }^{1098}$ 1446-ban már azzal védekeztek a pestiek az ispánállítás ellen, hogy a megyének sosem volt ispánja. ${ }^{1099}$ Vagyis - a kortársak álláspontja szerint - nem az alnádori hivatal mellé járt a pesti ispánság, hanem maga az alnádori hivatal foglalt magába olyan jogokat is, amely ispáni jellegü hatalmat biztosított a megye felett. A megyének tehát tényleg nem volt ispánja, „alnádora” volt. ${ }^{1100}$ Az alnádor kezdetben a pesti oldalon székelt, majd valamikor 1272 után átkerült Budára. ${ }^{1101}$

Az első, közvetett nyom az ispáni jogkörére a pesti hospesek 1244. évi kiváltságlevele, amelyben IV. Béla eltiltotta az alnádort (vicepalatinus) a pesti hospesek feletti ítélkezéstől és a körükben való megszállástól (mindkettő ispáni jog). ${ }^{102}$ Mivel Béla az oklevél szerint a hospesek tatárjárás előtti szabadságait erösítette meg, ezért már régóta arra gyanakszik a szakirodalom egy része, hogy az alnádor Pest megye feletti joghatósága is visszavetíthető az 1230-as évek elejére, esetleg korábbra is. ${ }^{1103}$ Ezzel ellentétesen vélekedett Györffy György a kiváltságlevél elemzésekor, mert szerinte bizonyos szimmetriák fedezhetőek fel az oklevél pontjainak első fele és második fele között. ${ }^{1104}$ A királyi tisztségviselők (princeps noster) megszállási jogát is tiltotta már egy korábbi rendelkezés. ${ }^{1105}$ Tény ugyanakkor, hogy bár

\footnotetext{
1098 AOkl VII. 7. sz.

1099 Zsoldos 1998. 24.; Tringli 2001. 156-158. Tegyük hozzá: itt elsősorban nem az ,alnádor az nem ispán” terminológiai megkülönböztetés vezette az érvelöket, hanem az, hogy az 1330-as évek óta, tehát már több, mint 100 éve, miután megszüntették a budai alnádorság intézményét, a megyének tényleg nem volt semmilyen ispánja, és még az alnádor sem bírt ilyen jogkörrel. Kizárólag a szolgabírák látták el a megye müködését (Tringli 2001. 155-156., ill. lásd még itt, alább). Az más kérdés, hogy az ispánnélküli megye helyzetének a kezdetekig való visszavetítése tényleg jogos, bár nem biztos, hogy tudatos meglátás volt.

${ }^{1100}$ Vö. Tringli 2001. 155.

1101 A pesti székhelyre lásd 1244: Elenchus III/2. 40.; 1272: Mon. Bp. I. 126. A budaira lásd 1279: Heves 51. (RP 197. sz.); 1270-es évek: Zala I. 118-119. (RP 203. sz.); 1288: DL 90791. (kiadása: RP 238. sz.); 1299: Zichy I. 98.; s. d.: ÁÚO X. 388. (RP 313. sz.). Pest kezdetben dunakétparti város volt (Kétpest), így a tatárjárás elötti pesti székhelyet - elvileg - felfoghatnánk úgy is, hogy az a mai budai oldalra esett. Ám a tatárjárás után a jobb parti Pestet következetesen Kispestnek (Minor Pest), majd az 1260-as évektöl Kelenföldnek (Kreynfeld) nevezték (ÁMTF IV. 571-572.). Így az 1272-es adatot a Pesten székelő alnádorról a dunabalparti „Nagy” Pestre vonatkoztathatjuk.

${ }^{1102}$ Elenchus III/2. 40; Zsoldos 1998. 26-27.

${ }^{1103}$ Pl. Hajnik 1899. 66.; Szovák 1989. 300.; Zsoldos 1998. 26-27.; Tringli 2010. 378-379.

${ }^{1104}$ Györffy 1997. 136-137.

${ }^{1105}$ Elenchus III/2. 40.
} 
nagyon hasonló megfogalmazású, de ezzel nem teljesen rokon az alnádorról szóló intézkedés, hiszen az nem csak a megszállásról, de a bíráskodás tiltásáról is szól ${ }^{1106}$ (a korban a kettő gyakran együtt járt, hiszen a bírói joghatóság ellenszolgáltatása volt a megszállás, tkp. egyes javaik fölélése). ${ }^{1107}$ Emellett vitatható, hogy az alnádort vajon a király princepseihez lehet-e sorolni, ${ }^{1108}$ akikröl a kiváltságok fentebb szóltak. Megfontolandó viszont Györffy azon meglátása, hogy „egyszeri szerkesztés esetén azt várnánk, hogy a rokon intézkedést tartalmazó pontok általában egymás mellett szerepeljenek." ${ }^{1109}$ Hogy a kiváltságokat nem gépiesen újították meg, mutatja, hogy pont az alnádorról szóló rendelkezés után Béla a tatárjárást is említi, ${ }^{1110}$ ez a rész tehát semmiképpen nem származhat egy 1241 előtti kiváltságlevélből. Ez ugyan nem egyértelmü bizonyíték arra, hogy az alnádorról szóló rész is csak az 1244-i megújítás bővítménye, de - másfelöl nézve - korántsem kétségtelen, hogy az alnádori jogot vissza lehetne vezetni a tatárjárás előttre.

Ha filológiai adatok biztosan nem is, de történeti érvek talán támogathatják azt, hogy a joghatóság mégis 1241 előtt jött létre. Az erősen valószínü, hogy az alnádor és a megye közti kapcsolatban szerepet játszott az a tény, hogy ebben a régióban különösen magas volt a királyi udvarbirtokok aránya, akiknek a népei épp a nádor fennhatósága alá tartoztak. ${ }^{111}$ A régió ismert formában történő külön megyékké szervezése csak a 12-13. század fordulóján indult meg, addig egyetlen ,óriásmegye” állt ott, Szent István korában még Visegrád (később talán Esztergom) központtal. Ez a „Visegrád megye” kezdett aztán felbomlani 4 utódispánsággá, amelyek közül az egyik Pest megye lett. ${ }^{1112}$ Zsoldos Attila szerint a megye keleti részeinek ispánsággá szervezésére II. András fia, Béla herceg tehetett kísérletet. Bár 1227-ből említettek egy budai (mai nevén: óbudai) ispánt, végül az óbudai uradalomból nem vált ispánság, mivel Béla herceget egyéb teendők foglalták le (az erdélyi ügyeket pont 1227-től vette át, és 1228tól irányította II. András adományainak felülvizsgálatát). Mivel a terület nem maradhatott megyei igazgatás nélkül, ezért az alnádort vonták be. „Az alnádor több szempontból is megfelelő ispánja lehetett Pest megyének. Ura, a nádor révén szoros szálak füzték a király udvari birtokszervezeteihez, másfelől pedig a megyei birtokosokat sem érhette sérelem a

\footnotetext{
1106 „nullus principum nostrum violentum descensum facere possit super eos” ill. „vicepalatinus violenter descendere non possit super eos, nec eosdem iudicare” Elenchus III/2. 40.

1107 Tringli 2010. 379.

${ }^{1108}$ Vö. Tringli 2001. 155.; Tringli 2010. 381.

${ }^{1109}$ Györffy 1997. 137.

1110 „Item omnia, que eis post recessum Tartarorum possint sine contradictione qualibet possidere.” Elenchus III/2. 40 .

${ }^{1111}$ Ugyan eltérő okokat felvázolva, de alapvetően ebből indult ki Zsoldos Attila (Zsoldos 1998. 28-31.) és Tringli István (Tringli 2010. 384.) is.

1112 Részletesen: Zsoldos 1998.
} 
megyésispáni jogoknak az alnádor kezébe adásával, hiszen annak ura, a nádor akkor már minden országlakos ügyében illetékes bíró volt." "1113 Tringli István inkább a királyi udvarnak és ezáltal igazságszolgáltatási rendszernek a budai régióba történő odatelepítésével indokolta a kapcsolatot (ezt a lehetőséget Zsoldos Attila is felvetette, de el is utasította). ${ }^{1114}$ Könnyen lehet azonban, hogy közelebbről sosem tudjuk meg, hogy részleteiben hogyan és mikor ment végbe az ispáni jogkör beépülése az alnádorságba.

A két jogkör egymáshoz kötődése, az 1320-as évek elején még létezett. 1322. november 27-én István, Dózsa budai alnádora (comes Stephanus vicepalatinus ... Dausa palatini ... Bude residens) Pest megye 4 szolgabírájával együtt ítélt egy ottani föld ügyében, ami ispáni jogkört sejtet. ${ }^{115}$ Mint láttuk, néhány hónappal később, 1323 januárjában már konkrétan is az alnádori hivatalhoz kapcsolták az ispáni teendők ellátását, de ez az utolsó nyoma annak, hogy az alnádornak ilyen jogköre lett volna. Úgy véljük azonban, hogy Fülöp nádor idején ez még fennállhatott, hiszen nála még az Árpád-kori szisztéma érvényesült a helyettesek állításakor. Druget János már csak alkalmi albírókat állított, ahogyan fia, Vilmos is. Mivel ekkor már állandó jellegü budai albírát sem neveztek ki (Vilmos esetében ezt a funkciót részben az óbudai nádori kúria vette át), ezért könnyen lehet, hogy ekkor már egyáltalán nem is volt senki, aki a pesti ispáni teendőket ellátta volna. A szakirodalom inkább 1342 utánra teszi azt az időszakot, amikortól a megyének nem volt ispánja, és a megyei hatóságot csak a 4 szolgabíró jelentette, ${ }^{1116}$ ám vannak arra közvetett források, hogy már Druget Vilmos nádorsága idején számolhatunk ezzel. Olivér királynéi udvarbíró 1338. július 15-i oklevele írta át tartalmilag Druget Vilmos nádor diplomáját, amelyet a Pest és Pilis megyei szolgabírákkal közösen adott ki a két megye számára tartott nádori közgyülésen (litteras ipsius domini Wyllermi palatini ac iudicum nobilium Pestiensis et Pelesiensis comitatuum, in

\footnotetext{
${ }^{1113}$ Zsoldos 1998. 28-31. (idézett rész: 31.)

1114 Tringli 2010. 384.; Zsoldos 1998. 28-29. Tegyük hozzá: Zsoldos Attila kritikáját (bár időben megelőzi Tringli István felvetését, csak saját magára reagál) helyesnek kell tartani. Tringli szerint a megyében magas volt a királyi birtokok aránya, akik népei felett a nádor gyakorolt joghatóságot. A nádori joghatóság később mindenkire - így a megye nem alávetett népeire is - kiterjedt. Ezek után „Pest megye szabad birtokosai ... könnyen kereshették fel, ha nem is a nádort, de a királyi udvarban tartózkodó állandó bírói helyettesét, az alnádort. A 13. században mihelyst egy kicsit is megszilárdult a királyi udvar helye, azonnal felbukkant az alnádor, mint a Pest megyei nemesek bírája" (Tringli 2010. 384.). Ám arra nincsen adatunk, hogy az alnádor valaha is a királyi udvarban tartotta volna bírói székét, így ha a kérdést a királyi udvari bíráskodás ódudai kihelyezésével és letelepítésével kapcsolnánk össze, akkor - mint azt Zsoldos is említette - inkább az alországbíró lett volna a pesti ispán (Zsoldos 1998. 29.). Más lenne persze a helyzet, ha nem a királyi, hanem a nádori kúria pesti állandósításával számolnánk, hiszen annak bírája az Aranybullák értelmében az alnádor volt. A felvetés ugyan magyarázatot adna arra a kérdésre, hogy miért az alnádor és nem a nádor lett a pesti ispán, ám sajnos éppúgy nem lehet egyértelmủ módon bizonyítani, mint a többi elméletet.

${ }^{1115}$ DL 86950. (AOkl VI. 848. sz.)

${ }^{1116}$ Tringli 2001. 155-156.
} 
congregatione sua generali emanatas). Ennek tartalma szerint a közgyűlésen a szolgabírók, az esküdtek és a két megye nemesei (tam predicti iudices nobilium et iurati, quam universi nobiles dictorum comitatuum) megerösítették a nádor számára, hogy a Pest megyei Pécel birtokot korábban ellentmondás nélkül Péter mester, nádori protonotárius részére iktatták. ${ }^{1117}$ Ekkorra a megyei közgyüléseken a nádor mellett jelen kellett lenni az ispánnak vagy alispánnak, a szolgabíráknak, a választott 12 esküdtnek, és persze a megyék nemes (és nem nemes) lakosságának. ${ }^{1118}$ Ez az oklevél viszont feltűnően hallgatott a jelenlévő ispánról, vagy bárki más, ispáni jogú résztvevőről, csak a szolgabírák, esküdtek és a helyi lakosok részvételét említette. Ugyanezzel találkozunk Vilmos 1341. április 27-i oklevelében, amikor szintén közgyülést tartott a megyének Újbécsen. A nádor a Pest megyei Zahyus birtok hovatartozásáról ítélt, és az oklevele felsorolta név szerint a jelenlévő 4 megyei szolgabírót, a 12 esküdt ülnököt (iuratos assessores) és jelenlévőként említette az „összes” Pest megyei nemest. ${ }^{1119}$ A pesti ispánról ismét hallgatott a felsorolás, pedig ha lett volna ott a közgyülésen olyasvalaki, aki ellátta volna ezt a jogkört, akkor a részletes, a megyei hatóságot név szerint is számba vevő oklevél bizonyára megemlítette volna. Úgy tűnik, hogy az Árpád-korban gyökeredző nádorhelyettesi rendszer összekuszálódása után Vilmos már nem foglalkozott azzal, hogy olyasvalakit állítson, aki ellátja Pest megye ispáni teendőit. Nem is volt semmilyen külön beavatkozásra szükség, mert, mint kiderült, a megyei hatóság ekkor már a szolgabírókkal is elműködött. Így az alnádori hivatal és a pesti ispánság összakapcsolását egy 1230/1240-1330/1340 között fennálló, kb. egy évszázados epizódnak tekinthetjük.

Végezetül tekintsük át a nádorhelyettesek müködését és jogkörét. E téren el kell választani a korai, tatárjárás elötti adatokat a későbbiektöl. A helyettesi jogkör ugyanis változásokon ment át fennállásának első 120 éve alatt. Az albírák rendszerének létrehozását Barc fia Miklóshoz köthetjük, aki legalább négy helyettessel dolgozott. A Váradi Regesztrum 1220. évi bejegyzései (amikor ez a tisztség először felbukkan) árulkodóak abból a szempontból, hogy az összes (dokumentálhatóan négy) alnádori esetnek a földrajzi vonatkozása a mai Dunántúlra esett, míg Barc fia Miklós ügyei mind keletmagyarországiak. ${ }^{1120}$ Ez mutat egy olyan látszólagos szabályszerüséget, hogy amíg Miklós az ország keleti felén tartózkodott, addig helyettesei intézték a nyugat-magyarországi ügyeket.

\footnotetext{
${ }^{1117}$ DF 251694. (AOkl XXII. 357. sz.)

${ }^{1118}$ Lásd a „6.2 - A nádori generalis congregatio intézménye 1290-1343 között” c. alfejezetet.

1119 AO IV. 84-85. (AOkl XXV. 237. sz.)

${ }^{1120}$ RV 248. sz. (Somogy m.), 266. sz. (Tolna m.), 271. sz. (Komárom m.), és 249. sz. talán Nógrád m. E négy ítéletet három alnádor hozta (Fila, Petus, Móric). Miklós esetei: RV 244-245. sz. (Heves m.), 269. sz. (KülsőSzolnok m.), 275. sz. (Szabolcs m.), lásd még Szőcs 2012. 417.
} 
Sajnos 1221-ből már nem ennyire egyértelmű a kép, ${ }^{1121}$ az Aranybulla után, 1222-től pedig az alnádori ítélkezés a nádori kúriába szorult vissza (már ha betartották ezt az intézkedést, ám ezt nem igazán tudjuk forrásokkal ellenőrizni).

Az alnádorok és albírák egyik fontos ismérve, hogy nem a király, hanem a nádor nevezte ki őket, ${ }^{1122}$ és valószínűleg az ő személyes környezetéből kerülhettek ki - ahogy a nádori iroda egyéb munkatársai is. Ciklusokon átívelő alnádorsággal nem találkozunk. ${ }^{1123} \mathrm{Az}$, hogy a helyettesek oklevelet bocsátottak ki, még nem jelentette azt - legalábbis kezdetben -, hogy önálló döntési jogkörrel rendelkeztek volna. Köbölkúti Péter két 1234. évi oklevelét nádorának, Dénesnek az átírásából és ezáltali megerősítéséből ismerjük. Dénes (aki Ampod fia Dénessel és Tomaj nembéli Dénessel is azonosítható, így nem tudjuk, hogy Köbölkúti Péter melyiküknek volt az alnádora) oklevele szerint „Köbölkúti Péter, mivel a mi helyettes bíránkként tevékenykedik, és megtárgyalásra rábíztuk az ügyet, amelyben Phile mester, a fivére: Tamás és Farkas pataki ispán vádolta meg Miklós fia: Mikót, személyesen a színünk elé járult, és élőszóban meg az ítéletét tartalmazó oklevele által beszámolt a következő módon...".1124 Dénes ezután átírta alnádora levelét, és mivel igazságosnak tartotta, megerősítette azt. Köbölkúti Péter másik, teljesen más tárgyú és földrajzi vonatkozású ítéletlevele szintén csak Dénes megerősítésében maradt ránk. ${ }^{1125}$ Tomaj nembéli Dénes albírájának, Albertnek a levelét is átírta Dénes. ${ }^{1126}$ A tatárjárás után az alnádor már biztosan Pest megye ispáni jogait is gyakorolta, és talán már ekkortájt is ott székelt (az első biztos adat erre 1267-ből való). Mint szó esett róla, esetleg már számolhatunk azzal a kettős rendszerrel is, hogy Pesten vagy Budán székelt a vicepalatinus, míg a nádor környezetében a viceiudex. Ha megnézzük az ismert döntéseiket, akkor kialakul egy feltünő különbség. A budai (pesti)

\footnotetext{
${ }^{1121}$ Szöcs 2012. 417.

${ }^{1122}$ Logikai érveken túl ugyanez következik I. Károly már többször idézett, 1322. évi Pest megyéhez intézett okleveléböl is, amelyet az alnádori hivatal üresedése révén nem tudtak kihírdetni. 1322 novemberében még helyén volt Dózsa budai alnádora, tehát bukott urával együtt. Ha pedig az alnádorok állítása királyi jog lett volna, Károly nyilván tisztában lett volna azzal, hogy csak a nádori hivatalt töltötte még be, az alnádorit nem. A levél mutatja, hogy a király éppen azzal számolt: új nádor emelésével hamarosan alnádora is lesz a megyének.

${ }^{1123}$ Az egyetlen kvázi-kivétel Perényi Miklós lehetne az Anjou-korból, aki Druget Fülöp után Vilmos szolgálatába állt, és albírája volt még annak nádorhelyettesi időszakában is. Ám Vilmos, teljes jogú kinevezése után már nem tartott igényt a szolgálataira. A Drugetek alatt egyébként kimutatható személyi kontinuitás a nádori iroda egyéb munkatársai között, lásd erről a következő alfejezetet.

1124 „Petrus de Cubulcuth, cum iudex vice nostra existeret, et nos causam, qua magister Phile, Tomas frater eius et Forcasius comes de Potoch Miconem filium Nicolai impetebant, sibi discuciendam commisissemus, ad nostram accedens presentiam, personaliter et viva voce et litteris suis propriis in quibus iudicia ipsius continentur, proposuit in hac forma" HO VIII. 32. (RP 38. sz.)

${ }^{1125}$ DF 200920. (kiadása: RP 40. sz.)

${ }^{1126}$ DL 96256. és DL 41010. (a vonatkozó részek kiadása: RP 52-53. sz.). Az átírás ellenére a felek megtartották Albert eredeti levelét is, mert a 14. században mindkettőt be tudták mutatni.
} 
alnádornak ismerjük lezárt, saját jogán kimondott döntéseit éppúgy, ahogy a per közbülső állomásaként kiadott okleveleket is (perhalasztás, idézés). ${ }^{1127}$ Hogy az alnádor a század második felében teljes jogú bíróként járhatott el, mutatja IV. László egy keltezetlen (de vlsz. 1279-ben kiadott) ${ }^{1128}$ oklevele. Az oklevélben László leírta, hogy Uza fia Péter a birtokait a margitszigeti apácáknak adta, amint ez V. István oklevelében is benne van. Ám miután az ellenfelei megölték őt a párbajtéren, a birtokai Gergely alnádor (comes Georgius vicepalatinus) kezére jutottak ítélkezése címén (pro suis iudiciis). Az apácák az adománylevélre hivatkozva maguknak kérték ezeket a birtokokat, és ezt László is jóváhagyta. ${ }^{1129}$ Az itt említett Gergely alnádor egy levelében a „vicepalatinus Bude residens” névvel illette önmagát, tehát biztosan az ott székelők közé tartozott. ${ }^{1130}$ Az pedig, hogy az ítélkezésből kifolyólag az ő kezére háramlott a pervesztes birtokainak egy része (a szokásjog szerint a kétharmad része), mutatja, hogy itt ő teljes jogú bíróként járt el. Azt is érdemes leszögezni, hogy az alnádor joghatósága az Árpád-kor folyamán éppúgy kiterjedt az egész országra, mint a nádoré. ${ }^{1131}$ Ezzel szemben olyan oklevéllel, amelyben a viceiudex zárt le egy pert saját jogon, nem találkozunk. Sándor, Roland albírája párbaj tartását rendelte el egy hatalmaskodási ügyben, Amadé egy ismeretlen albírája elhalasztott egy olyan pert, amely korábban Amadé előtt folyt, János albíró szintén elhalasztott egy pert, Pál albírónak pedig két olyan oklevelét is ismerjük, amiben a feleket a jászói konvent elé idéztette. ${ }^{1132}$ Emellett „hiteleshelyi” funkciót is folytattak azzal, hogy az előtte megegyező felek számára oklevelet állítottak ki a saját nevük alatt, megerősítve az egyezségüket. ${ }^{1133}$ Igaz, itt nem került sor a színe előtt perre, így az önálló bírói jogkört ezeken az eseteken nem lehet egyértelmű módon lemérni. Ugyanezt tapasztaljuk Kopasz nádor helyettese, László esetében. László Kopasz

\footnotetext{
${ }^{1127}$ Zichy I. 77. (RP 176. sz.); Heves 51. (RP 197. sz.); Zala I. 118-119. (RP 203. sz.); DL 90791. (RP 237-238. sz.); HO VIII. 383-384. (RP 288-289. sz.). Tamás alnádor esetében ugyan megkérdőjelezi az eljárásának saját jogúságát az, hogy Aba Amadé pecsétje függ az oklevelén (DL 90791., RP 238. sz. reg.), de ez valószínüleg utólagos fejlemény, hiszen a megerősítő formulában a saját pecsétjével (sigilli nostri) való pecsételésről írt. A pernyertes fél talán a biztonság kedvéért át akarta iratni Amadéval is az oklevelet, ami egyébként elég hosszú, és talán ezért, vagy más okból, de csak a pecsétet cserélték ki rajta.

${ }^{1128}$ Archont. 1000-1301. 21. (Gergely alnádornál)

${ }^{1129}$ Mon. Bp. I. 181. (RA 3568. sz.)

${ }^{1130}$ Heves 51. (RP 197. sz.)

${ }^{1131}$ Gergely alnádor 1279-ben egy Borsod megyei ügyben járt el (úgy, hogy közben Budán keltezett): Heves 51. (RP 197. sz.). Péter alnádor Bars megyei birtokvitában intézkedett úgy, hogy Pesten keltezett: HO VIII. 383384. (RP 289. sz.)

${ }^{1132}$ DL 93896. (RP 168. sz.), Zichy I. 121. (Datum pro memoria-oklevél, kibocsátójára vonatkozó érveket lás RP 272. sz.), DL 75215. (RP 318. sz.), HO VII. 360. (RP 327. sz.); AOk1 I. 706. sz.

${ }^{1133}$ DL 75155. és DL 75156. (kiadásuk: RP 317., 321. sz.); AOk1 III. 790. sz. (János országbíró 1314. évi oklevele, amelyben említette Pál albíró oklevelét írta át tartalmilag, amely a felek közti megegyezést hagyta jóvá)
} 
távollétében, 1314 nyarán ${ }^{1134}$ kezdett meg néhány pert, több alkalommal a leleszi konvent elé utalta a feleket, és új megjelenést írt elő. Máskor csak nyugtázta, hogy az egyik ügyben újra visszatértek a kijelölt időpontra, és bemutatták a leleszi konvent oklevelét. Bár a szokásjog szerint ez utóbbi esetben már meghozhatta volna ítéletét, de a konkrét döntés ebből az oklevélből is hiányzott. ${ }^{1135}$ László egyik oklevelében vicepalatinusnak, másikban viceiudex palatininek nevezte saját magát, ${ }^{1136}$ de az, hogy diplomáit Kopasz territóriumán keltezte (Adorjánban és Mérken), továbbá a konkrét döntésektől való „ódzkodása” egyértelműen az albírói, és nem a (budai) alnádori jogkörrel rokonítják hivatalát. Bár a fenti megfigyelést elvileg lehetne a kevés forrás által generált torzképpel is magyarázni, de úgy véljük, hogy ennyi adat mégis elegendő azon következtetés levonására, hogy a nádor környezetében székelő viceiudex nem rendelkezett az urától független bírói jogkörrel, ellentétben a vicepalatinusszal.

Igazán komoly változás e téren Debreceni Dózsa nádorsága idején sem állt be, legfeljebb elszórt, feltételezett ellenpéldákkal találkozhatunk. Dózsa idején kb. két évtizedes kihagyás után újra felállt az a rendszer, amely szerint a nádor székhelyén, és ezzel párhuzamosan Budán székeltek a helyettesek. Mint fentebb szó esett róla, a terminológia zavarosabb volt, hiszen míg a budai székhelyü István a saját megnevezésében a megszokott vicepalatinus Bude residens formulára állt be, addig a debreceni székhelyü Péter fia Miklós „nádori általános bírónak", iudex generalis ... palatininak nevezte magát. Ezen iudex generalis alá rendeltek egy külön albírót, aki viceiudex ... iudicis generalis címmel illette magát egyetlen fennmaradt oklevelében. ${ }^{1137}$ Péter általános bíró funkciójában hasonló ügyeket látott el, mint a legtöbb nádori albíró: igazolásokat adott ki arról, hogy bevallottak egy fizetési kötelezettséget, vagy éppen megfizettek egy tartozást. ${ }^{1138} \mathrm{Az}$ alá rendelt viceiudexe hasonló okból bocsátott ki oklevelet: igazolta egy bírság megfizetését. ${ }^{1139}$ Nem lehetetlen ugyanakkor, hogy egyéb ügyekben is eljárt, csak nem a maga nevében. Már említettük, hogy Dózsa idején mutatható ki először a párhuzamos nádori oklevéladás megjelenése, azaz a kúriától távollévő nádor nevében is születtek oklevelek. Elképzelhető, hogy a nádort ilyenkor a fent említett két debreceni helyettes bíró pótolta, bár erre konkrét bizonyíték nincsen. A budai alnádor viszont

\footnotetext{
${ }^{1134}$ Kopasz ugyanis ebben az időben a Délvidéken tartott közgyülést Szerém, Bács és Valkó megyéknek, lásd AOkl III. 793-794. sz.

${ }^{1135}$ AOk1 III. 759. sz. (vö. 756. sz.); 823. sz. (vö. 782-783. sz.)

${ }^{1136}$ DL 69660. és DL 69661. (AOkl III. 759., 823. sz.)

${ }^{1137}$ István budai alnádor: AOkl VI. 568., 570., 571., 629., 775-776. sz.; Miklós nádori általános bíró: AOkl VI. 508., 517., 600. sz.; Péter általános bírói albíró: AOkl VI. 508. sz.

${ }^{1138}$ AOkl VI. 517., 600. sz.

${ }^{1139}$ AOkl VI. 508. sz.
} 
egyértelmủen önálló pereket vitt, bírói döntéseket hozott. Olyan eseteket tárgyalt csak, ahol legalább az egyik fél Buda vagy Pest környéki volt. ${ }^{1140}$ Így fordult elő, hogy eljárt a Baranya megyei Oros birtok ügyében is, amely kapcsán a szekszárdi apát és a barsi ispán között robbant ki vita. Ennek a magyarázata, hogy Imre barsi ispán és lévai várnagy ekkor elég sokat tartózkodott Budán és többször is perelt az alnádor színe előtt.

Druget Fülöp idején hasonló kettős szisztémával találkozunk. A vizsolyi kúriáján müködött Perényi Miklós, aki már nádorsága elött is szolgálta Fülöpöt, udvarbírói (udex curie) tisztséget betöltve. Miután Fülöp elnyerte a nádori méltóságot, Miklós is viceiudexé emelkedett, de feladata lényegében ugyanaz maradt, amit udvarbírói megbízatása alatt is betöltött: Vizsolyban székelve ellátta a környező megyék bírósági ügyeit. Az ő feladata így nem is közvetlenül nádorhelyettesi tisztségéből fakadt, hiszen már azelőtt is ezt csinálta. Zömében ő is csak közvetlen bírói döntéseket nem igénylő rutinesetekben működött közre. Perbe idézett, a meg nem jelenteket bírsággal súlytotta, pert halasztott, igazolta az előtte tett bevallásokat és bírságmegfizetéseket, utasításokat adott a hiteleshelyeknek egy-egy vizsgálat elvégzésére, esetleg párbajt vagy esküt ítélt. ${ }^{1141} \mathrm{Ha}$ el is rendelt birtokba iktatást, birtokfelosztást, akkor az nem egy per lezárásaként, hanem a felek kérésére történt. ${ }^{1142}$ Egy olyan nagyobb szabású perfolyamáról tudunk, amelyben - úgy tünik - egyedül hozta meg a döntést is: 1324-ben kellett ítélkeznie a Szabolcs megyei Mihálylaka birtok ügyében, amelyet Perbard mester „a színünk előtt bírói úton” (coram nobis ordine iudiciario) kapott vissza tőle. ${ }^{1143}$ Mivel Fülöp nádorsága alatt legalább 84 oklevelet ismerünk Miklóstól, ${ }^{1144}$ ez az egyetlen alkalom semmiképpen nem tekinthető releváns példának. Olyan esettel is találkozunk ellenben, amikor Miklós albíró a nádor jelenlétének hiányára hivatkozva odázott el egy döntést. 1324. június 17-én elhalasztott egy pert a királyi sereg hadoszlásának 15.

\footnotetext{
${ }^{1140}$ A margitszigeti apácák Pilis megyei Derzsülése földjének ügye: AOkl VI. 568., 570., 571. sz. Az óbudai királyi udvar egyik officiálisának pere az Esztergom megyei gyermelyi népekkel: AOkl VI. 775-776. sz. Imre barsi ispán és a szigeti apácák hospesinek pere Imre Szigetbecse (Nagysziget) birtokának feldúlása miatt: AOkl VI. 830., 838. sz. Imre barsi ispán pere Domonkos szekszárdi apáttal a Baranya megyei Oros föld kapcsán: AOkl VI. 629., 848. sz., lásd még Druget Fülöp budai albírájának, Tamásnak az oklevelét is erröl: AOkl VII. 563.

${ }^{1141}$ Pl. AOkl VII. 337., 418., 428., 429., 505., 566., 657. sz.; AOkl VIII. 24., 61., 70., 141., 159., 229., 235., 279., 308., 315., 429., 450-451., 467-468., 473., 484., 531-532., 550. sz.; AOk1 IX. 20., 22., 45., 49., 103., 164., 216. , 246., 253., 293-294., 343., 355., 370., 392., 438., 465., 516., 523., 558. sz.; AOkl X. 15., 200., 279., 328., 337., 402., 411., 418., 465-466., 487., 498., 514., 525., 542-544., 552. sz.; AOkl XI. 70., 85-86., 206., 283., 289., 364. sz.

${ }^{1142}$ AOkl VII. 603. sz.; AOkl VIII. 106. sz.; AOkl X. 134., 150. sz.

${ }^{1143}$ AOkl VIII. 141., 160., 548-549. sz. Az idézett rész: Zichy I. 271. (548. sz.)

1144 Az Anjou-kori Oklevéltár vonatkozó kötetei (VII-XI.) szerint. Azért „legalább”, mert ehhez még hozzájöhetnek az esetleges keltezetlen és „damus pro memoria” oklevelek is, amelyek teljes körủ számbavétele még nem történt meg.
} 
napjára, és akkor „urunkat, Fülöp nádort megkérdezzük a fenti ügy kapcsán” (dominum nostrum Phylippum palatinum interrogabimus de premissis). ${ }^{1145}$ 1325-ben egy színe elött lezajlott megegyezésről kiállított egy oklevelet, emellett megígérte a feleknek, hogy amikor visszaviszik az oklevelet, ,az urunknak, a nádornak az autentikus oklevelét állíttatjuk ki a mondottakról". ${ }^{1146}$ A szokott záróformula átalakítása mutatja, hogy igazán jogbiztosító hitelességű oklevelet a nádor adott ki csak. Perényi Miklós bármilyen aktív albíró is volt tehát, olyan szintü döntéshozói jogosítványokkal nem rendelkezett, mint a vele párhuzamosan hivatalban lévő budai alnádor, Tamás.

Druget János és Vilmos alatt, mint említettük, felborult a szabályos, kettős helyettesi rend. Ők alkalmi albírókat állítottak csak, rövidebb időszakokra, és a budai alnádori tisztség Vilmos alatt már biztosan nem volt betöltve, de talán már János nádorsága idején sem. Az albíróik lényegében hasonló jogosítványokkal rendelkeztek, mint Perényi Miklós. Ezt leginkább Izsépen, Druget Vilmos 1339-1341 közötti vizsolyi viceiudexén lehet jól lemérni. Izsép hivatali idejének első néhány hónapjában rendszeresen kihangsúlyozta okleveleiben, hogy a ráruházott nádori jogosítványokkal, és a nádor engedélyével jár el. ${ }^{1147}$ Később ez már nem szerepelt, de a saját hatóságáról rendszeresen úgy beszélt, mintha az maga a Vizsolyban tartózkodó nádor lenne, és a neki szóló okleveleket is Vilmosnak címezték a hiteleshelyek (ez egyébként már Perényi Miklósra is jellemző volt). ${ }^{1148}$ A viceiudexre tehát a kor folyamán nem egy önálló jogkörrel rendelkező hatóságként tekintettek, hanem csak mint az aktuális nádor képviselőjére. Ez akkor is így volt, ha az albírók saját nevükben állították ki az okleveleket, és saját pecsétet is használtak. A Budán székelő alnádor, amíg betöltötték ezt a tisztséget, ugyanúgy a nádor embere volt, ám sokkal függetlenebb lehetett az urától, jogi értelemben is, hiszen önálló döntéshozó bírói fórumnak minősült. Ennek kialakulásában szerepet játszhatott az is, hogy a nádorok Druget Jánosig bezárólag nem a vicepalatinus kúriájában tartották a saját székhelyüket, így az alnádor fizikailag és jogilag is jobban el tudott távolodni a nádorispán hivatalától. Az ura mindenkori kúriáján (kivételes esetben: annak közelében) székelő albíró viszont soha nem volt egyéb, mint a nádor személyi helyettese, aki a tartományának egyes rutinügyeivel foglalkozott a nádor nevében.

\footnotetext{
${ }^{1145}$ DF 285783. (AOkl VIII. 316. sz.)

1146 ,cum autem presentes [litteras] nobis fuerint reportate, litteras autenticas domini nostri palatini super premissis faciemus emanary [!]” DL 96120. (AOkl IX. 122. sz.)

${ }^{1147}$ AOkl XXIII. 580., 643-644., 708., 715. sz.

${ }^{1148}$ Pl. AOkl XXIII. 738., 751. sz.; AOk1 XXIV. 567., 573. sz.
} 


\section{2 - A nádori „iroda” belső munkatársai: jegyzők, ítélőmesterek}

Az alábbiakban a nádori kúria belső, vagyis helyi munkatársait mutatjuk be. A nádor környezetében - föúri mivoltából adódóan - természetesen mindig sokan tartózkodtak, és egyes oligarchikus vagy tartományúri hatalmat kiépítő nádorok (pl. a Csákok vagy a Drugetek) szabályos kis „udvartartással” rendelkeztek. Ezek az emberek azonban nem tartoznak a nádori kúria segédszemélyzetéhez. Így a fejezetben jórészt csak az írásbeliségben segédkező hivatali személyzetet mutatjuk be. A különféle kancellárok, nótáriusok a 13. század második felétől kiegészültek a protonotáriussal. Mint a neve is mutatja, a tisztség betöltője eredetileg szintén a kancelláriai munkában segédkezett, aztán hivatali feladata a 14. század első harmadának végén gyakorlatiasabbá alakult: a különféle kúriai bírósági ügyeket irányította, tulajdonképpen ő lett a bírói kúria vezetője. Ekkor a tisztséget már joggal magyaríthatjuk „ítélőmesternek”. Az ítélőmesteri funkció bizonyos értelemben átmenetet jelent tehát az egyszerü hivatali segédszemélyzet, és az adott bíró (jelen esetben a nádor) személyét helyettesítő albírói tisztség között. Mivel azonban a protonotárius a tárgyalt korszakunk nagy részében inkább még a segédszemélyzeti funkcióhoz állt közelebb, és csak Druget Vilmos nádorságától kezdve (1334-1342) mutatható ki a nádori kúriát teljes egészében felügyelö és irányító ítélőmesteri feladatkör, ezért inkább ebben a fejezetben tárgyaljuk. A „nádori iroda” elméleti fogalmán persze nem kell valami komoly hivatali szervre gondolni. A 14. század második felében is egyidejüleg 2-3, a század végén 5-7 nótárius, és többnyire egyetlen ítélőmester alkotta a teljes személyzetet. ${ }^{1149}$ A korábbi időszakban ez a szám nyilván még kisebb volt. Állandó jellegű nádori hivatali személyzetről úgyszintén nem beszélhetünk. A neki segédkezők az adott fớúr környezetéböl kerültek ki, sokszor familiárisai voltak, és a nádor bukásával őket is lecserélték. ${ }^{150}$ Az egyetlen alkalom, amikor kontinuitást tudunk kimutatni a nádorok közti segédszemélyzetben, az a Drugetnádorok idején volt. Druget Fülöp halálával a tartományi kormányzást átvevő Vilmos egyébként is többeket átvett az ottani nádori és nem nádori személyzetből, bár azok nem mindig ugyanabban a tisztségben szolgáltak tovább. Perényi Miklós albíró megmaradt a vizsolyi tartomány bírájának, ám mivel az akkor még országos tisztséget nem kapó Vilmos szolgálatában maradt, ezért őt értelemszerüen nem számíthatjuk a nádori segédszemélyzet körébe, hiszen Vilmos a teljes jogú nádorsága idején, 1334-től már nem tartott igényt Miklós szolgálataira. Fordított helyzetet látunk Dénes fia Jakab esetében. Személyében ő is szolgálta

\footnotetext{
${ }^{1149}$ Nyers 1934. 26., 35.

${ }^{1150}$ Bónis 1963. 230; bőséges példával illusztrálva: Bónis 1971. 48-50.
} 
mindkét Drugetet, ám Fülöp idején csak a Borsod megyei Dédes várnagya volt, míg Vilmos már nádorként - megtette gömöri alispánnak, és egy rövid ideig nádori albírónak is. ${ }^{1151}$ Azonban nem csak személyükben, de hivatalukban is kontinuus nádori segédszemélyzetre is találunk példát Vilmos esetében. Az 1325-ben Fülöp nádor notariusaként említett Máté fia Mátyás mester 1329-1331 folyamán ugyanúgy Vilmos szolgálatában maradt jegyzőként, ahogy Perényi Miklós albíróként. ${ }^{1152}$ A kontinuitásra bizonyíték, hogy Vilmos 1331-ben „,nagybátyjánknak, Fülöp volt nádornak, és halála után nekünk teljesített hüséges szolgálatai miatt" adományozta meg Mátyást. ${ }^{1153}$ Ám Mátyás Vilmos nádorsága alatt is hivatalban maradhatott, 1340-ben is nótáriusaként és protonotáriusaként emlegették, és akkor már a füzéri várnagyságot is elnyerte. ${ }^{1154}$ Vilmos óbudai kúriájának élén pedig ugyanaz a Péter mester állt, aki már János nádor protonotáriusa is volt. ${ }^{1155}$ Mivel azonban a Drugetek egy famíliába tartoztak, ez nem jelent igazi példát a nádorokat túlélő hivatali személyzetre. Ám 1342 körül már találkozunk folytonosságokkal. A János, majd Vilmos kúriáján működő Péter ítélőmester Bónis György feltevése alapján azonosítható lehet azzal a Körmösdi Péterrel, aki 1345-től tárnokmesteri, majd 1355-től vajdai protonotarius lett, ${ }^{1156}$ így az ő személye már jelentett egyfajta kontinuitást az egyes hivatalok között, elszakadva a familiaritás kereteitől. A nem egy adott személyhez (vagy családhoz) kötődő klasszikus „hivatali” karriert a híres országbíró, Szepesi Jakab korai pályájával is jól lehet illusztrálni. Jakab 1351-ben Szécsényi Tamás országbíró nótáriusa volt. 1356-ban már Szécsi Miklós országbíró ítélőmestere lett, egészen 1358-ig. 1360-ban viszont átkerült a nádori kúriába ítélőmesternek, holott a nádorváltás még 1356-ban volt. „Kont” Miklós nádor halála után (1367) a következő nádor, Oppelni László ítélőmestere maradt. ${ }^{1157}$ A hivatali kontinuitás nem csak az ítélőmesterekre terjedt ki ebben a korszakban: Ruszkai Izsépet, aki Vilmos vizsolyi albírája volt, az 1356-tól hivatalba kerülő Raholcai „Kont” Miklós nádor is alnádorrá (vicepalatinus), továbbá szepesi ispánná és várnaggyá nevezte ki. ${ }^{1158}$

\footnotetext{
${ }^{1151}$ Zsoldos 2012d. 36., 39.; ill. „8.1 - A nádort helyettesítő tisztségek: alnádor, nádori albíró” c. alfejezet. 1152 AOkl IX. 316. sz.; AOkl XIII. 432. sz., XIV. 47-49., 51., 149., 473. sz., XV. 126. sz.

1153 „magistro Mathie filio comitis Mathei suo notario pro suis servitiis domino Phylipo condam palatino, patruo suo, et post ipsius obitum sibi fideliter inpensis et exhibitis" DL 57099. (AOkl XV. 126. sz.). Vilmos oklevele tartalmi átírásban maradt fent, ezért beszél róla is a szöveg E/3-ban.

${ }^{1154}$ AOkl XXIV. 493-494., 593-595. sz. 1342 júniusában (tehát még Vilmos nádor életében) már csak volt protonotárius, holott még élt: AOkl XXVI. 292., 295. sz. Személyére lásd még: Bónis 1971. 52.

1155 AOkl XVII. 469. sz.; AOkl XIX. 391., XXI. 253-254., XXII. 357. sz. „Péceli” Péter személyére lásd Bónis 1971. 49-52.

1156 Bónis 1971. 49-52.

${ }^{1157}$ Bónis 1971. 58.; Bertényi 1976. 139-140.

${ }^{1158}$ Archont. 1301-1457. 3.
} 
Már esett szó arról, hogy a 13. század folyamán a nádori „hivatal” még szoros összefüggésben állt a nádor személyével. Ez az összefüggés a század elején még annyira szorosnak mondható, hogy az akkori nádori „iroda” egyetlen állandó eleme maga a nádor volt! Ugyanis semmi jel nem mutat arra, hogy ekkoriban lett volna állandó jegyzőjük vagy kancellárjuk. A nádori oklevelek írásképének és sokszor megfogalmazásának a különbözőségéből arra következtethetünk, hogy az ítéleteiket többnyire egy, az adott helyszín közelében tartózkodó írástudóval foglaltatták írásba. Jellemző, hogy pl. 1255-ben a pozsonyi várföldek felülvizsgálatára kiküldött Roland nádor és Vince nyitrai püspök szinte egyidőben kiadott okleveleit ugyanaz a kéz írta és talán rajzolta be az iniciálékat. A kezdőbetük díszítésében még egyfajta „színvonalcsökkenés” is megfigyelhetö, ahogyan folyamatosan fáradt az ugyanaznap kiadott oklevelek írása közben. ${ }^{1159}$ Ám ez az írnok más Rolanddiplomáknál már nem azonosítható. Kemény fia Lőrinc 1268-ban vizsgálta felül a Somogy megyei királyi szolgáltatónépi és nemesi földeket. Mind az öt, ekkor kibocsátott oklevelében Sebestyén pozsegai éneklőkanonok és fehérvári prépost ${ }^{1160}$ tűnik föl a datum per manus formulában a nádor „protonotáriusaként” (a tisztségnevet ekkor még nem érdemes „ítélőmesternek” fordítani, mert a protonotariusnak még csak egyszerü kancelláriai feladatai voltak, megtévesztő lenne azonosítani a 14-15. századi nádori ítélőmesterekkel). ${ }^{1161}$ Lőrinc más okleveleiben viszont nem találkozunk a nevével. Igaz, Sebestyén már 1263-ban, Lőrinc országbírói hivatala alatt is megjelent, mint egyik oklevelének a kiállítója, szintén protonotariusi tisztségben. ${ }^{1162}$ Valószínű, tehát, hogy familiárisa volt Lörincnek, és ilyen minőségben kötődött hozzá, bármilyen hivatalt is viseljen éppen. ${ }^{1163} \mathrm{E}$ példa egyben arra is figyelmeztet, hogy egy adott tisztségviselő felbukkanásának a hiányából nem szabad a jelenlétének a hiányára is következtetni egyben, ugyanakkor ha Sebestyén egyszerre két fontos egyházi tisztséget is betöltött (fehérvári prépost és pozsegai éneklökanonok), az sejtetni engedi azt is, hogy mégsem tartózkodott mindig ura környezetében. Azaz, lehetett éppenséggel a nádor kancellárja is, de nem volt állandó jelleggel az. A nádorok melletti folyamatos kancelláriai személyzet hiányára utal a 13. század második felében, hogy pl. Héder nembéli Miklós 1284. augusztus 20-án, a székesfehérvári törvénynapon kiadott díszes kiállítású diplomáját, királyi oklevelekre jellemző arengával, szinte biztosan az ott tartózkodó

\footnotetext{
${ }^{1159}$ CDS II. 325-326., 352., 353., 354-355., ill. DL 3965. (RP 103-107. sz.) Lásd még: Marsina 1990. 51.

${ }^{1160}$ Lásd Bónis 1971. 48.; Koszta 1991. 47.; Koszta 2009. 244.

${ }^{1161}$ HO VIII. 115-116.; ÁÚO III. 184-185., 186-187., 188-189., 190-192. (hibáit javítja: Kubinyi 1867. 59.), ÁÚO VIII. 206-207. (RP 146-151. sz.) A protonotárius ezirányú korai szerepére: Bertényi 1964. 188.; Bónis 1971. 47-48.

${ }^{1162}$ Sopron I. 26-27.

${ }^{1163}$ Bónis 1971. 48.
} 
király kancelláriája állította ki a nádornak. ${ }^{1164}$ Egy évvel később, egy 1285. évi, a borsmonostori német ciszterci szerzetesek részére kiállított adománylevele viszont a német okleveles formulákat követi - nyilván ekkor is ott, helyben írták meg a levelet. ${ }^{1165}$ Ennek ellenére történtek kísérletek arra, hogy egy nádor állandó jegyzőt vegyen maga mellé. Tomaj nembéli Dénes egy 1239. évi oklevelének a végén egy datum per manus formulában ott találjuk Mátyás nevét, akit Dénes a saját jegyzőjének (notarius noster) nevez. Mátyáshoz köthetjük Dénes egy másik 1239. évi oklevelét is, bár annak már nincs ilyen formula a végén, ám az oklevél írásképe és az iniciálé kivitelezése szinte teljesen azonos. ${ }^{1166}$ A kísérlet mégsem lehetett sikeres, mert Dénesnek összesen 13 olyan eredeti oklevele maradt fent, amit biztosan hozzá köthetünk, de Mátyás kézírását más diplomákon már nem lehet beazonosítani. Tegyük hozzá: ugyanez a Mátyás tünik fel Ampod fia Dénes egy 1228. évi oklevelének datum per manus formulájában, de azt a szöveget az említett 1239. évi Dénes-oklevél alapján rakták össze, így az a rész is csak egy onnan való átvétel. ${ }^{1167}$ Az egyetlen Árpád-kori nádor, aki mellett sejthetjük egy komolyabb kancelláriai hivatal müködését, az Aba Amadé volt. 1290 körül és 1293-ban egy bizonyos Besenyő fia Istvánt nevezett meg kancellárjának, és könnyen lehet, hogy azonos Amadé 1295-ben felbukkanó István nevü protonotáriusával, ${ }^{1168}$ hiszen a notarius és protonotarius tisztségeket még az 1330-as években is gyakran szinoním fogalomként fogták fel. ${ }^{1169}$ 1299-ben egy bizonyos Miklós volt a gyürüspecsétjének kancellárja (cancellarius anulei sigilli nostri). ${ }^{1170}$ Valószínü, hogy ez az utóbbi pozíció nem egy egyszerű nótáriust takar, és Miklós a gyürűspecsét felelőseként Amadé bizalmi embere volt.

Jellemző egyébként, hogy a négy közül egyik említés sem az oklevelek kiadása kapcsán említette a jegyzőket, kancellárokat, hanem mint akik a nádor megbízásából, az ő nevében jártak el egy-egy peres ügyben, előrevetítve ezzel az ítélőmesteri szerepkör lassú kialakulását.

\footnotetext{
${ }^{1164}$ DL 1175. (kiadása: RP 219. sz.). Az arenga („Ut collationes principum perpetua firmitate solidentur, sollers prudentia sapientum adinvenit, quod donationes per ipsos legitime facte litterarum testimonio fulciantur.") paneljei a következö IV. László-kori királyi oklevelekben találhatóak meg: ÁÚO XII. 94-95. (1274); CD V/2. 393-394. (1277. júl. 28.); HO VI. 229-230. (1278); ÁÚO IV. 217-218. (1280); RA 3146. sz. (1282. júl. 9.); CD V/3. 398-400. (1288); CD V/3. 452-454. (1289. szept. 18.)

1165 UB II. 190-191. (RP 221. sz.). Hogy az oklevél a német okleveles hagyományokra emlékeztet, lásd Szentpétery 1916. 41-46., egyúttal hamisnak is tartva az oklevelet. Véleményünk szerint az oklevél hitelesnek fogadható el, az erre vonatkozó érveket lásd RP 221. sz. reg. kommentárjában.

${ }^{1166}$ PRT I. 763-764., 767-768. (RP 60-61. sz.). Az oklevelek írásképét és iníciáléját lásd: DF 206987., 206984.

${ }^{1167}$ CDCr III. 293-295. (RP 30. sz., a hamis voltára vonatkozó érveket lásd uo., a regeszta utáni kommentárban)

${ }^{1168}$ DL 285768. (vö. CD VIII/1. 258., 565-566., VIII/4. 641-642.), DL 83974., HOkl 145-147. (RP 245., 255., 267. sz.)

${ }^{1169}$ Lásd alább.

1170 ÁÚO XII. 635-637. (RP 292. sz.)
} 
De a funkciók elkülönítésének lassúságát jelzi, hogy még az 1330-as években is sokszor szinonímaként használták a jegyző (notarius) és az ítélőmester (protonotarius) titulust. A budai káptalan két ugyanaznap, 1327. május 8-i oklevelében Pétert egyszer Vilmos notariusának, egyszer pedig protonotariusának címezték. ${ }^{1171}$ Hogy nem csak véletlen elírásról lehet szó, mutatja, hogy Máté fia Mátyást, Vilmos Vizsolyhoz kötődő jegyzőjét/ítélőmesterét 1329 és 1340 között szintén párhuzamosan mindkét elnevezéssel címezték. ${ }^{1172}$ A terminusok összemosódása sejtetni engedi, hogy ekkoriban egy kúriai ítélőmesternek még egyszerre volt feladata a nádori oklevelek kiállítása, pecsételése, az ítéletek végrehajtásában való segédkezés, és az egyes rutinügyekben való szokásjogon alapuló mérlegelés. Ezen kívül, ha kellett, képviselte urát egyes hatóságok előtt is, mint annak serviense.

A kúriai személyzet kutatása azért is nehéz ebben az időszakban, mert - hasonlóan az Aba Amadé alatt tapasztaltakhoz - az egyes tisztviselőkkel itt sem az oklevelek záradékában, vagy akárcsak kúriai tevékenységgel összefüggő forrásokban találkozunk, hanem többnyire „magánemberi” mivoltukban: fogott bírók, tanúk nem nádori perek során, peres félként jelennek meg, vagy egyszerüen csak birtokot vásárolnak. Máskor serviensi mivoltukban a nádort képviselik. ${ }^{1173} \mathrm{Az}$ oklevelek hátulján a jegyzőkre utaló monogramm ${ }^{1174}$ ebben az időszakban még nem jelent meg, így még hozzávetőlegesen sem lehet megmondani, hogy hány személy dolgozhatott egyszerre pl. Druget Vilmos óbudai vagy visegrádi (nagymarosi) kúriáján, és hogy milyen személyi átfedések voltak az egyes kúriák között. Az alfejezet elején már jeleztük azt, hogy a kúriai személyzet a 14. század második felében is csak néhány fő volt (Lackfi István oklevelein 1387-1392 között összesen 10 különböző kézjegyet lehet elkülöníteni, de néhány különbözőnek látszó monogramm talán azonos személyt takar, másrészt ezek nem egyidejüleg jelentek meg, összesen csak egy olyat találunk, akiről valószínűsíthetjük, hogy végigszolgálta a teljes nádori ciklust). ${ }^{1175}$ Ebből, továbbá abból a tényből, hogy még Druget Vilmos nádorsága alatt sem különböztették meg a notariusi és az

\footnotetext{
1171 AOkl XXI. 253-254. sz.

1172 AOk1 XIII. 432. sz., XIV. 47-49., 51., 149., 473. sz., XV. 126. sz., XXIV. 493-494., 593-595. sz. Az ingadozó terminológia természtesen nem csak a nádori kúria munkatársai kapcsán jelent meg. Hogy a notariusnak nevezett személy valójában protonotariusi jellegü feladatokat látott el, annak felfedezhetőek nyomai az országbírói és a szlavón báni személyzet esetében is, lásd Bónis 1971. 47., 49.; B. Halász 2009. 70. 4. jz.

${ }^{1173}$ Pl. Egyed mester, Kőszegi János notariusa 1303-1304 folyamán: AOkl I. 489., 586. sz. András mester, Dózsa protonotariusa 1322-ben: AOkl 478. sz. E két nádor két jegyzőjét csak ilyen feladatkörből ismerjük.

${ }^{1174}$ Lásd Bónis 1963. 202-203.; C. Tóth 2009. 98-102.

1175 C. Tóth 2009. 99-102. A nádori kúriai irodák létszámára általában: Nyers 1934. 26., 35. Tegyük hozzá: Nyers Lajos adatai inkább csak hozzávetőlegesek, hiszen ő egyetlen konkrét nádori kúriára vonatkozóan sem végzett mikrotörténeti „mélyfúrást”, de a személyzet valós nagyságrendjét vélhetően helyesen láttatja.
} 
elvileg ezek főnökének számító protonotariusi tisztséget, hanem összemosódtak a feladatköreik, sejthetjük, hogy az irodák személyzete nem nagyon lehetett több 2-3 fönél.

Az ,iroda” természetesen nem csak oklevelek kibocsátásával foglalkozott, hanem a forrásokban registrum névvel illetett belső ügyviteli anyagokat is készített. Az első konkrét adat erre Aba Amadé hivatalából való, akinek egy 1299-i oklevele azzal igazolta néhány birtok kezére háramlását, hogy azok korábbi tulajdonosát „regisztrumunk alapján” (per formam registri nostri) elítélte. ${ }^{1176}$ Amadé kúriájában tehát, a „királyi könyvek” mintájára vezettek egy nyilvántartást arról, hogy korábban milyen ítéleteket hozott a nádor (hogy ez a teljes oklevél szövegének a lemásolását, vagy csak „regeszták” készítését jelentette, nem tudjuk). A 14. századból is vannak adataink erre a nyilvántartásra. Druget János és Vilmos nádorsága alatt többször is említették azt a regisztrumot, amelybe a bírsággal tartozók neveit (és persze a bírság összegét) jegyezték fel. ${ }^{1177}$ Emellett a különféle parancsleveleket is iktatták, és ennek a haszna meg is mutatkozott. 1339-ben a vizsolyi nádori kúria elrendelte Benedek fia Lászlónak, hogy állítson tanúkat a jászói konvent előtt november 8-ra Péter fia Miklós ellenében. Mikor Miklós november 7-én a tanúállítás megtekintésére igyekezett, rátámadtak, ruháit, lovát és fegyvereit elrabolták, bal kezén egy ujját levágták, és elvették tőle a tanúállítást elöíró nádori oklevelet is (equo, vestibus, armis, ac litteris suis contra eundem Ladislaum super facto ipsius productionis testium emanatis spoliatus). A kötelezett László viszont nem jelent meg sem a konvent, sem Izsép vizsolyi albíró színe előtt, Miklós pedig az elvett oklevél hiányában - még azt sem tudta volna bizonyítani, hogy peres ellenfelének egyáltalán ilyen kötelezettsége lett volna. Lászlót az albíró mégis elmarasztalta meg nem jelenése miatt, a nádori regisztrum tartalmára (continentia registri dicti domini nostri palatini) hivatkozva, amely így igazolta Miklós elrabolt oklevelének az állítását. ${ }^{1178}$ Mindez jól érzékelteti azt, hogy a nádori kúria, kúriák személyzete és munkarendje hogyan professzionalizálódott az idők folyamán.

\section{3 - A nádori „iroda” külső munkatársai és segítői: az ítélőtárs, a poroszló és a} nádori ember

A nádor nem minden esetben döntött egyedül. Alkalmi segítségként a környezetének tanácsát is kikérhette, nem hivatalosan, akár tekintélyüknél, akár szakértelmüknél fogva

\footnotetext{
${ }^{1176}$ HO VIII. 398. (RP 304. sz.), vö. Gerics 1969. 263-264.

1177 1333: AOkl XVII. 240-241. sz.; 1337: AOkl XXI. 325., 439.; 1339: AOk1 XXIII. 151. sz.

${ }^{1178}$ DL 3269. (AOk1 XXIII. 715. sz.)
} 
bevonva őket a perbe. Ez utóbbira látszik jó példának az a néhány eset, amikor oklevelek hitelességéről kellett dönteni. Már 1221-ben arról olvasunk, hogy Barc fia Miklós „ebben jártas emberek tanácsából” tudta meg, hogy Imre király egy neki bemutatott privilégiuma hiteles. ${ }^{1179}$ A „,tanács” egyébként nem volt tökéletes, mert Imre bemutatott oklevele hamis volt, valószínűleg éppen erre a nádori perre készítették. ${ }^{1180}$ Más alkalommal viszont lebuktak a hamisítók. 1226-ban szintén Miklós előtt zajlott az a per, amikor a pannonhalmi egyház néhány szolgája szabadnak nyilvánította magát Béla király egy oklevelére hivatkozva. „És amikor ezt a privilégiumot a kitűzött határnapra az esztergomi érsek és sokan mások színe előtt nekünk [ti. Miklós nádornak] bemutatták, és azt együtt az érsekkel és más alkalmas és illő egyházi személlyel együtt gondosan megtekintettük, megbizonyosodtunk, hogy teljességgel hamis." Az oklevelet prezentálók bevallották azt is, hogy az oklevelet egy Bulcsú nevü pap csinálta nekik. ${ }^{181}$ Itt már utalás történt arra, hogy Miklós nem egymaga folytatta le a pert, hanem egészen magas rangú segítői is voltak. A bizonyítási eljárásban az esztergomi érsek egyenrangú, külön felkért személyként volt jelen, nyilván a szakértelmét is figyelembe véve, ám az ítéletlevelet kizárólag Miklós nevében állították ki. Hogy az éppen körülötte tartózkodókat a nádor bevonta az ügyekbe, arról olvashattunk a Váradi Regesztrumban is. 1220-ban Miklós egy egyszerü, testi sértés kapcsán induló esetét átadta az éppen mellette lévő szolnok vármegyei ,jó embereknek” (boni homines), akik között egy comes is volt. ${ }^{1182} \mathrm{Ez}$ nyilván egy „ad hoc” eset volt. 1232-ben arról olvasunk hogy Ampod fia Dénes „a körülöttünk lévő ülnökök tanácsából és egyetértésével” zárt le egy hatalmaskodási esetet. ${ }^{1183}$ A különféle ítélőtársakra való hivatkozás végig nyomon követhető, ${ }^{1184}$ hiszen a nádori címet elnyerő foúr nem feltétlenül volt járatos a perjog minden apró részletében, abban azonban megegyeznek az esetek, hogy nem állandó személyzetről, hanem alkalmi, külső segítőkről volt szó.

Az egyes perek, ítéletek lebonyolításában és végrehajtásában segédkező személyzetet a 13. század közepéig egyöntetüen a poroszlónak nevezett személyek jelentették. Az

\footnotetext{
1179 „de prudentum virorum consilio” MES I. 231. (RP 11. sz.)

${ }^{1180}$ A hamis oklevél: RA 199. sz.

1181 „Cumque illud privilegium in statuto termino coram archiepiscopo Strigoniensi et aliis multis nobis presentassent et diligenter ipsum una cum archiepiscopo et omnibus aliis idoneis et discretis ecclesiasticis personis inspexissemus, comperimus omnino esse falsum.” PRT I. 676. (RP 19. sz.)

${ }^{1182}$ RV 277. sz.

1183 „accepto circa nos residentium consilio et consensu” ÁÚO VI. 507. (RP. 33. sz.)

${ }^{1184}$ Pl. 1238: PRT I. 760. (RP 58. sz.); 1242: DF 285988. (a vonatkozó rész kiadása: RP 67. sz.); 1268: CD VII/5. 351. (RP 143. sz.); 1279: UB II. 126. (RP 195. sz.); 1288: DL 90791. (kiadása: RP 238. sz.); 1299: HO VII. 282. (RP 300. sz.); 1327: AOkl XI. 84. sz.; 1337: AOkl XXI. 117. sz.; 1340: AOkl XXIV. 47. sz.; 1341: AOkl XXV. 386. sz.
} 
egységesített elnevezés természetesen, mint látni is fogjuk, korántsem takart egy egységes „hivatalt”. Bár a latinul pristaldus megnevezéssel illetett poroszló a 13. század második felében mind inkább visszaszorult, az adott nagybíró továbbra sem nélkülözte a segédszemélyzetet, csak terminológiailag egyre inkább pusztán „emberüknek” (homo noster) nevezték őket. Így beszélhetünk „,királyi emberekről”, „nádori emberekről”, „országbírói emberekről”, stb. (homo regius, homo palatini, homo iudicis curie). Arra, hogy a nádori (királyi, országbírói, stb.) embereknek mi volt a viszonyuk a poroszlókhoz, és hogy a két szerepkör kontinuus-e egymással, alább részletesen kitérünk. Annyit elöljáróban is érdemes leszögezni, hogy a „nádori emberi” szerepkör nem számított intézménynek, vagy hivatalnak, inkább csak funkciónak. Azaz: nem arról volt szó, hogy valaki állandó jelleggel megkapott volna egy olyan tisztet, hogy ő hivatalosan is „nádori embernek” minősül. Ezek alkalmi megbízások voltak, és az adott megbízás lejártával véget is értek. A 14. századra professzionalizálódó hivatali működés során újabb önálló megnevezéssel illetett külső segéderők jelentek meg. Így találkozunk pl. a nádori bírságbehajtók tisztségével is. Ebben a fejezetben azonban csak a poroszlókkal és a „nádori emberekkel” foglalkozunk. A bírságbehajtókra a nádori jövedelmekről szóló fejezetben térünk ki. ${ }^{185}$

A poroszlókkal a szakirodalomban a 19. századi áttekintések után ${ }^{1186}$ már viszonylag keveset foglalkoztak, legfeljebb rövid összefoglalások révén. Ezek közül hadd idézzük Solymosi Lászlót, aki tömören és lényegretörően vázolta föl a hivatal lényegét: „A délszláv eredetű jövevényszó ... hatósági személyt és közhitelü tanút jelölt egy személyben. Olyan személyt, aki - miként a szláv szó utal rá - jelen van valamilyen cselekménynél, és azt hitelt érdemlően tanúsítani tudja. Ezért támasztott a törvény a poroszlóval szemben ugyanolyan követelményt, mint amit a tanútól megkívánt. Alapvetően földbirtokkal kellett rendelkeznie, hogy esetleges hibáját legyen miből jóvátennie. A poroszló a bíró bizalmi embereként teljesítette a bíró megbízásait. Végigkísérte a peres eljárást, tevékenyen részt vett annak egyes fáziasaiban. A bíró idéző billogával a bíró törvényszéke elé idézte a feleket, majd az adott egyházi intézményhez kísérte őket, ha a bizonyításhoz esküre vagy istenítéletre volt szükség. Végül onnan a felekkel együtt visszatért a bíróhoz és beszámolt a történtekről. Részt vett az ítélet végrehajtásában. A pernyertes felet beiktatta a vitás föld birtokába, $\mathrm{s}$ ha kellett, megjelölte annak határait. A poroszló rendszerint világi személy volt, az ügyintézésben a szóbeliséget képviselte." ${ }^{1187}$ Mindehhez annyit tegyünk hozzá, hogy a poroszlókat a 11.

\footnotetext{
${ }^{1185}$ Lásd a „10 - A nádori hivatal jövedelmei” c. fejezetet.

${ }^{1186}$ Nagy 1876.; Érdujhelyi 1897.; Dudás 1897.; Hajnik 1899. 154-159.

${ }^{1187}$ Solymosi 2004. 225-226.
} 
század második felétől tudjuk kimutatni a magyarországi forrásokban, és már a 13. század 50es éveitől megindult a rendszer hanyatlása. Ennek oka a jogi írásbeliség egyre nagyobb térhódításában keresendő, amely a közhitelü szóbeli tanú müködését már szükségtelenné tette. Az 1231. évi Aranybulla rendelkezett arról, hogy mivel az országban sokat szenvedtek a hamisan tanúskodó poroszlóktól, ezért idézésük vagy tanúskodásuk csak a megyéspüspök vagy a káptalan által támogatva legyen érvényes. ${ }^{188}$ A 14 . század elejére a poroszló megnevezés végképp eltünt a magyar jogéletből. ${ }^{1189} \mathrm{Ha}$ az előbbi általános megállapítást a nádorokra vetítjük ki, akkor azt látjuk, hogy az 1230-as évekig kizárólagosan a poroszló elnevezést használták a saját segítőikre. ${ }^{1190}$ A homo noster-említések nem a poroszlói szerepkörben eljáró nádori embert jelentették ekkor még. ${ }^{1191}$ Bár egészen az 1260-as évek elejéig a pristaldus volt az uralkodó terminológia, ${ }^{1192}$ Tomaj nembéli Dénes alatt (1236-1241) kezdett megjelenni a másik elnevezés is. A korai időszakban mindig párhuzamos volt a terminológia, azaz az illetőt egyszer még pristaldusnak, máskor homo nosternek nevezte az oklevél. ${ }^{1193}$ Roland nádor pedig úgy fogalmazott egy 1252. évi levelében, hogy „Iolat bán azt kérte tőlünk, hogy Boymuch nevü emberünket (hominem nostrum) adjuk neki poroszló

\footnotetext{
${ }^{1188}$ DRMH I/1. 40.

${ }^{1189}$ Hajnik 1899. 158-159.

${ }^{1190}$ A teljes vonatkozó forrásbázist felesleges lenne felsorolni, csak néhány adat a Váradi Regestrumban: RV 9. 15., 19., 27., 62., 64., 89., 95., 97., 103., 148., 153., 162., 175., 180., 189., 213., 217., 220., 226., 244. 245., 248., 249., 266., 269., 271., 275., 280., 281., 282., 285., 288., 289., 290., 308., 309., 313., 314., 318., 321., $358 ., 387$. sz. Nádori oklevelekben: PRT I. 647., 647-648., 652-653.; Györffy 1990. 127.; PRT I. 675., 676-677., 677.; UB I. 139-140., 152.; DL 95539.; HO VIII. 31-32.; DL 70387.; MES I. 317-318.; Veszprém: pótkötet 94-95.; PRT I. 753-754., 756-757., 752-753.; MES I. 324-325.; CDS II. 25-26.; ÁÚO VII. 77-78. (RP 7-9., 16., 18., 2021., 33-34., 36-37., 41., 44., 46., 48-51., 55., 64. sz.); más hatóságok oklevelében: ÁÚO I. 182-183., VI. 435., 511-512. [= XI. 251-252.]; MES I. 241-242.; Rábik 2010. 6. sz. (vö. 5. sz.); RA 492. sz.; PRT I. 755-756. (vö. RP 47. sz.).

${ }^{1191}$ Pl. amikor 1227-ben Ampod fia Dénes nádor színe előtt két, tartalmilag ellentétes levelet mutattak be az ő hivatali elödjétől, Barc fia Miklóstól, akkor Dénes egy embere útján (per hominem nostrum) tudakolta meg Miklós volt nádortól az igazságot, hogy melyik oklevél köthető igazából hozzá: ÁÚO VI. 442-443. (RP 28. sz.). Ebben a szövegkörnyezetben nem is várható a poroszló megjelenése. 1238 körül Tomaj nb. Dénes nádor kérte a somogyi udvarispántól, hogy adjanak segítséget emberének, gyulai Iaco comesnek (homini nostro Iaco comiti de Iula) a szentmártoni egyháznak járó tizedek beszedéséhez (PRT I. 762., RP 59. sz.). Itt sem a poroszlói (későbbi nádori emberi) szerepkört kellett helyettesíteni, mert azok, mint látni fogjuk, csak egy-egy alkalomra, ügyre szóltak, míg itt egy ügy lezártát követő tartós segítségről volt szó.

1192 Csak az 1241 utáni nádori oklevelekben: Szovák 1996. 456-457.; PRT VIII. 288-289.; DF 200014. (vö. CD IX/7. 662-665., ill. RP 76. sz.); CDS II. 265.; PRT XII/A. 437-438.; UB I. 231-232., 252-253., 237-238.; CDS II. 461-462.; HOkl 40; PRT X. 524. (RP 68., 72., 76., 81-82., 84., 86., 92., 110., 114., 125., 127., 133. sz.)

${ }^{1193}$ Az első ilyen eset 1236-ból való, amikor ollári Jakó fia Estent Dénes nádor oklevele a homo noster elnevezés mellett pristaldus terminológiával is illette (a másik nádori végrehajtót, Volphar fia Pétert csak homo nosternek nevezte): HO VI. 30-34. (RP 43. sz.). Egy 1239. évi oklevél is egyszerre szólt nádori emberről és poroszlóról, de csak az utóbbit nevezte meg a szöveg (tahi Dénes), így - elvileg - nem biztos (bár valószínü), hogy ugyanazon személyt értették alatta (PRT I. 768-769., RP 62. sz.). Egy másik 1239. évi nádori oklevélben már biztosan tahi Gábort nevezték egy ízben nádori embernek, máskor poroszlónak (ÁÚO XI. 309-310., RP 63. sz.).
} 
gyanánt”, hogy a veszprémi káptalan egy tanújával együtt bejárhassák saját földjük határát. ${ }^{1194}$ A káptalan nádornak szóló oklevele már kizárólag pristaldusként emlegette Boymuchot. ${ }^{1195}$ Bár Roland okleveleiben még a régi terminológia dominál e téren, nála is megtalálható az a kettősség, hogy ugyanazt a személyt egy diplomán belül az emberének és poroszlójának is nevezte, ${ }^{1196}$ ezen kívül nála jelent meg elöször a homo noster terminológia önmagában, egészen biztosan a későbbi klasszikus „nádori ember” értelemben. Egy keltezetlen levelében kérte arra a nyitrai káptalant, hogy embere, vatai Damján comes mellé (Damiano comiti de Vatha homini nostro) adják tanúságukat egy határjáráshoz. ${ }^{197}$ Az 1260as évek közepétől aztán már szinte csak a „nádori ember” kifejezést használták, ${ }^{1198}$ a poroszló név feltüntetése ritkaságszámba ment. ${ }^{1199}$

Kérdéses persze, hogy a terminológia lassú átfordulása (egy időben pedig párhuzamossága) elegendő bizonyíték-e arra, hogy a „nádori embert” (és egyéb tisztségekhez kötött megfelelöit) a nádori poroszló intézményével azonosítsuk. Végleges választ csak a két rendszer szerkezeti összehasonlításából nyerhetünk. Amit a „nádori emberről” tudhatunk, azt - szakirodalmi előzmények mellett - leginkább Engel Pálnak köszönhetjük, aki a „királyi emberek” 14-15. századi Valkó megyei felbukkanását vizsgálta (a „királyi ember” és a többi nagybíróhoz kötött segítő között Engel sem tett különbséget). Borsa Iván megállapítását megerősítve azt látta, hogy egészen 1322-ig mindig csak egyetlen ilyen segítőt neveztek meg az oklevelek, azután szép lassan nőni kezdett a számuk. Kezdetben az oklevélkérő bemondása alapján két nevet ajánlott fel az oklevél írója a hiteleshelynek, hogy vele menjenek ki egy vizsgálat elvégzésére vagy egy ítélet, határjárás stb. végrehajtására, akik közül csak egyet kellett kiválasztani. A szám az idők folyamán egyre nőtt, a 14. század végétől általában 5-6 nevet tüntettek fel alternatívaként. A kijelölt „királyi (nádori, stb.) emberek” szinte mindig az

\footnotetext{
1194 „Iolat banus petivisset a nobis, ut hominem nostrum Boymuch nomine sibi in pristaldum daremus” Sörös 1908. 162. (RP 85. sz.)

${ }^{1195}$ Sörös 1908. 162.

${ }^{1196}$ PRT II. 290-291. (RP 98. sz.)

${ }^{1197}$ CDS II. 241. (RP 121. sz.)

${ }^{1198} 1260$ utáni nádori és alnádori oklevelek (illetve azok említései): DF 278431. = 280264.; Sztáray I. 10.; ÁÚO IX. 111-112.; Zichy I. 78-79.; DF 283094.; HO VI. 213.; UB II. 118-119.; HO VI. 238-239.; DL 38669.; Heves 51.; UB II. 129-130., 130-131.; HO VII. 138.; Kubinyi 1867. 113-114.; Zala I. 118-119.; HO I. 84.; UB II. 204., 206., 207-208.; ÁÚO IX. 481-482.; Zichy I. 80.; DL 84192.; HO VI. 430-431., VIII. 380-381.; ÁÚO XII. 653-654.; HO VIII. 397-398., VII. 288-289., 290-291., 301-302., 360. (RP 129., 135., 164., 178., 182., 184., 191., 193., 196-201., 203., 224., 227., 229., 231., 241., 250., 256., 283., 285-287., 304., 307., 309., 320., 327. sz.)

${ }^{1199}$ Kemény fia Lörincnél 1268-1269-ben: CD VII/5. 349-353., DL 93880. (RP 143., 153. sz.); Tombold fia Benedek ifjabb királyi nádornál 1268-ban: DL 83132. (RP 145. sz.). Ezek az elnevezések még az 1260-as évek „lecsengését” jelentik. Ezek után csak Csák nb. Máténál tünik fel egyszer 1279-ben (ÁÚO IV. 203., RP 202. sz.), illetve Amadé albírájánál, Jánosnál 1300-ban (DL 75156., RP 321. sz.).
} 
adott ítélet vagy vizsgálat helyszíneként szolgáló megyében voltak birtokosok, sőt, többnyire egészen az adott helyszín közelében. A 14. század első felében (legalábbis Valkó megyében) szinte mindig a tekintélyesebb megyei nemesek közül választották őket. Kiválasztásuk úgy történhetett, hogy az oklevelet kérelmező nevezte meg őket az adott kancellária számára, hiszen ő volt legjobban tisztában a saját környezetének birtok- és személyes viszonyaival. ${ }^{1200}$ Mindebből adódóan a „királyi emberi” megbízás nem egy állandó státuszt (hivatalt) jelentett, hanem csak egy alkalmi feladatot, így nem is várhatjuk azt el, hogy tartósan ugyanazon személyek jelenjenek meg az adott bírói hatóság okleveleiben e címen, legfeljebb ha egy másik per is ugyanarra a vidékre esett. Vizsgáljuk meg először is, hogy Engel Pál Valkó megyei „mélyfúrásának” eredményei mennyire vágnak össze a „nádori ember” intézményével. Annyi különbség mindenesetre már az elején adódik, hogy magunk nem egy adott helyszín összes hatóságának eljáró embereit, hanem egy bírói tisztség (a nádor) köré szerveződő „nádori embereket” vizsgáljuk meg. Időbeli kiindulópontnak az 1260. évet választottuk, amikor először vált általánossá az oklevelekben a nádori emberekre utaló megjegyzés, végpontként pedig Druget Fülöp nádor halálát (1327). Ezen időszakból 61 külön esetet tárgyaló oklevélben található név szerinti utalás nádori emberekre, és összesen 83 nevet említenek. $^{1201}$ Természetesen tovább is gyüjthettük volna az adatokat, egészen 1342-ig bezárólag, de annak megállapításához, hogy a nádori emberek rendszere mennyire vágott össze a Valkó megyei rendszerrel, ekkora minta is bőségesen elegendő volt. A korszak minden egyes „,nádori emberének” egyenkénti dokumentálása egyébként is csak felesleges adatszaporítás lenne.

$\mathrm{Az}$ adatok mindenben összevágnak az Engel által lefektetett szabályszerűségekkel. Helyes volt az a megállapítása is, hogy nem kell különbséget tenni a király, a nádor, vagy más hatóság emberei között, mert mind „ugyanabból a körből és ugyanazon a módon kerültek ki”. ${ }^{1202}$ Különös módon ez még az egyetlen hatóság (tehát ebből a szempontból homogénnek tetsző anyag) esetében is igazolható: ugyanazon ügy kapcsán lesznai (de Lezna) Istvánt Fülöp nádor 1325. szeptember 28-i oklevelében nádori, I. Károly pedig egy 1325. évi levelében királyi embernek nevezte. ${ }^{1203}$ A hatóságra utaló jelző tehát itt csak attól függött, hogy kinek a

\footnotetext{
${ }^{1200}$ Engel 1999. (2003.)

${ }^{1201}$ A tényleges oklevelek száma ennél több, mert egy perhez vagy bírói eljáráshoz általában több oklevél is kapcsolható (pl. a nádor utasítása egy hiteleshelyi eljáráshoz, a hiteleshely válasza, majd a nádor nyugtázó és jó esetben - az ügyet lezáró oklevele). Ilyenkor természetesen ugyanazokat a nádori embereket említették meg többször is. Ezeket nem vettük külön, vagyis a 61-es szám nem a nádori embereket feltüntető oklevelek mennyiségét, hanem az egyes esetek számát jelenti.

1202 Engel 1999. (2003.) 579.

${ }^{1203}$ AOkl IX. 422., 567. sz.
} 
kancelláriáján állították ki az eljáró embert megnevező oklevelet, és mindkét kancellária a saját urát írta be. A kérdésnek pedig nyilván semmi különösebb jelentősége nem volt már akkor sem. Engel ezen kívül elfogadta Borsa Iván azon megállapítását, hogy az 1321 előtti parancslevelekben mindig csak egy személyt neveztek meg királyi emberként. ${ }^{1204}$ Bár a fenti tétel a királyi oklevelekre vonatkozott, nádori diplomák esetében is elmondhatjuk, hogy az első olyan ismert év, amikor alternatívaként már két nevet kínáltak fel, 1322 volt. Nem is a nádor, hanem Dózsa budai alnádorának, Istvánnak a november 8-i oklevelében találkozunk ezzel, másodjára pedig Druget Fülöp vizsolyi albírájának, Perényi Miklósnak az 1323. november 25-i levelében. ${ }^{1205} \mathrm{Az}$ első olyan ténylegesen nádori oklevél, amelyben kettő személyt kínáltak fel, valamikor 1324. március 10-e előtt kelt. ${ }^{1206}$ Tegyük hozzá: ez csak az alternatívaként felkínált nádori emberekre vonatkozott (azaz, amikor az adott egyházi intézmény választhatott, hogy a felsoroltak közül melyikükkel küldjék ki saját egyházi tanújukat). Egyébként már az Árpád-korban, Aba Amadé 1288. évi levelében felbukkan az, hogy egyszerre 3 emberét nevezte meg, ám mivel akkor három birtok ügyében kellett eljárni, ez nyugodtan felfogható az „egy birtok: egy nádori ember” elvének. ${ }^{1207} \mathrm{Nem}$ áll fent ugyanakkor ez a helyzet Péc nembéli Apor 1298. évi oklevelében, amikor egyetlen birtokra, a Somogy megyei Ság határjárására három nádori embert küldött ki. ${ }^{1208}$ Az oklevélből nem derül ki, hogy ezt a három nevet alternatívaként kínálta fel a somogyi konventnek, vagy eleve mindhármukat kirendelte, és hogy mi volt ennek az oka. ${ }^{1209}$ A biztosan alternatívaként felkínált több név első felbukkanása így a jelzett 1322. évi alnádori oklevélben található.

Abban a kérdésben, hogy a felsorolt nádori emberek vajon az adott ügyben érintett birtok vagy személyek közeléből kerülte-e ki, mint Valkó megyében, szintén valószínüsíthetjük az igenlő választ. Sajnos sok esetben nem írták le a kiküldött emberek hovatartozását, és a kéttagú (de nem egyszer csak egytagú) nevek alapján nem lehet megállapítani, hogy abban az esetben mi volt a helyzet. Ám már az is beszédes, hogy az említett 83 felsorolt névből szinte

\footnotetext{
${ }^{1204}$ Engel 1999. (2003.) 581. (vö. RA 3702. sz.)

1205 AOkl VI. 830., VII. 603. sz.

${ }^{1206}$ AOkl VIII. 96. sz.

1207 ÁÚO IX. 481-482. (RP 241. sz.)

${ }^{1208}$ HO VIII. 380-381. (RP 286. sz.)

${ }^{1209}$ Az oklevél egyébként mára már elveszett, csak a 19. századi kiadásból ismerjük. Szövege nagyon hasonlít a nádor egy ugyanaznap, ugyanott kelt levelére, amelyben szintén a somogyi konventet utasította egy másik föld megjárására. Ebben csak egyetlen nádori embert említettek (és nem nevezték meg): HO VI. 430-431. (RP 285. sz.). Arra, hogy a csak nyomtatásban fennmaradt oklevél egy ezek alapján megszövegezett hamisítvány lenne, legfeljebb a nádori emberek ebben a korszakban magasnak tünő száma utalhatna, de véleményünk szerint ez még nem elégséges érv a hamisítás tényének kimondásához. A három nádori ember szereplése a korban kicsit szokatlan, de nem abszolút valószínütlen eset.
} 
mindegyik különböző személyt takart (természetesen azt nem vettük azt figyelembe, amikor ugyanarról a perről több oklevél is szólt, hiszen azokban természetes, hogy ugyanazon neveket említik). Összesen kétszer tudjuk ugyanazt a személyt két különböző eset kapcsán is azonosítani. Az 1288-ban Amadénál szereplő szakalyi (de Zokol) Gabranus bizonyára azonos az 1290-es évek elején kiadott oklevelében eljáró szakalyi (de Zokol) Gabrianusszal. ${ }^{1210}$ Mivel Gabr(i)anus 1288-ban részben a nádor ügyében járt el (felbecsült egy olyan földet, amit 1/3ad részben egy korábbi pernyertesnek, 2/3-ad részben Amadénak mint bírónak kellett átadni), ezért feltehetően ő a nádor ismerettségi körébe tartozott. Komorói Roland fia Tamás is két alkalommal is szerepel Fülöpnél nádori emberként, de egészen más okból, és időben meg térben egymáshoz nagyon közel. Gáva faluban az 1323. június 14-én megnyitott, Szabolcs megyének tartott közgyülésen járt el két esetben, amelyről egy június 16-i és június 17-i nádori oklevél tájékoztat. ${ }^{1211}$ A nádori ember származási helyére utaló Komoró falu mellesleg szintén Szabolcs megyében volt. Egyébként még az azonos megyék esetében is különböző nevek mindenképpen arra utalnak, hogy a nádori emberek megbízatása alkalomszerü feladatnak minősült. Amikor pedig azonosítani is tudjuk az eljáró ember származási helyét, az szinte mindig a kérdéses terület közelébe esett. ${ }^{1212}$ Van ugyan néhány eset, amikor az

\footnotetext{
1210 ÁÚO IX. 481-482.; DL 84192. (RP 241., 256. sz.)

${ }^{1211}$ AOkl VII. 273-274. sz.
}

1212 1264: a Nógrás megyei Zagyvaszántó birtokban járt el rádi Simon, Rád szintén Nógrád megyében volt (DF 278431, RP 129. sz.; ÁMTF IV. 287., 296.); 1274: a Zala megyei Egregy birtok határjárását a szintén megyei kerecsenyi (de Kerechen) Kerecseny végezte (ÁÚO IX. 111-112., RP 164. sz.; Csánki III. 49., 69.); a Pest megyei Berkiről és Szörényről való alpereseket gyömrői István idézte meg (Zichy I. 78-79., RP 178. sz.; ÁMTF IV. 520., 566-567., 576.); 1279: a Somogy megyei Pácodba a megyebeli kapolyi Miklós vezette be a felperest (HO VI. 238-239., RP 193. sz.; Csánki II. 616., 634.); 1288: az Abaúj megyei Felbárca, Pere és Tuzsa birtokok becslését gecsei János, szakalyi Gabranus és koksói Demeter végezte - mindhármuk faluja a megyébe esett (ÁÚO IX. 481-482., RP 241. sz.; ÁMTF I. 64-67., 86., 113-114., 130-131., 141., 152.); 1298: a Somogy megyei Ság birtok határjárását végző horpácsi István faluja ugyancsak Somogy megyei (HO VIII. 380-381., RP 286. sz.; Csánki II. 613., 638-639.); 1298: a Szatmár megyei Mérk ügyében eljáró piricsei Péter is megyei volt (ÁÚO XII. 653-654., RP 287. sz.; Szatmár 184-185., 232.). 1322: a Szabolcs megyei Apagyról való István szintén Szabolcs megyei birtok kapcsán intézkedett (AOkl VI. 588. sz.; Szabolcs 22-23.), ahogy a Szabolcs megyei balkányi Lőrinc fia István is (AOkl VI. 712., 716. sz.; Szabolcs 30-31.); a Csepel-szigeti Becse birtok lerontását az oda való Szentmihályi Gábor vizsgálta ki (AOkl VI. 830.; ÁMTF IV. 194-197., 205.). 1323: a Szabolcs megyének tartott közgyülés ügyeiben a megyebeli komorói Roland fia Tamás járt el (AOkl VII. 273. , 274. sz.; Szabolcs 113.); 1324: a szepesi káptalan Mindenszentek faluval szembeni eljárásában a Szepes megyei Zsigra faluból való Máté a nádori ember (AOkl VIII. 246. sz.; Csánki I. 269.); 1324: az Abaúj megyei Pere birtok perében fügödi Lack járt el, Fügöd szintén Abaúj megyében volt (AOkl VIII. 279. sz.; ÁMTF I. 81-82., 130-131.). Ugyancsak 1324-ben egy Zemplén megyei birtokba a megyei Izsépről való Mátyás iktatott (AOkl VIII. 584. sz.; Csánki I. 350.). 1325: Semjén falusiakat egyenesen semjéni János fia Péter idézte be (AOkl IX. 49. sz.; Csánki I. 508.), a Zemplén megyei (I)sztáncs és Kazsu birtokokat a Zemplén megyei Lesznáról való István járta meg és iktatta (AOkl IX. 422., 567., X. 355. sz.; Csánki I. 351., 355., 363.). 1326: a budai káptalan oklevele egyenesen kiemelte, hogy a Békásmegyer földet elhatároló alnádori ember, „Szakállas” Lörinc a birtok 
azonosítás távolabbi megyékbe mutat, vagy nem egyértelmủ a helyszín lokalizálása, ${ }^{1213}$ de ez a néhány kivétel nem borítja fel a fenti logikát (mellesleg, Engel Valkó megyei adataiban is találunk egészen távolról származó királyi embereket). ${ }^{1214}$ Hogy ezen emberek az ügyet elindító, és az oklevelet kérő személy megnevezése alapján kerültek a nádori ember átmeneti pozíciójába, Engel sejtése alapján ${ }^{1215} \mathrm{mi}$ is valószínüsíthetjük, külön kiemelve, hogy ha a nádor is érintett volt az eljárásban, akkor vélhetően ő maga nevezte ki embereit. ${ }^{1216}$

Az Engel Pál által felállított, 14-15. századi Valkó megyei mintákon alapuló rendszere tehát mutatis mutandis megfeleltethető a nádorok által 1260-1327 között alkalmazott „,nádori emberek" rendszerének. Ez egyébként sejthető volt, a kérdés igazi érdekessége abban rejlik, hogy hogyan viszonyul mindehhez az 1260 előtti poroszlói szisztéma? Tekinthetjük-e az egyiket a másik kvázi egyenes folytatásának? Ennek megválaszolásához ugyanilyen megközelítésből meg kell vizsgálni a poroszlói rendszer felépítését. Legföképpen azt, hogy léteztek-e hivatalhoz kötött poroszlók, avagy az egyes pristaldusok, a „nádori emberek” szisztémájához hasonlóan, ugyanúgy a területi közelség okán váltak idölegesen egy-egy bíró poroszlóivá, és az adott eljárás lezárultával a kapcsolatuk is megszakadt. A törvényszövegek (kezdve a legkorábbi, 11. század második feléből származóktól), és az egyes oklevelek az egyes intézményhez kötött poroszlókról beszélnek. László második törvénykönyve a királyi poroszlót említi, az 1092. évi szabolcsi zsinat pedig külön szól a püspök, az ispán és a király poroszlójáról. ${ }^{1217}$ A későbbi oklevelekben is előszeretettel nevezi a kibocsátó a felbukkanó poroszlót az ő saját emberének. ${ }^{1218}$ Ezt azonban betudhatjuk egy olyasfajta utalásnak is, hogy az illető éppen akkor volt a király, a nádor, az ispán, stb. nevében eljáró poroszló, és nem állandó jelleggel az ő szolgálatában állott, ahogyan a későbbi „királyi, nádori, stb. ember” titulust is értelmeznünk kell. A kérdést csak az döntheti el, hogy mennyire bukkannak fel ugyanazok a nevek egy adott nádor közelében - állandó jelleggel melléjük rendelt poroszlók esetében ugyanis ezt kellene várnunk. Ha azonban végignézzük a 13. század eleji nádori

\footnotetext{
határosa (AOkl X. 137., 169., 272. sz.); a Zemplén megyének okt. 6-án tartott közgyülésen természetesen a megyei Bánócról való János fia Miklós volt a nádori ember (AOkl X. 406. sz.; Csánki I. 341.).

${ }^{1213}$ AOkl VIII. 106. sz.; AOkl IX. 253. sz.; AOkl X. 234. sz.; AOkl XI. 154. sz.

${ }^{1214}$ Engel 1999. (2003.) 586. Ezekben az esetekben egyébként részben igazolható volt, hogy a más településről megnevezetett személy birtokos volt Valkó megyében is. A fenti, néhány kivételt jelentő esetben is ez lehetett a helyzet.

${ }^{1215}$ Engel 1999. (2003.) 590-596.

${ }^{1216}$ Ilyen eset pl. 1288: ÁÚO IX. 481-482. (RP. 241. sz.); 1326: AOk1 X. 536. sz.

${ }^{1217}$ Závodszky 1904. 165. (I/40.), 171. (II/18.)

${ }^{1218}$ A különbség látványos kihangsúlyozásaként pl. 1219-ben a Váradi Regesztrumban (RV 213. sz.) és egy 1220. évi nádori oklevélben (PRT I. 647-648., RP 8. sz.) is külön kiemelték, hogy az eljáró poroszlók közül az egyik a királyé, a másik a nádoré volt.
} 
pristaldusok névsorát, ritkán találjuk meg köztük kétszer ugyanazt a nevet. 1206 és 1248 között 75 esetben tudjuk beazonosítani a nádor illetve az alnádor eljáró poroszlóját. ${ }^{1219}$ Ebből a 75 esetből 65 különböző poroszlót tudunk elkülöníteni. 58-an csak egyszer bukkannak föl a nádor mellett. ${ }^{1220}$ Összesen csak 7 olyan poroszló van, akinél legalább kettő felbukkanást tudunk azonosítani: Osa-i Egyed (Aegidio de villa Osa) kétszer szerepel a Váradi Regesztrumban Miklós nádor poroszlójaként, két egymáshoz közeli, 1219. évi eset kapcsán. Mindkétszer a széplaki apát volt a vádló, aki lopással vádolt különböző faluból való embereket, ám mindkét alkalommal bebizonyosodott, hogy hamisan tette. ${ }^{1221}$ Nagyon valószínü, hogy itt egyszerre kísérte a nádori poroszló a lopási eset vádlottjait a káptalanhoz, csak mivel két külön esetről és más faluból származókról volt szó, ezért a káptalan külön jegyzőkönyvezte azokat. Ám ez logikailag egyetlen felbukkanást jelent a poroszló szempontjából. Két önálló felbukkanása van egy Leger (avagy Luger) nevü poroszlónak, aki 1213-ban Bánk nádor szolgálatában jelent meg, és két teljesen különböző ügy vádlottjait kísérte a váradi káptalanhoz. ${ }^{1222}$ Ugyancsak kétszer bukkan föl scundai Both, akit a másik alkalommal scundai Dochnak említenek, ám azonosságuk nagyon valószínű. Ampod fia Dénes nádor poroszlójaként jelennek meg egy 1232 végi és egy 1233. évi oklevélben, lényegében ugyanazon ügy kapcsán, csak a második alkalommal a volt alperes perelte vissza a volt felperest. ${ }^{1223}$ Azonosságukat indokolhatja az is, hogy itt a második ügy lényegében folytatása volt az előzőnek, így a régi poroszló alkalmazása természetesnek tűnhet. Háromszor is feltünik Budmér nembéli Budmér Barc fia Miklós nádor szolgálatában, igaz, egyik alkalommal csak egy „B” sziglával rövidítve, de az azonosság itt is feltételezhető. ${ }^{1224}$ Mindhárom oklevél 1226-ra tehető (az egyik diploma keltezés nélküli, de az 1226. évi kelet itt is feltételezhető), és a pannonhalmi monostor különféle, közelebbről össze nem függő ügyeit tárgyalják, így a közös szálat Pannonhalma jelentheti. A legtöbbször, 4 alkalommal, ladányi Csépán jelenik meg poroszlóként a nádora mellett, mindannyiszor a Váradi Regesztrumban 1219-1220. évi jogesetek folyamán. Két eset hasonló ahhoz, mint amit Osa-i Egyed esetében is láttunk. Balázs, nagykörüi apát vádolt be egyeseket tolvajlásért, másokat károkozásért a

\footnotetext{
1219 Az egyes források hivatkozását lásd fentebb, a nádori poroszlók elnevezését tárgyaló főszöveg lábjegyzeteiben, illetve Szőcs 2011. 154. 71.jz.

${ }^{1220}$ Amennyiben feltételezzük, hogy az 1219-ben, a Váradi Regesztrumban Barc fia Miklós poroszlójaként szereplő Toma, és az 1221-ben, Benedek tatai apát oklevelében felbukkanó, Móric alnádor poroszlójaként eljáró Thoma nem azonos (RV 226. sz. és ÁUUO I. 182.). Ha mégis, akkor csak 56 poroszló bukkan föl egy alkalommal a nádor mellett.

${ }^{1221}$ RV 175. és 180 . sz.

${ }^{1222}$ RV 9. és 15 . sz.

${ }^{1223}$ UB I. 139-140., 152. (RP 33-34. sz.)

${ }^{1224}$ PRT I. 675., 676-677. (RP 18., 20-21. sz.)
} 
nádor előtt. A feleket közösen küldhette Váradra a nádor Csépán poroszlójával, amit jól mutat, hogy két, egymás mellett álló bejegyzésről van szó. ${ }^{1225}$ Egy évvel korábban, egy 1219. évi bejegyzésben szintén Balázs, nagykörüi apát a vádló egy lopási ügyben. Ekkor is ladányi Csépán révén küldte a feleket Váradra, ám azok nem jelentek ott meg. ${ }^{1226}$ A negyedik alkalommal az ügynek már nem volt köze Balázs apáthoz. ${ }^{1227}$

Ezekben az esetekben az látszik tehát, hogy ha fel is bukkan egy poroszló többször, sokszor akkor is csak „megszorításokkal”. Ugyanazon vagy hasonló ügyek kapcsán, esetleg ugyanabban az évben. Egy esetben viszont egy jól láthatóan szervezett, a nádor mellett állandó jelleggel ott található poroszlói rendszer felállítására is történt kísérlet. Tomaj nembéli Dénes esetében több nádori poroszló is ugyanabból a rokonsági körből került ki. Rosd nembéli tahi Dénest (Dionisius de Toh de genere Rusd) három alkalommal találjuk Dénes nádor szolgálatában: 1237-ben két alkalommal, 1239-ben egyszer, mindannyiszor pannonhalmi vonatkozású ügyben. ${ }^{1228}$ Dénes poroszló rokona volt az a Rosd nembéli „P” sziglával jelölt személy, aki szintén 1237-ben volt Dénes nádor poroszlója, egy szintén pannonhalmi birtokperben. ${ }^{1229}$ Tahi Gábor talán ugyancsak rokona volt tahi Dénesnek. Gábor két 1239. évi, egymással némileg összefüggő (nem pannonhalmi) ügyet tárgyaló oklevélben bukkan föl, mint nádori poroszló. ${ }^{1230}$ Tomaj nembéli Dénesnek összesen 11 eset kapcsán tudjuk a poroszlóit azonosítani, ebből 6 alkalommal a fentiek szerepelnek, ami mindenképpen egy szervezett rendszerre utal. Tah település a Szentendrei-szigeten (régi nevén: Rosdszigeten) volt, amely szigetról a nemzetség is nyerte a nevét. Tahi Dénes később is felbukkan, mint fogott bíró egy szintén pannonhalmi vonatkozású perben. ${ }^{1231}$ Hogy Dénes nádor miért pont őket nevezte ki a poroszlóinak, nem tudjuk.

A nevek különbözősége tehát azt sugallja, hogy - a Rosd nembéli Tahiakat leszámítva - a poroszlók alapvetően nem egy adott hatósághoz voltak hozzárendelve. Ezt erősíti az is, hogy ugyanazon poroszló több, különböző bíró szolgálatában is felbukkant. A Váradi Regesztrum 1214. évi bejegyzésében található az az eset, amikor a bihari várnépek bevádolták Magnus klerikust, hogy földközösségen kívüli. Magnus erre azt felelte, hogy már volt ezzel kapcsolatban egy pere Mog nádor és bihari ispán előtt, amikor Tupa volt a poroszló. Tupát előállították, aki igazolta is mindezt. A felperesek erre a poroszlót vádolták be, hogy hamisan

\footnotetext{
${ }^{1225}$ RV 244. és 245. sz. (az eredeti, 16. századi kiadásban is egymás mellett állt a két bejegyzés)

${ }^{1226}$ RV 217. sz. vö. RP 5. sz.

${ }^{1227}$ RV 269. sz.

${ }^{1228}$ PRT I. 752-753., 753-754., 768-769. (RP 48., 50. és 62. sz.)

${ }^{1229}$ PRT I. 755-756. (vö. RP 47. sz.)

${ }^{1230}$ ÁÚO XI. 309-310., VII. 77-78. (RP 63-64. sz.)

${ }^{1231}$ Karácsonyi 1900. 931-932.; ÁMTF IV. 702.
} 
tanúskodott. Erre előállították azokat a bírókat is, akiknek Tupa - elmondása szerint korábban a poroszlója volt. A bejegyzés hét konkrét bíró nevét sorolta fel, ispánét, udvarispánokét, mások titulusát nem tüntetve fel. A vádlók kiválasztottak két ilyen bírót, akiknek a poroszlóval együtt esküt kellett tenniük, amely igazolta Tupa hitelét. Ám a káptalani eskü pillanatában a vádlók meghátráltak. ${ }^{1232}$ Mog nádor bíráskodása óta (amelynek 1206-ban kellett történnie, mert csak ebben az évben volt bihari ispán is egyben) ${ }^{1233}$ 1214-ig bezárólag legalább 8 bíró keze alatt fordult meg Tupa (a bejegyzés ugyanis azt is hozzátette a hét név felsorolása után, hogy „másokat” (et alios) is odaállított a poroszló a korábbi bírók közül), ami azt mutatja, hogy szinte „közkézen forgott”. Hasonló bizonyítási eljárással találkozunk egy 1236. évi ügyben is, amikor a zalai udvarnokok azzal vádolták ollári Jakó fia Eszten poroszlót, hogy hamisan állítja, hogy ők megverték volna őt. Itt a nádori poroszlót maga mellé vevő felperes, Zlaudus szervezte meg a nádor előtt a bizonyítást, és részint Kálmán herceg és Bertalan veszprémi püspök okleveleivel, továbbá Arnold zalai ispán, Gecha borsi ispán, Belid comes, Türje nembéli kopasz Dénes comes, és sok zalai vármegyeinek a tanúságával (testimonio ... aliorum quamplurimorum parochianorum) igazolta a poroszlót. ${ }^{1234}$ Vagyis Dénes ezen poroszlója minimum ennyi korábbi bíró keze alatt fordult meg. Természetesen mindez nem jelentett egy folyamatos rotációt. Éppen ez az oklevél árulja el, hogy az ügy befejeztét azért nem tudta Dénes nádor ezen poroszlóra bízni, „mert a mondott Eszten poroszló egy más ügyünkkel volt elfoglalva". ${ }^{1235}$

A „királyi emberek” esetében azt láttuk, hogy többnyire a helyi lakosokból kerültek ki az aktuális parancs végrehajtói. Ha a poroszlókat ebből a szempontból vizsgáljuk meg, akkor szintén fedezhetünk fel párhuzamosságokat. Már az is feltűnő, hogy az előbb tárgyalt, 1236. évi bizonyítási eljárás során is dunántúli bírókat állítottak elő. Ha a poroszló faluját (Ollár) nézzük, az is Zala megyében volt, ahová a per tárgya, Zalaszántó is esett. ${ }^{1236} \mathrm{~A}$ Váradi Regesztrum eseteiben is láthatunk összefüggéseket a poroszló faluja és a jogeset területi vonatkozása között, ${ }^{1237}$ és az okleveles anyagban is felbukkannak ilyen tendenciák. ${ }^{1238}$ Más

\footnotetext{
${ }^{1232} \mathrm{RV}$ 197. sz.

${ }^{1233}$ Archont. 1000-1301. 17.

${ }^{1234}$ HO VI. 32. (RP 43. sz.)

1235 „quia predictus pristaldus Esten impeditus erat aliis nostris negociis” HO VI. 33.

${ }^{1236}$ Csánki III. 87.

${ }^{1237} \mathrm{Pl}$. az előbb említett 97. sz. eset, bihari vonatkozású ügyben a poroszló Tupa faluja a Biharnagybajom mellett fekvő Görbely (K. Fábián 1997. 73.); 103. sz. Szabolcs megyei eset: a poroszló a közeli Kraszna megyei Lecsmér faluból való (K. Fábián 1997. 102.); 313-314. sz. Vas megyei eset: a poroszló „Symeonem de villa Sag”, amely a Vas megyei Alsósággal azonosítható (K. Fábián 1997. 119.); a négyszer is felbukkanó Ladányi Csépán poroszló faluja a Heves megyei Jászladánnyal azonosítható (K. Fábián 1997. 88.), jogesetei pedig három alkalommal hevesi vonatkozásúak (mikor Balázs, nagykörüi apát pereiben szerepelt), egyszer Külső-Szolnok
} 
esetekben viszont nem lehet kimutatni, hogy a poroszló lakhelye a jogesethez közel esett volna. Látható, hogy a poroszló nem feltétlenül volt közvetlenül szomszédos, de szinte mindig abból a tágabb régióból került ki, amelynek a perét éppen intézték. Ez logikus is abból a szempontból, hogy szükség esetén könnyebb volt elökeríteni őket, ahogy ők is jobban megjegyezték egy adott, sok esetben szülőföldjüknek számító régió terület viszonyait. Ráadásul a bírói intézmények többsége eleve regionális jellegű volt, csak néhány országos, vagy egy nagyobb országrészre kiterjedő hatáskörü nagybíróval számolhatunk ekkoriban. Valószínű tehát, hogy a poroszlói segéderő egy adott területhez kötődött, és amikor a nádor egy konkrét megyébe érkezett, akkor az ott felbukkanó peres ügyek intézéséhez az ottani, helyi poroszlók segítségét vette igénybe. Így a pristaldus megbízatása akár le is járhatott az ügy lezártával, de a nádor maga mellett is tarthatta még öt valamilyen más alkalomra. Ezt a jelenséget próbálta kivédeni az 1231. évi Aranybulla, amelyben kimondták, hogy „poroszlót senki se tartson magánál egy évig vagy két évig, vagy annál tovább, csak annak az ügynek az elintézéséig, amelyre küldték". ${ }^{1239}$ A törvényszöveg szintén azt az állapotot tekinti normálisnak, hogy a poroszló nem a bíró személyéhez, hanem a konkrét ügyhöz kapcsolódik, tehát a bírói kör mellett nem állandó poroszlók dolgoztak.

Ez látszólag hasonlít a „nádori emberek” szisztémájához, hiszen amikor ezeket a hasonló funkciókat ellátó személyeket a sajátjuknak mondták, ott is csak arra utaltak, hogy éppen abban az egy esetben járt el az illető a nádor nevében, egyébként többnyire a helyi lakosság közül kerültek ki. Ennek ellenére a „nádori emberi” szervezetet mégsem tekinthetjük a poroszlói intézmény szerves folytatásának (azaz nem csak egy névváltásról volt szó). A „nádori ember”, mint láttuk, nem minősült intézménynek, inkább a „fogott bíróhoz” hasonlíthatjuk ebből a szempontból, aki bárki lehetett (a szokásjog szabta tekintélyi kereteken

megyei (RV 217., 244-245., 269. sz.); 289. sz. Temes megyei eset: a poroszló Acsádi Peta, amely falu szintén Temes megyében volt (K. Fábián 1997. 23.); 266. sz. Tolna megyei eset: a poroszló Inokai, amely Tolna megyei település (K. Fábián 1997. 81.); 271. sz. Komárom megyei eset: a poroszló a közeli, Sopron és Györ megye határán fekvő Árpás faluból való (K. Fábián 1997. 25.).

1238 1234-ben egy Borsod megyei ügyben Péter alnádor poroszlója Nyék falubeli (HO VIII. 31-32., RP 37. sz.), és ilyen nevü település volt Borsod megyében is (ÁMTF I. 794-795.). Egy 1245. évi Veszprém megyei ügyben a nádori poroszló salamoni Márk (PRT VIII. 288-289., RP 72. sz.), és - más megyék mellett - Veszprém megyében is volt egy Salamon nevü település (Csánki III. 249.). Egy Sopron megyei ügyben a poroszló Majádi Declip (ÁÚO VI. 511-512. vö. Karácsonyi 1900. 1078.), és Majád volt Sopron megyében is (Csánki III. 619.). Vas megyei vonatkozású az az 1222 és 1225 közé tehető nádori itélet, ahol Koloni Farkas volt a poroszló (ÁÚO VI. 435.), Kolon pedig szintén Vas megyében volt (Csánki II. 766.). 1223-ban egy Esztergom megyei jogesetben kurali Csépán a nádori poroszló (MES I. 241-242.), amely település szintén Esztergom megyében volt (ÁMTF II. 297-298.).

1239 „Prestaldum nullus per annum vel biennium, vel ultra secum detineat, nisi usque ad decisionem cause, ad quam impetravit.” DRMH I/1. 40. Magyarul: Szöveggyüjtemény 276. 
belül, természetesen), de utána megbízása megszűnt, és nincs arra adatunk, hogy mindig ugyanaz a néhány személy lett volna a fogott bíró, vagy éppen a királyi, nádori ember. A poroszló ellenben - úgy tünik - intézményesítetten is poroszló volt, ezt a tisztséget nem csak egy alkalomszerü megbízás nyomán nyerte el. Hiszen fentebb több példát is láttunk arra, hogy több (helyileg azonos régióból kikerülő) bíró szolgálatába is állhattak, amolyan „,szóbeli hiteleshelyként” üzemelve. A poroszlói rendszer hanyatlását azonban a valódi, írásbeli alapon müködő hiteleshelyek hozták el, mert sokkal biztosabb alternatívát kínáltak az egyes jogügyletek bizonyítására. Amikor pedig törvénybe foglalták, hogy a poroszlók tanúsága csak a hiteleshelyi tanúsággal együtt legyen érvényes, akkor feleslegessé is tették egyben a létüket. Az adott hatóság azonban nem nélkülözhette a gyakorlatban is eljáró segédszemélyzetet, bár az innentől kezdve bárki lehetett, hiszen az ügy bizonyíthatóságát a hiteleshely közbenjárása garantálta. ${ }^{1240}$ Így alakult ki a „királyi ember” megbizatási szokása, amely sokban a poroszlói rendszert másolta, de nem abból jött létre, hanem a helyett. Az 1250-es évektől megjelenő „helyhez kötött” nádorok tartottak saját segédszemélyzetet, de ez inkább bárói mivoltukból eredt, nem számítottak klasszikus „hivatali” segédszemélyzetnek, bár nyilván arra is lehetett őket használni. Ám hogy már a korai időktől kezdve is mindig más név bukkan fel „,nádori emberként", arra kell gondolnunk, hogy a végrehajtó személyét már ekkor is spontán, rövidebb alkalmakra jelölték csak ki.

\footnotetext{
${ }^{1240}$ Elvileg felvethetjük, hogy az 1240-1250-es években és az után a forrásokban poroszló névvel illetett személyek voltaképpen poroszlónak tekinthetőek-e. Funkcionális szempontból semmiképpen, hiszen ekkor már nem közhitelü tanúként voltak jelen, csak hivatali segédszemélyzetként. A poroszlók visszaszorulásának és eltünésének az itt, és a korábbi szakirodalomban is emlegetett korszakhatárai így valójában az elnevezés eltünésének az idejét jelölik. Tanúságtevő és perben bizonyító poroszlóval a tatárjárás után már nem találkozunk (a nádori anyagban legalábbis), így a klasszikus poroszlói intézmény már akkor lehanyatlott, amikor a terminológia maga még fennállt. Ennek ellenére magunk ódzkodnánk attól, hogy ezeket az adatokat egy országos tendenciává tágítsuk, hiszen valószínü, hogy az ország hiteleshelyekkel kevésbé lefedett keleti részein még egy darabig virágzott a szóbeli bizonyítás rendszere. A kérdés tisztázása voltaképpen egy bizonyítási paradoxon lenne: ezt a témát csak írásbeli forrásokkal tudjuk kutatni, ám a nagyobb számú okleveles anyag megjelenése éppen a poroszlók létezését teszi feleslegessé. Vagyis abban a tatárjárás utáni régióban, amelynek viszonyait jól ismerjük, mert a korban kifejlett hiteleshelyi tevékenységet folytattak, biztosan visszaszorultak a poroszlók. Ahol viszont elviekben létezhettek, azt az írott források híján nem tudjuk igazolni.
} 


\section{9-A hivatal betöltése}

A korai időkre nézve meg kell elégednünk azzal a közhellyel, hogy a nádori hivatal betöltése a királytól függött, azaz saját jogon ő nevezte ki és tette le a nádorokat (ahogy minden más világi, sőt, kezdetben egyházi tisztségviselőt is). A legkorábbi írásos forrás a király ezen jogára 1199-ből való, amikor Imre király magyarázkodni kényszerült III. Ince pápa elött, hogy ezzel feleljen a lázadó öccse pártján álló püspökök vádjaira. Levelében többek között ezt írta: „... Elevinus, Várad említett püspöke ... midőn látta, hogy mi a nádorispánt [ti.: Mogot], aki által fegyveres támadást szerveztek elvesztésünkre, hütlensége lelepleződvén, méltóságától megfosztottuk, s helyébe kiváló hüségéért Mihály ispánt akartuk kinevezni, szándékunk megakadályozására Mihály ispánt kiközösítettnek nyilvánította”. ${ }^{1241}$ Az ármánykodás ekkor nem volt sikeres, mert Mihály (más néven Mika) 1199-től nádor lett (mellesleg a kiközösítés politikai fegyverré degradálása miatt parancsolhatta meg az év elején Ince a magyar föpapoknak, hogy nyilvánvaló ok nélkül ne közösítsék ki Imre király „famíliárisait és tanácsosait”). ${ }^{1242}$ Már ebben a levélben is találkozunk azzal a 13. századot szinte folyamatosan végigkísérő ténnyel, hogy a kinevezés ugyan a király joga volt, ám tekintettel kellett lennie a döntések meghozatalában a mindenkori politikai erőviszonyokra. Azon 13. századi forrásokban, amelyekben felbukkan a nádorváltás, többnyire jelen van az is, hogy a király ugyan de iure saját jogon állított nádort, de erről nem kizárólag saját maga döntött.

Az Aranybulla 1231. évi megújítása már törvényszerủen tartalmazta azt az 1222. évi változatban nem szereplő kitételt, hogy a nádort az éves augusztus 20-i fehérvári törvénynapon kérésre leváltja a király: „Ha a nádor eközben [ti. az év közben] rosszul intézné a király és az ország ügyeit, könyörögni fognak nekünk, hogy helyére hasznosabbat állítsunk, akit akarunk, és mi az ő kérésüknek engedni fogunk." "1243 A törvényt a középkori viszonyoknak megfelelően nem volt kötelező királyokon átívelő folyamatossággal szó szerint betartani (hacsak nem váltak passzusai időközben szokásjoggá), így ezt a rendelkezést sem

\footnotetext{
1241 „E[luinus] quoque frater eius Varadiensis dictus Episcopus ... videns nos palatinum comitem, per quem ipsi rabiem armorum in eversionem nostram incitaverant, propter deprehensam eius infidelitatem, dignitatibus suis denudare, et Michaelem comitem propter eminentiam sue fidelitatis eidem nos velle subrogare, ad impedimentum propositi nostri eumdem Michaelem comitem denuntiavit excommunicatum" ÁÚO VI. 199. Magyarul: ÁALev 122.

1242 „familiares et consiliarios suos” CD II. 350-351.

${ }^{1243}$ „Si palatinus interim male administraverit negotia regis et regni, supplicabant nobis, ut utiliorem loco eius constituamus, quem volemus, et nos eorum precibus annuemus." DRMH I/1. 38. Magyarul: Szöveggyüjtemény 274.
} 
célszerü úgy kezelni, mint a mindenkori király nádorválasztás terén meglévő jogának első szükítését, inkább csak mint egy lenyomatot II. András pillanatnyi belpolitikai mozgásteréről. Nincs is arról konkrét információnk, hogy ezzel a passzussal valaha is éltek volna. Legvalószínübben II. András bizalmi embere, Ampod fia Dénes nádor 1234-1235 folyamán történő leváltása esetében gyaníthatnánk ezen törvény alkalmazását, de az ottani nádorcsere pontos időpontja sajnos nem ismert. Később - a korábbi nádor utolsó, és a következőnek az első említései alapján - csak néhány esetben találunk olyan nádorváltást, amely biztosan augusztus 20-a környékére esett volna, de az említett törvény alkalmazása ezeknél sem bizonyítható. ${ }^{1244}$ Nagyon hasonló tartalommal rendelkezett az 1290. évi törvény 25. cikkelye, amely szerint az évenkénti székesfehérvári országgyülésen „országunk összes bárói és nemesei ... megvizsgálják a bárók tetteit, miképpen járt el ki-ki közülük a saját tisztségében, és tartották meg az ország jogait, és ki-ki érdemei szerint jutalmát, vagy mulasztásai és vétkei szerint büntetését a mi és tanácsosaink ítélete szerint még aznap elvegye." ${ }^{1245}$ A „tanácsosaink” kitétel a III. András király mellett müködő főpapi kört és hozzájuk tartozókat jelentette, akik így akartak biztosítékot szerezni a komoly tisztségeket viselő főurak ellenében. ${ }^{1246}$

Ám a fenti passzusnál érdekesebb az az 1290. évi törvénycikk, amely konkrétan a nádorválasztást szabályozta. Kimondta: ,a nádort, tárnokaink mesterét, az alkancellárt és az országbírót országunk nemeseinek tanácsából, országunk régi szokása szerint fogjuk kinevezni". ${ }^{1247}$ Bár a király kinevezési jogát ebben is alapnak tekintették, de ebben a cikkelyben már nem csak a hatalmaskodva müködő nádor leváltásának a(z elméleti) jogát kapták meg a nemesek vagy „tanácsosok”. A törvény alapvetőnek tekintette, és a kor egyik igen erős hivatkozási alapjaként az ország régi szokásából valónak (ex antiqua consuetudine regni nostri) állította be a nemesek tanácsának (consilium nobilium) kikérését a legfőbb méltóságviselők választásakor. A bárói hatalom politikai súlyának megnövekedése a 13. század második felére a történetírásunk egyik régi megállapításának számít. ${ }^{1248}$ Hogy a fenti passzusnak tényleg volt korábbi hagyománya, mutatja Csák nembéli Máté fia Máté egyik

\footnotetext{
${ }^{1244}$ Lásd Archont. 1000-1301. 19-25.

1245 „omnes barones et nobiles regni nostri ... inquirentes de factis baronum, qualiter quilibet ipsorum in suis comitatibus processerint et conservaverint iura regni, et secundum sua merita premia et demeritavel commissa suppliciaipso die secundum iudicium nostrum et consiliariorum nostrorum recepturi." DRMH I/1. 46. Magyarul: Szöveggyüjtemény 288.

1246 Zsoldos 2010a. 325.

1247 „palatinum, magistrum tavernicorum nostrorum, vicecancellarium, iudicem curie ex consilio nobilium regni nostri ex antiqua consuetudine regni nostri faciemus” DRMH I/1. 45. Magyarul: Szöveggyüjtemény 285.

${ }^{1248}$ Kristó 1979. 185-192. (korábbi szakirodalommal)
} 
1278. évi oklevele, aki a megválasztását úgy írta le, hogy „urunk, Magyarország kiváló királya őméltóságának és báróinak egyetértésével és tanácsára minket az ő nagylelküségének kegyelméből a nádorságra, illetve a somogyi, soproni és a bányai ispánságokba emelt". ${ }^{1249}$ Még érdekesebben fogalmazott egy néhány hónappal korábbi, 1278. március 25-i oklevél, amelyet Csák nembéli Máté fia Péter nádornak címzett Iharos fia Gergely és három bírótársa. ${ }^{1250}$ Öket még Péc nembéli Dénes nádor rendelte ki bíróként egy birtokperre március 6-án, ${ }^{1251}$ de mivel nem sokkal utána nádorváltás történt, és Dénes helyébe Péter került, ezért a kirendelt bírák március 25-én már csak Péternek címezhették válaszlevelüket. Ebben azt is leírták neki, hogy „királyi kegyből az egész ország révén nádor lettél” (de gratia regia per totum regnum estis palatinus). ${ }^{1252}$ Bár nem biztos, hogy érdemes lenne négy egyszerü fogott bíró oklevelének a szövegezésébe komoly szemantikai finomságokat keresni, de feltünő, hogy Péter nádori méltóságát ugyan „királyi kegyből” (de gratia regia) eredeztették, de a nádorrá emelésében a regnumnak tulajdonítottak tevékenyebb szerepet, hiszen Péter per totum regnum nyerte el a méltóságát. A regnum alatt ebben a szövegkörnyezetben az ország politikailag aktív közösségét érthetjük. ${ }^{1253}$ Mivel László nagykorúsítása után, 1277-1278 folyamán Lodomér esztergomi érsek és köre már megpróbálkozott bizonyos rendi intézmények bevezetésével, így ez utóbbi megfogalmazást talán ennek a nyomát őrző célzásnak is értelmezhetjük, és a regnum által kinevezett Péter nádor képe áll itt szemben a néhány hónappal későbbi, a „bárók egyetértésével és tanácsára” (baronum consensu ac consilio) kinevezett Máté nádorral, amely a IV. László alatti oligarchikus „túlhatalmat” tükrözné. Valószínű azonban, hogy ez az értelmezés túlságosan erőszakolt lenne, hiszen egyrészt, mint említettük, négy kirendelt Somogy megyei bíró oklevelének a latinságát nem feltétlenül lehet az akkori legmodernebb, rendi eszmékre utaló jogi terminológia alapján értelmezni. Másrészt a „lodoméri rendi konszolidáció” nádora nem az állítólag a regnum által választott Csák nembéli Péter volt, hanem éppen „a bárók tanácsára” kinevezett Máté, ${ }^{1254}$ és az oligarchaellenes föpapi körtől mi sem állhatott távolabb, mint hogy az oligarchikus hatalom egyik egyik hangsúlyos szereplőjét, Csák Pétert akarják a regnum által helyzetbe hozatni. Ha

\footnotetext{
1249 „Dominus noster inclytus rex Hungariae Excellentiae suae et suorum Baronum consensu ac consilio nos Magnitudinis suae ex gratia Palatinatu, Comitatibus videlicet Symighiensi, Suproniensi, et de Bana sublimando" CD V/2. 477. vö. RP 192. sz. (az oklevél már csak Fejér kiadásában maradt ránk, ezért nem változtattunk a nyilván általa anakronizált helyesíráson)

${ }^{1250}$ Kubinyi 1867. 109-110.

1251 ÁÚO IX. 48-49. (RP 185. sz.)

${ }^{1252}$ Kubinyi 1867. 110.

${ }^{1253}$ Gerics 1987. 258-259. ill. passim.

${ }^{1254}$ Lásd a „,4.3 - Az »oligarcha-nádorok« kora” c. alfejezetet.
} 
tehát a fenti két, nádorválasztást említő szövegrészletbe nem is kell a formálódó fôpapi rendiség és a bárói hatalom akkori eszmei ellentétét belelátni, kicsit általánosabban mégis bepillantást engednek abba, hogy az „oligarcha-nádorok” idejében milyen súlypontokkal zajlott a nádori szék betöltése. A legitimáció elméletileg a királytól eredt, de a gyakorlatban a politikai környezete döntött (finomabban fogalmazva: ,adott tanácsot”) a kérdésben, és láthatóan ezt fontosnak is tartották megemlíteni, a korabeli politikai modellben betöltött szerepüket kihangsúlyozandó. Egyáltalán nem túlzott tehát az 1290. évi törvény megfogalmazása akkor, amikor „országunk régi szokása szerintinek” tüntette azt fel, hogy III. András az ország nemeseinek tanácsából nevezze ki a fontosabb főméltóságokat. Itt tulajdonképpen a IV. László alatt megszokott helyzetet ígértették meg az új királlyal. Elképzelhető, hogy ennek a kényszerü „tanácsnak” a szándékos elhallgatását olvashatjuk IV. László azon 1287. évi oklevelében, amelyben az ekkor már a saját politikai elitjével erősen dacoló király vágyálmát jelenítették meg. Ugyanis amikor László a budai polgároknak különféle előjogokat adva mentesítette őket a nádori joghatóság alól is, hozzátette, hogy a nádor „mindenkor a királyi kegyből lesz, az ő méltóságának érdemei szerint”. ${ }^{255}$ Ezek az apró megjegyzések azonban csak sejtetni engedik azt a politikai háborút, ami IV. László és az egymással is ellentétes érdekeket képviselő alattvalói között zajlott egy-egy magasabb pozíció betöltése körül.

Az 1290. évi nádorválasztást (is) szabályozó törvény szövegére egyébként szinte rímel egy jóval későbbi passzus a nádorválasztásról. Az 1439. évi, budai országgyülésen hozott, és Albert király által szentesített törvény vonatkozó része szerint „minthogy a nádor az országlakosok részéről az országlakosoknak törvényt és igazságot szolgáltathat s kötelessége is ezt tenni: azért az ország nádorát, így kívánván ezt az ország régi szokása, a királyi felség a főpapoknak, báróknak és az ország nemeseinek tanácsára velük egyetértőleg válassza ki."1256 C. Tóth Norbert kutatásai és megállapítása szerint a Nagy Lajos-kori állapotok visszaállítását szorgalmazó törvénykorpusz itt a nádor országgyülésen történő megválasztását szögezte le, amely szokás - ritka kivétellel - 1342-től kezdve az Anjou-korban, majd később, a Zsigmond korban is élt. ${ }^{1257} \mathrm{Az}$ 1342. év nádorváltását pedig úgy írta le Zsámboki Miklós egy nem sokkal kinevezése után kiadott oklevélben, hogy Vilmos nádor halála után ,a király kegyessége, a főpapok, bárók és az ország nemeseinek egyetértő tanácsával, az isteni

\footnotetext{
1255 „exemptam a iurisdictione regni nostri palatini, qui regia de gratia pro tempore fuerit illius in fasscibus dignitatis" Elenchus III/2. 83. (Mon. Bp. I. 229.) Tegyük hozzá: az oklevél hitelessége a szakirodalomban vitatott, de újabban már nem tekintik hamisnak (lásd RA 3449. sz., Györffy 1997. 189.).

${ }^{1256}$ CJH I. 280. Magyarul: uo. 281.

${ }^{1257}$ A Zsigmond korra: C. Tóth 2012a., különösen 64-65. Lajos korára: C. Tóth 2012b. 439-440., 443-447.
} 
gondviselés révén a nádori hivatallal díszítette fel" öt. ${ }^{1258}$ C. Tóth Norbert az emögötti megfogalmazás mögött is egy országgyülésre való utalást sejtett. ${ }^{1259}$

Felvetődik a kérdés, hogy a 13. század végén, amikor a fentiekhez hasonló szóhasználattal írtak a nádorok kinevezéséről, és amikor amúgy is egy kísérlet történt a rendiség kiépítésére, ${ }^{1260}$ kimutatható-e, hogy a nádort az országgyüléseken (is) választották? A felvetésre nem lehet igenlő választ adni. Ha elfogadjuk, hogy az tekinthető országgyülésnek, ahol egyszerre jelentek meg és léptek föl a főpapok és bárók mellett az ország serviensei, akkor az 1277. május végén tartott rákosi gyülés tekinthető az első ilyen alkalomnak. ${ }^{1261}$ Láttuk, hogy 1278 tavaszán Pétert (legalábbis egy oklevél megfogalmazása szerint) „per totum regnum” emelték nádorrá. Mint fentebb szó esett róla, nem biztos, hogy ezt a korabeli rendi terminológia alapján kellene értelmezni, és egy esetleges országgyülésen való választást feltételezni. Ebben az évben tartott országos gyülésről egyébként sincs tudomásunk. Szól ugyan egy oklevél egy 1278. évi rákosi országgyülésről, de az biztosan hamis, mivel az ott olvasható bárónévsor nem illik a korba (mellesleg Roland nádor részvételét említette, többek között ez is anakronizmus). ${ }^{1262}$ Tágabban vizsgálva a kérdést, 1277 és 1290 között egyetlen olyan országgyülést, de még szűkebb országos gyülést sem találunk, ${ }^{1263}$ amelynek az időpontja egyértelmüen egybeesett volna a nádorváltások időpntjával. ${ }^{1264}$ A III. András uralma (1290-1301) alatti nádorváltások logikáját részletesen feldolgozta Zsoldos Attila. Eszerint III. András az uralma kezdetén egy, a legfontosabb bárói famíliákat maga mellé emelő rendszert dolgozott ki (vagy talán inkább javasoltak neki), szerepet juttatva nekik a kormányzatban. A nádori tisztség betöltője évente cserélődött, rendszerint nyáron, III. András koronázása (július 23.) körüli időpontban. Ezt az általános szabályt írta felül egy másik szabályosság: a kormányzati válságperiódusokban, ami a

\footnotetext{
1258 „regia benignitas de prelatorum et baronum ac regni sui nobilium unanimi consilio divina nobis favente clementia ipsius palatinatus honore decorarat" C. Tóth 2012b. 443-444., 51. jz.

${ }^{1259}$ C. Tóth 2012b. 444.

${ }^{1260}$ Gerics 1987. 265-309.

${ }^{1261}$ A feltételrendszerre lásd Gerics 1987. 279.

1262 RA 2932. sz., lásd még S. Kiss 1971. 34.

${ }^{1263}$ Listaszerü felsorolásukat lásd S. Kiss 1971. 51-52.

${ }^{1264}$ Két esetben van elméleti lehetőség rá: 1286. június végén Rákoson tartottak országos gyülést, Henrik fia Miklós nádor pedig 1285. dec. 14-én jelent meg utoljára, az őt követő Aba nb. Makján 1286. okt. 13 -án először (és utoljára). A másik lehetőség az 1289. június végi fövényi gyüléshez köthető, amikor Aba Amadé 1288 augusztusa utáni utolsó felbukkanását Básztély nb. Rénold nádor 1289. aug. 21-i felbukkanása követte (Archont. 1000-1301. 22-23.). Mivel mindkét esetben egy, vagy több mint egy év hiátus található a nádorok névsorában, ezért ezeket az alkalmakat sem kapcsolhatjuk biztosan össze. Ha ehhez hozzávesszük, hogy a többi esetben biztosan nem az országgyülésekhez kötődött a nádorváltás, akkor kimondhatjuk: érdemi összefüggést nem lehet kimutatni.
} 
gyakorlatban egy-egy föúri família András elleni lázadását jelentette, egyszerre két nádort választottak, egyet a „dunáninneni”, egyet „dunántúli” jogkörrel. ${ }^{1265}$ A nádori hivatal betöltésének logikája tehát itt eleve nem is az országgyülésekhez kapcsolódott.

$\mathrm{Az}$ Árpád-korban tehát még nem tudjuk kimutatni, hogy a nádorok választása országgyülésen történt volna. Az 1290. évi 9. törvénycikkben szokásjogként felhozott „nemesek tanácsa” a király közvetlen környezetét alkotó fơúri kört jelentette inkább, akikre való hivatkozás szinte az egész 13. század folyamán jelen van az oklevelekben, ${ }^{1266}$ és akik a kezdeti koalíciós kormányzás biztosítékát is így szentesítették. A befolyásuk a tisztségviselők megválasztására viszonylag nagy lehetett már IV. László uralkodása alatt is, sokszor egyetlen família ragadta magához a szinte teljes hatalmat a közigazgatásban. ${ }^{1267}$ A helyzetet III. Andrásnak sem sikerült érdemben megváltoztatnia, így hát a maga javára fordította, és kompromisszumos megoldásként alkalmazta a folyamatos cseréket és párhuzamosságokat a hivatal betöltésekor. Az Anjou-kor nádorváltásaiban szintén nem mutatható ki az országgyülések szerepe, ${ }^{1268}$ és még nem meggyökeresedő, alkalmi ellenpéldákkal sem találkozunk, így ezt az intézményt legkorábban I. Lajos korától kapcsolhatjuk össze a nádori hivatal betöltésével.

\footnotetext{
1265 Zsoldos 2010a, különösen 324-326.; lásd még a „4.3 - Az »oligarcha-nádorok« kora” c. alfejezetet.

1266 Gerics 1987. 265-270.

${ }^{1267}$ Példákkal illusztrálva: Kristó 1979. 185-187.

${ }^{1268}$ Vö. C. Tóth 2012b. 441-442.
} 


\section{0 - A NÁDORI HIVATAL JÖVEDELMEI}

Végezetül ki kell térni a nádori hivatallal kapcsolatos jövedelmekre. Hétköznapiasabban megfogalmazva: „miből élt” a nádor? Elöljáróban le kell szögeznünk, hogy a nádorokat szinte mindig az ország hatalmasabb főuraiból választották ki, akiknek „magánemberként” is komoly jövedelmük volt családi birtokaik után, így elméletileg nem is lenne lényeges, hogy valamilyen hivatali javadalmazást kapjanak. Ennek ellenére mindenképpen számolhatunk ilyennel is. A javadalmazás milyenségére az 1320-as évek utáni időszakra nézve viszonylag könnyü válaszolni, és ebben is Engel Pálé az úttörő szerep. Ö fejtette ki az ún. honor-rendszer Anjou-kori elvét, amely értelmében egy-egy főméltóság hivatalviselési ideje alatt megkapta bizonyos várak és a hozzá tartozó birtokok jövedelmét addig, amíg betöltötte ezt a hivatalt. A hivatallal együtt a honort is visszavették, majd egy részét (de általában nem pontosan a hivatali elődje által bírt tételeket) az új méltóságviselő kapta meg. ${ }^{1269}$ Engel szerint ugyanakkor a rendszer - általa részleteiben nem tisztázott módon - visszanyúlt az Árpádkorba is. A honor előzményét várispánságokban vélte megtalálni, amelyet a vármegyéhez hasonlóan szintén comitatusnak neveztek. ${ }^{1270}$ Tény, hogy az egyes ispánságoknak a nádori cím melletti birtoklását akár ezen honor-rendszer nyomának vagy előzményének is felfoghatjuk, de az is igaz, hogy a valamilyen főméltósággal párhuzamosan bírt comitatusok a korai időkben sohasem várispánságok, hanem mindig vármegyék voltak. ${ }^{1271}$ Később is csak elvétve fordultak elő várispánságok. Már volt róla szó, hogy először III. Béla idején kezdtek tételesen ispáni címeket rendelni az egyes nagyobb méltóságokhoz. 1192-től párosították ispánsággal a nádori és az országbírói (akkori nevén: királyi udvarispáni) titulust, majd Imre korától kezdve (1198-1200-tól) a tárnokmester, a szlavón bán és az erdélyi vajda is kapott egy-egy ispánságot a főméltósága mellé, igaz, nem minden esetben. ${ }^{1272}$ Nem lehetetlen, hogy mindezt a főméltóság javadalmazásának szánták. Feltünő ugyanis, hogy a nádori méltóság esetében kezdetben nem össze-vissza társították az ispáni címet, és ez már önmagában is egy szervezett rendszert sejtet. A nádori szék mellé az első időkben következetesen a bácsi ispánság tartozott. Mog 1192-től viselte ezt a titulust mind III. Béla, mind Imre alatti hivatali ciklusában. A közte felbukkanó Ézsau nádor 1197-1198 folyamán szintén bácsi ispán volt.

\footnotetext{
${ }^{1269}$ Engel 1981.; Engel 1982. 880-887.

${ }^{1270}$ Engel 1981. 16-17.; Engel 1982. 898.

${ }^{1271}$ Erre már Nógrády Árpád is felfigyelt: Nógrády 1995. 177.

1272 Archont. 1000-1301. 16., 27., 37., 42., 62. Elszórtan már korábban is előfordult, hogy egy főméltóság mellé más méltóság is kapcsolódott, erre leginkább a szlavón báni titulus esetén volt példa.
} 
Tanulságos 1199-től Mika esete. Ö eredetileg bihari ispán volt 1198-1199 folyamán. A bihari ispáni címe mellé megkapta a tárnokmesteri, majd az udvarispáni tisztséget. Ám amikor 1199-ben kinevezték nádorrá, akkor a bihari ispánságát lecserélte a bácsi ispánságra. Tehát a nádori tisztséghez hozzá volt rendelve a bácsi ispáni poszt, és amikor Mika nádor lett, akkor meg kellett szabadulnia a régi megyéjétől. Ám az új nádor láthatóan vissza akart térni előző megyéjéhez, és 1200-tól vissza is kapta a bihari ispánságot, elhagyva a bácsit. Nyilván nem véletlen, hogy ezek után az őt követő nádor, Benedek 1202-től már bihari ispán is lett egyben. Pedig Mika élt (sőt, II. András alatt 1214 és 1221 között ismét Bihar megye élén találjuk), de akkor a nádori pozíciójával együtt a megyét is elveszítette. ${ }^{1273}$ III. Béla és Imre alatt tehát a nádori hivatalhoz egy meghatározott megye ispáni címe is kapcsolódott. Fügedi Erik szerint a „jelenség oka ismeretlen. Feltehető egyrészt, hogy ezeknek a tisztségeknek [ti. nádor, udvarispán, tárnokmester, akiknél megjelent ekkortájt az ispánsággal való párosítás] nem volt független jövedelme, az ispánságoknak viszont volt, ezért az udvari tisztségviselők ispánságot is kaptak, amivel egy csapásra megoldódott a honorálás kérdése is; de olyan feltevés is lehetséges, hogy az udvari tisztségek viselőit eleve a megyésispánok közül választották ki." ${ }^{1274}$ Az utóbbi feltételezés biztosan elvethető, éppen a nádor példája alapján, hiszen nem az ispánok nyerték el valamelyik udvari tisztséget, hanem ahhoz járt egy ispánság. Ám az előbbi feltételezésben lehet logika, hiszen a III. Béla-kori jövedelemösszeírás alapján az ország 72 ispánsága - ha nem túlbecsültek az arányok ${ }^{1275}$ - évi 25 ezer márkával látták el a királyt a neki járó kétharmad címén. ${ }^{1276}$

A nádori rendszer a kezdeti állandó bácsi ispánsággal magában áll: az udvarispáni megyék párosításában semmilyen logika nem fedezhető fel, és II. András korától fogva már a nádor esetében is változott a helyzet. Ennek illusztrálására álljon néhány példa a kezdeti időszakra. II. András első nádora, Miklós, pozíciójában nyitrai, majd gyors váltással újvári ispán volt. Az őt követő, a nádori tisztet immár harmadszorra elnyerő Mog először soproni,

\footnotetext{
${ }^{1273}$ Mindezekre lásd Archont. 1000-1301. passim

${ }^{1274}$ Fügedi 1986. 51.

1275 III. Béla jövedelemjegyzékének hitelességéről már száz éves vita folyik a szakirodalomban. Kezdetben alapvetően hitelesnek fogadták el (némi felülreprezentációt látva benne), majd inkább megbízhatatlannak, manapság ismét affelé hajlik a kutatás, hogy kis túlzásokat leszámítva hitelesnek tekinthető. A kérdés kutatástörténetére lásd Barta-Barta 1993. 413-414.; legújabban Vajda 2013. 148-150. Legutóbb Weisz Boglárka gazdaságtörténész is felhasználhatónak, és néhol eltúlzottnak tekintette számadatait egy 2013. február 19-i elöadásában: http://www.tti.hu/esemenyek/715-beszamolo-weisz-boglarka-eloadasarol-a-tortenettudomanyiintezetben.html (letöltés ideje: 2013. március 11.).

${ }^{1276}$ Béla emlékezete 82. Ez ugyan - a maradék ispáni egyharmaddal számolva - csak megyénként évi 173 márka átlagos jövedelem lenne, ami igen kevés, de jelentős különbségek voltak az egyes megyék között, hiszen éppen ez a jegyzék emeli ki, hogy a királyt évente vendégül látó megyék mindegyike a királynak érkezésekor „legkevesebb száz márka ajándékot ad, de van, aki közülük ezer márkát is” (uo.).
} 
majd bihari ispán is lett egyben. 1207-től az addig csak bácsi ispáni címet viselő Csépán lett a nádor, és együtt kezdte viselni mindkét tisztséget, tehát „magával vitte” megyéjét a nádori hivatalába. Ugyanezt látjuk a leváltásánál: az 1209-től őt követő Pot, addig csak mosoni ispán, nádor és mosoni ispán lett. ${ }^{1277}$ Innentől fogva II. András idején sem a nádori, sem más hivatalhoz nem kapcsolódtak konkrét megyék, ha tendenciákkal lehet is számolni. ${ }^{1278}$ IV. Béla korától aztán újra előfordult az is, hogy több cikluson át ismét egy adott ispánsággal párosították a nádori méltóságot: Hahót nembéli Arnold 1240-től somogyi ispán volt, majd amikor a tatárjárás után, 1242-től nádorrá nevezték ki, néhány hónapos méltóságviselése alatt mindkét címet együtt birtokolta. Eddig nincs is benne semmi különös, ám 1242 őszétől, amikor Kán nembéli László váltotta őt, akkor a nádori méltóság mellé ő is megkapta a somogyi ispánságot (pedig Arnold nem halt meg, és nem sokkal később a soproni ispánsággal vigasztalódhatott). László leváltása után utódja, Türje nembéli Dénes is somogyi ispán lett, ahogy annak utódja, Gutkeled nembéli István is. Pedig egyik leváltott nádor sem halt meg, csak más méltóságokba helyezték át őket, ám utódjuk a nádori cím mellett mindig megkapta Somogy megyét is. ${ }^{1279}$ A megye azonban még István hivatala alatt kikerült a nádori cím égisze alól, és Héder nembéli Henrik kapta meg. Az Istvánt követő nádorok sem maradtak megye nélkül, és innentől kezdve hosszabb ideig Pozsony töltötte be a nádori „honor” szerepét. A címet újra elnyerő Türje nembéli Dénes hivatalviselése után Rátót nembéli Roland a pozsonyi ispáni címét is megörökölte elödjétől. Majd amikor Rolandot más méltóságba helyezte IV. Béla, akkor a helyébe kerülő Héder nembéli Henrik, addigi országbíró és somogyi ispán nem csak föméltóságát, de megyéjét is lecserélte, és ő is pozsonyi ispán lett. ${ }^{1280} \mathrm{Az}$ 1267-től nádori székbe kerülő Kemény fia Lőrinc pedig ismételten somogyi ispán lett. Később az „oligarcha-nádorok” méltóságpárosításában is fel lehet fedezni azt a logikát, hogy a nádori cím mellé legfőképpen a soproni és a somogyi, kisebb részt a pozsonyi és tolnai ispánságokat rendelték, egyebeket csak elvétve. ${ }^{1281}$ Mindez III. András koráig mutatható ki, onnantól kezdve ritkán párosították megyével a nádori hivatalt. ${ }^{1282}$ Bár tagadhatatlan tény,

\footnotetext{
1277 Archont. 1000-1301. 17.

1278 Ezekre lásd Nógrády 1995. 174-178.

${ }^{1279}$ Archont. 1000-1301. 19. és passim

${ }^{1280}$ Archont. 1000-1301. 19-20. és passim

1281 Archont. 1000-1301. 20-25.

${ }^{1282}$ Ez nem azt jelenti, hogy az adott méltóságviselő ne lett volna megyésispán is egyben. Aba Amadé pl. Ung megye örökös ispánja volt, amit soha nem tüntettek fel neki a titulációk során. De ez a cím nem a nádori hivatalához kapcsolódott, hanem örökadomány volt. Hogy Amadé 1299-1300 között Újvár megye mellett a territóriumától igen messze eső Zala vármegye és a Vas megye területén található karakói várispánság ispáni címét is megkapta, annak nyilván aktuálpolitikai okai voltak: a királlyal szembeforduló Kőszegi-família
} 
hogy az 1270-es évektől a somogyi és soproni ispánság viselése sokkal gyakrabban kapcsolódott a nádori címhez, mint bármi máshoz, óvatosnak kell lennünk a tekintetben, hogy kinevezhetjük-e valamiféle „honor-megyének” ezeket. Egyrészt, mivel ekkor (és talán már korábban is) a nádorok egyszerre több megye ispáni címét is viselhették, köztük olyanokét is, amit fel sem tüntettek a titulációk során. 1269-ben pusztán egy ízben a Körös megye területén található kemléki várispánsági cím is felbukkan Kemény fia Lőrinc nádor és somogyi ispán mellett. ${ }^{1283}$ Nem lehetetlen, hogy hivatali ideje alatt mindig is viselte ezt a posztot, csak nem tették ki. Ráadásul az Anjou-kori példákból tudjuk, hogy a honor-megyék többségét az intitulációkban szinte alig tüntették fel. Ezeket az egyéb megyéket, ha voltak ilyenek nagyobb számban egyáltalán, nem tudjuk pontosan beazonosítani, jobb híján meg kell elégednünk azzal, hogy a fent felsorolt vármegyék ispánságát kössük össze a nádori méltósággal. A gyakorlatból látszik, hogy nem volt „kőbe vésve”, hogy egy új nádornak milyen megyét, megyéket kell adni, de ritkán léptek ki egy meghatározott, és nem is túl tágra szabott körből. A főbb méltóságviselők ispáni címmel párosítása nyilván kettős célt szolgált: egyrészt tényleges jövedelemforrást biztosíthatott, ${ }^{1284}$ másrészt - föként a korai időkre nézve nem elhanyagolható szempontként - egyfajta hatalmi tényező is volt. Az ispáni címhez kötődtek olyan elemek is, pl. a megyei katonai csapatok parancsnoka, amelyekkel még az ország főbírái sem rendelkeztek, hiszen sem a nádor, sem az országbíró címéhez nem kötődött külön katonai funkció.

Néhány, sajnos többféleképpen is értelmezhető adat megengedi azt a feltételezést, hogy a nádor az egyes megyék ispáni-jellegü jövedelmén túl másfajta állandó jövedelemben is részesült. Amikor IV. Béla 1238-ban megerősítette a johannita lovagrend számára adott birtokokat és kiváltságokat, az egyik ilyen kiváltság az volt, hogy „bárhol az országunkban senki ne merészelje a mondott rendháztól, jobbágyaitól vagy népeitől a tributum vagyis a disznótizedek királyt, nádort vagy a megyésispánokat illető [részét] beszedni”. ${ }^{1285}$ A tributum kifejezést hagyományosan vámnak szokták fordítani, ám a 13. század első felében többször

gyengítése. Amikor III. András 1300 nyarán kibékült a Kőszegiekkel, Amadé is elvesztette ezen címeit (sőt, vélhetően az egész országra kiterjedő nádori fennhatóságát is).

${ }^{1283}$ Archont. 1000-1301. 161.

${ }^{1284}$ Hogy a megyésispánt milyen jövedelmek illették vármegyéje (és nem csak várispánsága!) jövedelmei után, lásd Weisz 2012. 50-55.

1285 „Item concessimus, quod nullus audeat recipere tributum vel decimas porcorum, regi, palatino et comitibus castrorum debitam a praedicta domo, sive iobagionibus, vel populis eiusdem per universum regnum nostrum" DL 106180. (RA 637. sz.). Fejér György forráskiadása (CD II. 107-108.; CD IV/1. 107.) e helyütt helytelen szöveget hoz, ott „regni palatino” szerepel. Egyrészt paleográfiailag is valószínübb a „regi, palatino” változat, ráadásul a „regni palatinus” kifejezés az 1230-as években még erősen anakronisztikusnak számított, lásd az „1.1 - Az elnevezés" c. alfejezetet. 
említették a disznótizeddel párban, vagy azzal keverten. Weisz Boglárka szerint az ilyen esetekben nem vámot, hanem magát a disznótizedet jelentette. ${ }^{1286}$ Ezt az értelmezést erősíti, hogy itt is „tributum vel decimas porcorum” formában írtak róla, a vel tehát „vagyis” értelemben fordítható. A sertéstizedet azok fizették, akik a vármegye vagy várispánság várához tartozó erdőkben legeltették a disznóikat. ${ }^{1287}$ Bár a sertéstizedet alapvetően királyi adónak tekinthetjük (a megnevezése nem egyszer egyenesen porci regis volt), valamennyi rész biztosan megillette az ispánt is, a szintén királyi adónak tekinthető ${ }^{1288}$ csöböradó analógiája alapján. ${ }^{1289}$ De mit keres ott a nádor neve? Találkozunk máskor is hasonló esettel. Amikor II. András 1225-ben a borsmonostori egyházat kiváltságolta, akkor a király a monostor minden népétől beszedett csöböradót, szabadok dénárjait és nehezéket a monostornak adományozta, hozzátéve, hogy mindezek nem tartoznak senki máshoz, sem a nádorhoz, sem a soproni ispánhoz, csak őhozzá. ${ }^{1290}$ Weisz Boglárka azzal magyarázta a nádor külön kiemelését, hogy az adományozás időpontjában éppen az a Gyula volt a nádor, aki a soproni ispáni méltóságot is betöltötte egyben, így „nem látunk a nádor megjelenésében semmi különöset”. ${ }^{1291}$ Ez tényleg így van, a magyarázat azonban aligha áll meg az 1238. évi példa esetében. Akkor ugyanis Tomaj nembéli Dénes nádor a szolnoki ispánságot viselte, ${ }^{1292}$ és a johannitáknak kiváltságokat adó oklevél részletesen felsorolta a rend teljes akkori birtokállományát szerte az országban, de olyat, amelyet Szolnok megye területére lokalizálhatnánk, egyet sem találunk. ${ }^{1293}$ Könnyen lehet tehát, hogy a nádor titulusa a soproni példa esetében sem azért került az ispán címe mellé, mert akkor a két tisztség ideiglenesen egy kézben összpontosult. Egy másik lehetséges (bár kétségtelen, hogy korántsem biztos) magyarázat megadásában segíthet, hogy 1225-ben II. András oklevele meg is indokolta, hogy

\footnotetext{
${ }^{1286}$ Weisz 2012. 54-55.

${ }^{1287}$ Weisz 2012. 54.

1288 Ebben a kérdésben egyébként nem egységes a szakirodalom, az ellentétes véleményekre lásd pl. Solymosi 1998. 153-154.; Weisz 2012. 52-54.

${ }^{1289}$ A csöböradó elviekben kizárólag a királyt illette, és „csak a várföldeken - és nem a megye egész területén szedett csöbrök harmada járt az ispánnak" (Weisz 2012. 54.). A várbirtokok után szedett jövedelemből tehát még egy királyi adó esetében is részesült a várispán (vagy megyésispán). Mivel a disznótizedet a várföldekhez tartozó erdők használatáért kellett fizetni, ezért feltételezhetjük, hogy ebből is járt az egyharmad rész az ispánnak.

1290 „Dedimus igitur ipsis libertinos denarios, qui vulgo fumarii vocantur, et pondera, et omnes cybriones ab omni populo eorum tam de iobagionibus quam hospitibus ubique demorantibus cuiuscumque conditionis sint, ad nullam enim pertinent nec ad palatinum nec ad comitem de Supprun nisi ad nos, quoniam possessiones eorum libere semper fuerunt” UB I. 107. (RA 420. sz.)

${ }^{1291}$ Weisz 2012. 53.

1292 Archont 1000-1301. 19.

${ }^{1293}$ CD IV/1. 104-111. Az azonosításokat jelentősen megkönnyíti (és biztosabbá teszi), hogy az oklevél szövege többnyire megnevezte a megyét is a birtoknév mellett. A rend egyébként ebben az időben föként a nyugati országrészben terjeszkedett, lásd Hunyadi 2010. 37-38.
} 
a csöböradó és a többi járulék miért nem tartozik sem a nádorhoz, sem a megyésispánhoz, csak a királyhoz: „quoniam possessiones eorum libere semper fuerunt”, „mivel az ő [ti. a monostor] birtokai mindig is szabadok voltak". ${ }^{1294}$ Fentebb már esett róla szó, hogy a várföldeken szedett csöböradó harmadrésze megillette az ispánt, csak a nem várhoz tartozó részek jártak teljes egészében a királynak. Erre utalhatott II. András itt is: mivel a monostor birtokai nem a várispánsághoz tartoztak (tehát „szabadok voltak”), ezért az ott szedett csöböradóból nem jár rész az ispánnak... és a nádornak sem. Ugyanezt látjuk az 1238. évi johannitáknak adott disznótized-mentesség kapcsán. Azt a várföldek erdejének használata után szedték, és ott viszont megemlítették a király mellett a nádor és a megyésispán részét. Ha arra akarunk választ adni, hogy az ispán mellett a nádornak milyen jogon járt volna valamennyi hányad a várszervezet birtokállományához kötődő adókból, akkor leginkább a nádor udvarnokok feletti fennhatóságára kell gondolnunk. Mint az udvarnokok feletti joghatóságot tárgyaló fejezetben láttuk, a kapcsolat a 13. század első felében még élénken élt (1221-ben Barc fia Miklós nádor egyenesen a saját hivatala alá tartozónak mondta az udvarnokok földjeiről szóló intézkedéseket!). ${ }^{1295}$ A század második felében még kimutatható kapcsolat a 14. századra aztán teljesen elhalt. Sajnos a kérdésben ennél biztosabbat magunk sem tudunk mondani, de feltételezhetjük, hogy valamennyi jövedelem az ispánhoz hasonlóan hivatali jogon megillette a nádort is a megyei udvarnokföldekből származó jövedelmekből. Ez esetben érdekes kérdés lenne, hogy ez a nádori rész melyik fél hányadából volt „lecsípve”: a királyi kétharmadból, vagy az ispáni egyharmadból (gyaníthatóan az utóbbiból, bár erre végképp nincs semmi forrás). Mivel az erre vonatkozó adatok a 13. század első feléből bukkannak fel, az „utazó nádorok” időszakában, ezért azt is feltételezhetjük, hogy a megyébe érkező nádor és kísérete talán „ebből élt” (ahogyan az „utazó király” és udvara a megye jövedelmeit élte fel). A tatárjárás után, a „lokális nádorság” megjelenésével pedig el is halt ez a jövedelemforrás. Tény, hogy ez a gondolatmenet csak hipotézis, ám a fenti adatok hézagmentesen illeszkednek bele, míg a „hagyományos”, a nádor részesedésével nem számoló modell nem magyarázza az 1238. évi adatot. ${ }^{1296}$

Egy hamis oklevélben egy másik, nádort illető jövedelemről is írtak. A pécsi egyházmegye kiváltságait tartalmazó híres oklevélről van szó, amelybe belefoglalták Szent

\footnotetext{
${ }^{1294}$ UB I. 107.

${ }^{1295}$ Lásd a „7.1 - Az udvarnokok feletti joghatóság” c. alfejezetet.

${ }^{1296}$ Hacsak nem nyilvánítjuk az 1238. évi oklevelet hamisnak, mert „,zavaró részek” találhatóak benne, lásd az RA 637. sz. reg. kommentárját, ám Szentpétery Imre szerint ez még nem ok arra, hogy hamisnak tekintsük a diplomát. A johannita rend hazai történetét a 14. századig feldolgozó Hunyadi Zsolt is hitelesként kezelte az oklevelet: Hunyadi 2010. 37., 171.
} 
István 1009. évi (részben eredeti) és Radó 1057. évi (hamis vagy interpolált) oklevelét is. ${ }^{1297}$ Ebben, többek között, III. Béla állítólag olyan kiváltságot adott volna az egyházmegyének, hogy ,,az egyházak tizedéből sem a nádorispánt nem illeti meg a húszad-, sem a megyésispánt a századrész" ${ }^{1298}$ Az oklevélbe foglalt egyéb kiváltságok (pl. a nádori generalis congregatio püspöki engedély nélküli tilalmazása) igen anakronisztikusak, és legalább egy szük évszázaddal későbbre helyezik a hamisítás időpontját, ${ }^{1299}$ ám gondolni lehet arra, hogy ha a fentieket tilalmazták, akkor valamikor talán tényleg létezett a nádornak járó dézsmahúszad különben nem lett volna értelme egy hamis kiváltságlevélbe belefoglalni. Arra is találunk Árpád-kori példát, hogy Héder nembéli Miklós nádor egy 1275-1276 körüli levelében a Sopron megyei dézsmahúszadot (vicesimam decimarum in comitatu Supruniensi provenientem) a szentmáriahegyi (borsmonostori) cisztercita barátoknak engedte át. ${ }^{1300} \mathrm{Az}$ oklevélből - és a történelmi háttérből - azonban kiderül, hogy Miklós itt nem a neki mint nádornak járó dézsmahúszadról intézkedett, hanem megerősítette V. István és IV. László korábbi adományait. A királyok a nekik járó ${ }^{1301}$ Sopron megyei húszadról mondtak le az adományaikban a monostor javára, és ezt Miklós soproni ispáni minőségében erősítette meg, intve szolgálattevőit, hogy ne szedjék be a monostornak járó részt. ${ }^{1302}$ Ebben az esetben tehát biztosan nem a nádornak járó dézsmahúszadról esett szó. Mályusz Elemér úgy értelmezte a pécsi kiváltságot, hogy az egyházi tized begyüjtésekor az egyház az államhatalom segítségét kérte, és ezért nekik is juttatott a tizedből valamennyit: a tizedek „huszada ... a királyt és a nádort illette meg, századrésze pedig a megyés ispánt”. ${ }^{1303}$ Tegyük hozzá: Mályusz a mondott arányra (és általában a nádornak juttatott részre) forrásként egyedül az általa is hangsúlyozottan hamisnak nyilvánított pécsi oklevelet hozta fel, más 13-14. századi forrást, amiben szó esne a nádori részről, ő sem talált. ${ }^{1304}$ A tized beszedésekor a megyésispán (pontosabban annak egy embere) részvételéröl III. András 1291. évi törvénye is

\footnotetext{
${ }^{1297}$ Az oklevél hamis voltára rámutatott: Pauler 1899. II. 590-592. Az okleveles szöveghagyományt legutóbb Kiss Gergely foglalta össze: Kiss 2009. 43.

1298 „Item nec comes palatinus viceasimam [!], nec comes parochialis centesimam in decimis ecclesiarum omnium habere debeat” Elenchus III/2. 17. (vö. CD II. 256. ill. CD III/2. 427-428.)

1299 Pauler Gyula szerint I. Károly uralkodásának legvégén keletkezett, és László pécsi püspök az „értelmi szerzője": Pauler 1899. II. 593.

${ }^{1300}$ Sopron I. 51. (RP 177. sz.)

${ }^{1301}$ A királyt az egyházi tized húszadrésze illette meg: Holub 1929. 392-393.

1302 A borsmonostori dézsmahúszad-adományt részletesen elemzi: Szentpétery 1916. 101-104. lásd még RA 1983., 1990., 2302., 2306-2307. sz. reg.

${ }^{1303}$ Mályusz 1953. 323.

${ }^{1304}$ Mályusz 1953. 323. 19. jz. vö. uo. 321.
} 
megemlékezett, ám a nádort ott sem említették ilyen összefüggésben. ${ }^{1305}$ Elviekben nem kizárható, hogy a 14. században az ispán mellett a nádor segítségét is igénybe vették a tized beszedésekor (pl. ha a megyei hatóságnak ellenszegült valaki, és felsőbb fórummal kellett nyomatékosítani), de ha ez így is volt, ez a ,jövedelem”, amellett, hogy jóformán alig bizonyítható, erősen alkalminak is számított.

Szólni kell azonban egy olyan forrásról, amely minden bírói intézményhez, így a nádorihoz is kötődött, ez pedig nem más, mint hogy a szokásjog szerint a mindenkori bírónak valamennyi illetmény járt az ítélkezésért cserébe. Ez a 13. századra már úgy állandósult, hogy a pervesztes fél büntetésül elkobzott javainak a kétharmad része a bíró tulajdonába ment át, az egyharmad rész pedig a pernyertes félé volt. ${ }^{1306}$ Péc nb. Dénes 1273 . évi oklevele ezt úgy fogalmazta meg, hogy ,az ország szokásjoga szerint az ... elítélendőknek, sőt a már elítélteknek a javai és birtokai a nádorság kezére kell hogy jussanak". ${ }^{1307}$ Ha az illetőt hamis vádaskodásban találták bünösnek, akár még a teljes birtokállományát is elkobozhatták (egy 1268. évi megfogalmazás szerint: ,a bizonyítottan hamisan vádaskodók birtokainak és javainak az ország szokásjoga szerint a bíró és a másik fél kezére kell jutniuk”). ${ }^{1308}$ Csak a bíró jóindulatán múlott, hogy meghagyott-e valamennyit a régi tulajdonos vagy örökösei kezén. ${ }^{1309}$ Ezeket az ingatlanokat többnyire nem tartotta meg a nádor, hanem túladott rajtuk. Szintén a szokásjog szabályozta azt, hogy elöször a távolabbi rokonságnak kellett a földet felkínálni eladásra, utána a szomszédságnak. Ha senki közülük nem érdeklődött (vagy nem volt elég pénzük), akkor bárkinek eladhatta a földet. ${ }^{1310}$ Még arra is találunk példát, hogy a

\footnotetext{
${ }^{1305}$ DRMH I/1. 46.

${ }^{1306}$ Erre az egész, általunk elemzett korszakon végighúzódó arányra lásd pl. 1239: ÁÚO VII. 78.; 1268: CD VII/5. 352-353.; 1288: ÁÚO IX. 481. (RP 64., 143., 240-241. sz.); 1333: AOkl XVII. 241. sz.; 1342: AOkl XXVI. 434. sz.

1307 „condempnandorum, ymo condempnatorum res et possessiones iuxta regni cosuetudinem ad manus palatinatus debeant devolvi” ÁÚO IX. 39. (RP 162. sz.)

1308 ,possessiones et bona in calumnia convictorum in manus iudicis et partis adversae devolvi debent de regni consuetudine approbata" CD VII/5. 352-353. (RP 143. sz.)

${ }^{1309}$ A fenti, 1268. évi példában (RP 143. sz.) Lőrinc nádor semmit nem hagyott meg, és a pervesztes család teljes birtokállományának a 2/3 részébe beiktatták a nádort. Más esetben bizonyos földeket (ahogy írta: könyörületből) meghagyott a pervesztes kiskorú fiának (de nem magának az elmarasztaltnak) a kezén: ÁÚO IX. 481-482. (RP 241. sz.)

1310 Nádori oklevelek esetében ezt az eladási sorrendet szabályozó szokásjog legkorábbi ismert felbukkanása 1234-ből ismert (DL 95539., kiadása: RP 36. sz.). További esetek a bírói tevékenységből eredő birtokszerzésre: 1227: ÁÚO VI. 445-447., 1244: Szovák 1996. 456-457., 1268: CD VII/5. 349-353., HOkl 53-55., 1273: ÁÚO IX. 38-40., 1288: ÁÚO IX. 481-482., 1298: ÁÚO XII. 653-654., 1299: HO VIII. 397-398., 1300: HO VII. 290-291. (RP 29., 68., 143., 144., 162., 241., 287., 304., 309. sz.); 1308: AOkl II. 344. sz.; 1324: AOk1 VIII. 379., 424. sz.; 1325: AOkl IX. 117., 183. sz.; 1327: AOkl XI. 160., 223. sz.; 1329: AOkl XIV. 64. sz.; 1331: AOkl XV. 375. sz.; 1333: AOkl XVII. 239-241., 309. sz.; 1337: AOkl XXI. 628. sz.; 1342: AOkl XXVI. 364., 434. sz.
} 
pénzzel ügyesen bánó Ampod fia Dénes (II. András gazdasági rendszerének biztos támasza) a kezére jutott földet bérbe adta addig, amíg az elítélt rokonai meg nem vásárolták tőle, hogy a köztes idő alatt is készpénzt fialjon. ${ }^{1311}$ Nem csak a földet, de egy halálra ítélt ember életét is meg lehetett váltani birtokban vagy pénzen, amely az ismert arányok szerint szintén a nádor vagyonát gyarapította. ${ }^{1312}$ Bár már nincs rá konkrét utalás az ítéletlevelekben, de a bírót minden ítélet után megillette valamennyi eljárási díj, sőt, ha csak egy olyan közös megegyezést szentesített, ahol jogilag nem is volt vesztes fél, akkor is ki kellett fizetni az ún. békebírságot. Ilyen esetekben az is a megegyezés részét képezte, hogy a bíró (és adott esetben a poroszló) díját milyen arányban állják a felek. Már a Váradi Regesztrum is rendszeresen kitért arra, hogy megegyezés esetén a bírót és a poroszlót ki fizette ki, ${ }^{1313}$ de későbbről is találunk a békebírság fizetésére példát. ${ }^{1314}$

Emellett nem csak a perek vagy megegyezések lezárásakor, de közben is kiszabhattak bírságokat valamelyik félre, pl. meg nem jelenés miatt. A bírságon is a szokásos 1/3-2/3-ad arányban osztozott a nádor és a másik fél. Druget Fülöp idejéből van arra halvány adatunk, hogy ha a bírságot nem maga a nádor, hanem vizsolyi albírája, Perényi Miklós szabta ki, akkor a nádori rész egy hányada az albírót is megillette. ${ }^{1315}$ A bírságokat kezdetben a poroszló vagy a nádor egyéb embere hajtotta be, esetleg a megyésispán segítségével. ${ }^{1316}$

Druget Fülöptől találkozunk azzal a módszerrel, hogy a nádor embere mellé adott hiteleshelyi tanúbizonysággal, a megye 4 szolgabírójának a jelenlétében szedték be a járandóságot. ${ }^{1317}$ Bár az ilyesfajta hatóság éppen a komolyabb visszaélések elkerülését célozta, Perényi Miklós albíró 1323. évi okleveléből kiderül, hogy még így sem zajlott békésen egy ilyen esemény. Történt ugyanis, hogy Tamás fia Loránd panaszt tett Miklós albíró előtt, hogy az albíró a Szabolcs megyei Lidér (ma: Baktalórándháza) falvát ok nélkül lerontatta (destrui fecissemus sine culpa). Az albíró azzal védekezett, hogy őt a megyei 4 szolgabíró úgy tájékoztatta, hogy a falu azé a Syuge fia Lászlóé, aki elmaradt a neki járó bírság fizetésével (qui nobis in iudicio remanserat), és a megyei szolgabírák ezt a falut jelölték meg behajtásra (et ipsi quatuor iudices nobilium provincie de Zobolch in eadem villa

\footnotetext{
1311 ÁÚO VI. 445-447. (RP 29. sz.)

1312 Pl. 1314: AOkl III. 793-794. sz.; 1322: AOkl VI. 416. sz.; 1323: AOkl VII. 485. sz.

${ }^{1313}$ RV 89. sz., 189. sz., 244. sz., stb.

1314 Pl. 1279: ÁÚO IV. 203. (RP 202. sz.); 1325: AOkl IX. 20., 392. sz.; 1326: AOkl X. 428., 498. sz.; 1335:

AOkl XIX. 352., 590., 689. sz.

1315 Az erre utaló adatok: AOkl IX. 522., 558. sz.

${ }^{1316}$ Lásd Gerics 1969. 627. (vö. UB I. 236-237., RP 116. sz.)

1317 AOkl VII. 63. sz.; AOkl X. 201. sz.; AOkl XVII. 159. sz.
} 
reciperare assignarunt). ${ }^{1318}$ Jól érzékelteti, hogy milyen stílusban zajlott az elmaradt bírság természetbeni beszedése, ha az igazi tulajdonos, Loránd panaszát a destruo (lerombol, elpusztít) igével tolmácsolta a nádori írnok. Druget János korától találkozunk először néven is nevezett nádori bírságszedővel. Úgy tünik, hogy a bírságszedők is a nádor környezetéből kerültek ki, János legalábbis a serviensének nevezte egyiküket, és megbízásuk egy konkrét megyére (esetleg annak a környezetére) szólt. ${ }^{1319}$ Hogy a bírságszedőnek „civilben” mi volt a kapcsolata az adott megyével, nem teljesen egyértelmü. Marcell fia Gergely 1333-ban még Gömör megyei behajtó volt, 1339-től viszont már Szabolcs megyeinek címezték. Könnyen lehet, hogy azonos azzal a Marcell fia Gergellyel, aki 1337-ben a budai nádori kúria elött Zsadány (Sadan) földet átadta Tekus fia István fiainak. ${ }^{1320}$ A föld talán a Zemplén megyei, későbbi Sárazsadánnyal azonosítható, amely területileg nem esett nagyon messze hivatali müködési területétől. A bírságszedők munkáját regisztrumok segítették, amelybe gondosan bejegyezték, hogy ki mennyivel tartozik. A Drugetek alatt utalnak elöször adatok a bírságkönyvre, ${ }^{1321}$ és annak jellegét segíti elképzelni a leleszi konvent 1337 . évi oklevele, amely szerint a Szatmár megyei azévi bírságok mind abba voltak bevezetve, a faluhelyet is tartalmazó név mellett az összegek feltüntetésével. ${ }^{1322}$

Nyilván volt valamennyi (általunk sajnos nem ismert) díja az oklevelek kiállításának is. A megyékbe kimozduló, közgyüléseket tartó nádort emellett megillette a megszállás joga (descensus), vagyis a megyei nemesek voltak kötelesek őt és kíséretét ellátni. 1330-ban Valkó megye magyarázkodott Druget János nádornak, hogy a körükbe érkező nádor élelmezésére összegyüjtött 60 márkát még nem adták át teljes összegben neki, mivel egyes helyi nemesek még nem fizettek. ${ }^{1323}$ Ebből az esetből az is kitetszik, hogy a nádor „élelmezésére” (pro

\footnotetext{
${ }^{1318}$ DL 96098. (AOkl VII. 63. sz.)

1319 Druget János Antal nevü serviense az összes Újvár, Gömör, Borsod, Zemplén, Ung, Bereg és Ugocsa megyéknek tartott közgyülésén kiszabott valamennyi bírság behajtására kapott megbízást 1330-ban: AOkl XIV. 171. sz. Marcell fia Gergelyt a nádor Gömör megyei bírságbehajtójaként említették 1333-ban (AOkl XVII. 129. sz.). Ugyancsak 1333-ban csataji Márk is a nádor bírságbehajtójának nevezte magát, és Csanád megyében járt el. 1337-ben és 1339-ben Marcell fia Gergelyt már Szabolcs megyei bírságszedőnek címezték, ám egy alkalommal Szatmár megyében is eljárt (AOkl XXI. 180., 325., 329., 439. sz.; AOkl XXIII. 153. sz.) - innen sejthetjük, hogy esetleg nem minden megyének volt saját bírságszedője, hanem a szomszédos megyékben is tevékenykedhettek. Jakab albíró 1337-ben Vilmos nádor Sáros megyei bírságszedőihez címzett oklevelet (név nélkül): AOkl XXI. 189. sz. 1339-ből ismerjük még a Szepes megyében tevékenykedő Kázmért, és a Zala megyében eljáró Lukácsot (AOkl XXIII. 295., 486. sz.). 1341-ben már Dama mester volt a Zala megyei bírságszedő, és az ő oklevelében már csak volt behajtóként említették Lukácsot (AOkl XXV. 586. sz.). Csanád megyére (esetleg környékére) terjedt ki fennhatósága 1341-ben Vörös Domonkosnak: AOkl XXV. 815. sz.

${ }^{1320}$ AOkl XXI. 475. sz.

1321 1333: AOkl XVII. 240-241. sz.; 1337: AOkl XXI. 325., 439.; 1339: AOkl XXIII. 151. sz.

1322 AOkl XXI. 439. sz.

${ }^{1323}$ AOkl XIV. 370., 381. sz.
} 
victibus) ${ }^{1324}$ fordított összeg ekkor már egyszerü készpénzadó volt. Egy évvel később, 1331ben a soproni polgárok panaszkodtak arról, hogy a soproni ispán és a megye szolgabírái és nemesei a nádornak fizetendő különféle költségekre, úgymint élelem és adó fizetésére kényszerítik őket (pro expensis seu sumptibus et victualibus ac diversis exactionibus seu collectis ipsi palatino faciendis, et aliis dandis seu solvendis sibi eosdem contribui cogerent). A király ezért kivette Sopront - ahogy más városait is - a nádori bíráskodás alól, és felmentette őket azon költségektől, amit a megye nemességének fizetnie kell. ${ }^{1325}$ I. Károly Sopron megyéhez is címzett egy ugyanilyen tartalmú parancslevelet. ${ }^{1326}$ Ezek a költségek, amelyet mindkét forrás egybehangzó állítása szerint a megye tisztikara hajtott be a nemesektől (és jogtalanul a városiaktól is) csak akkor illették meg a nádort, ha az adott megyébe érkezett, tehát nem minősíthető állandó jövedelemnek.

A forrásadatok sajnos nem teszik lehetővé, hogy bemutassuk, egy-egy nádor birtok- és vagyongyarapodása mennyiben köszönhető hivatalának, és mennyiben tartományúri mibenlétének, de biztosak lehetünk abban, hogy nádornak lenni nem csak hatalmi presztízst jelentett, hanem anyagilag is „kifizetődő” volt.

\footnotetext{
${ }^{1324}$ DL 91248. (AOkl XIV. 381. sz.)

${ }^{1325}$ Házi I. 59-60. (AOkl XV. 348. sz.)

${ }^{1326}$ AOkl XV. 349. sz.
} 


\section{FÜGGELÉK: KIEGÉSZÍTÉS AZ ÁRPÁD-KORI NÁDOROK ÉS HELYETTESEIK KRITIKAI JEGYZÉKÉHEZ}

A jelen disszertáció forrásbázisának szánt, majd önálló kötetként is megjelent „Az Árpádkori nádorok és helyetteseik kritikai jegyzéke" (RP) c. munkából sajnálatos módon kimaradt néhány nádori oklevél. Ezeket az alábbiakban pótoljuk, a „kritikai jegyzék” formáját és rövidítési rendszerét követve. Az egyes regesztákat viszont számok helyett betűjelekkel jelöltük.

(1255.) febr. 15. -

Regede

Rátót nb. Domonkos fia Roland és [Türje nb.? Péc nb.?] Dénes szolnoki ispán (Damus pro memoria): a király színe előtt per támadt egyik részről Belud comes fia: Belud, másik részről Osl comes fiai, ti. Herbord, János fia: Tamás és ifjabb Osl fiai között a megboldogult Osl fia: Miklós bármely - úgy saját, mint mások - jogán bírt birtokrészei ügyében, ti. Csáva (Chawa) falu felerésze, Aranaz, Bezernuk, Csorna (Chorna) és Széplak (Zeplak) falvakban bírt része kapcsán. A király az oklevél kibocsátójára és Dénes szolnoki ispánra (Dionisio comiti de Zavnuk) bízta az ügyet végső döntés céljából, akik elrendelték a feleknek, hogy az összes fent nevezett - úgy vásárolt mint öröklött - birtokot Péter fia: Péter, Görgy és Ábrahám comes közbenjárásával osszák öt részre, és az öt ember, ahogy az ő része megkívánja, kapjon egyet-egyet. Azt is elrendelték, hogy Miklós széplaki tornyát (turris ... in Zeplak) szintén osszák öt részre, és egyvalaki az öt emberből, akinek az első rész jut (cui prima pars se optulatur) köteles a torony másik négy részét saját jogába megvenni méltányos, a mondott értékbecslők közbenjárásával felbecsült áron. Továbbá megszabták, hogy a felosztásnak böjtközépig meg kell történnie, és ugyanekkor, ha Herbort comes leteszi az esküt Széplak falu egyházában a mondott felosztást felügyelők színe előtt arról, hogy a 15 márkát megfizette a birtokok igénylése kapcsán, továbbá ha ezt nem kaphatja teljesen vissza ugyanezen birtokok jövedelméből, akkor Osl comes fiai és unokái a közösből kötelesek visszaadni neki. És - ha esküszik - a megfizetés napját jelölje meg Herbortnak ugyanezen három felügyelö, ti. Péter, György és Ábrahám, és addig Herbort várjon Csáva faluban, amíg a fivérei őt teljesen ki nem fizetik. Böjtközép nyolcadán pedig a felek térjenek vissza a színük elé, és mutassák be a mondott három felügyelő oklevelét a történtek lefolyásáról. Datum in Rudugvey, in quindena purificationis gloriose virginis Marie.

Eredeti: 15,7 X 9,5 cm, hártyaszalagoknak való bevágásokkal, hátulján két rányomott pecsét foltja - DL 24444. (Kincstári levéltárból, MKA, Neo-regestrata acta 50. 47.)

Kiadása: Sopron I. 22-23.; UB I. 240-241.

Az oklevél kiadási évét Hans Wagner a burgenlandi okmánytár kiadásában 1255-ben határozta meg a kelethely Magyarországhoz kerülése (1254 tavasza) és Dénes szolnoki ispán felbukkanása alapján, aki oklevelekben 1254 októberében tűnik föl utoljára, ezért szerinte 1255 februárja a legvalószínúbb (UB I. 240.). A szolnoki ispán, Türje nb. Dénes fia Dénes tényleg 1255 folyamán halt meg (PRT 
VIII. 293.), ám őt Péc nb. György fia Dénes követte, és nem egyértelmű, hogy itt kiről van szó. Az oklevélen két pecsét foltja is kivehető halványan, az egyik átméröje kb. $55 \mathrm{~mm}$, ami megegyezik Roland nádor pecsétméretével. A másik pecsétfolt méretei sokkal elmosódottabbak, de egyértelmúen kisebb, kb. 46-47 mm-es pecsétátmérőre emlékeztetnek. Türje nb. Dénes pesétnyomóját sajnos nem ismerjük, Péc nb. Dénesét sem szolnoki ispán korából, ám már nádorként, 1273-ban kiadott oklevelén megtalálható pecsétje, ami kb. $60 \mathrm{~mm}$ átmérőjú (DL 845., RP 162. sz.). Ez tehát biztosan nem lehet azonos az itteni oklevélre nyomott pecséttel, ugyanakkor nem lehetetlen, hogy Dénesnek időközben változott a pecsétnyomója, mint arra más esetben is láthattunk példát (pl. Aba Amadé 1293 körül cserélte le pecsétnyomóját, lásd RP 238. sz. reg. kommentárja). Így talán Türje nb. Dénessel való azonosításnak van nagyobb esélye (ez esetben az oklevél kelte valóban csak 1255 lehet). Kérdés továbbá, hogy a másik kibocsátó valóban Roland nádorral azonosítható-e, mint azt Szovák Kornél is vélte (Szovák 1989. 303.), és ez mennyiben befolyásolja a keltezést. A pecsétméret egyezik, és Roland egy 1255. február 9-i oklevelének (amelynek széle le van tépve, és a kelthely sajnos pont nem látszik) írásképe erősen emlékeztet az itteni "damus pro memoria"-ra (DF 209105., RP 99. sz.). 1255. máj. 13-án Roland szintén Regede mellett tartózkodott (UB I. 243-244., RP 102. sz.), és a köztes időpontban, 1255. márc. 11-én a délvidéki Vaskán, a király környezetében (PRT II. 293., RP 100. sz.). A pecsét és az írásképek egyezősége, továbbá Türje nb. Dénessel kapcsolatban mondottak alapján tehát a legvalószínűbb, hogy az egyik kibocsátó tényleg Roland nádor, és az oklevél kiadási éve 1255.

(1267-1268.) júl. 25. - Bereg
Balog nb. Tombold fia Benedek oklevele arról a megegyezésről, amely Buken fiai és Simon között jött létre három ember elhurcolása ügyében, és amely értelmében Simon a megadott két határnapra 13 márkát fizet Buken fiainak, cserébe megtarthatja az elhurcolt három embert.

Eredeti: 13,4 X 7,3 cm, hártyaszalagoknak való bevágásokkal, hátulján zárópecsét foltja - DL 63602. (Családi levéltárak, Dobos család 1.)

Az oklevél szövege:

Nos Benedictus iudex curie domini regis Stephani, comes Bachiensis et de Scybinio damus pro memoria, quod cum duellum Buhtha, Miko et Zepcha filii Buken contra Symonem filium Thobie super tribus capitibus hominum, videlicet Meach, Odulhoych et Ola, quas receptas ${ }^{a}$ manu violenta $^{\mathrm{b}}$ ab ipsis per eundem Symonem asserebant, habuissent coram nobis, adveniente termino duelli mediantibus et componentibus regni et consentientibus partibus talis compositio intervenit, quod idem Symun eisdem fratribus pro tribus capitibus hominum predictis coram capitulo Agriensi in duobus terminis solvere tenetur tredecim marcas, videlicet in festo nativitatis beatissime virginis Marie solvet sex marcas et dimidiam in estimatione, qui si diem solutionis omiserit, iudicio in crastino soluturus. Item residuas sex marcas et dimidiam solvet eisdem in die sancti Martini proximo ventura in argento decime combustionis. Qui si diem solutionis, id quod primo solvat amittus, facta autem solutione predicta tertia capita hominum ipsi Symoni remanebunt perpetualiter possidenda. Ceterum iudicium Symun, et pristaldum fratres predicti placare tenentur. Datum in Bereg, in die sancti Jacobi apostoli.

\footnotetext{
${ }^{a}$ sor fölé beszúrva ${ }^{b}$ a szövegben: violenti
} 
Az oklevélen nem szerepel Benedek nádori címe, de az itt feltüntetett ispánságok alapján (bácsi, szebeni) biztosak lehetünk abban, hogy már viselte ezt a titulust. Ezeket az ispánságokat ui. elődjétől, az István ifjabb királyhoz hűtlenné vált Csák nb. Domonkostól örökölte (vö. Zsoldos 2007. 96., 144. jz.), annak nádori méltóságával együtt. Archontológiailag az 1269. év talán kizárható, mert 1268 végén, 1269-ben Benedek többször is szerepel kizárólag szepesi ispánként, a bácsi ispánságot nem feltüntetve (RP 145., 154. sz., vö. Archont. 1000-1301. 289. és passim). Nem lehetetlen, hogy ekkor már megvált ettől a megyétől, hiszen a régió, amiben mozgott amúgy is az ország északi fele volt. Az 1267. évre vonatkozóan viszont nincs semmilyen adatunk Benedek ispáni címeiről, és - bár 1267 nyarán volt egy fegyveres készülődés IV. Béla részéről, amely végül nem torkollott összecsapásba - köztörténeti adatok sem zárják ki ez év nyarát. Így az oklevél keltét 1267 vagy 1268-ban határozhatjuk meg.

- (B. palatinus, iudex curie) István ifjabb királyhoz (Excellentissimo domino suo St[ephano] Dei gratia iuniori regi Ungarie, duci Transsilvano, domino Cumanorum): jelenti a királyának, hogy kiment Pest megyébe a gonosztevők kihírdetésére és a tulajdonosaitól jogtalanul elidegenített földek számbavételére (in comitatu Pestiensi ad indicandos malefactores et cognoscendas causas terrarum indebite alienatarum a suis possessoribus), és ekkor tudomására jutott, hogy az öröklött, vásárolt és adomány útján elnyert Oszlár föld (terra Ozlar ... tam hereditaria, emptitia, quam et donativa) Kristóf, Péter és péteri (de Patery) rokonságának a tulajdona, és jelenleg István húga: Margit apáca (karissima soror vestra domina Margareta) birtokolja. Mivel a földet a mondott úrnő bírja, így a nádor nem merte visszaadni a mondott tulajdonosoknak, hanem a király akaratára bízta rá, hogy az ő ítélete döntsön erről.

Eredeti: 16,9 X 6,1 cm, hártyaszalagnak való bevágásokkal, hátulján zárópecsét foltja - DL 577. (Kincstári levéltárból, MKA, Acta ecclesiastica ordinum et monialium Vbuda 31. 6.)

Kiadása: ÁúO VIII. 276.

Regesztája: Bártfai Szabó 1938. 44. sz.; Bakács 1982. 93. sz.

Az oklevél hátulján ugyanazon kézírással: „Domino suo benefactori regi Stephano". A kiadásban a 2. sorban a prelatus helyett: palatinus; alulról a 2. sorban mandem helyett mandemus. Az oklevél keltét a regeszták 1259 utánra és 1264 körülre helyezték, amely archontológiai okokból nem lehetséges. Zsoldos Attila 1268-ra keltezte (Zsoldos 2005. 139.), vélhetően az alapján, hogy Benedek egy másik jelzett oklevele (ÁÚO VIII. 211-212., RP 145. sz.) is ekkor kelt. Bár Benedek már 1266 legvégén megkapta a nádori és országbírói címet, és egészen 1269-ig (de valószínúleg 1270 tavaszáig) meg is maradt ezen tisztségekben (Archont. 1000-1301. 26.), az 1268. évre utal néhány más jelenség is. Egyrészt ekkor volt egy másik ítélkező fórum is Pest megyében István ifjabb király parancsára 1268 októberében (HOkl. 53-55., RP 144. sz.). Ez nem volt azonos Benedek itteni külön megbízásával, de úgy tünik, ekkor kezdődtek az ilyesfajta, külön megbízás alapján zajló ítélkezések. Másrészt az idősebb király országrészében ugyancsak számos hasonló birtokfelülvizsgálat indult meg 1268 folyamán. Ennek kiváltó oka az 1267. évi törvény volt, amelynek 5. cikkelye elrendelte, hogy „a nemesek földjeit, melyeket a mi vagy a királynéasszony szabad falvainak a népei, avagy az udvarnokok, vagy pedig a várnépek bármilyen ürüggyel elfoglaltak vagy elfoglalva tartanak, e nemeseknek vissza 
kell adni" (DRMH 1/1. 42. Magyarul: Szöveggyưijtemény 279.). Az első bizottságok külön királyi megbízás alapján 1268-ban álltak föl, és több nyugatmagyarországi megyében is megkezdték a nemesektől elfoglalt birtokok visszaadását (részletesen adatolva: Szűcs 1984. 376-378.). Arról ugyan nem tudunk, hogy ezek a felülvizsgálatok az ifjabb király országrészében is megindultak, sőt, a jelek éppen arra utalnak, hogy az 1267. évi törvényt csak István nevében, de nem részvételével adták ki (soha nem lógott rajta a pecsétje, és valószínúleg nem is volt jelen a kiadásakor, ráadásul a cikkelyben említett „királynéasszony” biztosan IV. Béla feleségére vonatkozik, lásd minderről Zsoldos 2007. 104-108.). Ám nem lehetetlen, hogy néhány, a serviensek számára "népszerü" intézkedést ő is átvett apjától, hiszen ha katonai értelemben 1267 után már nem is lett köztük ellentét, egyfajta politikai „verseny” végig fennállt a két országrész között. Ez a gondolatmenet ugyanakkor nem ad biztos támpontot az 1268. évre nézve, és az oklevelet tartalma alapján sem lehet másképpen leszűkíteni. Oszlár (lásd ÁMTF IV. 535.) ügyében még IV. Béla 1259. évi adományával kezdődött az ellentét, amellyel többek között ezt a földet is az épülő szigeti apácakolostornak adta adományul, és ezt István ifjabb király is megerősítette 1264-ben (RA 1225., 1826. sz.). Benedek nádor ezen oklevelében is jelezte a problémát, és a per egy újabb állomásával találkozunk egy szintén keltezetlen Damus pro memoria oklevélben, amelyet Budán, a hadoszlás 22. napjának ötödnapján (quinto die post vicesimum secundum diem residentie exercitus) állítottak ki (DL 603., kiadása: ÁÚO XII. 676.). Az oklevél kiállítója ebben előadja, hogy azt a pert, amit Kristóf, Péter és péteri rokonságuk folytat Oszlár birtok kapcsán a Szűz Mária szigeti apácák ellenében a hadoszlás 22. napján a színe elött, áttette Szent György 15. napjára (május 8.), hogy akkor a király és bárói ítélkezzenek ez ügyben, mivel a felek hiába mutatták be okleveleiket, nem tudott dönteni. Bár egyértelmúen kiderül, hogy Oszlár (és Pest megye) területén az ifjabb király volt illetékes, az oklevél kelethelye (Buda) azt sugallja, hogy ezt a Damus pro memoriat már az orszegegyesítés után, legkorábban 1271ben állították ki (hiszen az oklevél kiállításának időpontjában már megtörtént az országegyesítés, amely hivatalosan IV. Béla halála, 1270. május 3. után jött létre, és ha itt május 8-ra halaszt, akkor biztosan nem járhatunk 1270-ben.). A per felújítását ekkor talán az váltotta ki, hogy Erzsébet, a szigeti apácák procuratora még 1270-ben megerősítette V. István előtt a monostornak szánt adományokat, így átiratta István ifjabb király 1264. évi megerősítését is (RA 1971. sz.). A per végül 1274-ben zárult le, amikor a felek megosztoztak a földön a váci káptalan színe előtt (ÁÚO IV. 46-48.). A per ezen állomásai tehát nem nyújtanak támpontot Benedek oklevelének közelebbi keletjéhez. Mivel az itt említett Margit 1270 januárjában halt meg (KMTL 443.) ami vélhetően kizárja az 1270. évet, továbbá 1266 esetén Benedek csak az év legeslegvégén nyerte el itt említett nádori tisztségét, ezért az oklevelet 1267 és 1269 közé tehetjük, azzal a megjegyzéssel, hogy a birtokvisszaadások nyugat-magyarországi párhuzamai miatt talán az 1268. év a legvalószínúbb

$(1278-1280)$

Csák nb. Máté fia Máté oklevele (privilegium Mathey palatini bone memorie ... confectum seu compilatum), amelyben megerősíti a komáromi (de Komarum) hospesek korábbi kiváltságait.

Tartalmilag átírta: Csák Máté nádor 1307. aug. 14. (AOkl I. 224. sz.): Štátny archív v Nitre (sídlo v Ivánka pri Nitre) Pobočka Komárno (Szlovákia), Komárom város levéltára: Mohács előtti oklevelek 3. (DF 274777.) 
Kiadása (TÁ): CD VI/2. 402-403.; CD VIII/1. 238-239.; CD VIII/6. 11.; Juck 1984. 66., 83.

Regesztája (TÁ): Jerney 1855. 20.; RDES I. 230.

Fejér György egyik kiadása (CD VIII/1. 238-239.) Péter nádor privilégiumát közli a tartalmi átírásban, amit Jerney János is átvett (Jerney 1855. 20.), és emiatt a későbbi szakirodalom némelyike is kettős szöveghagyományról ír (pl. Kristó 1973. 22-23.; ÁMTF III. 431.). A szövegben Máté neve szerepel. Mivel Komárom ura 1277-ben még Tamás bán volt, és ő adott nekik kiváltságokat (CD VI/2. 401402.), ezért Máté oklevelét ez utánra kell keltezni. A Csákok 1278 körül szerezhették meg maguknak a várost, mert Máté 1278-1279 folyamán már ott keltez (RP 204. sz.; vö. Kristó 1973. 22-23.). A komáromiak nyilván az új urukkal is megerősítették korábbi kiváltságaikat, ezért nevezte 1307-ben Máté a nagybátyja oklevelét compillátumnak (privilegium ... compilatum), hiszen csak a korábbi kiváltságok összegyüjtését tartalmazta.

Péc nb. Márk fia Apor levele a somogyi konventhez, hogy Óvári Konrád fia: Jakab tegyen esküt Szent Miklós nyolcadán [dec. 13.] 50 nemessel egyetemben a színük előtt, hogy a nádor serviensét, Zuda mestert nem fosztotta ki, servienseit nem sebesítette meg és vetette fogságba, és nem okozott neki 60 márka kárt akkor, amikor a király Kőszeg vára alatt volt.

Tartalmilag átírta: somogyvári konvent 1298. dec. 13. - DL 38674. (Családi levéltárak, Ovári család, Győr nembéli)

Regesztája (TÁ): Borsa 1995. 40. sz.

A tartalmi átírás szövege:

Nos conventus monasterii [sancti Egedii] de Symiginesis damus pro memoria, quod cum secundum continentiam litterarum Opour palatini magister Jacobus filius Corrardi de Owar contra magistrum Zudam servientem eiusdem palatini cum quinquaginta nobilibus ${ }^{\text {a }}$ octavis sancti Nicolaia iurare coram nobis debuisset super eo, ut ipsam magistrum Zudam non spoliaverit, duos servientes suos non vulneraverit, nec etiam eosdem servientes suos captivaverit, et captivatos in suo carcere non tenuerit, nec in receptione equorum suorum ac in armis ${ }^{b}$ dampnum sexaginta marcarum sibi non intulerit eo tempore, quo dominus rex sub castro Kuzeg fuisset.

${ }^{a-a}$ sor fölé beszúrva ${ }^{b}$ a szövegben: arrmis

A megadott határnap fényében a nádori oklevél 1298 októbere-novembere táján kelhetett. 


\section{RöVIDÍTÉSEK ÉS BIBLIOGRÁFIA ${ }^{1327}$}

ÁALev

ÁKÍF

ÁMTBF

ÁMTF I-IV.

AO I-VII.

AOkl I-XXXI.

Makkai László, Mezey László /szerk./: Árpád-kori és Anjou-kori levelek, XI-XIV. század. Bp., 1960. (Nemzeti Könyvtár, Levelestár)

Az államalapítás korának írott forrásai /szerk: Kristó Gyula/. Szeged, 1999. (Szegedi Középkortörténeti Könyvtár 15.)

Az Árpád-kori magyar történet bizánci forrásai. Fontes Byzantini historiae Hungaricae aevo ducum et regum ex stirpe Árpád descendentium. Összegyüjtötte, fordította és jegyzetekkel ellátta Moravcsik Gyula. Bp., 1988. ${ }^{2}$

Györffy György: Az Árpád-kori Magyarország történeti földrajza I-IV. Bp., 1963-1998.

Anjoukori Okmánytár /szerk. Nagy Imre, Tasnádi Nagy Gyula/ I-VII. Bp., 1878-1920.

Anjou-kori Oklevéltár I-XXXI. /szerk. Almási Tibor, Blazovich László, Géczi Lajos, Köfalvi Tamás, Kristó Gyula, Makk Ferenc, Piti Ferenc, Sebők Ferenc, Tóth Ildikó Éva/ Bp.-Szeged, 1990-2012.

Archont. 1000-1301 Zsoldos Attila: Magyarország világi archontológiája 1000-1301. Bp., 2011. (História Könyvtár. Kronológiák, adattárak 11.)

Archont. 1301-1457 Engel Pál: Magyarország világi archontológiája 1301-1457. I. Bp., 1996. (História könyvtár. Kronológiák, adattárak 5.)

ÁÚO I-XII. Wenzel Gusztáv: Árpád-kori új okmánytár I-XII. Pest-Budapest, 1860-1874. (MagyarTörténelmi Emlékek, első osztály: Okmánytárak)

Babai 1775 Babai, Franciscus: Ungariae palatini, propalatini, et locumtenentes regii bello, paceque clarissimi. Tirnaviae, 1775.

Bakács 1982 Bakács István: Iratok Pest megye történetéhez (oklevélregeszták) 10021437. Bp., 1982. (Pest megye multjából 5.)

Balics I-II/1-2. Balics Lajos: A római katholikus egyház története Magyarországban. III/1-2. Bp., 1885-1890.

\footnotetext{
${ }^{1327}$ Mivel több művet egyszerre használtunk forráskiadványként és narratív feldolgozásként, ezért a két műfaj bibliográfiai szétválasztásától eltekintünk. A vezetéknevek elött álló megkülönböztető előnevet jelölő betűt az ábécérendbe soroláskor nem vettük figyelembe (vagyis pl. az „S. Kiss 1971” tételt a K- és nem az S-betűnél kell keresni).
} 
Bándi 1979

Bándi 1987

Bárány 2011

Bárczi 1941

Barta-Barta 1993

Bártfai 1907

Bártfai Szabó 1938

Bél 1749

Béla emlékezete

Belitzky 1937

Berend 2002

Bertényi 1964

Bertényi 1965

Bertényi 1976
Bándi Zsuzsanna: Ágostonos remeték Körmenden. In: Vasi Szemle 33. (1979) 359-366.

Bándi Zsuzsanna: Körmend a középkorban. Körmend, 1987. (Körmendi Füzetek)

Bárány Attila: Debreceni Dózsa küzdelme a bihari oligarchákkal. In: Debrecen város 650 éves. Várostörténeti tanulmányok /szerk.: Bárány Attila, Papp Klára, Szálkai Tamás/. Debrecen, 2011. 67-113.

Bárczi Géza: Magyar szófejtő szótár. Bp., 1941.

ifj. Barta János, Barta Gábor: III. Béla király jövedelmei (Megjegyzések középkori uralkodóink bevételeiről) In: Századok 127. (1993) 411-449.

Bártfai Szabó László: Három árpádkori pecsét. In: Turul 25. (1907) 6270.

Bártfai Szabó László: Pest megye történetének okleveles emlékei 10021599-ig. Bp., 1938.

Bel, Caroli, Andreae: De archiofficiis regni Hungariae Hungari baronatus vocant commentario. Lipsiae, 1749.

III. Béla emlékezete. Bev., jegyz.: Kristó Gyula, Makk Ferenc. Bp., 1981. (Bibliotheca Historica)

Belitzky János: A nyugatdunántúli és felvidéki besenyő telepek. In: Emlékkönyv Domanovszky Sándor születése hatvanadik fordulójának ünnepére: 1937 május 27. Bp., 1937. 59-95.

Berend Nóra: Az 1279-i kun törvények szövege és keletkezési körülményei. In: Jászkunság kutatása 2000: Tudományos konferencia a Kiskun Múzeumban /szerk. Bánkiné Molnár Erzsébet/. Kiskunfélegyháza-Jászberény, 2002. 147-153.

Bertényi Iván: A nádori és az országbírói ítélőmester bírósági müködése a XIV. században. In: Levéltári közlemények 35. (1964) 187-205.

Bertényi, Iván: Zur Gerichtstätigkeit des Palatins und des Landesrichters (judex curiae regiae) in Ungarn im XIV. Jahrhundert. In: Annales Universitatis Scientiarum Budapestiensis de Rolando Eötvös nominatae. Studio Historica. Tom. III. Bp., 1965. 29-42.

Bertényi Iván: Az országbírói intézmény története a XIV. században. Bp., 1976. 
Bertényi 1996

Bolla 1957

Bónis 1963

Bónis 1971

Bónis 2003

Borsa 1995

Botka 1872

Bunyitai 1888

$\mathrm{CAH}$

CD I-XI.

CDCr I-XII.

CDS I-II.

CFH I-III.

CJH I.
Bertényi Iván: A magyar királyi udvar tisztségviselői a középkorban. In: Rubicon 7. (1996) 1-2. sz. 7-11.

Bolla Ilona: Az Aranybulla-kori társadalmi mozgalmak a Váradi Regestrum megvilágításában. In: Annales Universitatis Scientiarum Budapestiensis de Rolando Eötvös nominatae: Sectio Historica 1. (1957) 84-105.

Bónis György: A kúriai irodák munkája a XIV. és XV. Században. In: Levéltári Közlemények 34. (1963) 197-243.

Bónis György: A jogtudó értelmiség a Mohács elötti Magyarországon. Bp., 1971.

Bónis György: Hübériség és rendiség a középkori magyar jogban. Sajtó alá rend. és az utószót írta Balogh Elemér. Bp., 2003. (Millenniumi magyar történelem. Historikusok.)

Borsa Iván: A somogyi konvent oklevelei az Országos Levéltárban (Forrásközlés). Első közlemény 1215-1300. In: Somogy Megye Múltjából - Levéltári Évkönyv 26. (1995) 3-18.

Botka Tivadar: Trencsényi Csák Máté nádor halálának éve és napja. In: Századok 6. (1872) 190-193.

Bunyitai Vince: Kopasz nádor: életrajz a XIII-XIV. századból I-II. In: Századok 22. (1888) 15-32., 129-155.

Chartae antiquissimae Hungariae. Árpád-kori oklevelek: 1001-1196. Főszerk.: Györffy György. Bp. 1997.

Codex Diplomaticus Hungariae ecclesiasticus ac civilis. Studio et opera Georgii, Fejér. I-XI. Budae, 1829-1844.

Smičiklas, Tadija: Codex diplomaticus regni Croatiae, Dalmatiae ac Slavoniae I-XII. Zagrabiae, 1904-1914.

Codex diplomaticus et epistolaris Slovaciae I-II. /szerk. Richard Marsina/ Bratislava, 1971-1987.

Catalogus fontium historiae Hungaricae aevo ducum et regum ex stirpe Arpad descendentium ab anno Christi DCCC usque ad annum MCCCI. Coll. Albinus Franciscus GOMBOS. I-III. Bp., 1937-1938.

Magyar Törvénytár. 1000-1526. évi törvényczikkek. Az 1000-1301 közt alkotott törvényeket ford., jegyz. Nagy Gyula, az 1301-1526 közt alkotott törvényeket ford., jegyz. Kolosvári Sándor, Óvári Kelemen, 
magyarázatokkal és utalásokkal kíséri Márkus Dezső. Bp., 1899. (Magyar Törvénytár. Corpus Juris Hungarici 1000-1895. Millenniumi emlékkiadás I.)

Czech 1850

CZ-F I-VI.

Csánki I-V.

Csukovits 2009

Csukovits 2012

Dankovszky 1833

Descriptio

DF

DHA I.

DL

DL-DF 5.1

DRH II.
Czech János: [A nádorok s az ország egyéb footisztjei chronologiája. Bemutatva az MTA 1850. augusztus 17-i ülésén]. In: Magyar Academiai Értesítő 10. (1850) II. sz. 73.

Czuczor Gergely, Fogarasi János: A magyar nyelv szótára. I-VI. Pest, 1862-1874.

Csánki Dezső, Fekete Nagy Antal: Magyarország történelmi földrajza a Hunyadiak korában. Bp., 1890-1941.

Csukovits Enikő: Az Anjou-kori intézményi újítások nápolyi párhuzamai. In: Honoris causa. Tanulmányok Engel Pál tiszteletére /szerk.: Neumann Tibor, Rácz György/ Bp.-Piliscsaba, 2009. (Társadalom- és művelödéstörténeti tanulmányok 40. Analecta Mediaevalia III.) 19-62.

Csukovits Enikő: Az Anjouk Magyarországon I. I. Károly és uralkodása (1301-1342). Bp., 2012. (Magyar Történelmi Emlékek. Értekezések)

Magyaricae linguae Lexicon critico-etymologicum. Studio et opera Dankovszky, Georgius. Posonii, 1833.

Anonymi Descriptio Europae Orientalis. Imperium Constantinopolitanum, Albania, Serbia, Bulgaria, Ruthenia, Ungaria, Polonia, Bohemia anno MCCCVIII. exarata. /ed.: Olgierd Górka/. Cracoviae, 1916.

Magyar Országos Levéltár, Diplomatikai Fotótár

Diplomata Hungariae Antiquissima I. Edendo operi praefuit: Georgius, Györffy. Budapestini, 1992.

Magyar Országos Levéltár, Diplomatikai Levéltár

Collectio Diplomatica Hungarica. A középkori Magyarország levéltári forrásainak adatbázisa. Internetes kiadás (DL-DF 5.1) 2009.

Decreta regni Hungariae - Gesetze und Verordnungen Ungarns 14581490 /coll. Francisci Döry; add., comm., not. Georgius Bónis, Geisa Érszegi, Susanna Teke/. Bp., 1989. (Publicationes Archivi Nationalis Hungarici 2. Fontes 19.) 
DRMH I/1.

DSAd

Dudás 1897

Elenchus III/2.

Ember 1946

Engel 1981

Engel 1982

Engel 1988

Engel 1998

Engel 1999 (2003)

Engel 2000

EO I-III.
The Laws of the Medieval Kingdom of Hungary - Decreta regni mediaevalis Hungariae I. /transl. and ed.: Bak, János, Bónis, György, Sweeney, James Ross/ Schlacks, 1989. (The Laws of Hungary I/1.)

Vladimír Rábik: Középkori oklevelek a Nagyszombati Szent Adalbert Egyesület levéltárában (1181) 1214-1543. Szeged, 2010. (Capitulum VII.)

D[udás] Gy[ula]: A pristáldokról. In: Századok 31. (1897) 463-464.

Elenchus fontium historiae urbanae /ed.: András Kubinyi/ III/2. Bp., 1997.

Ember Győző: Az újkori magyar közigazgatás története Mohácstól a török kiüzéséig. Bp., 1946. (Magyar Országos Levéltár kiadványai III. Hatóság- és hivataltörténet 1.)

Engel Pál: A honor (A magyarországi feudális birtokformák kérdéséhez). In: Történelmi Szemle 24. (1981) 1-19.

Engel Pál: Honor, vár, ispánság. Tanulmányok az Anjou-királyság kormányzati rendszeréről. In: Századok 115. (1982) 880-922.

Engel Pál: Az ország újraegyesítése. I. Károly küzdelmei az oligarchák ellen (1310-1323). In: Századok 122. (1988) 89-147.

Engel Pál: A nemesi társadalom a középkori Ung megyében. Bp., 1998. (Társadalom- és mủvelődéstörténeti tanulmányok 25.)

Engel Pál: Királyi emberek Valkó megyében. In: Uő: Honor, vár, ispánság. Válogatott tanulmányok. Válogatta, szerkesztette, a jegyzeteket gondozta Csukovits Enikő. Bp., 2003. (Millenniumi Magyar Történelem. Historikusok) 578-599. [első megjelenés: Mediaevalia Transilvanica 3. (1999) 71-88.]

Engel Pál: Az „1300 körüli” tanácsi határozat keltezéséhez. In: Magyarország a (nagy)hatalmak erőterében. Tanulmányok Ormos Mária 70. születésnapjára /szerk.: Fischer Ferenc, Majoros István, Vonyó József/. Pécs, 2000. 125-132.

Erdélyi okmánytár. Oklevelek, levelek és más írásos emlékek Erdély történetéhez I-III. /szerk.: Jakó Zsigmond, Hegyi Géza és W. Kovács András közremüködésével/ Bp., 1997-2008. (Magyar Országos Levéltár Kiadványai II. Forráskiadványok 26., 40. és 47.) 
Érdujhelyi 1897 Érdujhelyi Menyhért: A pristáldokról. In: Századok 31. (1897) 266272.

EWU I-III. $\quad$ Etymologisches Wörterbuch des Ungarischen. I-III/1-6. /hrsg.: Benkő, Loránd/ Bp., 1992-1997.

K. Fábián 1997 K. Fábián Ilona: A Váradi Regestrum helynevei. Szeged, 1997. (Szegedi Középkortörténeti Könyvtár 13.)

Fejérpataky 1893 Fejérpataky László: A Gutkeled-biblia. In: Magyar Könyvszemle 17. (1893) 5-22.

Frankl 1863

Frankl [Fraknói] Vilmos: A nádori és országbírói hivatal eredete és hatáskörének történeti kifejlödése. Pest, 1863.

Fügedi 1961 Fügedi Erik: Középkori magyar városprivilégiumok. In: Tanulmányok Budapest múltjából XIV. Bp., 1961. 17-107. (Budapest várostörténeti monográfiái XXII.)

Fügedi 1986 Fügedi Erik: Ispánok, bárók, kiskirályok. A középkori magyar arisztokrácia fejlódése. Bp., 1986. (Nemzet és emlékezet)

Gábor 1908 Gábor Gyula: A megyei intézmény alakulása és müködése Nagy Lajos alatt. Bp., 1908.

Gálos 1928

Szent Gellért legendája (Vita S. Gerardi). Fordította: Gálos Rezső. Makó, 1928. (Csanádvármegyei Könyvtár 14.)

Gerics 1962 Gerics József: A királyi bírói jelenlét a XIII-XIV. század fordulóján. In: Jogtudományi Közlöny 17. új évf. (1962) 651-657.

Gerics 1966 Gerics József: A magyar királyi kúriai bíráskodás és központi igazgatás Anjou-kori történetéhez. In: Jogtörténeti tanulmányok I. /szerk.: Csizmadia Andor/. Bp., 1966. 285-308.

Gerics 1969 Gerics József: Árpád-kori jogintézmények és terminológia törvényhozásunk egyik keltezetlen emlékében. In: Századok 103. (1969) 611-640.

Gerics 1987 Gerics József: A korai rendiség Európában és Magyarországon. Bp., 1987.

Gerics 1988 Gerics József: A korai államelmélet érvényesülése István korában. In: Szent István és kora /szerk.: Glatz Ferenc, Kardos József/. Bp., 1988. 90-94.

Gerics-Ladányi 1998 Gerics József-Ladányi Erzsébet: A Kálmán-kori szinodális bíráskodás valószínü mintája. In: Iustum, aequum, salutare. Emlékkönyv Zlinszky 
János tiszteletére /szerk.: Bánrévy Gábor, Jobbágyi Gábor, Varga Csaba/. Bp., 1998. 112-115.

Gyárfás I-IV. Gyárfás István: A jász-kunok története I-IV. Kecskemét-Szolnok-Bp., $1870-1885$.

Györffy 1953 Györffy György: A kunok feudalizálódása. In: Tanulmányok a parasztság történetéhez Magyarországon a 14. században /szerk.: Székely György/ Bp., 1953. 248-275.

Györffy 1964 Györffy György: Adatok a románok XIII. századi történetéhez és a román állam kezdeteihez. In: Történelmi szemle 7. (1964) 1-25., 537568.

Györffy 1977

Györffy György: István király és műve. Bp., 1977.

Györffy 1990

Györffy György: A magyarság keleti elemei. Bp., 1990.

Györffy 1997

Györffy György: Pest-Buda kialakulása. Budapest története a honfoglalástól az Árpád-kor végi székvárossá alakulásig. Bp., 1997.

Hajnik 1899 Hajnik Imre: A magyar bírósági szervezet és perjog az Árpád- és a vegyes-házi királyok alatt. Bp., 1899.

B. Halász $2009 \quad$ B. Halász Éva: Szlavón hercegi és báni ítélőmesterek a XIV. században. In: Acta Universitatis Szegediensis. Acta Historica, tomus CXXX. (2009) 69-83.

Hampel 1881 Hampel József: A Drugethek őseiről. In: Századok 15. (1881) 133145., 207-213.

Hanvay $\quad$ Borsa Iván, Ila Bálint: Az Abaffy család levéltára 1247-1515. A Dancs család levéltára 1232-1525. A Hanvay család levéltára 1215-1525. Bp., 1993. (A Magyar Országos Levéltár kiadványai II. Forráskiadványok 23.)

Hatházi 1990 Hatházi Gábor: Az Árpád-kori magyar hadszervezet nomád elemeinek kérdéséhez. A besenyők. In: Hadtörténelmi Közlemények 103/2. (1990) $22-60$.

Hatházi 1996 Hatházi Gábor: Besenyők és kunok a Mezőföldön. In: Zúduló sasok. Új honfoglalók - besenyők, kunok, jászok - a középkori Alföldön és a Mezőföldön. Gyula, 1996. (Gyulai katalógusok 2.) 37-56.

Haugwitz 1901 Haugwitz, Eberhard: Der Palatin. Seine Geschichte und seine Ruinen. Rom, 1901. 
Havas 2004

Havassy 1986

Havassy 1989

Havassy 2000

Hegyi 2012

Helyt. olv.

Heves

Hincmarus

HO I-VIII.

Hodinka 1916

HOkl

Holub 1929

Horger 1941

Hunyadi 2010
Sancti Stephani regis primi Hungariae: Libellus de Institutione Morum sive Admontio Spiritualis - Szent István: Erkölcstanító Könyvecske avagy Intelmek. Szöveget gond., ford.: Ladislaus, Havas. Debrecini,

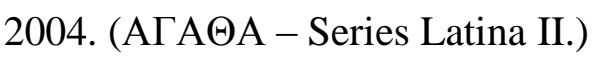

Havassy Péter: Heves megye középkori tisztségviselői. Eger, 1986. (Studia Agriensia 6.)

Havassy Péter: Hont és Nógrád vármegye nádori közgyülései a XIVXV. században. In: Nógrádi Történeti Évkönyv Belitzky János emlékének tiszteletére (1989). (Nógrád Megyei Múzeumok Évkönyve) XV. 45-57.

Havassy Péter: Gömör és Torna vármegyék nádori közgyűlései a 1415. században. In: A Herman Ottó Múzeum Évkönyve 39. (2000) 141150.

Hegyi Géza: Magyarország vagy Erdély? A Szilágyság hovatartozása a középkorban a társadalmi kapcsolatok tükrében. In: Erdélyi Múzeum 74. (2012) 3. sz. 23-45.

Helytörténeti olvasókönyv I. Bereg, Szabolcs és Szatmár megye történetéhez a honfoglalástól 1849-ig/szerk.: Hársfalvi Péter, Takács Péter/. Nyíregyháza, 1985.

Árpád-kori oklevelek a Heves Megyei Levéltárban /szerk.: Kondorné Látkóczki Erzsébet/. Eger, 1997.

Hincmarus: De ordine palatii. Ed.: Krause, Victor. (Monumenta Germaniae Historica: Leges: Fontes iuris Germanici antiqui in usum scholarum separatim editi 3.) Hannoverae et Lipsise, 1894.

Hazai okmánytár. /Szerk: Ipolyi Arnold, Nagy Imre, Páur Iván, Ráth Károly és Véghely Dezső/ I-VIII. Győr-Budapest, 1865-1891.

Hodunka Antal: Az orosz évkönyvek magyar vonatkozásai. Bp., 1916. Hazai oklevéltár 1234-1536 /Szerk. Nagy Imre, Deák Farkas, Nagy Gyula/. Bp., 1879.

Holub József: Zala megye története a középkorban. I. Pécs, 1929.

Horger Antal: Nádorispán. In: Magyar Nyelv 37. (1941) 115-116.

Zsolt, Hunyadi: The Hospitallers in the Medieval Kingdom of Hungary c. 1150-1387. Bp., 2010. (METEM Könyvek 70., CEU Medievalia 13.) 
ÍFMT

Iongelinus 1659

Istványi 1939

Istványi 1940-1941

Janits 1940

Jerney 1855

Juck 1984

Kandra 1891

Karácsonyi 1900

Károly emlékezete

Károlyi I-V.

Keglevich 2012

Kenyeres 2002
Írott források az 1050-116 közötti magyar történelemről. /szerk: Makk Ferenc, Thoroczkay Gábor/. Szeged, 2006. (Szegedi Középkortörténeti Könyvtár 22.)

Caspar Iongelinus: Catalogus Palatinorum regni Hungariae et vetustissimis litteris ac diplomatibus ejusdem Regni digestus. Catalogus Judicum Curiae Regiae per Regnum Hungariae. In: Petrus de Rewa: De Monarchia et Sacra Corona Regni Hungariae Centuriae Septem. Francofurti, 1659.

Istványi Géza: A generalis congregatio I. In: Levéltári közlemények 17. (1939) 50-83.

Istványi Géza: A generalis congregatio II. In: Levéltári közlemények 18-19. (1940-41) 179-207.

Janits [Borsa] Iván: Az erdélyi vajdák igazságszolgáltató és oklevéladó müködése 1526-ig. [Bp.], [1940.]

Jerney János: A' magyarországi káptalanok és konventek', mint hielmes és hiteles helyek' története. In: Magyar Történelmi Tár 2. (1855) 1-166.

Juck, L'ubomir: Výsady miest a mestečiek na Slovensku, 1238-1350. I. Bratislava, 1984.

Kandra Kabos: Aba Samu király. Bp., 1891.

Karácsonyi János: Magyar nemzetségek a XIV. század közepéig. Bp., 1900., reprint: Bp., 2004.

Károly Róbert emlékezete. A szöveganyagot válogatta, szerkesztette, a bevezetőt és a jegyzeteket írta Kristó Gyula és Makk Ferenc. A képanyagot Marosi Ernő válogatta. Bp., 1988.

A Nagy-Károlyi gróf Károlyi család oklevéltára /szerk. Károlyi Tibor, Géresi Kálmán/ I-V. Bp., 1882-1897.

Keglevich Kristóf: A garamszentbenedeki apátság története az Árpádés az Anjou-korban (1075-1403). Szeged, 2012. (Capitulum VIII.)

XVI. századi uradalmi utasítások. Utasítások a kamarai uradalmak prefektusai, udvarbírái és ellenőrei részére/szerk. és a bev. tanulmányt írta Kenyeres István; a szerkesztésben közreműködött Kis Péter; munkatársak Babcsányi István, Ligeti Zsuzsa, Sarusi Kiss Béla/. I-II. Bp., 2002. (Fons könyvek 2.) 
Képes Krónika Képes Krónika. Ford. Bollók János. Utószó és jegyz. Szovák Kornél, Veszprémy László. Bp., 2004. (Millenniumi magyar történelem Források)

Kis 2010

S. Kiss 1971

Kiss 2009

Kis Péter: A királyi szolgálónépi szervezet a 13-14. században. Szeged, 2010. (Szegedi Középkortörténeti Könyvtár 25.)

S. Kiss Erzsébet [Karácsonyi Béla]: A királyi generális kongregáció kialakulásának történetéhez. In: Acta Universitatis Szegediensis de Attila József nominatae. Acta Historica 39. Szeged, 1971. 3-56.

Kiss Gergely: A püspökség határai. In: A pécsi egyházmegye története I. A középkor évszázadai (1009-1543). Szerk.: Fedeles Tamás, Sarbak Gábor, Sümegi József. Pécs, 2009. 43-54.

KMTL

Kniezsa 1937

Kniezsa 1941

Korai Magyar Történeti Lexikon (9-14. század). /Főszerk.: Kristó Gyula, szerk.: Engel Pál, Makk Ferenc/. Bp., 1994.

Kniezsa 1955

Kniezsa István: A nyugatmagyarországi besenyők kérdéséhez. In: Emlékkönyv Domanovszky Sándor születése hatvanadik fordulójának ünnepére: 1937 május 27. Bp., 1937. 323-337.

Kocsis 2005

Komáromy 1891 Komáromy András: Dózsa nádor és a Debreczeni család. In: Turul 9. (1891) 1-9., 67-78.

Korai helyneveink Kristó Gyula, Makk Ferenc, Szegfü László: Adatok „korai” helyneveink ismeretéhez. I-II. In: Acta Universitatis Szegediensis de Attila József nominatae. Acta Historica 46. (1973) 3-95., 48. (1974) 355.

Kordé 1990

Kordé Zoltán: A magyarországi besenyők az Árpád-korban. In: Acta Universitatis Szegediensis de Attila József nominatae. Acta Historica 90. (1990) 3-21.

Kordé 1991

Kordé Zoltán: A székelyek a XII. századi elbeszélő forrásokban. In: Acta Universitatis Szegediensis de Attila József nominatae. Acta Historica 92. (1991) 17-24. 
Korm. rendsz.

Koszta 1991

Koszta 2009

Kovács 1964

W. Kovács 2012

Körmendi 2001

Kring 1932

Kristó 1973

Kristó 1974

Kristó 1979

Kristó 1988

Kristó 1999a

Kristó $1999 b$

Kristó 2001

Kristó 2002

Kristó 2003a
Font Márta, Fedeles Tamás és Kiss Gergely, Raffayné Kálsecz Kata közremüködésével: Magyarország kormányzati rendszere (1000-1526). Egyetemi tankönyv. Pécs, 2007.

Koszta László: A pozsegai társaskáptalan tagjai a XIV. század közepéig. In: Aetas 1991/3-4. 40-58.

Koszta László: A pozsegai társaskáptalan. In: A pécsi egyházmegye története I. A középkor évszázadai (1009-1543) /szerk.: Fedeles Tamás, Sarbak Gábor, Sümegi József/. Pécs, 2009. 235-246.

Kovács Ferenc: A magyar jogi terminológia kialakulása. Bp., 1964. (Nyelvészeti tanulmányok 6.)

W. Kovács András: Középszolnok és Kraszna vármegyék hatóságának középkori történetéhez. In: Erdélyi Múzeum 74. (2012) 3. sz. 46-67.

Körmendi Tamás: A premontrei rend megtelepedése az Árpád-kori Magyarországon. A rend korai hazai története a kezdetektől az 1235-i Catalogus Ninivensisig I. In: Turul 74. (2001) 103-111.

Kring [Komjáthy] Miklós: Kun és jász társadalomelemek a középkorban. In: Századok 66. (1932) 35-63, 169-188.

Kristó Gyula: Csák Máté tartományúri hatalma. Bp., 1973.

Kristó Gyula: A XI. századi hercegség története Magyarországon. Bp., 1974.

Kristó Gyula: A feudális széttagolódás Magyarországon. Bp., 1979.

Kristó Gyula: A vármegyék kialakulása Magyarországon. Bp., 1988. (Nemzet és emlékezet)

Kristó Gyula: A tizenegyedik század története. H. n. [Bp.], 1999. (Magyar századok)

Kristó Gyula: I. Károly király foúri elitje (1301-1309). In: Századok 133. (1999) 41-62.

Kristó Gyula: Tartományúri rezidenciák Magyarországon (1301-1320). In: Acta Universitatis Szegediensis. Acta Historica 115. (2001) 33-40. Kristó Gyula: A korai Erdély (895-1324). Szeged, 2002. (Szegedi Középkortörténeti Könyvtár 18.)

Kristó Gyula: Nem magyar népek a középkori Magyarországon. Bp., 2003. 
Kristó $2003 b$

Kristó 2003c

Kruták 2012

Kubinyi 1867

Kun László

Kurcz 1988

Langó 2006

Leschka 1825

LexMA I-IX.

Magy. Tört. I-V.

Majláth 1883

Makk 1980

Makk 1998
Kristó Gyula: Tájszemlélet és térszervezés a középkori Magyarországon. Szeged, 2003. (Szegedi Középkortörténeti Könyvtár 19.)

Kristó Gyula: I. Károly harcai a tartományurak ellen (1310-1323). In: Századok 137. (2003) 297-347.

Kruták Anita: A nádori congregatio intézménye Druget Vilmos nádorsága alatt. In: Középkortörténeti tanulmányok 7. /szerk.: Kiss P. Attila, Piti Ferenc, Szabados György/. Szeged, 2012. 425-438.

Kubinyi Ferencz: Árpádkori oklevelek. Pest, 1867. (Magyar Történelmi Emlékek 1.)

Kun László emlékezete. A bevezetőt írta, a forrásszövegeket válogatta és a jegyzeteket összeállította Kristó Gyula. Szeged, 1994. (Szegedi Középkortörténeti Könyvtár 5.)

Kurcz Ágnes: Lovagi kultúra Magyarországon a 13-14. században. Bp., 1988.

Langó Péter: Kun László kun törvényei. Megjegyzések a kunok jogállásáról a középkori magyar források tükrében. In: Jászok és kunok a magyarok között. Ünnepi kötet Bánkiné Molnár Erzsébet tiszteletére /szerk. Bathó Edit, Ujváry Zoltán/ Jászberény 2006. 60-77.

Leschka, Stephanus: Elenchus vocabulorum Europaeorum cumprimis Slavicorum Magyarici usus. Budae, 1825.

Lexikon des Mittelalters / Red. Avella-Widhalm, Gloria; Lutz, Liselotte et alii/ I-IX. München und Zürich, 1980-1998.

Hóman Bálint, Szekfü Gyula: Magyar történet I-V. Bp., $1935{ }^{2}$

Majláth Béla: Péter alnádor pecsétje 1298-ból. In: Turul 1. (1883) 1216.

Makk Ferenc: Megjegyzések a II. Géza-kori magyar-bizánci konfrontáció kronológiájához. In: Acta Universitatis Szegediensis de Attila József nominatae. Acta Historica 67. (1980) 41-56.

Makk Ferenc: A korai magyar történelemről. In: Uő: A turulmadártól a kettőskeresztig. Tanulmányok a magyarság régebbi történelméről. Szeged, 1998. 9-44. 
Mályusz 1953

MaMüL I-XII. Magyar müvelődéstörténeti lexikon: középkor és kora újkor. I-XII. Főszerk.: Kőszeghy Péter. Bp., 2003-2012.

Marczalli 1896 Marczalli Henrik: Magyarország története az Árpádok korában (10381301). Bp., 1896, $1995^{2}$. (A magyar nemzet története 2.)

Markó 2006

Marsina 1990

MCS

MES I-IV.

Mikó 2011

Mitteis 1953

Mon. Bp. I.

MT I/1-2.

MTK I-IV.

MUSZ

Muszka 1763

Mályusz Elemér: Az egyházi tizedkizsákmányolás. In: Tanulmányok a parasztság történetéhez Magyarországon a 14. században /szerk.: Székely György/ Bp., 1953. 320-333.

Markó László: A magyar állam főméltóságai Szent Istvántól napjainkig. Bp., 2006.

Marsina, Richard: A XIII. század derekén kelt oklevelek diplomatikai és írástani vizsgálata. In: Levéltári Közlemények 61. (1990) 43-62.

Anonymus: A magyarok cselekedetei. Kézai Simon: A magyarok cselekedetei. Ford. Veszprémy László és Bollók János. Bp., 2004. (Milleniumi Magyar Történelem - Források)

Monumenta Ecclesiae Strigoniensis I-IV. /Szerk.: Knauz Nándor, Dedek Crescens Lajos, Dreska Gábor, közrem.: Hegedűs András, Érszegi Géza, Tóth Krisztina, Kalász Márton és Mudrák Attila/. Strigonii, 1874-1999.

Miklosich 1882 Miklosich Ferenc: A Magyar nyelvbeli szláv szók. In: Magyar Nyelvőr 11. (1882) 68-73., 114-121., 161-169., 219-225., 268-273., 316-321., 359-366., 411-417., 456-459., 511-515., 563-568.

Mikó Gábor: Szent István törvényeinek XVI. századi kézirata Lőcse város levéltárában. In: Fons 18. (2011) 111-145.

Mitteis, Heinrich: Der Staat des hohen Mittelalters. Weimar, $1953^{4}$.

Budapest történetének okleveles emlékei. Monumenta diplomatica civitatis Budapest I. (1148-1301). Csánky Dezső gyüjtését kiegészítette és sajtó alá rendezte Gárdonyi Albert. Bp., 1936.

Magyarország története. I/1-2. Előzmények és a magyar történet 1242ig /főszerk: Székely György/ Bp., 1984.

Magyarország történeti kronológiája. A kezdetektől 1970-ig /főszerk.: Benda Kálmán/ I-IV. Bp., 1981-1982.

Budenz József: Magyar-ugor összehasonlító szótár. Bp., 1873-1881.

Muszka, Nicolaus: Palatium regni Hungariae; seu palatinorum sub regibus Hungariae vitae. Pars I. ad annum 1515. Viennae, 1736. 
Mủvészet 1342-1382 Művészet I. Lajos király korában 1342-1382. Katalógus. /szerk.: Marosi Ernő, Tóth Melinda, Varga Lívia/. Bp., é.n. [1982.]

M-Zs Okl I-XVIII Magyar-zsidó oklevéltár /szerk.: Scheiber Sándor et alii/ I-XVIII. Bp., 1903-1980.

Nacsa 1985

Borzákné Nacsa Mária: A Descriptio Europae Orientalis eszmei háttere és politikai célzatossága. Doktori értekezés. Kecskemét, 1985. (Kézirat: SZTE Klebelsberg Könyvtár B 2678.)

Nagy 1876

Németh 1839

Nagy Aladár: A pristaldusok. In: Századok 10. (1876) 337-343.

Németh János: A Nádor-Ispán szavaknak igaz eredetiről. In: Tudományos Gyüjtemény 23. (1839) VIII. köt. 13-42.

Nógrády 1995 Nógrády Árpád: „Magistratus et comitatus tenentibus”. II. András kormányzati rendszerének kérdéséhez. In: Századok 129. (1995) 157194.

Nyers $1934 \quad$ Nyers Lajos: A nádor bírói és oklevéladó müködése a XIV. században (1307-1386.) Kecskemét, 1934. (Palesta Calasanctiana 4.)

OCD

Orosz 1754

The Oxford Classical Dictionary /ed: Hammond, N. G. L. - Scullard, H. H./ Oxford, $1970^{2}$.

Orosz, Franciscus: Orationes regum et principum magni regni Hungariae, ab Atilae primi Hunnorum regis temporibus, usque annum Christi 1598 inclusive. Ginsburgi, 1754.

Pálfi 1907 Pálfi Márton: Kolozsvári glosszák. Különnyomat a Magyar Nyelvőrből. Bp., 1907. (Nyelvészeti füzetek 45.)

Pálóczi 1996 Pálóczi Horváth András: Nomád népek a kelet-európai steppén és a középkori Magyarországon. In: Zúduló sasok. Új honfoglalók besenyők, kunok, jászok - a középkori Alföldön és a Mezőföldön. Gyula, 1996. (Gyulai katalógusok 2.) 7-36.

Pauler 1879 Pauler Gyula: Szent István és alkotmánya. In: Századok 13. (1879) 1$30 ., 101-125$.

Pauler 1899. I-II. Pauler Gyula: A magyar nemzet története az Árpádházi királyok alatt. I-II. Bp., $1899^{2}$.

Piti 2001

Piti Ferenc: „...de adventu regis Hungarie” (Károly Róbert tervezett dalmáciai hadjáratáról az 1340. évi oklevelek tükrében). In: Acta Universitatis Szegediensis. Acta Historica, tomus CXV. (2001) 41-53. 
Piti 2006

Piti Ferenc: Az 1342. évi nádorváltás. In: Századok 140. (2006) 435441.

Prímási nádor

Podhradczky 1850

Podhradczky 1856

Pór 1889

PRT I-XII/B

Püspöki 1978

RA

Rábik 2010

Rákos 1974

RDES I-II.

Róna-Tas 1995

Róna-Tas 1997

Róna-Tas 1998

Róna-Tas 1999

[s. a.]: Prímási nádor és korlátnok. In: Magyar Sion 3. (1865) 473-475.

Podhradczky József: [A nádori hivatal és név eredete. Felolvasva az MTA 1850. július 8-i ülésén]. In: Magyar Academiai Értesítő 10. (1850) I. sz. 29-38.

Podhradczky József: A nádorispán eredete, s egykori hatásköre 1492-ig. (Előterjesztetett oct. 27. 1856.). In: Magyar Academiai Értesítő 16. (1856) VIII. sz. 486-500.

Pór Antal: Rénold nádor és ivadéka. In: Turul 7. (1889) 114-118.

A Pannonhalmi Szent-Benedek-rend története. I-XII/B. /szerk.: Sörös Pongrác/. Bp., 1902-1912.

Püspöki Nagy Péter: Nagymorávia fekvéséről. In: Valóság 21. (1978) 11. sz. 60-82.

Szentpétery Imre, Borsa Iván szerk.: Az Árpád-házi királyok okleveleinek kritikai jegyzéke. I-II/1-4. Bp. 1923-1987.

Vladimír Rábik: Középkori oklevelek a Nagyszombati Szent Adalbert Egyesület levéltárában (1181) 1214-1543. Szeged, 2010. (Capitulum VII.)

Rákos István: IV. Béla birtokrestaurációs politikája. In: Acta Universitatis Szegediensis de Attila József nominatae. Acta Historica 47. (1974) 3-32.

Regesta diplomatica nec non epistolaria Slovaciae I-II. Ad edendum praeparavit Vincent Sedlák. Bratislavae, 1980-1987.

Róna-Tas András: Hogyan hívták Árpád dédunokáját. In: Kelet és nyugat között. Történeti tanulmányok Kristó Gyula tiszteletére /szerk.: Koszta László/. Szeged, 1995. 417-430.

Róna-Tas András: A honfoglaló magyar nép. Bevezetés a korai magyar történelem ismeretébe. Bp., $1997^{2}$

Róna-Tas András: Nagyszentmiklós. Zsupán. In: Századok 132. (1998) 940-949.

Róna-Tas, András: Hungarians and Europe in the Early Middle Ages. An Introduction to Early Hungarian History. Bp., 1999 
Róna-Tas 2007 Róna-Tas András: Kis magyar östörténet. A magyarok korai története az államalapításig. Bp., 2007.

$\mathrm{RP}$

Az Árpád-kori nádorok és helyetteseik okleveleinek kritikai jegyzéke /szerk.: Szőcs Tibor/ Bp., 2012. (A Magyar Országos Levéltár kiadványai II. Forráskiadványok 51.)

RV

Regestrum Varadiense examinum ferri candentis ordine chronologico digestum - Az időrendbe szedett váradi tüzesvaspróba-lajstrom. /szerk.: Borovszky Samu, Karácsonyi János/ Bp., 1903.

Sándor 1801 Sándor István: Sokféle. VIII. kötet. Győr, 1801.

Schmidt 1973

Schmidt, Erwin: Die Hofpfalzgraf enwürde an der hessendarmstädtischen Universität Marburg/Gießen. Giessen, 1973.

Schmith 1739 [Schmitth, Nicolaus]: Palatium regni Hungariae Rebus pace, belloque gestis palatinorum, locumtenetium, pro-palatinorum sub regibus Hungariae Austricis illustratum. Cassoviae, 1739.

Solymosi 1984 Solymosi László: A hiteleshelyi pecséthasználat kezdeteihez. In: A magyar hivatali írásbeliség fejlődése 1181-1981. /szerk.: Kállay István/. Bp., 1984. (Magyar Herold. Forrásközlő, családtörténeti és címertani évkönyv I.) 91-139.

Solymosi 1998 Solymosi László: A földesúri járadékok új rendszere a 13. századi Magyarországon. Bp., 1998.

Solymosi 2002 Solymosi László: A perjogi írásbeliség első százada. In: Vigilia 67. (2002/7.) 521-527.

Solymosi 2004 Solymosi László: A világi bíráskodás kezdetei és az oklevéladás Magyarországon. In: Várak, templomok, ispotályok: tanulmányok a középkorról / szerk.: Neumann Tibor/. Bp. 2004. (Analecta Mediaevalia II.) $221-236$.

Sopron I-II. Sopron vármegye története. Oklevéltár I-II. /szerk.: Nagy Imre/ Sopron, 1889-1891.

Sörös 1908 Sörös Pongrác: A Pannonhalmán őrzött Guary-levéltár Árpád- és Anjou-kori kiadatlan oklevelei. In: Történelmi Tár. Új folyam 9. (1908) 161-195.

SRH I-II. Scriptores Rerum Hungaricarum I-II. Edendo operi praefuit Emericus Szentpétery. Budapestini, 1937-1938. 
Sulán 1957

Szabados 2006

Szabados 2007a

Szabados 2007b

Szabados 2011

Szabó1865

Szabó 1886

Szabó 2009

Szabolcs

Szamota 1896

Szarka 1775

Szatmár

Szatmár megye
Sulán Béla: A cseh szókincs magyar elemeiből [második közlemény]. In: Magyar Nyelv 53. (1957) 160-165.

Szabados György: A magyar történelem kezdeteiről. Az előidőszemlélet hangsúlyváltásai a XV-XVIII. Században. Bp., 2006.

Szabados György: „Árpád-házi” „szent” királyunk Aba Sámuel. In: Középkortörténeti tanulmányok 5. /szerk: Révész Éva, Halmágyi Miklós/ Szeged, 2007. 151-158.

Szabados György: A régi magyar taktika Árpád-kori írott kútfökben. A steppei eredetű harci müveltség nyomai és megjelenítése a XIII. század végéig. In: Hadtörténelmi Közlemények 120. (2007) 475-500.

Szabados György: Magyar államalapítások a IX-XI. században. Szeged, 2011. (Szegedi Középkortörténeti Könyvtár 26.)

Emlékiratok a magyar kereszténység első századáról. /ford: Szabó Károly/. Pest, 1865. (Magyarország történetének forrásai I/4.)

Szabó Károly: Kun László 1272-1290. Bp., 1886. (Magyar történeti életrajzok)

Szabó Pál: Merénylet a merénylet árnyékában? Megjegyzések Csépán nádor halálához (1209). In: X. RODOSz Konferencia-kötet: társadalomtudományok /szerk.: Kovács Csongor, Székely Ilona, Székely Tünde/ Kolozsvár, 2009. 380-391.

Németh Péter: A középkori Szabolcs megye települései. Nyíregyháza, 1997.

Szamota István: A Murmelius-féle latin-magyar szójegyzék 1533-ból. Bp., 1896. (Értekezések a nyelv- és széptudományok köréből XVI/7.)

Szarka János: Coniectura de origine, potestate, et antiquitate nominis nador-ispán, quod vulgo palatinum regni Hung. comitem interpretantur, rationibus philologicis et historicis firmata. Sopronii, s. a. [1775.]

Németh Péter: A középkori Szatmár megye települései a XV. század elejéig - Aşežarile comitatului medieval Satu Mare pâna la începutul secolului al XV-lea. Nyíregyháza, 2008. (A nyíregyházi Jósa András Múzeum kiadványai 60.)

Piti Ferenc, C. Tóth Norbert, Neumann Tibor: Szatmár megye hatóságának oklevelei (1284-1524). Nyíregyháza, 2010. (A nyíregyházi Jósa András Múzeum Kiadványai 65.) 
Szende 2011

Szentpétery 1916

Szentpétery 1921

Szentpétery 1985

Szilágyi 1937

Szovák 1989

Szovák 1996

Szőcs 2007

Szőcs 2009

Szőcs 2010

Szőcs 2011

Szőcs 2012
Szende Katalin: A magyar városok kiváltságolásának kezdetei. In: Debrecen város 650 éves. Várostörténeti tanulmányok /szerk.: Bárány Attila, Papp Klára, Szálkai Tamás/. Debrecen, 2011. 23-48.

Szentpétery Imre: A borsmonostori apátság árpádkori oklevelei. Bp., 1916.

Szentpétery Imre: V. istván ifjabbkirálysága [!]. In: Századok 55-56. (1921-1922) 77-87.

Szentpétery Imre: A kronológia kézikönyve. Sajtó alá rend.: Gazda István, kieg.: Érszegi Géza, Raj Tamás, Szögi László. Bp., 1985.

Szilágyi Loránd: Az Anonymus-kérdés reviziója. In: Századok 71. (1937) 1-54., 136-202.

Szovák Kornél: Rátót nembéli Rolánd nádor kúriája. In: A Dunántúl településtörténete 7. (1989) 299-316.

Szovák Kornél: A pannonhalmi konvent hiteleshelyi müködésének kezdetei (1244-1387). In: Mons Sacer 996-1996. Pannonhalma 1000 éve I. /szerk.: Takács Imre/, 1996. 422-462.

Szőcs Tibor: A 14. századi krónikaszerkesztmény interpolációi és 11. századi okleveleink. In: Fons 14. (2007) 59-95.

Szőcs Tibor: Nádorispán szavunk latin és magyar megnevezése és etimológiája. In: X. RODOSz Konferencia-kötet: bölcsésztudományok - élő- és élettelen természettudományok - orvostudományok - müszaki tudományok. Szerk.: Székely Tünde. Kolozsvár, 2009. 187-201.

Szőcs Tibor: A nádori oklevéladás kezdeti szakasza. In: "Fons, skepsis, lex". Ünnepi tanulmányok a 70 esztendős Makk Ferenc tiszteletére /szerk.: Almási Tibor, Révész Éva, Szabados György/. Szeged, 2010. 429-436.

Szőcs Tibor: Intézményes szóbeliség: a poroszlói rendszer az Árpádkorban. In: A varázsgyürütől az interkonfesszionális kommunikációig. Információtudományi metszéspontok bölcsészeti megközelítésben /szerk.: Tóth Zsófia Anna/. Szeged, 2011. 151-160. [E-könyv]

Szőcs Tibor: A nádori ítélkezés és jogkör területi vonatkozásai a 13. század első felében. In: Középkortörténeti tanulmányok 7. /szerk.: Kiss P. Attila, Piti Ferenc, Szabados György/. Szeged, 2012. 411-423. 
Szöveggyüjtemény Magyar történeti szöveggyüjtemény 1000-1526. /szerk. Bertényi Iván, közremük.: Dreska Gábor, Thoroczkay Gábor/ Bp., 2000. (Osiris tankönyvek)

Sztáray I-II. $\quad$ A nagymihályi és sztárai gróf Sztáray család oklevéltára I-II. /szerk.: Nagy Gyula/. Bp., 1887-1889.

Szücs 1984

Szűcs Jenő: Az 1267. évi dekrétum és háttere. Szempontok a köznemesség kialakulásához. In: Mályusz Elemér emlékkönyv /szerk.: H. Balázs Éva, Fügedi Erik, Maksay Ferenc/. Bp., 1984. (Társadalomés müvelődéstörténeti tanulmányok) 341-394.

Szűcs 1993 Szűcs Jenő: Az utolsó Árpádok. Bp., 1993. (História könyvtár. Monográfiák 1.)

Takáts 1931 Takáts Lajos: Csanád vezér. Makó, 1931. (Csanádvármegyei Könyvtár 22.)

Tatárjárás emlékezete A tatárjárás emlékezete. A kötet anyagát Katona Tamás válogatta és szerkesztette, szakmai szempontból Györffy György és Szücs Jenő nézte át. A bevezető tanulmányt Györffy György írta. [Bp.], 1981.

TESZ I-IV. A magyar nyelv történeti-etimológiai szótára. I-IV. /főszerk.: Benkő Loránd, szerk.: Kiss Lajos, Papp László/ Bp., 1967-1984.

Theiner I-II. Vetera monumenta historica Hungariam sacram illustrantia. Maximam partem nondum edita ex tabulariis Vaticanis deprompta, collecta ac serie chronologica disposita ab Augustino Theiner. I-II. Romae, 18591860.

Thoroczkay 2009 Thoroczkay Gábor: Ellenszegülő ispán vagy független törzsfö? Megjegyzések Ajtony történetéhez. In: Auxilium Historiae. Tanulmányok a hetvenesztendős Bertényi Iván tiszteletére /szerk.: Körmendi Tamás, Thoroczkay Gábor/ Bp., 2009. 351-364.

Thoroczkay 2012 Thoroczkay Gábor: A dömösi prépostság története alapításától I. Károly uralkodásának végéig. In: Fons 19. (2012) 409-433.

Timon 1734 Timon Sámuel: Imago novae Hungariae, repraesentans regna, provincias, banatus, et comitatus ditionis Hungaricae. Cassoviae, 1734.

Tótfalusi 2001 Tótfalusi István: Magyar szótörténeti szótár. H. n., é. n. [Bp.], [2001.]

Tóth 2001 Tóth Ildikó: Adalékok a Valkó megyei oklevéladás kezdeteihez. In: Acta Universitatis Szegediensis. Acta Historica, tomus CXV. (2001) $23-31$. 
Tóth 2007

C. Tóth 2001

C. Tóth 2002

C. Tóth 2008

C. Tóth 2009

C. Tóth 2011

C. Tóth $2012 \mathrm{a}$

C. Tóth $2012 b$

Török 1907

Tringli 1997

Tringli 2001

Tringli 2009

Tringli 2010
Tóth Ildikó: Károly Róbert első országbírói. In: Tszatáj 61. (2007/12.) $78-82$.

C. Tóth Norbert: A Győr-nemzetség az Árpád-korban. In: Tanulmányok

a középkorról /szerk.: Neumann Tibor/. [Bp., 2001.] (Analecta Mediaevalia I.) 53-72.

C. Tóth Norbert: Vingárti Geréb Péter országbíró ítéletlevele 1498-ból. In: Levéltári Közlemények 73. (2002) 131-175.

C. Tóth Norbert: Szabolcs megye müködése a Zsigmond-korban. Nyíregyháza, 2008.

C. Tóth Norbert: A nádori hivatal müködése Lackfi István tisztségviselése alatt (1387-1392). In: Acta Universitatis Szegediensis. Acta Historica, tomus CXXX. (2009) 85-104.

C. Tóth Norbert: Nádorváltás 1458-ban. Mátyás király első országgyülésének időpontja. In: Turul 84. (2011) 98-101.

C. Tóth Norbert: Nádorváltások a Zsigmond-korban (1386-1437): Az 1439. évi 2. tc. nyomában. In: Tiszteletkör. Történeti tanulmányok Draskóczy István egyetemi tanár 60. születésnapjára /szerk.: Mikó Gábor, Péterfi Bence, Vadas András/. Bp., 2012. 53-65.

C. Tóth Norbert: Az ország nádora. In: Középkortörténeti tanulmányok 7. /szerk.: Kiss P. Attila, Piti Ferenc, Szabados György/. Szeged, 2012. 439-450.

Török Pál: A nemesi vármegye megalakulása. Kolozsvár, 1907.

Tringli István: Két szokásjogi norma a közgyűlések müködéséről. In: Történelmi Szemle 39. (1997) 387-400.

Tringli István: Pest megye a késő középkorban. In: Pest megye monográfiája I/2. A honfoglalástól 1686-ig. /szerk.: Zsoldos Attila/ Bp., 2001. 75-194.

Tringli István: Megyék a középkori Magyarországon. In: Honoris causa. Tanulmányok Engel Pál tiszteletére /szerk.: Neumann Tibor, Rácz György/. Budapest-Piliscsaba, 2009. (Társadalom- és művelődéstörténeti tanulmányok 40. Analecta Mediaevalia III.) 487518.

Tringli István: Pest és Pilis megye sajátos viszonyai a török hódítás előtt. In: Megyetörténet. Egyház- és igazgatástörténeti tanulmányok a 
Veszprémi Püspökség 1009. évi adománylevele tiszteletére. /szerk.: Hermann István, Karlinszky Balázs/ Veszprém, 2010. (A Veszprém Megyei Levéltár kiadványai 22. A veszprémi egyházmegye múltjából 22.) $369-419$.

Tubero 1746

Ludovici Tuberonis, Dalamatae abbatis Comentariorum de rebus suo tempore. In: Scriptores rerum Hungaricarum veteres ac genuini. Tom. II. Cura et studio Ioannis Georgii Schwandtneri. Vindobonensis, 1746. 107-381.

UB I-III.

Urkundenbuch des Burgenlandes und der angrenzenden Gebiete der Komitate Wieselburg, Ödenburg und Eisenburg. I-III. /Hrsg.: Wagner, Hans; Lindeck-Pozza, Irmtraut/ Graz-Köln, 1955-1979. (Publikationen des Instituts für Österreichische Geschichtsforschung 7.)

UDS I-VII. Urkundenbuch zur Geschichte der Deutschen in Siebenbürgen /hrsg.: Zimmermann, Franz; Werner, Carl et alii/ I-VII. Hermannstadt-KölnWien-Bucaresti, 1892-1991.

Váczy 1938 Váczy Péter: A királyság központi szervezete Szent István korában. In: Emlékkönyv Szent István király halálának kilencszázadik évfordulóján II. Bp., 1938., 33-69.

Vajda 2013

Vajda Tamás: Meghatározható-e a Dél-Alföld késő középkori lélekszáma? In: Mühelyszemináriumi dolgozatok I. /szerk.: Kovács Szilvia, Révész Éva/. Szeged, 2013. 145-180.

Veszprém: pótkötet Érszegi Géza, Solymosi László: Veszprém város okmánytára. Pótkötet (1000-1526) Veszprém, 2010. (A veszprémi egyházmegye múltjából 20.)

Weisz $2003 \quad$ Weisz Boglárka: Ampod fia Dénes. In: Szürke eminenciások a magyar történelemben /szerk.: Szentpéteri József/. [Bp.], 2003. 14-15.

Weisz 2012 Weisz Boglárka: II. András jövedelmei: régi és új elemek. In: II. András és Székesfehérvár /szerk. Kerny Terézia, Smohay András/. Székesfehérvár, 2012. 49-80.

Weisz-Zsoldos 2010 Weisz Boglárka, Zsoldos Attila: A báni joghatóság Szlavóniában és a Dráván túl. In: „Fons, skepsis, lex” Ünnepi tanulmányok a 70 esztendős Makk Ferenc tiszteletére /szerk.: Almási Tibor, Révész Éva, Szabados György/ Szeged, 2010. 469-482. 
Wertner 1891a

Wertner 1891b

Wertner 1892

Wertner 1893

Wertner 1894

Wertner 1895

Wertner 1897

Wertner 1898

Wertner 1907

Zaicz 2006

Zala I-II.

Závodszky 1904

Zichy I-XII.

Zsilinszky 1872

Zsoldos 1991

Zsoldos 1997a

Zsoldos 1997b
Wertner Mór: II. Moys nádor és családja. In: Századok 25. (1891) 392405.

Wertner Mór: A Drugeth-ek genealógiájához. In: Turul 9. (1891) 151.

Wertner Mór: Kemény fia Lőrincz nádor és utódai. In: Századok 26. (1892) 41-55.

Wertner Mór: Mizse nádor és családja (1290-1334). In: Erdélyi Múzeum 10. (1893) 584-587.

Wertner Mór: Az árpádkori nádorok sorozata. In: Történelmi Tár 17. (1894) 1-14.

Wertner Mór: Ompud nádor és utódjai. In: Turul 13. (1895) 91-93.

Wertner Mór: Ötödik Dénes nádor nemzetsége. In: Századok 31. (1897) 607-610.

Wertner Mór: Az árpádkori nádorok genealógiája. In: Turul 16. (1898) 73-78., 113-125.

Wertner Mór: Adalékok a XIV. századbeli magyar világi archontológiához (második közlemény). In: Történelmi Tár 8. (Uj folyam) (1907) 1-69.

Etimológiai szótár. Magyar szavak és toldalékok eredete /főszerk.: Zaicz Gábor/. Bp., 2006. (A magyar nyelv kézikönyvei XII.)

Zala vármegye története. Oklevéltár I-II. /szerk.: Nagy Gyula, Nagy Imre, Véghely Dezső/. Bp., 1886-1890.

Závodszky Levente: A Szent István, Szent László és Kálmán korabeli törvények és zsinati határozatok forrásai (függelék: a törvények szövege). Bp., 1904.

A zichi és vásonkeői gróf Zichy-család idősb ágának okmánytára I-XII. Pest-Bp., 1871-1931.

Zsilinszky Mihály: Tót történelmi szemle 1871-ről. A „Matica Slovenska” évkönyvei. Két kötet. In: Századok 6. (1872) 39-46.

Zsoldos Attila: Adalékok a királyi várszervezet udvarispáni tisztségének történetéhez. In: Levéltári Szemle 41. (1991/4.) 20-31.

Zsoldos Attila: Az Árpádok és alattvalóik (Magyarország története 1301-ig). Debrecen, 1997. (Történelmi kézikönyvtár)

Zsoldos Attila: Téténytől a Hód-tóig. (Az 1279 és 1282 közötti évek politikatörténetének vázlata) In: Történelmi Szemle 39. (1997) 69-98. 
Zsoldos 1997c

Zsoldos 1998

Zsoldos 1999

Zsoldos 2001

Zsoldos 2003

Zsoldos 2005

Zsoldos 2007

Zsoldos 2009

Zsoldos 2010a

Zsoldos 2010b

Zsoldos 2011a

Zsoldos 2011b
Zsoldos Attila: „Eléggé nemes férfiak...” A kehidai oklevél társadalomtörténeti vonatkozásairól. In: Zalai történeti tanulmányok /szerk.: Káli Csaba/. Zalaegerszeg, 1997. (Zalai Gyüjtemény 42.) 7-19. Zsoldos Attla: Visegrád vármegye és utódai. In: Történelmi Szemle 40. (1998) 1-32.

Zsoldos Attila: A szent király szabadjai. Fejezetek a várjobbágyság történetéből. Bp., 1999. (Társadalom- és müvelődéstörténeti tanulmányok 26.)

Zsoldos Attila: Pest megye az Árpád-korban. In: Pest megye monográfiája I/2. A honfoglalástól 1686-ig. /szerk.: Zsoldos Attila/ Bp., 2001. 31-73.

Zsoldos Atiila: Az özvegy és a szolgabírák. In: Századok 137. (2003) 783-808.

Zsoldos Attila: Az Árpádok és asszonyaik. A királynéi intézmény az Árpádok korában. Bp., 2005. (Társadalom- és művelődéstörténeti tanulmányok 36.)

Zsoldos Attila: Családi ügy. IV. Béla és István ifjabb király viszálya az 1260-as években. Bp., 2007. (História könyvtár. Monográfiák 27.)

Zsoldos Attila: Miklós országbíró. In: Honoris causa. Tanulmányok Engel Pál tiszteletére /szerk.: Neumann Tibor, Rácz György/ Bp.Piliscsaba, 2009. (Társadalom- és Müvelődéstörténeti Tanulmányok 40. Analecta Mediaevalia III.) 519-549.

Zsoldos Attila: III. András nádorai. In: Történelmi Szemle 52. (2010) $303-327$.

Zsoldos Attila: A Henrik-fiak. A Héder nembéli Kőszegiek „családi története”. In: Vasi Szemle 64. (2010) 651-661.

Zsoldos Attila: III. András hat nádora. In: Erősségénél fogva várépítésre való. Tanulmányok a 70 éves Németh Péter tiszteletére /szerk. Juan Cabello, C. Tóth Norbert/ Nyíregyháza, 2011. 289-300. (A Józsa András Múzeum Kiadványai 68.)

Zsoldos Attila: Debrecen, mit igazgatási központ a 14. század elején. In: Debrecen város 650 éves. Várostörténeti tanulmányok /szerk.: Bárány Attila, Papp Klára, Szálkai Tamás/. Debrecen, 2011. 49-66. 
Zsoldos 2012a Zsoldos Attila: A Drugetek és a „hét vármegye”. In: „Köztes-Európa” vonzásában. Ünnepi tanulmányok Font Márta tiszteletére /szerk.: Bagi Dániel, Fedeles Tamás, Kiss Gergely/. Pécs, 2012. 577-585.

Zsoldos 2012b Zsoldos Attila: Rátót nembéli Domokos nádor megyéi. In: Tiszteletkör. Történeti tanulmányok Draskóczy István egyetemi tanár 60 . születésnapjára /szerk.: Mikó Gábor, Péterfi Bence, Vadas András/. Bp., 2012. 47-52.

Zsoldos 2012c Zsoldos Attila: Nádor és helyettese: Druget János és Vilmos. In: Történelmi Szemle 54. (2012) 527-541.

Zsoldos 2012d Zsoldos Attila: A Druget-tartomány várnagyai. In: Castrum. A Castrum Benes Egyesület Hírlevele 15. (2012/1-2.) 33-42.

Zsoldos 2012e Zsoldos Attila: Hüséges oligarchák. In: A történettudomány szolgálatában. Tanulmányok a 70 éves Gecsényi Lajos tiszteletére /szerk.: Baráth Magdolna, Molnár Antal/. Bp.-Győr, 2012. 347-354.

Zsoldos-Neumann Zsoldos Attila, Neumann Tibor: Székesfehérvár középkori kiváltságai. Székesfehérvár, 2010. (Közlemények Székesfehérvár történetéből) 